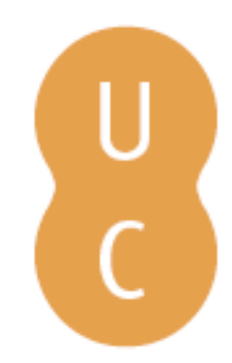

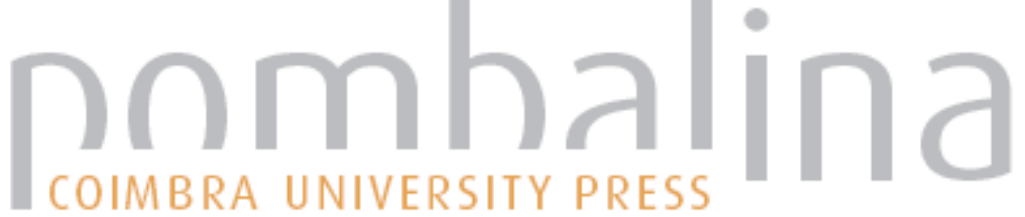

\section{Commonitiones Sanctorum Patrum: uma nova colecção de apotegmas: estudo filológico: texto crítico}

\author{
Autor(es): $\quad$ Freire, José Geraldes \\ Publicado por: Centro de Estudos Clássicos e Humanísticos; Imprensa da Universidade \\ de Coimbra \\ URL \\ DOI: $\quad$ DOI:http://dx.doi.org/10.14195/978-989-8281-71-5 \\ Accessed : $\quad$ 26-Apr-2023 12:36:08
}

A navegação consulta e descarregamento dos títulos inseridos nas Bibliotecas Digitais UC Digitalis, UC Pombalina e UC Impactum, pressupõem a aceitação plena e sem reservas dos Termos e Condições de Uso destas Bibliotecas Digitais, disponíveis em https://digitalis.uc.pt/pt-pt/termos.

Conforme exposto nos referidos Termos e Condições de Uso, o descarregamento de títulos de acesso restrito requer uma licença válida de autorização devendo o utilizador aceder ao(s) documento(s) a partir de um endereço de IP da instituição detentora da supramencionada licença.

Ao utilizador é apenas permitido o descarregamento para uso pessoal, pelo que o emprego do(s) título(s) descarregado(s) para outro fim, designadamente comercial, carece de autorização do respetivo autor ou editor da obra.

Na medida em que todas as obras da UC Digitalis se encontram protegidas pelo Código do Direito de Autor e Direitos Conexos e demais legislação aplicável, toda a cópia, parcial ou total, deste documento, nos casos em que é legalmente admitida, deverá conter ou fazer-se acompanhar por este aviso.

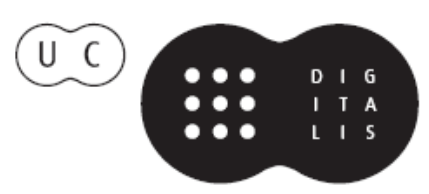




\section{José Geraldes Freire}

\section{Commonitiones Sanctorvm Patrvm \\ Uma nova colecção de apotegmas}


Autor: José Geraldes Freire

Título: Commonitiones Sanctorum Patrum. Uma nova colecção de apotegmas

Editor: Centro de Estudos Clássicos e Humanísticos

Imprensa da Universidade de Coimbra

Coordenador Científico do Plano de Edição: Maria do Céu Fialho

Conselho Editorial: José Ribeiro Ferreira, Maria de Fátima Silva, Francisco de Oliveira e Nair Castro Soares

Director Técnico da Colecção: Delfim F. Leão

Concepção Gráfica e Paginação: Miguel Sena, Paula Barata e Rodolfo Lopes

Impressão: Simões \& Linhares, Lda. Av. Fernando Namora, no 83 - Loja 43000 Coimbra

Obra Realizada no âmbito das Actividades da UI\&D Centro de Estudos Clássicos e Humanísticos

Universidade de Coimbra Faculdade de Letras Tel.: 239859 981 | Fax: 239836733

ISBN: 978-989-8281-70-8

ISBN Digital: 978-989-8281-71-5

Depósito Legal: 321156/10

(C) Imprensa da Universidade DE COIMBra

(C) Centro de Estudos Clássicos e Humanísticos da Universidade de Coimbra

(C) Classica Digitalia Vniversitatis Conimbrigensis (www.classicadigitalia.uc.pt)

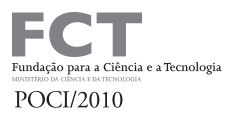

Reservados todos os direitos. Nos termos legais fica expressamente proibida a reprodução total ou parcial por qualquer meio, em papel ou em edição electrónica, sem autorização expressa dos titulares dos direitos. É desde já excepcionada a utilização em circuitos académicos fechados para apoio a leccionação ou extensão cultural via e-learning. 


\section{PARENTIBVS}

\section{MAGISTRIS}

\section{ALVMNIS}

COMMONITIONES vi, $3^{\mathrm{a}-\mathrm{b}}$

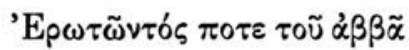

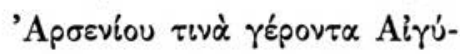

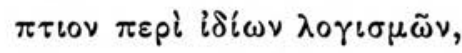

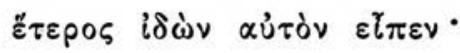

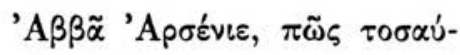

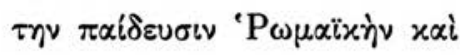

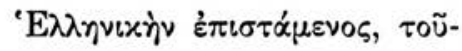

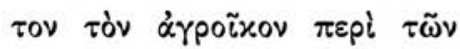

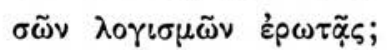

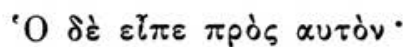

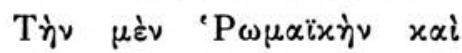

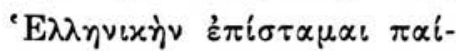
$\delta \varepsilon v \sigma \iota v \cdot \tau \dot{v} \nu \delta \dot{\varepsilon} \alpha \lambda \varphi \dot{\alpha} \beta \eta \tau o v$

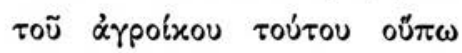
$\mu \varepsilon \mu \alpha \dot{\theta} \theta \eta \alpha$.
ARSENIVS 6 (PG 65,89)

Idem beatus Arsenius interrogabat quendam aegyptium uenerabilem monachum de diuersis cogitationibus et impugnatione daemonum. Superuenit autem quidam de amicis antiquis eius, uidensque eum sollicite et intente requirentem a monacho, ait ad eum: Valde admiror, pater, quia cum tanta eruditione perfecte studeris tam graecae quam latinae scientiae, cur ab isto inerudito et idiota homine requiras quae ad salutem animae conueniunt?

Respondens autem beatus Arsenius ait: Licet tam graece quam latine, ut dicis, eruditus sim, tamen alphabetum uerae scientiae huius aegyptii non didici. 
Par la force des choses, l'A. devait bien rencontrer sur son chemin cette autre collection «mineure" d'apophtegmes attribuée à Rufin par Rosweyde au 1 . III de ses Vitae Patrum et dont la parenté avec la coll. de Paschase est évidente. Là encore, l'étude de Freire débrouille un écheveau qui avait longtemps exercé la sagacité des chercheurs. Le compilateur du l. III se serait servi, en effet, d'une collection encore inédite (que l'A. appelle al'authentique 1 . III") de 61 apophtegmes en 6 chapitres. Cette collection n'est plus une hipothèse. L'A. la restitue et en donne une table précise avec indications et incipits. Les 40 premiers numéros de Rosweyde en seraient une anthologie.
G. C.
Collectanea Cisterciensia
35,1973 , p. 318
Abbaye de N. D. de Scourmont Forges BELGIQUE

De cet *Authentique livre III, la composition est reconstituée, vol. II, 173-178: 61 pièces, réparties en six chapitres, dont 40 seulement ont été reprises au debut du livre III de Rosweyde. Evidemment, on ne peut que souhaiter que J. Freire poursuive une oeuvre si bien commencée, et nous donne maintenant une édition critique de cette petite collection qu'il a lui-même decouverte.

$\begin{array}{cc}\text { Jean-Claude Guy } & \text { 15, rue Monsieur, } \\ \text { Revue d'Histoire de la Spiritualité } & 75-\text { Paris VII } \\ 48,1972, \text { p. } 105 & \text { FRANCE }\end{array}$

El libro III de Rosweyd es entonces un simple florilegio tomado de Pascasio y otras fuentes, y contendría en los n.os 1-40 las dos terceras partes de un libro original $\gamma$ hasta ahora desconocido, una colección de apotegmas: el «auténtico libro III".

Esperamos que el A. edite criticamente lo que el llama el «auténtico libro III", pues las sumarias referencias dejan una gran curiosidad en el lector.
Martín de Elizalde
R. Villanueva, 955
Cuadernos Monásticos
Buenos Aires $26 \mathrm{~B}$
VII, 1972, pp. 304-305
ARGENTINA

This means that 233 of the sententiae of Paschasius had never been published. It shows in a vivid manner how new to scholars is the text of Paschasius as now edited by Geraldes Freire. It is his special gift to the rest of the World that we now know exactly what Paschasius wrote close to 556 A.D. and that we have a firm foundation upon which to base continued study of the other Latin translations and of the several Greek versions current previous to the years 500 . This material is still voluminous, but will repay detailed study for what it can tell us of the lives of the monks of the Egyptian desert, who were one element in the tradition of the Christian world from antiquity to early Spain and thence to other European countries.

$$
\begin{aligned}
& \text { Claude W. Barlow } \\
& \text { Classical Folia } \\
& \text { XXVI, 1972, p. } 160
\end{aligned}
$$

\author{
Clark University \\ Worchester \\ Massachussetts (U.S.A.)
}




\section{PRÓLOGO}

Na nossa tese de doutoramento, A versão latina por Pascásio de Dume dos Apophthegmata Patrum (Coimbra, 1971), demos conhecimento, suficientemente amplo, da descoberta de uma nova colecção latina de apotegmas dos padres dos desertos, intitulada Commonitiones Sanctorum Patrum.

Dadas as ligações de carácter paleográfico e orgânico existentes entre o texto de Pascásio e o das Commonitiones, ambos compilados numa antologia que constitui o chamado Livro III das Vitae Patrum, editadas, pela primeira vez, em 1615, por Heribertus Rosweydus, tivemos já então de adiantar bastante o estudo do texto genuíno das Commonitiones para podermos continuar, com segurança, a investigação sobre a obra autêntica de Pascásio.

Concluida a primeira tarefa, impunha-se-nos aproveitar todos os elementos até essa altura recolhidos para a edição das Commonitiones Sanctorum Patrum, pesquisar novas fontes da transmissão manuscrita, estabelecer definitivamente o texto crítico e aquilatar os problemas de carácter filológico levantados pela nova colecção. Dentro do âmbito das nossas preocupações, o exame linguístico do latim das Commonitiones constituía ponto de honra indispensável. Com efeito, não desejávamos apresentar-nos a provas para o concurso de professor extraordinário de Filologia Clássica sem dar à luz da 
publicidade esta obra que descobríramos, cujos manuscritos principais indicáramos e de cuja autenticidade não podíamos duvidar.

$A$ crítica à nossa tese sobre Pascásio, aparecida em diversas revistas, sobretudo estrangeiras, apercebeu-se também do interesse que as Commonitiones têm para um mais amplo conhecimento do género apotegmático. As pesquisas sobre o apotegma como género literário, nas mais diversas linguas, têm recrudescido nos últimos tempos, tanto por parte dos orientalistas, como dos filólogos clássicos, medievais e de idiomas modernos. Por isso, de diversos lados nos vieram incentivos para levarmos a cabo, o mais rapidamente possível, a obra anunciada.

Só que trabalhos deste género não podem compaginar-se com a rapidez... A velocidade do tempo não conta aqui como factor decisivo. O que importa é proceder a uma análise atenta e conscienciosa do texto crítico, atender à geografia codicológica, perscrutar indícios que nos levem a reconhecer o autor, o tradutor, a data $e$ a expansão obtida pela obra em causa. Quem ler este nosso estudo verificará que tivemos de partir, em todos os campos, do zero: um livro até agora desconhecido, escrito por autor desconhecido, vertido para latim por tradutor desconhecido, data de composição grega e de tradução latina também desconhecidas... Mas o texto das Commonitiones veio ao nosso encontro! Importava auscultar tudo quanto ele poderia revelar-nos. E este foi o objectivo constante do nosso trabalho. 
Concordamos com a observação de quantos consideraram editio princeps a nossa publicą̧ão da obra de Pascásio, apesar de o nome deste tradutor e de parte da sua obra já serem conhecidos, através da imprensa, desde o final do século XV. Que dizer então das Commonitiones Sanctorum Patrum, copiadas pela última vez, como unidade temática, no século XIV? Compreende-se, pois, a natural alegria e emoção íntima com que lançamos a público esta obra.

Cumpre-nos agradecer ao Instituto de Alta Cultura que, através do Centro de Estudos Clássicos e Humanísticos, anexo à Faculdade de Letras da Universidade de Coimbra, subsidiou a nossa investigação, a confiança em nós depositada. Não podemos deixar de referir ainda uma bolsa especial de estudo para uma estadia na Bélgica e Holanda durante os meses de Setembro e Outubro de 1973, em busca de novos manuscritos e de actualização bibliográfica.

No trabalho de pesquisa bibliográfica deu-nos valioso contributo a equipa que constitui a Société des Bollandistes, de Bruxelas, a qual dispõe de uma riquíssima biblioteca com índices sistemáticos perfeitamente actualizados. Também a Dom Lucien Regnault, da abadia de Solesmes, devemos manifestar reconhecimento por nos ter fornecido indicações sobre fontes gregas constantes do seu "Quadro de lugares paralelos dos apotegmas", cuja próxima publicação muito virá ajudar todos os investigadores deste género literário. 
A formação do carácter $e$ da metodologia científica são um investimento de capital humano que passa a render cada vez mais. Daí a permanente gratidão para com a nossa diocese de origem (Portalegre e Castelo Branco), para a "escola de Coimbra" (com particular menção da Prof. ${ }^{2}$ Dr. ${ }^{2}$ Maria Helena da Rocha Pereira) e para a "escola de Nimega» (referindo especialmente a Prof. ${ }^{2}$ Dr ${ }^{2}$ Christine Mohrmann).

Ao Sr. Doutor Américo da Costa Ramalho, professor infatigável $e$ amigo a quem somos dedicado em todas as horas, a nossa homenagem por ter querido incluir este livro na série do Centro de Estudos Clássicos e Humanísticos, de que é dinâmico Director.

A todos quantos nos ajudaram, em Portugal e no estrangeiro, manifestamos o nosso reconhecimento.

As Commonitiones Sanctorum Patrum aí vão. Esperemos que elas não sejam o último aproveitamento de materiais de trabalho que vimos acumulando desde 1962. Comeşámos a desenredar o fio de um grande novelo. Há tanto, tanto que estudar... Sic nos Deus adiuuet!

Coimbra, 10 de Junho de 1974.

P. José Geraldes Freire 
COMMONITIONES SANCTORVM PATRVM

ESTUDO FILOLÓGICO 



\section{Cap. I - UMA NOVA COLECÇÃO DE APOTEGMAS}

Os livros conhecidos pelo título geral de Vitae Patrum adquiriram a sua forma mais ampla, e ainda hoje consagrada, com a edição do jesuíta natural de Utreque, Heribertus Rosweydus $\left({ }^{1}\right)$, reproduzida na Patrologia Latina $\left({ }^{2}\right)$. Dos 10 livros e 3 apêndices publicados por Rosweydus, são constituídos pelo género literário de apotegmas dos padres dos desertos do Egipto, Palestina e Síria, sob a designação de Verba seniorum, os Livros: - III, «auctore probabili Rufino», segundo pensava Rosweydus; V e VI, atribuídos pela tradição manuscrita a Pelágio, diácono, e a João, subdiácono, ambos do clero de Roma; VII, «interprete Paschasio»; e o apêndice terceiro intitulado Aegyptiorum patrum sententiae (...) Martino Dumiensi episcopo interprete $\left({ }^{3}\right)$.

(1) Vitae Patrum siue historiae cremiticae libri decem (...), opera et studio Herirertı ROSWEYDI, Vltraiectini, Antuerpiae, ${ }^{1} 1615,{ }^{2} 1628$. Há ainda uma edição de Léiden, saída em 1617, de que subsistem raros exemplares.

(2) J.-P. Migne, Patrologiae Latinae cursus completus, tt. 73 e 74, Parisiis, 1879. Passaremos a designar esta obra apenas por PL. Sobre as mais antigas edições das Vitae Patrum, cf. Prolegomena XVII-XXIII de Rosweydvs, PL 73, colunas 63-79.

(3) Sobre o género literário dos apotegmas, cf. José Geraldes Freire, $A$ versão latina por Pascásio de Dume dos «Apophthegmata Patrum», Instituto de Estudos Clássicos, Coimbra, 1971, t. I, pp. 34-38 e bibliografia aí indicada. Passaremos a referir esta nossa obra apenas por Pascásio de Dume...

O Livro III de Rosweydvs foi objecto da nossa análise em Pascásio de Dume..., t. II, pp. 167-235, e o Livro VII constitui a base dos dois tomos daquele nosso trabalho, encontrando-se o texto crítico no t. I, pp. 157-333.

Os Livros V e VI foram estudados por Columba M. Batlle, em Die Adhortationes sanctorum patrum ( Verba seniorums) im lateinischen Mittelalter, Aschendorffsche Verlagsbuchhandlung, Münster, 1972. Aí se estudam também as primeiras referências literárias às Vitae Patrum (pp. 1-9) e a influência destes livros, especialmente das Adhortationes, ao longo de toda a Idade Média até Lutero (pp. 208-297). Batlle investiga também a transmissão manuscrita dos Livros V e VI, mas não dá uma 
A análise da transmissão manuscrita do Livro III das Vitae Patrum editado por Rosweydus, dividido em 220 números, a grande maioria dos quais (44-199 e 207-217) são uma recensão abreviada da obra original de Pascásio (motivo por que tivemos de a estudar) revelou-nos que apenas os seus nn. 1-40 são autênticos, constituindo uma antologia de uma colecção de 61 apotegmas divididos em 6 capítulos, o primeiro dos quais é precedido do título de Commonitiones sanctorum patrum $\left({ }^{4}\right)$. Como já então deixámos entrever, além dos 40 números conservados no Livro III de Rosweydus, encontram-se publicados mais 8, interpolados no texto da Palladii Lausiaca (PL 74, coll. 343-377), e ainda mais 3 , incluídos no cap. XX (todo ele espúrio) da mesma Palladii Lausiaca (coll. 377-382). Ficaram inéditos 11 apotegmas. Com efeito, aos 40 números de Rosweydus correspondem apenas 39 apotegmas do texto autêntico, uma vez que o apotegma n. 1 do cap. I foi por Rosweydus dividido em 1 e 2 , como se poderá ver no quadro dos lugares paralelos que damos a seguir, pp. 63-64.

Apesar de apenas 11 números não terem sido publicados até agora, devemos insistir em que a obra começada pelo título: Commonitiones sanctorum patrum, dividida em 6 capítulos, é uma nova colecção de apotegmas. Efectivamente, a todos os estudiosos de manuscritos passou despercebido que estes 6 capítulos, com os seus 61 apotegmas, constituíam uma unidade. Os próprios manuscritos conhecidos $(5)$, com excepção dos de Viena e Dresda, - ou apresentam a colecção toda seguida,

edição crítica. O texto que temos de continuar a utilizar é ainda o da PL, t. 73, a que se devem juntar 19 apotegmas omissos, publicados por C. M. BATLLE no artigo "Vetera Noua». Vorläufige kritische Ausgabe bei Rosweyde fehlender Väterspruche in Festschrift Bernard Bischoff, Anton Hiersemann, Stuttgart, 1971, pp. 32-42.

Um conspecto geral das coleç̧ões latinas de apotegmas, algumas das quais não publicadas por Rosweydus, pode ver-se no artigo: J. G. Frerre, Traductions latines des aApoplithegmata Patrum,, publicado nas Mélanges Christine Mohrmann, Nouveau recueil offert par ses anciens éleves, Spectrum Éditeurs, Utrecht/Anvers, 1973, pp. 164-171.

(4) Cf. Pascásio de Dume..., t. II, pp. 170-178.

(5) Cf. Pascásio de Dume..., t. II, pp. 188-191 e 216-232. 
sem títulos nem divisão de capítulos, continuando depois indistintamente com outros materiais (é o caso do ms. de Reims), ou dão primeiro os nn. 1-40 da antologia que é o Livro III de Rosweydus e colocam em lugar muito afastado, e com total independência, os restantes apotegmas exclusivos dos 6 capítulos iniciados pelas Commonitiones (como fazem os ms. de Berlim, Namur, Londres e Munique), - ou trazem escassos elementos desta nova coleç̧ão, dispersos por entre apotegmas traduzidos por outros intérpretes (tal como acontece nos restantes que mencionamos a seguir, pp. 22-45) e 262-264).

Nenhum editor nem investigador moderno de apotegmas publicados ou de manuscritos em latim tinha dado pela existência desta colectânea ou demonstrado que ela deveria existir, apesar das dificuldades por vários encontradas para identificar algumas das suas peças que ocasionalmente se lhes depararam $\left(^{6}\right)$.

Foi ao estudar, em fins de Novembro de 1965, a parte de Pascásio no manuscrito de Dresda, Biblioteca Nacional da Saxónia, A 207, que entre apotegmas de Pelágio e João, de fragmentos dos Livros II e III de Rosweydus e de outros extractos das Vitae Patrum, verificámos a existência nos ff. $188 \mathrm{r}-216 \mathrm{v}$ de uma obra com carácter unitário começada por: Incipit comocio sanctorum patrum, com capítulos, índices e apotegmas bem delimitados. Tudo quanto se encontra nos nn. 1-40 do Livro III de Rosweydus aí está também. Mas tornou-se-nos logo patente que os primeiros 40 números de Rosweydus não passavam de uma antologia desta colecção desconhecida.

${ }^{6}{ }^{6}$ É o caso dos autores do Catalogue of additions to the manuscripts in the British Museum in the years 1906-1910 (London, 1912) ao descreverem o ms. add. 37400 , Pp. 28-33; e de G. MEYer und M. BuckhARdT, Die mittelalterlichen Handscliriften der Universitätsbibliothek Basel, Abt. B, I Band (Basel, 1960) quando descrevem o ms. B. V. 2, pp. $417-433$.

Idênticas dificuldades tiveram os Bolandistas de Bruxelas, ao analisarem o cod. bolland. 27 quando encontraram passos de Pascásio então ainda inéditos e que nós demonstrámos pertencerem à recensão longa. Cf. Pascásio de Dume..., t. II, pp. 143-144. 
A busca da tradição manuscrita do Livro III das Vitae Patrum trouxe até nós o manuscrito de Viena, Biblioteca Nacional da Áustria 433, o qual contém nos ff. 113v-165r as Commonitiones sanctorum patrum com títulos, índices $\mathrm{e}$ apotegmas numerados por capítulos, isolados de qualquer outra colecção ou de extractos de sentenças de padres do deserto. Não havia dúvidas, do ponto de vista externo, de que estávamos perante uma nova e autêntica colecção de apotegmas $\left({ }^{7}\right)$.

O seu carácter é sistemático, tópico e didáctico, versando cada capítulo um tema e ordenando nele os apotegmas de forma lógica $\left({ }^{8}\right)$.

(7) Não se estranhe que tenhamos começado a crer na autenticidade das Commonitiones sanctorum patrum quando apenas conhecíamos o manuscrito de Dresda. A prova veio depois com o manuscrito de Viena e os restantes 15 que descrevemos adiante (pp. 22-45). Aliás há muitas obras salvas por um só manuscrito, por vezes mutilado e sem indicação de autor. Ocorrem-nos os casos do Díscolo, de Menandro; das Dissertações, de Epicteto; da Anábase, de Arriano; dos Stromata, de Clemente de Alexandria (exemplos estes colhidos em A. DaIN, Les manuscrits, Paris, 1964); do De Republica, de Cícero (cf. edição de K. Ziegler, Lipsiae, 1965); da Peregrinatio Aetheriae (cf. Éthérie, Journal de voyage, edit. Hélène Pétré, Paris, 1964); da Vita Antonii, versão diferente da de Evágrio (cf. H. HoppenBrouwers, La plus anciène version latine de la vie de S. Antoine par S. Athanase, Utrecht-Nijmegen, 1960); do De Regimine Sanitatis, atribuído a Pedro Hispano (cf. M. H. DA Rocha Pereira, Obras médicas de Pedro Hispano, Coimbra, 1973); e em geral das obras filosóficas atribuídas a Pedro Hispano (com excepção das Summulae Logicales): Scientia libri de anima, Quaestiones super libro de animalibus, Expositio libri de anima, Quaestiones libri de anima e De rebus principalibus naturarum. (Sobre os problemas de autenticidade ou inautenticidade de cada um destes opúsculos [transmitidos só por um ou por dois manuscritos, mas então divergentes], cf. J. M. DA CRUZ PONTES, $A$ obra filosófica de Pedro Hispano Portugalense, Coimbra, 1972).

$\left.{ }^{8}\right)$ Sobre a organização das colecções gregas e latinas em séries - nominal, alfabética, anónima, sistemática (tópica, didáctica ou lógica), miscelânea, compilatória ou desordenada, cf. C. ButLer, The Lausiac History of Palladius, I vol., Cambridge, 1898, pp. 210-211; F. NAU, Le chapitre Пepi ¿̀v $\chi \omega p \eta \tau \tilde{\omega} \nu \dot{\alpha} \gamma(\omega \nu$ et les sources de la vie de Saint Paul de Thèbes in Revue de l'Orient Chrétien, X (1905) p. 391 (Paris); M. Chaine, Le texte original des apophtegmes des Pères in Mélanges de la Faculté Orientale (Université de Saint Joseph, Beyruth) V (1912), pp. 543-545; P. Nikrtin, Das griechische asketischex Paterikón und seine alte lateinische Uberzetzung in Vizantysky Vremennik XXII (1915-1916), pp. 127-171, texto eslavo (utilizámos o resumo dado na recensão da Byzantinische Zeitschrift XXIII (1914), Leipzig, 1920, p. 457); THEODOR HOPFNER, Úber die koptisch-saidischen Apophthegmata Patrum Aegyptiorum und verwandte griechische, lateinische, koptisch-bohairische und syrische Sammlungen in Akademie der 
$\mathrm{O}$ aparecimento de mais 15 manuscritos (que enunciaremos adiante, pp. 22-45), onde se encontram apotegmas até aqui desconhecidos, mas que puderam agora ser identificados, graças à chave fornecida pelas Commonitiones, veio confirmar a genuinidade desta colecção.

O seu sentido de unidade tinha-se quebrado totalmente, com o isolamento de 39 numa antologia, a mistura de 11 na edição espúria da Palladii Lausiaca e com 11 nunca publicados. Urgia reconstituir esta nova colecção, fazendo-a voltar à sua forma primitiva.

Quando tivemos de estudar em pormenor todo o Livro llI de Rosweydus e verificámos que nele todos os números desde 41 a 220 eram espúrios, pois na realidade pertenciam a outras obras, vimo-nos na necessidade de distinguir os nn. 1-40 de Rosweydus do conjunto das Commonitiones que, convencionalmente, passámos então a chamar o "Autêntico Livro III das Vitae Patrum». $\mathrm{Na}$ realidade, se houvesse de se fazer uma edição crítica da obra do precursor dos Bolandistas $\left({ }^{9}\right)$, o Livro III das Vitae Patrum deveria passar a ser formado apenas pelo texto dos 61 apotegmas por nós editados na segunda parte deste livro.

Wissenschaften in Wien, Philosophisch-historische Klasse, Denkschriften LXI (1919) p. 22; W. Bousset, Apophthegmata. Studien zur Geschichte des ältesten Mönschtums, Tübingen, 1923, p. 23; P. DE LABriolle, artigo Apophthegmata Patrum in Dictionnaire d'Histoire et de Géographie Ecclésiastiques, t. III, Paris, 1924, coll. 1021-1023; R. Draguet, Les Pères du Désert, Paris, 1949, p. XIV; J.-C. GuY, Recherches sur la tradition grecque des Apophthegmata Patrum, Bruxelles, 1962, pp. 11-12.

Deve, pois, terminar a discussão sobre a natureza da primeira parte do Livro III de Rosweydus, nn. 1-40. Sobre a classificação e origem dos restantes números, cf. Pascásio de Dume..., t. II, pp. 170-171, 179-180. Neste aspecto, o Livro III tem também sido diversamente interpretado: para uns é desordenado (Butler e Labriolle), para outros tem ordem de matérias (Hopfner, Bousset). Esta última hipótese é a que mais se aproxima da realidade.

( $\left.{ }^{9}\right)$ Sobre H. Rosweydus e os Bolandistas, cf. Hippolyte Delehaye, L'oeuvre des Bollandistes à travers trois siècles, 1615-1915, Bruxelles, 21959. A sua actividade pode continuar a ser seguida pela revista Analecta Bollandiana, que em 1973 completou o seu XCI volume, e pelos Subsidia Hagiographica, livros em boa parte da sua autoria, cujo n. 56 , J. VAN DER STRAETEN, Les manuscrits hagiographiques de Charleville, Verdun et Saint-Mihiel é já de 1974. 
Agora que a colecção é reconstituída criticamente à sua configuração original, podendo designar-se cada apotegma pelo capítulo e número que tem no conjunto, a edição de Rosweydus apenas poderá continuar a usar-se quando motivos de ordem prática assim o aconselhem. Desfeito o enigma que envolvia o Livro III, para os seus nn. 1-40 será preferível utilizar antes a sua numeração exacta no texto genuíno das Commonitiones sanctorum patrum. 


\section{Cap. II - MANUSCRITOS CONHECIDOS}

Em princípios de 1966 fizemos uma investigação geral e sistemática sobre a transmissão manuscrita do Livro das Vitae Patrum começado pelo prólogo: Vere mundum quis dubitet meritis stare sanctorum, e cujo primeiro apotegma principia por: Quidam sanctorum seniorum patrum, interrogantibus se monachis de causa abstinentiae dixit... (Livro III da edição de Rosweydus). Tomámos como ponto de partida a valiosa coleç̧ão de catálogos de manuscritos que se encontra numa das salas de leitura da Biblioteca da Universidade de Lovaina. Deparámos assim com um total de 85 manuscritos de que demos notícia, tão desenvolvida quanto necessário (ou possível), no tomo II de $A$ versão latina por Pascásio de Dume dos "Apophthegmata Patrum» (Coimbra, 1971), pp. 188-253.

Tendo chegado à conclusão de que os nn. 1-40 do III Rosw. são uma antologia de uma coleç̧ão mais vasta principiada pelas Commonitiones sanctorum patrum, que nos propomos agora editar, voltámos de novo, em Setembro e Outubro de 1973, a fazer uma pesquisa em busca de novos manuscritos. A esperança de algum êxito deste trabalho baseava-se no facto de, entretanto, terem sido publicados novos catálogos de códices de várias bibliotecas, de se terem enriquecido as colecções de catálogos que consultámos em 1966 e ainda na circunstância de podermos insistir numa área geográfica bem determinada. Com efeito, os manuscritos conhecidos das Commonitiones são quase todos provenientes de uma área que se delimita genericamente do seguinte modo: Áustria, Suiça, Alemanha, norte da França e Flandres. Atendendo a que, entre estas regiões, a França e a Bélgica têm há mais tempo uma rede bastante perfeita de catálogos 
de manuscritos, demorámo-nos em 1973 sobretudo nas outras áreas, incluindo também a Checoslováquia e a Holanda. Uma investigação sistemática deste género nunca é infrutífera. É verdade que, no caso presente, apenas conseguimos encontrar dois novos manuscritos com texto inédito das Commonitiones, mas deparámos com vários outros que interessam a temas que temos entre mãos, como por exemplo Pascásio, Martinho, a vida de Táisis e o próprio Livro III de Rosweydus, o qual tem que continuar a ocupar-nos, pois que a primeira parte é tirada das Commonitiones e, na segunda, Pascásio está largamente representado, além de possuir também uma breve selecção das Sententiae patrum Aegyptiorum de S. Martinho de Dume $\left({ }^{10}\right)$.

$\left.{ }^{10}\right)$ Oportunamente faremos a análise dos seguintes novos manuscritos, que indicamos por ordem alfabética das cidades: A) - Com texto de Pascásio de Dume -1) Bona, Biblioteca da Universidade 362, séc. xv, ff. 116r-125r; 2) Udine, Biblioteca Arquiepiscopal, fundo da Abadia de Moggio 7, séc. Ix, ff. 1r-115v (Pascásio), ff. $115 v-132 v$ (Martinho); 3) Viena, Biblioteca Nacional da Áustria 4793, séc. xv, fl. 1r (prefácio), ff. 54v-64v (apotegmas de Pasc.), ff. 64v-67r (Martinho).

B) - Com texto do Livro III de Rosweydus - 1) Berlim, Biblioteca Nacional dos Tesouros Culturais da Prússia, Theol. Fol. 36, séc. xv, ff. 27v-50v; 2) Dêventer, Bibl. do Ateneu 35, séc. xv, ff. $40 \mathrm{r}-48 \mathrm{r}$; 3) Munique, Bibl. do Estado da Baviera (= CLM) latino 21544, séc. Xv, ff. 194v-196v; 4) Munique, CLM 22035, séc. xII ff. 1r-52r; 5) Munique, CLM 23418, séc. xıv, ff. 1r-71r; 6) Munique, CLM 23591, séc. $\mathrm{xI}, \mathrm{ff}$. 41r-60r e ff. 69r-110r. (A omissão de todos estes manuscritos de Munique no nosso estudo sobre Pascásio deve-se, sem dúvida, ao facto de, na ocasião em que consultámos o respectivo Catalogus, faltar na colecção da Biblioteca da Universidade de Lovaina o «tomus II, pars IV», o qual foi reimpresso em 1969. Não tendo dado por este lapso quando estivemos em Munique em 1966, pedimos em Outubro de 1973 ao Dr. C. M. Batlle para examinar, entre os códices que no Catalogus apenas têm a indicação de Vitae Patrum, quais as partes que poderiam interessar aos nossos temas. Aqui lhe deixamos a expressão do nosso reconhecimento. 7) Praga, Biblioteca Universitária VII. D. 2, séc. xIv, ff. 9r-63r; 8) Praga, Bibl. Univ. XIII. E. 6, séc. xII-XIv, ff. $139 \mathrm{v}-170 \mathrm{v}$ e $183 \mathrm{r}-220 \mathrm{r}$; 9) Praga, Bibl. Univ. III. C. 15, séc. xv, ff. 15v-34r; 10) Praga, Bibl. Univ. III. C. 18, séc. xrv-xv, ff. $240 v-263 v$ e $264 v-268 r$; 11) Viena, Bibl. Conventual de Santa Maria dos Escoceses 324, séc. xv, ff. 56r-111v; 12) Viena, Bibl. Nac. Áustria 4410, séc. xrv, ff. 21r-31r (=51r); 13) Vyssí Brod, Bibl. Conventual 53, séc. $x v$, ff. 1r-54r; 14) Wolfenbiitel, Bibl. do Arquiduque Augusto, cod. Guelf. 59. 6. Aug. 2., séc. xII-XII, ff. 1r-53r; 15) Wolfenbiutel, Bibl. do Arquiduque Augusto, cod. Guelf. 85. 3. Aug. $8^{\circ}$, séc. xIv, ff. $39 v-147 r$.

Sobre os outros mss. que são do nosso conhecimento com a tradução de Martinho, cf. P. J. Geraldes Freire, Manuscritos das eSententiae patrum Aegyptiorum. 
Não sendo nosso intento voltar agora a Pascásio nem apenas à transmissão dos números que se encontram no Livro III de Rosweydus, vamos por isso fornecer os elementos essenciais dos manuscritos que contêm apotegmas só identificáveis por quem conhecer as Commonitiones sanctorum patrum. Acrescentaremos breves elementos paleográficos. Quando o texto transmitido for o da recensão que, resumida, entrou no Livro III de Rosweydus, para aí remeteremos, sendo fácil encontrar a versão exacta e a sua numeração própria no conjunto das Commonitiones, consultando o quadro de lugares paralelos que publicamos no capítulo III, pp. 63-64. Em ordem a uma possível localização desta nova colecção noutros manuscritos, damos também notícia do texto que precede e que se segue imediatamente às Commonitiones.

\section{ARQUÉTIPO $\beta$}

Como veremos ao tratar da genealogia dos códices principais (pp. 265-268), o texto que possuímos das Commonitiones supõe a existência, entre o original do tradutor e os manuscritos chegados até nós, de um hiperarquétipo perdido, designado pela letra $\alpha$. Alinhamos a descrição dos manuscritos pela sua posição no stemma codicum, que publicamos na p. 262. Os códices vão ordenados a partir dos mais antigos, em cada série.

Se alguém comparar a distribuição que fizemos no estudo sobre Pascásio, com a que aparece no $\sigma \tau \varepsilon \dot{\mu} \mu \alpha$, verificará que elas se correspondem nas suas grandes linhas. Como é natural, os códices que antes considerámos «não agrupados» ocupam

de S. Martinho de Dume in Repertorio de Historia de las Ciencias Eclesiásticas en España, 2, Salamanca, 1971, pp. 83-97.

Não indicamos os novos mss. com a Vita Taisis porque ainda não houve oportunidade de dar uma lista dos que já antes conhecíamos, os quais atingem cerca de uma centena. 
agora, depois do exame interno do seu texto, o lugar que lhes compete.

No caso de, no primeiro estudo, termos dado o número que os episódios apresentam na edição do Livro III de Rosweydus, a apotegmas que pertencem a modelos anteriores à organização da editio Vulgata dos nn. 1-40, fazemos agora a conversão para o seu número real nas Commonitiones.

1. $(=V)-$ Viena, Biblioteca Nacional da Áustria $433-$ - Trata-se de um códice do século xI, provavelmente escrito perto de Estugarda. Depois do Heraclidis Paradisus (BHL 6532) e do De octo principalibus uitiis de S. Nilo, temos nos ff. $113 \mathrm{v}-165 \mathrm{r}$ o texto completo das Commonitiones sanctorum patrum, a que se segue a Vita sancti Frontonii (BHL 3192). Particularidades externas deste manuscrito fundamental para a reconstituição das Commonitiones já foram por nós descritas $\left({ }^{11}\right)$.

A caligrafia é carolina, de uma limpidez perfeita, o que torna a leitura fácil e agradável. Cada apotegma começa, em princípio de linha, com letra maiúscula. O primeiro apotegma de cada capítulo, com excepção do cap. III (fl. 129v), principia com maiúscula iluminada e com miniaturas geométricas. $\mathrm{Na}$ margem inferior do fl. $154 \mathrm{v}$ estão desenhadas três folhas de árvore.

2. (= A) - Vaticano, Biblioteca Apostólica, latino 1201 - Este códice do século xI foi por nós minuciosamente estudado $\left({ }^{12}\right)$, no respeitante ao conteúdo dos seus fólios $75 \mathrm{r}-166 \mathrm{v}$. Oferece-nos a particularidade de ser o único conhecido, além dos manuscritos de Viena e de Dresda, que nos fornece, no fl. 166va-b, o n. V, 1 das Commonitiones. A sua lição vem

(11) Cf. Pascásio de Dume..., t. II pp. 188-189. Ao indicar outros tratados mencionamos, sempre que possível, o seu número na Bibliotheca Hagiographica Latina (= BHL), editada pelos Bolandistas, Bruxellis, t. I, 1898-1899, t. II, 1900-1901.

${ }^{(12)}$ Cf. Pascásio de Dume..., t. II, pp. 192-193, 229-231, 240 e 253. 
garantir-nos a autenticidade deste livro de apotegmas e a maior valia do códice de Viena acabado de descrever.

Como ressalta da nossa primeira descrição, o Vaticanus latinus 1201 contém, noutros lugares, extractos do Livro III de Rosweydus. A parte das Commonitiones é a seguinte, com um texto semelhante ao do arquétipo $\eta$ :

- fl. 86ra-b: III Rosw. 20;

- ff. 104(A)ra-108rb: III Rosw, 1-7, 17-19, 21, 22, 188

(fl. 106vb-107ra), 23-26;

- ff. 108vb-112ra: III Rosw. 27-40;

- ff. 139va-142ra: III Rosw. 8-16.

Como se poderá verificar, a antologia das Commonitiones que constitui os nn. 1-40 do Livro III de Rosweydus está completa, embora desordenada e dispersa por diversos grupos de fólios.

3. (=D) - Dresda, Biblioteca Nacional da Saxónia, A 207 - Não conhecemos a proveniência deste manuscrito do séc. XIv. A parte referente às Vitae Patrum começa com o prólogo de Pascásio (fl. 159r) (BHL 6531) e continua com Pelágio (BHL 6527), selecção do Livro III de Rosw. a partir do n. 110 (BHL 6525) e Palladii Lausiaca (BHL 6534). Vêm então nos ff. $188 \mathrm{r}-216 \mathrm{v}$ as Commonitiones sanctorum patrum, seguidas de novo do III Rosw. a partir do n. 45, de Pelágio, da Vita Pauli (BHL 6596) e de outras biografias. Nos ff. 279v-280r está o prólogo do Livro III de Rosw., mas segue-se-lhe Pelágio I,5 e outra vez III Rosw. para além do n. 107, com excepção do último apotegma que é III Rosw. n. 1 (= Commonitiones I, $1^{2}$ ), este no fl. 282r. Prossegue outra vez Pelágio, João (BHL 6529), III Rosw. 60 e 220, e IV Livro de Rosw. (BHL 6526). Nos ff. 312r-v temos III Rosw. 10, continuado por Pelágio; III Rosw. 208; João IV, 6; III Rosw. 209; de novo João; outra vez III Rosw. a partir do n. 49, Pelágio e por passos ainda a identificar. Nos ff. 319r-320r lê-se III Rosw. 20, concluindo 
com extractos de João, Sulpício Severo (BHL 6526) e Pelágio. $\mathrm{O}$ manuscrito está mutilado no fim $\left({ }^{13}\right)$.

Curioso observar que no meio desta massa informe, onde apenas o prólogo de Pascásio vem identificado, se encontre nos ff. 188r-216v o texto completo das Commonitiones, com cada um dos apotegmas a começar por maiúscula no princípio de linha, estando todos bem numerados até ao fl. 199r, com excepção de III,1 e IV,1. A começar em IV,3 (fl. 199r) não há mais numeração nem dos apotegmas nem da $V$ capitulatio. (O capítulo VI, como se poderá ver no texto crítico, não tem capitulatio em nenhum manuscrito). No fl. $214 \mathrm{v}$, onde está o apotegma V,9 e o princípio de VI,1, as duas iniciais maiúsculas estão iluminadas, encontrando-se o $\mathrm{H}$ de Hic com uma ornamentação superior a sugerir um ramo de árvore e na parte inferior as suas raízes. A grafia é gótica, com muitas abreviaturas, por vezes difíceis de decifrar. $\mathrm{Na}$ margem direita do fl. $208 \mathrm{r}$ alguém escreveu, posteriormente, nota e no fl. $216 \mathrm{r}$ o último período de VI, 5 foi assinalado à margem com um parêntesis recto, por debaixo do qual julgamos dever-se ler desunt. Não entendemos o sentido desta observação, pois o apotegma, que é o penúltimo da colectânea, está completo.

\section{ARQUÉTIPO $\gamma$}

4. (=C) - Paris, Biblioteca Nacional, fundo latino 5601 - Este manuscrito merece-nos agora maior atenção do que em estudo anterior $\left({ }^{14}\right)$. Foi copiado no século XI e pertenceu

(13) Cf. Pascásio de Dume..., t. II, pp. 189-191. Além de Franz Schnorr von KAROLSFeld, Katalog der Handschriften der königl. öffentl. Bibl. zu Dresden, Leipzig, 1882, I, p. 88, podem consultar-se também Die Merkwürdigkeiten der königlichen Bibliothek zu Dresden ausführlich beschrieben und mit Unmerkungen erläutert, I, Dresden, 1743, pp. 343-345 (sem indicação de autor, mas que Von Karolsfeld atribui a Götze), onde Pascásio é identificado como um monge da Galiza, sprovavelmente também originário da Panónia, como S. Martinho de Dume».

(14) Cf. Pascásio de Dume..., t. II, p. 232. 
noutros tempos a S. Marcial de Limoges. Os catalogadores não têm apreciado devidamente o seu conteúdo $\left({ }^{15}\right)$. O nosso exame pessoal e o estudo crítico do texto referente às Vitae P'atrum permitem-nos pormenorizar um pouco mais.

Após os índices iniciais, um prefácio in Vitas Patrum e os capitula libri sequentis (ff. 1-5), vem o texto, em 55 capítulos, da Vida de João Eleemosinário ou Alexandrino (ff. 5v-53v), isto é, BHL 4390.

Sem qualquer título ou rubrica, seguem-se nos ff. $53 \mathrm{v}-57 \mathrm{r}$ extractos dos apotegmas traduzidos por Pelágio e João.

Continua imediatamente nos ff. $57 \mathrm{r}-64 \mathrm{r}$ um extracto das Commonitiones sanctorum patrum, bem caracterizado como pertencente ao nosso arquétipo $\gamma$, constituído pelos seguintes números: IV, 15; João III, 11 (ff. 57v-59r); Commonit. IV: 12, $13,14,-, 16,17$ e 6 .

Nos ff. $64 \mathrm{r}-82 \mathrm{v}$ seguem-se extractos vários de S. Gregório, da Historia Monachorum (Livro II de Rosweydus) e da Historia Anglorum.

O maior interesse para nós consiste no fragmento extraído das Commonitiones. Pena é serem apenas 7 apotegmas. Atesta, no entanto, que na região limusina corria, já no século XI, a recensão $\gamma$ desta obra de que se veio a perder a memória. A reforçar tal certeza temos o manuscrito que descrevemos a seguir, o qual, embora mais tardio, também proveio de Limoges.

5. $(=P)$ - Paris, Biblioteca Nacional, fundo latino 2941 - Fizemos uma descrição pormenorizada deste manuscrito, provindo de Limoges, a propósito dos fragmentos que ele contém de Pascásio e do Livro III $\left({ }^{16}\right)$. Já então dissemos

(15) Catalogus codicum manuscriptorum bibliothecae regiae, t. IV, Parisiis, 1744, p. 139; Catalogus codicum hagiographicorum latinorum antiquorum saeculo XVI qui asseruantur in bibliotheca nationali Parisiensi, ediderunt Hagiographi Bollandiani, t. II, Bruxellis, 1890, p. 515.

(16) Cf. Pascásio de Dume..., t. II, pp. 78-80 e 231. 
que, segundo confissão do próprio copista, numa porção do manuscrito atribuível ao século XII, principia no fl. 66r um Liber sanctorum patrum collectus ex diversis libris. A parte seleccionada de todo o Livro III, segundo então apontámos, ocupa os ff. $70 \mathrm{v}-75 \mathrm{v}$, notando-se a partir do fl. $73 \mathrm{v}$ algumas interpolações de Pelágio.

Os apotegmas das Commonitiones ocupam os ff. 70vb-73va. Sujeita esta fracção do manuscrito a uma análise textual rigorosa, verifica-se que o texto transcrito foi copiado de um modelo do arquétipo $\gamma$. O conjunto extraído das Commonitiones tem a seguinte constituição - I: $1^{\text {a }}, 1^{\mathrm{b}}, 3,5,14$; II: 5,7 ; IV: 2,13,17,18; V: $5,8^{\mathrm{b}}, 9$; VI: 2 e 5 .

Trata-se apenas de cerca de uma quarta parte do texto total. O seu interesse é, no entanto, bastante grande, pois vem confirmar muitas das lições genuínas do manuscrito de Reims, Bibl. Munic. 1400, que tem quase completo o texto das Commonitiones. Felizmente este códice de Paris, Bibl. Nac. lat. 2941 possui também o número I,3. Podemos assim comprovar que o fragmento de I,3, linhas 11-12 da nossa edição, omitido por uns e interpolado pelo ms. de Namur, foi salvo apenas pelo arquétipo $\gamma$, pois há uma coincidência perfeita entre o texto deste fragmento, tal como é dado pelo manuscrito de Paris, Bibl. Nac. lat. 2941 e pelo de Reims, Bibl. Munic. 1400.

6. (= R) - Reims, Biblioteca Municipal 1400 - Escrito no século XIII, provavelmente na própria zona de Reims, a parte referente às Vitae Patrum começa neste códice com o Livro II de Rosweydus (BHL 6524), a que se segue a Vita Pauli (BHL 6596) e o cap. VIII da Palladii Lausiaca (BHL 6534). Sem qualquer título, principiam as Commonitiones sanctorum patrum no fl. $98 \mathrm{rb}$ até fl. $107 \mathrm{rb}$, continuando imediatamente o Livro III de Rosweydus nn. 41-220 (BHL 6525) ( ${ }^{17}$ ).

(17) Cf. Pascásio de Dume..., t. II, pp. 217-219. Na descrição bastante pormenorizada que então fizemos dos ff. $98 \mathrm{r}-107 \mathrm{r}$ escrevemos que também faltava 
Servimo-nos deste manuscrito para estabelecer o texto crítico, por ser ele o maior representante do arquétipo $\gamma$. Como se poderá ver pela observação do aparato crítico, faltam-lhe apenas 5 apotegmas em relação ao texto completo das Commonitiones, a saber, os nn. V: 1,4,6; VI: 3 e 6 .

Não há dúvida de que o copista(ou o seu modelo) possuía um exemplar integral das Commonitiones. A atestá-lo está não só a quase totalidade, seguida, dos apotegmas, como o título do capítulo III (fl. 101rb) e do capítulo IV, este com toda a sua capitulatio (fl. 101va). Tivemos o prazer de manusear este manuscrito, de pequeno formato, com uma antiga encadernação de camurça vermelha, em letra gótica muito encadeada, a duas colunas, e com iluminuras numerosas, no geral a iniciar os apotegmas. Pena é que o princípio desta colecção esteja desprovido de qualquer título. Todavia, o copista assinalou o fim da peça anterior, pois nas linhas $12-13$ do fl. $98 \mathrm{rb}$ lê-se: Hic triumphus beati Nathanael fuit et conuersatio. $\neq$ Hic finis. A linha 13 tem ainda o início, defeituoso, das Commonitiones I,1, com maiúsculas nas duas primeiras letras de INterrogantibus | I se monachis de causa abstinentiae dixit (sem indicar o precedente sujeito da oração: Quidam sanctorum seniorum patrum). Em tais condições não admira que esta parte do manuscrito nunca tivesse sido assinalada pelos catalogadores.

\section{ARQUÉTIPO $\delta$}

7. $(=B)-$ Berlim, Biblioteca Nacional dos Tesouros Culturais da Prússia, 780, theol. lat. fol. 275 - Só em 1974 conseguimos obter um microfilme deste manuscrito de Berlim,

o apotegma I, 5. Na realidade este número encontra-se lá, no seu lugar próprio (fl. $98 \mathrm{va}-\mathrm{b})$. Acontece, porém, que a maiúscula $\mathrm{R}$ da primeira palavra do apotegma (Referebant), na 12.2 linha a contar do fim, tem muito menos relevo que outras maiúsculas no princípio das frases do apotegma anterior. Daí a nossa omissão na primeira análise. 
escrito a toda a largura da página em letra carolina do século $\mathrm{x}$ e proveniente de um mosteiro desconhecido, situado junto ao Reno $\left.{ }^{18}\right)$.

Identificamos primeiro o seu conteúdo global e deter-nos-emos depois nos ff. 50v-65v e $111 \mathrm{v}-117 \mathrm{v}$.

1 - ff. 1r-5r: Vita Pauli (BHL 6596);

2 - ff. 5r-16r: Vita Hilarionis (BHL 3879);

3 - ff. 16r-19r: Vita Malchi (BHL 5190);

4 - ff. 19r-50v: Historia Monachorum, ou seja, o Livro II das Vitae Patrum de Rosweydus (BHL 6524);

5 - ff. 50v-65v: Livro III de Rosweydus, nn. 1-40 (BHL 6525);

6 - ff. 65v-87r: Livro IV de Rosweydus (BHL 6526);

7 - ff. 87r-91r: apêndice frequente do Livro IV, constituído por extractos de Pelágio (BHL 6527);

8 - ff. 91r-111v: Palladii Lausiaca, sem os passos espúrios que se encontram na edição de Rosweydus (BHL 6534);

9 - ff. $111 \mathrm{v}-117 \mathrm{v}$ : extracto das Commonitiones sanctorum patrum, que a seguir identificaremos;

10 - ff. $117 \mathrm{v}-119 \mathrm{v}$ : Vita Frontonii, mutilada - últimas palavras: ...camelis imposita dirigebat (BHL 3190).

Deparamos aqui, nos ff. $50 \mathrm{v}-65 \mathrm{v}$, com a mais antiga antologia das Commonitiones sanctorum patrum, contendo apenas o prólogo Vere mundum quis dubitet meritis stare sanctorum... e os nn. 1-40, publicados por Rosweydus no seu Livro III das Vitae Patrum (PL 73, coll. 739-764). O seu interesse resulta ainda

(18) VALENTIN Rose, Verzeichniss der lateinischen Handschriften der königlichen Bibliothek zu Berlin, Bd. 2., Berlin, 1903, pp. 809-811. A falta deste volume na sala de catálogos de manuscritos na Biblioteca da Universidade de Lovaina explica que tenhamos passado em claro esta parte da obra de V. Rose. 
de esta colectânea ser aparentemente muito semelhante à que se encontra nos mss. de Reims, Bibl. Munic. 1390, ff. 74r-98v; Danzig, Bibl. da Cidade 1950, ff. 55v-72r; Munique, Bibl. Est. da Baviera, lat. $18535^{2}$, ff. 252 r- 267 r, que já noutra ocasião descrevemos $\left({ }^{19}\right)$.

Dissemos aparentemente porque, na realidade, o estudo crítico dos textos provou que os três manuscritos acabados de indicar são já uma reelaboração, com leves alterações, do texto que nos dá o ms. de Berlim e os seus pares. No stemma codicum, Berlim, theol. lat. fol. 275 e afins enquadram-se no arquétipo $\delta$, ao passo que os três restantes (Reims 1390, Danzig 1950 e Munique CLM 18535²) constituem o arquétipo $\zeta\left({ }^{20}\right)$.

Vejamos como este manuscrito de Berlim apresenta vestígios bem sensíveis de conter, nesta porção, uma antologia extraída das Commonitiones sanctorum patrum, vestígios estes que não existem na edição de Rosweydus.

No fl. $50 \mathrm{v}$, após o prólogo, lê-se o título: Incipiunt monita e seguem-se, sem rubricas nem numeração, os apotegmas 1-7 Rosw. Ora este título é precisamente o que se encontra a abrir o cap. I das Commonitiones no manuscrito de Dresda. O de Viena é um pouco mais completo: Incipiunt monita sanctorum patrum. A dependência é manifesta.

No fl. 52r temos novo título: Incipiunt exempla sanctorum patrum contra spiritum fornicationis. Seguem-se-lhe os nn. 8-16 Rosw. O título condiz exactamente com o do cap. II das Commonitiones, cujos apotegmas são todos transcritos, à excepção de II,3.

No fl. 55r, a meio da página vem a rubrica: Incipiunt monita ex exempla sanctorum patrum de virtute humilitatis et patientiae, seguindo-se-lhe os nn. 17-30 de Rosw. É este justamente

(19) Cf. Pascásio de Dume..., t. II, pp. 197-198.

(20) Cf. a gravura que publicamos na p. 262. 
o título que precede o texto do cap. IV das Commonitiones. Anote-se que antes do n. 20 Rosw (=IV,4) se encontra o título De sancto Poemen (fl. 56v); antes do n. 22 Rosw. (= IV,8) vem a rubrica De amore humilitatis (fl. $57 \mathrm{v}$ ), indicação esta igualmente copiada, embora incompleta, do texto longo das Commonitiones; também o n. 30 Rosw. (= IV, 17) está precedido da indicação Beati abbatis Anastasii laudabilem. Trata-se aqui de um engano de copista, que tomou como título o princípio do apotegma, pois torna a repetir estas palavras no começo da linha seguinte (fl. 60v).

Terminado o n. 30 Rosw. prosseguem, sem qualquer anotação, os nn. 31-35 Rosw., concluindo este último a meio do fl. $63 \mathrm{v}$.

O copista interrompeu o seu trabalho. Aproveitando a meia folha em branco, alguém escreveu, mais tarde, uma antífona à Virgem, com sinais musicais por cima de cada sílaba: Quid regina poli faciat nunc dic, frater, orbi; mane puerum Christum genuit, gremioque locauit. Te Deum laudamus. O resto da página guarda vestígios de um texto que foi raspado e do qual subsistem algumas letras, não sendo possível entender qualquer palavra.

Como bem nota o autor do Catálogo, o texto dos apotegmas foi retomado por outro copista. O fl. $64 \mathrm{r}$ tem todo o n. 36 Rosw. $(=\mathrm{V}, 9)$, que termina a pouco mais do meio da página.

Vem então o título Incipit de beato Arsenio (fl. 64r), seguido dos nn. 37-40 Rosw. até ao fl. 65v. Como se poderá verificar, são aquelas palavras que iniciam o cap. VI das Commonitiones.

Temos assim, no texto transcrito nos $f . .50 \mathrm{v}-65 \mathrm{v}$, não só mais de metade do texto das Commonitiones, mas ainda, o que é precioso e significativo, sinais bem claros dos títulos originais dos seus capítulos I, II, IV e VI. Do cap. III, com um só apotegma, nada foi transcrito; para o cap. V, do qual foram tirados os nn. 31-36 de Rosweydus, também não há qualquer alusão ao seu título. Mas o que deixámos apontado é suficiente 
para não poderem subsistir quaisquer dúvidas de que esta porção do códice de Berlim foi importada das Commonitiones sanctorum patrum.

Igual atenção nos merecem os ff. 111v-117v. Esta parte do códice de Berlim e dos seus pares nunca foi identificada devidamente, porque faltava aos catalogadores um ponto de referência, ou antes, a chave que abre o seu segredo.

No fl. $111 \mathrm{v}$ lê-se, na última terça parte da página: Incipiunt commonitiones sanctorum patrum, qui in studio spiritalis uitae senuerunt, quae ad instructionem iunioribus dixerunt fratribus. Comparando com o nosso texto crítico, ver-se-á que é este precisamente o título da colecção que nós editamos. Seguem-se, sem mais títulos nem numeração de apotegmas, todos eles assinalados por uma inicial maiúscula, saída para a margem esquerda, os números seguintes da nossa edição - I: 2,3,6,7,8, $9,10,12,15$ e 16 . Consultando a tábua de lugares paralelos que damos adiante, nas pp. 63-64, verificar-se-á que são todos os números do cap. I que não foram incluídos na antologia publicada por Rosweydus no princípio do Livro III. Antes de I, 12 está o título isolado De abbate Nitera, correspondente só a este apotegma.

A meio do fl. $113 \mathrm{v}$ lê-se: De spiritu fornicationis, a preceder o nosso n. II,3. Fora, de facto, o único apotegma do capítulo com este título, aqui abreviado, que ficara excluído da selecção anterior.

No mesmo fl. $113 \mathrm{v}$, na sexta linha a contar do fundo, foi escrito o título: Exhortatio sancti Macarii ad monachos. É a designação exacta do nosso cap. III, seguida do único apotegma que o constitui e que não fora incluído na antologia da primeira parte.

Em 114r, no último quarto da página, ressalta o título: Incipiunt de uirtute humilitatis et patientiae monachorum monita sanctorum. São estas palavras que precedem a capitulatio do nosso cap. IV. Seguem-se os nn. IV: 6,15,18 e 19. Acrescen- 
tando estes números à selecção anterior, fica completo o cap. IV, excepto o n. 5. O copista colocou apenas o título De sancto Poemene (fl. 114r) antes de IV,6.

No fl. 116v temos, a meio da página, o título Incipit de doctrina monachorum que corresponde ao do nosso cap. V. Vêm então os nn. V: 4 e 6 . Antes do n. V,6 (fl. 117r) está a rubrica: Incipit de abbate Apollonio. O título do cap. V, omitido na primeira selecção, está aqui a garantir a autenticidade da divisão das Commonitiones. Comparando as duas partes, nota-se que do cap. $\mathrm{V}$ foi totalmente excluído o n. 1 .

No mesmo fl. 117r, sem qualquer título, encontra-se também a maior parte do n. VI,6, que termina na segunda linha do fl. 117v. O título deste capítulo, De beato Arsenio, fora dado na primeira parte. Juntando este aos números incluídos atrás, verifica-se que do cap. VI também um apotegma ficou de parte, o n. 3 .

Resumindo os materiais encontrados nos ff. $50 \mathrm{v}-65 \mathrm{v}$ e ff. $111 \mathrm{v}-117 \mathrm{v}$ diremos que o manuscrito de Berlim, da antiga Bibl. Nacional da Prússia, theol. lat. fol. 275, permite reconstituir o título geral e o de cada um dos seis capítulos das Commonitiones, bem como a quase totalidade do seu texto, com exclusão apenas de IV,5; V,1; e VI,3.

Nenhum outro manuscrito deste arquétipo é tão rico em títulos como o de Berlim. Todavia, os manuscritos de Namur e de Londres, que passamos a descrever, contêm precisamente os mesmos apotegmas. Dado que só muito tardiamente obtivemos o microfilme do códice de Berlim (quando o original do texto e aparato crítico já se encontravam na tipografia) não utilizámos, para a nossa edição, este manuscrito, mas sim o de Namur. Lançámos, porém, todo o texto do códice berlinense no nosso manuscrito das Commonitiones, podendo assim reconsiderar, a tempo, todos os problemas de crítica textual. Devemos acrescentar que o copista do códice de Berlim (o qual pertence indubitavelmente ao arquétipo $\delta$ ) tinha com toda a probabilidade diante de si também um 
modelo do arquétipo $\alpha$ ou $\beta$. O testemunho de Berlim veio assim reforçar, várias vezes, a maior valia principalmente do manuscrito de Viena.

8. $(=N)-$ Namur, Museu de Arqueologia 12-Tivemos ocasião de examinar pessoalmente este manuscrito, o que nos possibilitou descobrir nele a segunda parte extraída das Commonitiones. Foi escrito no século XII ou XIII nas Ardenas belgas. $\mathrm{O}$ códice principia com um texto mutilado, pertencente ao ao fim do prefácio da Vida de S. Pacómio (BHL 6410); continua com as Vidas de S. Antão (BHL 609), Paulo eremita (BHL 6596), Hilarião (BHL 3879) e Malco (BHL 5190); seguem-se o II Livro de Rosweydus (BHL 6524), uma Admonitio ad monachos: Frequenter diximus: Semper christiani persecutionem patiuntur... e a Exortação de Santo Atanásio (PL CIII, coll. 664-672). Contém em seguida, nos ff. 74r-84v, o prólogo e os nn. 1-40 do Livro III de Rosweydus. Depois continua com o Livro IV (BHL 6526), Pelágio (BHL 6527) e a Palladii Lausiaca (BHL 6534). Vêm então, nos ff. 108va-112ra as Commonitiones sanctorum patrum, seguidas da Vita Frontonii (BHL 3190), da segunda parte de III Rosw. a partir do n. 47, de Pelágio (BHL 6527), de João (BHL 7529) e de várias biografias $\left({ }^{21}\right)$.

Agora interessam-nos especialmente os ff. 74ra-84vb. O prólogo, espúrio, Vere mundum, encontra-se em $74 \mathrm{va}$, linhas 10-34. Então, sob o título: Incipiunt monita, principia o extracto das Commonitiones vulgarizado pelo Livro III de Rosweydus. Quase todos os apotegmas são precedidos de um título, como se poderá ver no aparato crítico, pois servimo-nos deste manuscrito, sob a sigla $\mathrm{N}$. Há ainda sinais da divisão primitiva em capítulos, visto que os apotegmas II,1 (= 8 Rosw.); IV,1

(21) Cf. Pascásio de Dume..., t. II, pp. 216-217, onde se descreve apenas a parte do ms. que vai dos ff. 74 a 130 . 
(=17 Rosw.); e VI, 1(= 37 Rosw.) vêm precedidos dos títulos correspondentes, como se anota no nosso rodapé crítico.

Também este manuscrito nos guarda, quase completa, a porção de apotegmas que haviam sido omitidos pelo compilador do Livro III de Rosweydus. Com efeito, nos ff. 108va-112ra encontra-se o resto da colecção (excepto os nn. IV,5; V,1; e VI,3), encimada pelo título completo (apenas com as variantes: monitiones - em vez de commonitiones, e spiritualis - por spiritalis). A escrita de todo o manuscrito, a duas colunas, é carolina de transição. Os apotegmas começam todos com inicial maiúscula. Nesta segunda parte do texto das Commonitiones (indicada no início do aparato crítico por $\mathrm{N}^{2}$ ) os apotegmas não são precedidos de título (excepto o $1 .^{\circ}$ (= I,2), com o título geral; o $2 .^{\circ}(=\mathrm{I}, 3)$ : De abstinentia eius; o $3 .^{\circ}$ (= I, 6): De quoddam sene; e o $5 .^{\circ}(=\mathrm{I}, 8):$ De abbate Poemen). Há uma anomalia de paginação que coincide exactamente com este fragmento. Os fólios estão numerados na face, no ângulo superior direito, com algarismos árabes de desenho fino. Porém, no fl. $108 \mathrm{v}$, alguém escreveu, no centro da margem superior, com números de grosso desenho, 108. Apesar de o fl. 109r estar bem marcado no rosto, também o seu verso tem a estranha numeração 109 , em desenho forte. O resto da paginação está em ordem, apenas com a repetição do número 111 na margem superior, ao centro. Por debaixo deste número (escrito por pessoa diferente da que paginou os cantos superiores direitos e da que escreveu os estranhos 108 e 109) está uma linha em forma de título: Instructio salutaris renuntiationis saeculi. A importância deste manuscrito é confirmada pelos seus pares, principalmente de Berlim, Londres e Munique.

9. (= L) - Londres, Museu Britânico, add. 37 400-Escrito talvez no século xIv, na Flandres ou na Germania, este manuscrito tem nos ff. $37 \mathrm{v}-72 \mathrm{v}$ o Livro III de Rosweydus, com 
excepção dos nn. 194 e 195; seguem-se-lhe, nos ff. 72v-74r, três apotegmas da recensão longa de Pascásio $\left({ }^{22}\right)$.

Uma análise mais recente permite-nos identificar ainda:

1 - ff. 74r-77v: extractos de Pelágio (BHL 6527) e João (BHL 6529), a saber: Ioan. I, 13; Plg. XVIII: 3,5,6,8,19,14; XII,8; XIII: 6,13; XIV,14; XV: 1,43;

2 - ff. $77 \mathrm{v}-81 \mathrm{r}$ : vida de santa Pelágia (BHL 6605);

3 - ff.81r-85r: vida de santa Eufrósina (BHL 2723).

- O fl. 85v está em branco.

4 - Em 86ra começa abruptamente: mutarent, sed super illam fetidam aliam addebat... sinal de que um outro manuscrito começa aqui mutilado, repetindo-se o final do III Livro de Rosweydus n. 39 e o n. 40;

5 - ff. 86ra-99va: têm o Livro IV de Rosweydus (BHL 6526);

6 - ff. 99va-102ra: o apêndice habitual com apotegmas de Pelágio (BHL 6527).

7 - ff. 102ra-115ra: Palladii Lausiaca (BHL 6534). Conferimos o texto com o da PL 74, coll. 343-382 e verificámos que os capítulos IV, V, IX, (os capítulos XI, XII e XIII são totalmente omitidos) não têm os passos alheios a esta recensão, pois pertencem às Commonitiones sanctorum patrum. A obra termina com o cap. XIX (PL 74, coll. 376-377) no fl. 115ra. Note-se a ausência do cap. XX, tido como espúrio, em relação à obra de Paládio.

8 - Os ff. $115 \mathrm{ra}-118 \mathrm{vb}$, sem qualquer sinal de mudança de obra ou de fonte, contêm os mesmos apotegmas das Commonitiones que os manuscritos de Berlim e de Namur apresentam também em segundo lugar, a sabe1: I: $2,3,6,7,8,9$, 10,12,15,16; II,3; III,1; IV: 6,15,18,19; V: 4,6; e VI,6.

9 - ff. 118vb-120rb, a vida de Frontónio (BHL 3190).

(22) Cf. Pascásio de Dume..., t. II, pp. 94-96 e 219-220. 
Seguem-se biografias várias até final do códice.

Tomando em conta os apotegmas que se encontram nos ff. $37 \mathrm{vb}-48 \mathrm{rb}$ que são a antologia, em 40 números, das Commotiones e o suplemento que está nos ff. $115 \mathrm{r}-118 \mathrm{v}$, verificamos também que da colecção completa das Commonitiones sanctorum patrum apenas faltam os $\mathrm{nn}$. IV,5; V,1; e VI,3. Tanto numa como noutra parte, o texto está escrito em esplendente letra gótica, a duas colunas, com belas iniciais para cada apotegma. Mas enquanto na primeira série foi dado um título a cada narrativa, na segunda não há títulos até quase ao fim. Com efeito, só os três últimos números são precedidos das rubricas: De famulo Dei Marciano (V,4); De alio quodam sene (V,6); e De abbate Daniele (VI,6).

Notemos ainda que no fl. $37 \mathrm{vb}$, antes de começar o Livro III de Rosweydus, o copista escreveu apenas: Explicit liber primus. Incipit secundus. Mas no fl. 72va, quando acaba este texto, avança mais, atribuindo-lhe um autor: Explicit liber secundus sancti Hieronimi presbyteri in Vitas Patrum.

10. (= M) - Munique, Biblioteca do Estado da Baviera, latino 2540 - Veio do mosteiro de Alderspach este manuscrito atribuído ao século $\mathrm{xv}\left({ }^{23}\right)$. A nós parece-nos um pouco mais antigo, pelo seu tipo de letra, que se assemelha muito à carolina de transição. Está por fazer a sua descrição pormenorizada. Dado o seu interesse para o nosso presente estudo vamos apresentá-lo, utilizando elementos colhidos no exame pessoal do próprio códice.

Após três folhas de índices, tem:

1 - ff. 1v-3v: a história de Malco (BHL 5190);

2 - ff. 3v-6r: Paulo eremita (BHL 6596);

3 - ff. 6r-14v: Vita Hilarionis (BHL 3879);

4 - ff. 14v-38r: o Livro II de Rosweydus (BHL 6524);

(23) Cf. Pascásio de Dume..., t. II, pp. 220-221. 
5 - ff. 38ra-71ra: o Livro IIJ de Rosweydus (BHL 6525), sem atribuição de autor. Após o prólogo e um título para o primeiro apotegma, começa o texto deste, em 38rb: Quidam sanctorum seniorum, com uma grande inicial, iluminada com miniaturas em forma de folhas de árvore. O mesmo tipo de iluminura se encontra no fl. 39va após o título: Incipit de spiritu fornicationis (um vestígio do cap. II das Commonitiones), na inicial da primeira palavra: Discipulus. No fl. $41 \mathrm{v}$ está o título correspondente ao cap. IV, embora o texto seja o divulgado pelo Livro III de Rosweydus, terminando o n. 40 no fl. 49vb. O resto do III Rosw. prolonga-se até ao fl. 71ra, cujo explicit também nada diz sobre o autor do livro.

6- ff. 71r-82r: Livro IV de Rosw. (BHL 6526);

7 - ff. 82r-85r: Pelágio (BHL 6527);

8 - ff. 85r-88v: Vida de Pelágia (BHL 6605);

9 - ff. 88v-97r: Maria Egipcíaca (BHL 5415);

10 - ff. 97r-107r: Santa Paula, por Jerónimo (BHL 6548);

11 - ff. 107r-130v: Santo Antão (BHL 609);

12 - ff. 130v-155v: Pachomius (BHL 6410);

13 - ff. 155v-160r: Vita sancti Symeonis (não identificámos mais);

14 - ff. 160r-164r: Vita sanctorum Iulii et Iuliani fratrum;

15 - ff. 164r-180r (24): Palladii Lausiaca (BHL 6534).

16 - ff. 180rb-184ra: Uma colectânea de apotegmas, idêntica à dos manuscritos de Berlim, Namur e Londres acabados de descrever. No nosso primeiro estudo deste códice de Munique apontámos já o erro existente na ordem dos fólios

(24) Devemos corrigir um lapso verificado em Pascásio de Dume..., t. II, p. 220. O cap. XIX da Palladii Lausiaca termina no fl. 180rb. Reparemos mais uma vez que falta o espúrio cap. XX. Na mesma coluna de 180 rb (e não 180va, como então dissemos) se encontram ainda, sem qualquer título, sem indício de mudança de obra ou de fonte, as três últimas linhas da coluna: Dicebant sancti patres de Sancto abbate Ioanne qui /, que é já Commonitiones I, 2. (Todas as letras acabadas de sublinhar estão escritas em maiúsculas, com relevo para o D inicial). 
e a perda do que deveria ser o seu fl. 183. Em comparação com o conteúdo acabado de fornecer na descrição do manuscrito anterior (Londres, Mus. Brit. add. 37 400, ff. 115r-118v) faltam aqui, por perda do fl. 183, o final de IV,15; IV,18 e o princípio de IV,19. São também omitidos (mas estes por deficiência do modelo) os apotegmas IV,5; V,1; e VI,3.

17 - ff. 184ra-185vb - Vita Frontonis, incompleta, por mutilação no final do manuscrito (BHL 3190).

11. (=Z) - Munique, Biblioteca do Estado da Baviera, lat. 23757 - Este códice, também designado, pela sua proveniência, por ZZ 757, foi escrito no século xv. Os primeiros 35 fólios pertencem a um outro antigo manuscrito. O fólio que vem a seguir, não numerado, contém a capitulatio de toda a segunda parte do códice. Passamos então a ter uma dupla paginação: a contínua, mais alta, marcada no canto superior direito; e a própria da segunda parte, que segue com 36 unidades de atraso, escrita em números menores ao centro da margem superior, entre as duas colunas da página. O conteúdo relativo às Vitae Patrum é o seguinte:

1 - ff. 37r-72r (1-36): Historia Monachorum = Livro II de Rosweydus (BHL 6524);

2- ff. $86 \mathrm{v}-87 \mathrm{r}$ (50-51): o prefácio Vere mundum do Livro III de Rosweydus (BHL 6525);

3 - ff. 87r-90v (51-54): De Malco monacho (BHL 5190);

4 - ff. 90va-107rb (54-71): III Rosw. nn. 1-40;

5 - ff. 107r-127v (71-91): Livro IV de Rosweydus (BHL 6526);

6 - ff. 127v-129v (91-93): apêndice de Pelágio (BHL 6527);

7 - ff. 129v-151r (93-115): Palladii Lausiaca (BHL 6534);

8 - ff. 151rb-156ra (115-120): segunda parte das Commonitiones sanctorum patrum, em complemento da antologia publicada por Rosweydus no Livro III.

9 - ff. 156r-158v (120-122): Vita Frontonii (BHL 3190); 
10 - ff. 158v-163v (122-127): extractos da obra de Pascásio de Dume, a começar em X,4 até LII,5 da nossa edição;

11 - ff. $163 \mathrm{v}-166 \mathrm{v}$ (127-130): miscelânea de apotegmas tirados de Pelágio, Pascásio e Martinho de Dume; 6527);

12 - ff. 166v-177r (130-141): extractos de Pelágio (BHL

13 - ff. 177r-178r (141-142): De Taisi meretrice (=Pascásio LVII,4 - recensão a determinar);

14 - ff. 178r-188v (142-152): extractos de Pelágio (BHL 6527);

15 - ff. 188v-190r (152-154): Vita Marinae (BHL 5528).

Não temos filme do resto do códice, que tem 248 fólios. Podemos, no entanto, observar ainda que no fl. 190ra (154) começa a Visio Baronti (BHL 997).

Deixando para outra oportunidade as restantes partes, principalmente as referentes a Pascásio e Martinho, importa agora estudar especialmente os elementos tirados das Commonitiones sanctorum patrum.

Nos ff. 90va (54va)-107rb(71rb) temos, completamente isolados, os $\mathrm{nn}$. 1-40 do Livro III de Rosweydus, isto é, a primeira antologia das Commonitiones. $\mathrm{O}$ n. 1 começa sem qualquer título ou rubrica a separar este tratado do final da Vida de Malco. Dos nn. 1 a 7 Rosw. só este último tem o título: De sancto Zenone. Na margem, ao lado do n. 8 está o título: Incipit liber de fornicatione, ou seja, um vestígio seguro do nosso cap. II (fl. 56rb). Continuam os nn. 8-21 Rosw. O n. 19 é precedido do título: De sancto Poemen, e o n. 21 assinalado com as palavras: De sancto Agathone. No fl. $62 \mathrm{rb}$, a meio desta narrativa, encontra-se à margem, deslocado, o título: Incipit liber de patientia, um vestígio do nosso cap. IV, que deveria ter sido escrito antes do n. 17 Rosw. Seguem-se os nn. 22-40, sendo precedidos de títulos um tanto arbitrários, os nn. 27: Liber de oboedientia (fl. 65rb); 29: De beato Eulalio magnae humilitatis uiro (fl. 66ra) e neste mesmo fólio ainda, 
à margem, outro título: Liber de humilitate; o n. 35 (fl. 69rb) traz o título: De beato Pachomio abbate, e o n. 37 (fl. 70rb) a indicação: De beato Arsenio.

Apesar da irregularidade dos títulos, é possível divisar ainda resíduos da distinção que se verifica nos capp. II, IV e VI das Commonitiones.

Os ff. 151rb(115rb)-156ra(120ra) embora não indiquem a fonte, pois estão desprovidos de título, contêm, de facto, a segunda parte das Commonitiones, constituída pelos nossos nn. I: $2,3,6,7,8,9,10,12$ e 16 . Falta, portanto o n. I,15, constante do arquétipo $\delta$. Também o n. II,3, o único deste capítulo que não fora transcrito na antologia 1-40 de III Rosw., foi aqui omitido. Retoma o seu modelo no fl. $152 \mathrm{vb}$ com III,1; IV: 6, 15, 18 e 19; V, 4 (omite o n. V,6); e VI,6. Isto é, além da omissão dos nn. IV,5; V,1; e VI,3 que já faltavam no modelo $\delta$, este manuscrito de Munique, lat. 23757 suprimiu ainda os nn. I,15; II,3; e V,6. Apesar de intimamente relacionado com os quatro manuscritos anteriores é, pois, mais imperfeito que eles.

12. (=U) - Basileia, Biblioteca da Universidade, B. V. 2 - Dada a natureza especial deste manuscrito, (que é talvez um pouco mais antigo que o de Munique acabado de descrever) guardámos para o fim a sua análise. Já anteriormente apreciámos, sobre microfilme, o conteúdo dos seus ff. $255 \mathrm{v}-264 \mathrm{v}$, referentes a Pascásio. A menção que lhe fizemos, a propósito do Livro III, sobre os seus ff. $122 \mathrm{v}-154 \mathrm{v}$, fora então apenas baseada nos dados do Catálogo $\left({ }^{25}\right)$.

A necessidade de estudar agora criticamente os seus extractos das Commonitiones levou-nos a requisitar novo filme, desta vez sobre os ff. 122v-187r. Em boa hora o fizemos. Poucos catálogos de manuscritos estão compostos com tanto

(25) Cf. Pascásio de Dume..., t. II, pp. 281-282 e 232. 
rigor e erudição como este de Basileia. Apesar disso, a interpretação que dá do conteúdo dos ff. $148 \mathrm{v}-151 \mathrm{v}$ e ff. $185 \mathrm{r}-186 \mathrm{v}$ está completamente errada $\left({ }^{26}\right)$. Vamos, pois, resumir a matéria contida nos ff. $122 \mathrm{v}-186 \mathrm{v}$ agora à nossa disposição.

$\mathrm{O}$ ms. B. V. 2 da Universidade de Basileia pertenceu à Cartuxa de Santa Margarida menor, de Basileia, e tem como data de conclusão o ano de 1398. Contém:

1 - ff. 122va-124vb: Notemos em primeiro lugar o Explicit uita uel actus sancti Pachomii. Segue-se logo: Incipit prologus in librum secundum de uitis ac moribus patrum. Vem então o prólogo Vere mundum, típico do Livro III de Rosweydus (BHL 6525), seguido do título: Incipit de abstinentia, com os nn. 1-7 Rosw., depois dos quais está, deslocado, o Explicit liber secundus.

2 - ff. 124rb-127va: Incipiunt exempla sanctorum patrum contra spiritum fornicationis. Como se vê, é exactamente o título do cap. II das Commonitiones. Vêm então os nn. 8-16 Rosw.

3 - ff. 127va-133vb: uma selecção do cap. V de Pelágio, aqui interpolada, por este libellus ter também o título De fornicatione (BHL 6527).

4-133vb-136va: Incipiunt monita sanctorum patrum et exempla de uirtute humilitatis et patientiae, isto é, o cap. IV das Commonitiones, aqui constituído pelos nn. 17-21 Rosw. Este extracto do cap. IV das Commonitiones continuará após a fracção que passamos a indicar.

5 - ff. 136va-141vb: extractos de Pelágio, misturando diversos capítulos.

6- ff. 141vb-147va: com o título De amore humilitatis começam os nn. 22-33 Rosw., muitos deles com títulos próprios.

(26) Estamos a referir-nos ao catálogo de Gustav MEYER und MAX BuRCKHARdt, Die mittelalterlichen Handschriften der Universitätsbibliothek Basel, Abt. B, Erster Band, Basel, 1960, pp. 417-433. Não regateamos louvor ao esforço dos catalogadores para identificarem peça por peça, com remissão para as fontes conhecidas. 
7 - ff. 147va-148vb: nn. 36-40 Rosw. Como se poderá reparar, foram omitidos os nn. 34 e 35, referentes a S. Pacómio. A explicação está no facto de o copista ter acabado de transcrever, nos ff. 93r-122v a Vita Pachomii, onde há lugares paralelos para os dois números omitidos.

Confrontando a nossa tábua de lugares paralelos (pp. 63-64) verificar-se-á que o último número, 40 Rosw., é o próprio texto do cap. VI,5 das Commonitiones, aqui dado segundo o modelo do arquétipo $\delta$. O copista já deu provas, transcrevendo os títulos dos capp. II e IV, de que possuía um texto extenso das Commonitiones. Reparando nas omissões feitas, começa agora um trabalho complementar, numa disposição que só vemos neste manuscrito.

8 - ff. 148vb-151vb: os seguintes números das Commonitiones IV: 6,15,18,19; V: 4 e 6; VI,6. Observe-se que estes apotegmas são exactamente os mesmos que os mss. de Berlim, Namur e Londres colocam no fim da sua segunda compilação das Commonitiones, a partir do cap. IV.

9 - ff. 151vb-172ra: sem qualquer título, o copista do ms. B. V. 2 de Basileia continuou com uma nova selecção de Pelágio.

10 - ff. 172ra-185ra: Palladii Lausiaca (BHL 6534).

11 - ff. 185ra-186va: sob o título - Incipiunt commonitiones sanctorum patrum qui in studio spiritalis uitae persenuerunt ad instructionem iunioribus fratribus dixerunt, que, como sabemos é a rubrica inicial de todas as Commonitiones, são transcritos os apotegmas do cap. I: 2,3,6,8,9,12 e 15; III, 1. Comparando de novo com o modelo de Berlim e seus pares, vê-se que a fonte é a mesma, mas o copista de Basileia mais uma vez fez trabalho pessoal, omitindo os nn. I: 7,10 e 16; e II,3.

No fl. 186va retoma-se a miscelânea de Pelágio, a começar no liber de hospitalitate (XIII,1).

Recolhendo, por entre esta desordenada transcrição, tudo quanto provém das Commonitiones, notar-se-á que os materiais 
dos ff. 122va-127va, 133vb-136va, 141vb-151vb e ainda dos ff. 185ra-186va apresentam iniludiveis características de pertencerem ao arquétipo $\delta$. De facto, a aplicação dos métodos de crítica textual confirmam esta convicção.

\section{ARQUÉTIPO $\varepsilon$}

Apontamos em seguida, de forma sumária, um grupo de 5 manuscritos em que se encontram alguns apotegmas das Commonitiones sanctorum patrum não incluídos na antologia divulgada pelos nn. 1-40 do Livro III das Vitae Patrum de H. Rosweydus $\left({ }^{27}\right)$. Tanto a constituição externa como a análise do texto mostram que eles constituem uma unidade à parte, dependente do arquétipo $\delta$.

13. $\left(=T^{1}\right)-$ Troyes, Biblioteca Municipal $777-E$ originário de Claraval este manuscrito do séc. XII, que está organizado como se os seus ff. 1r-98r fossem apenas um Livro, começado pelo prólogo Vere mundum. Na realidade, com o Livro III de Rosweydus andam misturados muitos elementos de Pelágio, João, Pascásio e da Palladii Lausiaca.

Os apotegmas pertencentes às Commonitiones provêm de duas recensões: uma, secundária, semelhante à que se encontra no Livro III de Rosweydus; a outra está ligada ao texto do arquétipo $\delta$. Vamos indicá-los de acordo com esta dupla proveniência:

III Rosw. 1-40 (ff. 1ra-16rb);

Commonit. V,4 (fl. 47rb-47va);

Commonit. III, 1 (fl. 55ra-b);

(27) Cf. Pascásio de Dume..., t. II, pp. 222-229. 
Pelágio $\mathrm{X}, 18$ até sustinere eum, continuando sicut dicit apostolus: uos firmiores sustinete infirmos... até final de VI,6 (fl. 62va) segundo a versão das Commonitiones $\left({ }^{28}\right)$.

14. (= G) -Dijon, Biblioteca Municipal 194-É do séc. XII este manuscrito proveniente de Cister. Atenda-se a que houve engano na encadernação dos fólios, devendo seguir-se, na leitura, a ordem da paginação por nós reorganizada.

Os elementos tirados das Commonitiones são os seguintes, consoante as duas recensões:

III Rosw. 1-40 (ff. 1rb-11vb, 134ra-135vb e 12ra-13rb);

Commonit. V,4 (fl. 43rb-va);

Commonit. III,1 (fl. 50rb-vb);

Pelágio X,18 contaminado com Commonit.VI,6 (fl.58rb-va).

15. (= H) - Londres, Museu Britânico, add. 33 518-Originário da França, este manuscrito da segunda parte do séc. XII deve ser lido segundo a reorganização do texto por nós indicada. Pertencem às Commonitiones:

III Rosw. 1-40 (ff. 1r-8v e 17r-23r);

Commonit. V,4 (fl. 53r);

Commonit. III,1 (fl. 60r-v);

Pelágio X,18 contaminado com Commonit. VI,6 (fl. 67r).

16. (= I) - Paris, Biblioteca Nacional, fundo latino 5624 - Veio do norte da França este códice do séc. XIII, de cujo conteúdo nos interessa agora:

III Rosw. 1-40 (ff. 1r-17r);

Commonit. V,4 (fl. 46v);

(28) O apotegma a seguir é Pelágio X, 36 e não Palladii Lausiaca XX, 18. Este é um lugar paralelo daquele, mas o texto é de facto o de Pelágio. Deve fazer-se esta emenda em Pascásio de Dume..., t. II, p. 223 e no lugar correspondente dos outros 4 manuscritos seguintes, agrupados com o de Troyes, Bibl. Mun. 777. 
Commonit. III,1 (fl. 53v-54r);

Pelágio X,18 contaminado com Commonit. VI,6 (fl. 60v).

17. $(=K)-$ Valenciennes, Biblioteca Municipal 168-Foi copiado no norte da França este manuscrito do final do séc. xiII. Um anotador mais tardio escreveu no fl. 159r que o livro aí começado é trabalho de Postumiano, atribuindo-lhe assim a parte que nos interessa:

III Rosw. 1-40 (ff. 159ra-165rb);

Commonit. V,4 (fl. 179ra);

Commonit. III,1 (fl. 182va);

Pelágio X,18 contaminado com Commonit. VI,6 (fl. 185vb-186ra).

Além destes 17 manuscritos que têm, de momento, particular interesse para nós, demos já notícia anteriormente $\left({ }^{29}\right)$ de mais 60 códices, sobre os quais nada temos, de momento, a acrescentar. Apresentámo-los assim distribuídos: antologia isolada das Commonitiones, contendo apenas os nn. 1-40 da edição do Livro III de Row.; os nn. 1-40 do III Rosw. seguidos de outros números de acordo com a edição do Livro III Rosw. que vai de 1 a 220; elementos do Livro IIl Rosw., (contamos agora só os que têm os números de 1 a 40) interpolados com apotegmas e outros passos de diversa proveniência.

Além disso, indicámos atrás (nota 10, pág. 20) mais 15 manuscritos, que descreveremos ulteriormente, com elementos todos publicados no Livro III de Rosweydus. É nossa conviç̧ão de que vários outros surgirão à medida que se prolongue a investigação neste sentido. A publicação do texto integral das Commonitiones poderá contribuir para a sua descoberta noutros manuscritos, isoladas (caso de Viena) ou não de colecções de apotegmas e de textos das Vitae Patrum. Quando

(29) Cf. Pascásio de Dume..., t. II, pp. 197-198; 199-215, 233-253. 
um dia se fizerem edições críticas da Historia monachorum in Aegypto (o Livro II da edição de H. Rosweydus) e da Palladii Lausiaca, estamos certo de que crescerão bastante os materiais de que dispomos actualmente, dado que as Commonitiones andam frequentemente ligadas a estas duas obras $\left({ }^{30}\right)$.

(30) Não se estranhe a certeza de que deve haver muitos mais manuscritos com texto (pelo menos parcial) das Commonitiones. Columba M. Batlle, ao estudar as Adhortationes sanctorum patrum (Livros V e VI de Rosweydus) enumera 375 manuscritos com o seu texto (Münster, 1972, pp. 17-138); em Pascásio de Dume..., t. II, estabelecemos nós o stemma de 147 códices (ou fragmentos dentro do mesmo manuscrito); na obra editada por W. A. Oldfarher, Studies in the text tradition of St. Jerome's Vitae Patrum (Urbana, The University of Illinois Press, 1943) são enunciados 111 a propósito da Vita Pauli, V. Hilarionis e da V. Malchi; com as Sententiae patrum Aegyptiorum de S. Martinho de Dume (ou só fragmentos desta obra) conhecemos nós actualmente 108 manuscritos. Isto prova a grande expansão que as Vitae Patrum tiveram ao longo de toda a Idade Média. Não admira, pois, que, além dos 92 manuscritos com as Commonitiones sanctorum patrum (ou seus fragmentos) de que já demos conhecimento, muitos outros se venham a encontrar ainda. 


\section{Cap. III - EM BUSCA DE LUGARES PARALELOS}

Não vamos aqui repetir indicações sobre a origem do apotegma, por meados do século IV, a sua integração posterior na Literatura Cristã e a sua evolução estrutural, ou sobre a data da elaboração das grandes coleç̧ões $\left({ }^{31}\right)$. As próprias Commonitiones fornecem-nos, para tanto, valioso material (cf. pp. 99-100 e 132-133). Importa no entanto, realçar que nos últimos anos se tem assistido a um renovado interesse pela leitura dos apotegmas dos padres dos desertos do Egipto, Palestina e Síria, como o provam traduções em línguas modernas e estudos de data recente $\left.{ }^{32}\right)$.

(31) Cf. Pascásio de Dume..., t. I, pp. 34-41, com a bibliografia aí indicada.

(32) Mencionemos entre as traduções, geralmente precedidas de um estudo histórico-literário: JeAn-Claude Guy, Les apophtegmes des pères du désert, Série alphabétique, Textes de Spiritualité Orientale, n. 1, Abbaye de Bellefontaine, Bégrolles, 1966, 434 pp.; Les sentences des pères du désert, Recension de Pélage et Jean, introduction de L. Regnault, traduction de J. Dion et G. OURY, Abbaye Saint-Pierre de Solesmes, Sarthe, 1966, 309 pp.; Les sentences des pères du désert, Nouveau recueil, Apophtegmes inédits ou peu connus, rassemblés et présentés par L. REGNAULT, traduits par les moines de Solesmes, Abbaye Saint-Pierre de Solesmes, Sablé-sur-Sarthe, 1970, 338 pp.; M. DE Elizalde, Dichos de los padres del desierto. Suplemento a la serie alfabética in Cuadernos Monásticos, ano 6, fasc. 17, Victoria (Argentina), s/d, pp. 151-169; C. W. BArLow, Martin of Braga, Paschasius of Dumium, Leander of Seville (= Iberian Fathers, vol. I), Washington, 1969, onde são traduzidas para inglês as Sententiae de Martinho (pp. 17-34) e os apotegmas de Pascásio, tomando como ponto de partida a edição de H. Rosweydus (pp. 117-171). Os números do autêntico Pascásio de Dume omitidos por Rosweydus e toda a capitulatio foram já traduzidos (tendo por base a nossa edição crítica) por C. W. BARLOW, sob o título Paschasius of Dumium, Sayings of the greek fathers in Classical Folia, New York, t. 26 (1972) pp. 289-314; t. 27 (1973), pp. 3-27 e pp. 151-172.

Muito ligados ao estilo apotegmático estão os seguintes livros com introduções apropriadas: Maîtres spirituels au désert de Gaza: Barsanuphe, Jean et Dorothée, textes choisis, traduits et presentés par L. Regnault, Éditions de l'Abbaye de Solesmes, 1967, 267 pp.; Abbé Isaie, Recueil ascétique, introduction et traduction française par les moines de Solesmes, Spiritualité Orientale n. 7, Abbaye de Bellefontaine, Bégrolles-en-Mauges, 1970, 313 pp.

Convém ainda anotar os seguintes estudos: L. Lerorr, La Bible et les pères du désert d'après les deux collections armeniennes des apophtegmes in La Bible et les Pères, 
A descoberta das Commonitiones sanctorum patrum, como uma nova colecção unitária, veio pôr-nos o problema da busca de lugares paralelos. Esta pesquisa tem como primeiro objectivo a procura de uma presumível fonte grega, partindo da hipótese que o original não é o próprio latim nem qualquer outra língua do Oriente cristão. Com efeito, temos notícia certa de que as outras principais colecções latinas - a de Pelágio e João ( $\left.{ }^{33}\right)$, a de Pascásio e a de Martinho $\left({ }^{34}\right)$, foram traduzidas do grego. Pode igualmente provar-se que todos os outros Livros das Vitae Patrum, editados por H. Rosweydus, com excepção do Livro IV (que é um original latino extraído dos escritos de João Cassiano e de Sulpício Severo) foram também traduzidos do grego para latim.

Entregámo-nos, por isso, à leitura dos apotegmas em grego e alargámos a nossa investigação a obras afins. Manda a verdade dizer que o trabalho já se nos apresentava, em pequena parte, facilitado. Acontece que 39 apotegmas das Commonitiones foram publicados por Rosweydus nos números 1 a 40 do seu Livro III e 3 no cap. XX da Palladii Lausiaca. Ora Wilhelm Bousset no seu meritório estudo $\left(^{35}\right)$ elabora quadros dos lugares paralelos por ele conhecidos para os apotegmas cujo texto latino estava então publicado. Restava-nos verificar a exactidão destas remissões e procurar novas equivalências. De facto, para os 42 apotegmas latinos das Commonitiones já registados, Bousset só encontrou texto grego paralelo para 17. Se alguém

Strasbourg, 1971, pp. 113-134; L. Regnault, Connaissez-vous les pères du désert? in La Vie Spirituelle, n. 582, 1971, pp. 609-615; L. Regnault, L'enfance spirituelle chez les pères du désert in Vie Thérésienne, n. 45, 1972, pp. 8-24; C. M. Batlle, Die Adhortationes sanctorum patrum» («Verba Seniorum») im lateinischen Mittelalter, Aschendorffsche Verlagsbuchhandlung, Münster, 1972, 340 pp. (Passaremos a indicar esta obra apenas por BATlle, Die Adhortationes...).

(33) Batlle, Die Adhortationes..., p. 11.

(34) Para os textos referentes a Pascásio e Martinho, cf. Pascásio de Dume..., t. I, pp. 1-11.

(35) W. Bousset, Apophthegmata. Studien zur Geschichte des ältesten Mönchtums, Tübingen, 1923, pp. 129-130 e 137. 
se der ao trabalho de examinar o quadro publicado no fim deste capítulo, verificará que para aqueles 42 apotegmas nós apresentamos 40 paralelos gregos.

Mas, além daqueles 42 , há ainda mais 8 apotegmas, que foram indevidamente incluídos no texto (bastante corrompido) da Palladii Lausiaca até ao cap. XIX, e 11 até agora inéditos. Em relação a estes 19 apotegmas conseguimos texto grego equivalente para 15. Quer dizer que para o conjunto dos 61 apotegmas das Commonitiones obtivemos um total de 55 lugares gregos paralelos (não contando a subdivisão de alguns números em diversas alíneas, porque a um só apotegma latino correspondem por vezes fontes gregas de diferente proveniência). Isto significa uma percentagem de $90,1 \%$ de abonação grega (pelo menos parcial) para o latim das Commonitiones $\left({ }^{36}\right)$.

Devemos ainda referir que, embora não tenhamos paralelo grego publicado, há 9 apotegmas das Commonitiones sanctorum patrum que têm o seu equivalente na versão latina de Pelágio (Livro V das Vitae Patrum). Isto garante-nos que o texto grego que esteve na base de ambos existiu, embora seja ainda hoje por nós desconhecido.

Contamos ainda 6 apotegmas com lugares paralelos em obras latinas de género literário diferente do apotegmático. É o caso do Philotheus, da Vita Pachomii, das Conlationes de João Cassiano (passo não incluído por Rosweydus nas suas Vitae Patrum), da Historia Monachorum e do Heraclidis Paradisus, obras que adiante (pp. 60-62) identificaremos melhor.

Restam finalmente 4 apotegmas para os quais não conseguimos encontrar qualquer paralelo. $\mathrm{O}$ interesse destes é, do

(36) Sabendo, em virtude de contacto epistolar havido após o nosso trabalho sobre Pascásio de Dume, que Dom Lucien Regnault, beneditino de Solesmes, trabalha há anos na preparação de umas "Tables des Apophtegmes», (que espera publicar em 1974), pedimos a sua ajuda para os números que resistiram à nossa pesquisa. É-nos assim possível apresentar um "quadro" de paralelos gregos enriquecido por duas dezenas de remissões (nem todas coincidentes com os apotegmas inéditos) em relação ao que tínhamos elaborado. Por esta colaboração amiga, testemunhamos a Dom Lucien Regnault o nosso reconhecimento. 
ponto de vista das fontes literárias, ainda maior. Juntamente com os 6 apotegmas anteriores, eles passarão a ser o único testemunho, em grego e latim, de que estes 10 episódios faziam parte da tradição apotegmática. E esta contribuição é muito de apreciar.

Vamos analisar um só destes casos que têm paralelo apenas em obras estranhas ao género apotegmático, para melhor distinguir a sua situação da que em seguida estudaremos a propósito das interpolações no texto latino da Palladii Lausiaca.

Conta-nos o narrador da Historia monachorum (cap. XX,1-4) que durante a visita prolongada ao Egipto com os seus companheiros, viram, na Tebaida, o presbítero Dióscoro, o qual tinha o máximo escrúpulo em que os monges do seu convento se não aproximassem da Eucaristia com qualquer mancha de deleitação sensual, mesmo ocorrida durante o sonho. E aconselhava a que se vivesse de tal modo que a natureza, por si mesma, não levasse à polução, ainda que involuntária. Vejamos o texto grego $\left({ }^{37}\right)$ e depois, lado a lado, a sua tradução latina,

(37) Utilizamos o texto grego da edição de Festugière abaixo indicada $\mathrm{e} o$ latino da PL 21, coll. 387-462. O problema literário da Historia monachorum interessa-nos sobremaneira. Com efeito, tanto o Livro II de Rosweydus (= Hist. Mon.) como o Livro III (= selecção das Commonitiones e de outros autores) têm sido considerados como tradução de Rufino. Por outro lado, a tradição manuscrita traz com muita frequência o Livro II seguido do Livro III. Por isso, bem desejaríamos que fosse feita uma edição crítica do texto latino da Hist. Mon. e se inventariassem os códices que transmitem esta versão.

O estudo crítico mais completo, em nossos dias, sobre esta obra é o de A.-J. Festugrère, Le problème littéraire de l'Historia Monachorum in Hermes 83 (1955), Wiesbaden, pp. 257-284. Os resultados actuais da investigação podem resumir-se no seguinte: o texto grego é o original; o seu autor é provavelmente o diácono de Alexandria, Timóteo; a viagem descrita realizou-se nos anos de 394/395 e o relato foi escrito cerca de 400; Rufino é, com certeza, o tradutor, mas serviu-se de uma recensão bastante diferente do texto grego que possuímos; a tradução foi feita entre 402 e 405. Cf. ainda A.-J. Festugière, Historia Monachorum in Aegypto, édition critique du texte grec, Société des Bollandistes (= Subsidia Hagiographica, n. 34), Bruxelles, 1961; A.-J. Festugrère, Les moines d'Orient, IV, 1: Enquête sur les moines d'Égypte (= tradução do texto grego anterior), Les Éditions du Cerf, Paris, 1964. Os dois trabalhos precedentes foram reunidos num só volume, com o título do 
em comparação com o apotegma correspondente, que só se encontra nas Commonitiones(I, 15):

HIST. MON. IN AEG. (Festug. $\mathrm{xx}, 3^{\mathrm{b}}-4$ )

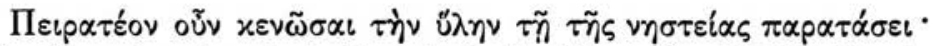

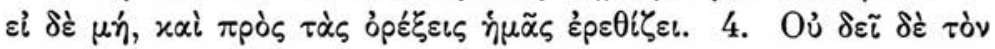

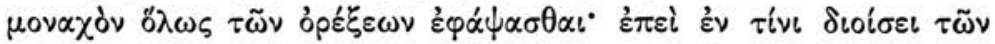

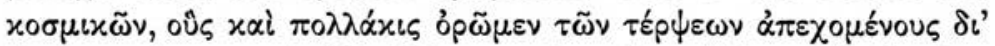

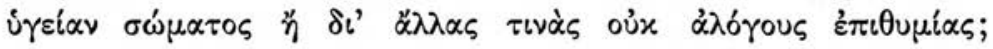

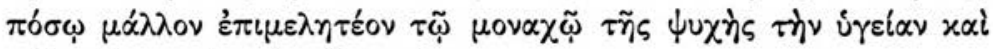

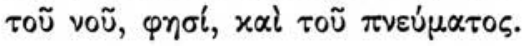

RVFINVS (PL 21, col. 443)

COMMONITIONES I,15

Sed laborandum est monachis, ut etiam naturalem humorem per multam ieiuniorum abstinentiam et frequentes orationes doment ac superent: $f u$ xamque eius labem, orationis et ieiunii continuatione restringant. Denique aiebat, et hi qui in deliciis uiuunt, si forte corporis sui aegritudo deposcat $\mathrm{ab}$ omnibus quae noxia esse iudicauerit medicus, abstiDicebat sanctus abbas Dioscorus presbyter, qui in eremo Sceti habitabat: Quia non oportet monachum desideria gulae uentrisque facere. Nam in quo differt a saecularibus, si expleat delectationes suas? Denique frequenter uidemus homines saeculares pro causa aegritudinis a deliciis et delectationibus se abstinere, ut sanitatem corporis adipiscan-

primeiro, nos Subsidia Hagiographica, n. 53, editado pelos Bolandistas, Bruxelas, 1971. Outra tradução com introdução e notas encontra-se em S. Frank, Mönche im frühchristlichen Ägypten, Düsseldorf, 1967. PaUl Devos, Les nombres dans l'aHistoria Monachorum in Aegypto in Analecta Bollandiana, t. 92 (1974), pp. 97-108. Várias obras que daqui a pouco indicaremos sobre a viagem de Paládio ao Egipto e o seu relato dedicado a Lauso tratam também do tema do Livro II de Rosweydus, isto é, a Historia monachorum in Aegypto (cf. pp. 53-54). 
nebunt; cur non hoc multo magis monachus faciat, cui animae et spiritus sanitas expetenda est? tur. Quanto magis diligenter studere debet monachus pro salute et incolumitate animae suae, ut possit ad illas ueras et aeternas paradisi delicias et ad caelestis regni gloriam peruenire?

A observação destes três textos mostra que em todos está explícito o mesmo pensamento de Dióscoro. Todavia, Rufino ainda se afasta mais do grego que possuímos do que o próprio apotegma. Apenas a partir de $\varepsilon \pi \varepsilon i ́$, a que corresponde em ambas as traduções latinas denique, se torna claro que todos exprimem quase pelas mesmas palavras um conceito típico de Dióscoro, o de que até as pessoas do mundo são capazes de levar vida de sacrifício, se isso for necessário para a saúde; quanto mais o monge...

Sublinhámos, tanto em Rufino como nas Commonitiones, as expressões que não têm qualquer correspondente no texto grego. Em Rufino insiste-se no jejum e oração; as Commonitiones rejeitam os prazeres da gula e do estômago. Lembram-nos o título e os apotegmas do cap. III de Pascásio: De uincendo desiderio gulae $\left.{ }^{38}\right)$. Mas notem-se dois pormenores que nos põem em contacto com os processos de elaboração dos apotegmas.

Possuindo um núcleo fundamental (uma exortação de carácter ascético), o reelaborador construiu para o efeito uma introdução, com indicativo do nome da pessoa (Dióscoro) e do lugar (Scétis), devendo nós assinalar a independência das Commonitiones em relação à Historia monachorum, pois nesta - lugar citado é a Tebaida; um segundo ponto consiste no acrescento final, de acordo com o carácter tipicamente edificante do género apotegmático na sua última fase, bem caracterizado

(38) Cf. Pascásio de Dume..., t. I, pp. 169-171. 
no autor das Commonitiones pelos tópicos da esperança de recompensa no paraíso e pelo temor dos tormentos eternos $\left({ }^{39}\right)$.

O caso acabado de apresentar constitui um bom exemplo de um lugar paralelo que se encontra fora do género apotegmático. Mas o texto genuíno das Commonitiones veio colocar-nos diante de um problema aparentemente mais difícil de solucionar. Com efeito, na nossa busca de episódios equivalentes, deparámos com porções do texto das Commonitiones integradas na Palladii Lausiaca. Resumimos aqui a situação $\left({ }^{40}\right)$ :

\begin{tabular}{|c|c|c|c|}
\hline COMMONIT. & PaLLAD. Lavsiaca & COMMONIT. & PaLLAD. LAVSiaca \\
\hline I, 2 a,b & $\mathrm{XI}$ a,b & I, 15 & IV $\mathrm{f}$ \\
\hline I, 3 a,b,c & XI c,d,e & III,1 & IX k \\
\hline I, 8 & $\mathrm{XX}, 1$ & IV, 19 & $\mathrm{IX}_{\mathrm{j}}$ \\
\hline I, 9 a,b,c & VI $c, d, c$ & $\mathrm{~V}, 4$ & XII \\
\hline I, 10 a,b & VI $f, g$ & $\mathrm{v}, 6$ & $x x, 7$ \\
\hline I, 12 & $\mathrm{XX}, 18$ & & \\
\hline
\end{tabular}

Impunha-se-nos estudar também, na medida do necessário, o valor do texto da Palladii Lausiaca editado por Rosweydus. E assim fomos obrigado a ocupar-nos da obra de Paládio $\left({ }^{41}\right)$. Os elementos essenciais são os seguintes:

Paládio, que veio a ser bispo de Helenópole e depois de Aspuna (Ásia Menor), viajou e viveu no Egipto com os

(39) Cf. cap. VI, pp. 108-113.

(40) A divisão dos capítulos da Palladii Lausiaca em alíneas segue, em primeiro lugar, a distinção dos parágrafos tipográficos da edição reproduzida na PL 74, coll. 343-382. Quando o texto das Commonitiones o exigiu (no geral para estabelecer equivalências com outros lugares paralelos) subdividimos ainda os parágrafos da Palladii Lausiaca.

(41) A principal bibliografia sobre Paládio é: E. Amélineau, De Historia Lausiaca. Quaenam sit huius ad monachorum Aegyptiorum historiam scribendam utilitas, Parisiis, 1887; E. Preuschen, Palladius Helenopolitanus et Rufinus Tyranius. Ein 
monges desde 388/389 até 399 e de 406 a 412 . Escreveu, sobre as principais figuras do monaquismo egípcio, nos anos de 419-420, um relato do que viu e ouviu, dedicado a Lauso, prefeito do palácio imperial (daí o nome de História Lausíaca). Do texto grego conservam-se duas redacções: uma, breve, obra de Paládio; e outra mais longa, retocada por Heraclides, bispo de Nissa (donde o nome de Paraíso de Heraclides). Ainda no século V apareceu uma tradução latina, impressa por Rosweydus como I apêndice aos seus 10 livros das Vitae Patrum, sob o título de Heraclidis Paradisus (PL 74, coll. 243-342); também antiga, o mais tardar do século VII, é uma outra tradução latina de que foi publicada uma recensão por Rosweydus, como II apêndice às Vitae Patrum, com o nome de Palladii Lausiaca (PL 74, coll. 343-382). Uma terceira tradução feita pelo humanista Gentianus Hervetus teve a honra de ser publicada por Rosweydus como Livro VIII das Vitae Patrum, sob a designação de Historia Lausiaca (cf. PL 73, coll. 1065-1234).

Beitrag zur Quellenkunde des ältesten Mönschtums, Giessen, 1897; C. BuTLER, The Lausiac History of Palladius, Cambridge, I vol. 1898, II vol. 1904; E. A. W. BuDGE, The book of Paradise being the histories and sayings of the monks and ascetics of the Egyptian desert by Palladius, Hieronimus and others, I-II, Text, Translation, London, 1904; A. Lucor, Palladius, Histoire Lausiaque, texte grec, traduction française, introduction, Paris, 1912; R. Rerrzenstern, Historia Monachorum und Historia Lausiaca, Göttingen, 1916; W. Bousset, Komposition und Charakter der Historia Lausiaca in Nachrichten von der kön. Gesellschaft der Wissenschaften zu Göttingen, Philolog.-hist. Kl., 1917, pp. 173-217; IDEM, Zur Komposition der Historia Lausiaca in Zeitschrift für die neutestamentliche Wissenschaft XXI (1922), pp. 81-98; M. СHAINE, La double recension de l' Histoire Lausiaque dans la version copte in Revue de l'Orient Chrétien XXV (1925-1926), pp. 232-275; Dom Antoni Ramón I ARrufat, Historia Lausiaca, text revisat i tradució, Barcelona, 1927; René Draguet, Les Pères du Désert, Paris, 1949, p. VIII-XIII; IDEM, L'inauthenticité du "Prooemium» de l'Histoire Lausiaque in Mélanges L. Th. Lefort, (Le Muséon LIX) 1946, pp. 529-534; IDEM, Un nouveau témoin du texte $G$ de l'Histoire Lausiaque (Ms. Athènes 281) in Analecta Bollandiana LXVII (1949) pp. 300-308; E. Honigmann, Heraclidas of Nissa (about 440 A. D.) in Patristic Studies, col. Studi e Testi, t. 173, Vaticano, 1953, pp. 104-122; R. T. MEYER, Palladius. The Lausiac History, translated and annoted by..., Westminster (Maryland),

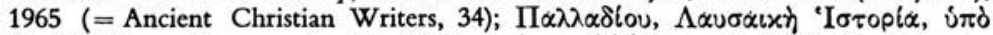

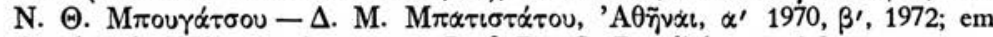
Outubro de 1973 comunicou-nos o Prof. Dr. G. Bartelink que tinha pronto para a tipografia um comentário ao texto grego da História Lausíaca. 
Segundo a crítica moderna, a versão intitulada Heraclidis Paradisus é a que mais se aproxima do original. Quanto à Palladii Lausiaca (a tradução latina que a nós mais nos interessa) já o próprio Rosweydus anotara à margem do cap. IX que uma parte do texto "est uerbotenus in Ruff., supra, lib. II, c. 28" e, comparando com o Heraclidis Paradisus a Palladii Lausiaca escreveu, à margem de vários episódios desta última, nos capítulos VI, IX, X, XI, XII e XIV, "deest Heraclidi». Quanto ao cap. XX, Rosweydus observou logo no seu começo: Deest Heraclidi. Sequentia habentur fere supra in aliis libris inter Verba Seniorum; Ruff. 1. III, n. 52;Pelag. libell. IV, n. 29\%. Além desta nota inicial remete ainda, para o total dos seus 19 apotegmas, mais 3 vezes para Pascásio, 2 para Pelágio e 1 para o Livro III.

Infelizmente não existe ainda uma edição crítica de nenhuma das traduções latinas da obra de Paládio. O único estudioso que se pronunciou sobre a Palladii Lausiaca, baseando-se em alguns manuscritos latinos, foi Dom Cuthbert Butler $\left({ }^{42}\right)$. $\mathrm{O}$ douto beneditino inglês deixou bem explícito que a Palladii Lausiaca tem muitas interpolações nos capítulos IV, VI, IX, X, $\mathrm{XI}, \mathrm{XII}, \mathrm{XIV}$ e XX. Alguns dos passos espúrios conseguiu Butler identificá-los; quanto a outros confessa o seu desconhecimento.

Eis-nos na altura de fornecer a C. Butler alguns dos episódios cuja origem ignorava. Quem olhar para o quadro que deixámos ao iniciar o estudo do texto das Commonitiones transmitido pela Palladii Lausiaca (p. 53) notará que todos os capítulos que contêm elementos desta nova colecção de apotegmas se encontram entre os indicados por Butler como tendo texto interpolado. Em muitos casos as identificações dos passos interpolados correspondem perfeitamente aos apotepp. 64-69.

$\left({ }^{42}\right)$ C. Butrer, The Lausiac History of Palladius, I vol., Cambridge, 1898, 
gmas das Commonitiones. Estamos certo de que um texto crítico da Palladii Lausiaca apareceria expurgado de todas estas interpolações. Já atrás citámos manuscritos que delas estão isentos (pp. 28 e 35).

O cap. XX da Palladii Lausiaca merece-nos uma atenção particular. Rosweydus e Butler assinalaram o seu carácter suspeito e mesmo espúrio. Bousset $\left({ }^{43}\right)$ considerou-o como uma colecção independente de apotegmas, para o qual constituiu uma "tabela" à parte de lugares paralelos. Sendo assim, admite que este capítulo é estranho à Palladii Lausiaca e por isso o cita por "App." e o número do apotegma.

Por nossa parte podemos dizer: os nn. 1,7 e 18 são literalmente tirados das Commonitiones; o n. 9 é textualmente igual a Pascásio II,3 (da nossa edição). Ficam os outros 15 apotegmas. $\mathrm{O}$ n. 4 verificámos ser absolutamente igual a Pelágio $\mathrm{X}, 61$.

Em nossa opinião o n. 11 tem aspecto de ser um arranjo desenvolvido, mas com passos literais de Pascásio LXXXVI,1; o n. 14 parece-nos Pascásio: XXVIII,2 seguido de XXI,2, com leves retoques; o n. 15 pode dividir-se assim: - a) contaminação de Pelágio XVI, 10 com Pascásio XXXIV,7; b) contaminação de Plg. XV,61 com Pasc. XXI,3b; c) arranjo de Martinho $15 ;-d)$ remodelação de Martinho 59.

Restam ainda 10 números que, quanto a nós, parecem ser originais. Supomos que o Dr. Columba M. Batlle, estudioso de Pelágio-João, poderá dizer algo mais que venha a desvendar o mistério deste já desmantelado cap. XX da Palladii Lausiaca.

Caso à parte é o n. V,6 das Commonitiones. Este encontra-se, com muito ligeiras diferenças, nas Conlationes de João Cassiano (cap. XXIV,9). Guardamos o seu estudo para a ocasião em que tratarmos do tradutor das Commonitiones (pp. 136-149).

(43) W. Bousset, Apophthegmata, Tübingen, 1923, pp. 25 e 137. 
Quando afirmamos que há paralelos gregos para os apotegmas das Commonitiones, não queremos dizer que encontrámos o texto grego exacto que serviu de base ao tradutor das Commonitiones. Estamos convencido de que o autor que elaborou esta colecção em grego refez os materiais que estavam ao seu alcance, desenvolvendo vários episódios e acrescentando considerações de ordem moral, como se verá em capítulos seguintes (pp. 69, 83-85, 88, 100, 183, 247). Notar-se-á também, então, que mesmo para pormenores em que o grego à nossa disposição não corresponde ao latim das Commonitiones, pois estas acrescentam alguns aspectos, mesmo então é por vezes possível, através da comparação com outras traduçõos latinas de apotegmas gregos, garantir que havia recensões gregas, em parte divergentes da que chegou até nós, que registavam esses pormenores. É, pois, difícil saber, em certos casos, com precisão até que ponto foi inovador o autor grego desta colecção (cf. pp. 71-76, 80, 166).

Podemos, no entanto, testemunhar que a par de versões resumidas dos apotegmas havia em grego outras redacções bastante mais ampliadas. F. Nau apresentou, lado a lado, duas recensões breves da história de Táisis, muito próximas entre si, em confronto com uma outra redacção que, utilizando os mesmos materiais, introduz diversas ampliações de feição edificante ${ }^{(44)}$.

Não querendo alongar, damos apenas um exemplo seguro de uma reelaboração que já devia existir nas coleç̧ões gregas.

É sabido que tanto Pelágio como Pascásio seguiam como norma a tradução literal (cf. pp. 68, 73, 76, 77, 78, 80, 81, 90, 93, $118,150,156,167,170,175,182,187,191,207,231,243,246)$. Ao texto latino que eles nos transmitem, quando divergente,

(44) F. Nau, Histoire de Tais. Publication de textes grecs inédits et de divers autres extes et versions in Annales du Musée Guimet XXX (1903), Paris, pp. 86-113. A versão mais resumida é tirada do ms. do Vaticano, Ottobonianus 1; uma outra com poucas divergências é colacionada dos mss. do Vaticano, Palatinus 364 e de Berlim, Qu 22; a recensão mais desenvolvida foi transcrita do ms. de Paris, grec 1596. 
correspondiam, por certo, originais gregos diferentes (cf. sobre literalismo pp. 73, 76, 158-163).

Pois bem. Em Nau 164 temos um apotegma grego, cujo sentido global se encontra em Pelágio V,13a; em Pascásio LXXIII, 4; e nas Commonitiones II, 2. A primeira parte do apotegma é quase idêntica em Nau, Pelágio e Pascásio; a segunda parte, porém, exige redacções gregas bastante retocadas. Damos aqui a segunda parte nas três versões, para se poder depois comparar com a redacção das Commonitiones.

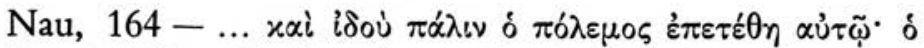

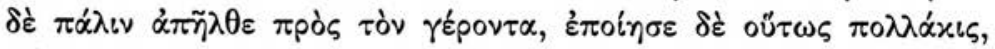

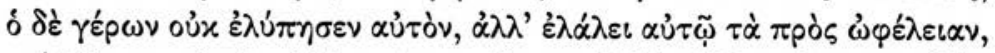

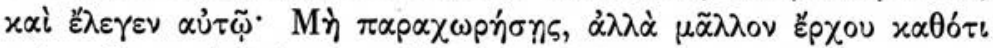

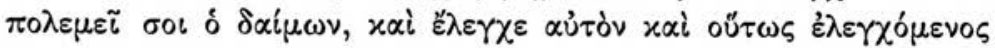

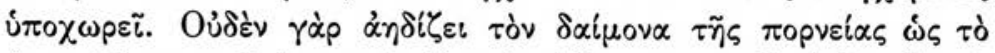

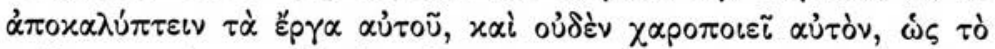

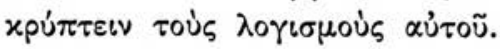

$$
\text { PELÁGIO v,132 }
$$

Et ecce iterum spiritus fornicationis tentauit eum. Ille autem iterum abiit ad senem. Factum est autem hoc frequenter. Senex uero non contristauit eum, sed loquebatur ei quae ad utilitatem ipsius pertinerent,dicens:Non concedas diabolo, nec relaxes animum tuum; sed magis, quoties molestus est daemon, ueni ad me, et increpatus abscedet. Nihil enim sic extaediat daemonem fornicationis, quomodo si reuelen-

\section{PASCÁSIO LXXIII,4}

Et ecce iterum impugnabatur et iterum reuertebatur ad senem. Decies ipse profectus est ad senem. Et dicit ei senex:

Semper ueni frater et renuntia mihi, quia nihil sic daemonem impugnatorem contristat, quomo- 
tur stimulationes eius. Et do manifestare opera eius; et nihil eum sic laetificat, quo- nihil sic illum laetificat quomodo si abscondantur cogi- modo abscondi cogitationes tationes. eius.

O relato das Commonitiones II,2, correspondente ao que acabamos de transcrever, principia (lin. 8): et ecce iterum impugnatio insistebat ei. Esta tradução continua também quase literal até à linha 11. O conselho, o novo regresso à cela e o retorno ao ancião foram fabricados para as Commonitiones (lin. 11-17). Há uma omissão de Pascásio, mas atestada em Pelágio, equivalente a estas palavras das Commonitiones: Ne pertimescas... isto é, as nossas linhas 18-19. As linhas 20-21 pertenciam, de certeza, ao núcleo primitivo, pois encontram-se no nosso grego e nas três versões latinas que estamos examinando. Daqui para diante (lin. 22-32) é uma segura reelaboração das Commonitiones: o primeiro conselho e a citação da Escritura; um novo conselho e nova citação bíblica, e finalmente uma frase de conclusão (cf. pp. 79-80, 85-87, 88, 100, 116, 156-157, 269).

Este breve exemplo mostra-nos como era complicada, já em grego, a transmissão escrita do género apotegmático e como seria presunção vã afirmar que possuímos o texto grego das Commonitiones. Apenas podemos indicar redacções gregas com o mesmo episódio, isto é, lugares paralelos.

\section{EXPLICAÇÃO DAS ABREVIATURAS E NÚMEROS DO QUADRO DOS LUGARES PARALELOS}

A primeira coluna refere-se à nossa edição das Commonitiones, com indicação do capítulo (número romano), apotegma (algarismo árabe) e parágrafo tipográfico (letra em expoente).

A segunda coluna remete para os lugares onde já foi publicado texto parcial das Commonitiones, embora numa edição não crítica: Livro III das Vitae Patrum publicado por 
H. Rosweydus (R), com indicação do número que o apotegma tem neste editor. Seguimos a reprodução feita na Patrologia Latina, vol.73, coll. 739-764.

A abreviatura $P d$, seguida de um número romano e por vezes de uma letra em expoente, indica a Palladii Lausiaca até ao cap. XIX. Entre parêntesis vai a coluna em que o texto principia na transcrição que desta obra faz a PL 74, coll. 343-377. App. L. remete para o cap. XX, que é na verdade um apêndice apócrifo à Palladii Lausiaca, com menção do número do apotegma e da coluna na PL 74, coll. 377-382.

A terceira coluna diz respeito às fontes gregas. Um nome próprio seguido de um número dizem respeito à colecção nominal-alfabética de apotegmas, publicada na Patrologia Graeca, vol. 65, coll. 73-440. A indicação entre parêntesis tem por fim facilitar o encontro da coluna onde a narrativa principia.

$N$ seguido de um número representa o texto editado por F. Nau nos artigos Histoires des solitaires égyptiens, aparecidos na Revue de l'Orient Chrétien nos voll. XII a XIV (1907 a 1909) e XVII-XVIII (1912 e 1913). Nau deu a conhecer o conteúdo do ms. de Paris, Coislin 126 só até ao n. 400. Os restantes apotegmas, os chamados anónimos, deste manuscrito não foram ainda publicados em grego. Temos, no entanto, deles uma tradução francesa, que atinge o n. 669, em Les sentences des pères du désert. Nouveau recueil, graças aos monges de Solesmes (Abbaye Saint-Pierre-de-Solesmes, 72-Sablé-sur-Sarthe), 1970. Os nn. 401-669 vêm nas pp. 51-162. Para esta obra remete a nossa referência a IV,12 (N 451), querendo o parêntesis significar que o texto grego existe no manuscrito começado a publicar por Nau, mas nós não pudemos cotejá-lo.

A abreviatura H. M. Aeg. indica o texto grego de A.-J. Festugière, Historia Monachorum in Aegypto, Bruxelles, 1961, cap. XX, nn. 3-4, p. 119.

Patr. Orient. remete para o apêndice de Textes complémentaires, publicado por F. Nau na revista Patrologia Orientalis, t. VIII, 1912, pp. 162-183 (Paris). 
Hist. Laus. 39,3 e 1-2, paralelo de Commonitiones V,2b,d, indica a numeração e a obra de Antoni Ramón i Arrufat, Palladi. Historia Lausíaca, incluída na série Escriptors Cristians, Barcelona, 1927, pp. 83-84.

Vita Pach. alt. é uma remissão para a edição de $\mathrm{H}$. van Cranenburgh, $\mathrm{La}$ vie latine de Saint Pachôme, traduite du grec par Denys le Petit, (= Subsidia Hagiographica, n. 46), Société des Bollandistes, Bruxelles, 1969. Indicamos o capítulo, o parágrafo e entre parêntesis a página do texto grego. Halkin remete para as Vitae Graecae citadas na nota. Mencionamos esta obra entre parêntesis porque o passo referido nos foi indicado por L. Regnault numa altura em que já não podjamos consultar a edição de Halkin $\left({ }^{45}\right)$.

A quarta coluna é reservada à tradução das Adhortationes sanctorum patrum por Pelágio $(\mathrm{Pg})$ e João (Ioan), que constituem os Livros V e VI das Vitae Patrum (PL 73, coll. 855-1022). Juntamente com o nome do tradutor vai o capítulo (libellus) em romano; em algarismos árabes, o número do apotegma, e entre parêntesis a coluna onde principia o texto na PL.

A quinta coluna remete para o capítulo e apotegma da tradução de Pascásio, segundo a edição crítica que publicámos em 1971 (cf. J. G. Freire, A versão latina por Pascásio de

(45) Como se poderá verificar, o cap. V: 7 e 8 contém dois longos apotegmas referentes a S. Pacómio. A colecção nominal não regista nenhum dito de Pacómio. A leitura das suas biografias em grego permitiu-nos encontrar alguns lugares paralelos, mas para um parágrafo $(\mathrm{V}, 7 \mathrm{c})$ não deparámos com o que procurávamos. Orientação e textos principais sobre este tema: F. Halkın, Sancti Pachomii Vitae Graecae, Bruxelles, 1932 (descreve os manuscritos e apresenta o texto de seis Vitae); IDem, Les vies grecques de S. Pachbme in Analecta Bollandiana XLVII (1929) pp. 376-388 (diz que na Vita tertia há strois ou quatre traits qui semblent provenir d'une collection d'apophtegmes, cf. p. 378); IDEM, L'Histoire Lausiaque et les vies grecques de S. Pachôme in Analecta Bollandiana XLVIII (1930) pp. 257-301 (apesar de reconhecer a anterioridade da tradução do Heraclidis Paradisus, diz que a Palladii Lausiaca eremonte en tout cas au Ve siècles, cf. p. 262); L. Th. LeForT, Les vies coptes de saint Pachôme et ses premiers successeurs, traduction française, Louvain, 1943; A.-J. Festugrère, Les moines d'Orient, Tome IV/2: La première vie grecque de Saint

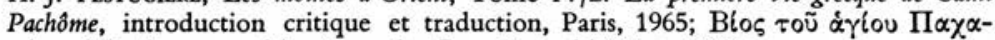

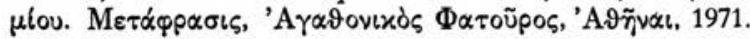


Dume dos "Apophthegmata Patrum», t. I, pp. 159-333. Não nos pareceu necessário indicar a página onde se encontra cada apotegma, dada a facilidade de o situar no texto de Pascásio). Para Commonitiones IV, $1^{\mathrm{b}}$ indica-se como paralelo Pascásio $\mathrm{XCVI}, 4^{\mathrm{b}}$. Entre parêntesis vai a indicação de que este passo de Pascásio se encontra reproduzido no Livro III de Rosweydus 199b. De facto, esta última remissão não tinha lugar na segunda coluna, porque aí só têm direito a figurar os números 1 a 40 do Livro III de Rosweydus, ou seja, uma recensão do próprio texto das Commonitiones.

$\mathrm{Na}$ última coluna agrupámos os restantes paralelos latinos: H. M. significa Historia Monachorum, versão de Rufino, cap. XX, linhas finais (cf. PL 21, coll. 387-462); Herac. Par. seguido do capítulo, parágrafo e coluna, envia para a edição do Heraclidis Paradisus reproduzida na Patrologia Latina, vol. 74, coll. 251-342; Philotheus siue Theophiles é o título do Livro IX das Vitae Patrum, com indicação do capítulo e coluna (PL 74, coll. 9-116); Cassianus, Conlat. leva-nos à obra Iohannis Cassiani Conlationes XXIIII, texto crítico estabelecido por M. Petschenig, Vindobonae, 1886. O cap. XXIV,9 é fácil de encontrar porque a edição tem informações concretas ao cimo de cada página ímpar; finalmente Vita Pach. é uma indicação para o capítulo e a coluna da Vita sancti Pachomii reproduzida na PL 73, coll. 227-272. O paralelo de V,8 $8^{\mathrm{b}}$ vai entre parêntesis porque a Vita Pachomii acabada de indicar tem apenas 54 capítulos. É Rosweydus quem coloca neste passo do seu Livro III a remissão: In Vita Pachomii per Metaphr., c. 55, apud Surium, tom. III, Maii 14, texto que não conferimos. 


\section{QUADRO DOS APOTEGMAS DAS COMMONITIONES E DOS SEUS LUGARES PARALELOS}

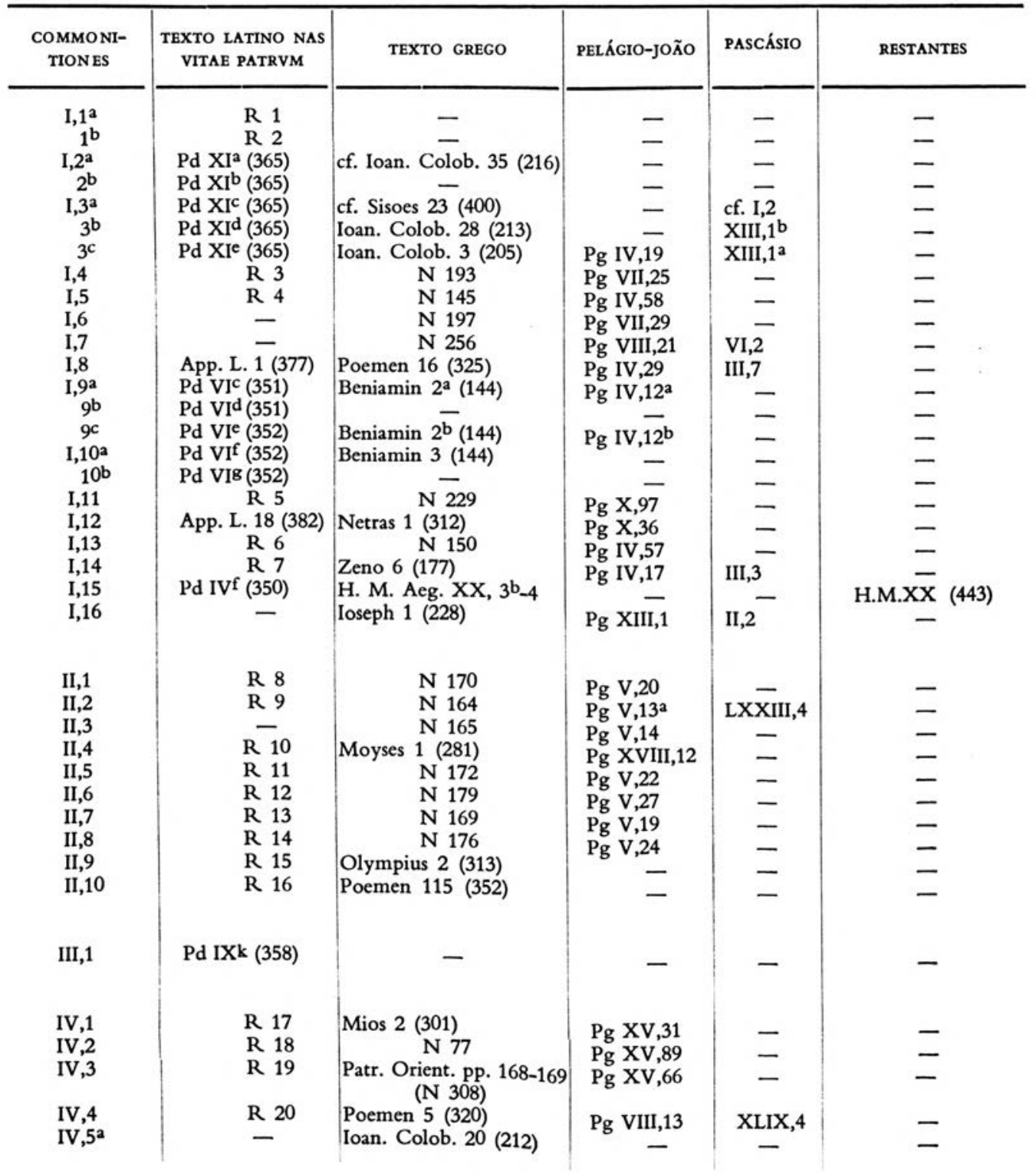




\begin{tabular}{|c|c|c|c|c|c|}
\hline $\begin{array}{l}\text { COMMONI- } \\
\text { TIONES }\end{array}$ & $\begin{array}{l}\text { TEXTO LATINO NAS } \\
\text { VITAE PATRVM }\end{array}$ & TEXTO GREGo & PELÁGIO-JOÃo & PASCÁSIO & RESTANTES \\
\hline IV, $5^{b}$ & - & - & - & - & - \\
\hline IV,6 & - & Poemen 9 (324) & Ioan. IV,32 & $\mathrm{XCII}, 3$ & - \\
\hline IV,7 & R 21 & Agathon 5 (109) & $\mathrm{Pg} \mathrm{X}, 10$ & $\mathrm{XXV}, 2$ & 一 \\
\hline IV, 8 & R 22 & Isaac 1 (224) & - & $\mathrm{XC}, 2$ & - \\
\hline IV,9 & R 23 & N 343 & - & - & - \\
\hline IV, 10 & R 24 & cf. Cassianus 2 (244) & - & - & - \\
\hline IV,11 & R 25 & N 307 & $\mathrm{Pg} X \mathrm{XV}, 65$ & - & - \\
\hline IV,12 & R 26 & (N 451) & - & - & - \\
\hline IV, 13 & R 27 & Ioan. disc. Pauli 1 (240) & $\mathrm{Pg}$ XIV,4 & XLIII,2 & - \\
\hline IV,14 & R 28 & N 27 & Ioan. II,17 & - & - \\
\hline IV, 15 & - & cf. Romaeus 2 (389) & Pg XVI,17 & - & - \\
\hline IV,16 & R 29 & N 328 & $\mathrm{Pg} \mathrm{XV}, 86$ & - & - \\
\hline IV, 17 & R 30 & Gelasius 1 (145) & $\mathrm{Pg}$ XVI,1 & - & - \\
\hline IV, 18 & - & - & $\mathrm{Pg} X V, 52$ & - & - \\
\hline IV, $19^{\mathrm{a}}$ & $\operatorname{Pd~IXj~(356)~}$ & - & - & - & - \\
\hline $19 \mathrm{~b}$ & $\operatorname{Pd} \operatorname{IX}^{j}(357)$ & $\begin{array}{l}\text { Macarius } 23 \text { (272) } \\
\text { (cf. Anub 1 b (129) }\end{array}$ & cf. $\mathrm{Pg} \overline{\mathrm{X}} \mathrm{V}, 11^{\mathrm{b}}$ & $\begin{array}{l}\text { cf.XCVI,4b } \\
(\in \mathrm{IIIR} 199 \mathrm{~b})\end{array}$ & - \\
\hline $19 c$ & $\operatorname{Pd} \mathrm{IX}^{\mathrm{j}}(357)$ & - & - & - & - \\
\hline $\mathrm{v}, 1$ & - & - & - & - & - \\
\hline $\mathrm{V}, 2^{\mathrm{a}}$ & R $31^{\mathrm{a}}$ & - & - & - & - \\
\hline $2^{b}$ & R $31^{\mathrm{b}}$ & Hist. Laus. 39,3 & - & - & Herac. Par. 26b (313) \\
\hline $2^{c}$ & $\mathrm{R} 31^{c}$ & Pior $2^{\mathrm{a}}(373)$ & $\mathrm{Pg}$ IV, $34^{\mathrm{a}}$ & - & - \\
\hline $2^{\mathrm{d}}$ & R $31^{\mathrm{d}}$ & Hist. Laus 39,1-2 & - & - & Herac. Par. 26a (312) \\
\hline $\mathrm{V}, 3$ & R 32 & ${ }^{2}$ & - & - & - \\
\hline $\mathrm{V}, 4$ & Pd XII (366) & - & $\overline{-}$ & - & cf. Philotheus 3 (34) \\
\hline V,5 & R 33 & N 153 & $\mathrm{Pg}$ IV,61 & $\mathrm{XLIX}, 3$ & - \\
\hline $\mathrm{V}, 6$ & App. L. 7 (379) & - & - & - & Cassian. Conl. XXIV, 9 \\
\hline $\mathrm{V}, 7^{2}$ & R $34^{\mathrm{a}}$ & cf. Vita Pach. alt. $28^{\mathrm{a}}$ (147) & - & - & Vita Pach. $28^{\mathrm{a}}$ (248) \\
\hline $7 \mathrm{~b}$ & R $34^{b}$ & cf. Vita Pach. alt. 33 (159) & - & - & Vita Pach. 31 (251) \\
\hline $7 c$ & R $34^{c}$ & - & - & - & - \\
\hline $\mathrm{V}, 8^{\mathrm{a}}$ & R $35^{a}$ & cf. Vit. Pach. alt. $20^{c}(125)$ & - & - & Vita Pach. 20 (241) \\
\hline $8^{b}$ & R 35b & (Halkin, $\mathrm{G}^{1}, 55$ ) & - & - & (Vita Pach. 55) \\
\hline $\mathrm{v}, 9$ & R 36 & N 359 & Ioan. 1,3 & - & - \\
\hline $\mathrm{VI}, \mathbf{1}^{\mathrm{a}}$ & R $37^{a}$ & - & - & - & - \\
\hline $1 \mathrm{~b}$ & R $37 \mathrm{~b}$ & Arsenius $4 \overline{(88)}$ & $\operatorname{Pg} \overline{X V}, 6$ & $\mathrm{XIX}, 2$ & - \\
\hline $\mathrm{VI}, 2$ & R 38 & Arsenius 33 (100) & Pg XVIII,2 & $\mathrm{XCIX}, 2$ & - \\
\hline $\mathrm{VI}, 3^{\mathrm{a}}$ & - & Arsenius $6^{\mathrm{a}}(89)$ & $\operatorname{Pg} x \vee, 7^{a}$ & LXXXIII,1a & - \\
\hline $3^{b}$ & - & $\begin{array}{l}\text { Arsenius } 6^{\mathrm{b}}(89) \\
\text { cf. Euprepius } 7^{\mathrm{b}}(172)\end{array}$ & $\mathrm{Pg} \times V, 7^{\mathrm{b}}$ & LXXXIII, $1 \mathrm{~b}$ & - \\
\hline $3 c$ & - & N 206 & Pg VII,38 & - & - \\
\hline VI,4 & R 39 & Arsenius 18 (92) & $\mathrm{Pg}$ IV,5 & - & - \\
\hline VI,5 & R 40 & $N 148^{b}$ & $\mathrm{Pg} \mathrm{V}, 32^{\mathrm{b}}$ & $\mathrm{X}, 2^{\mathrm{b}}$ & - \\
\hline VI,6 & - & Daniel 6 (156) & $\mathrm{Pg} \times, 18$ & - & - \\
\hline
\end{tabular}




\section{Cap. IV - CONSTITUIÇÃO UNITÁRIA, EXTERNA E INTERNA, DA COLECÇÃO}

O modo como os manuscritos nos transmitem a colecção começada por: Commonitiones sanctorum patrum, não nos deixa dúvidas de que constituía uma unidade, dividida em seis capítulos.

O manuscrito de Viena, Bibl. Nac. da Áustria 433 é o que apresenta melhor divididos os capítulos e o único que no fim do cap. VI escreve: Explicit de beato Arsenio. Poderia perguntar-se se o relato seguinte (incipit uita sancti Frontonii) deveria ou não agregar-se à colecção de apotegmas. Para mais, a mesma vida vem também imediatamente a seguir nos manuscritos de Berlim, Bibl. Nac. Prússia, theol. lat. fol. 275; no de Namur, Museu de Arqueologia 12; no de Londres, Mus. Brit., add. 37400, e nos de Munique, Bibl. Est. da Baviera, lat. 2540 e 23757.

Repare-se, no entanto, que o ms. de Dresda, Bibl. Nac. da Saxónia, A 207, que transmite os seis capítulos completos, marcando nitidamente o princípio do cap. VI, embora não traga o explicit de beato Arsenio, continua imediatamente com outra coleç̧ão de apotegmas, a de Pascásio, sem qualquer referência a Frontónio. O mesmo se passa com os manuscritos de Reims, Bibl. Municipal 1400, e de Basileia, Bibl. Univ. B. V. 2.

Igualmente nos merece consideração o facto de o organizador da «antologia» que é o Livro III de Rosweydus ter reco- 
lhido os seus números 1 a 40 apenas dos seis capítulos iniciados pelas Commonitiones, com exclusão, portanto, da vida de Frontónio.

Finalmente, a Vita sancti Frontonii deve ser excluída desta colecção de apotegmas pela simples razão de pertencer a um género literário diferente: é uma biografia com individualidade própria.

Devemos justificar a constituição, à parte, do cap. III. Quem ler a capitulatio que precede o cap. II nos manuscritos de Viena e Dresda, encontra o enunciado de onze apotegmas, o último dos quais é: $X I-$ Exhortatio sancti Macarii ad monachos... Acontece, porém, que depois de II,10 os mesmos manuscritos de Viena e Dresda, e ainda os de Reims e Berlim, apontam explicitamente o fim deste capítulo II, contra spiritum fornicationis, com um explicit. Por outro lado, estes quatro manuscritos precedem o apotegma seguinte com um incipit exhortatio sancti Macarii ad monachos. Fica assim claramente constituído este capítulo, o qual é formado por um apotegma apenas, uma espécie de homilia. E como vamos ver já, o género homilético era do agrado do elaborador do texto grego desta colecção. (cf. p. 67)

A unidade deste conjunto de apotegmas pode comprovar-se também por argumentos internos, o mais importante dos quais é a igualdade de técnicas de reelaboração dos materiais primitivos, ao longo de toda a obra. Com efeito, o seu autor não se limitou a reunir uma série de episódios edificantes, de acordo com o tema que pretendia tratar. A intenção do seu trabalho caracteriza-se pela escrita em forma de relato e pela apresentação dos exemplos como se estivesse a fazer uma conferência ou homilia a um grupo de monges $\left({ }^{46}\right)$.

$\left({ }^{46}\right)$ Sobre outras caraterísticas do estilo do autor cf. infra pp. 107-120. 
O passo mais evidente, em que o apotegma se transforma em reportagem de quem conta o que pôde observar com os seus próprios olhos, encontra-se em IV,10. Aí se descreve como um ancião, doente, foi durante anos assistido por uma virgem. Não faltaram suspeitas sobre a sua virtude no trato com quem lhe servia de enfermeira. Para testemunhar a sua inocência, o ancião, à hora da morte, recomendou que plantassem o seu bordão sobre a sua sepultura. Se rebentasse e florisse, seria sinal da sua virtude; se continuasse seco poderiam tê-lo como culpado. Após a sua morte o bordão foi plantado e produziu fruto. Muitos vinham admirar o prodígio. E conclui a narrativa num tom de evidente relato da autoria de quem compôs a colecção (IV,10, linhas 41-42): Nam et nos ipsam arbusculam uidimus et benediximus Dominum...

O mesmo aspecto de descrição, tendo em mente uma comunidade de ouvintes, e talvez de leitores, se divisa no princípio de IV, 17, lin. 1-4: Beati abbatis Athanasii laudabilem humilitatis et patientiae uirtutem oportet ut cognoscatis, quatenus admirabilem magnanimitatem et tranquillitatem animae eius considerantes, imitemur exemplo. Está bem explícito que o relato que vai ser feito tem como finalidade a edificação e o exemplo. Os intervenientes são identificados: cognoscatis, imitemur.

Muito semelhante no estilo e intenção é o começo de V,7, lin. 1-2: Etiam de beato Theodoro oportet nos exempla uirtutum proferre (cf. outros exemplos nas pp. 100, 107).

O processo narrativo transforma-se, por vezes, de modo claro, em exortação de tipo homilético, com apóstrofe directa aos ouvintes ou leitores. E que esta característica é uma inovação do autor da Commonitiones prova-o a comparação com os lugares paralelos.

A João Cólobo é atribuída esta observação [28(213)]:

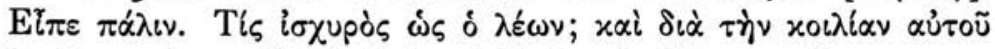

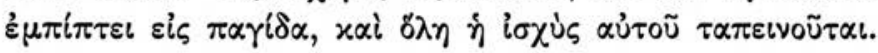


Veja-se agora a tradução própria das Commonitiones a par da de Pascásio:

COMMONITIONES I, $3^{\mathrm{b}}$

Dicebat etiam monendo fratres: Considerate, dilectissimi, quoniam nihil fortius est in bestiis leone et tamen propter uentrem suum cadit in laqueum et illa feralis et magna fortitudo eius humiliatur.
PASCÁsIo XIII, $1^{\mathrm{b}}$ 
perturbá-lo, o monge resolve afastar-se para o Egipto. Assim

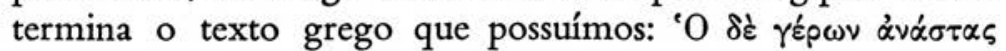

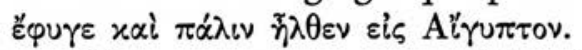

Veja-se agora como o elaborador do livro traduzido por Pelágio se manteve fiel à narrativa existente, ao passo que o autor das Commonitiones ampliou a frase e lhe acrescentou uma exortação.

commonit. Iv,3 (lin. 43-45)

Haec igitur omnia homo Dei secum cogitans, eadem nocte fugit inde et perrexit in Aegyptum ad sanctos patres in eremum. Itaque consideremus, fratres dilectissimi, cum quanta sollicitudine uirtutem humilitatis custodire famulus Dei studuit, ut in caelesti regno aeternam gloriam pro labore sanctae uitae suae, quam propter nomen Domini exercuerat, percipere a Christo Domino mereretur.

Este exemplo mostra claramente como o autor das Commonitiones partia de apotegmas correntes para os adaptar às suas intenções moralizantes. $\mathrm{O}$ acrescento final, com o vocativo fratres dilectissimi, não deixa sequer aos outros a possibilidade de colherem uma lição pessoal. O próprio reelaborador do texto grego teve o cuidado de adaptar a narrativa ao seu capítulo De uirtute humilitatis et patientiae.

Também em IV,5 após uma breve interpretação de um passo da Escritura, se colocam na boca do abade Poemen estas palavras de exortação (lin. 17-20): Oportet nos ergo, filioli, constanter ac fortiter uirtutem humilitatis tenere... Pelo estilo parenético adoptado, não temos dúvida de que se trata de uma inovação introduzida pelo autor das Commonitiones.

A tendência para a homilia torna-se absolutamente clara em dois números em que se dá a palavra a $\mathrm{S}$. Macário. O capítulo III: Exhortatio sancti Macarii ad monachos, é constituído só 
por esta exortação (commonebat... et docebat), feita no melhor estilo parenético, condimentado com a abonação da Sagrada Escritura, no caso presente, duas citações do "Apostolus", modo de designar S. Paulo.

O número IV,19 contém a mais longa exortação de toda a colectânea. $\mathrm{O}$ apotegma atribuído aqui a Macário tem, para a sua parte central, paralelo em Macário 23 (272). Mas enquanto o conselho final de Macário se resume, em grego e nos seus paralelos latinos de Pelágio $\left(\mathrm{XV}, 11^{\mathrm{b}}\right)$ e Pascásio (XCVI, $4^{\mathrm{b}}$ ), a umas cinco linhas de texto (só a meia coluna), o autor das Commonitiones prolonga as palavras de Macário, esboçando um autêntico sermão, incluindo cinco citações explícitas de livros diversos da Sagrada Escritura (cf. IV,19, lin. 39-96).

Este processo de embelezamento dos elementos tradicionais, com o acrescento de pormenores edificantes, é posto em relevo por A.-J. Festugière que cita, explicitamente as «amplificações homiléticas» $\left({ }^{47}\right)$. Damos uma lista dos apotegmas em que foi introduzida uma exortação ou homilia nas pp. 100, 108, 194.

Vemos assim que não só a transmissão manuscrita, mas também a unidade característica de processos deste reelaborador de apotegmas gregos, são favoráveis a que o conjunto seja considerado como uma só obra, na qual o exemplo edificante é por vezes apresentado em forma de relato pessoal e com tendências para a homilia.

(47) A.-J. Festugrère, Le problème littéraire de l'Historia Monachorum in Hermes, Zeitschrift für klassische Philologie LXXXIII (1955), pp. 280-281. 


\section{Cap. V - PROCESSOS DE COMPOSIÇÃO E DE TRADUÇÃO}

\section{1 - PRELIMINARES SOBRE O TEXTO GREGO UTILIZADO}

Neste estudo vamos servir-nos com frequência de um texto grego, pondo-o em paralelo com traduções latinas. Queremos, no entanto, deixar, uma vez mais, bem expresso que estamos convencido de que o grego que possuímos não é exactamente o que serviu de original à tradução das Commonitiones. Embora Pelágio-João, Pascásio e Martinho de Dume se revelem mais próximos do grego que chegou até nós, mesmo estes devem ter utilizado um texto que os autores das colectâneas gregas por vezes retocaram, de acordo com os seus objectivos. Parece-nos lícito supor que as alterações e diferenças fundamentais entre as versões latinas se devem atribuir ao reelaborador grego. Com efeito, a prática constante dos tradutores de apotegmas é produzir uma versão literal, mais ou menos artística, segundo a capacidade de cada um $\left({ }^{48}\right)$.

Apontemos breves exemplos de diferenças entre os diversos textos.

Diz-se que Arsénio, quando se retirou para o deserto, procurava andar vestido de modo mais modesto que todos os

(48) Cf. infra pp. 158-163. 
demais. Servimo-nos do texto grego que se encontra na Patrologia Graeca, LXV:

ARSENIVS 4 (88)

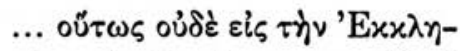

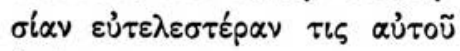

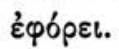

$$
\text { PELÁGIO Xv,6 }
$$

... ita et dum in conuersatione moraretur, nemo eo uilius tegebatur.
PASCÁsıo $\mathrm{xIX}, 2$

... ita constitutus in eremo uiliora uestimenta uti prae ceteris festinabat.

соммоNIт. vi,1 (lin. 10-12)

... ita postmodum in eremo Sceti degens, studebat ut $a b$ omnibus monachis uiliora et despecta uestimenta haberet.

Verifica-se que nenhum dos tradutores tem o equivalente

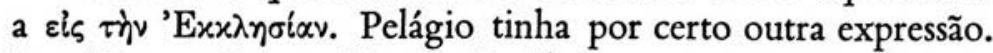
Pascásio e as Commonitiones coincidem quase: constitutus in eremo (Pascásio); in eremo Sceti degens (Commonitiones). Apesar disso este último ainda acrescenta: Sceti. Cremos, pois, que para esta breve expressão havia quatro textos gregos ligeiramente diferentes. Observe-se, desde já, que, no geral, as Commonitiones são mais extensas e ricas em pormenores.

Podem assinalar-se casos em que o grego à nossa disposição contém omissões. João Cólobo dizia que, quando um rei quer tomar uma cidade, primeiro corta-lhe a água e a alimentação. E continua:

IOAN. COLOB. 3 (205)

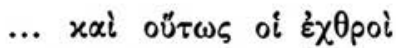

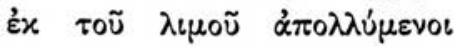

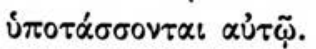

PELÁGIO IV,19

... et fame periclitantes tunc subiciuntur ei. 
V - PROCESSOS DE COMPOSIÇÃO E TRADUÇÃO 73

PASCÁSIO XIII, $1^{2}$

... et ita inimici eius fame compulsi subiciunt se regno eius. commonit. I, $3^{c}$ (lin. 11-13)

... et ita fame ac penuriae necessitate contriti humiliantur et subiciuntur imperio eius.

Pascásio é o mais literal. Note-se, no entanto, a palavra regno, que não está no grego nem em Pelágio; mas devia constar de outra versão grega, pois as Commonitiones têm o seu equivalente, imperio. Este é um dos pormenores que nos levam a pensar que os tradutores de apotegmas eram bastante fiéis ao texto grego que tinham diante de si. Muitos exemplos apresentados a seguir confirmar-nos-ão neste pensamento.

POEMEN 9 (324)

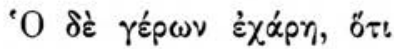

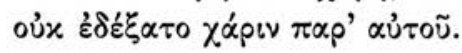

PASCÁSIO $\mathrm{xCII}, 3$

Ille autem grauisus quod ei ad primum sermonem non pracstitisset, reuersus est.
JOÃo IV,32

Gauisus est autem senex, quia non obtinuit apud iudicem gratiam, quam postulauit, et sic rediit in cellam suam.

commonIT. Iv,6 (lin. 28-30)

Haec autem cum audisset beatus Poemen, laetificatus est ualde quod non praestiterat ei iudex quae postulauerat et reuersus est in cellulam suam.

A primeira observação que desejamos fazer diz respeito a uma lacuna certa do nosso texto grego. Podemos afirmar com segurança que as redacções correntes no século Vİ tinham o grego correspondente a $e$ voltou para a sua cela, porque esta conclusão aparece quase pelas mesmas palavras nas três tradu- 
ções latinas. Em segundo lugar, observe-se que o redactor grego das Commonitiones alongou a frase final: introduziu-lhe uma expressão de abertura; reforçou o verbo com ualde;

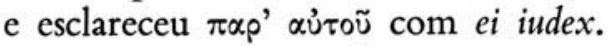

Outras omissões do texto grego que possuímos se poderiam assinalar. Brevemente, diremos que a frase inicial de Isaac 1 (224) deveria terminar com a menção de Scétis, pois ela vem em Pascásio XC,2 e nas Commonitiones IV,8. Quase a terminar o primeiro apotegma de João, discípulo de Paulo

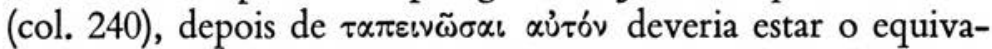
lente a Pascásio (XLIII,2): humiliare eum, ne elatus fieret, e a Commonitiones (IV,13, lin. 25-26): humiliare sensum eius, ne extolleret se in cogitationibus discipulus eius. Não deixe de se registar, todavia, que Pelágio $(\mathrm{XIV}, 4)$ também conserva apenas: humiliare illum. Aqui podemos concluir que já o fundo grego tinha versões diferentes $\left({ }^{49}\right)$. E uma vez mais se verifica que o texto grego das Commonitiones deveria ser o mais extenso, por obra do reelaborador.

Pelo contrário há passos no grego à nossa disposição que não têm equivalente nas Commonitiones, mas que são autênticos, pois encontram-se confirmados por outra tradução latina paralela.

Assim, quando nas Commonitiones (1,12, lin. 10) o abade Nítera responde: ibi eremus erat et secreta uita ac paupertas, o para-

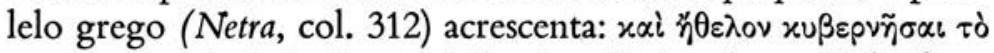

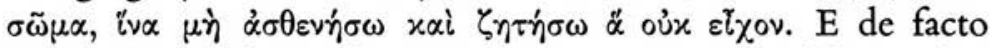
Pelágio $(\mathrm{X}, 36)$ depois de paupertas junta: propterea nolebam gubernare corpus meum, ne infirmarer et quaererem quod non habebam.

(49) Quando uma análise filológica necessita de descer a pormenores deste género sentimos a falta de um texto crítico tanto dos apotegmas gregos, como da tradução de Pelágio-João. Tal trabalho, porém, aguarda ainda filólogos pacientes... As conclusões só serão, pois, válidas na medida em que os textos em confronto correspondam ao original. 
Poderíamos perguntar-nos porque rejeitou o reelaborador grego este inciso, que descreve um aspecto da ascética monástica.

A maior omissão de texto grego encontra-se em I,16 das Commonitiones, a que correspondem Ioseph 1 (228), Pelágio XIII,1 e Pascásio II,2. Todo o passo que descreve o procedimento alegórico do abade José, o qual mudava de vestuário e tirava daí uma lição, foi eliminado, isto é, umas dezassete linhas do nosso texto grego. Aqui a explicação pode estar no facto de ao reelaborador grego das Commonitiones não lhe interessarem tanto pormenores descritivos deste género, mas sobretudo a lição moral. E esta aproveita-a ele totalmente, dando-lhe mesmo algum desenvolvimento.

Nas Commonitiones II,7, lin. 12, falta a oração, em discurso directo, que o ancião dirigiu a Deus, pedindo lhe revelasse por que não eram ouvidas as suas preces. Que ela existia na tradição apotegmática prova-o a sua presença em Nau 169 e em Pelágio V,19.

Ao terminar em IV,13, lin. 26-27, a historieta do discípulo que por obediência agarrou uma leoa, não diz que o seu mestre, por desprezo, classificou a fera de $x \tilde{v} v \alpha \sigma \alpha \lambda o^{\prime}$, como vem $\mathrm{cm}$ Ioannes discipulus Pauli, col. 240, e nos paralclos Pelágio XIV,4 (canem fatuum) e Pascásio XLIII,2 (istum canem miserum). Note-se ainda uma variante certamente já da tradição grega. O texto que possuímos fala de uma ư $\alpha \iota \nu \alpha$, e Pascásio traduz por hyaena; mas Pelágio e as Commonitiones citam a fera como leaena. De Pelágio não temos ainda um texto crítico. Quanto às Commonitiones não há variantes nos manuscritos, sendo portanto de supor que já o seu original tinha leaena e não hyaena.

No princípio de IV,16, lin. 1-9, as Commonitiones mencionam apenas acusações vagas contra o irmão Eulálio. Mas o grego equivalente, em Nau 328, além das generalidades aponta

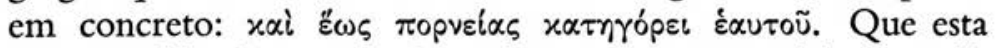
acusação falsa fazia parte da tradição vê-se no paralelo de Pelágio XV,86: ita ut se etiam de fornicatione accusaret. Registe-se desde já que o apotegma em grego e em Pelágio é anónimo 


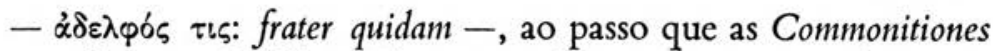
o atribuem a Eulálio. Há quem veja neste pormenor do nome um sinal de que as Commonitiones remontam a uma fonte mais rigorosa $\left({ }^{50}\right)$.

No final da primeira frase de VI, 4 , lin. 3 das Commonitiones falta a indicação da natureza e horário de trabalho do abade Arsénio. O grego (Arsenius 18 [92]) diz: દ̌ $\pi \lambda \varepsilon x \varepsilon \gamma \grave{\alpha} \rho$

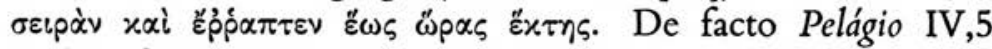
traduz: faciebat quoque plectam de ipsis palmis et cusabat usque ad horam sextam.

Estas observações são suficientes para não atribuirmos a qualquer tradutor de apotegmas toda a responsabilidade das diferenças existentes entre o grego e o latim. Em princípio, podemos supor que a uma tradução latina com alterações correspondia um texto grego diferente do actual. Cada caso deverá, no entanto, ser examinado de per si.

\section{2 - TRADUÇÃO LITERAL (OU QUASE)}

Não podemos ter dúvidas de que as Commonitiones foram originariamente escritas em grego e depois vertidas para o latim, porque em numerosos passos o autor conservou quase sem alteração a versão grega corrente do apotegma. Apresentamos dois exemplos por extenso e apontamos outros que poderiam ser estudados.

Arsénio, antes de se fazer monge, tinha vivido no palácio de Constantinopla e recebera formação literária. Um dia, um seu amigo de juventude, ao vê-lo pedir direç̧ão espiritual a um monge egípcio, sem cultura, interpela-o. Eis a pergunta do amigo e a resposta de Arsénio no grego que temos e em duas traduções latinas independentes.

(50) Cf. infra pp. 95, 156, 167; e p. 83 para Pascásio. 


\section{V - PROCESSOS DE COMPOSIÇÃO E TRADUÇÃO 77}

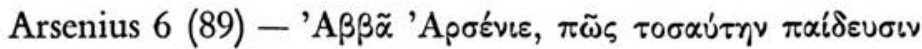

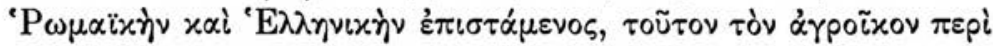

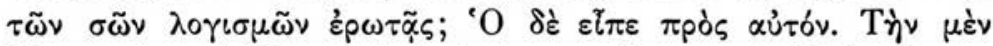

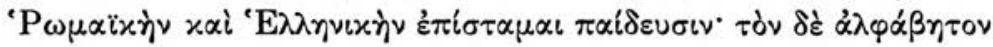

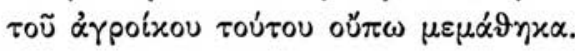

commonIt. vi,3 (lin. 5-11)

Valde admiror, pater, quia cum tanta eruditione perfecte studeris tam graecae quam latinae scientiae, cur $a b$ isto inerudito et idiota homine requiras quae ad salutem animae conueniunt? Respondens autem beatus Arsenius ait: Licet tam graece quam latine, ut dicis, eruditus sim tamen alphabetum uerae scientiae huius aegyptii non didici.

\section{PASCÁsIo LXXXIII,1}

Quemadmodum tu tantarum litterarum tam in graeco quam in latino sermone doctrina adeptus, ab hoc rustico interrogare aliquid non fastidis? Cui Arsenius: Graecas quidem me litteras ac latinas plurimas legisse commemini; istius autem senis adhuc alphabetum me nec attigisse profiteor.

Pode dizer-se que ambas as traduções são literais. A de Pascásio apresenta traços da sua conhecida concisão; a das Commonitiones é um pouco mais ampla: hendíades em inerudito et idiota, especificação do alfabeto uerae scientiae. A versão de Pelágio em XV,7 mantém-se igualmente fiel ao grego que possuímos.

Vamos reproduzir agora, por completo, um pequeno apotegma.

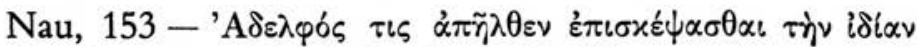

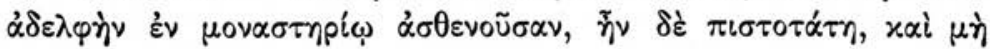

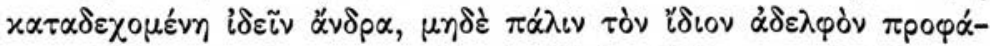

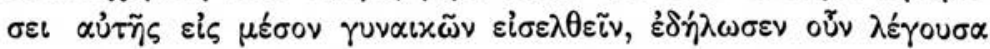




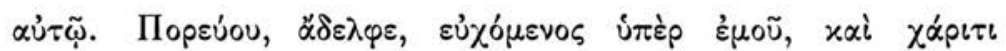

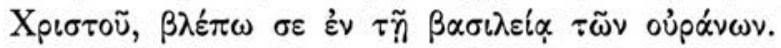

COMMONITIONES $\mathrm{v}, 5$

Sed et alius quidam monachus abiit ad sororem suam ut uisitaret eam. Audierat enim eam aegrotantem in monasterio. Erat enim ipsa famula Dei nominata in sancta conuersatione. Itaque non acquieuit illa suscipere et uidere fratrem suum, ut non per occasionem eius ingrederetur in monasterium feminarum. Sed mandauit ei dicens: Vade, domine frater, et ora pro me. Praestante enim gratia Dei et Saluatoris nostri, uidebo te in futuro saeculo, in regno Domini nostri Iesu Christi.

A tradução de Pascásio pode considerar-se absolutamente literal; a das Commonitiones também não introduz nenhum elemento novo. Apenas se poderá observar que a redacção é um pouco alargada, à custa de expressões correntes no estilo monástico. É o caso das perífrases que traduzem $\pi \iota \sigma \tau 0 \tau \dot{\alpha} \tau \eta$,

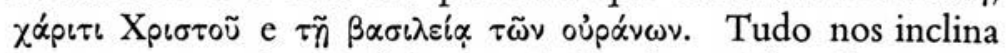
a pensar que o desenvolvimento é obra do reelaborador grego.

Outros exemplos de tradução quase literal podem examinar-se em II,5; II,6; IV,8; VI,1 e VI,2. Oportunamente (pp. 167, 195) observaremos mais casos de literalismo $\left({ }^{51}\right)$.

(51) Cf. teoria e exemplos apontados na p. 57. 


\section{3- BREVES RETOQUES E PEQUENAS AMPLIAÇÕES DO TEXTO}

Por vezes as Commonitiones apresentam-nos um texto bastante aproximado do grego, mas vê-se que a redacção original foi levemente retocada e ampliada. Vejamos o tratamento dado ao princípio de um apotegma.

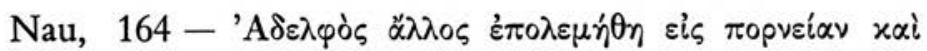

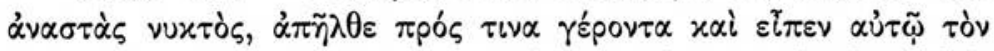

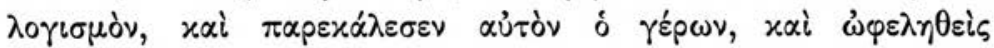

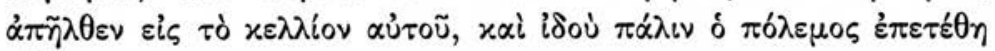

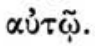

commonIt. II,2 (lin. 1-9)

Et alius etiam frater uehementer impugnabatur $a b$ immundo spiritu fornicationis. Exsurgens autem nocte, abiit ad quendam sanctum probatum in uirtutibus seniorem, confessus est ei quam patiebatur impugnationem a spiritu fornicationis. Haec cum audisset senior consolabatur eum spiritalibus nerbis de nirtute patientiae dicens, sicut scriptum est: "Viriliter agite et confortetur cor uestium, omnes qui speratis in Dominon. Reuersusque est frater ad cellulam suam et ecce iterum impugnatio insistebat ei.
PASCÁSIO LXXIII,4

Quidam frater impugnatus est a cogitatione et exsurgens per noctem profectus est ad quendam senem et dixit ei cogitationem suam. Quem senex monuit et dimisit. Reuersus ergo in cella sua, iterum coepit impugnari. 
A tradução de Pascásio é literal, substituindo apenas sí $\pi$ ropveíav por a cogitatione, de acordo com o seu conhecido sentido de recato $\left({ }^{52}\right)$. O latim das Commonitiones revela que o texto grego foi reforçado com o equivalente às palavras que sublinhámos na tradução, merecendo especial nota as ampliações próprias da linguagem monástica: sanctum probatum in uirtutibus e spiritalibus uerbis de virtute patientiae dicens, seguindo-se uma citação da Sagrada Escritura.

O texto grego de Pascásio e das Commonitiones não deveria ter o particípio $\omega \varphi \varepsilon \lambda \eta \theta \varepsilon i \varsigma$, porque ambos o omitem na tradução. Que ele fazia parte de uma redacção grega prova-o, porém, o seu equivalente em Pelágio V,13: ex qua consolatione proficiens.

Outro exemplo com um acrescento de tipo diferente:

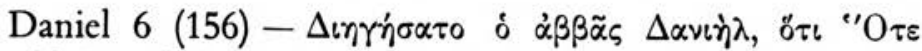

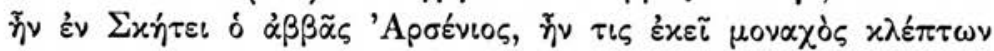

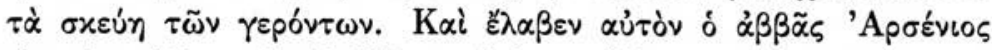

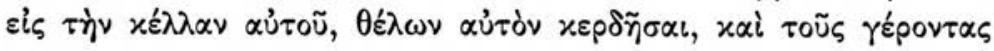

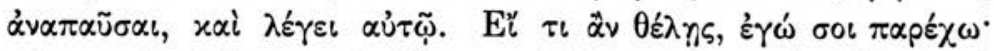

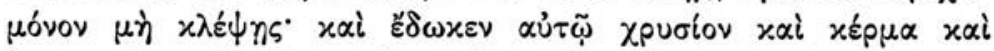

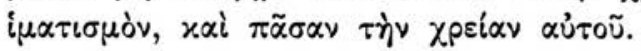

commonit. vi,6 (lin. 1-9)

Dicebat abbas Daniel:Quia dum in eremo Sceti esset beatus Arsenius, erat ibi quidam, schema quidem, monachus et furabatur de cella monachorum quodcumque inuenire potuisset. Beatus autem Arsenius festinabat saluare ani-

\section{PELÁGIO $\mathrm{x}, 18$}

(52) Cf. Pascásio de Dume..., t. I, pp. 108-118. 
mam eius, fecitque ei cellulam prope suam cellulam et dixit ei: Si quid necessarium habes, ego tibi praebeo. Tantum cessa et noli furari et condemnare animam tuam in aeternum ignem gehennae in iudicio Dei. Misit autem ad quendam amicum suum et accepit solidos et nummos et uestimenta et dedit ei. suam et dicit ei: Quidquid uis ego tibi dabo, tantum non rapias; et dedit ei aurum et nummos et rescellas, et omne quod in responso suo habebat dedit ei.

A tradução de Pelágio pode considerar-se fiel ao grego. A das Commonitiones parte do mesmo fundo comum, mas tinha por certo um texto grego reelaborado, onde foram suprimidas

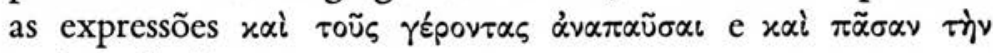

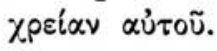

Em contrapartida, o organizador da colectânea introduziu - equivalente a schema quidem (monge só de hábito), de cella e três expressões que lhe pareceram tornar o episódio mais aceitável: em vez de levar o monge para a sua cela, Arsénio ter-lhe-ia construído uma própria, junto da sua; à exortação acrescenta um motivo de ordem espiritual e escatológica; e pretende justificar a pobreza do santo, explicando que recorreu a um amigo.

Quanto a nós, não deve subsistir qualquer dúvida de que as omissões e os três principais acrescentos são obra do reelaborador grego e não iniciativa do tradutor. $O$ apelo para $o$ juizo de Deus e para o castigo do inferno é um tópico do autor grego, como se observará em vários outros apotegmas, nos quais (à excepção de um só), como veremos oportunamente $\left({ }^{53}\right)$, podemos verificar que também tal tópico se não encontrava na redacção primitiva dos apotegmas.

(53) Cf. infra, pp. 110-113. 
Vejamos agora num só episódio as três características até aqui já observadas.

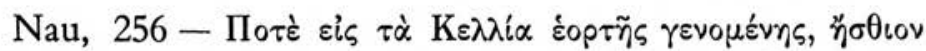

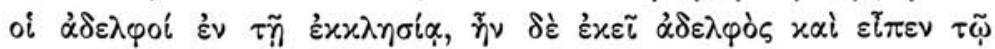

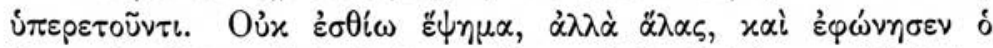

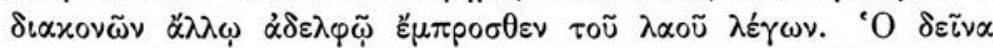

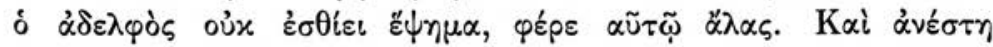

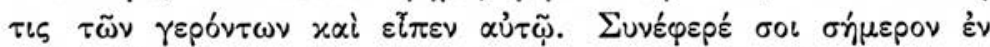

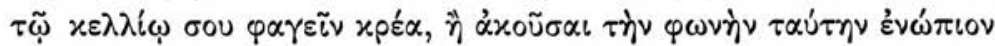
$\tau \circ \tilde{~} \lambda \alpha \circ \tilde{u}$.

COMMONITIONES I,7

Dicebant etiam fratres de quodam fratre habitante in loco qui dicitur Cellia: Contigit autem ut in die festo omnes monachi in ecclesiam, quae est in eremo, conuenirent. Praeparatus est autem eis omnibus cibus coctus, ut post completas missas ibi reficerent omnes fratres. Erat autem ibi quidam frater et cum sedissent ad mensas uocauit fratrem, qui eis ministrabat, et dixit ei: Defer mihi salem, ut cum pane possim accipere. Tunc clamauit ille, qui ministrabat, alio fratri, audientibus cunctis, dicens: Da huic modicum salis ut possit hic frater cum pane ede$r e$, quia coctum cibum non accipit. Tunc surrexit $a$ men-

\section{PASCÁsIO VI,2}

Facta autem congregatione in ecclesia, cum esset festiuitas et ceteri comederent, unus ministranti dicit: Quia nihil coctum comedo, sal mihi deferri praecipito. Quo uerbo minister audito, cum clamore audientibus ceteris cunctis, alii imperauit dicens: Quoniam coctum frater ille nihil comedit, parum illi salis afferto. Tunc beatus Theodorus dixit: Oportuit te, inquit, carnes in cella tua comedere quam hunc praesentibus omnibus audire sermonem. 
$s a$ unus ex senioribus et dixit ei: Oportebat te, frater, in cella tua hodie carnem comedere quam istam talem uocem de tua abstinentia praesentibus cunctis dicere fratribus. An ignoras quoniam, si qui propter laudem et gloriam palam faciunt abstinentiam suam, omnem laborem abstinentiae suae perdunt et non percipiunt mercedem a Domino, sed magis culpabiles inueniuntur in conspectu eius?

Pascásio tinha, por certo, um grego muito próximo do nosso. Pode dizer-se que apenas omite o lugar onde a cena

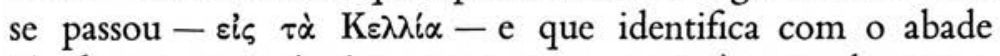
Teodoro o ancião (anónimo nas outras versões) que se levantou.

A redacção das Commonitiones não contém elementos essenciais novos. Mas, a par de expressões que foram mantidas intactas e de que se dá uma tradução literal, o apotegma foi retocado, adaptando-se-lhe uma introdução, descrevendo-se melhor a refeição e as suas circunstâncias de lugar e de tempo e sobretudo, além de outros pormenores, a reprimenda do ancião foi desenvolvida. Não cremos que um tradutor fizesse por sua conta todo este trabalho de reelaboração.

\section{4 - LONGO DESENVOLVIMENTO, INCLUINDO CITAÇÕES BÍBLICAS}

A característica mais importante do reelaborador grego das Commonitiones talvez seja a sua tendência para desenvolver os aspectos morais do apotegma, passando a escrever em tom de lição ou homilia. 
Um caso típico encontra-se em $\mathrm{II}, 7$, onde a um ancião, que rogava a Deus a protecção para um irmão em crise moral, veio a ser revelado que a culpa estava no próprio irmão que, em vez de resistir, se deleitava nas tentações. Damos o final do apotegma para se ver como, partindo de uma transcrição literal, o autor das Commonitiones constrói uma lição a seu gosto.

$$
\text { NAU, } 169
$$

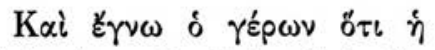

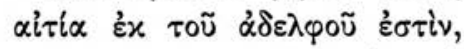

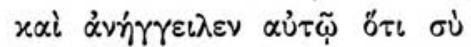

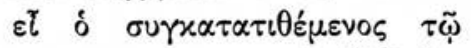

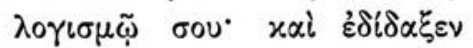

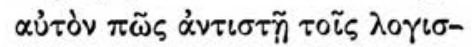

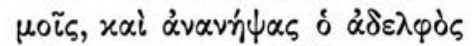

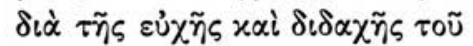

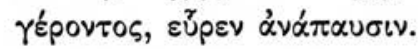

PELÁGIO v,19

Et agnouit senex quia causa magis ab eodem fratre esset, et annuntiauit ei dicens: Tu consentis cogitationi tuae. Et docuit eum quomodo talibus cogitationibus deberet obsistere. Et respirans frater per doctrinam senis illius et orationem, inuenit requiem a tentatione sua.

\section{COMMONITIONES II,7 (lin. 22-30)}

Cognouit autem quia culpa et negligentia illius monachi erat, ut non exaudirentur orationes eius. Et tunc dixit ei senior: Quia tua culpa est, frater, quia condelectaris cogitationibus malis. Impossibile est enim discedere a te spiritum fornicationis immundum, aliis orantibus et Deum pro te deprecantibus, nisi et tu ipse laborem assumas in ieiuniis et orationibus et uigiliis multis, cum gemitu deprecans ut misericordiam suam et adiutorium gratiae suae praebeat tibi Dominus Christus, ut possis resistere malis cogitationibus...

E a exortação continua por mais 13 linhas do nosso texto crítico. Tudo isto, apresentado sob a forma de discurso directo, temo-lo como uma interpretação edificante destas breves pala- 


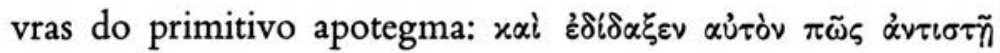

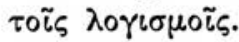

A última frase, breve conclusão do episódio em grego c em Pelágio, é tambén desenvolvida com a menção de práticas ascéticas (II,7, lin. 43-47):

Et haec audiens frater, compunctus est corde et cum omni sollicitudine, secundum doctrinam senioris, tam in ieiuniis quam in orationibus et uigiliis, semetipsum afflixit et meruit misericordiam Domini. Et recessit ab eo spiritus immundae passionis.

Alguns acrescentos que supomos serem do reelaborador das Commonitiones são ilustrados com passos da Sagrada Escritura. Advirtamos que mesmo os apotegmas mais antigos por vezes citam a Bíblia. Quando ocorriam, o autor incluiu também habitualmente tais citações. $\mathrm{O}$ que está agora em causa é o reforço bíblico introduzido pelo novo redactor grego. Agatão, acusado de vários defeitos, que não possuía, por humildade não se defendia, excepto quando lhe chamaram herético. Então reagiu energicamente. Tendo-lhe os irmãos acusadores pedido uma explicação sobre a diferença de reacção, ele respondeu:

AGATHON 5 (109)

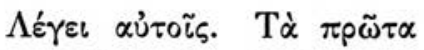

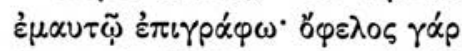

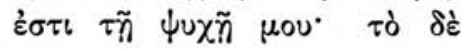

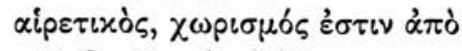

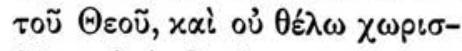
$\theta \tilde{\eta \eta \nu \alpha \iota ~ \alpha ̇ \pi o ̀ ~ \Theta \varepsilon o u ̃ . ~}$

\section{PASCÁsIo $\mathrm{xxv}, 2$}

Dicit eis: Priora quae dixistis adscribo mihi pro iuuamine animae meae; haereticum autem esse diuidi est a Deo et nolo ab eo separari.

COMMONITIONES IV,7 (lin. 27-37)

Dicit eis senior: Illas priores culpas atque peccata propter humilitatem sustinui, ut peccatorem me esse crederetis. Nouimus 
enim quia si custodiatur humilitatis uirtus magna, salus est animae. Nam Dominus et Saluator noster Iesus Christus, cum ei iudaei multas contumelias et conuicia irrogassent, patienter cuncta tolerauit, ut nobis humilitatis praeberet exempla. Immissi etiam falsi testes, multa aduersus eum falsa dixerunt; et usque ad mortem crucis patienter cuncta sustinuit. Ita enim et apostolus Petrus praedicat dicens: "Christus passus est pro nobis, nobis relinquens exemplum ut sequamur uestigia eius".

E a explicação continua, desenvolvendo também o segundo membro da resposta, em forma de autêntica homilia, como se vê pelo típico final (lin. 45-47):

... reconiungitur Deo uero Creatori ac Saluatori nostro Christo, qui est in Patre Filius semper cum Sancto Spiritu. Ipsi gloria in saecula saeculorum. Amen.

A visão de Arsénio, incluída pelas Commonitiones em VI,2, sobre o modo estulto como muitos homens procedem, é quase toda transposta, sem alterações, das antigas versões de apotegmas, enquanto se trata de narrar factos. Quando, porém, se começa a dar uma interpretação moral de cada categoria de pessoas, o reelaborador grego deixou expandir o seu gosto pela divagação apoiada pela Bíblia. Damos apenas a primeira interpretação, mas, como se poderá ver, também a terceira classe de homens é explicada com o recurso à Escritura.

ARSENIVS 33 (101)

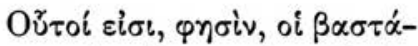

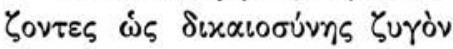
$\mu \varepsilon \tau \dot{\alpha}$ ú $\pi \varepsilon p \eta \varphi \alpha v i \alpha \varsigma, \quad x \alpha i$ oủx

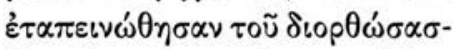

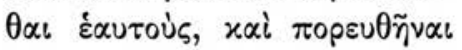

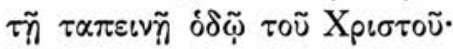

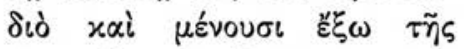

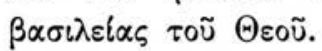

PELÁGIO XVIII,2

Hi sunt qui portant uelut iustitiae cum superbia iugum et humiliati non sunt ut corrigant se et ambulent humiliter in uia Christi, propter quod et remanent foris a regno Dei. 
COMMONITIONES VI,2 (lin. 23-28)

Hi qui lignum portant, hi sunt qui habent iugum sanctum monachorum, sed iustificantes semetipsos in corde suo cum exaltatione superbiae, non humiliantur inuicem. Noluerunt enim ambulare in humilitatis uia Domini Saluatoris nostri Iesu Christi qui dixit: "Discite a me quia mitis sum et humilis corde et inuenietis requiem animabus uestris».

Pode ver-se uma lista de 17 apotegmas com acrescentos bíblicos na p. 100. Para se ter uma ideia do uso frequente das Escrituras em todas as Commonitiones, cf. o aparato bíblico que vai no rodapé do nosso texto crítico.

\section{5 - ALTERAÇÃO DO SENTIDO PRIMITIVO}

Quanto registámos até agora corresponde à ideia fundamental expressa pela antiga versão dos apotegmas. Podem, no entanto, apontar-se alguns exemplos em que o reelaborador das Commonitiones abandonou o texto primitivo e redigiu conforme lhe pareceu mais propriado.

O abade Nítera, depois de ter recebido a sagração episcopal, levava ainda uma vida mais austera do que quando vivia no deserto. Tendo-lhe o seu discípulo perguntado qual a razão deste modo de proceder, justificou-se, dizendo:

NETRA, col. 312

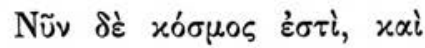

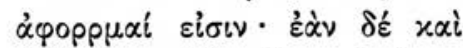

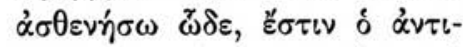

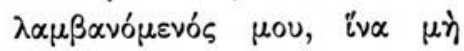

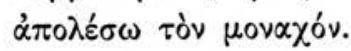

PELÁGIO $\mathbf{x}, 36$

Nunc autem hic saeculum est, et occasiones sunt excedendi plurimae; et si in infirmitatem incurrero, sunt hic qui succurrant, ne propositum monachi perdam. 
COMMONITIONES I,12 (lin. 10-19)

Nunc autem egressi de eremo cum saecularibus hominibus conuersamur et multae et uariae occasiones nobis occurunt et ideo timeo ne in fine uitae meae in aliqua occasione offendamus Dominum. Si enim sanctus apostolus Paulus, qui Christum in se loquentem habebat et qui tantas uirtutes animi possidebat ut usque ad tertium caelum adhuc in corpore positus ascenderet, tamen dicebat: "Macero corpus meum et seruituti subicio, ne forsitan aliis praedicans ipse reprobus inuenian, - quid nos humiles et peccatores oportet facere?

O autor desenvolveu apenas a primeira parte da resposta, acrescentando-lhe um pensamento novo, ilustrado com uma citação bíblica. O final do texto ficou por traduzir. Ao que parece a declaração de segurança episcopal não interessava aos propósitos edificantes do autor...

A tendência para a alteração do sentido original verifica-se também em VI,2. Após ter sido explicada espiritualmente cada uma das três classes de homens que procedem insensatamente, concluía já a redacção primitiva:

Arsenius 33 (101) - X

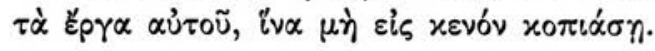

соммоNIт. vi,2 (lin. 38-39)

PELÁGIO XVIII,2

Oportet ergo hominem, sicut dicit apostolus, "cum timore et tremore salutem suam operariv.
Quapropter conuenit omnem hominem sobrium esse in considerandis operibus suis, ne in uanum uideatur sustinere labores. 
Não cremos que os acrescentos e alterações acabadas de apresentar se devam atribuir ao tradutor. A explicação deve remontar mais longe-ao autor da nova colectânea de apotegmas $\left({ }^{54}\right)$.

\section{6-QUALIDADES DO TRADUTOR}

A comparação entre o texto grego que possuímos e a tradução latina das Commonitiones já nos fez concluir que, embora haja vários passos em que ambas as redacções se correspondem literalmente (ou quase), à grande maioria dos apotegmas da nova coleç̧ão apresenta uma versão reelaborada, com explicações e acrescentos que por vezes atingem grande extensão. Sendo assim, é com reservas que se aborda o tema das qualidades do tradutor, partindo da comparação do grego com o latim, pois não podemos ter a certeza de que o texto grego não foi alterado. Por isso, não nos alongaremos agora neste estudo, uma vez que não podemos garantir que as trocas entre discurso directo e indirecto, as hendíades, o tom retórico, a própria dificuldade de compreensão, não pertenceriam jà à redacção grega, reelaborada pelo autor das Commonitiones.

1 - Anotemos primeiro uma passagem do discurso directo para o indirecto.

$$
\text { NAU, } 176
$$

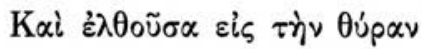

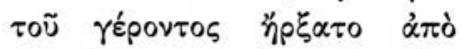

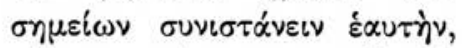

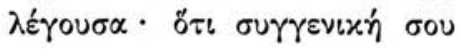

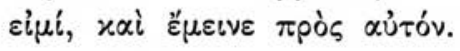

PELÁGIO v,24

Quae cum uenisset ad ianuam senis, coepit signis indicare seipsam, dicens: Ego illa parens tua, et mansit apud eum.

(54) Adiante procuraremos penetrar mais fundo no trabalho e formação do autor grego das Commonitiones, pp. 103-120. 
Quo inuento, ingressa est cellulam eius, asserens ei quia ex genere et parentela eius fuisset, mansitque ibi apud eum.

A tradução de Pelágio é absolutamente literal; a das Commonitiones, além da mudança do discurso directo, apresenta a primeira parte também reelaborada.

2 - Mas pode registar-se também o fenómeno contrário. Repare-se neste começo:

IOSEPH 1 (228)

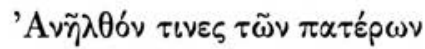

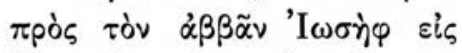

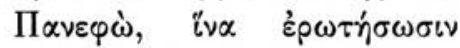

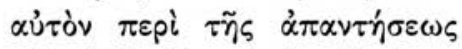

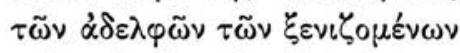

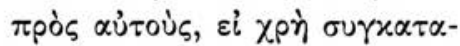

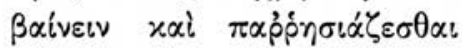

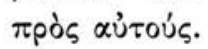

PASCÁSIO II,2

Quidam de patribus ad abbatem Ioseph in Panepho perrexerunt ut eum requirerent de susceptione fratrum, si licet illo tempore uel fiduciam cum is uel laetitiam habere.

COMMONITIONES I,16 (lin. 1-5)

Quidam fratrum pergentes ad sanctum abbatem Ioseph, uirum perfectum, habitantem in Panepho, interrogauerunt eum dicentes: Quomodo oportet nos suscipere aduenientes ad uisitandum nos peregrinos, siue spiritales fratres, si oportet, inquiunt, propter eos relaxare regulam abstinentiae nostrae?

No grego e em Pascásio a construção sintáctica é a típica das interrogativas indirectas. Nas Commonitiones há um primeiro membro, introduzido por dicentes, claramente directo; mas 


\section{V - PROCESSOS DE COMPOSIÇÃO E TRADUÇÃO 91}

também o segundo membro, apesar de iniciado por si, tem a construção verbal das interrogativas directas. Sublinhámos acima ainda dois atributos e um aposto. É de supor que fossem introduzidos pelo reelaborador grego.

3-O discurso directo é frequentemente iniciado nos tradutores latinos por quia, quoniam e nas Commonitiones muitas vezes também por quomodo, conjunções que no geral são o equivalente à construção grega começada por ö $\tau$. Curioso será observar que a rotina pode ter contribuído para o uso de quia mesmo quando em grego se omitiu ö $\tau$. Um exemplo:

SISOES $23(400)$

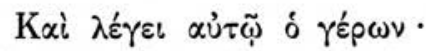

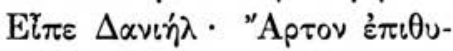

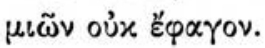

PASCÁsIo I,2

\section{COMMONITIONES I,32 (lin. 2-4)}

...et respondit eis dicens: Quia Daniel propheta dixit: «Panem in concupiscentia non comedi».

4 - Já observámos atrás (p. 68) a tradução de uma palavra grega por duas latinas que se reforçam mutuamente. Hendíades deste tipo encontram-se com frequência nas Commonitiones. Eis dois casos num só breve parágrafo:

IOANNES COLOBVS 3 (205)

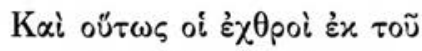
$\lambda \iota \mu \circ \tilde{\alpha} \dot{\alpha} \pi \circ \lambda \lambda \dot{u} \mu \varepsilon v o \iota$ i் $\pi \circ \tau \dot{\alpha} \sigma-$

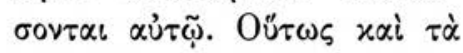

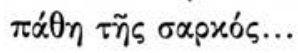

PELÁGIO IV,19

Et ita inimici eius fame compulsi subiciunt se regno eius. Ita et passiones carnales... 


\section{COMMONITIONES I,3c (lin. 11-13)}

Et ita fame ac penuriae necessitate contriti humiliantur et subiciuntur imperio eius. Similiter etiam passiones ac uitia corporis nostri...

5 - Dum modo geral, a impressão que colhe o leitor das Commonitiones é a de que o tradutor latino escrevia bem, de modo fluente, sabendo dar amplitude e harmonia à frase. Poderíamos até atribuir-lhe um certo gosto pela retórica se pudéssemos garantir que o seu texto grego era igual ao nosso $\left({ }^{55}\right)$. Veja-se este desenvolvimento enfático (talvez exigido por uma redaç̧ão grega reelaborada):

POEMEN 5 (320)

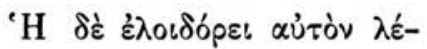

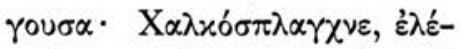

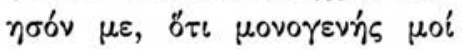

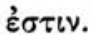

\section{PASCÁSIO XIIX, 4}

At illa foris clamabat dicens: Ferree, miserere mei quoniam unigenitus mihi est.

\section{COMMONITIONES IV,4 (lin. 31-35)}

Tunc illa coepit maledicere ei ac dicere: Durissime et impiissime et ferrea uiscera gerens, quomodo te tantus dolor fletus mei non flectit ad misericordiam, quomodo ipsum unicum filium habeo quem in periculo mortis uideo constitutum.

6 - Devemos, no entanto, confessar que em alguns casos a tradução parece retorcida e a frase se torna de compreensão difícil. Eis a continuação do apotegma I,3c, no ponto em que há pouco o interrompemos, a propósito das paixões da carne (lin. 13-16):

(55) Adiante estudaremos em pormenor as acaracterísticas do latim do tradutor, pp. 150-258, especialmente 192-199. 
... si fame ieiuniorum atque uigiliarum labore macerentur, tunc etiam aduersariorum nostrorum daemonum humiliatur uirtus quam per corporis nostri fortitudinem contra nos exercere solent.

IOANNES COLOBVS 3 (205)

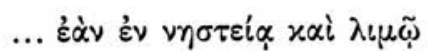
$\pi \circ \lambda \iota \tau \varepsilon \dot{\sigma} \sigma \eta \tau \alpha \iota$ \& $\alpha \theta \rho \omega \pi \circ \zeta$, of

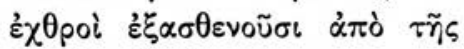

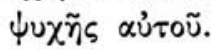

PASCÁSIO XIII,1

... si in ieiunio et fame uolueris uiuere, deterrescunt et non sunt fortes aduersus animam.

Antes de mais, note-se o desenvolvimento que a este breve passo deram as Commonitiones. O segundo membro da frase podia traduzir-se assim: os inimigos tornam-se fracos em relação à alma. E foi esta, aproximadamente, a interpretação que lhe deu Pascásio. As Commonitiones, introduzindo o complemento per corporis nostri fortitudinem, dificultam a singeleza do pensamento. Em vez de fortitudinem parece que antes se deveria esperar infirmitatem, dando a per o valor de complemento de causa: graças $a$, devido $a$. Na realidade, porém, as mortificações são um meio de fortalecimento e de aumentar a resistência da alma. Neste sentido se poderá compreender o inciso, tendo por palavra-chave fortitudinem. Mas não há dúvida de que o pensamento não flui com limpidez.

O breve apotegma V,6 apresenta duas passagens de difícil interpretação. Falta-nos o texto grego e qualquer outro paralelo latino que nos ajudem a esclarecer o sentido. Sobretudo a última frase está demasiado sobrecarregada de elementos, de modo que se torna difícil dar-lhe uma ordenação clara e garantir uma interpretação segura. Estudaremos em pormenor todo este número quando tratarmos do problema do tradutor (pp. 136-149). 


\section{Cap. VI - TRÊS PROBLEMAS: DATA, AUTOR E TRADUTOR}

\section{1 - A DATA}

A data da composição das Commonitiones só parcialmente até agora poderia ter sido considerada, uma vez que historiadores e filólogos apreciavam todo o Livro III das Vitae Patrum de Rosweydus como uma unidade. As suas observações apenas serão válidas na medida em que digam respeito aos nn. 1-40 de Rosweydus, isto é, à antologia das Commonitiones divulgada pelo Livro III.

$1-\mathrm{M}$. Chaine, num juízo global sobre a redacção grega primitiva do Livro III e dos textos que serviram de base às traduções de Pascásio e de Martinho de Dume, afirma que não lhe parece exagerado atribuir a estas três colecções de apotegmas uma data anterior à elaboração da série nominal $\left({ }^{56}\right)$. Ora W. Bousset estabeleceu como data aproximada em que (das diversas colecções existentes, as quais repetiam por vezes os mesmos apotegmas com pequenas divergências) um coleccionador organizou uma compilação por ordem alfabética dos nomes dos Padres, "os últimos decénios do século V, aproximadamente entre $460(70)$ e $500 »\left({ }^{57}\right)$.

(56) M. Chaine, Le texte original des Apophtegmes des Pères in Mélanges de la Faculté Orientale, Université de Beyrouth, V (1912), pp. 545-546.

(57) W. Bousser, Apophtheghmata, Studien zur Geschichte des ältesten Mönschtums, Tübingen, 1923, p. 68. 
Mas quando o próprio Bousset se refere em particular ao Livro III, limita-se a dizer que ele surgiu "em data indeterminada»; depois, considerando em conjunto os Livros III e VII, supõe que eles remontam a um texto grego comum, colecção esta que seria de "grande antiguidade e valor", texto diferente do da obra que foi traduzida por Pelágio e João, o que contribui "para a valorização independente desta colecção». Apesar de Bousset trabalhar com edições defeituosas, a análise que faz dos nn. 1-43 do Livro III é quase perfeita, pois pressentiu que «esta parte não remonta, provavelmente a uma fonte comum» $\left({ }^{58}\right)$.

Mais pertinente é o estudo de Theodor Hopfner no capítulo em que estuda as colecções latinas do Livro III, VII e de S. Martinho de Dume $\left.{ }^{59}\right)$. Examina a lista dos Padres mencionados no Livro III e conclui que «nenhum destes homens viveu para além do ano 450 aproximadamente». O mesmo conclui em relação às figuras do livro de Pascásio. Ao nosso propósito importa ainda a observação de que o Livro III apresenta o nome de alguns Padres, em apotegmas que noutras colecções são dados como anónimos. Isto leva-o a supor que a organização original do Livro III remonta a uma antiguidade maior que a das outras coleç̧ões. E apresenta como exemplos os nn. 107, 25, 29 e 30. Como sabemos, o n. 107 é uma reelaboração da tradução de Pascásio $\left({ }^{60}\right)$. Mas os outros três apotegmas pertencem realmente às Commonitiones.

2 - Cremos que Hopfner estava no bom caminho. Agora que temos o texto genuíno deste livro, podemos perscrutar qual a época a que as Commonitiones se reportam e qual o

(58) Op. cit., pp. 22-23.

(59) TH. HopfNER, Uber die koptisch-said dischen Apophthegmata Patrum Aegyptiorum und verwandte griechische, lateinische, koptisch-bohairische und syrische Sammlungen, Wien, 1919 , cap. VI, pp. 22-28.

${ }_{(60}{ }^{\circ}$ Cf. Pascásio de Dume..., t. II, p. 182. Cf. também supra p. 76. 
último facto nelas mencionado, datável historicamente (61). Observemos os nomes mais conhecidos.

Abbas Antonius (referido em Commonitiones V: 1,2 e 8 ) entrou na vida eremítica entre 270 e 275 . No ano de 341 visitou Paulo (o iniciador da vida solitária, aí por 250 a 257). Tendo Antão falecido em 356, Atanásio, arcebispo de Alexandria, escreveu logo a sua vida, em 357.

O eremita P'or $(\mathrm{V}, 2)$ fez-se em 325 discípulo de Antão. Passou para as montanhas da Nítria em 330 e veio a falecer em 360 .

Abbas Pachomius (V: 7 e 8 ) entrou na vida monástica em 314, fundou o primeiro mosteiro em 318, viu o florescimento da vida cenobítica e morreu a 9 de Maio de 346. As Pachomii Vitae Graecae foram redigidas entre 357 e 368. Theodorus, discipulus fuit sancti Pachomii $(\mathrm{V}, 7)$, entrou no mosteiro de Tabennísi em 328. Após a morte de Pacómio foi o seu terceiro sucessor, talvez a partir de 350 , até que faleceu em 27 de Abril de 368.

Abbas Macarius (III,1; IV,19) iniciou-se na vida eremítica cerca do ano 330 , foi ordenado presbítero por 340 e veio a falecer por volta de 390 .

Abbas Dioscorus, presbyter $(\mathrm{I}, 15)$ veio a ser sagrado bispo de Hermópolis em 394.

(61) Para este estudo utilizámos as tábuas cronológicas e as referências a cada Padre que se encontram nas seguintes obras: $\mathrm{TH}$. HOPFNER, op. cit., na nota 59, pp. 9-10; W. Bousser, op. cit. na nota 57, pp. 60-66; C. Butler, The Lausiac History of Palladius, II, Cambridge, 1904, pp. C-CII (com um mapa na p. XCVIII); H. G. E. WhITE, The monasteries of the Wâdi 'n Natrûn. Part II: The history of the monasteries of Nitria and Scétis, New York, 1932, pp. 12-167, obra muito rica em elementos e de profunda investigação histórica; KARL Heussi, Der Ursprung des Mönschtums, Tübingen, 1936, pp. 138-144; A. Fliche-V. Martin, Histoire de l'Église, t. III, Paris, 1939, pp. 321-327 (com um mapa na p. 298); P. Deserrle, Les saints moines d'Orient, Namur, 1959, pp. 10-11. Para situar os lugares mencionados nas Commonitiones e os mosteiros ou desertos onde viveram os Padres aqui indicados cf. além dos dois mapas já referidos: F. van Der MEer-Christine MoHrmanN, Atlas van de oudchristelijk wereld, Amsterdan, 21961 , n. 17, 18 e 34; M.-J. Rouet De Journel, Jean Moschus, Le pré spirituel, Paris, 1946, (colocado no fim do livro); J.-P. Migne, Patrologia Latina, t. 73, no verso do ante-rosto e no do rosto deste primeiro volume consagrado às Vitae Patrum. 
Pater Isaac, presbyter $(\mathrm{IV}, 8)$ poderá ser o discípulo de S. Macário ou o discípulo de Crónio. $\mathrm{Na}$ primeira hipótese teria vivido na passagem do IV para o V século; na segunda, poderíamos precisar mais, pois Isaac foi o sucessor de Crónio em 395.

Para abbas Isidorus (II,4) não temos elementos exactos, dado que há vários com este nome. Um esteve com Santo Atanásio em Roma, em 340; outro, presbítero de Scétis, teve como sucessor Pafnúcio e este foi substituído por João Cólobo; e Isidoro de Pelúsio (contemporâneo do patriarca de Alexandria, Cirilo, eleito em 412), já tinha morrido em 435.

Abbas Moyses (JI,4) aparece-nos em conferência espiritual com abbas Isidorus. Ora de Moisés sabemos que morreu durante o assalto que os bárbaros fizeram ao mosteiro de Scétis, em 407. Daí pensarmos que o Isidorus mencionado neste apotegma, em conversa com Moisés, é o segundo acabado de referir.

Abbas Ioannes Colobus, com quem abrem as Commonitiones (I: 2 e 3) é sem dúvida a personagem estudada por Amélineau $\left({ }^{62}\right)$ que o identifica como um contemporâneo do patriarca Teófilo de Alexandria (385-412), tendo a sua morte ocorrido por 435.

Do senior Agathon, nominatissimus (IV,7) sabemos que tinha muitos discípulos, alguns dos quais, quando se espalhou a fama de Arsénio, passaram a viver junto deste, em Scétis.

De beato Arsenio é o título para todo o cap. VI e, de facto, cada um dos seis apotegmas o menciona. Arsénio nasceu em Roma, de família senatorial, cerca de 354. Convidado por Teodósio I (379-395) para preceptor de Honório e Arcádio, viveu em Constantinopla desde 383 até que em 394 resolveu

(62) E. AmÉlinenu, Histoire des monastères de la Basse-Égypte. Vies des saints Paul, Antoine, Macaire, Maxime Domèce, Jean le Nain, etc., Paris, 1894. Inclinamo-nos para a identificação proposta por Amélineau, porque a sua biografia contém episódios que se encontram também nas Commonitiones - IV: 14 e 15 (cf. pp. 334-336 e 346 de Amélineau). Nesta tradução do orientalista francês descobrimos também alguns lugares paralelos para os apotegmas vertidos por Pascásio de Dume. 
retirar-se para Scétis, donde teve de sair, em 407, devido à invasão dos Mazices (cf. Pascásio XCVI,4). Permaneceu depois noutros mosteiros até que faleceu com mais de 90 anos, em data que pode ter oscilado entre 445 e 449 .

Abbas Daniel começou cedo a vida monástica. Foi primeiro discípulo de Pafnúcio (que tinha mais de 90 anos em 399) e depois de Arsénio (VI: 2, 4 e 6), cujos ditos e feitos contava aos irmãos mais novos e aos visitantes.

Abbas Zeno (I,14) foi discípulo de Silvano, viveu em Scétis e peregrinou pela Palestina e Síria. Sabemos que morreu no ano de 450.

O abbas Poemen de que falam as Commonitiones (I,8; II,10; IV: 3, 4, 5 e 6; VI,5) deve ser distinguido de um outro abbas Poemen que viveu no círculo de Santo Antão, em Pispir, no princípio do século IV. O nosso abbas Poemen nasceu à volta de 340; aos 15 anos entrou para o mosteiro de Scétis donde fugiu, com seu irmão Anub e mais cinco irmãos (cf. Pascásio XCVI,4), para Terenútis, em 407, por ocasião do saque de Scétis. O episódio que ele nos conta sobre a visita do imperador Teodósio II a um monge, em Constantinopla, ocorreu no ano de 446, segundo averiguou Nau $\left({ }^{63}\right)$. Assistiu à morte de Santo Arsénio, que segundo White ocorreu em 449. Depois das restrições decretadas pelo concílio de Calcedónia (451) e postas em vigor pelo imperador Marciano (450-457) foi ainda visitado por um monge de nome João. A sua morte deve colocar-se, portanto, o mais cedo, depois de 451.

Resumindo os elementos históricos acabados de apontar, verificamos que o ambiente monástico descrito nas Commonitiones abrange um período que vai de meados do século IV

(63) F. NAU, Recueil de monographies, IV, in Patrologia Orientalis VIII (1912) pp. 5-156, com um Appendice (pp. 157-183) do qual constam Textes complémentaires (pp. 162-183), sendo um Sur Théodose le Jeune et les moines (pp. 166-174). A datação exacta do episódio narrado em Commonitiones IV, 3 encontra-se na p. 167 . Da p. 164 deste estudo recolhemos também os elementos fornecidos sobre abbas Zeno. 
(quando visitou Paulo, em 341, Antão tinha já 90 anos) até meados do século V, pois João visitou Poemen após 451.

3 - Observando agora os apotegmas das Commonitiones sob o ponto de vista da evolução deste género literário, concluímos que representam a última fase do processo evolutivo ${ }^{(64)}$.

Não há qualquer dúvida de que a colecção mantém o espírito do género apotegmático. $\mathrm{O}$ apotegma nasceu da consulta feita pelo discípulo ao seu pai espiritual que the responde com uma sentença breve. Estes diálogos rápidos ou os simples ditos de carácter gnómico, tão frequentes em Martinho, em Pascásio e em Pelágio-João, faltam quase por completo nas Commonitiones. Nestas, mesmo quando o apotegma se reduz a pouco mais de meia dúzia de linhas (cf. sobretudo o cap. I) a redaç̧ão está sempre ampliada, relativamente ao paralelo grego que possuímos. Todavia, o espírito original do apotegma pode ainda ser surpreendido nas Commonitiones.

Em I,16 vemos alguns irmãos a consultar o abade José sobre o modo de receber os visitantes. Depois da resposta, o autor acrescenta (linhas 12-13): Haec itaque audientes fratres tamquam uiri Dei praeceptum susceperunt uerbum eius. O conselho foi recebido e acatado como se fosse uma ordem, porque o ancião era considerado pelos consulentes como «um homem de Deus".

Em IV,12, no meio de uma narração bastante longa, deparamos com o motivo das visitas aos anciãos (linhas 9-10): desiderantes ab eo audire uerbum salutis aeternae; e indica-se clara-

(64) Sobre os diversos tipos de apotegmas, sua evolução e características, cf. W. Bousset, Apophthegmata, Tübingen, 1923, pp. 77-88; E. A. Wallis BuDGE, The wit and wisdom of the christian fathers of Egypt, Oxford, 1934, p. VI; K. HeussI, Der Ursprung des Mönschtums, Tübingen, 1936, pp. 146-153; R. Dragué, Les Péres du Désert, Paris, 1949, p. XIV; e sobretudo J.-P. GuY, Remarques sur le texte des apophthegmata patrum in Recherches de Science Religieuse, XLIII (1955), pp. 252-258; IDEM, Note sur l'évolution du genre apophtegmatique in Revue d'Ascétique et de Mystique XXXII (1956), pp. 63-68; IDEM, Les apophthegmata patrum in Théologie de la vie monastique, Lyon-Paris, 1961, pp. 73-83. 
mente o dom carismático do monge consultado (linhas 10-11): habebat enim gratiam spiritalem docendi uerbum Domini.

Características da última fase dos apotegmas são as longas narrações que se vão assemelhando a uma novela (cf. I,11; II: 6,7,8,9; IV:1,2,3,4,6,7,10,12,16,17,19; V:2,3,7,); os acrescentos bíblicos, a confirmar o pensamento primitivo (cf. I: 8,12,14; II: $1,2,4,6,10$; lV: 7,11,14,19; V: 2,7,8; VI: 2,6); a inclusão de milagres e revelações (cf. II,4; IV: 11,13,16,18; V: 8,9; VI: 2); o carácter de exortação ou homilia (cf. I: 1,3,6; III,1; IV: 3,5,9; V: $1,8,9)$; a interpretação alegórica ou espiritual da Escritura (cf. I: 8,13); o ensinamento feito através de alegorias (cf. V, 9; VI,2). Este conjunto de processos estilísticos levam-nos a concluir que os apotegmas aqui apresentados não se encontram na sua primeira versão, mas testemunham antes uma reelaboração, num período em que este género tinha entrado na literatura com as suas peculiaridades típicas de época mais tardia.

4-O próprio modo de se referir aos "padres" mais famosos deixa entrever que as figuras descritas são vistas a certa distância, já sob o ângulo da veneração e glorificação. Será bom comparar com outras colecções de apotegmas.

O famoso Santo Antão é uniformemente tratado apenas por abbas Antonius em Pelágio (I,1), Martinho (53) e Pascásio (XIV,2); o grande Macário Egípcio é também somente abbas Macarius (Pelágio I,6; Martinho 15; Pascásio X,4); o mesmo acontece com o letrado Arsénio que não passa de abbas Arsenius (Pelágio II,3; Pascásio III,4; Martinho não o menciona); finalmente o mais sentencioso de todos, Poemen, é igualmente tratado por abbas Poemen (Pastor, como traduz sempre para latim) Pelágio I,12, etc.; Martinho 3, etc.; Pascásio I,4, etc.

Vejamos agora como o autor (não deve tratar-se de inovação do tradutor) das Commonitiones considera estas quatro figuras:

- beatus abbas Poemen (I,8; II,10; IV,3), ipso sancto Poemen $(\mathrm{IV}, 4)$; 
- sanctus abbas Macarius (III,1);

- sanctus ac beatissimus Antonius (V:1,2,8);

- de beato Arsenio (incipit de VI); sanctus Arsenius (V,2).

Pacómio recebe os qualificativos de sanctus, beatus, beatissimus (V: 7,8) e o seu discípulo Teodoro o de beatus $(\mathrm{V}, 7)$. Aliás, este processo de beatificação pode considerar-se quase uma constante do estilo do autor. Os grandes modelos da vida monástica são propostos como dignos de veneração: sanctus abbas Ioannes $(\mathrm{I}, 2)$, sanctus abbas Dioscorus, presbyter (I,15), sanctus abbas Ioseph (I,16); beatus abbas Moyses (II,4); sanctus abbas Isidorus (II,4); Agathon, nominatissimus in uirtute humilitatis et patientiae (IV,7); beatus pater Isaac, presbyter (IV,8); beatus abbas Apollo (IV,11); beatus abbas Athanasius (IV,17); famulus Dei Martianus (V,4). Mesmo quando o nome não é indicado, persiste uma genérica fórmula de respeito: uenerabilis famula Christi (V,3, linhas 12-13); beatus senior, sem outra identificação (V,9, linha 13); quidam aegyptius uenerabilis monachus (VI,3, linha 1-2).

Há, no entanto, alguns casos em que não se vai além do simples epíteto de abbas: Beniamin (I: 9,10), Nitera (1,12), Siluanus (I,12), Zeno (I,14), Paulus (IV,13), Ioannes (V,3), Daniel (VI: 2,4,6); ou então de uma designação corrente: discipulus nomine Petrus (IV,15), frater Eulalius (IV,16), eremita nomine Pior (V,2; mas na capitulatio respectiva sanctus Pior).

Apesar destas últimas designações comuns, deve reconhecer-se que a tendência geral é para a exaltação honorífica dos "Padres». Não há nenhuma colecção latina de apotegmas em que apareça tantas vezes a expressão sancti patres (a começar pelo título) com um valor global de «monges, eremitas». Em II,2, linhas 20-22, um ancião aconselha o discípulo a abrir-se ao director espiritual, dizendo-lhe: Nihil enim ita allidit uirtutem daemonum quomodo si quis secreta immundarum cogitationum reuelauerit sanctis ac beatissimis patribus. Este pensamento encontra-se em grego (Nau, 164) e nos paralelos latinos 
(Pelágio V,132) e Pascásio (LXXIII,4), mas nenhum deles faz referência directa aos "sanctis ab beatissimis patribus" $\left.{ }^{65}\right)$.

Não queremos valorizar demasiado o valor cronológico desta atitude de beatificação dos Padres. Todavia, não deixa de impressionar a diferença existente entre as Commonitiones e as outras colecções.

Este conjunto de circunstâncias - acontecimentos narrados até pouco depois de 451 , apotegmas que representam a última fase deste género literário, distanciamento respeitoso do autor em relação às personagens referidas, as quais, mesmo as mais tardias, já estão nimbadas com a auréola da santidade - tudo nos leva a concluir que as Commonitiones são uma colecção tardia. Atendendo a que o género atingiu o seu florescimento literário, em grego, na segunda metade do século $\mathrm{V}$, parece-nos lícito supor que a reelaboração grega que deu origem às Commonitiones deve ter sido realizada pelos fins do século $\mathrm{V}$ ou princípios do século VI (cf. também pp. 116, 119-120, 132-133, $150,215,246)$.

Talvez por isso mesmo nós não disponhamos de um texto grego que corresponda literalmente às Commonitiones. A série alfabético-anónima, compilada, segundo Bousset ( $\left.{ }^{66}\right)$ entre 460 e 500, não disporia ainda desta nossa colecção, apesar de o fundo, quanto ao conteúdo, ser o mesmo. Pode pôr-se ainda a hipótese de as Commonitiones já existirem, mas o compilador do grego chegado até nós teria preferido os apotegmas mais breves, melhor representados nas restantes colecções. As Commonitiones, por mais tardias e desenvolvidas, teriam sido preteridas.

(65) Sobre a origem, significado e uso de sanctus já no latim clássico, cf. H. FUGIER, Recherches sur l'expression du sacré dans la langue latine, Paris, 1963, pp. 155-292.

(66) Cf. nota 57, p. 94. 


\section{2-O AUTOR}

1 - O problema da autoria do Livro III das Vitae Patrum, cujos primeiros 40 números são, de facto, das Commonitiones, tem sido largamente discutido. H. Rosweydus rejeita a opinião dos que o atribuem a Evágrio ou a Postumiano. Em seu entender, acumulando argumentos de ordem externa e levado pelo estilo, Rufino é "com certeza o autor ou pelo menos o traduton $(67)$.

Este juízo, expresso por Rosweydus logo na primeira edição das Vitae Patrum, em 1615, foi imediatamente contestado por Georgius Garnefeld $\left({ }^{68}\right)$, em 1621. Com vigor afirma que "não são necessários muitos argumentos" para rebater Rosweydus: "basta um só passo, o n. 163, onde se descreve a morte de Santo Arsénio. Ora Rufino não sobreviveu até esta altura, pois Baronius assinala para a sua morte o ano de 410m. Tendo Arsénio falecido a 450, conclui: da oposição destas datas ressalta que "Rufino não pode ser o autor do Livro III de Rosweydus». Em seu parecer "o autor e mesmo o tradutor é desconhecido. As leves conjecturas baseadas no estilo e no prólogo não têm qualquer valor».

O raciocínio de Garnefeld é justo. Simplesmente... o n. 163 do Livro III de Rosweydus não passa de uma recensão do cap. LII, 5 de Pascásio, de modo que apenas podemos hoje concluir que o original grego de que se serviu Pascásio foi elaborado após o ano 450. Todavia, chegaremos ao mesmo resultado se observarmos, por exemplo, que o episódio narrado nas Commonitiones IV,3 se passou em 446, pelo que Rufino, cuja morte ocorreu em 410, não podia ter sido o autor ou o tradutor desta colecção de apotegmas $\left({ }^{69}\right)$.

${ }^{(67)}$ H. Rosweydvs, Vitae Patrum, in Patrologia Latina, t. 73, prolegomenon V, coll. 38-39.

${ }^{68}$ ) G. GaRnefeld, Elucidationes sacrae in quinque libros de imaginibus antiquorum eremitarum, Coloniae Agripinae, 1621, pp. 620-622.

${ }^{(69)}$ Sobre a datação deste episódio, cf. supra, nota 63, p. 98. 
Dominicus Vallarsius, editor das obras de Rufino (retomadas pela Patrologia Latina) nega também que Rufino tenha escrito ou traduzido o Livro III de Rosweydus, observando mesmo que este livro é composto de extractos de vários autores $\left({ }^{70}\right)$.

C. Butler escreve textualmente: "A atribuição de Rosweydus do Livro III a Rufino é certamente errónea» (71). Perante este consenso, admira que um estudioso como Th. Hopfner fale sempre de Rufino como se ele fosse o autor dos apotegmas do Livro III $\left({ }^{72}\right)$. Mais prudente, W. Bousset diz apenas que o "Livro III das Vitae Patrum é de origem anónima" $\left({ }^{73}\right)$. Como veremos no parágrafo seguinte, ao tratar do tradutor, Salonius, convencido da inautenticidade do Livro III, passou a designá-lo por Pseudo-Rufino, terminologia inexpressiva que muitos críticos têm adoptado.

Se bem que não mencione qual o autor do Livro III. J. Pérez de Urbel é o único historiador do monaquismo que, até agora, avançou com uma hipótese estranha sobre o tempo e lugar em que surgiu esta colecção. Depois de elogiar a tradução de Pascásio, de cujo "original solo queda el último capítulo» (!), afirma que "ella inspiró otra collección de anécdotas monásticas, compuesta algun tiempo después, acaso también en España». E em nota esclarece: "Me refiero al libro III de las Vidas de los Padres hecho con centones de Pascasio, Rufino y S. Jerónimo" $\left({ }^{74}\right)$. Tão longe vai a imaginação de um espanhol!

(70) Cf. J.-P. Migne, Patrologia Latina, t. 21, Parisiis, 1878, coll. 388, 390, 458.

(71) C. Butrer, The Lausiac History of Palladius, Cambridge, 1898, p. 210.

(72) TH. HopfNer, Úber die koptisch-saidischen Apophthegmata Patrum Aegyptiorum (...) Sammlung, Wien, 1919 , pp. 22-28.

(73) W. Bousset, Apophthegmata, Tübingen, 1923, p. 22.

(74) Justo Pérez DE URBex, Los monjes españoles en la Edad Media, I, Madrid, 1945, p. 220. Note-se que o "último capítulo» a que Dom Justo se refere, - XLIV da edição de Rosweydus, não pertence a Pascásio. (Cf. Pascásio de Dume..., t. I, pp. 28-30; t. II, pp. 167-187 e 274-279). Quanto à data e local sugeridos, gostaríamos de conhecer as provas que apoiam esta hipótese nacionalista... 
2 - Faltam, de facto, quaisquer testemunhos externos que nos indiquem qual o autor das Commonitiones. A observação atenta do texto genuíno chegado até nós deixa-nos entrever, porém, alguns traços da sua personalidade.

Em V,8, linhas 35-36, lemos a expressão: Ipse autem beatus pater noster Pachomius docebat fratres... e continua fazendo o elogio do tipo de vida dos monges pacomianos. Neste passo, pater tem, de modo evidente, o valor de "fundador de uma ordem religiosa». Com tal significado aparecera já antes, em V,7, linhas 3-4, referido também a S. Pacómio, qui fuit pater infinitae multitudinis monachorum.

Nos outros casos, além do valor corrente de "pai» e "pai espiritual", aparece a expressão pater monasterii para designar o superior do convento (cf. IV,16: linhas 11 e 17; IV,18: linhas 8-9,10 e 17; V,7: linhas 4, 29 e 31). O cargo de superior é também indicado pela palavra praepositus ( $\mathrm{V}, 8$, linha 15) e por abbas monasterii (IV,18, linhas 15-16).

$\mathrm{O}$ autor das Commonitiones é, sem dúvida, um monge da regra de S. Pacómio. Só assim se compreende que, propondo-se contar um episódio ocorrido com Teodoro, o qual discipulus fuit sancti Pachomii (V,7, linhas 2-3), a simples menção deste nome o leve a fazer uma digressão entusiasta sobre a fecundidade da acção de S. Pacómio e as suas virtudes, entre as quais o dom da profecia (linhas 3-7). E só então retoma o caso de Teodoro. Parecendo não ter ficado satisfeito, após o episódio ocorrido com Teodoro junta um novo elogio de sanctum Pachomium que, entre outros milagres, tinha o dom de expulsar demónios e de curar enfermos (V,7, linhas 60-64).

O n. V,8 é todo ele dedicado a S. Pacómio, classificado de beatissimo patre (linhas 13-14), insistindo em que foi, ut diximus, multorum monasteriorum in regione Tabennensiotarum praepositus (linhas 14-15). E para não surgirem dúvidas sobre o papel importantíssimo de S. Pacómio para a vida monástica, começa-se por compará-lo com Santo Antão, pois tal como este certamen bonum certauit, sicut athleta ueritatis (linhas 2-3). Ora 
sanctus ac beatissimus Antonius foi um uerus in Christo pater monachorum $(\mathrm{V}, 1)$.

Neste contexto adquire novo significado o apotegma dedicado a Teodoro $(\mathrm{V}, 7)$, o discípulo que se mostra tão zeloso do recolhimento da vida monástica, a ponto de argumentar vigorosamente perante uma cedência de $\mathrm{S}$. Pacómio, já movido pelas cartas de recomendação dos bispos e pela afeição familiar da irmã de Teodoro.

Ora este Teodoro tornara-se famoso entre os cenobitas pacomianos $\left({ }^{75}\right)$. Tendo grassado uma peste no ano de 346 , S. Pacómio morreu vítima dela a 9 de Maio. Sucedeu-lhe Petrónio, que dois meses depois foi levado pela mesma peste. O segundo sucessor de Pacómio foi Orsiesius, cujo governo não agradou. Para evitar um cisma na congregação, Orsiesius nomeou, em 350, a Teodoro como seu coadjutor, o qual veio a ser o terceiro sucessor efectivo de S. Pacómio. Teodoro morreu a 27 de Abril de 368.

O tipo de vida implantado por S. Pacómio despertou tanto entusiasmo que, quando da sua morte, ele dirigia já 9 mosteiros de homens e 2 de mulheres. Cassiano, que viveu no Egipto de 385 a 399, diz que havia então 5000 monges; Paládio, que visitou e viveu em diversos mosteiros desde 388 até 400, fala de 7000 monges; e S. Jerónimo, que em 404 traduziu as Regras de S. Pacómio, eleva a contagem para 50000 . Seja ou não exagerado este último número, ele reflecte que no século $\mathrm{V}$ o cenobitismo tinha empolgado os cristãos mais desejosos de perfeição espiritual.

Neste ambiente viveu o autor das Commonitiones. A confirmar a sua profissão monástica segundo as Regras de S. Pacómio estão precisamente os nn. 7 e 8 do cap. V. Com efeito, os ditos e feitos de Pacómio não pertencem à tradição apotegmá-

(75) Sobre Pacómio, os seus sucessores e a sua obra, cf. P. LAdeuze, Étude sur le cénobitisme pakhomien pendant le $I V^{*}$ siècle et la première moitié du $V^{e}$, Louvain, 1888; Enciclopedia Cattolica, Vaticano, IX vol., 1952, coll. 511-514. 
tica. A série nominal não regista o seu nome. Todavia, o autor das Commonitiones, ao coligir e reelaborar exemplos edificantes da vida dos padres do deserto, não se conteve que não fosse à $V i d a$ de S. Pacómio e daí recolhesse dois passos que transformou em apotegmas, exaltadores das figuras de Pacómio e de Teodoro. Não somos nós que estamos a forçar os textos; são os textos que nos obrigam a ver, por detrás da sua forma, vivacidade e entusiasmo, o discípulo apaixonado pelos fundadores da sua congregação.

\section{3-ALGUNS TÓPICOS DO AUTOR}

A personalidade do autor das Commonitiones revela-se também através do seu estilo e dos seus tópicos preferidos. Vimos já $\left.{ }^{76}\right)$ que os apotegmas são por vezes apresentados em forma de narração ou reportagem. Aos exemplos então apresentados, embora sumariamente, podemos agora acrescentar mais um, precisamente a respeito do beatus pater noster Pachomius (V,8, linhas 35-36). Depois de uma introdução em que compara beatus abbas Pachomius (linha 1) com beatus Antonius (linha 3), começa a descrição propriamente dita com estas palavras típicas do género narrativo (linhas 13-16):

Referebant autem nobis fratres de eodem beatissimo patre Pachomio, qui fuit, ut diximus, multorum monasteriorum in regione Tabennensiotarum praepositus, referebant ergo de eo quod frequenter dicebat patribus...

Repare-se na anáfora de referebant, a marcar o tom coloquial, e na expressão ut diximus, a remeter para o princípio do apotegma anterior $(\mathrm{V}, 7)$, onde a simples menção do nome de sancti Pachomii leva logo a apresentá-lo como uiri de magnis

(76) Cf. cap. IV, pp. 67, 100. 
patribus, qui fuit pater infinitae multitudinis monachorum, multorumque monasteriorum pater in partibus Thebaidae (linhas 3-5).

Outra característica já apontada (77) é a conversão do apotegma em exortação ou homilia. De facto, além dos casos citados, várias outras vezes ocorrem expressões como: oportet, filioli, ut... (I,1, linha 2); credite mihi, filioli, quia... (I,6, linhas 3-4); praecipiebat discipulis suis et saepe monebat eos ut... (V,1, linhas 2-3), apotegma este todo ele em tom de oratória sacra: oportet ergo et ualde conuenit ut... (linha 11), ita enim debent monachi pro suis parentibus interuenire et deprecari Dominum, ut aeternam salutem mereantur accipere in uita perpetua, et regno Iesu Christi Domini nostri sors eorum inueniatur. Amen (linhas 19-22). E o mesmo se passa em $\mathrm{V}, 4$, linhas 1-2: simile exemplum referemus; em V,8, linhas 28-29: ideoque, fratres mei dilectissimi, semper oportet ut...; e em V,9, linhas 15-16: exhortabantur ergo sancti patres per monasteria et commonebant fratres dicentes: Cauete, fratres,... Aliás, os vocábulos commonitio, monitio, monitum, commonere, admonere e semelhantes, aparecem desde o título da colecção até à penúltima linha do último apotegma (VI,6).

Além destas características do estilo, há alguns tópicos que sem dúvida eram queridos do autor das Commonitiones e por isso os introduziu várias vezes.

\section{A - A felicidade celeste como prémio}

Contámos 30 referências à recompensa que Deus dará aos justos no Céu. Todavia, só duas vezes o texto grego que possuímos aponta para este motivo. Confrontemos primeiro estes dois passos, de I,6 e V,5.

(77) Cf. cap. IV, pp. 67-70. 
Em I,6 conta-se que alguns irmãos exortavam um ancião a que não se entregasse a tão duras penitências. E ele respondeu-lhes:

$$
\text { NAU, } 197
$$

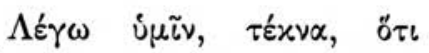
'A

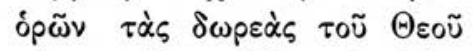

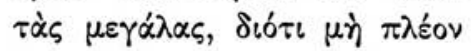
$\dot{\eta} \gamma \omega v i ́ \sigma \alpha \tau$.
COMMONIt. I,6 (lin. 3-8)

Credite mihi, filioli, quia Abraham, Isaac et Iacob, sancti patriarchae, et omnes sancti poeniteri habent in illo futuro beato saeculo uidentes illa inenarrabilia dona Dei, magna et ineffabilia bona, quae praeparauit Deus diligentibus se et custodientibus praecepta eius...

É evidente que o autor tirou partido da menção feita no texto tradicional para introduzir uma explicitação muito embelezada.

O n. V,5 é todo ele uma tradução quase literal do grego primitivo. Um monge, ouvindo dizer que sua irmã estava doente, num mosteiro feminino, resolveu ir visitá-la. Para que ele não entrasse num convento de mulheres, ela recusou-se a recebê-lo, dizendo:

$$
\text { NAU, } 153
$$

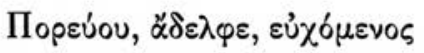

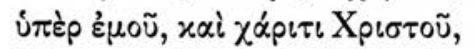

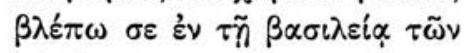

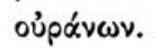

соммоNIт. v,5 (lin. 6-8)

Vade, domine frater, et ora pro me. Praestante enim gratia Dei et Saluatoris nostri, uidebo te in futuro saeculo, in regno Domini nostri Iesu Christi. 
Aqui temos um passo quase literalmente aproveitado, notando-se apenas breves ampliações.

O mesmo se passa com II,2 cujo texto latino, até à linha 22, corresponde aproximadamente a Nau, 164. A um jovem fortemente tentado aconselhava um ancião: Não temas, vem revelar-me a tentação, porque assim o demónio se afastará. Mas o autor das Commonitiones prolonga a exortação com três passos da Escritura e junta ainda por sua conta (linhas 26-28):

Considera ergo, filiole, quia certamen tuum expectat Dominus, tibique contra diabolum dimicanti parat aeternitatis coronam.

Para o n. IV, $19^{\mathrm{b}}$ temos um paralelo bastante ajustado em Macário 23 (272). Mas enquanto o nosso grego termina com uma exortação em 5 linhas (a meia coluna), o autor das Commonitiones elabora, por sua conta, um longo conselho, que ocupa as linhas 39-96 do nosso texto, entre as quais se encontram os seguintes passos: ... illam solam caelestem aeternamque gloriam concupiscunt qui Christo placere desiderant (linhas 66-67); ... caue etiam ne (...) mercedem in aeterna uita non consequaris a Domino (linhas 76-80); e... quatenus possimus ad caelestia praemia et ad aeternae uitae gloriam peruenire (linhas 94-95).

Baste-nos enunciar os outros passos em que este tema é introduzido, por conta do reelaborador das Commonitiones: I,1 (linhas 5-7 e 23-24); I,4 (lin. 9-10); I,7 (lin. 16-17); I,15 (lin. 8-9); II,2 (lin. 12-13); III,1 (lin. 30-32); IV,1 (lin. 36-37); IV,3 (lin. 28-29 e 47-49); IV,5 (lin. 16-17 e 19-20); IV,9 (lin. 18-20); IV,10 (lin. 13-15 e 25-28); IV,12 (lin. 48-52 e 72); V,1 (lin. 20-22); V,2 (lin. 25-27); V,7 (lin. 16-18, 20-21 e 58-59).

\section{B - O dia de juizo e o castigo eterno}

Das 9 vezes que as Commonitiones aludem às penas do inferno só uma tem fundamento no grego por nós conhecido: é em I,4. 
Em I,4 uns irmãos perguntam a um ancião por que motivo leva ele vida tão austera num lugar desconfortável. Eis a sua resposta (linhas (5-7):

$$
\text { NAU, } 193
$$

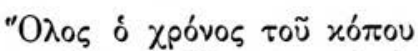

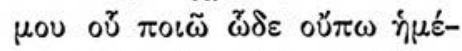

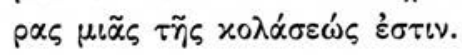

соммоNIт. I,4 (1. 5-7)

Omnis labor totius temporis quo hic degeo nondum unius horae aeternorum tormentorum gehennae spatium habet.

Apesar da proximidade dos dois textos, mesmo aqui se nota a tendência do reelaborador para ampliar e impressionar: as penas de $u m$ dia foram concentradas em uma hora e $o$ castigo transformado nos tormentos eternos do inferno.

Que se trata de um tópico introduzido pelo autor vê-se claramente no final de IV,4. Um juiz prendera um sobrinho do beatus Poemen a fim de criar uma oportunidade para este famoso monge vir rogar-lhe a sua libertação. Mas apenas conseguiu uma carta com esta observação (linhas 40-45):

POEMEN 5 (320)

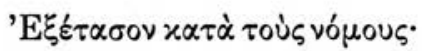

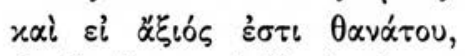

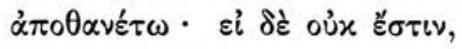

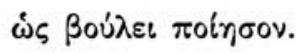

соммоNIт. IV,4 (lin. 44-46)

Iubeat nobilitas tua diligenter requirere causam illius; et si quid dignum morte admisit moriatur, quatenus in hoc praesenti saeculo exsoluat crimen peccati sui, ut euadat aeternas ac perpetuas gehennae poenas; $\sin$ autem nihil dignum morte commisit, quod iustum uidetur legibus ita de eo iube disponere. 
Como se vê, o princípio e o fim da missiva é aproximadamente o mesmo; o sofrimento nesta vida para fugir ao castigo eterno na outra é uma interpolação do reelaborador.

Demos ainda um terceiro exemplo que documenta magnificamente o processo de amplificação literária e a inclusão do tópico em estudo, desta vez apresentado também desenvolvidamente. Em II,6 conta-se que dois irmãos foram à cidade. Tendo um deles caído em pecado, recusava-se a voltar à sua cela. Para o convencer, o outro irmão respondeu-lhe:

$$
\text { NAU, } 179
$$

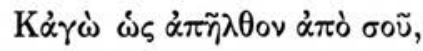

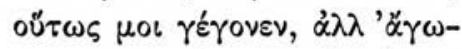

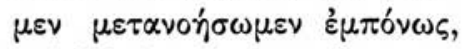

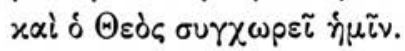

commonit. II,6 (lin. 13-19)

Quia et ego, cum egressus essem a te, lapsus sum similiter in fornicationem. Verumtamen reuertamur et ponamus nos in poenitentiam. Omnia enim possibilia sunt Deo, ut poenitentibus nobis indulgentiam donare dignetur, ut non in aeterno igne tormentis et poenis in inferni tartaro cruciemur, ubi poenitentia non est, sed ignita semper et sine cessatione dira tormenta.

Já anteriormente $\left({ }^{78}\right)$ apresentámos a primeira parte de VI,6 onde este tópico aparece também (linhas 7-8), apesar de faltar no grego e na tradução latina de Pelágio. Os outros pontos em que as Commonitiones inserem este tema são: II,8 (linhas 38-39: in die illo terribili magni iudicii Dei); III,1 (lin. 18-20: nam tormenta et cruciatus animae et corporis in igne aeterno gehennae

(78) Cf. cap. V, pp. 80-81. Cf. também pp. 53, 131, 170, 194, 247. 
in perpetuas permanent poenas); IV,5 (lin. 10-11: Omnipotentis Dei commisit indicio); V,1 (lin. 18-19: iudicare uiuos et mortuos in die illo magno et terribili iudicii Dei); e VI,4 (lin. 12-13: ut in die iudicii de illo gehennae inenarrabili fetore liberet me Dominus).

Mas terão estes tópicos, aparentemente vulgares na ascese cristã, algum significado? Recordemos que nos apotegmas de Pascásio, 4 vezes mais numerosos, os temas do Céu e do Inferno aparecem com raridade. $O$ mesmo se pode dizer, proporcionalmente, em relação à maior de todas as colecções latinas, a de Pelágio-João. Estes elementos podem, pois, contribuir para caracterizar um autor e o seu ambiente.

\section{C - Elogio da perfeição espiritual na vida monástica}

$a-\mathrm{O}$ carácter descritivo e o cunho pessoal que o autor das Commonitiones imprimiu ao seu trabalho deu-lhe oportunidade de expressar o seu apreço pelo género de vida que levavam os monges, quer anacoretas quer cenobitas. Limitamo-nos a fazer um elenco das expressões utilizadas para designar a vida de trabalho, mortificação, oração e contemplação, implícitas no conceito de "perfeição espiritual na vida monástica" $\left({ }^{79}\right)$ :

conuersatio: I,9 (linha 18); IV,4 (lin. 10); conuersatio sancta: IV,18 (lin. 4 e 21); V,5 (lin. 3); V,7 (lin. 57);

(79) Não é nossa intenção fazer um estudo linguístico dos termos indicados. Com esta orientação, cf. para as palavras supramencionadas: L. TH. A. LoRIÉ, Spiritual terminology in the latin translations of the Vita Antonii, with reference to fourth and fifth century monastic literature (= Latinitas Christianorum Primaeua, 11), Utrecht-Nijmegen, 1955 (autêntico dicionário com o estudo monográfico de cada vocábulo); H. HoppenBrouwers, Conuersatio, Graecitas et Latinitas Christianorum Primaeua - Supplementa, fasciculus I, Nouiomagi, 1964, pp. 47-95; JULIO DB Campos, El propositum monástico en la tradición patristica in La Ciudad de Diós, 1968 (El Escorial), pp. 117-129. 
conuersatio sanctae uitae: V,7 (lin. 16);

conuersatio secreta: IV,6 (lin. 19);

conuersatio spiritalis: II,5 (lin. 2);

conuersor: I,12 (lin. 8); III,1 (lin. 3); V,3 (lin. 3); V,7 (lin. 9);

conuersor secundum praecepta Dei: V,8 (lin. 31);

conuersor spiritaliter: IV,1 (lin. 38);

doctrina spiritalis: V,7 (lin. 57);

intentio mentis: I,2 (lin. 9); II,7 (lin. 36 e 40);

iugum sanctum monachorum: VI,2 (lin. 24);

labor spiritalis: IV,1 (lin. 36);

obseruare: I,11 (lin. 16);

opus spiritale: II,7 (lin. 41); IV,1 (lin. 33);

propositum monachorum: IV,19 (lin. 2);

propositum sanctum: IV,19 (lin. 41); V,3 (lin. 3); V,7 (lin. 25);

propositum sanctum monachorum: V,2 (lin. 2-3);

propositum spiritale monachi: IV,2 (lin. 2);

scientia spiritalis: V,7 (lin. 37);

seruitium Christi: IV,12 (lin. 72);

studium sanctae uitae: I,6 (lin. 9);

studium spiritale: I,4 (lin. 2);

studium uitae spiritalis: I,6 (lin. 2-3);

uita sancta: IV,3 (lin. 48);

uita sancti propositi monachorum: IV,2 (lin. 27-28);

uita secreta: I,12 (lin. 10); IV,4 (lin. 9); IV,6 (lin. 12); VI,1 (lin. 3-4);

uita secretior: I,9 (lin. 14).

Não esquecemos que todas estas expressões são latinas e a sua fixação é fruto da escolha do tradutor. Queremos, todavia, afirmar que a sua frequência e significado não pode deixar de corresponder a um texto grego, onde transparece a preocupação do autor com o realce a dar à vida de perfeição monástica. 
$b$ - No mesmo caso se encontram alguns exercícios da vida do asceta: a exaltação das vigílias, a insistência na oração, a prática do jejum, etc. É oportuno recordar aqui uma expressão compósita que aparece com frequência, sinal de que era também um tópico ou hábito linguístico do autor: a menção conjunta dos «jejuns, orações e vigílias».

Que conjuntos deste tipo faziam parte da tradição apotegmática, em grego, pode demonstrar-se até pelos paralelos de alguns passos das Commonitiones. Em I,2 (linhas 5-6) diz-se que o abade João Cólobo se entregava orationibus et lectionibus ac meditationibus Scripturarum sanctarum. O grego correspondente,

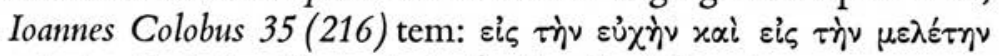

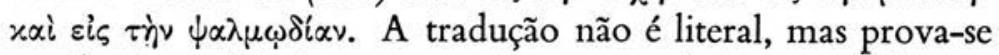
que havia tendência para mencionar cumulativamente diversas práticas ascéticas.

Em I,3 (linhas 13-14) o mesmo João Cólobo diz que o inimigo da alma é vencido fame ieinniorum atque uigiliarum labore, expressão enfática a traduzir o grego paralelo (3 [205]): ह̇v

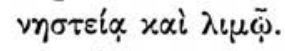

Apontemos algumas expressões deste género, todas elas acrescentadas pelo autor das Commonitiones, se tomarmos como base o grego que chegou até nós: II,1 (lin. 3-4): ieiuniisque et orationibus et in opere manuum (cf. N 170); II,7 (lin. 27-28): in ieiuniis et orationibus et uigiliis multis, e (lin. 45): tam in ieiuniis quam in orationibus et uigiliis (cf. N 169); III,1 (lin. 14): in orationibus ac ieiuniis (sem paralelo conhecido); IV,1 (lin. 32-33): in ieiuniis et orationibus seu in sanctis uigiliis uel in omni opere spiritali (cf. Mios 2 [301]); IV,19 (lin. 78-79): fructusque ieiunii et abstinentiae tuae, uigiliarumque et orationum (cf. Macarius $23[272])$. 


\section{D - Outros elementos caracterizadores}

$a$ - Como se poderá ver pelo rodapé bíblico que acompanha o nosso texto crítico, são bastante numerosas (apontamos 52) as citações explícitas ou implícitas da Sagrada Escritura. Algumas delas, como já tivemos ocasião de notar, foram introduzidas pelo reelaborador das Commonitiones $\left({ }^{80}\right)$.

Além disso, ao longo da colecção, várias vezes se refere que os "padres do deserto" se entregavam à leitura e meditação da Bíblia - I,2 (lin. 5-6): lectionibus ac meditationibus Scripturarum sanctarum; I,13 (lin. 7-8): de Scripturis sanctis (...) duas prophetias (...) recitarunt; II,4 (lin. 5-6): cumque de Scripturis sanctis abbas Isidorus proferens testimonia consolaretur eum; IV, 5 (lin. 2-3): cumque de sanctae Scripturae diuersis capitulis dissereret eis; V,8 (lin. 39-40): meditantes quae de sanctis Scripturis didicerant; V,9 (lin. 5): conferebant inter se de sanctis Scripturis; VI,5 (lin. 2): meditari festino de sanctis Scripturis; (lin. 3-4): non intelligo uirtutem Scripturae diuinae; (lin. 5-6): oportet (...) incessanter meditari eloquia Domini; (lin. 12): intelligere diuinarum Scripturarum uirtutem.

Para avaliar do uso frequente da Escritura entre os monges, segundo o autor desta colecção, devem ainda mencionar-se as referências aos salmos, por vezes com menção explícita de cantar, em cada dia, todo o saltério: I,5 (lin. 13); I,11 (lin. 8,21,27,29); I,13 (lin. 5); IV,9 (lin. 6).

Esta nossa insistência em realçar o lugar importante da Escritura nas Commonitiones vem confirmar a observação de que esta colectânea deve ser tardia ( $\left.{ }^{81}\right)$. Com efeito, tanto Bousset como Guy têm como característica da primeira fase do género apotegmático o escasso uso da Bíblia $\left({ }^{82}\right)$.

${ }^{80}$ Cf. cap. V, pp. $85-87,79-80,88,100,164,166$.

(81) Cf. a data, pp. 94-102, 127.

(82) W. Bousset, Das Apophthegma, Tübingen, 1923, pp. 82-83; J.-C. GuY, Les Apophthegmata Patrum in Théologie de la vie monastique, Paris, 1961, p. 81. 
$b$ - Cremos também ter interesse o final do apotegma IV,7. Trata-se de um episódio passado com um de magnis patribus, senior nomine Agathon (lin. 1). Acusado de vários defeitos, tudo suportou. Quando, porém, lhe chamaram herético respondeu com toda a energia e justificou-se. O apotegma é antigo. Vale a pena comparar o texto grego com as traduções de Pelágio, de Pascásio e das Commonitiones.

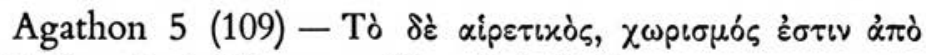

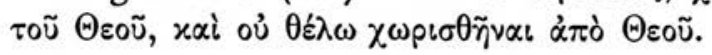

$$
\text { PELÁGIO } \mathrm{x}, 10
$$

Quod autem dixistis haereticum me esse, ideo non acquieui, quia separatio est a Deo, et non opto separari a Deo.
PASCÁsIo $\mathrm{xxV}, 2$

Haereticum autem esse diuidi est a Deo et nolo ab eo separari.

\section{COMMONITIONES IV,7 (lin. 38-47)}

Nam sermonem quem de haeretico dixistis non potui sustinere et ualde abominatus sum, quia haeresis separatio a Deo est. Haereticus enim separatur a Deo uiuo et uero et coniungitur diabolo et angelis eius. Alienatus enim a Christo, iam non habet Deum quem exoret pro peccatis suis; ex omni parte periit. Si autem conuersus fuerit ad ueram et catholicam sanctae ecclesiae fidem, suscipitur a bono et pio Saluatore nostro Christo, et reconiungitur Deo uero Creatori ac Saluatori nostro Christo, qui est in Patre Filius semper cum Sancto Spiritu. Ipsi gloria in saecula saeculorum. Amen.

A amplificação que sublinhámos, mais que como processo de trabalho, interessa agora por demonstrar que o autor das Commonitiones faz profissão de fé na Igreja Católica e defende a divindade de Cristo, Filho de Deus, na unidade da Trindade. Isto não pode deixar de recordar o ambiente de polémica 
teológica $\left({ }^{83}\right)$, em que os monges estiveram com frequência envolvidos, especialmente os temas candentes do final do século V: os resíduos das controvérsias nestoriana e eutiquiana, após a definição da ortodoxia nos concílios de Éfeso (431) e Calcedónia (451) e o primeiro cisma da Igreja grega, a partir de Acácio, de 485 a 519.

c- O espírito de piedade do autor revela-se também nas magníficas orações que compôs, embelezando uma antiga narrativa. Damos apenas um exemplo.

Em IV,6 vemos o jovem, mas já famoso, beatus Poemen, assediado pelos seus conterrâneos para que intercedesse junto do juiz, a fim de libertar alguns presos, naturais da sua aldeia. Receando que as preocupações do mundo viessem perturbar a sua união com Deus, assentiu no pedido, mas fez primeiro a seguinte oração, segundo o apotegma tradicional, traduzido literalmente por João IV,32 e por Pascásio XCII,3:

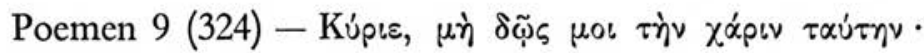

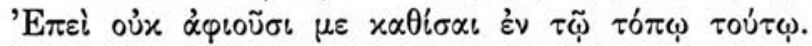

Eis como o autor das Commonitiones elevou em doutrina e estilo este pequeno fragmento:

COMMONITIONES IV,6 (lin. 9-22)

Domine Deus, Creator et Saluator humani generis, exaudi me peccatorem seruum tuum, qui nosti multiformes insidias aduersariorum daemonum qui impugnant nos et festinant diuersis occasionibus inquietare secretam uitam nostram, ut separent mentem nostram de timore et amore tuo, Domine. Ideoque deprecor maiestatem dininae potentiae

(83) Cf. L. Marion, Histoire de l'Église, t. I, Paris, 1942, pp. 492-510; t. III, pp. 12-20. 
tuae, Christe Domine, Saluator noster, ne permittas me talem gratiam habere apud indicem saeculi istius, ut audiat petitionem meam, sed magis aduersetur me et non praestet quae petiero $a b$ eo. Si enim praestiterit mihi quae petiero, manifestum est quia turbatur secreta conuersatio mea. Non enim permittunt me homines requiescere in loco isto, sed uenientes per singula deprecantur me, ut pro eis suggeram iudicibus pro causis eorum.

Podem ver-se outras expressões espirituais de confiança em Deus, formuladas de modo estilisticamente elevado nos apotegmas IV,10 (linhas 20-28); IV,14 (lin. 8-11) e IV,18 (lin. 3-5).

d-Aos elementos acabados de pesquisar, onde se desvenda um pouco da personalidade do autor, podemos juntar ainda a perspectiva histórica.

Em V,2 começa: Fuit quidam eremita Pior nomine, de antiquis patribus... Ora nós sabemos que Píor ${ }^{84}$ ) se fez discípulo de Antão em 325 e faleceu em 360. Pertenceu de facto à primeira geração dos "padres do deserto". O autor marca bem a distância no tempo, não só em relação a si próprio, mas em contraste com os "padres" mais recentes. Pior é de antiquis patribus.

Quem prestar atenção às figuras dominantes da colectânea encontrará João Cólobo (I: 2,3 e IV,5), falecido provavelmente em 435; Poemen (I,8; II,10; IV: 3,4 e 6) cuja morte ocorreu depois de 451; e Arsénio, a quem é consagrado todo o cap. VI, 1 a 6. Sabemos que Arsénio morreu em 449. Note-se, porém, que alguns episódios da sua vida são narrados pelo seu discípulo Daniel (VI: 2,4 e 6), o qual sobreviveu ao seu "pai espiritual". Parece que Daniel é um memorialista a quem os monges e visitantes mais recentes vêm pedir que conte episódios da vida de sanctus Arsenius. Estas narrativas foram referidas, por certo,

(84) Cf. fontes cronológicas mencionadas na p. 96. 
durante e após a década de 450. Tudo leva a concluir que o autor das Commonitiones se preocupou bastante com os últimos grandes representantes da tradição apotegmática, dando-nos assim um livro novo e com novidades.

Quem é o autor das Commonitiones? Nós procurámos reunir os elementos que ficaram implícitos na sua obra. Oxalá os historiadores do monaquismo pacomiano dos finais do século $\mathrm{V}$ e dos anos subsequentes pudessem encontrar um nome a quem os dados recolhidos se aplicassem perfeitamente, vindo assim a trazer luz para a sua descoberta.

\section{3-O TRADUTOR}

$a$ - Ao tratar do Autor das Commonitiones citámos já a opinião de Rosweydus, segundo a qual Rufino seria o autor "ou pelo menos o traduton" do seu Livro III, cujos números 1-40 são tirados das Commonitiones $\left({ }^{85}\right)$. Mostrámos também que Garnefeld tinha razão ao rebater a opinião de Rosweydus, concluindo ele que tanto o autor como o tradutor são desconhecidos $\left.{ }^{86}\right)$. A esta opinião aderiram Vallarsius, Butler e Bousset que rejeitam a autoria ou tradução de Rufino, mas não propõem qualquer outro $\left({ }^{87}\right)$. Columba M. Batlle chegou a propor, sem convicção, a hipótese de Pascásio ter feito «duas versões de uma tradução original, por vontade do autor deliberadamente diversas, ou talvez duas selecções diferentes duma versão primitiva única, aparentemente perdida, de maior extensão que $<$ a recensão breve e longa $>$ a qual se poderia reconstituir a partir de

(85) Cf. parágrafo anterior, nota 67, p. 103.

(86) Cf. parágrafo anterior, nota 68, p. 103.

(87) Cf. parágrafo anterior, notas 70, 71 e 73, p. 104. 
estas duas” ( $\left.{ }^{88}\right)$. Isto é, Pascásio seria então o tradutor de todo o Livro III e do Livro VII das Vitae Patrum. A inconsistência desta hipótese fica demonstrada pelo nosso estudo sobre Pascásio e o texto crítico da sua tradução, e pela publicação, agora, das Commonitiones sanctorum patrum.

$b$ - O exame mais atento do problema do tradutor é, porém, o de Salonius $\left({ }^{89}\right)$. Para averiguar a autenticidade da tradução e na impossibilidade de comparar o Livro III com toda a obra de Rufino, tomou apenas como base de confronto a Historia Ecclesiastica (Livros II e IX) e a Historia Monachorum (cf. Salonius, pp. 12-13).

As diferenças tornam-se logo evidentes (pp. 15-16). E analisa em pormenor, em Rufino e no III Rosweydus, os graus de comparação (pp. 16-18), o uso dos pronomes (pp. 18-21), a sintaxe dos verbos (pp. 21-22), o uso dos modos (pp. 22-26), as maneiras de fazer citações (pp. 26-27), a selecção dos adjectivos e advérbios (pp. 27-28), o uso das preposições compostas (p. 28), o vocabulário (pp. 28-30) e o emprego das conjunções (p. 31).

Um estudo deste género não pode deixar de nos interessar. Salonius concluiu que o Livro III não é tradução de Rufino (daí ter passado a designá-lo por Pseudo-Rufino); que é composto de elementos diversos provindos de S. Jerónimo, da Historia Monachorum e de Pascásio e que é independente da tradução de Pelágio-João (pp. 31-33).

(88) Columba M. Batlle, Contribució a l'estudi de Pascasi de Dumi i la seva versió de Verba Seniorum in Estudis Romànics, VIII (1961), p. 66. É o próprio Batlle, que dispunha já então de uma forte base documental, quem mostra a escassa viabilidade desta hipótese. No entanto, há casos em que uma dupla edição em vida do autor, mesmo em séculos recuados, é apresentada como certa - cf. HiLDF:BerTI Cenomanensis episcopi, Carmina minora, recensuit A. Brisn Scott, Leipzig, 1969, pp. XXI-XXV.

${ }^{(89)}$ A. H. Salonius, Vitae Patrum. Kritische Untersuchungen über Text, Syntax und Wortschatz des spätlateinischen Vitae Patrum, Lund, 1920, pp. 12-33. A marcha do estudo de Salonius e respectiva paginação vai indicada no texto. 
Faltou-lhe descobrir que os nn. 201-206 são adaptações das Sententiae traduzidas por S. Martinho de Dume. Chegou, porém, a entrever que há no Livro III de Rosweydus alguns passos não dependentes de Pelágio-João nem de Pascásio, mas que lhes são paralelos e portanto ou "O autor do Livro III (...) os traduziu de um modelo grego (...) que estava muito próximo $<$ de Pelágio e de Pascásio $>$ ou foi buscar estes episódios a uma obra latina por nós desconhecida” (p. 33).

Ficou quase tudo dito: se Salonius tivesse trabalhado sobre manuscritos (e não apenas sobre os textos editados por Rosweydus) e tivesse deparado com o texto completo das Commonitiones sanctorum patrum, teria resolvido o enigma dos nn. 1-40 do Livro III de Rosweydus. De facto, os nn. 1-40 são os "fragmentos de uma obra latina por $<$ ele $>$ desconhecida» - as Commonitiones.

c-Compete-nos continuar a fazer a pergunta: Quem foi o tradutor das Commonitiones? Ouvidas as opiniões dos cruditos, examinemos os manuscritos.

a) Dos manuscritos com o texto completo (ou quase) das Commonitiones, apresentadas, paleograficamente, como uma unidade - Viena, Bibl. Nac. Áustria 433; Dresda, Bibl. Nac. da Saxónia, A 207; Reims, Bibl. Munic. 1400 - nenhum traz qualquer indicação sobre o autor ou tradutor $\left({ }^{90}\right)$. Com efeito, não merece crédito a rubrica que se encontra no ms. de Reims, Bibl. Munic. 1400 , séc. XIII, fl. $78 v$ onde se lê: Incipit liber sancti Hieronimi, pois na realidade segue-se-lhe a Historia Monachorum (traduzida por Rufino), a Vita Pauli (da autoria de S. Jerónimo), De Nathanaele (extraído da Palladii Lausiaca, cujo

$\left({ }^{90}\right)$ Cf. descrição supra pp. 22-24, 26-27 e infra, aparato crítico do incipit e explicit., pp. 311 e 398. 
tradutor é desconhecido). Pelo menos no fim deste trecho (no fl. 98rb) devia estar: Explicit liber primus. Incipit liber secundus, pois aí começam as Commonitiones até ao fl. 107rb, logo seguidas dos nn. 41 a 220 do Livro III de Rosweydus, apenas com uma falha. Só então, se bem que nunca tenha anunciado o fim do Liber primus, o copista escreveu, no fl. 120v: Explicit liber secundus. Continua depois com extractos dos Dialogi de Sulpício Severo e das Conlationes de Cassiano, acrescidos de apotegmas de Pelágio. No fim de tudo isto (fl. 132v) está escrito: Explicit liber beati Hieronimi presbyteri de uitis sanctorum patrum (91). É evidente que do silêncio dos primeiros e desta miscelânea (onde só uma pequena parte é de S. Jerónimo) nada se pode concluir sobre o autor ou tradutor das Commonitiones.

Dos outros 14 manuscritos que, além de apotegmas que foram seleccionados para o Livro III de Rosweydus, contêm elementos só identificáveis através das Commonitiones, apenas um, o de Londres, Museu Brit. add. 37400, séc. XIV, tem, no fim da colectânea quase completa dos 220 números publicados no Livro III, a indicação: Explicit liber secundus sancti Hieronimi presbyteri (fl. $72 \mathrm{v}$ [70 velha numeração]) e Liber secundus de Vitis Patrum beati Hieronimi presbyteri no índice final (fl. 190v). Bem sabemos que entre estes 14 manuscritos se encontra também o de Paris, Bibl. Nac., fundo lat. 2941, séc. XII-XIII, em cujos ff. 66r-76r o mais recente catálogo diz que há extractos das Vitae Patrum, atribuindo-os a S. Jerónimo (cf. Pascásio de Dume..., t. II, pp. 79-80). Nós manuseámos pessoalmente o manuscrito (e temos microfilme das partes que interessam ao nosso estudo) e observamos que tanto no índice que precede o fl. 1 como no fl. 66ra apenas se escreve: Liber sanctorum patrum collectus ex diuersis libris (et uarias historias solitariorum continens - acrescenta o índice inicial).

(91) Cf. para mais pormenores, Pascásio de Dume..., t. II, pp. 217-219. 
ß) Nos outros 75 manuscritos que só contêm elementos da recensão vulgarizada pelo Livro III obtemos as seguintes indicações $\left({ }^{92}\right)$, colocando a documentação por ordem alfabética:

- Atribuem o Livro III de Rosweydus (e portanto também as Commonitiones) a S. Jerónimo: Melk, Bibl. do Mosteiro Bened. 8, séc. xv; Oxford, Bibl. Bodleiana, canoniciano 395, séc. Xv; Vaticano, Bibl. Apost., Urbinat. 396, séc. xv. Como se vê, os testemunhos são poucos e tardios.

A questão da atribuição das Vitae Patrum a S. Jerónimo tem sido posta várias vezes. Dominicus Vallarsius, ao editar as obras de Rufino, dá uma explicação aceitável. S. Jerónimo escreveu as Vidas de Paulo eremita, de Hilarião e de Malco. Partindo desta base, os manuscritos desde tempos antigos têm-lhe atribuído outras que não lhe pertencem $\left({ }^{93}\right)$.

Ocorre-nos um explicit que lemos a encerrar o ms. de Munique, Bibl. Est. da Baviera, lat. 18475: Item Vitas Patrum Antonii, Pauli et Hilarionis et omnium eremitarum; quas tamen beatus scribit Hieronimus omni honore suscipimus; reliquas uero uidetur per magnam partem Ioannes Cassianus conscripsisse (...). Quicumque conscripsit non sunt tantae autem (...) sicut quas beatus Hieronimus scripsit. Esta confusão e prestígio vinha já do séc. VI, pois o Decretum Gelasianum diz, cap. IV,4: Item Vitas Patrum Pauli, Antonii, Hilarionis et omnium eremitarum, quas tamen uir beatissimus descripsit Hieronimus, cum [omni] honore suscipimus $\left({ }^{94}\right)$.

$\mathrm{A}$ autoridade de $\mathrm{S}$. Jerónimo era tão grande que no ms. de Vercelli, Arq. Capitular LX, séc. XIII, se lê: Incipit prologus atque praefatio beati Hieronimi ... e logo a seguir vem a dedicatória de ... Pascásio a S. Martinho de Dume! (95).

(92) Destes manuscritos, 60 foram apresentados em Pascásio de Dume..., t. II, pp. 197-215 e 233-253. Os restantes 15 foram apenas mencionados supra, p. 20.

(93) Cf. Patrologia Latina, t. 21, Parisiis, 1878, coll. 235, 241-243. p. 5.

(94) Servimo-nos do texto transcrito por C. M. BAtrle, Die Adhortationes...

(95) Cf. Pascásio de Dume..., t. II, p. 158. 
- Atribuem o Livro III de Rosweydus (e consequentemente também as Commonitiones) a Postumiano: Reims, Bibl. Munic. 1390, séc. XI-XII (atribui a Postumiano, em conjunto, os Livros II, III e IV da edição de Rosweydus); Valenciennes, Bibl. Munic. 168, séc. XIII-XIV (mão posterior escreveu, antes do prólogo V'cre mundum, que este livro, só o III de Rosweydus, era de Postumiano); Lille, Bibl. Municipal, possuía um manuscrito, hoje perdido, mas mencionado em catálogos antigos como copiado por 1200, que atribuía a Postumiano os Livros II e III de Rosweydus $\left({ }^{96}\right)$. Encontrámos outros manuscritos $\left({ }^{97}\right)$ que atribuem a Postumiano a Historia Monachorum (Bruxelas, Bibl. Real da Bélgica 3177 (7462-81), séc. XIII) e o Livro IV de Rosweydus (Troyes, Bibl. Munic. 777, séc. XII).

Achamos curiosa esta atribuição porque, tratando-se de uma personagem quase desconhecida, poderia, por isso mesmo, abrir alguma pista. Ora nós sabemos que Postumiano $\left({ }^{98}\right)$ jornadeou pelo Egipto e Palestina nos anos de 401-402. Se as Commonitiones foram escritas, em grego, só por volta de 500 , não poderia ele tê-las traduzido para latim... Há, no entanto, uma razão aparente para que o seu nome ande ligado a descrições das vidas dos padres do deserto. Sulpício Severo conta-nos, no primeiro dos seus Diálogos, como seu amigo Postumiano regressava impressionado do Oriente com a vida dos ascetas. A conversa não foi muito longa, pois não ocupa sequer todo o primeiro diálogo $\left({ }^{99}\right)$. Mas alcançou o mérito de ter sido recolhida pelos manuscritos, conjuntamente com parte das Institutiones e das Conlationes de João Cassiano, no que veio a constituir o livro IV de Rosweydus $\left({ }^{100}\right)$.

(96) Cf. Pascásio de Dume..., t. II, pp. 197, 228-229 e 288.

(97) Não fizemos uma investigação sobre outras obras atribuídas a Postumiano. Citamos apenas dois manuscritos que de momento temos presentes.

(98) Cf. bibliografia sobre cronologia p. 96.

(99) Cf. J.-P. Migne, Patrologia Latina, t. 20, Parisiis, 1845, coll. 183-198.

(100) Cf. J.-P. Migne, Patrologia Latina, t. LXXIII, Parisiis, 1879. A parte de Postumiano ocupa as coll. $815-825$. 
- Do ponto de vista paleográfico (e só para o enunciado ser completo fazemos esta referência) um outro nome podia ser aduzido. O ms. de Dresda, Bibl. Nac. da Saxónia, A 207, séc. XIV, tem nos ff. $159 \mathrm{r}-324 \mathrm{v}$ uma longa colecção de extractos sobretudo de apotegmas, iniciada pelo prefácio que Pascásio de Dume dirigiu ao seu abade Martinho. Do exame que já fizemos deste manuscrito $\left({ }^{101}\right)$ ressalta que ao prólogo de Pascásio não se segue a sua versão dos apotegmas, mas vêm trechos de diversos autores sem nunca se mencionar a sua autoria. Ora entre a miscelânea do manuscrito de Dresda encontram-se, nos ff. 188r-216v as Commonitiones sanctorum patrum. Mas o conjunto da transmissão manuscrita, tanto da obra de Pascásio como das Commonitiones, não nos permite sequer pôr a hipótese de Pascásio ter sido o tradutor das Commonitiones.

Resumindo, diremos que nenhum dos nomes que se encontram, bem raramente, antes do texto das Commonitiones, apresenta probabilidade de poder ser o seu tradutor. Estas falsas atribuições não nos devem admirar. As Adhortationes sanctorum patrum, com toda a verosimilhança traduzidas por Pelágio, João e um outro colaborador desconhecido, são também muitas vezes atribuídas a S. Jerónimo $\left({ }^{102}\right)$; o prólogo da Historia Monachorum apresenta-se por vezes com o nome de Paládio (v. g. Cambrai, Bibl. Munic. 817, séc. xIv-xv; Viena, Mosteiro dos Escoceses 324, séc. xv; Poitiers, Bibl. da Cidade 249, séc. $\mathrm{xv}$, mas este em vez de Paládio escreve: "prologus Pellagii» - dizendo os três que o texto seguinte, a Historia Monachorum, é tradução de S. Jerónimo...), etc., etc. $\left({ }^{103}\right)$.

(101) Cf. Pascásio de Dume..., t. II, pp. 189-191 e supra pp. 23-24.

(102) C. M. Batlle, Die Adhortationes..., pp. 11-12. Admira, no entanto, Batlle não ter citado um só manuscrito em abono desta falsa atribuição. Entre os que nós estudámos temos presentes dois com tal remissão, o de Évora, Bibl. Publ. CXXIV/1-12, séc. XIV; e o de Wiesbaden, Bibl. Est. Hessen 8, séc. Xv. Cf. Pascásio de Dume..., t. II, pp. 150-152 e 139-140.

(103) Entre a bibliografia sobre falsificações, cf. J. vAN DEN BESSELAAR, Introdução aos Estudos Históricos, São Paulo, 1970, pp. 181-186; G. BARDy, La question des 
Depois desta pesquisa devemos declarar que não vemos qualquer indício escrito a indicar-nos qual teria sido o tradutor das Commonitiones.

\section{DATA E LOCAL DA TRADUÇ̃̃O}

Se ao menos pudéssemos determinar com segurança em que altura foram traduzidas...

Luís Ribeiro Soares julgou ter encontrado um argumento decisivo quando aproximou a Regra de S. Bento, cap. XVIII,25, do Livro III de Rosweydus, n. 6. Em seu entender, S. Bento, cuja Regra foi escrita antes de 547 - data da sua morte conheceu o Livro III de Rosweydus, tanto a sua primeira parte (que afinal é uma antologia das Commonitiones) como a parte que foi resumida da versão extensa de Pascásio (104). Apenas nos interessa aqui considerar o n. 6 Rosw., isto é, Commonitiones I,13.

Diz a Regula Benedicti XVIII,25:

... dum quando legamus sanctos patres nostros uno die hoc strenue implesse quod nos tepidi utinam septimana integra persoluamus...

Ribeiro Soares diz que não há para este passo outro lugar paralelo nas Vitae Patrum (105). Ora C. M. Batlle compara precisamente o mesmo texto com as Adhortationes IV,57, isto é,

langues dans l'Église ancienne, t. I, Paris, 1947, p. 142; M. Martins, Correntes da filosofia religiosa em Braga dos séc. IV a VII, Porto, 1950, pp. 279-280; F. Halkin, Bibliotheca Hagiographica Graeca, t. III, Bruxelles, 1957, p. 250; P. LehmanN, Psendoantik Literatur des Mittelalters in Erforschung des Mittelalters, t. III, Stuttgart, 1960; O tradutor da «Vita Taisis» é Pascásio e não Dionísio, o Exíguo in Pascásio de Dume..., t. I, pp. 18-24. Em 1970 foi anunciado o trabalho de W. SPEYER, Die literarische Fälschung in Antike und Christentum, mas não temos notícia da sua publicação (cf. Association Internationale d'Études Patristiques, Bulletin d'information et de liaison, n. 2 (1970), Amsterdam.

(104) Cf. L. R. Sonres, A linhagem cultural de S. Martinho de Dume, I-Fundamentos, Lisboa, 1963, pp. 217-223.

(105) Op. cit., pp. 219, 222-223. 
a tradução de Pelágio $\left({ }^{106}\right)$. Vale a pena transcrever, lado a lado, ambas as referências. S. Bento diz que os antigos padres recitavam o saltério inteiro em cada dia. A sua fonte de informação seria, para Batlle e Ribeiro Soares, respectivamente:

$$
\text { ADHORTAT. (= PLG) IV,57 }
$$

... faciamus opus Dei et gustemus. Et unus quidem eorum compleuit totum psalterium...
COMMONITIONES I,13 (1. 4-6)

... ut prius ex more complerent orationes et psalmodiam et postea cibum caperent. Cum autem ingressi fuissent psallebant, totumque psalterium compleuerunt...

Não há dúvida de que S. Bento tinha uma informação igual à que estas duas traduções de um apotegma grego testemunham. A dependência linguística é, no entanto, muito problemática. Das palavras de S. Bento apenas implesse tem correspondente, nas Adhortationes, a compleuit e, nas Commonitiones, a compleuerunt.

Acontece, porém, que os estudiosos $\left({ }^{107}\right)$ apontam uma dezena de passos em que S. Bento poderia remeter para as Adhortationes. Em contrapartida, nenhum outro apotegma das Commonitiones encontra eco na Regula Benedicti. Devemos con-

(106) C. M. Batlle, Die Adhortationes... p. 208.

(107) Cf. vasta bibliografia pertinente $\mathrm{cm} \mathrm{L.} \mathrm{R.} \mathrm{SOARES,} \mathrm{op.} \mathrm{cit.,} \mathrm{p.} 221$ e C. M. BAtlle, op. cit., pp. 208-209. Em nosso entender, as referências aos padres do deserto apresentadas pela Regula Benedicti e, forçosamente, pela Regula Magistri (escrita provavelmente, em ambiente romano, por volta de 520) não devem necessariamente ser postas em paralelo com as traduções latinas dos apotegmas que chegaram até nós, v. g. a de Pelágio-João que data de 535 a 550, a de Pascásio de cerca de 555, a de Martinho vulgarmente considerada posterior a 556 . O monaquismo Ocidental há muito se nutria da doutrina e exemplos dos grandes ascetas do Oriente. Lembrar os célebres peregrinos escritores, do final do séc. Iv: Rufino, S. Jerónimo, Cassiano, etc. Parecem-nos extrapoladas as conclusões de carácter cronológico baseadas apenas na coincidência de alguns pensamentos da ascética corrente que se encontram em S. Bento e nas versões dos apotegmas. 
cluir, portanto, que a data da redacção da Regra, isto é, pouco antes de 547, não pode ser apresentada como ponto ante quem as Commonitiones foram traduzidas.

Há, no entanto, um marco seguro de referência. Um monge chamado Defensor, do mosteiro de Ligugé, perto de Poitiers, escreveu, por volta do ano 700 , um livro a que ele próprio chama Scintilla ou Scintilla Scripturarum. Trata-se de uma selecção, em 80 capítulos, de pensamentos da Escritura e dos Padres da Igreja, sendo o mais recente dos citados Santo Isidoro de Sevilha (c. 570-636). Várias vezes indica como sua fonte as Vitae Patrum. Ora no cap. X, De abstinentia, vem, a terminar, como último pensamento que tirou Ex Vitis Patrum, o seguinte $\left({ }^{108}\right)$, que desde já colocamos em paralelo com as Commonitiones:

SCINTILla $\times(626)$

Passiones et uitia corporis nostri, si fame ieiuniorum $a c$ uigiliarum labore macerentur, tunc aduersariorum nostrorum daemoniorum humiliatur uirtus.

\section{соммоNIт. I, $3^{c}$ (lin. 13-16)}

Similiter etiam passiones ac uitia corporis nostri: Si fame ieiuniorum atque uigiliarum labore macerentur, tunc etiam aduersariorum nostrorum daemonum humiliatur uirtus, quam per corporis nostri fortitudinem contra nos exercere solent.

Cremos que não pode subsistir qualquer dúvida, tão literal é a transcrição. Este apotegma não foi seleccionado pelo orga-

(108) Os elementos acabados de fornecer sobre Defensor de Ligugé encontram-se em J.-P. Migne, Patrologia Latina, t. 88, Parisiis, 1862. O Scintillarum liber ocupa as coll. 597-718; a informação histórica, as coll. 595-598; o passo que transcrevemos está na col. 626 . 
nizador do Livro III de Rosweydus. O seu texto encontra-se, portanto, num ponto que só podia ser conhecido por quem tivesse o conteúdo integral das Commonitiones. Se o compararmos com o aparato crítico da nossa edição, notaremos dois pormenores que também se verificam no manuscrito de Reims, Bibl. Munic. 1400: a presença de et e ac contra o texto dos melhores manuscritos. É verdade que depois de ieiuniorum acrescenta nostrorum o ms. de Reims; mas esta adição não é confirmada pelo outro manuscrito da mesma família, o de Paris, Bibl. Nac., fundo lat. 2941 que, por sorte, também seleccionou este apotegma. As duas outras pequenas variantes que assinalámos na transcrição de Defensor, ou foram introduzidas por ele ou pelo seu modelo. क

$O$ passo acima transcrito tem, felizmente, paralelos $\mathrm{em}$ duas outras versões latinas. Ei-los:

$$
\text { PELÁGIO IV,19 }
$$

PASCÁSIO XIII, $1^{2}$
Ita est et passio uentris. $\mathrm{Si}$ in ieiunio et fame conuersetur homo, inimici eius, qui sollicitant animam ipsius, infirmantur.
Ita et passiones carnales: $\mathrm{Si}$ in ieiunio et fame uolueris uiuere, deterrescunt et non sunt fortes aduersum animam.

Perante esta tríplice fonte das Vitae Patrum é evidente que Defensor nos transmitiu o texto das Commonitiones. Se de facto a sua informação provinha de um modelo do tipo do ms. de Reims, Bibl. Munic. 1400, o qual já representa uma elaboração secundária do original das Commonitiones, então podemos afirmar, com segurança, que as Commonitiones foram traduzidas muito antes do fim do século viI. Recordemos que Santo Isidoro de Sevilha, falecido em 636, é o último escritor a ser explicitamente citado por Defensor de Ligugé. 
Além deste passo, só um outro pensamento transmitido por Defensor faz lembrar as Commonitiones. No cap. XLIX, De tribulationibus, do Scintillarum liber lê-se (PL 88, col. 683):

Melius est hic persoluere poenas quam post exitum uitae huius in aeterno cruciari igne.

Segundo um apotegma grego (PG 65, Poemen 5 [320]) um juiz, desejoso de falar com o abade Poemen, recusando-se este a recebê-lo, resolveu prender um seu sobrinho a fim de que o monge viesse a interceder pelo seu familiar. Poemen apenas acedeu, no entanto, a escrever-lhe uma carta, em que dizia, segundo as Commonitiones IV,4 (linhas 41-46):

Iubeat nobilitas tua diligenter requirere causam illius; et si quid dignum morte admisit moriatur, quatenus in hoc praesenti saeculo exsoluat crimen peccati sui, ut euadat aeternas ac perpetuas gehennae poenas; sin autem nihil dignum morte commisit, quod iustum uidetur legibus ita de eo iube disponere.

Vejamos as duas outras traduções da carta em referência:

PELÁGIO VIII,13

Examina causam secundum legem; et si dignus est morte, moriatur; si autem non est, fac quomodo uis.
PASCÁSIO XLIX, 4

Discute illum secundum leges, et si dignus est moriatur; si autem dignus non est fac quod uis.

Apesar de Defensor de Ligugé dizer explicitamente que a sua frase é tirada Ex Vitis Patrum e de, entre os apotegmas, segundo pensamos, só as Commonitiones apresentarem uma ideia semelhante, a diferença verbal é tão grande que neste caso não julgamos prudente deduzir que Defensor se inspirou nas Commonitiones. O dito em causa está tão de acordo com a teologia corrente que é bem possível encontrar-se literalmente noutros livros das Vitae Patrum. Não obstante, impossível seria neste 
exemplo imaginar uma dependência dos fragmentos citados de Pelágio ou Pascásio $\left({ }^{109}\right)$.

Se Defensor de Ligugé, isto é, o fim do século VII é o limite máximo ante quem as Commonitiones já estavam traduzidas, em nossa opinião o trabalho de versão do grego para o latim deve ter-se realizado muito antes. O que vamos expor, rapidamente, não passa de uma estimativa ou hipótese que julgamos verosímil.

Em todas as Literaturas há géneros literários que em certa época estão em moda; depois passam, podendo vir mais tarde a ser retomados. Lembremos a épica nas Literaturas Grega e Latina ou o bucolismo nas Literaturas Clássicas e Modernas.

$\mathrm{O}$ apotegma como género literário surgiu na Literatura Cristã no século IV. Todavia, as maiores colecções gregas de que nos chegou conhecimento através das suas traduções latinas - de Pelágio-João, de Pascásio, das Commonitiones e de Martinho de Dume - se atendermos às personagens nelas mencionadas, as colecções gregas, (dizíamos) devem ter sido redigidas na segunda metade do século $\mathrm{V}\left({ }^{110}\right)$.

Quanto às suas traduções latinas, para algumas podemos apresentar datas bastante aproximadas. As Adhortationes sanctorum patrum (111) foram traduzidas, em Roma, pelo diácono Pelágio, pelo subdiácono João e por outro tradutor desconhe-

(109) C. M. Batlle, Die Adhortationes... faz nas pp. 208-297 um importante estudo sobre a presença e influência dos apotegmas na literatura medieval, desde S. Bento a Martinho Lutero. Ao citar a obra de Defensor de Ligugé (pp. 211-212) remete, com alguma hesitação, para a tradução de Pelágio. Mais provável lhe parece que as citações sejam do Livro III de Rosweydus (o qual, no entanto, não contém o n. I,3 das Commonitiones) ou de Pascásio «numa recensão extensa». Efectivamente - Scintillarum liber contém várias transcrições de Pascásio, extraídas de manuscritos da família dos de Seo de Urgel, Arq. Capit., anno 938; Salamanca, Bibl. Univ. 2537 (cf. Pascásio de Dume..., t. II, pp. 61-93). A análise de tais citações levar-nos-ia para fora do âmbito deste estudo.

(110) Cf. Pascásio de Dume..., t. I, pp. 34-37 e a bibliografia aí indicada.

(111) Cf. C. M. Batlle, Die Adhortationes..., pp. 10-15 e 298-300. 
cido, no máximo entre 526 e 556 ou, precisando mais, entre 535 e 550. O Liber Geronticon de octo principalibus uitiis de Pascásio $\left({ }^{112}\right)$ deve ter sido vertido, em Dume, pouco antes de 556. As Sententiae patrum Aegyptiorum quas de graeco in latinum transtulit Martinus Dumiensis episcopus $\left({ }^{113}\right)$ supõe-se serem trabalho dos primeiros tempos do episcopado de Martinho em Dume, isto é, após 5 de Abril de 556.

Resumindo, a época de tradução das principais colecções, para latim, pode fixar-se entre 530 e 560 . Traduzir este género literário estava então em voga. A julgar pelas aparências externas, as Commonitiones poderão ter sido traduzidas também por essa altura.

A falta de um nome do tradutor e de uma data rigorosa, podemos pelo menos supor que entre 500 (data que permite margem para se fazerem as reelaborações que deram origem ao texto citado, por volta de 700 , por Defensor de Ligugé) - entre 500 e 600 , portanto, deve ter vivido o tradutor das Commonitiones.

Oxalá o estudo da literatura latina desta época nos apresentasse um nome que pudesse reivindicar esta tradução. Entre os tradutores célebres do século VI conta-se também Dionísio, o Exíguo. Ao mesmo período pertencem igualmente Cesáreo de Arles, Gregório de Tours, Boécio, Cassiodoro e tantos outros $\left({ }^{114}\right)$. É bem possível que o tradutor seja um ignorado monge que não quis deixar-nos memória do seu nome.

(112) Cf. Pascásio de Dume..., t. I, pp. 15-16.

(113) Claude W. Barlow, Martini episcopi Bracarensis opera omnia, New Haven, 1950 , p. 3.

(114) Sobre a Literatura Latina dos séculos v e vi podem ver-se, entre outras, as seguintes obras: M. SCHAnz, C. Hosrus und G. KRÜGER, Geschichte der Römische Literatur, IV. Teil, II. Band, München, 1959, pp. 360-650; M. ManIrIUs, Geschichte der lateinischen Literatur des Mittelalters, I. Band, München, 1965, pp. 3-242; E. NoRden, Die römische Literatur. Mit Anhang: Die lateinische Literatur im Übergang vom Altertum zum Mittelalter, Leipzig, 1961, pp. 107-132 e 205-214; IDEM, Die antike Kunstprosa vom VI. Jahrhundert v. Chr. bis in die Zeit der Renaissance, II. Band, B. G. Teubner Verlagsgesellschaft, Stuttgard, 51958: capp. sobre a literatura 
Poderemos nós, ao menos, utilizar a área de circulação dos códices das Commonitiones para lançar suspeitas sobre uma determinada região? Os melhores manuscritos que chegaram até nós vieram de Viena, Dresda, Munique, Reno, Flandres... O nosso olhar volta-se, vagamente, para a antiga Germania (115).

Resta-nos a obra: as Commonitiones sanctorum patrum aí estão para quem quiser perscrutar nelas não só a arte do seu tradutor, mas também algum possível indício da sua personalidade. Há, de facto, peças literárias cujo autor tem sido identificado, com segurança, apenas a partir das características do seu estilo. Mas para isso é preciso que alguma das suas obras tenha sido assinada ou lhe seja atribuída por testemunhos fidedignos $\left({ }^{116}\right)$. A questão fica em aberto. Têm a palavra os filólogos.

latina tardia, especialmente pp. 573-656, e o cap. sobre a época de transição entre a Antiguidade e a Idade Média, pp. 661-669; F. A. Wrigth and T. A. Sinclair, $A$ history of later latin literatur from the middle of the fourth to the end of the seventeenth century, London, 1969, pp. 67-133; P. DE LABRIOLLE, Histoire de la littérature latine chrétienne, Paris, 1947, pp. 577-825.

(115) Cf. alguns leves indícios linguísticos, também orientados para a Germania, infra pp. 166, 219, 224, 229, 241 e também 149, 249, 257.

(116) Entre as obras cujo autor tem sido identificado através do exame do seu estilo lembramos: de Potâmio de Lisboa, a Epistula de substantia Patris et Filii et Spiritus Sancti e as homilias De Lazaro e De martyrio Isaiae prophetae - ao passo que o Libellus "Dauid gloriosus» lhe não pertence (cf. A. Montes Morerra, Potamius de Lisbonne et la controverse arienne, Louvain, 1969, pp. 230-231, 246-250, 287-288 e 303-308); de dois autores diferentes, um latino outro grego, a Passio Perpetuae et Felicitatis (cf. ÅKe FridH, Le problème de la passion des saintes Perpétue et Félicité, Göteborg, 1968); de Eusébio de Cesareia fragmentos até há pouco tidos como de Orígenes (cf. C. CurTI, Due articoli Eusebiani, Noto, 1971); e para citar um caso português, a Alexandre Herculano o conto Destruição de Auria (cf. Ofélia M. C. Parva Monteiro, Coimbra, 1973). Também por motivos filológicos foi negada a Anacreonte a autoria do frag. 44 D (cf. Maria Helena da Rocha Pereira, Sobre a autenticidade do fragmento 44 Diehl de Anacreonte, Coimbra, 1961); S. Jerónimo

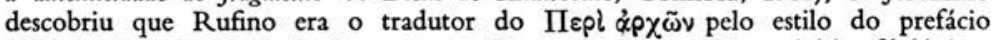
(cf. PL 73, col. 38); J. A. SEGURAdo в CÁmpos aplica também critérios filológicos na tentativa de descobrir o autor da tragédia Octania, atribuída geralmente a Séneca (cf. J. A. S. e Campos, A tragédia Octauia, I e II vol., Lisboa, 1972. $\mathrm{E}$ quantas mais obras não estão nas mesmas condições: que de estudos sobre a Appendix Vergiliana, etc. 
Ponhamos de novo os três problemas:

$10^{\circ}-$ Quando foi redigido o texto grego das Commonitiones? Cremos que por volta do ano 500 .

$2 .^{\circ}-$ Quem as escreveu, no original grego? Pensamos que um monge pacomiano do Egipto.

3. - Q Qual o seu tradutor? O enigma mantém-se. Alguém que, talvez na Germania, por meados do século VI, supomos nós, conhecia bem o grego e o latim.

Há, porém, uma resposta segura para cada uma destas três perguntas: - com certeza, não sabemos. 


\section{Cap. VII - UM APOTEGMA IMPORTADO DE CASSIANO}

O problema acabado de estudar, o do tradutor, obriga-nos a prestar especial atenção ao n. V,6 das Commonitiones. Quem observar o quadro de lugares paralelos que fornecemos $\left({ }^{117}\right)$ reparará que o texto latino das Commonitiones já fora em grande parte publicado no Livro III de Rosweydus e na Palladii Lausiaca. Mas, enquanto para os apotegmas editados nestes dois livros nos é fácil hoje provar que eles são extractos das Commonitiones, com o n. V, 6 passa-se algo de diferente.

O texto da Palladii Lausiaca XX,7 é de facto uma reprodução retocada das Commonitiones V,6. Porém, este mesmo texto se encontra nas Conlationes XXIV,9 de João Cassiano (118). No último capítulo das suas Colações ou Conferĉncias, o XXIV, temos uma exposição do abade Abraão sobre a mortificação, dirigindo-se ao próprio Cassiano e a seu amigo Germano. Após uma conversa sobre a intenção dos dois amigos de deixarem o Egipto e de partirem para o seu país, fala Abraão sobre os lugares mais apropriados para a vida monástica e os trabalhos próprios de um monge. No parágrafo 7 intervém Germano, perguntando porque deverão os mosteiros no seu país natal ser construídos longe da família dos religiosos, quando no Egipto há monges que vivem junto dos seus parentes. Abraão começa, no parágrafo 8 , por dizer que as instituições devem adaptar-se ao temperamento de cada povo. E no parágrafo 9 apresenta o exemplo concreto do abade Apolo, que

(117) Cf. supra pp. 63-64.

(118) Deve corrigir-se a remissão de W. Bousset (Apophthegmata, Tübingen, 1923, p. 137) que envia para "Kassian, Instit. 24, 9". Na realidade a obra em causa são as Conlationes. 
soube resistir a um apelo de ordem temporal feito por um seu irmão. Se eles, estabelecidos em regiões de características diferentes, fossem capazes de tão grande desapego, então também lhes não faria mal a vizinhança da família (119).

Transcrevemos o texto integral de XXIV,9 colocando a par, no lugar próprio, o apotegma V,6 das Commonitiones. Diz o abade Abraão:

Vt uero ad certum districtionis examen uestrarum uirium quantitatem metiri congrua aestimatione possitis, cuiusdam uobis senis, id est, abbatis Apollo factum breuiter indicabo, ut, si uos intimum uestri cordis examen huius proposito atque uirtuti haud inferiores esse censuerit, absque iactura propositi uestri professionisque periculo patriae inhabitationem ac parentum uiciniam praesumatis, certi quod districtionem humilitatis huius, quam uobis in hac prouincia non solum uoluntas, sed etiam necessitas peregrinationis extorquet, propinquitatis adfectus aut locorum oblectatio non possit euincere.

Ad hunc igitur quem praediximus senem cum germanus suus intempesta nocte uenisset, implorans ut de monasterio suo paulisper egressus ad euellendum bouem, quem caeno palustri eminus inhaerere flebiliter querebatur, ei esset auxilio,

COMMONITIONES v,6

Ad hunc igitur senem cum germanus suus intempesta nocte uenisset, petens ut de monasterio suo paulisper egressus ad eleuandum bouem, qui in paludis caeno cecidisselt, flebiliter quaerebatur ut ei praeberet auxilium,

(119) Estamos seguindo a edição de E. PICHERY, Jean Cassien. Conférences XVIII-XXIV, Paris, 1959. O texto latino e a tradução francesa da Conferência 24 estão nas pp. 169-206. O parágrafo 9 que vamos reproduzir ocupa as pp. 179-180. 
quia eum solus nequaquam posset eruere, abbas Apollo pertinaciter obsecranti:

Cur, ait, iuniorem fratrem nostrum, quem praeteriens propiorem quam me habueras, non rogasti ? Cumque ille eum mortem olim sepulti fratris oblitum et ex nimia continentiae ac solitudinis iugitate uelut impotem mentis existimans respondisset: quemadmodum poteram de sepulcro eum qui ante annos quindecim obiit inuocare? Abbas Apollo: ignoras ergo, ait, me quoque ante annos uiginti huic mundo esse defunctum nullaque iam posse de huius cellae sepulcro quae ad praesentis uitae pertineant statum tibi conferre solacia? Quem in tantum Christus $\mathrm{ab}$ intentione mortificationis adreptae uel modicum ad extrahendum bouem tuum non patitur relaxari, ut ne breuissimi quidem momenti indutias pro patris indulserit sepultura. Quac multo utique celerius, honestius et religiosius fuerat exhibenda. Rimamini itaque quia eum solus non posset eruere. Cui abbas Apollo instanter obsecranti:

Cur, ait, iuniorem fratrem nostrum, quem praeteriens uiciniorem quam me habueras, non rogasti ? Cumque ille, mortem olim sepulti fratris oblitum et ex nimia abstinentia ac solitudinis iugitate uelut impotem mentis existimans, respondisset: Quemadmodum poteram eum de sepulcro, qui ante annos quindecim obiit, inuocare ? Et abbas Apollo respondit dicens: Ignoras ergo me quoque ante annos uiginti huic mundo fuisse defunctum? Nullaque iam posse de huius cellulae sepulcro, quae ad praesentis uitae pertineant statum, tibi conferre solacia, quem in tantum Christus $\mathrm{ab}$ intentione abrenuntiationis mundi arreptae uel modicum ad extrahendum bouem tuum non patitur relaxari, ut ne breuissimi quidem momenti indutias sequenti se discipulo pro patris indulserit sepultura. 
nunc arcana pectoris uestri prudenterque conicite, an talem etiam uos iuxta parentes uestros districtionem mentis iugiter retentare possitis, cumque uos in hac animi mortificatione consimiles eidem senseritis, tunc demum scitote parentum fratrumque uiciniam uobis quoque similiter noxiam non futuram, ut scilicet eis quamuis in proximo constitutis uelut mortuos uos esse credatis, ita ut nec illos uestris foueri solaciis nec uos illorum sinatis obsequiis relaxari.

Propositadamente transcrevemos o parágrafo completo de Cassiano, não só para se apresentar todo o contexto, como para dar um exemplo do estilo deste autor (cf. também pp. 93, 143, 244).

Antes de termos feito o nosso estudo sobre o autor e o tradutor das Commonitiones, comparámos os dois textos na parte que têm de comum (ou quase). Utilizando apenas critérios de comparação estilística e de processos de tradução, chegámos à conclusão de que as Commonitiones apresentavam um texto importado das Conlationes, tendo-lhe dado alguns retoques. A nossa transcrição assinala todas as pequenas omissões, breves acrescentos e pormenores de reelaboração. Tudo bem ponderado, parece-nos que o tradutor das Commonitiones, apropriando-se embora do texto de Cassiano, procurou ser mais claro, tornando a sintaxe e a compreensão mais acessíveis.

Agora que sabemos terem as Commonitiones sido traduzidas, com certeza, após o ano 500, não se pode sequer pôr de novo o problema da anterioridade do texto latino, uma vez que as Conlationes foram compostas, muito provavelmente, nos anos 425-426.

Cassiano é, com efeito, uma figura bem conhecida $\left({ }^{120}\right)$. Nascido por 365 na Cítia (ou antes na Gália ?) foi atraído para

${ }^{120}$ Entre a vasta bibliografia sobre Cassiano, c com as suas obras, seleccionamos: J.-P. Migne, Patrologia Latina, t. 49, Parisiis, 1874: coll. 53-476, De coenobiorum institutis; coll. 477-1326, Collationum XXIV collectio; IonNNIS Cassiani Opera, 
o convívio com os cenobitas da Palestina e do Egipto, com os quais viveu desde 385 a 399. Dirigiu-se depois para Constantinopla, para junto de S. João Crisóstomo, cuja causa foi encarregado de defender em Roma, em 405. Pouco depois de 415 fixou-se em Marselha, onde fundou um mosteiro de homens e outro de nulheres. A sua missão levou-o a escrever duas obras célebres para o monaquismo ocidental: as Institutiones, publicadas em 424-425, e as Conlationes, escritas provavelmente em 425-426. Veio a morrer por 435.

É o problema das suas fontes que de momento nos interessa. Além das recordações pessoais, resultantes de longos anos de convivência com célebres monges, serviu-se de documentação literária, como a Historia Monachorum, a Historia Lausiaca e os Apotegmas dos Padres do Deserto. Cita pensamentos de Evágrio e de Orígenes, mas sem nunca mencionar estes autores, dada a polémica doutrinal levantada à volta deles $\left({ }^{121}\right)$.

Somos de opinião que nas Conlationes XXIV,9 João Cassiano põe na boca do abade Abraão um apotegma sobre o abade Apolo. A contextura deste apotegma é de tipo secundário: a "palavra de salvação" é apresentada já sob a forma de narrativa. Podemos assim presumir que esta redacção do

Conlationes XXIV, Corpus Scriptorum Ecclesiasticorum Latinorum, t. XIII, Vindobonae, 1886; IDEM, Institutionum libri XII, t. XVII, 1888 (ambos os volumes apresentados criticamente por M. Petschenig); O. СнsDwrck, John Cassian, A study in primitive monasticism, Cambridge, 1950; IDEM, Western ascetism. Selected texts. The saying of the fathers, The Conferences of Cassian, The Rule of St. Benedict, Philadelphia, 1958; Jean Cassien, Conférences, Paris, t. I (I-VII); t. II (VIII-XVII); t. III (XVIII-XXIV), 1955, 1958, 1959, introd., texte, trad. et notes par E. PICHERY (= Sources Chrétiennes 42, 54, 64); Jean Cassien, Institutions Cénobitiques, texte latin revue, introd. trad. et notes par J.-C. GuY, Paris, 1965; J. LEROY, Les prêfaces des écrits monastiques de Cassien in Revue d'Ascétique et de Mystique XLII (1966) pp. 157-180; M. MaRTINs, João Cassiano, Fragmentos em medievo-português in Estudos de Literatura Medieval, Braga, 1956, pp. 272-274. Foi anunciado, em 1968, um estudo literário sobre Cassien, écrivant a realizar por Melle JARZaGuet, sob a direç̧ão de J. Fontaine, mas não temos conhecimento da sua publicação.

(121) Sobre as fontes de Cassiano, cf. o resumo de E. PICHERY, na introdução às Conférences, Paris, 1955, pp. 58-63. J.-C. GuY menciona também os apotegmas entre as fontes de Cassiano no artigo Les apophthegmata patrum in Théologie de la Vie Monastique, Paris, 1961, p. 78. 
apotegma já existia, em grego, no primeiro quartel do século $\mathrm{V}$ e que ele foi inserido, sem reelaboração profunda, tanto por Cassiano nas Conlationes, como nas Commonitiones pelo autor grego desta colectânea. Repare-se que ele está perfeitamente ajustado ao tema do cap. V, que sob o título De doctrina ad monachos trata, nos apotegmas 1 a 6 , do desprendimento da família.

Pensamos que Cassiano traduziu, de facto para aqui, à letra, um apotegma grego. Por sua vez, o tradutor das Commonitiones, que, segundo podemos supor, teria o apotegma no seu texto grego, conhecia o trabalho de Cassiano e, entregando-se à autoridade de um mestre, tomou-o como modelo, embora lhe tenha introduzido pequenas alterações, no desejo de simplificar. Com efeito, não se trata de duas recensões diferentes do texto de Cassiano, mas de um único texto latino, o de Cassiano, reelaborado levemente pelo tradutor das Commonitiones, de acordo com o seu gosto e suas preferências vocabulares.

A edição de M. Petschenig é crítica, baseada em seis manuscritos $\left({ }^{122}\right)$. As variantes apresentadas em XXIV,9 na parte equivalente às Commonitiones V,6 não têm especial significado. Regista Petschenig diferenças ortográficas, omissão de uma só palavra em dois códices e pequenas alterações morfológicas em um, dois ou três códices no respeitante a sete vocábulos. Não restam, pois, dúvidas de que o texto de Petschenig, retomado por E. Pichery, está bem estabelecido, segundo a transmissão manuscrita das Conlationes.

Observemos agora as diferenças entre este texto, que supomos ser o original de Cassiano, e o que nos dão as Commonitiones. Nestas, apenas foram omitidas três palavras ou expres-

(122) Ioannis Cassiani Conlationes XXIV, Vindobonae, 1885. A lista dos manuscritos usados vem na p. 502; o texto de XXIV,9 está nas pp. 683-684. 
sões: quem praediximus senem, que bem se pode considerar uma ligação de Cassiano, típica na sua obra, para retomar um assunto $\left({ }^{123}\right)$; eum e ait, que não têm especial significado no conjunto sintáctico.

Em contrapartida, a lição das Commonitiones tendo (segundo a nossa pontuação) terminado uma frase depois de eruere, acrescentou um cui para abrir novo período; remodelou um começo de resposta, juntando et respondit (este equivalente ao omitido ait) dicens; especificou a mortificação ou renúncia com a adição de mundi; e no fim temos a inclusão de sequenti se discipulo que fica muito bem no contexto, mas que não percebemos por que motivo (se estivesse na sua hipotética fonte grega) Cassiano teria omitido, ele que acrescentou, sem dúvida por sua conta, uma justificação para o dever da "patris sepultura».

Há outras diferenças que resultam da substituição de um vocábulo pelo seu sinónimo, as quais nada de especial nos podem dizer. Colocamos frente a frente a lição das Conlationes e a das Commonitiones:-implorans: petens; nequaquan: non; pertinaciter: instanter; propiorem: uiciniorem; esse: fuisse; cellae: cellulae; mortificationis: abrenuntiationis.

Mais significativas são outras alterações. Não temos registada nas Commonitiones a expressão implorare ut, ao passo que petere ut se encontra em IV,1 (linha 6); IV,6 (lin. 3); V,3 (lin. 9-10); e V,4 (lin. 5-6).

Veja-se o passo em que foi mais retocado o latim das Commonitiones, afastando-se das Conlationes:

(123) Quando fazemos aqui referências a hábitos linguísticos de Cassiano, baseamo-nos na observação das Conlationes. Uma leitura atenta, só que seja da Conferência XXIV, fará ressaltar a veracidade das nossas afirmaçð̋es. 
CONLATIONES

... cum germanus suus uenisset (...) implorans ut de monasterio suo paulisper egressus ad euellendum bouem, quem caeno palustri eminus inhaerere flebiliter querebatur, ei esset auxilio, quia...
COMMONITIONES

... cum germanus suus uenisset $(\ldots)$ petens ut de monasterio suo paulisper egressus ad eleuandum bouem, qui in paludis caeno cecidisset, flebiliter quaerebatur $u t$ ei praeberet auxilium, quia...

Este troço da frase (uma frase longa, bem típica de Cassiano e que o tradutor das Commonitiones dividiu, quebrando-a depois de eruere) foi intencionalmente reelaborado pelo "plagiador" das Conlationes. Em Cassiano o verbo dependente do $u t$ inicial só pode ser esset auxilio, bastante afastado. Euellere e eleuare, verbo este que substituiu aquele, significam fundamentalmente o mesmo, neste contexto: «retirar».

A oração relativa foi completamente transformada. Cassiano faz de quem o objecto de querebatur, cujo sujeito subentendido é o germanus suus da oração temporal-causal iniciada por cum; o tradutor das Commonitiones reorganizou a oração relativa, fazendo de qui o sujeito (mantendo o mesmo antecedente: bouem), cujo predicado foi introduzido por iniciativa própria: cecidisset (a substituir eminus inhaerere). A origem desta alteração deve estar na interpretação de querebatur: quaerebatur. Cassiano entende que o irmão «se lamentava, chorando, de o seu boi se ter atolado profundamente num lodaçal pantanoso»; as Commonitiones dizem simplesmente que "o boi caiu na lama de um pântano». Esta modificação levou a fazer de quaerebatur (repare-se na mudança de significado) o verbo da oração subordinante, a qual passa a exigir a construção de $u t$ ei praeberet auxilium: o irmão "pedia-lhe entre lágrimas que lhe prestasse auxílio». 
Além disso, o verbo dependente de petens ut deixou de estar expresso, devendo subentender-se em egressus $<$ esset $>$. Mas omissões deste tipo devem encarar-se como aceitáveis, tanto mais que nas Commonitiones há várias palavras que ficam subentendidas $\left({ }^{124}\right)$.

Regressando à alteração introduzida, note-se que a expressão auxilio esse (ou esse com dativo) não aparece mais nas Commonitiones; pelo contrário estas têm com frequência o verbo praebere com acusativo: p. misericordiam (II,7, linhas 28-29); p. occasionem (IV,4, lin. 19); p. exempla (IV,7, lin. 32; IV,19, lin. 51-52); p. omnia (V,4, lin. 9).

Verifica-se assim que a palavra-chave de toda esta refundição é a forma verbal querebatur, originária e certa no texto de Cassiano. Parece-nos que a sua confusão com quaerebatur (o que exigiu nova organização sintáctica) só podia dar-se num tradutor que tivesse, aqui, perdido o contacto com o original grego, mas apenas tentou interpretar a grafia de que-ror, dado que o ditongo ae se tinha monotongado (não somente no latim tardio, mas já em séculos anteriores) na linguagem campesina $\left({ }^{125}\right)$. O verbo quaero aparece outras vezes nas Commonitiones (II,5, linha 16; IV,19, lin. 81). Para queror não temos registado nenhum outro passo. Este ponto parece-nos fundamental para provar que o apotegma foi importado, directamente, do texto latino de Cassiano.

Decisiva também é a expressão:

CONLATIONES

... ex nimia continentiac ac solitudinis iugitate...

\section{COMMONITIONES}

... ex nimia abstinentia ac sollicitudinis iugitate...

(124) Cf. infra pp. 189-192.

(125) Sobre a evolução do ditongo ae, cf. M. Leumann, Lateinische Laut-und Formenlehre, München, 1963, pp. 75-76; E. FARIA, Fonética histórica do latim, Rio de Janeiro, 1957, pp. 171-172; C. H. GRANDGENT, Introducción al latin vulgar, Madrid, 1952, pp. 141-142; V. Vล̈̈̈N̈̈NEN, Introducción al latin vulgar, 1968, pp. 74-75. 
O texto que damos aqui é o dos «melhores» manuscritos, os de Viena e de Dresda. O de Reims omite este apotegma. Acontece, porém, que o manuscrito de Namur (e outros, como veremos, pp. 282-283) nos transmite, neste passo, a palavra solitudinis em vez de sollicitudinis, certamente por ter, neste ponto, um modelo melhor (apesar de ser certo que não possuía o texto de Cassiano, pois adopta todas as variantes típicas das Commonitiones - omissões, acrescentos, substituições). Não há, de facto, qualquer dúvida de que solitudinis é a lição acertada.

O substantivo iugitas, «frequência, prolongamento», não é raro em Cassiano. A expressão solitudinis iugitate tem pleno sentido, se entendermos que, "devido a um demasiado prolongamento da abstinência e da solidão", o irmão impetrante pensava que o outro, o monge, tinha perdido a memória.

A palavra sollicitudo aparece várias vezes nas Commonitiones (II,7, lin. 3,35,44; IV,3, lin. 28; IV,12, lin. 68; V,1, lin. 5,6,8) sempre com o valor de «solicitude, preocupação". O seu uso, aqui, está inteiramente fora do contexto. Não há outra hipótese senão admitir que os "melhores» manuscritos, isto é, VD, dependem de uma fonte errada, devendo nós supor que a confusão foi introduzida no arquétipo $\beta$. Não nos parece que o tradutor das Commonitiones, tão atento na interpretação de querebatur, muito mais difícil, tenha sido o causador deste erro de leitura ou de cópia. Temos, por isso, como provável, que a boa lição - solitudinis - ainda se encontrasse no hiperarquétipo $\alpha$ de que dependeu toda a restante transmissão manuscrita das Commonitiones. Curioso será notar que a palavra solitudo não aparece mais nas Commonitiones. Emprega-se eremus; usa-se mesmo solitarius (IV,3, lin. 7; IV,15, lin. 2), mas nunca mais solitudo.

Menor importância tem a troca, nesta mesma expressão, de continentiae por abstinentia. Alterou-se o vocábulo e a morfologia, mas o sentido último mantém-se o mesmo. Observe-sc, no entanto, que abstinentia é frequente nas Commonitiones, sobre- 
tudo no capítulo I (cf. capitulatio I; I,1, linha 2; I,3, lin. 2; I,12, lin. 5; I,16, lin. 5,8,10-11; II,3, lin. 2). Em contrapartida, não registámos a presença de continentia, nem mesmo no capítulo II: contra spiritum fornicationis, onde, segundo a terminologia ascética actual, seria de esperar.

Este apotegma permite-nos também observar, num outro passo, o valor do manuscrito de Namur. Cristo exige uma renúncia tal à família que não concede a quem deseja segui-lo tempo livre sequer para cumprir o dever de sepultar o pai. Neste final do episódio a lição de Cassiano é uniforme em transmitir um ut (linha 17) com valor consecutivo. O copista do arquétipo $\beta$ transformou, certamente por erro, ut em et. Que esta conjunção coordenativa (como se de parataxe se tratasse) está deslocada, prova-o o verbo indulserit, no conjuntivo, só explicável se de facto depender de $u t$.

Eis ainda algumas palavras de uso corrente que aparecem neste apotegma, e se encontram frequentemente em Cassiano, mas não registámos mais nas Commonitiones: arreptus, eruere, impotis, intempestus, inuocare, ingitas, olim, propior, solacia, etc. $\left({ }^{126}\right)$.

O estudo do apotegma n. V,6 das Commonitiones coloca-nos, pois, perante alguns problemas de não fácil solução. Nós pensamos que na Conlatio XXIV,9 Cassiano se serviu de um apotegma grego cuja elaboração já estava fixada no fim do primeiro quartel do século V. A predilecção apotegmática de Cassiano, além de já estar provada por outros investigadores,

(126) O apotegma V,6 tomado pelas Commonitiones das Conlationes de Cassiano, encontra-se todo na p. 180 da edição de E. PiChery, Paris, 1959. Damos aqui algumas palavras ou expressões, que vêm neste apotegma e que se encontram também na Conlatio XXIV, mas não são típicas das Commonitiones. Indicamos apenas a página:

- quem praediximus (ou equivalente): 181, 183, 188;

- ingitas: 175, 185; iugiter: 171, 173, 174, 176, 180; ingis: 175, 179, 185, 190 , 192, 193, 195, 196, 199, 201;

- arreptus: 178,200 ;

-utique: 183, 190, 194, 200. 
confirma-se pelo facto de o próprio Cassiano ser um dos "padres" a quem a série nominal atribui 8 apotegmas gregos (cf. Patrologia Graeca, LXV, coll. 243-246).

Admitimos também, como provável, que esse mesmo apotegma tenha sido incluído pelo autor das Commonitiones na sua compilação grega, organizada por temas ascéticos.

O tradutor latino das Commonitiones depararia, portanto, a certa altura, com um texto grego que já havia antes sido vertido para latim por Cassiano. Perante a autoridade deste escritor, um dos pilares do monaquismo ocidental e sempre venerado como santo, o tradutor das Commonitiones teria adoptado a versão de Cassiano, introduzindo-lhe algumas alterações, de pouca monta.

Devemos, no entanto, confessar que não nos repugnaria que o tradutor incluisse aqui um passo que condizia perfeitamente com o tema do capítulo $\mathrm{V}$ das Commonitiones. A ser assim, talvez se pudesse pôr o problema de considerar o n. V,6 como uma interpolação. Nesse caso, perguntamos: em rigorosa crítica textual, deveria ser excluído? Contra esta exclusão temos nós duas objecções a opor:

1 - o apotegma pertence, sem dúvida, desde a origem, à colecção latina das Commonitiones. Repare-se que os melhores manuscritos, o de Viena e de Dresda, representantes do único arquétipo que nos transmite a capitulatio do capítulo $\mathrm{V}$, inserem o apotegma em causa numa ordem perfeitamente lógica. Trata-se, desde o n. 1, de conselhos aos monges sobre qualem oportet affectum circa corporales parentes seu propinquos habere. Nesta organização sistemática, o n. 6 está enquadrado com toda a perfeição estilística. Vejam-se os números mais próximos: IV-De famulo Dei Martiano; $V-D e$ famula Dei et fratre eitu; VI - De abbate Apollo et fratre eius; VII $-D e$ beato Theodoro, discipulo sancti Pachomii. Cremos, por isso, que o n. 6 pertencia, sem dúvida, à primitiva redacção latina desta colecção. 
2 - Se o apotegma "sobre o abade Apolo e seu irmão" tivesse sido interpolado, com muita probabilidade o falsário - seria este o nome a dar ao tradutor das Commonitiones tê-lo-ia colocado no fim, em apêndice à série sobre o desprendimento da família. Ora o que se verifica é que ele está na linha de pensamento que o autor grego traçou para o capítulo V.

Mais ainda, supomos que a série sobre o desapego familiar termina, propositadamente, com um exemplo do beato Theodoro (n. 7). Se, conforme pensamos ter provado $\left({ }^{127}\right)$, o autor do texto grego é um monge da Ordem de S. Pacómio, facilmente se compreende que à série de apotegmas sobre o tema da família, o autor quisesse juntar um exemplo de um dos fundadores da sua Congregação. E assim se explica que os casos narrados sobre Teodoro e Pacómio, que não se encontram na tradição apotegmática, tenham sido recolhidos das Pachomii Vitae Graecae, onde Teodoro assume o lugar de discípulo predilecto de S. Pacómio. Somos assim induzido a concluir que o n. V,6 está de facto no seu lugar e foi aí colocado, muito provavelmente, pelo primeiro responsável pelas Commonitiones, o autor do seu texto grego.

Há pelo menos uma acusação de que o tradutor das Commonitiones se não pode livrar: se não foi falsário, pelo menos foi plagiário. Com efeito, é indubitável que ele copiou, das Conlationes de Cassiano, a tradução latina deste apotegma, embora the introduzisse algumas modificações.

Enfrentamo-nos aqui com a questão literária do plágio $\left.{ }^{128}\right)$. É sabido que na Antiguidade, em que não havia

(127) Cf. supra pp. 105-120.

$\left({ }^{128}\right)$ Sobre o conceito de plágio, seu uso e (de)mérito na Antiguidade, o melhor trabalho que conhecemos ainda é o de K. ZIEGLER no artigo Plagiat da Realencyclopädie der klassischen Altertumswissenschaft de PAuLY-Wissowa, vol. 40, 1 , Stuttgart, 1950, coll. 1956-1997. Sobre a teoria e prática do plágio nas literaturas modernas é muito rica em citações e exemplos a obra de Cruz MalpiQue, Filosofia do Plágio (Ensaio), Braga, 1955, 180 pp. A este problema pode ligar-se o dos escritos 
registo e "direitos de autor", o plagiário não era apodado, como hoje, pura e simplesmente, de «ladrão». A transcrição de pensamentos ou de páginas inteiras de outros autores, sem lhes indicar o nome, era moeda corrente. O próprio Cassiano se serviu de pensamentos de Orígenes e de Evágrio, tendo porém a prudência de não os mencionar $\left({ }^{129}\right) \ldots$

Temos assim que ao tradutor das Commonitiones não se pode assacar crime literário de grande responsabilidade, pelo menos segundo a ética do seu tempo. Além disso, ele modificou ainda um pouco o texto, tornando-o mais conforme ao seu estilo e vocabulário.

Reflectindo mais sobre o caso, talvez até tenha sido um bem este plágio. Se para o autor das Commonitiones podemos apontar elementos característicos da sua pessoa - um monge pacomiano do Egipto, do final do século V ou princípios do VI - quanto ao tradutor estamos quase na penumbra... Poderia este apotegma, plagiado de Cassiano, fazer voltar o nosso olhar para Marselha ou para os centros da sua irradiação? Bem débil indício! Cassiano morreu por 435 e as Commonitiones foram traduzidas talvez uns 100 anos depois. Entretanto a obra de Cassiano tinha corrido mundo. Importa continuar a auscultar os textos. Quem copiou? Onde copiou? Quando copiou ?

cujo autor a crítica moderna classifica de Pseudo..., como o Pseudo-Salústio, Pseudo-Ovídio, Pseudo-Séneca, Pseudo-Agostinho, Pseudo-Dionísio Areopagita, Pseudo-Crisóstomo, Pseudo-Calístenes, etc., etc., etc. Em certos aspectos estas últimas obras podem ligar-se também ao tema das falsas atribuições a que já aludimos (pp. 126-127, nota 103). p. $62-63$.

$(129)$ Cf. E. Pichery, introd. a Conférences de Jean Cassien, Paris, 1955, 


\section{Cap. VIII - EXAME LINGUÍSTICO DO LATIM DAS COMMONITIONES}

\section{1 - OPINIÃO DE HOPFNER E DE SALONIUS}

Considerando a qualidade do latim do Livro III das Vitae Patrum (edição de Rosweydus), Theodor Hopfner dizia, em 1916, que a sua redacção "é mais correcta, fluente e, por assim dizer, elegante do que a de Pelágio-João, pois esta é de tal modo escrava da simplicidade do original grego que chega a violentar o bom latim, a ponto de às vezes a sua tradução se tornar quase ininteligível». O Livro III, pensava ele, "fornece apenas o sumário do original grego, apresentado de modo bastante exacto, tomando, no entanto, uma forma latina própria c agradável. Muitas vezes não parece mesmo uma tradução, mas uma reclaboração do material grego» $\left({ }^{130}\right)$.

Salonius concluiu também que a linguagem do Livro III, «em comparação com a de Pelágio e de João é mais elevada, polida e mais livre do influxo grego; por isso mesmo, é mais artificiosa e denuncia, na selecção do vocabulário, uma época mais tardia» $\left({ }^{131}\right)$. E depois de ter comparado a língua e estilo do Livro III com os hábitos linguísticos de Rufino, manifestou a sua convicção de que quanto mais se estudar Rufino mais se

(130) Cf. Th. Hopfner, na sessão de 5 de Julho de 1916, em Praga, da Akademie der Wissenschaften in Wien. Philosophisch-historische Klasse, Denkschriften, 61. Band, Wien, 1919, p. 26.

(131) A. H. SAlonius, Vitae Patrum. Kritische Untersuchungen über Text, Syntax und Wortschatz der spätlateinischen Vitae Patrum. (Bücher III, V, VI, VII). Acta Societatis Humaniorum Litterarum Lundensis II, Lund, 1920, p. 33. 
confirmará a certeza de que o Livro III não é da autoria de Rufino (132).

Estas opiniões de Hopfner e de Salonius, concordantes na superioridade do estilo do Livro III em comparação com Pelágio e João, necessitam hoje de ser bem interpretadas. Ambos os filólogos consideraram o Livro III como uma unidade da qual excluíam apenas os apotegmas tirados da Historia Monachorum e de S. Jerónimo, isto é, III,41-43 e 218-220. Ora nós sabemos agora que os nn. III,44-199 e 207-217 são de Pascásio de Dume e os nn. 201-206 de Martinho de Dume $\left({ }^{133}\right)$. A superioridade do estilo de Pascásio ressalta também do estudo que lhe dedicámos $\left({ }^{134}\right)$. Aliás a maior correcção do latim da Hispania, em comparação com o da Itália dos séculos V-VII, tem sido reconhecida pelos linguistas. A Prof. ${ }^{2}$ Christine Mohrmann disse há pouco: «Mais que na Itália, a literatura latina visigótica é caracterizada por um normativismo clássico-retrospectivo» (135).

Restam, portanto, apenas os nn. 1-40 do Livro III sobre os quais recaiu também o juízo favorável de Hopfner e de Salonius. Infelizmente, porém, esta parte do Livro é poucas vezes citada, pelo que é difícil comprometer hoje aqueles dois filólogos a respeito da porção que constitui, verdadeiramente, "o autêntico Livro III", isto é, as Conmonitiones sanctorum patrum. Por exemplo, Salonius ao fazer o paralelo entre Rufino e o Livro III, nas pp. 17-31 do seu notável estudo sobre as Vitae Patrum, apenas menciona, de passagem, os $\mathrm{nn} .18,21$ e 24 ; todas as outras referências dizem respeito a um texto que de facto é de Pascásio.

(132) IDEM, op. cit., p. 31. Sobre as técnicas de tradução de Rufino escreveu posteriormente MONICA WAGNER, Rufinus, the translator, Washington, 1945.

(133) Cf. Pascásio de Dume..., t. II, pp. 168-171 e 181-183.

(134) Cf. Pascásio de Dume..., t. I, pp. 55-153.

(135) С.. A. E. M. Mohrmann, De studie van het middeleeuws latijn. Verleden, heden, toekomst. Afscheidscollege, 10-XI-1973, Amsterdam. 
Cremos, no entanto, que os qualificativos de "correcto, fluente e elegante» de Hopfner, e de "elevado, polido, livre e artificioso" de Salonius podem continuar a aplicar-se, mesmo que nos restrinjamos apenas ao texto genuíno das Commonitiones, ou seja, aos seus 61 apotegmas: - melhor dizendo, à tradução de 60 apotegmas, uma vez que o n. V,6 é importado de Cassiano, como já vimos, e mantém as características próprias deste escritor (136).

\section{2- COMPARAÇÃO COM PASCÁSIO E COM PELÁGIO}

Vale a pena apreciar, embora tenhamos que nos restringir a um escasso número de peças de pequeno formato, como os diversos autores e tradutores aproveitaram o mesmo fundo comum da tradição apotegmática.

Eis um episódio que em latim se encontra só nas Commonitiones e em Pascásio de Dume.

COMMONITIONES IV, 8

Consilium inter se habuerunt seniores patres: et omnes monachi habitantes in eremo Sceti consenserunt ut beatus pater Isaac presbyter eis ordinaretur in ecclesia, quae in ipso eremo sita est, ubi conuenit omnis multitudo
PASCÁSIO xc,2

Abbas Isaac audiens quia presbyterum eum patres uellent facere in Sceti, fugit in Aegyptum et ingressus in agrum latuit inter herbas. Contigit autem ut et patres qui eum sequebantur in eodem agro requiescerent quia

(136) Cf. supra pp. 136-149. Também nós já dissemos, antes de termos feito um estudo sistemático sobre a natureza do latim das Commonitiones, que o tradutor escrevia bem, tinha fluência, amplitude e harmonia de frase e até certo gosto pela retórica (cf. p. 92). 
monachorum qui in illa eremo conuersantur. Audiens autem supradictus abbas Isaac, fugit in Aegyptum et abscondit se in quodam agro inter frutecta, arbitrans indignum se esse honore presbyterii. Quam plurimi autem fratres monachi sequebantur, ut comprehenderent eum. Cum autem applicuissent, ad uesperum, ad eundem agrum pro longius, ut reficerent fatigati de itinere, erat enim nox, dimiserunt asellum qui eis sumptus portabat in iter, ut pasceret. Cum autem pasceret asellus, peruenit in locum ubi supradictus abbas Isaac latitabat. Cumque illuxisset dies, requirentes monachi asellum, peruenerunt ad eundem locum ubi senior se occultauerat et admirantes ualde dispensationem diuinam, comprehendentes ligare et constringere eum uoluerunt et ita perducere. Venerabilis autem senior non permisit dicens: Iam non possum contradicere uobis, quia forsitan uoluntas Dei est, ut licet indignus, suscipiam ordinationem presbyterii. iam nox erat et dimiserunt asinum suum ut pasceretur. Ille autem in pascendo peruenit ad locum ubi latebat abbas Isaac. Et mane facto, quaerentes asinum, inuenerunt et senem et admirati sunt. Cum autem uellent eum ligare, dicit eis: Iam non fugio quia scio hoc ex iussione Dei esse et quocumque fugero ad hoc peruenturus sum. 
A comparação dos dois textos latinos revela imediatamente que a redacção das Commonitiones é mais ampla, de leitura fácil c agradável. Note-se, porém, que todos os elementos que se encontram em Pascásio estão também nas Commonitiones. As diferenças não podem ser atribuídas à simples iniciativa do tradutor. Torna-se claro que o reelaborador grego das Commonitiones conhecia bem os costumes da vida monástica do Egipto. Só assim se explica a naturalidade e exactidão dos pormenores acrescentados (cf. também pp. 169 e 207).

A versão de Pascásio é perfeitamente correcta para o latim de meados do século VI. Note-se a esperada tradução de b́vos por asinus (duas vezes) e de répov por senex (uma só vez). Há ainda a uariatio de pasceretur: in pascendo. Para o apotegma grego, cf. PG LXV, Isaac 1 (224).

Neste apotegma das Commonitiones observamos já algumas características dos hábitos do seu tradutor: seniores (duas vezes), supradictus (duas vezes), asellus - um diminutivo (duas vezes), pasceret (duas vezes); duas expressões preposicionais: pro longius e de itinere; o uso de applicuisset aparecerá noutros apotegmas. $O$ agrado geral da primeira leitura termina pela verificação de que o latim do tradutor das Conmonitiones, se bem que aceitável, é menos polido que o de Pascásio, apresentando tendências vulgarizantes $\left({ }^{137}\right)$.

Reproduzamos agora um exemplo em que o mesmo texto grego fundamental foi assumido por três colecções, depois vertidas para latim.

$\left.{ }^{(137}\right)$ Para a apreciação dos vulgarismos servimo-nos de C. H. Grandgent, Introducción al latin vulgar, Madrid, 1952; V. VÄÄNÄNEN, Introducción al latin vulgar, Madrid, 1968; J. B. Hofmann, El latin familiar, Madrid, 1958; R. A. Handsma et J. Nuchelmans, Précis de latin vulgaire suivi d'une anthologie annotée, Groningen, 1963; Th. H. Maurer JúnIOR, Gramática do latim vulgar, Rio de Janeiro, 1959. 
NAU, $184^{b}$

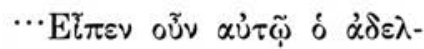
pós. 'I $\delta \circ \dot{\nu} \mu \varepsilon \lambda \varepsilon \tau \tilde{\omega}, \alpha \beta \beta \tilde{\alpha}, x \alpha i$ ou่

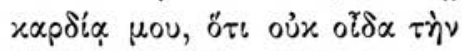

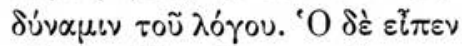

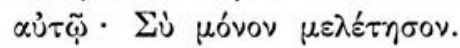

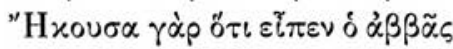

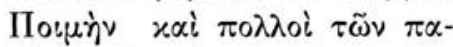

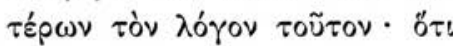

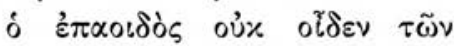

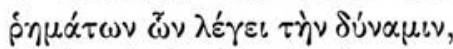

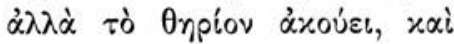
$0 i \delta \varepsilon v \quad x \alpha i \quad \dot{\pi} \pi 0 \tau \alpha \dot{\alpha} \sigma \sigma \varepsilon \tau \alpha i \quad x \alpha i$

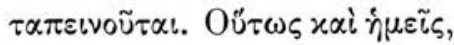

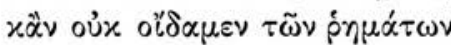
$\tau \dot{\eta} \nu \delta \dot{v} v \alpha \mu \nu v, \tilde{\omega} \nu \lambda \alpha \lambda \circ \tilde{\nu} \mu \varepsilon v, \dot{\alpha} \lambda \lambda$ '

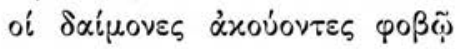

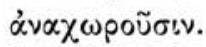

\section{PASCÁsIO $\mathrm{x}, 2^{\mathrm{b}}$}

... Dicit ei frater: Ecce meditor et non est compunctio in corde meo quia uirtutem uerbi nescio. Cui senex: Tu tantummodo meditare. Audiui enim quod abbas Poemen diceret, sed et alii patres, hunc sermonem: Quoniam incantator nescit uirtutes uerborum quae dicit, sed tamen serpens
PELÁGIO $\mathrm{v}, 32^{\mathrm{b}}$

... Dixit autem ei frater: Ecce meditor, abba, et non est compunctio in corde meo, quia nescio uirtutem uerbi. Et ille dixit: Et tu tamen meditare. Audiui enim quia dixerit abbas Pastor, sed et alii patres hoc uerbum: Quoniam incantator uirtutem uerborum quae dicit nescit; sed serpens audit, et scit uirtutem eorum quae incantantur, et subicitur incantanti, et humiliatur. Sic et nos, quamuis ignoremus uirtutem eorum quae loquimur, daemones tamen audientes terrentur atque discedunt.

\section{COMMONITIONES VI,5}

Quidam de fratribus dixit beato Arsenio: Ecce, pater, meditari festino de sanctis Scripturis quae didici et non sentio compunctionem in corde meo, quomodo non intelligo uirtutem Scripturae diuinae, unde et ualde contristatur anima mea. Respondens autem beatus Arsenius ait: Oportet te, 
audiens, intelligit uirtutem uerborum et obaudit et humiliatur. Sic et nos. Etsi uirtutem uerborum quae dicimus ignoramus, sed tamen daemones, audientes, ex timore discedunt.

\begin{abstract}
o fili, incessanter meditari eloquia Domini. Audiui enim quia dixit beatus abba Poemen et alii multi sanctorum patrum: Quomodo incantatores illi qui serpentes solent incantare, non intelligunt ipsi uerba quae loquuntur, sed serpentes audientes intelligunt uirtutem uerborum illorum et conquiescunt et subduntur eis. Ita ergo et nos faciamus. Quamuis enim non ualemus intelligere diuinarum Scripturarum uirtutem, sed tamen daemones audientes diuini uerbi uirtutem terrentur et effugati discedunt, non sustinentes eloquia Spiritus Sancti, quae per seruos suos prophetas et apostolos est locutus.
\end{abstract}

A tradução de Pelágio, bem como a de Pascásio, pode dizer-se literal. Apenas em Pascásio se nota um dos seus típicos abreviamentos de resposta, na frase: Cui senex... (138).

As Commonitiones têm indubitavelmente o mesmo texto de base. Há, porém, duas inovações a apontar: aqui o apotegma é nominal, atribuído ao abade Arsénio, ao passo que em todos os outros textos é anónimo; a palavra é interpretada explicitamente como sendo a Sagrada Escritura. Esta expressão aparece sob formas variadas: sancta Scriptura, Scriptura diuina, eloquia

(138) Cf. Pascásio de Dume..., t. I, pp. 88-90. 
Domini, diuinum uerbum, eloquia Spiritus Sancti. Além disso, o relato das Commonitiones tem uma tonalidade mais sentimental e subjectiva: meditari festino; unde et ualde contristatur anima mea; o fili. Esta versão torna-se, assim, a mais penetrante e directa. Quem lê apreende melhor o sentido de edificação visado pelo apotegma. O tradutor manifesta a sua preferência por quomodo (tanto com valor causal, como a introduzir uma oração completiva). E neste aspecto não se pode dizer que tenha melhor gosto que Pelágio ou Pascásio, os quais usam, por igual, as conjunções quia e quoniam.

Estes dois exemplos põem já em relevo como a tradução das Commonitiones se nos apresenta guase sempre ornada com expressões explicativas e com pormenores enriquecedores do contexto. Cremos que estes acrescentos deviam fazer parte do original grego; e o tradutor soube dar-lhes uma forma clara e expressiva. Anteriormente estudámos já algumas qualidades do tradutor, a propósito das técnicas por ele adoptadas $\left({ }^{139}\right)$.

\section{3 - O TEXTO LATINO É UMA TRADUÇÃO; NÃO É UM ORIGINAL}

As diferenças notáveis que por vezes se verificam entre o texto das Commonitiones e o grego que possuímos, e também em comparação com os outros paralelos latinos, obrigam-nos a demonstrar que as Commonitiones sanctorum patrum não são um original latino, mas sim uma tradução do grego.

De facto, $\mathrm{H}$. Rosweydus estava convencido, baseado no estilo, que o seu Livro III tinha como «autor ou tradutor» a Rufino de Aquileia. Insiste depois, ao tratar da língua original, em que, segundo conjectura sua, "foi escrito por Rufino",

(139) Cf. supra, cap. V, pp. 89-93. 
embora declare logo a seguir que ué incerto se o traduziu do grego». Finalmente afirma que "os Livros II, III e IV foram escritos em latim, ou não há a certeza de que sejam uma tradução" $\left({ }^{140}\right)$.

Hopfner, como já vimos, pensava que o Livro III (e a afirmação é válida sobretudo para a parte tirada das Commonitiones) tem o grego apenas como ponto de partida e «muitas vezes não parece mesmo uma tradução" $\left({ }^{141}\right)$.

Nós, pelo contrário, estamos inteiramente convencido de que as Commonitiones são, de facto, uma tradução do grego para o latim. Os exemplos apresentados no parágrafo anterior c no capítulo V (pp. 71-83 e 152-157) provam, à evidência, que o latim se encontra em vários passos muito próximo, quase literal, em confronto com o texto grego de que dispomos. E foi-nos possível organizar um quadro de lugares paralelos em que para $90 \%$ do texto latino encontrámos uma narrativa grega equivalente $\left({ }^{142}\right)$. O leitor pode seguir com relativa segurança este critério de apresentação externa: os apotegmas mais breves ou mesmo de média extensão encontram-se, no geral, muito próximos do paralelo grego.

Mas não poderia - perguntará alguém - um escritor que conhecesse os apotegmas gregos organizar directamente em latim uma colecção, servindo-se do fundo grego, mas reelaborando-o com bastante independência, como se de um original latino se tratasse?

Esta interrogação levanta o problema dos processos de tradução e de reelaboração, em voga na Literatura da Antiguidade Cristã. Não é aqui o lugar para apresentar sequer um esboço do método usado pelos diversos tradutores. Observemos, no entanto, que o princípio da versão literal não era apenas

\footnotetext{
(140) Cf. J.-P. Migne, Patrologia Latina 73, coll. 39, 48 e 49.

(141) Cf. supra p. 150.

(142) Cf. supra pp. 47-64.
} 
utilizado pelos tradutores da Bíblia. Pelo contrário, ele teve sempre adeptos, desde o século Il até ao século VI (época esta que de momento nos interessa), incluindo S. Jerónimo, Rufino e as escolas de Boécio e Cassiodoro $\left({ }^{143}\right)$.

Os estudiosos têm observado que em certos géneros literários se criou a tradição de adoptar uma tradução quanto possível literal $\left({ }^{144}\right)$. Aliás, toda a tradução deve tender a comunicar o mesmo que o original exprime. "A regra de ouro, para uma versão, será sempre pensar e dizer na própria

(143) Sobre os métodos de tradução na antiguidade, sobretudo cristã, consultámos: F. BLATt, Remarques sur l'histoire des traductions latines in Classica et Mediaetualia, I (1938), pp. 217-242; H. DörRIE, Passio SS. Machabaeorum. Die antike lateinische Übersetzung des IV Makkabäerbuches, Göttingen, 1938; G. BARDY, La question des langues dans l'Église ancienne, t. I, Paris, 1948, especialmente o cap. IV: Traducteurs et adaptateurs an VIe siècle, pp. 231-289; A. SIEGMUND, Die Überlieferung der griechischen christlichen Literatur in der lateinischen Kirche bis zum zwölften Jahrlundert, München, 1949; Sv. LUNDSTRöM, Übersetzungstechnische Untersuchungen auf dem Gebiete der christlichen Latinität, Lund, 1955; Сн. MohrmanN, Note sur la version latine la plus ancienne de la vie de Saint Antoine par Saint Athanase in Antonius Magnus Eremita (= Studia Anselmiana, 38, (1956), pp. 35-44; G. Garitre, Le texte grec et les versions anciennes de la vie de Saint Antoine in Studia Anselmiana XXXVIII (1956) pp. 1-12; H. W. F. M. Hoppenbrouwers, La plus ancienne version latine de la vie de S. Antoine par S. Athanase. Étude de critique textuelle, Utrecht-Nijmegen, 1960; IDEM, La technique de la traduction dans l'Antiquité d'après la première version latine de la Vita Antonii in Mélanges Christine Molrmann. Nouveau recueil offert par ses anciens élèves, Utrecht-Anvers, 1973, pp. 80-95; G. Q. A. MeErshoek, Le latin biblique d'après Saint Jérome. Aspects linguistiques de la rencontre entre la Bible et le monde classique, Nijmegen-Utrecht, 1966; F. WinkelmanN, Spätantike lateinische Übersetzungen christlicher griechischer Literatur in Theologische Literaturzeitung XCII (1967), pp. 230-240; S. EKLUND, The periphrastic, completive and finite use of the present participle in Latin, with special regard to translations of christian texts in Greek up to 600 A. D., Uppsala, 1970. Também útil, em parte, para o nosso intento, a tese de Custódio Magueijo, Helenismo sintáctico e estruturas latinas, Évora, 1973.

Do ponto de vista linguístico interessa também conhecer as traduções do latim para grego. Cf. um conspecto geral com bibliografia em E. DeKKERs, Les traductions grecques des écrits patristiques latins in Sacris Erudiri V (1953), pp. 193-233. Há ainda úteis tratados de carácter geral, como Silverra BrenNo, $A$ arte de traduzir, S. Paulo, 1954; Sprachwissenschaft und Übersetzen. Symposion an der Universität Heidelberg, 24-26, II, 1969, edit. Max Hueber Verlag, 1969; J. S. Holmes, The nature of translation: Essays on the theory and practice of literary translation, The Hague-Paris, 1970. Sobre problemas de tradução e suas diversas implicações publica-se em Berlim a revista Babel.

(144) Para um breve quadro das traduções do grego para latim, segundo os diversos géneros literários: filosofia, filologia, escritura, história, hagiografia, moral, direito, etc., cf. F. WINCKELMANN, artigo citado na nota anterior. 
língua o que o autor original pensou e disse na sua. Levar a imitação até reproduzir a maneira particular do pensamento e do estilo seria o ideal» $\left({ }^{145}\right)$. Ideal difícil, se não impossível de atingir, digamos desde já.

Com acerto o reconhece um moderno tradutor português da Bíblia: «Traduzir é... escravizar-se, porque um tradutor não diz o que quer, nem mesmo sempre como quer, a não ser que ladeie ou evite as dificuldades (...). Uma tradução, porém, não precisa de ser servil para ser literal; e nem por isto deixa de corresponder ao ideal de ser fiel e elegante" $\left({ }^{146}\right)$.

Ainda não se fez - que saibamos - uma apreciação global sobre as técnicas de tradução no género apotegmático. Vejamos o que sabemos das principais colecções.

Pascásio de Dume foi o único que escreveu um prefácio para a sua tradução. Aí diz explicitamente: Vitas patrum, Graecorum ut cetera (...) iussus (...) in latinum transferre sermonem... Si quid (...) minus eleganter expressum, ne meae culpae reputetur exoro. Quia sicut in dato mihi codice reperi scripta sic transtuli. O seu propósito foi, portanto, o de fazer uma tradução literal, embora, como já demonstrámos, a sua versão não seja "servil», mas "cuidada, artística» $\left({ }^{147}\right)$.

Também de Martinho temos a certeza de que traduziu do grego, pois o título do seu trabalho é: Sententiae patrum Aegyptiorum quas de graeco in latinum transtulit Martinus Dumiensis episcopus. E C. W. Barlow ao referir-se ao método adoptado afirma: «É difícil conceber uma tradução mais literal do

(145) Dom E. Pichery, na introdução a Jean Cassien, Conférences I-VII, Paris, 1955, p. 69.

(146) Sebastiño Martins dos Reis, na introdução a Evangelhos e Actos dos Apóstolos, Porto, 1973, p. [XI].

Sobre traduçõcs literais e traduções-«recriação» na poesia moderna são muito pertinentes as observações de MANuEL DE SeABRA nas introduções a Antologia da Poesia Provençal Moderna, Lisboa, 1972, pp. 33-35 e a Mryamoto Masao, Da arte e da morte, Lisboa, 1973, pp. 13-18.

(147) Cf. Pascásio de Dume..., t. I, p. 66 e in genere, pp. 55-122. 
que esta» $\left.{ }^{148}\right)$. Falta-nos, porém, ainda hoje um estudo filológico pormenorizado.

Para a maior colecção latina que possuímos, as Adhortationes sanctorum patrum, temos também duas rubricas preciosas: - no fim do libellus XVIII acrescentam os manuscritos: Vsque hic de graeco in latinum transtulit Pelagius, diaconus ecclesiae Romanae. Subdita Ioannes subdiaconus; e ao terminar toda a obra: Expliciunt sermones sanctorum patrum, interpretati de graeco in latinum a diacono Pelagio sanctae ecclesiae Romanae et Ioanne subdiacono $\left({ }^{149}\right)$. Quanto à técnica adoptada, já vimos que Hopfner considera a tradução dos clérigos romanos "escrava do original grego" $\left({ }^{150}\right)$. E nós próprio ao comparar o trabalho de Pascásio com o grego c com a versão de Pelágio-João tivemos ocasião de verificar que a destes é muitas vezes de um literalismo extremo, "autêntica escravidão" ao original (151).

Temos ainda pequenas colecções, como as Meditationes duodecim anachoretarum e as Sententiae patrum para as quais também há texto grego. Os apotegmas destas colectâneas são, no geral, tão breves que não podem deixar de ser uma tradução literal $\left({ }^{152}\right)$.

Estes testemunhos são, pois, concordes em que o género apotegmático sobre os padres dos desertos está representado, em latim, apenas por traduções do grego, subordinadas à norma geral do literalismo (cf. exemplos citados na p. 57).

Acontece mesmo que para obras que primeiramente se julgou serem originais latinos e depois se pensou que eram traduções livres do grego, uma crítica mais atenta postula um

(148) Claude W. Barlow, Martini episcopi Bracarensis opera omnia, New Haven, 1950 , p. 17.

(149) Cf. C. M. Batlle, Die Adhortationes..., pp. 11-12.

(150) Cf. texto citado supra, p. 150.

(151) Cf. Pascásio de Dume..., t. I, pp. 56, 57, 58, 62, 63, 68, 69, 70, 71, etc.

(152) Cf. bibliografia indicada por J. G. Frerre, Traductions latines des Apophthegmata Patrum in Mélanges Christine Mohrmann, Utrecht-Anvers, 1973, pp. 167-168 e C. M. Batlle, Die Adhortationes... pp. 13-14. 
modelo grego, o qual deve ter existido, com elementos diferentes da recensão grega chegada até nós. O caso mais impressionante ocorre com a tradução de Rufino (um escritor que goza da fama de traduzir livremente) da Historia Monachorum in Aegypto. A.-J. Festugière demonstrou que o texto latino que chegou até nós (para o qual não há ainda - lamenta ele uma edição crítica) foi feito sobre uma recensão grega diferente da que hoje conhecemos e diferente também da que utilizou Sozómeno para a sua História Eclesiástica. Festugière assegura mesmo que havia ainda outras. "Para disso nos convencermos aí está a extrema complexidade da traditio dos Apophthegmata» $\left({ }^{153}\right)$.

É verdade que no nosso caso já é conhecida uma recensão grega, em muitos passos, de certeza, próxima do original. Porém, para os acrescentos que não são puramente retóricos, mas introduzem elementos concretos, úteis ao sentido, ou homilias longas que dificilmente se podem admitir num tradutor, então é lícito supor, e mesmo propor, que deve ter existido uma recensão grega com estes novos pormenores.

A existência de recensões diferentes para um texto de base não nos deve admirar, quando se trata de uma obra muito divulgada - afirma ainda Festugière. $O$ copista não se limitava então a reproduzir o seu modelo, «mas reconhece o seu direito de corrigir, embelezar e por vezes amplificar o que está copiando». "Os que copiavam estes textos no Egipto ou na Palestina eram eles próprios apreciadores de episódios sobre os padres e de discursos dos padres. Estavam mergulhados numa tradição em contínuo crescimento. Segundo os hábitos da época, não receavam, aqui e ali, inserir algum acrescento que embelezava a narrativa ou a tornava mais útil ainda, pela adição de um

(153) Cf. A.-J. Festugière, Le problème littéraire de l'Historia Monachorum in Hermes, 83 (1955) pp. 257-284. A frase transcrita está na p. 281. 
episódio maravilhoso (...) ou de pormenores exactos sobre tal congregação de monges (...) ou de amplificações homiléticas" $\left({ }^{154}\right)$.

Estas observações aplicam-se perfeitamente ao autor das Commonitiones, se as considerarmos escritas originariamente em grego por um monge da Regra de S. Pacómio, no final do século $\mathrm{V}\left({ }^{155}\right)$. Os tradutores de apotegmas tinham por norma o literalismo, mais ou menos artístico. $\mathrm{O}$ género apotegmático nasceu e foi cultivado no Próximo Oriente. O Ocidente limitou-se a importar e a traduzir as colecções já organizadas e divulgadas. Foi assim com Pelágio-João, com Pascásio, Martinho e com os demais. Porque haveria de ser de modo diferente com as Commonitiones?

Além destas deduções, temos ainda a possibilidade de recorrer (e desejamos fazê-lo sempre com prudência) a argumentos linguísticos. Ainda que não possuamos o texto grego exacto das Commonitiones, há nestas, passos latinos que só se compreendem recorrendo a paralelos gregos ao nosso alcance. Além disso, existem construções sintácticas que não seriam de admitir num original latino, mas se explicam tendo em mente um trabalho de tradução nem sempre levado até às exigências da perfeição. Examinemos primeiro alguns destes sintomas.

\section{4 - LATIM OBSCURO, ESCLARECIDO PELO GREGO}

Quando um texto é claro em grego, recorrendo mesmo a expressões típicas, e o latim é confuso ou ininteligível, devemos concluir que o original é o grego e que o latim é uma tradução imperfeita.

(154) Cf. op. cit., pp. 280-281.

(155) Cf. sobre o problema do autor, supra pp. 103-120. 
1 - Em I,13 conta-se de um irmão que foi visitar um ancião. Este recebeu-o bem e preparou uma refeição para ambos. Resolveram, porém, começar por rezar algumas orações e cantar salmos. Continuam as Commonitiones (linhas 5-8):

Cum autem ingressi fuissent psallebant, totumque psalterium compleuerunt. Nam et de Scripturis sanctis, tamquam legentes, duas prophetias, absentes habentes, recitarunt.

Por este fragmento podemos deduzir que as profecias foram recitadas à maneira de quem lê: tamquam legentes; em contrapartida, os salmos eram cantados. Psallere, psalterium e psalmodiam aparecem várias vezes nas Commonitiones, devendo entender-se sempre que se tratava de uma oração cantada, sentido aliás corrente no latim dos autores cristãos $\left({ }^{156}\right)$. Mas que significa o inciso, com dois particípios: absentes habentes? Por nossa parte, só entendemos a expressão quando consultámos os lugares paralelos:

NAU, 150

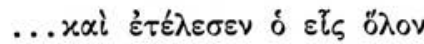

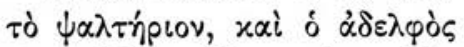

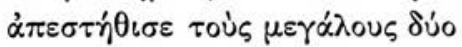
$\pi \rho \circ \varphi \dot{\eta} \tau \alpha \varsigma$.
PELÁGIO IV,57

... Et unus quidem eorum compleuit totum psalterium; alter uero ex corde duos prophetas maiores lectoris ordine recitauit.

(156) A nossa pesquisa lexical latina incidiu principalmente sobre as seguintes obras: Thesaurus linguae latinae, Lipsiae, I, 1900, ss.; A. ForcenLINI-V. DE VIT, Totius latinitatis lexicon, Prato, I-VI, 1858-1875; A. ERnOut et A. Memlet, Dictionnaire étymologique de la langue latine, Paris, 1959; A. BlaIse, Dictionnaire latin-français des auteurs chrétiens, Turnhout, 1954; СH. T. Lewis and $\mathrm{CH}_{\text {H }}$ SHORT, A latin dictionary, Oxford, 1962; Ch. Dufresne (Du CANGE), Glossarium mediae et infimae latinitatis, Parisiis, 1840; J. F. NIERMEYER, Mediae latinitatis lexicon minus, Leiden, 1965; H. RosweYDVs, Onomasticon rerum et uerborum difficiliorum, em apêndice às suas Vitae Patrum (cf. PL 74, coll. 399-516); A. H. Salonius, Vitae Patrum, Lund, 1920, pp. 359-440; W. MEYER-LÜBKE, Romanisches etymologischesWörterbuch, Heidelberg, 1968. Oportunamente será dada informação de outras fontes, quando for caso disso. 
Rosweydus deixou passar em claro, no Livro III, a expressão absentes habentes (cf. PL 73, col. 742). Porém, em Pelágio (col. 871) remete para uma nota a ex corde, em que diz (col. 988): "Gallismus par coeur, id est, memoriter". E abona-se com outro passo de Pelágio X,91 e com o comentário de Hildegardis à Regra de S. Bento, onde se explica: «Praedictas lectiones ex corde et memoriter, id est, sine libro, quoniam breues sunt recitabunt». E conclui Rosweydus: «Sic Graecis à $\pi \grave{o} \sigma \theta \dot{n} \tau$ rous

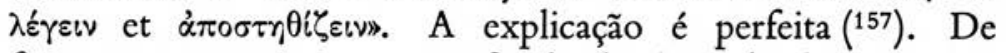
facto $\alpha \pi \circ \sigma \tau \eta \theta i \zeta_{\varepsilon \iota \nu}$ tem o significado de «learn by heart, repeat from memory" $\left({ }^{158}\right)$. O coração ficou consagrado, em várias línguas, nesta expressão, como o órgão da memória; também em português dizemos: saber de cor.

Podemos agora interpretar os enigmáticos particípios das Commonitiones. Segundo o grego, o irmão recitou de cor os dois profetas maiores. Isto é o que afinal quer dizer: absentes habentes (scilicet: codices), precisamente como Hildegardis explica para a Regra de S. Bento: ex corde et memoriter, id est, sine libro.

Parece-nos, apesar de tudo, um pouco estranho, para os nossos hábitos linguísticos, o conjunto absentes habentes. Meditando nele, perguntámo-nos: haverá alguma língua em que a expressão de cor ande ligada à ideia de "ausência»? Ocorreram-nos então duas línguas germânicas. Em alemão diz-se auswendig e em neerlandês van buiten. Literalmente, qualquer destas duas expressões significa «de fora». Só em sentido figurado adquiriram o valor de «de cor».

Atendendo a tudo isto, julgamos lícito pôr uma hipó-

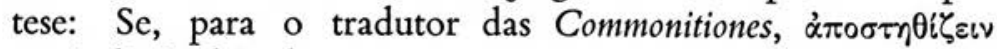
equivalia à ideia de «não ter o texto presente para ler, saber de

(157) Também SAlonius (op. cit., pp. 372 e 439) estuda em pormenor ex corde e ex animo, mas sobre absentes habentes nada diz.

(158) Para o grego servimo-nos dos dicionários de H. G. LIDDEL, R. Scotr, H. S. Jones, A greek-english lexicon, Oxford, 1966 e de G. W. H. LAMPE, A patristic greek lexicon, Oxford, 1968. 
cor”, não seria porque ele vivia numa região em que a fala corrente usaria expressões do tipo auswendig ou van buiten? A ser assim, ao pensar no tradutor lançaríamos o nosso olhar para a Germania... Leve indicação, esta. Não deixemos, no entanto, de referir que a transmissão manuscrita está quase limitada à área geográfica da antiga Germania. Pura coincidência ? (cf. também p. 134).

Esta nossa observação não significa que absens habere com o valor de de cor, tenha nascido ou fosse só de uso na Germania. Forcellini (I, p. 27) e o Thesaurus linguae latinae (I, col. 215) registam este passo de Aulo Gélio $(20,10,4)$ : tum ego hos uersus ex octauo annali Enni absentes (i. memoriter) dixi. Mas não se nos deparou outra abonação para tal significado.

Voltando a I,13 repare-se que as Commonitiones fazem do canto do Saltério e da leitura dos Profetas um acto comum. O grego e Pelágio atribuem uma parte ao ancião, outra ao visitante. Num ponto, porém, estão de acordo Pelágio e as Commonitiones: lectoris ordine do primeiro é o mesmo que tamquam legentes do segundo. Provavelmente este pormenor, embora falte em Nau 150, estava no texto grego de Pelágio e no do tradutor das Commonitiones, as quais, como vemos, testemunham, até em minúcias, a tradição grega, pelo que bem devemos supor que o seu original era grego.

2 - Mais delicado se apresenta o caso de VI,3c. Este apotegma das Commonitiones só se encontra nos manuscritos de Viena e Dresda. A sua lição é, no parágrafo em causa, sem variantes, a seguinte:

Dicebat autem beatus Arsenius fratribus: Quia cella studiosi monachi, qui festinat uirtutes animi possidere et omnia praecepta Saluatoris nostri Christi Domini adimplere, similis est fornaci Babyloniae, ubi tres pueri uidere meruerunt Filium Dei, etiam in columna luminis, ubi Dominus locutus est Moysi. 
Os lugares paralelos são:

$$
\text { NAU, } 206
$$

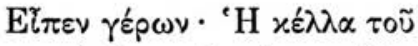

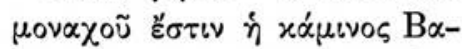

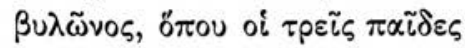

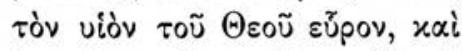

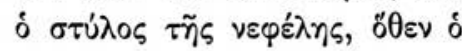

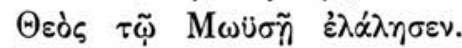

PELÁGIO VII, 38

Dixit senex: Cella monachi est caminus ille Babylonius, ubi tres pueri Filium Dei inuenerunt; sed et columna nubis est ex qua Deus locutus est Moysi.

Não há qualquer dúvida de que o grego de Pelágio devia ser exactamente igual à versão que reproduzimos, tão literal é a sua tradução. As Commonitiones apresentam as reelaborações que colocámos a itálico: o apotegma deixa de ser anónimo para se atribuir ao abade Arsénio; limitam-se as qualidades da cela apenas à do monge que for studiosus; e explica-se o valor deste conceito: qui festinat uirtutes... Pensamos que estas alterações foram introduzidas pelo autor das Commonitiones. $\mathrm{O}$ tradutor garante-nos a sua norma de fidelidade ao grego na última parte do apotegma.

Confessamos, porém, que precisamente o último cólon se nos apresenta obscuro. Procurámos interpretá-lo recorrendo a figuras de estilo $\left({ }^{159}\right)$ : etiam in...ubi... poderiam introduzir uma braquilogia, assíndeto, silepse, vulgarismo? Nenhuma hipótese nos pareceu aceitável. s $\theta \varepsilon v \ldots$

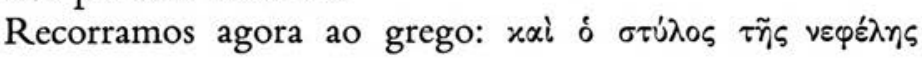

Pelágio traduziu bem: sed et columna nubis est ex qua... Seguimos como norma, em crítica textual, respeitar quanto

$\left({ }^{159}\right)$ Neste e noutros casos que estudaremos, servimo-nos das seguintes estilísticas: J. B. Hofmann-A. Szantyr, Lateinische Syntax und Stilistik, München, 1965; J. Marouzenu, Traité de stylistique latine, Paris, 1946; Aem. Springhetri, Institutiones stili latini, Romae, 1954; J. Gumlén, Estilística latina, Salamanca, 1954. 
possível a lição dos manuscritos. Já temos retirado hipóteses de emendas, porque afinal surgiu uma interpretação provável dentro da transmissão manuscrita. Neste caso, porém, a clareza do grego e da tradução de Pelágio levam-nos a concluir que houve um erro de copista já num arquétipo de que dependem os mss. de Viena e Dresda. Onde está escrito in deverá ler-se est. É verdade que Viena tem in por extenso, ao passo que Dresda emprega a abreviatura $\tilde{i}$. Proveniente ou não de uma confusão de $\bar{e}(=$ est) com $\tilde{i}(=$ in), o certo é que o passo se clarifica totalmente com a nossa correcção. Cremos mesmo que só esta nova leitura corresponderá à tradução original: ...similis est fornaci Babyloniae, ubi...; etiam est columna luminis, ubi...

Mas esta emenda só foi possível, recorrendo ao grego. Além disso, a proximidade de todo este n. VI,3 com o grego que chegou até nós e com outras traduções latinas, de certeza vertidas do grego, não podem levar-nos senão a esta conclusão: o latim das Commonitiones é uma tradução do grego e não um original. E a autenticidade deste apotegma, apesar de transmitido só por um arquétipo, não está em causa, tão evidentes são os seus processos de elaboração e de tradução, comparados com o resto das Commonitiones.

Para avaliar do trabalho de Rosweydus repare-se que para Pelágio VII,38 não é indicado nenhum lugar bíblico paralelo. A nós parecem-nos indiscutíveis as remissões para o profeta Daniel, cap. III, e para o Exodo, fim do cap. XIII-princípio do cap. XIV.

3 - Há um passo em V,2 que se compreende muito melhor se tivermos presente um apotegma grego e outra tradução latina, que em parte lhe são paralelos. Faz-se aí o elogio do espírito de mortificação do eremita Píor e apresenta-se também este testemunho (lin. 28-29):

Dicebant ergo fratres quia unum tantum paximatium et quinque oliuas in cibo accipiebat, et hoc deambulando foris. 
A primeira parte da frase é bem clara e tem o mérito de documentar a parca alimentação de Píor: um pedaço de pão e cinco azeitonas - pormenor que não vemos na série nominal (PG LXV, coll. 373-376). Menos compreensível nos parece a intenção do acrescento: et hoc deambulando foris. Tudo se esclarece, porém, se lermos o grego e a tradução de Pelágio:

PIOR 2(373)

'O $\dot{\alpha} \beta \beta \tilde{\alpha} \varsigma \Pi_{\varsigma} i \omega \rho \pi \varepsilon \rho เ \pi \alpha \tau \tilde{\omega \nu}$

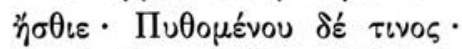

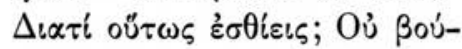

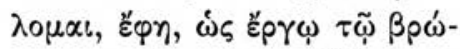
$\mu \alpha \tau \iota \quad \chi \rho \dot{\eta} \sigma \alpha \sigma \theta \alpha \iota, \dot{\alpha} \lambda \lambda \lambda^{\prime} \dot{\omega} \varsigma$ $\pi \alpha \rho \varepsilon ́ \rho \gamma \omega$. Проे

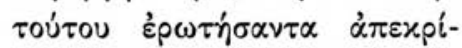

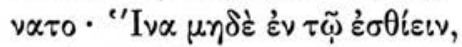

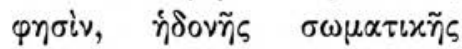

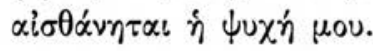

\section{PELÁGIO IV,34}

Dicebant de abbate Pior, quia ambulando comederet. Et interrogante eum quodam quare sic manducaret respondit se non hoc uelut opus aliquod agere, sed uelut quiddam superfluum uti. Alii autem de hoc interroganti respondit: $\mathrm{Vt}$ non uel in comedendo corporalem delectationem habeat anima.

Eis aqui muito bem explicada a intenção ascética de Píor Mas para isso tivemos que recorrer a um seguro original grego.

\section{5 - CONSTRUÇÃO SINTÁCTICA DESCUIDADA}

Um autor que compõe uma história, podendo livremente dispor dos recursos da língua, da sintaxe e da estilística, normalmente entende-se que, se tem capacidade para isso, escreve sempre com correcção. As Commonitiones têm muitos trechos perfeitos. Por vezes, porém, a sintaxe apresenta irregularidades. Este tipo de desarmonia compreende-se melhor se pensarmos 
que quem escreveu está limitado por um texto que se encontra diante de si para o traduzir $\left({ }^{160}\right)$.

1 - Vejamos o final da II,8 (linhas 34-39):

Magis autem oportet ut maneas in hoc loco in afflictione cordis et corporis, et cum intimi cordis gemitu ac lacrimis usque in exitum uitae deprecare Domini ac Saluatoris nostri pietatem, ut possis inuenire misericordiam in die illo terribili magni iudicii Dei.

O apotegma encontra-se, também, em grego, em Nau 176 e, em latim, em Pelágio V,24. Enquanto Pelágio corresponde literalmente, neste final, ao modelo grego, as Commonitiones apresentam aqui uma exortação que lhe é exclusiva.

Analisando bem, um monge, ao aconselhar o outro, talvez devesse usar dois imperativos: mane... et... deprecare. O que se verifica, porém, é um desequilíbrio no uso dos modos e da expressão. Primeiro, à maneira de sugestão, usa oportet ut com o presente do conjuntivo maneas; depois, apesar da copulativa et, emprega o imperativo.

Para desculpar esta falta de correspondência no uso dos modos, pode sublinhar-se a grande distância a que os verbos se encontram. A acentuar o carácter vulgarizante do período lá está ainda, a principiar, magis.

Note-se, além disso, que o tradutor parece dar à copulativa et um grande valor, em ordem à independência das regências dos modos e dos casos. Veja-se o n. X da capitulatio II: De

(160) Para efeitos de sintaxe, além das obras citadas na nota anterior, consultámos também: M. BAssols DE Climent, Sintáxis histórica de la lengua latina, I, Barcelona, 1945; II, 1948; A. Tovar, Sintáxis, Madrid, 1946; A. Ernout-F. Thomas, Syntaxe Latine, Paris, 1953; E. FARIA, Gramática superior da língua latina, Rio de Janeiro, 1958; J. Guilı́́n, Gramática latina, Salamanca, 1960; A. BLAISE, Manuel du latin chrétien, Strasbourg, 1955. Têm-se presentes ainda os manuais de latim vulgar e tardio citados noutras ocasiões (pp. 154 e 208). 
fratre qui interrogabat sanctum Poemen (...) et responsio sancti Poemenis. De esperar seria um novo ablativo, do tipo que aparece um pouco antes: IV - De beato abbate Moyse et de impugnatione eius; $\mathrm{V}-\mathrm{De}$ monacho... et de quadam muliere. No n. X, porém, o primeiro tema, precedido de $d e$, ficara tão afastado que a redacção do segundo membro foi considerada de modo independente. Daí o nominativo: et responsio... (Cf. outros exemplos citados na p. 188).

2 - Em IV,9 conta-se que um "sanctus uir" para experimentar a paciência de dois irmãos pegou num cajado e destroçou-lhes as couves do quintal. Em vez de se irritarem, adorantes eum dixerunt (linhas 12-14):

Si praecipis, domine, ut eamus et eum qui remansit caulem coquentes gustemus, quia iam hora est ut cibum sumamus.

A função de $u t$ não nos parece clara. A frase ficaria mais perfeita e com melhor sentido, sem ele: Si praecipis, eamus et... gustemus. Interpretamos estes conjuntivos como uma hipótese de decisão para agir. Pensamos que ut está ali a mais, colocado como que automaticamente, de acordo com a expressão praecipere ut... Tal como está, não vemos onde se encontre a oração principal ou subordinante.

Quando muito, a $u t$ poderá dar-se-lhe um valor expletivo. Alguns copistas viram a dificuldade. $O$ do manuscrito de Namur suprimiu apenas o $u t$. A edição de Rosweydus (PL 73, col. 752, sub fine) vai mais longe, para apresentar uma sintaxe mais congruente: Si praecipis, domine, ibimus ut eum qui remansit caulem coquentes gustemus... $\mathrm{O}$ verbo ire passou para $\mathrm{o}$ futuro do indicativo; $u$ ficou a reger apenas gustemus. Mas esta lição é arbitrária. As fontes manuscritas não a apoiam.

Já é mais aceitável o primeiro ut que se encontra em $\mathrm{V}, 7$ (lin. 18-21):

Tracta ergo apud te, quia haec sola est uera et firma spes, ut faciat homo praecepta Domini, ut mereatur peruenire ad gloriosa et aeterna promissa Domini Saluatoris nostri Christi. 
Na expressão ut faciat homo... a função de ut é explicativa, com valor de "a saber, isto é». Note-se a sua construção com o conjuntivo. $\mathrm{O}$ segundo $u t$ tem manifesto valor final, expresso na perífrase solene mereatur peruenire...

3-Em V,8 faz-se o elogio de S. Pacómio e referem-se conselhos que ele dava à sua comunidade, a qual seguia com perfeição as exortações do beatus pater noster Pachomius (linhas 35-36).

O tradutor demonstra neste apotegma que é capaz de construir uma frase longa, sem perder a sequência do pensamento. Veja-se na linha 13: Referebant autem nobis fratres... seguido de um excurso, pelo que, utilizando uma anáfora, o tradutor retoma a narração, repetindo (linha 15): referebant ergo de eo... Repare-se ainda numa frase sintacticamente perfeita, com o verbo principal no indicativo, ligado a dois particípios do presente (linhas 37-40):

Postmodum uero discedebat unusquisque fratrum in cellulas suas, operantes manibus suis et meditantes quae de sanctis Scripturis didicerant.

Apenas se pode notar que discedebat está no singular, perfeitamente, em concordância com unusquisque, mas depois vão para o plural os particípios operantes (...) et meditantes. Trata-se, neste último caso, duma compreensível concordância ad sensum (161) implícita em unusquisque: cada um deles, isto é, todos, os quais trabalhavam e meditavam...

Mais complexa é a situação da frase seguinte (linhas 40-44): Impossibile est enim aliquem apud eos uerbum otiosum loqui, sed ea tantum quae de sanctis Scripturis didicerant inter se conferentes et exponentes de capitulis sanctarum Scripturarum, quae

(161) Cf. número seguinte "Concordância ad sensum», pp. 179-181. 
ad timorem et amorem Domini confirmarent et illuminarent animas eorum.

Esta é a redacção de $\beta$, documentada pelos melhores manuscritos, os de Viena e Dresda, e também pelo arquétipo $\delta$, de que depende o ms. de Namur. Mas assim a sintaxe da oração adversativa: sed ea tantum (...) inter se conferentes et exponentes... está imperfeita. Esperar-se ia um predicado no modo indicativo, por exemplo, conferebant ou exponebant. Mas não. Aqueles particípios ficam ali, sintacticamente, pendentes, sem outro verbo a que se apoiem.

Alguns copistas viram a dificuldade e tentaram remediá-la. O ms. de Reims, único representante genuíno, neste apotegma, do arquétipo $\gamma$, tem: erant inter se conferentes et exponentes. Esta lição foi retomada por alguns manuscritos secundários e Rosweydus seguiu-a. Porém o arquétipo $\delta$, representado por Namur, Berlim, Londres e seus pares, e ainda outros manuscritos só com os nn. 1-40, mantêm-se fiéis à lição de $\beta$, colhida de $\alpha$ (como o deixa ver a redacção preferida por $\delta$, um arquétipo contaminado de $\alpha$ e $\gamma$ ). Só um outro copista, isolado, procurou salvar a situação doutro modo. Foi o de Namur que substituiu et exponentes por exponunt, ficando portanto: sed ea (...) inter se conferentes, exponunt... Tentativa desesperada, sem apoio da tradição.

Depois de pensar maduramente, pareceu-nos preferível incluir erant no nosso texto crítico, fazendo-o embora preceder de uma crux. Julgamos que o acrescento de erant é uma engenhosa intervenção do arquétipo $\gamma$. Observemos, todavia, que a perda de erant, já existente no hiperarquétipo $\alpha$, é paleograficamente fácil de compreender. Suponhamos que, de facto, o tradutor escreveu didicerant erant. A uniformidade de terminação pode ter levado o modelo $\alpha$ a omitir o segundo verbo, traído pela memória que interiormente ditava ao copista - cerant erant. Apesar de tudo, consideramos a inclusão de erant um tanto problemática, embora com ela se salve a sintaxe (cf. p. 266). 
3 - Observámos atentamente a construção de necesse est. Temos as modalidades esperadas em IV,4 (lin. 9): Poemen pensava que, se interferisse em questões do mundo, necesse est ut per haec perturbentur secreta nitae meae; e em IV,4 (lin. 24-25) o juiz manda a Poemen o seguinte recado: si uoluerit uenire ad me, necesse est ut statim educamus eum de carcere. Em ambos os casos um corrente necesse est ut... seguido de conjuntivo. Todavia em V,3 (lin. 13-14) lê-se que a irmã de João Cólobo lhe escreveu dizendo: Quia si nolueris uenire ad me, necesse me est ut ego ueniam ad te.

O que está em causa é a construção rara: necesse me es ut... Rara, mas não totalmente insólita. Szantyr regista-a a par do genitivo e do dativo. De facto, a redacção que temos como original só se encontra no manuscrito de Viena. Os de Dresda e Londres resolveram omitir me; os de Reims e Namur pensaram simplificar, escrevendo mihi. E entre estas duas soluções se baloiça a maioria dos restantes manuscritos. A edição de Rosweydus apresenta uma versão ainda mais alterada (PL 73, n. 32, col. 759): necesse habeo ut ego... Todas estas variantes são afinal motivadas pelo desejo de eliminar uma dificuldade. Necesse me est ut... é uma lectio difficilior e rara, mas nada impede de a aceitar como genuína, precisamente perante a hesitação dos outros manuscritos (cf. p. 188).

4-Aproveitamos o ensejo para mostrar que o recado mandado pelo juiz ao abade Poemen, em IV,4, a propósito da libertação de um seu sobrinho, não se encontra redigido da melhor maneira pelo tradutor das Commonitiones. Vejamos os lugares paralelos:

POEMEN 5(320)

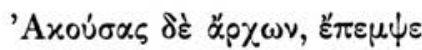

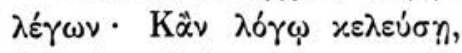

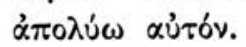

PELÁGIO VIII,13

Audiens autem iudex misit, dicens: Vel uerbo iubeat, et ego eum dimittam. 
PASCÁSIO XIIX, 4

Audiens uero iudex misit dicendo: Quia uel si uerbo mihi praeceperit, dimittam eum.
COMMONIT. Iv,4 (lin. 22-25)

Dixitque ad officium suum ut non contristaretur sanctus senior: Mandate ei, si uoluerit uenire ad me, necesse est ut statim educamus eum de carcere.

As traduções de Pelágio e Pascásio podem dizer-se inteiramente literais. Como habitualmente, as Commonitiones apresentam uma redacção mais ampla. Parece-nos, porém, que não é feliz a expressão:

...si uoluerit uenire ad me, necesse est ut statim educamus eum de carcere.

Comparando com o sentido seguro dos lugares paralelos, julgamos que (aproveitando as construções das Commonitiones) a frase deveria ser assim construída:

...necesse est ut ueniat ad me si uoluerit ut statim educamus eum de carcere.

A própria ordem das palavras poderia manter-se e o sentido ficaria perfeito, substituindo necesse por sufficiens:

...si uoluerit uenire ad me sufficiens est ut statim educamus eum de carcere.

Teríamos ainda outro processo de manter todas as palavras e normalizar o sentido, acrescentando apenas «somente isto": ...si uoluerit uenire ad me, $<$ hoc tantum $>$ necesse est $u t$ statim educamus eum de carcere.

O certo é que a redacção das Commonitiones, apesar de defeituosa, quanto à clareza do sentido, não apresenta variantes em nenhum manuscrito. Por isso julgámos prudente não tocar no texto transmitido. De facto, por vezes colhe-se a impressão de que o tradutor se distraiu e não tornou a rever a sua obra (cf. também pp. 171, 173, 178, 188-189 e 265). 
5 - Entre os problemas de consecutio temporum suscitados nas Commonitiones, o mais impressionante é a preferência permanente pelo conjuntivo presente possit, em vez do imperfeito posset. A conjunção dos testemunhos manuscritos é, em certos casos, de tal ordem que não devemos pensar na confusão paleográfica de $i$ com $e$.

Nos exemplos que vamos apresentar convém ter presentes os arquétipos e as siglas que damos no stemma codicum e na descrição dos manuscritos (pp. 262 e 22-45), utilizando destes apenas os que remontam às fontes primitivas.

Em IV,16 (lin. 19-22) lemos, a propósito da atitude tomada pelo superior do mosteiro, após as acusações feitas contra o irmão Eulálio:

Ingressus uero cellulam, prostrauit se in orationibus, obsecrans misericordiam Domini, ut ei manifestare dignaretur quid ordinare aut definire possit de saepe dicto fratre.

O verbo da oração principal está no perfectum:-prostrauit; o verbo dependente, introduzido por $u t$ foi, normalmente, para o imperfeito do conjuntivo: dignaretur. $\mathrm{O}$ mesmo, parece, deveria suceder com o outro verbo dependente, precedido de uma interrogativa indirecta: quid ordinare... possit. Seria fácil emendar para posset, alegando a consecutio temporum e o exemplo de dignaretur. Vejamos, porém, os manuscritos: - possit VRBL, possint $\mathrm{D}$, posset N. Sabido que VD são os melhores; que $\mathrm{R}(=\gamma)$ remonta igualmente ao hiperarquétipo $\alpha$; e que BL dispõem simultaneamente de $\alpha \mathrm{e} \gamma$, torna-se claro que a lição possit era já a de $\alpha$. Apenas $\mathrm{N}$ emendou para posset, mas contra o seu arquétipo $\delta$, representado aqui também por BL. Nestas condições julgámo-nos obrigado a manter possit.

Em IV,19 (lin. 1-6) fala-se de alguém que viera ao encontro de S. Macário et deprecaretur... ut instrueret ac doceret et... confirmaret et qualiter possit... impugnationes maligni euadere praemoneret... Vemos todos os verbos no imperfeito do conjun- 
tivo, excepto possit. Os manuscritos principais têm: - possit $\mathrm{VRBL}$, posset $\mathrm{DN}$. Isto significa que $\beta(=\mathrm{V}), \gamma(=\mathrm{R})$ e $\delta$ $(=\mathrm{BL})$ são uniformes na lição possit, que certamente todos receberam de $\alpha$. As emendas para posset são de $\mathrm{D}$, um manuscrito tardio, habitualmente pior que o seu par, V; e de $\mathrm{N}$, que fica isolado contra os seus pares, BL. Cremos que, se os modelos tivessem posset, ninguém emendaria para possit. Por isso temos esta lição como primitiva e originária.

Casos semelhantes se verificam em IV,10 (lin. 10): - possit $\mathrm{VBN}$, possint $\mathrm{L}$, posset $\mathrm{D}$, possent $\mathrm{R}$ (esta divisão favorece possit);

I,5 (lin. 5) - possit VB, posset DRNL;

II,8 (lin. 12) - possit VBL, posset DRN;

IV,12 (lin. 5) - possit VB, posset DRNL;

V,9 (lin. 3) - possit VB, posset DRNL.

Perante estes exemplos, mantivemos também possit na $V$ capitulatio (lin. 15) só transmitida por $\mathrm{V}$ (possit) e $\mathrm{D}$ (posset).

Quanto a nós, a presença da forma possit sempre em V não é sinal de que o copista de Viena (ou o seu modelo) confundisse $e$ com $i$. Temos anotado um exemplo em que $\mathrm{V}$ foi o único manuscrito que confundiu $i \operatorname{com} e(\mathrm{~V}, 8$, lin. 22): surgit et prosternit (:prosternet só em V). Julgamos antes que se trata de um hábito do tradutor que utilizava sempre (contra as boas normas gramaticais) o presente possit, podendo dizer-se que relegava sistematicamente o imperfeito posset.

Seriam de emendar todos estes presentes do conjuntivo? Chegámos a normalizar a sintaxe, adoptando a lição posset, também sempre documentada. A autoridade dos códices com possit e as divergências verificadas, por vezes, em todos os outros, levaram-nos a preferir, finalmente, esta lição. Mau hábito do tradutor ou do hiperarquétipo $\alpha$ ? Pensamos dever remontar ao tradutor; doutro modo não se justificaria a persistência do estranho possit. 
6 - Embora diferente, um outro passo evoca a presença da terminação com $i$. Em IV,12 (lin. 39-41) vê-se:

Si iubes, pater, praecedo te et uideo, ne forsitan aliqui fratres ad salutandum eum uenerunt et si uiderint te scandalizentur.

Depois de ne esperar-se-ia o conjuntivo. E de facto, RN têm uenerint. Mas o indicativo uenerunt impõe-se pela autoridade de VDBL, os quais afiançam a sua fidelidade ao hiperarquétipo $\alpha$. Em contrapartida, uiderint não apresenta qualquer variante.

7 - Um último exemplo de sintaxe controvertida. Em II,1 (lin. 13-15) um ancião diz ao seu discípulo:

Ecce nunc cognoui, fili, quia fideliter intelligis hoc spiritale certamen, per patientiam ad salutem animae proficiat.

Temos na frase dois verbos cognoscendi: o primeiro está, regularmente, construído com quia, seguido de indicativo: cognoui... quia... intelligis; o segundo está construído sem qualquer conjunção. Neste caso deveria esperar-se que o seu objecto directo fosse uma oração infinitiva. Vejamos, porém, o que sucedeu:

- intelligis hoc spiritale certamen... ad salutem... proficiat é o texto de VB. A construção com conjuntivo pareceu estranha a DN que passaram o verbo para o futuro do indicativo: proficiet. $\mathrm{O}$ ms. $\mathrm{R}$ transpôs o verbo para o infinitivo: proficere. Finalmente $\mathrm{L}$ introduziu, compreensivelmente, um quod, mas deixou o verbo no conjuntivo: intelligis quod... proficiat. É esta última lição que se encontra na edição de Rosweydus (PL 73, n..$^{\circ}$, col. 743). Mas note-se que os manuscritos secundários, de que Rosweydus depende, também não são concordes na inclusão de quod. O que todos confirmam é o conjuntivo: proficiat. E contudo perguntamo-nos: como se justifica o conjuntivo? Não seria preferível o futuro do indicativo ou a oração infinitiva? O tradutor tem lapsos de sintaxe - é a nossa conclusão. 
Os exemplos acabados de apontar, tanto no parágrafo sobre a obscuridade do latim, como no da sintaxe descuidada, poderão dar a impressão de pouca aptidão do tradutor $\left({ }^{162}\right)$. Estas faltas são um facto; mas diluem-se no conjunto da obra. Em breve veremos que o tradutor dispõe também de apreciáveis recursos estilísticos $\left({ }^{163}\right)$.

\section{6- CONCORDÂNCIA AD SENSVM}

Por vezes, o tradutor parece esquecer-se de qual é o sujeito real da oração e por isso cai em erros de concordância. Melhor dizendo: organiza uma concordância exacta quanto ao sentido, mas gramaticalmente imperfeita.

1 - Em V,3 fala-se de um monge que prezava tanto o recolhimento que nem sequer acedia a ir visitar sua irmã, já avançada em idade. Ela escrevia-lhe com frequência (linhas 9-11), petebatque ut ante exitum eius de hoc corpore ueniret ad eam, ut in caritate Christi de praesentia sua laetarentur.

Não temos dúvida de que o sujeito gramatical de todos estes verbos é ela, a irmã. Por isso, esperar-se-ia laetaretur. No ânimo do tradutor, porém, ou a alegria havia de ser comum ao irmão e à irmã, como se estivesse: ambo laetarentur, ou talvez já tivesse em mente que a ida do monge a sua casa provocaria também a alegria dos alii parentes ac propinqui de que fala mais adiante (linha 18).

O singular laetaretur foi, de facto, tido como a lição exacta por alguns copistas, como se pode ver no manuscrito de Dresda e, ocasionalmente, noutros secundários, a partir do arquétipo $\delta$. Foi esta sintaxe regularizada que Rosweydus preferiu para a sua edição; mas contra a tradução original.

(162) Cf. pp. 163-178.

(163) Cf. principalmente os parágrafos 7, 8, 9 e 10, pp. 181-199. 
2 - Conta-se em V,2 que o eremita Píor se retirou para a solidão. Ao abrir um poço pensou para consigo (linhas 11-13):

...qualemcumque aquam inuenero, oportet me ipsa contentum esse. Quod et factum est ad augmentum uirtutum eius talis occasio.

O sujeito do segundo período é, sem dúvida, talis occasio. O verbo deveria, pois, estar com a forma participial no feminino: facta est. O tradutor ou fosse por sugestão de quod, neutro, ou do augmentum seguinte, escreveu, com certeza, factum est. Houve copistas que pretenderam evitar a falta de concordância: o de Namur suprimiu talis occasio; outros, secundários, escreveram facta. Emenda compreensível, mas criticamente reprovável.

3-Mais aceitável é um outro tipo de concordância praticado pelo tradutor das Commonitiones. Depois de um colectivo (singular), seguido de um genitivo de qualidade no plural, faz por vezes a concordância com o verbo no plural.

Em IV,12 lemos que um monge foi de visita a Célia (linhas 3-4), ubi multitudo monachorum diuisis cellulis habitabant. O plural habitabant (a concordar com monachorum, em vez do singular habitabat ligado a multitudo) foi objecto de muitas divergências entre os copistas, mas só de recensões secundárias. $\mathrm{O}$ tradutor, porém, prendeu-se mais ao sentido do que ao rigor gramatical.

4 - Do mesmo género, embora aparentemente mais complicado, é o que se verifica em II,4. O abade Isidoro mostrou ao abade Moisés uma visão. Então este (linhas 10-12):

Cumque respiceret, uidit multitudinem daemonum uehementer cum furore perturbari et quasi ad proelium praeparatos, festinantesque pugnare.

Os particípios da frase deveriam apresentar as formas praeparatam e festinantem, a concordar com multitudinem. 
Os organizadores dos arquétipos $\gamma$ e $\delta$ julgaram resolver o problema emendando para multitudines. Na realidade, caíram noutra incongruência: a sua correcção colocou o substantivo no plural, como está praeparatos; mas cometeu o erro de deixar praeparatos no masculino, quando multitudines é feminino.

Quanto ao tradutor das Commonitiones, deixou-se sugestionar por outro facto: ao ter que traduzir os particípios, pensou que o complemento de objecto anterior, multitudinem daemonum, equivalia apenas ao acusativo do plural daemones; e assim já praeparatos e festinantes se explicam suficientemente. Trata-se de uma autêntica concordância ad sensum.

5 - Esta mesma interpretação sintáctica poderá estar subjacente no passo seguinte, em que o demónio interpela o abade Apolo (IV,11, lin. 12-13):

...tamen interrogo te sermonem ut dicas mihi quid est quod scriptum est in Euangelio: Qui sunt haedi et qui sunt oues.

$\mathrm{O}$ sujeito qui não está em concordância de género com o nome predicativo oues. Entende-se, no entanto, que qui concorda com um subentendido homines. Encontramo-nos, pois, perante uma comparação entre os bons (oues) e os maus (haedi).

O mesmo pensamento justifica, na resposta, a concordância ad sensum (lin. 16): oues autem Deus nouit qui sunt.

- Cf. outro exemplo na p. 172,3.

\section{7 - ARTIFÍCIO NA ORDEM DAS PALAVRAS}

Começamos aqui uma série de parágrafos nos quais se verifica que o tradutor das Commonitiones, apesar de algumas imperfeições de carácter sintáctico, tinha também preocupações estilísticas, apresentando-nos, por vezes, passos de saboroso latim. 
Uma das manifestações da sua busca de tonalidade literária é o modo artificioso como, aqui e além, organiza a distribuição das palavras na frase $\left({ }^{164}\right)$.

1 - Vamos seleccionar pequenos fragmentos, colocando-os, quanto possível, ao lado de outras traduções latinas paralelas, as quais, como sabemos, costumam estar muito próximas do grego que chegou até nós.

commonit. II,1 (lin.7-10)

Video, pater, quia etsi laborem sustineo, sentio fructum tamen in me proficere bonum, quia per occasionem impugnationis huius et amplius ieiunio et amplius in uigiliis et orationibus tolero.
PELÁGIO $\mathrm{v}, 20$

Video, abba, quia si laboro, tamen ex pondere laboris huius considero fructificare me.

Trata-se bem do mesmo passo em Pelágio e nas Commonitiones, embora estas desenvolvam a segunda parte do pensamento. Repare-se como nelas o verbo vai para o final em todas as orações, excepto na que sublinhámos. A oração adversativa foi em Pelágio introduzida pela conjunção tamen. Não assim nas Commonitiones. Nestas faz-se uma oposição quiástica entre laborem sutineo e sentio fructum. Que este efeito não é casual, prova-o o facto não só de a conjunção ter sido levada para depois do complemento directo, mas ainda a colocação, no fim de toda a oração, duma palavra importante para o pensamento: bonum.

(164) Sobre este problema específico, cf. J. MArouzenu, L'ordre des mots dans la phrase latine, I: Les groupes nominaux; II: Le verbe; Volume complémentaire avec exercices d'application et bibliographie, Paris, 1953. 
Observe-se a presença do conjunto que expressa as ocupações próprias da consagração religiosa: ieiunio et... in uigiliis et orationibus tolero.

2-Em IV,7 pergunta-se a Agatão porque não suportou terem-lhe chamado «hereje». $\mathrm{O}$ apotegma tem paralelo em Pelágio X,10 e em Pascásio XXV,2; mas o passo que vamos transcrever é uma amplificação ascética das Commonitiones (IV,7 lin. 28-30):

Nouimus enim quia si custodiatur humilitatis uirtus magna, salus est animae.

Nada de especial haveria a notar na simples expressão humilitatis uirtus. O problema está na posição de magna. Nós interpretamo-la como atributo de uirtus. Seria, por isso, de esperar, e resultaria até mais claro o sentido, se ficasse: magna humilitatis uirtus. O tradutor, porém, mais uma vez levou o adjectivo valorizador de uirtus para o fim da expressão, apesar do perigo de poder juntar-se, para quem ouve ou lê, ao nome predicativo salus animae. Parece-nos que de modo algum se deve entender: magna salus animae.

3 - Mais complicada é uma parte do princípio de IV,19 (lin. 1-7):

Quodam tempore cum ad beatum Macarium quidam uenisset, desiderans in proposito monachorum seruire Christo, et deprecaretur sanctum senem, ut instrueret ac doceret et ex fonte doctrinae salutaris, quae in eo per Sancti Spiritus gratiam abundabat, confirmaret et qualiter possit iuuante Domino insidias atque impugnationes maligni euadere praemoneret, respondensque beatus Macarius ait...

A frase é longa e por isso presta-se à confusão. O tradutor podia, no entanto, tornar o pensamento linear, se seguisse aproximadamente a ordem directa. Intencionalmente tornou o estilo rebuscado. Depois de doceret subentende-se o pronome 
eum, uma elipse frequente nas Commonitiones $\left({ }^{165}\right)$. A copulativa, a seguir, tem o verbo muito afastado, embora se mantenha a concordância: et... confirmaret; igualmente a outra copulativa tem os seus elementos muito afastados: et... praemoneret; intercalada dentro desta última oração foi construída uma interrogativa indirecta cujo verbo está também afastado do infinitivo que rege: possit... euadere. É evidente que toda esta disposição das palavras não se conseguiu ao correr da pena. Os diversos $x \tilde{\omega} \lambda \alpha$ estão fechados sobre si mesmos, graças a uma hábil distribuição dos elementos lexicais.

Não deixe de se observar ainda a perífrase para dizer esse monachum: in proposito monachorum seruire Christo $\left({ }^{166}\right)$.

4 - Uma técnica muito utilizada pelo tradutor das Commonitiones é o lançamento para o fim duma frase (ou membro de oração) do substantivo fundamental.

commonIT. II,4 (lin.14-16)

Cumque respiceret, uidit innumerabiles multitudines sanctorum angelorum, gloriosum et splendentem super lumen solis caelestium uirtutum exercitum.
PELÁGIO XVIII,12

Et attendit et uidit innumerabilem multitudinem angelorum in gloria.

Embora o pensamento se corresponda nas duas traduções, veja-se como in gloria de Pelágio foi desenvolvido nas Commonitiones. $\mathrm{O}$ nome predicativo do complemento directo fez-se esperar até ao fim do cólon: exercitum.

(165) Cf. pp. 144, 189-192.

(166) Cf. expressões para designar a perfeição monástica (pp. 113-114) e o uso de perifrases, pp. 192-199. 
Aproveitamos a oportunidade para mais duas observações: a) - à parataxe de Pelágio: et attendit et uidit, corresponde, em melhor estilo, a subordinação: Cumque respiceret, uidit; $\beta)-$ em vez do comparativo do tipo clássico gloriosiorem... lumine, temos uma construção mais vulgarizante: gloriosum... super lumen $\left({ }^{167}\right)$.

5-O n. II,7 tem paralelo em Pelágio V,19. Mas o conselho e o seu efeito, que neste se reduz a 4 linhas (as últimas), ocupa, nas Commonitiones, 24 linhas do nosso texto. Observemos apenas II,7, lin. 39-43:

Sed nisi et ipsi cum omni intentione mentis, tam in orationibus quam in omni opere bono spiritali, quae Deo placita sunt fecerint, non eis proficient, negligentibus et resolutis, ad salutem animae orationes sanctorum.

Quem está em causa são os que consentem nas tentações, indicados no princípio da frase por ipsi e depois retomados em eis. Este pronome está junto ao verbo que o rege: proficient. O sujeito desta oração só se encontra, porém, no fim da frase: orationes sanctorum.

Uma vez mais podemos observar como é expressa a preocupação espiritual. Mencionam-se duas práticas: $\alpha$ ) - cum omni intentione mentis significa aqui o exercício da "meditação" (cf. IV,2, linhas 32-33: humilitatis intentio = prática da humildade); $\beta$ ) - a oração; e depois apontam-se ainda, complexivamente, todas as obras típicas do monge virtuoso: in omni opere bono spiritali.

6 - Podem ver-se outros exemplos deste tipo em I capitulatio (linhas 13-14); I,7 (lin. 13-14); IV,5 (lin. 10-11); V,3

(167) Cf. infra pp. 212-219, especialmente 213, 218. 
(lin. 20-21); V,7 (lin. 60-61); V,8 (lin. 14-15); VI,1 (lin. 3-4); VI,2 (lin. 36-37). A esta forma de preocupação artística pertence também a colocação do antecedente do relativo após este pronome, processo de que passamos a tratar, por merecer estudo à parte.

\section{8 - COLOCAÇÃO DO ANTECEDENTE APÓS O PRONOME RELATIVO}

Normalmente o pronome relativo encontra-se colocado após o seu antecedente. Há, porém, outras posições mais artificiosas, que levam, por vezes, à alteração da sintaxe. $\mathrm{Na}$ chamada "atracção do relativo", o antecendente pode ser transposto para dentro da oração relativa, deixando o seu "caso" próprio para tomar o do relativo. Embora não seja muito raro, este processo já revela perícia e domínio da língua. Devemos considerar ainda a passagem do antecedente para depois do relativo, mantendo cada um deles o seu caso próprio. Esta técnica é mais frequente quando o antecedente é acompanhado por um pronome demonstrativo, o qual então fica fora da oração relativa. Mesmo assim demonstra bom gosto por parte do redactor latino.

1 - Observemos um bom exemplo:

commonit. II,6 (lin. 19-22) PELÁGIO v,27

Ita ergo reuersi sunt in cellulam suam. Abierunt autem ad sanctos patres et prostrauerunt se ad uestigia eorum. Cum multo ululatu et lacrimis gementes confessi sunt quae euenisset eis ruina et tentatio.

Qui cum uenissent ad cellam, retulerunt senibus quod eis contigerat... 
Ainda outra vez as Commonitiones são mais desenvolvidas que Pelágio, embora a substância do relato seja a mesma. O tradutor das Commonitiones poderia muito simplesmente terminar assim:... confessi sunt ruinam et tentationem quae euenisse $(n) t$ eis. Preferiu, no entanto, recorrer ao processo da atracção do antecedente, lançando-o para dentro da oração relativa e alterando-lhe o caso que lhe competia. Daí a concordância: quae... ruina et tentatio.

2-Mais complexo é o exemplo seguinte:

commonit. II,7 (lin. 12-14)

PELÁGIO V,19

Eadem autem nocte reuelauit ei Dominus, quae circa illum monachum erant negligentiae et ignauiae resolutio, et delectationes corporeas cordis eius.

Além da brevidade, devemos notar que, em Pelágio, o pronome relativo quae é um nominativo neutro do plural, a servir de sujeito. Não assim nas Commonitiones. Nestas poderia estar:... reuelauit ei Dominus negligentias et ignauiae resolutionem, quae erant circa illum monachum, et delectationes corporeas cordis eius. O tradutor resolveu, porém, utilizar a técnica da atracção do antecedente. Assim passaram para depois do relativo, e a concordar com ele, as palavras negligentiae et... resolutio.

O passo tem maior interesse porque, após a oração relativa, o tradutor colocou então em acusativo um outro elemento da oração que, de facto, serve de complemento directo a reuelauit: delectationes corporeas, apesar da distância a que estas palavras se encontram do verbo. Não restam dúvidas de 
que a copulativa et tinha para este tradutor muita força $\left({ }^{168}\right)$. Aqui provocou a mudança de tratamento dado a negligentiae, resolutio (em nominativo, por atracção a quae) e a delectationes corporeas (em acusativo, como também se esperaria encontrar negligentias e resolutionem).

Esta diferença de tratamento dos substantivos que servem de complemento directo não deixou de provocar perturbação em alguns copistas. $\mathrm{O}$ de Namur entendeu que delectationes era também um nominativo do plural e por isso emendou corporeas para corporeae. Outros the seguiram o exemplo. Também nós hesitámos, a princípio, sobre qual seria a lição exacta. Depois que fomos penetrando nos hábitos do tradutor, não duvidámos mais de que os melhores manuscritos eram os da lectio difficilior.

3 - Encontramos no texto das Commonitiones um passo ainda mais difícil. Na $V$ capitulatio temos o título VIII: De sancto Pachomio, commonitionem qui solebat referre fratribus... O texto é dado só pelos manuscritos de Viena e Dresda. Atendendo ao sentido deste resumo e ao apotegma apresentado à frente, sob o n. 8, apetecia-nos emendar assim: - De sancto Pachomio: commonitio quam solebat referre fratribus... O certo é que a única variante digna de atenção está na forma qui (Dresda): quae (Viena - note-se que o ditongo ae está bem nítido). Julgamos que a forma quae de Viena, mesmo que estivesse em vez de um anterior que ou quem não permite qualquer defesa.

Resta-nos, por conseguinte, se quisermos respeitar o texto, interpretar a lição de Dresda. Quanto a nós deu-se apenas uma inversão da ordem das palavras: qui tem como antecedente Pachomio; commonitionem é complemento directo de referre. Perguntamos: esta inversão foi propositada, por parte

(168) Cf. pp. 170-171, 191, 226, 270. 
do tradutor? Ter-se-ia dado, inconscientemente, ao estabelecer os arquétipos $\alpha$ e $\beta$, de que os manuscritos de Viena e Dresda descendem? Inclinamo-nos para um artifício voluntário do tradutor, pois o sabemos sensível à alteração da ordem das palavras.

4- Observem-se outras transposições do antecedente para o interior da oração relativa: confessus est eis quam patiebatur impugnationem (II,3, lin. 6-7); ille qui egressus fuerat frater dixit (II,6, lin. 6); desiderabat per quam occasionem uideret sanctum uirum (IV,4, lin. 17-18); descendens autem frater ille in eam quae in proximo erat ciuitatem (IV,17, lin. 13-14).

\section{9 - OMISSÃO DE UMA PALAVRA OU EXPRESSÃO}

O idioma latino tem um ritmo próprio, diferente do das línguas modernas. Ora prefere formas mais concisas ora emprega expressões redundantes.

Entre os processos de concisão conta-se a elipse, isto é, a omissão de uma palavra que facilmente se subentende. $\mathrm{O}$ tradutor das Commonitiones utilizou também este processo.

1 - Note-se a supressão do verbo sum, no modo infinitivo, neste exemplo:

V,2 (lin. 31-34): Contava-se do eremita Píor quia triginta et amplius annis (...) nunquam ei suasum est, etiam cum defunctos audisset parentes suos $<$ fuisse $>$, ut pergeret ad requirendum (...) propinquos suos. finito:

2-Mas há também supressão de verbos em tempo

IV,8 (lin. 19-20): ... forsitan uoluntas Dei est, ut licet indignus $<\operatorname{sim}>$, suscipiam ordinationem presbyterii. 
IV,18 (lin. 17-18): Tunc monasterii pater < ait>: Siquid dixero, obaudis ut facias?

3-Embora seja mais rara na época clássica, já então se admitia também a elipse de um substantivo. Também as Commonitiones apresentam exemplos desta forma de síntese literária.

V,9 (lin. 16-18): Cauete, fratres, a multiloquio et ab otiosis sermonibus linguam, quia malus $<$ sermo $>$ interitus animae generatur...

VI,2 (lin. 11-14): A Arsénio uma visão ostendit ei alium hominem stantem super lacum et haurientem aquam de lacu, mittentemque eam in collectaculum et de alio <latere >, pertuso, defluebat aqua de subter in eundem lacum.

4 - Omissão do pronome demonstrativo que facilmente se subentende:

IV,4 (lin. 20-21): Comprehendens enim filium sororis beati Poemenis misit $<$ eum $>$ in carcerem...

IV,19 (lin. 3, 5, 6): ... et deprecaretur sanctum senem, ut instrueret ac doceret $<\mathrm{eum}>$ et... confirmaret $<\mathrm{eum}>$ et... praemoneret $<$ eum $>$...

5 - Vale a pena prestar atenção ao seguinte passo, $\mathrm{cm}$ que se omite o advérbio potius ou magis, no primeiro termo da comparação:

I,7 (lin. 12-14): Oportebat te, frater, in cella tua hodie carnem <magis $>$ comedere quam istam talem nocem de tua abstinentia praesentibus cunctis dicere fratribus.

Podemos, quase com segurança, garantir que a omissão do advérbio de comparação já fazia parte da redacção grega primitiva, pois nos lugares paralelos deste apotegma temos traduções equivalentes: 
PELÁGIO VIII,21

Expedierat tibi hodie in cella tua comedere carnes, quam audiri hanc uocem coram tantis fratribus.
PASCÁsIo VI,2

Oportuit te, inquit, carnes in cella tua comedere quam hunc praesentibus omnibus audire sermonem.

Repare-se ainda como Pelágio redige toda a frase na ordem directa. Pascásio e as Commonitiones (traduzindo independentemente um do outro) lançaram para o fim da frase um substantivo que se fazia esperar desde que foi introduzido o seu atributo.

O exemplo prova a fonte grega comum c a maior preocupação estilística de Pascásio e do tradutor das Commonitiones.

6-Anotámos um caso em que foi omitido o segundo correlativo. A construção regular seria do tipo que encontramos, por exemplo, em VI,3 (lin. 6): ... perfecte studeris tam graecae quam latinae scientiae. Veja-se, porém, a seguinte construção:

V,8 (lin. 31-32) ... secundum praecepta Dei conuersamini, tam in orationibus et psalmodia.

A tam deveria corresponder um quam. O tradutor das Commonitiones mostrou, uma vez mais, a força que dá à copulativa et, aqui a substituir quam in $\left({ }^{169}\right)$.

7 - Um pouco diferente é o caso que vamos apresentar. $O$ sentido perfeito da frase e a sintaxe exigiriam a repetição de um verbo e do seu complemento directo. Colocados estes no meio do conjunto sintáctico, funcionam simultanea-

(169) Cf. supra pp. 170-171, 187-188. 
mente para duas orações. É a figura de estilo chamada silepse.

Em II,6 fala-se de dois irmãos. Um pecara, o outro não. $\mathrm{O}$ que estava inocente resolveu, porém, confessar-se igualmente culpado para ajudar o primeiro na conversão. A comunidade impôs-lhes uma penitência. Prossegue a narrativa (lin. 24-25):

Ille ergo alius qui non peccauerat, sed pro fratre, qui peccauerat, poenitentiam agebat, < agebat poenitentiam > quasi et ipse peccasset.

Só a repetição normaliza a sintaxe da oração principal e da adversativa. O tradutor mostrou-se bastante hábil para evitar uma tal repetição, fastidiosa para o estilo.

\section{0 - AMPLIDÃO DE ESTILO E PERÍFRASES SOLENES}

Observemos diversos processos de redundância estilística.

a) - ÊNFASE QUe Já DeVeria estar No ORIGINAL GREgo

Quem lê o texto das Commonitiones não pode deixar de se impressionar com a amplidão, quase oratória, de certas frases. Pensamos que uma tal forma alongada do discurso se deve, em primeiro lugar, ao autor grego $\left({ }^{170}\right)$. Queremos, no entanto, deixar aqui uma palavra de apreço pela expressão latina, no geral muito agradável, conseguida pelo tradutor.

1 - Em IV,1 fala-se de um monge a quem os seus antigos senhores concederam a liberdade, possibilitando-lhe assim o ingresso na vida religiosa. Em sinal de gratidão, todos os anos lhes levava o seu tributo de vassalagem. Da

(170) Cf. supra, tópicos do autor, pp. 107-120. 
primeira vez eles queriam recusar-se, mas o monge respondeu (lin. 13-17):

Ego seruus uester sum; nam uos dominos meos esse Omnipotens Deus constituit et gratias ago Domino uestro, quia dignati estis me permittere ut seruiam Domino uiuo et uero, Creatori ac Dominatori caeli et terrae et ideo detuli uobis pensionem seruitutis meae.

No lugar paralelo de Pelágio XV,31 lê-se apenas, em vez destas quatro linhas e meia:

Ego confiteor, quia seruus sum uester; et gratias ago, quia dimisistis me liberum seruire Deo.

É evidente a reelaboração das Commonitiones. De momento chamamos a atenção ainda para a reverência e abundância de qualificativos que exornam o nome de Deus.

2- Esta tendência para exaltar os atributos divinos é frequente. $\mathrm{O}$ mesmo respeito glorificador se verifica quando se menciona o nome de Jesus. Vejamos também um exemplo, tirado de V,5 (lin. 7-9):

Praestante enim gratia Dei et Saluatoris nostri, uidebo te in futuro saeculo, in regno Domini nostri Iesu Christi.

O passo correspondente de Pelágio diz apenas (IV,61): Cum gratia Christi uidebo te in regno caelorum.

Repare-se desde já que esta solenidade de estilo se consegue pela junção de sinónimos ou de expressões equivalentes à do texto grego que serviria de base à reelaboração das Commonitiones. Quando se trata de acrescentos deste tipo não é de excluir que o tradutor possa ter nisso alguma responsabilidade.

3- O n. V,1 é todo ele repleto de imponência literária. Atente-se na exaltação de Antonius (lin. 1-2); na insistência da forma praecipiebat (lin. 2-3); nas expressões de desapego da família (lin. 3-10). Antão recomenda, porém, aos monges (lin. 11-22): 
Oportet enim et ualde conuenit ut pro salute animarum parentum ac propinquorum suorum monachi intente semper Dominum exorare non cessent, ut eripiat et saluet eos de superueniente huic mundo ignis aeterno iudicio et ut mereantur habere partem in uero aeternoque lumine iustorum, cum aduenerit Christus, Filius Dei, rex aeternus, in gloria maiestatis suae cum angelis sanctis et cum omnibus uirtutibus et potestatibus caelestibus iudicare uinos et mortuos in die illo magno et terribili iudicii Dei. Ita enim debent monachi pro suis parentibus interuenire et deprecari Dominum, ut aeternam salutem mereantur accipere in uita perpetua, et regno Iesu Christi Domini nostri sors eorum inueniatur. Amen.

Se alguém quiser ler apenas o essencial da recomendação feita por Santo Antão, basta-lhe seguir as palavras que sublinhámos. Tudo o mais, e é quase metade do discurso, é ampliação de estilo retórico e parenético. Cremos ter ficado bem patente, neste exemplo, como, de uma exortação inicial, possivelmente breve, o autor soube construir uma autêntica homilia.

4-A tendência para o estilo enfático pode divisar-se mesmo em pequenos conjuntos, onde a segunda parte do membro frásico é uma explicação ou reforço da primeira. Exemplos:

II,6 (lin. 16-17): ... ut non in aeterno igne tormentis et poenis in inferni tartaro cruciemur...

IV,1 (linha 23): ... ut reuerteretur ad loca eremi, ad cellulam suam.

$\mathrm{V}, 7$ (lin. 23-24): ... et ingressa in monasterium uirginum famularum Dei.

V,9 (lin. 13-15): ... abiit ad cellulam suam et per totam noctem, cum grandi fletu et ulutatu, gemendo deflebat miserias nostras. 
b) AMPLIDÃo DE ESTILO, ATRIBUível aO TRADUTOR

Nas transcrições acabadas de fazer julgamos que o tradutor apenas se conformou com a amplidão do seu original grego, cabendo-lhe o mérito de valorizar estilisticamente o latim.

1 - Há, no entanto, outras formas de alongamento da expressão que podem, com muita probabilidade, atribuir-se exclusivamente ao gosto do tradutor. Eis um exemplo seguro:

commonit. I,11 (lin. 11-12)

Quoniam isti eremitae magis melius ad refectionem cibantur quam qui in monasteriis conuersantur.
PELÁGIO $\mathrm{x}, 97$

Quia solitarii uiri plus repausant in eremo quam nos in congregatione.

Além de locuções mais amplas como ad refectionem cibantur e in monasteriis conuersantur, repare-se na forma reforçada (não dizemos melhor!) do primeiro termo de comparação: magis melius.

2 - Este tipo de reforço encontra-se noutros passos. Um exemplo, sem paralelo latino, mas com grego quase literal:

OLYMPIVS $2(316)$

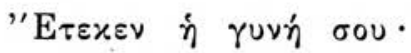

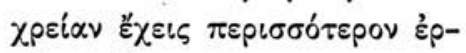
$\gamma \alpha \dot{\alpha} \sigma \sigma \alpha \sigma \theta \alpha \ldots \ldots$
соммоNIт. II,9 (lin. 11-12)

Ecce generauit uxor tua filiam; necessarium est ergo ut magis magisque amplius exerceas opera manuum.

O que está em causa é a expressão do comparativo $\pi \varepsilon \rho\llcorner\sigma \sigma o ́ \tau \varepsilon \rho o v$, com redundância traduzido por magis magisque amplius. 
3-Há também genitivos epexegéticos ou de inhacrentiae que são uma simples concretização acrescentada ao substantivo anterior:

II,8 (lin. 7): Et cecidit in ruinam peccati cum ea. Bastaria in peccatum.

V,8 (lin. 26-27): Saepe enim exardescere eum in iracundiam facio et in contentiones rixae et pigritiam... Seria suficiente contentiones, mas o tradutor explicou, como se dissesse: id est, rixas.

VI,2 (lin. 28-30): Ideoque (...) remanserunt foris de regno caelorum Christi exclusi.

Podemos comparar esta expressão com dois lugares paralelos:

PELÁGIO XVIII, 2

... propter quod et remanent foris a regno Dei.
PASCÁsIO XCIX,2

... atque ideo extra regnum Dei (...) remanserunt.

Pelágio e Pascásio traduzem literalmente a expressão grega

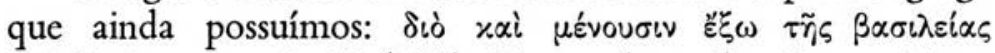

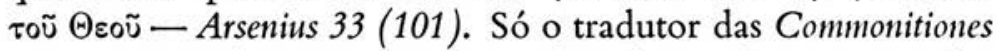
acrescentou Christi, genitivo que identifica qual é o «reino dos céus", e ainda o atributo exclusi, em concordância com o subentendido sujeito de remanserunt. Neste caso parece-nos seguro que a amplificação latina deve pertencer à técnica de tradução das Commonitiones.

c) PEŔf́rASES DE DIGNOR, MEREOR, POSSVM + INFINITIVO

As expressões perifrásticas podem contribuir também para dar ao latim maior solenidade. Algumas estavam mesmo consagradas pelo formulário da liturgia e da hagiografia 
cristãs: é o caso de dignari, mereri e posse seguidos de infinito $\left({ }^{171}\right)$. Poderiam ser substituídas por uma só palavra.

Vamos exemplificar, contrastando, sempre que possível com outra tradução latina.

II,6 (lin. 15-16): ...ut poenitentibus nobis indulgentiam donare dignetur.

IV,1 (lin. 14-15): ... quia dignati estis me permittere ut...; mas Pelágio XV,31: quia dimisistis me...

IV,10 (lin. 26-27): ... sicut dignatus es propter bonitatem tuam promittere his qui...

IV,3 (lin. 47-49): ... aeternam gloriam (...) percipere a Christo Domino mereretur.

V,1 (lin. 14-15): ... ut mereantur habere partem in (...) lumine iustorum; e (lin. 20-21): ut aeternam salutem mereantur accipere.

V,3 (lin. 14-15): ... ut post tanta tempora adorare merear sanctam caritatem tuam.

V,7 (lin. 20-21): ... ut mereatur peruenire ad gloriosa et aeterna promissa Domini Saluatoris nostri Christi; e (lin. 58-59): ... ut merear peruenire ad aeternam uitam, quam promisit Dominus noster Iesus Christus diligentibus se.

IV,5 (lin. 19-20): ... ut ad aeternam caelestemque gloriam peruenire possimus.

V,7 (lin. 16-17): ... ut peruenire possis ad aeternam uitam et ad caelestia bona...

\section{d) OUTRAS EXPRESSÕES PERIFRÁSTICAS}

Há ainda outras expressões de tipo perifrástico e com valor enfático. Consideremo-las por partes:

(171) Cf. Ch. Mohrmann, Études sur le latin des chrétiens, Roma, II, 1961, pp. 107, 334; III, 1965, pp. 96, 251, 256 e 259. Sobre várias perifrases deste tipo cf. também Pascásio de Dume..., I, pp. 78-83. 
$\alpha$ ) - modo de substituir um imperativo que poderia parecer duro, e de formular um pedido em termos delicados. Um dos processos preferidos é o imperativo de iubeo seguido de infinitivo:

I,11 (lin. 31-32): Magis iubete facere nobiscum aliquantos dies;

IV,4 (lin. 45-46): ... quod iustum uidetur legibus ita de eo iube disponere;

IV,12 (lin. 20): Iube mihi mandare qualiter habeas, audiui enim te infirmari;

IV,12 (lin. 23-24): ... ut uel duos dies iubeas indutias dare, ut possit sibi aliam cellulam prouidere;

IV,17 (lin. 19-20): Iube considerare, pater, codicem istum et aestimari eum si...

IV,18 (lin. 11-12): Vide ut dicas ei quatenus accipiat flagellum...

V,3 (lin. 27-28): Rogamus te, domina mater, ut iubeas nobis aquam dare ad bibendum. Não se trata de pedir a uma superiora de convento que dê ordem a outra irmã. Pouco depois, com efeito, lê-se (lin. 36): Ipsa uero egressa es ad nos et dedisti nobis aquam.

3) - manifestação da tendência para a passagem de formas sintéticas do latim clássico para outras mais analíticas e alongadas:

VI,6 (linhas 5-6): Si quid necessarium habes, ego tibi praebeo. Pelágio em X,18 (linha 6) tem apenas: Quidquid uis, ego tibi dabo.

$\gamma)$ - prenúncio do futuro «imperfeito» das línguas românicas, tanto com habeo como com debeo, seguidos de infinitivo $\left({ }^{172}\right)$ : tollere;

I,14 (lin. 5-6): Nihil enim, inquit, grande est quid habeo

(172) Cf. Manuel de Parva Boléo, Os valores temporais e modais do futuro imperfeito e do futuro perifrástico em português, Coimbra, 1973. 
I,14 (lin. 8-9): Oportet ergo et meipsum probare debeo si possim sustinere tormenta...

II,8 (lin. 25): ... ego autem quid habeo facere...

III,1 (lin. 23-24): ... quare non magis reuereri et timere debes maiestatem Omnipotentis Dei...

Não incluímos aqui as expressões perifrásticas em que debeo marca um estrito sentido de obrigação (I,15, lin. 7; V,1, lin. 19).

\section{1 - FORMAS DE TRATAMENTO}

Algumas expressões acabadas de mencionar, $-d, \alpha-c$ (omo: iube considerare, pater; rogamus te, domina mater) colocam-nos perante o interessante tema do formulário de tratamento em latim, principalmente entre os cristãos. Não é nossa intenção alongar-nos com excursos diacrónicos. Parece-nos, no entanto, útil alinhar, primeiramente, as diversas fórmulas de tratamento empregadas nas Commonitiones Sanctorum Patrum (173).

1 - De acordo com a norma tradicional, a segunda pessoa, no singular, é tratada por $t u$. Num só caso registámos o que parece ser um plural de majestade. Em IV,3 o imperador

(173) Cf. A. A. R. BAstIAENSEN, Le cérémonial épistolaire des chrétiens latins in Graecitas et Latinitas Christianorum Primaeua, Supplementa, Fasciculus II, Nijmegen, 1964 , pp. 7-45 (com larga bibliografia sobre fórmulas de tratamento tanto em latim cristão como profano). Úteis elementos sobre este tema podem colher-se também em Mariuina dos Santos Luz, Fórmulas de tratamento em português arcaico, Coimbra, 1958 (com bibliografia sobre o latim) e no artigo de L. F. LINDLey CinTrA, "Tum e *Vbs» como formas de tratamento de Deus, em orações e na poesia em língua portuguesa in Revista da Faculdade de Letras de Lisboa, III Série, n. 13, 1971, depois inserido no livro do mesmo autor Sobre aformas de tratamentow na língua portuguesa (ensaios), Livros Horizonte, Lisboa, 1972. O tratamento por meio de fórmulas abstractas, durante todo o período imperial, foi objecto do estudo do Prof. F. Rebelo Gonçalves, A expressão "tranquilitas uestra" de um passo de Eutrópio in Humanitas (Coimbra) II (1948), pp. 131-173. Sobre a linguagem afectiva e o plural de cortesia nos autores cristãos cf. também A. Blarse, Manuel du latin chrétien, Strasbourg, 1955, pp. 52-66 e 112-113. 
Teodósio II visita um monge, sem se dar a conhecer. A certo passo pergunta (lin. 14-16): Quomodo sancti patres degunt in Aegypto? E o monge respondeu: Omnes exorant Dominum pro salute uestra. Será lícito inquirir se uestra se refere só ao visitante ou antes a todo o povo, à comunidade cristã. Com efeito, um pouco adiante lê-se (lin. 22-23): Tunc dixit imperator: Scis quis sim ego? Respondens monachus dixit: Nescio. Quis es domine? Deste breve diálogo conclui-se que tanto o imperador como o monge são tratados por $t u$.

2 - Não há vocativos directos, de tipo abstracto, como fórmulas de cortesia, levando o verbo para o plural ou para a terceira pessoa do singular. O plural uos só é usado quando dirigido a mais de uma pessoa, construído então com o verbo na segunda pessoa do plural. O maior interesse reside na variedade do formulário expressivo da afeição, obediência ou respeito manifestado pela pessoa que fala. Para os casos em que os exemplos são muito numerosos indicamos apenas as primeiras abonações nas Commonitiones.

O monge superior, isto é, o mais velho trata o discípulo ou os consulentes do seguinte modo:

- filius (II,1, linhas 6, 13; II,2 lin. 12, 22; etc);

- filiolus (I,1, lin. 2; I,6, lin. 4; II,2, lin. 26; etc);

- frater (II,7, lin. 24; II,8, lin. 20; III,1, lin. 10; etc);

- fratres dilectissimi (IV,3, lin. 45; V,8, lin. 29);

- carissimi fratres (IV, 9, lin. 17);

- dilectissimi (1,3, lin. 5).

3- $\mathrm{O}$ inferior dirige-se ao superior (incluímos também as invocações a Deus e a Cristo) por estas palavras:

- abba (IV,3, lin. 19; IV,7, lin. 23);

- domine (I,12, lin. 7; IV,2, lin. 11);

- Domine (a Deus): IV,6, lin. 14;

- Domine Deus (IV,6, lin. 9);

- Christe Domine (IV,6, lin. 15); 
- Domine Deus meus (a Cristo): IV,10, lin. 25;

- Domine Deus noster (a Cristo): IV,10, lin. 20;

- domine frater (V,5, lin. 6);

- domine pater (IV,12, lin. 21; IV,17, lin. 35; IV,19, lin. 37);

- domini patres et fratres (à comunidade monástica): IV,10, lin. 31;

- pater (II,1, lin. 7; IV,7, lin. 6; IV,12, lin. 40; etc.);

- beatissime pater (II,7, lin. 4; IV,1, lin. 12; IV,19, lin. 17; $\mathrm{V}, 2$, lin. 44);

- carissime pater (IV,12, lin. 48-49).

4-Em IV,6, lin. 24-25, um juiz trata o abade Poemen por famule Dei.

Em V,3, lin. 27, um monge que falava a sua irmã, à porta do mosteiro, sem ela o reconhecer, chama-lhe domina mater.

5 - Uma virtude ou qualidade não serve nas Commonitiones como fórmula directa de tratamento, no vocativo. Há, no entanto, um pequeno número de expressões que se encontram nessa linha e representam já processos de tratamento, pelo menos, indirecto:

- iubeat nobilitas tua diligenter requirere causam: escreve o abade Poemen a um juiz (IV,4, lin. 41);

- mandauit abbas meus sanctitati tuae: diz um irmão para um monge famoso (IV,12, lin. 19);

- nimis rogat angelum tuum ut...: é a resposta que o mesmo irmão transmite ao seu abade (IV,12, lin. 23);

- gratias ago, domine, sanctae caritati tuae quia...: responde o monge famoso ao irmão, para que este leve ao seu superior o agradecimento (IV,12, lin. 31-32); mais próxima do tratamento de delicadeza e reverência está a mesma expressão noutro contexto: ego ueniam ad te ut (...) adorare merear sanctam caritatem tuam, escreve uma irmã que pedia uma audiência a seu irmão, religioso (V,3, lin. 14-15); 
- etiam et nunc satis deprecatur sanctitatem tuam: é o pedido feito por um monge a outro, por intermédio do discípulo do segundo (IV,12, lin. 34-35).

6-É possível ainda divisar nas Commonitiones alguns dos modos como os monges se cumprimentavam. Partimos das expressões mais simples para as mais solenes:

- salutate eum ex me: assim mandava um eremita cumprimentos para outro $(\mathrm{I}, 11$, lin. 15-16);

- factum est ut circa horam nonam salutarent se inuicem: refere-se à despedida de dois monges ( $\mathrm{I}, 13$, lin. 12-13);

- cumque alterutrum sibi pacem dedissent: descreve a saudação no momento do encontro (IV,18, lin. 14-15);

- complexus eum, induxit in cellulam: assim faz as pazes um ancião com o seu discípulo (IV,15, lin. 7-8);

- cucurrit in amplexum eius et osculatus est eum: é um cumprimento afectuoso entre dois monges considerados (IV,12, lin. 53-54);

- prostrauit se in orationibus (IV,16, lin. 19-20); e prostrauit se in orationem cum lacrimis (IV,14, lin. 7): são duas fórmulas simples para designar quem pede a ajuda de Deus;

- proiecit se ad pedes eius: gesto da irmã de Píor ao vê-lo (V,2, lin. 50-51);

- fratres (...) prostraucrunt se in terram ad pedes eius: manifestação de respeito perante a humildade de Agatão (IV,7, lin. 22-23); senior statim prostrauit se in terram ad pedes discipuli: assim um ancião se reconhece inferior, em virtude, ao seu discípulo (IV,12, lin. 63); prostrauit se in terram ad pedes eius cum fletu et lacrimis poenitendo, modo como um irmão pede perdão ao abade Atanásio (IV, 17, lin. 30-31);

- tunc senior adorauit eos: exprime a atitude de admiração de um ancião perante a virtude de dois irmãos (IV,9, lin. 14-15);

- prosternebat se in terram adorans cos: refere a atitude de Eulálio diante dos que o acusavam (IV,16, lin. 5-6); prostrauit se protinus in terram, adorabatque senem: assim procede um monge 
virtuoso perante outro que lhe emprestava uma cela (IV,12, lin. 47); procidensque pronus in terram adorabat eosdem fratres: designa uma forma de pedir perdão e auxílio (IV,7, lin. 13-14);

- benedicite et audite peregrinos: é expressão com que dois monges se anunciam ao chegar à porta de um mosteiro de monjas (V,3, lin. 22-23).

Se alguém procurar inserir todas estas formas e fórmulas de tratamento no seu contexto, verificará que elas contribuem para dar ao estilo tonalidade afectiva e beleza literária.

\section{2 - DIMINUTIVOS}

No latim tardio, e mesmo no período clássico, o uso de diminutivos tem na linguagem familiar uma grande área de expansão. O que importa salientar é que, do ponto de vista semântico, muitas vezes perderam os diminutivos o seu valor próprio - indicar menor dimensão ou grau de qualidade e estilisticamente deixaram também, por vezes, de significar maior afectividade. Usar o substantivo simples ou o seu diminutivo passou a ser quase indiferente, quanto ao sentido $\left({ }^{174}\right)$.

Observemos o valor dos diminutivos que aparecem nas Commonitiones.

ADOLESCENTVLVS - Em V,2 diz-se que a irmã de Píor, desejando visitá-lo, mandou os seus dois filhos, sobrinhos do eremita, para descobrirem primeiro em que mosteiro ele habitava. Pela apresentação inicial pode parecer que estes se encontravam no limiar da adolescência (lin. 34-35):

Verumtamen soror eius cum esset uidua, habens duos filios iam adolescentulos, misit eos...

(174) Além das estilísticas e gramáticas latinas já indicadas, cf. P. A. W. STEYeN, Stylistische opmerkingen aangaande het gebruik der deminutiva in het latijn, Nijmegen, 1953. 
Um pouco mais abaixo, porém, são tratados assim (linha 40): Perrexerunt autem adolescentes... Não há qualquer diferença semântica entre adolescentulos (linha 35) e adolescentes (linha 40). Trata-se das mesmas pessoas, na mesma época da sua vida. Podemos até suspeitar que o diminutivo é o menos apropriado. Com efeito, não só se afirma que sua mãe já era viúva (linha 35), mas os próprios filhos dão a entender que ela já era idosa (lin. 38-39): Nos filii sororis tuae sumus, quae nimio desiderio optat te uidere, ante exitum suum. Além disso, sabemos que Píor depois de se fazer monge (quando era ainda adolescente linha 2) viveu alguns anos com Santo Antão e aos 25 anos retirou-se para outro lugar solitário (linhas 3-5). Ali viveu durante mais de 30 anos (linha 31). Só depois - tinha mais de 55 anos - se deu o episódio da visita dos sobrinhos. Que idade teriam estes? Não sabemos. A adolescentia entre os romanos ia dos 12 aos 30 anos. Certo é que, no contexto, adolescentulus é perfeitamente idêntico a adolescentes.

$A R B V S C V L A$ - Não podemos saber qual o porte da árvore a que se refere o texto de IV,10, (lin. 41-42): Nam et nos ipsam arbusculam uidimus. É certo, porém, que se trata de uma planta que deitou raízes, floresceu e deu fruto (cf. lin. 31-38).

ASELLVS - Em IV,8 (lin. 12, 13 e 15) fala-se de uns irmãos que, ao irem procurar Isaac, levaram consigo um asellus que transportava os mantimentos. Neste caso podemos recorrer a lugares paralelos. O grego - Isaac 1 (224) - tem ó b́voc; Pascásio traduz por asinus. Com muita probabilidade o diminutivo é da responsabilidade do tradutor das Commonitiones.

BVCCELLA -É um diminutivo de bucca. No latim tardio formou-se buccella com o valor de 'migalha', 'pequeno pão'. É este o sentido que tem em IV,3 (lin. 19-21): Statimque festinauit monachus et misit aquam et salem et misit buccellas et comederunt pariter. Não há paralelo para esta frase. 
CELLVLA - Trata-se de um diminutivo de cella, mas sem que haja nas Commonitiones qualquer diferença de significado. Cf. cella em I capitulatio, lin. 18; I,7, lin. 12; II,2, lin. 32; etc. Para cellula cf. I,2, lin. 4 e 13; I,5, lin. 19; etc. Registámos 45 vezes a forma cellula. Há casos em que os manuscritos divergem: uma recensão tem cella, outra cellula. Da preferência do tradutor das Commonitiones pelo diminutivo (sem qualquer valor semântico) há um exemplo significativo em V,6, lin. 13. Este apotegma foi traduzido por Cassiano, cujo texto, como vimos (pp. 138 e 142), tem invariavelmente cella. Foi o reelaborador das Commonitiones que emendou para cellula, forma sem variantes.

FENESTELLA - A palavra aparece só uma vez, em I,5, lin. 17-19: ... uidit de sportella, ubi panis, id est, paximatia reposita crant, surrexisse fumum magnum et egressum esse per fenestellam cellulae eius. Este diminutivo de fenestra está já documentado no latim clássico, desde Propércio. De notar a hesitação dos códices. A forma fenestella julgamos ser a originária. Todavia, a transmissão manuscrita a partir de $\delta$ emprega a grafia fenestrella, também documentada como lectio uarians. Note-sc que o substantivo simples, fenestra, está largamente representado nas línguas românicas, entre as quais o português "fresta", ao passo que fenestella e fenestrella não deixaram descendentes. Não temos lugar paralelo para este pormenor, pelo que não sabemos qual a forma grega (um diminutivo também?) a que fenestella corresponderia.

GILLVNCVLVS - Em II,8 aparece 3 vezes a forma gillo (também grafada por alguns manuscritos gello e gillon) cf. linhas 9,14 e 21 . Trata-se de um vaso para água. Porém, neste caso, quando, na linha 24 , vemos a palavra gillunculus, ela tem aí um sentido depreciativo. Um irmão tinha um pequeno incómodo por causa do seu vaso de água (gillo) que, para tentação sua (julgava ele), se entornava. Foi consultar 
um outro monge, o qual tinha um problema de consciência bem mais grave. Este responde então, desprezivelmente, ao seu consulente (lin. 23-25): Tu quidem uenisti interrogare me quia gillunculus tuus uertit se et effunditur aqua; ego autem...

Em Pelágio V,24, lugar paralelo deste apotegma, o equivalente latino de gillo é, nas duas primeiras vezes, suriscula; na terceira, uasculum aquae; e a gillunculus corresponde finalmente, de novo, apenas suriscula.

Em grego (Nau, 176) o vocábulo usado é invariavelmente

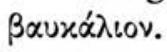

Temos, pois, nas Commonitiones um diminutivo expressivo, que denota o estado de espírito de quem o emprega.

MENSVLA - A mesa existente na cela de cada um dos dois eremitas de que fala o n. I,11 é designada uniformemente por mensula (lin. 4 e 27). A este diminutivo não deve, no entanto, ser dado qualquer valor semântico especial. É fruto da tendência linguística do tradutor das Commonitiones. O grego (Nau, 229)

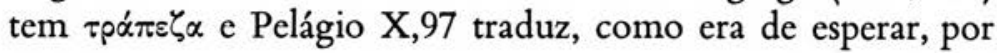
mensa.

MONASTERIOLVM - O n. V,3 emprega 9 vezes a palavra monasterium (linhas 5, 6, 7, 12, 21, 22, 30, 34 e 38), aliás frequente em toda a colecção. Opõe, no entanto, o mosteiro do abade João ao de sua irmã, a qual desejava que ele ante exitum eius de hoc corpore ueniret ad eam (lin. 10). Parece que ela já estaria velha e doente, porque insiste com ele $u t$ ueniret et uideret eam ante exitum suum et orationem faceret in monasteriolo eius (lin. 32-33). Supomos que o diminutivo aplicado ao mosteiro da irmã não terá qualquer valor especial. Faltam-nos lugares paralelos para confrontar.

SPORTELLA - Uma das actividades usuais dos monges era o fabrico de cestos de vime, com asas. Nas Commonitiones menciona-se este trabalho em I,11 (lin. 19): operarentur texentes 
sportas; e em VI,4 (lin. 1-2): cum operaretur sportas. Sabemos que um dos destinos desses cestos era guardar o pão. Em IV,3 (lin. 17-18) o imperador não viu na cela de um monge nisi paucos panes siccos in sporta pendentes. Este passo é precioso para interpretar o valor de sportella em I,5 (lin. 17-18): um monge uidit de sportella, ubi panis, id est, paximatia reposita erant surrexisse fumum.

Muito provavelmente este diminutivo não tem qualquer valor especial. Para o tradutor das Commonitiones usar sporta ou sportella devia ser quase indiferente. Há lugares paralelos.

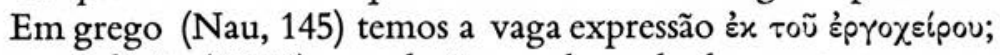
em Pelágio (IV,58) a tradução ou depende de um texto grego diferente do que possuímos ou o latim (faz-nos falta uma edição crítica) não está perfeito. A tradução de Pelágio de que dispomos é: uidit opus diaboli sicut fumum exeuntem a se. Esperaríamos: exeuntem a sporta / a sportella. Aguardemos um texto crítico, com o qual se está ocupando o dr. Columba M. Batlle.

VASCVLVM - O termo aparece em I,9 (lin. 4): Ecce illud modicum uasculum... O grego tem também um diminutivo:

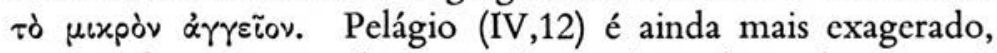
pois traduz por paruulum uasculum. Tratando-se de um vaso ou almotolia para azeite, não é de admirar o emprego do diminutivo em sentido próprio.

Diferente é o caso de V,2 lin. 15. A água do poço do eremita Píor era tão mal saborosa que quem o visitava in proprio uasculo aquam sibi portaret. A bilha ou cantil que o visitante levava não precisaria talvez de diminutivo. Os paralelos que temos para este passo não descem a um tal pormenor. 


\section{3 - VÁRIAS ANOTAÇÕES SOBRE MORFOLOGIA E SINTAXE}

Pode dizer-se que a morfologia e a sintaxe das Commonitiones são correntes em textos de latim tardio. Às tendências da língua vulgar e às inovações da «língua especial» dos cristãos há a acrescentar as características de uma língua que se vai abastardando, em relação aos ideais da época clássica. Não é nossa intenção fazer aqui um estudo aprofundado e comparativo da sintaxe desta antologia latina de apotegmas, no estilo que caracteriza a escola sueca $\left({ }^{175}\right)$. Julgamos útil, no entanto, apontar algumas das características e das tendências principais do tradutor das Commonitiones $\left({ }^{176}\right)$.

\section{a) FLEXÃO NOMINAL}

1 - O substantivo cuja declinação se apresenta mais hesitante é o nome do abade Poemen. Este antropónimo é uma simples transliteração do grego, onde se encontra com a flexão

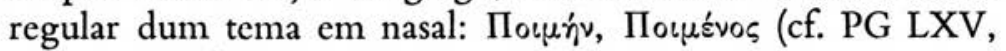
coll. 317-368).

Nas Commonitiones, como em Pascásio e Martinho de Dume, aparece transposto para os temas latinos em nasal:

(175) Quando falamos da escola sueca» temos principalmente no pensamento os estudos de figuras consagradas como E. LöFstedT, Philologischer Kommentar zur Peregrinatio Aetheriae, Darmstadt, ${ }^{3}$ 1962; IDEM Syntactica, I e II, Lund ${ }^{3}$ 1957; IDEM, Late latin,Oslo, 1959; D. Norberg, Syntaktische Forschungen auf den Gebiet des Spätlateins und des frühen Mittellateins, Uppsala, 1943; IDEM, Beiträge zur spätlateinischenn Syntax, Uppsala, 1944; B. Löfstedt, Studien über Sprache der longobardischen Gesetze. Beiträge zur frühmittellateinischen Latinität, Lund, 1961.

(176) Ao tomarmos esta posição, procuramos evitar o defeito em que caiu Salonius: - tentar um estudo filológico de conjunto antes de haver edições críticas e monografias linguísticas para cada autor (cf. J. G. FreIre, Traductions latines des Apophthegmata Patrum in Mélanges Christine Mohrmann, Utrecht/Anvers, 1973, p. 170). A propósito desta nossa crítica à obra de Salonius sobre as Vitae Patrum escreveu-nos a Prof." Mohrmann: «je suis tout à fait d'accord avec vous en ce qui concerne Salonius» (carta de 17-I-74). 
Poemen, Poemenis. Todavia, tal como se poderá observar pelo nosso texto crítico de Pascásio $\left({ }^{177}\right)$, também nas Commonitiones as formas de alguns casos oscilam.

$\mathrm{O}$ nominativo e dativo do singular são, invariavelmente, Poemen e Poemeni.

No genitivo, a forma corrente, que consideramos regular, é Poemenis. Mas note-se que na I capitulatio, só transmitida pelos melhores manuscritos, os de Viena e Dresda, encontramos com o n. VIII (lin. 19): De expositione sancti Pemenii (Viena): ... Pomenii (Dresda). A desinência está tão clara que não nos atrevemos a corrigir para Poemenis.

No acusativo a forma regular é Poemenem. Aparece, no entanto, também o acusativo igual ao nominativo. Veja-se a II capitulatio, n. X (lin. 20): De fratre qui interrogabat sanctum Pemen (Viena): ... Panem (Dresda). Parece-nos que não há dúvida quanto a uma forma dissilábica. A redução do ditongo oe a $e$ no ms. de Viena é normal; o duplo erro de cópia do ms. de Dresda, trocando o primeiro $e$ por $a$ e $m$ por $n$ mostra que o copista (este ou o do seu modelo) ou se distraiu ou não entendeu o que tinha diante dos seus olhos. Esta mesma forma de acusativo, Poemen, se encontra em II,10 (lin. 1). Já os reelaboradores dos arquétipos $\gamma, \delta$ (e seus derivados) regularizaram a desinência. Igual problema se põe para IV,5, tanto na capitulatio como no texto (cf. o aparato crítico).

O ablativo normal é Poemene. Contudo, em IV,4, tanto na capitulatio como no texto (linha 1), a forma para que tendem todos os manuscritos, mesmo aqueles cuja lição não reproduzimos, é Poemen.

(177) Cf. Pascásio de Dume..., t. I, pp. 159-333. Para exame das lectiones uariantes do nome de Poemen poderá utilizar-se o índice que se encontra na p. 356, depois da palavra Nestor. Infelizmente este parágrafo ficou empastelado". O seu lugar próprio seria na p. 357, após Pior. Também o título deste II índice onomástico apresenta um "salto" (p. 355). A sua redacção original é: Personagens mencionadas no texto de Pascásio ou no estudo dos seus lugares paralelos. A omissão de "no texto» torna o título quase ininteligível. 
Vê-se que, à semelhança de alguns nomes próprios hebraicos, (Dauid, Iob, etc.) havia uma certa tendência para tornar Poemen indeclinável, excepto no genitivo (onde as formas são divergentes) e no dativo.

2 - Podemos acrescentar outras observações sobre a flexão dos nomes, tanto próprios como comuns.

$\mathrm{Na} V$ capitulatio, só transmitida por VD, temos sob o n. II: De sancto Pior (Pior V: Piore D). No apotegma correspondente - V,2 - temos 4 vezes Pior em nominativo (lin. 1, 9, 52 (bis), sem quaisquer variantes. Também o vocativo Pior (lin. 7) não sofre hesitações. $\mathrm{O}$ acusativo, porém, apresenta duas formas - Piorem VD: Pior RN, forma esta última também usada nos arquétipos $\eta$ e $\theta$. Todavia alguns manuscritos de $\delta$ e os de $\zeta$ escrevem Piorem.

Fora da capitulatio $V$ não aparece o ablativo. Mas a editio Vulgata de 1-40 Rosw. por vezes coloca um título antes de cada apotegma. A preceder o n. $31(=\mathrm{V}, 2)$ verifica-se também divisão dos manuscritos: De sancto Piore escreve $\mathrm{N}$ : de abbate Pior lê-se em F. Concluímos, portanto, que também a flexão de Pior é hesitante, havendo, em todos os casos em ocorrência, testemunhos da forma invariável.

3-O antropónimo Apollo não oferece maiores facilidades. Na IV capitulatio, n. XI, são uniformes os manuscritos que o transmitem: De beato Apollo VDR. Este ablativo não aparece mais no texto. E dos manuscritos com a série 1-40 Rosw. só temos registado título para $\mathrm{N}$ : de demoniaco (post correctionem) abbate Appoline. Supomos que o copista queria dizer: «De um possesso do demónio 〈com〉 o abade Apolo». O título está em parte rasurado no manuscrito, sendo a sua leitura muito difícil e, tal como se encontra, sem qualquer sentido. O nome do abade só volta a aparecer neste capítulo no próprio apotegma IV,11 (lin. 1): ad beatum abbatem Apollo 
VDBS: Apollinem R Apollonium L. Há lição diferente em N: ad cellam abbatis Apollinis.

Vejamos o que se passa com este nome no cap. V. Lê-se na capitulatio, n. VI - De abbate Apollo VD, únicos manuscritos que transmitem este índice. No texto V,6 temos duas vezes o nominativo Apollo (lin. 5 e 11) sem variantes. Considerado o conjunto das formas apresentadas, vê-se que a tendência é para tomar o nome como indeclinável.

4 - Os outros nomes próprios não levantam problemas especiais. Seguimos a ordem do seu aparecimento nas Commonitiones:

- Zeno $(\mathrm{I}, 14$, lin. 1) só está documentado em dois casos: no nominativo (com a grafia Zenon em NL e em manuscritos secundários); e no ablativo, na respectiva I capitulatio, n. XIV - De abbate Zenone, sem variantes.

- Agathon (IV,7, lin. 1) é um nominativo sem variantes; na respectiva capitulatio temos o genitivo Agathonis também sem qualquer divergência.

- Daniel só aparece no nominativo - I,3 (lin. 3); VI: 2 (lin. 1), 4 (lin. 1) e 6 (lin. 1).

- São completamente indeclináveis: Beniamin (I: 9 e 10); Nitera (I,12); Ioseph (I,16); e Isaac (IV,8).

Os restantes antropónimos integraram-se totalmente na flexão latina: Arsenius, Dioscorus, Ioannes, Macarius, etc.

5 - Entre os substantivos comuns, poucos são os que precisam de referência:

a) O nominativo normal é abbas. Todavia, registamos este caso sob a forma $a b b a$ em III,1 (lin. 1) só nos mss. VL; em V,4 (lin. 13), onde $a b b a$ VBL se opõe a abbas D (R omite o apotegma, e N salta esta palavra); em V,8 (lin. 1) abba só está em Viena, e em VI,5 (lin. 7), tendo abba VR e abbas DBNL.

ß) Em I,11 (lin. 26) temos o acusativo sal (neutro) em VD, mas salem (masculino) em RNLB. 
r) A flexão de cucumis já era hesitante no latim clássico. Em I,14 (lin. 3) registamos o ablativo do plural cucumeris: só L escreve cucumeribus; em contrapartida, um pouco adiante (lin. 5), o mesmo ablativo do plural tem a forma cucumeribus documentada por VDB, mantendo cucumeris $\mathrm{R}$, enquanto NL utilizaram, variando a construção, o acusativo cucumeres.

8) O helenismo plasma foi normalmente incorporado nos temas em consoante. O seu ablativo do singular deve ser, por conseguinte, plasmate. Todavia, em IV,11 (lin. 10) os melhores manuscritos têm: de plasma Dei VDB, enquanto emendaram para plasmate RNL.

Em resumo, observa-se a tendência para tornar indeclináveis os nomes próprios de uso mais raro; dos nomes comuns apenas um escasso número apresenta flexão anómala, tendendo os manuscritos menos seguros para normalizar a declinação.

\section{b) FORMAS DE COMPARAÇÃo}

São variadas as manciras de exprimir nas Commonitiones as diversas modalidades que a comparação sintáctica assume.

1 - Há, evidentemente, processos inteiramente de acordo com as normas clássicas. Eis adjectivos com o sufixo normal de comparativo de superioridade, seguidos de um segundo termo em ablativo (I,3, lin. 5-6):

Considerate, dilectissimi, quoniam nihil fortius est in bestiis leone.

Além do comparativo, normalmente construído, registe-se também, neste exemplo, uma forma normal de superlativo: dilectissimi.

2 - Vejamos agora um segundo termo de comparação introduzido por quam $(\mathrm{I}, 11$, lin. 11-12): 
Isti eremitae magis melius ad refectionem cibantur quam qui in monasteriis conuersantur.

De notar também, desde já, o comparativo melius reforçado pelo advérbio magis, processo este da sintaxe tardia e vulgar.

3 - O segundo termo de comparação, expresso pela preposição super, seguida de acusativo, estava consagrado principalmente nas traduções latinas da Bíblia e na língua dos escritores cristãos. Dois exemplos:

II,3 (lin. 8-9): ... presbyteri praeceperunt omni multitudini fratrum ut (..) amplius super consuetudinem ieiunarent... II,4 (lin. 14-16): ... uidit (...) gloriosum et splendentem super lumen solis (...) exercitum.

Este segundo exemplo exige maior atenção. O primeiro termo de comparação está no grau positivo. Esperar-se-ia: gloriosiorem et splendentiorem (cf. p. 185).

4 - Também o segundo termo da comparação, introduzido por $a b$, com ablativo, tem consagração bíblica.

VI,1 (lin. 11-12): ... studebat ut ab omnibus monachis uiliora ct despecta uestimenta haberet.

Além da construção com $a b$ veja-se o desequilíbrio verificado no primeiro termo. Regular seria: uiliora et despectiora. De facto, alguns copista assim o entenderam. Por isso corrigiram despecta, embora dentro do mesmo arquétipo haja manuscritos (não anotados no aparato crítico) que se mantiveram fiéis ao original. $\mathrm{O}$ mesmo devemos dizer da omissão de $a b$. Os mss. de Reims e Namur suprimem-no. Mas da família deste último têm-no, por exemplo, os mss. de Berlim e Londres.

5 - Igualmente se encontra, uma vez, documentado o segundo termo da comparação introduzido por prae, numa frase em que se subentende o sujeito abbas Arsenius: 
VI,1 (lin. 8-9): sicut cum in saeculi conuersatione esset, nimis pretiosis uestimentis prae omnibus utebatur; ita postmodum...

6- Há formas de comparativo sem menção do segundo termo da comparação. Em certos casos, porém, é fácil subentendê-lo.

Em IV,2 fala-se de dois irmãos muito unidos. Apresentando o primeiro diz o texto (lin. 5):

... ille iunior frater accendens lucernam...

Um pouco adiante fala do segundo assim (lin. 9):

Surgensque senior frater...

Também há exemplos de comparativos de superioridade sem segundo termo de comparação, que assumem, segundo a norma clássica, o valor de «intensidade, bastante mais».

I,1 (lin. 14-16): Vigiliae (...) mentem nostram subtiliorem ac puriorem efficiunt.

II,2 (lin. 23-24): Vbi enim durior pugna, ibi gloriosior erit et corona.

7 - Não faltam também exemplos em que o comparativo perdeu o seu valor próprio e equivale, praticamente, ao grau positivo.

IV,6 começa assim: Item quodam tempore, dum adhuc iunior esset hic ipse beatus Poemen... Não se faz em todo o apotegma referência a outra idade do abade Poemen. Iunior tem aqui o valor de 'jovem', 'novo', sem conotação explícita de qualquer comparação.

Esta equivalência de iunior a iuuenis torna-se mais clara em IV,19. Há alguém (quidam) - linha 1-que, sózinho, vem pedir conselho a Macário. Mas adiante, após a resposta do grande abade, lemos (lin. 16-17): Haec audiens iunior dixit... E a mesma forma de comparativo desvalorizado se vê adiante (lin. 25): His auditis iunior statim perrexit... 
O caso mais evidente de um comparativo com valor de positivo é o uso da palavra senior. É impressionante a insistência quase uniforme deste comparativo para traduzir o grego

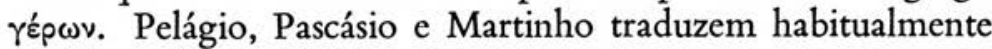
por senex. Poderá esta preferência por senior tomar-se como indício de que a tradução das Commonitiones é a mais tardia ? Não o cremos. É verdade que as línguas românicas documentam o uso generalizado de seniorem para indicar uma pessoa mais considerada, o 'senhor', suplantando o clássico dominus. Mas desde longa data senior e senex se equivaliam. Em Cassiano (abram-se as Conlationes ao acaso) estes dois termos aplicam-se indiferentemente à mesma pessoa, a poucas linhas de distância um do outro. E Cassiano estava em plena actividade literária por volta de 425 .

As próprias Commonitiones, apesar do absoluto predomínio de senior, nos deixaram testemunhos da perda de valor deste comparativo. Em I,11 emprega-se 6 vezes a forma senior. Porém, na linha 14, o senior de que se vinha tratando é designado por senex. Aproximadamente o mesmo se passa em I,13. Principia:

Quidam salutationis causa profectus est ad alium seniorem...

Parece dever subentender-se: quidam 〈senior〉 profectus est ad alium seniorem. Todavia adiante (linha 13) este primeiro senior é tratado como senex. De facto, Pelágio em IV,57 começa logo: Alter quidam senex uenit ad quendam patrum. E a terminar: ... discessit senex ille qui uenerat. No grego (Nau, 150) um é descrito como $\gamma \varepsilon$ é $\omega \nu$, o outro como $\pi \alpha \tau \eta \dot{p}$.

8 - Aparecem também advérbios com formas de comparativo de superioridade. Vejamos os principais.

a) Em V,9 conta-se que um certo "padre", quando os irmãos falavam de coisas espirituais, via os anjos, cheios de alegria, circa eos (lin. 6-7). Quando conversavam sobre outros 
assuntos, statim sancti angeli recedebant longius indignantes contra eos (lin. 9-10).

Apesar de longius apresentar uma forma de superioridade, cremos que o seu valor equivale ao positivo, como se estivesse apenas longe. Há, pois a oposição circa: longius.

Podemos, aliás, saber como o tradutor das Commonitiones reforçava a ideia de distância: empregava com esse fim a preposição pro.

Em IV,8 os irmãos procuram Isaac, que deles se apartara. Finalmente (lin. 10-11):

Cum autem applicuissent, ad uesperum, ad eundem agrum pro longius, ut reficerent fatigati de itinere...

Entende-se que o campo aonde chegaram era já muito longe do mosteiro. Que assim se deve interpretar prova-o o começo de IV,14 (lin. 1-2):

Quidam de sanctis senioribus misit discipulum summ ad hauriendam aquam; pro longius autem erat puteus a cella senioris.

Cremos que não é possível traduzir por «muito mais longe», pois não há outro ponto para comparação. Trata-se apenas de um processo de exprimir a intensidade. Pro longius equivale só a muito longe.

Não se julgue, porém, que o advérbio simples não era conhecido deste tradutor. No mesmo n. IV,14 diz-se que o irmão, ao verificar que não tinha uma corda para tirar a água do fundo do poço, contristatus est ualde, quia longe erat cella eorum (lin. 4-5).

Ainda que pro longius esteja a par de longe neste apotegma, não quer dizer que se equivalham inteiramente. Trata-se aqui de cambiantes estilísticas.

ß) O advérbio melius, comparativo, está usado em sentido próprio na frase (IV,12, lin. 30-31):

... abbas meus (...) misit me requirens si melius habeas. 
Entende-se: se estás melhor de saúde. Mas este mesmo comparativo pode ser reforçado, como se vê na frase que já citámos (p. 213; cf. também p. 230):

I,11, lin. 11-12: isti eremitae magis melius ad refectionem cibantur quam qui in monasteriis conuersantur.

r) $\mathrm{O}$ advérbio comparativo amplius aparece com o valor normal de 'mais' em diversos passos:

I,11 (lin. 25): propter uos debemus aliquid amplius cenare.

II,3 (lin. 9): ut per totam septimanam amplius super consuctudinem ieiunarent...

IV,10 (lin. 15-16). Cumque per tres et amplius annos sedule obsequeretur...

Construção igual a esta última se cncontra também em $\mathrm{V}, 2$, lin. 31. Diferente é já o uso seguinte:

VI,2 (lin. 35-37): Ille autem qui aquam de lacu hauriebat, homo est qui aliqua bona operatur, sed quia mala etiam amplius per peccata operatur...

É claro que etiam está a reforçar amplius. Perguntamo-nos, no entanto, se em vez do advérbio amplius não deveria estar o adjectivo no acusativo neutro do plural: mala etiam ampliora...

8) $\mathrm{O}$ advérbio magis é largamente usado pelo tradutor das Commonitiones. Por vezes poderia ser substituído por formas mais puristas.

I,15 (lin. 4-7): ... frequenter uidemus homines saeculares (...) a deliciis et delectationibus se abstinere (...). Quanto magis diligenter studere debet monachus...

Bastaria escrever: quam diligentius. Mas o tradutor preferiu uma forma analítica.

$\mathrm{O}$ valor de magis adquire diversos matizes.

Em III,1 (lin. 21-23): Si erubescis homines (...) quare non magis reuereri et timere debes maiestatem Omnipotentis Dei..., pode traduzir-se: porque não deves recear e temer sobretudo... Da mesma maneira em IV,2 (lin. 21-23): Considerans enim 
quonodo magis seductio et perditio animarum est cultus idolorum... O culto dos idolos é sobretudo...

Em VI,2 (lin. 32-33): ... quem oportebat magis poenitentiam agere de prioribus peccatis, sed negligens emendare uitia peccatorum priorum, magis alia super priora addit peccata. Nesta meia frase temos duas vezes magis. $\mathrm{Na}$ segunda expressão poderemos entender: aos primeiros pecados acrescenta outros ainda; na primeira é o seguinte o seu valor: convinha-lhe antes fazer penitência por causa dos seus pecados anteriores.

Magis com o significado de 'antes', 'pelo contrário', 'de preferência' é muito frequente nas Conımonitiones:

I,10 (lin. 5-6): Pater, magis de alio bono oleo mitte; I,11 lin. 31-32: Magis iubete facere nobiscum aliquantos dies... (Note-se também a forma perifrástica em vez do imperativo facite).

I,14 (lin. 12-13): ... non oportet me furtum facere, sed magis exercere secundum consuetudinem opera manuum; etc., etc.

9 - A preposição super, além de se usar para introduzir um segundo termo de comparação, como já vimos $\left({ }^{178}\right)$, é empregada também, isoladamente, com o valor de comparativo:

I,11 (lin. 20-21): Vespere autem ad luminaria, addidit super consuetudinem, alios psalmos...: mais do que era costume;

II,9 (lin. 8-9): necessarium est ergo ut super consuetudinem addas in opere manuum tuarum.

Evidentemente que super aparece muitas vezes com o valor normal de 'sobre', 'em cima de': cf. IV,2 (lin. 6, 17); etc. Menos frequente é já o seu emprego com o significado de 'por causa de', como em II,10 (lin. 19-20): Et glorificauit Dominum super magnitudine gratiae eius.

10 - Os superlativos de tipo corrente encontram-se a cada passo nas Commonitiones: dilectissimus, maximus, pessimus, etc.

Note-se, porém, este uso de maxime:

(178) Cf. supra pp. 185 e 213. 
VI,6 (lin. 15-17): Furem autem non expedit sustinere, maxime quia saepe commonitus non cessat:... principalmente porque...

Curiosa também a expressão maxime seniores fratres. Nela seniores funciona (o que é raro) como um adjectivo no comparativo, elevado por maxime ao grau superlativo:

IV,16 (lin. 10-12): ... conuenientes pariter maxime seniores fratres ad patrem monasterii, dixerunt ei...: os mais velhos de todos os irmãos...

Há ainda superlativos perifrásticos como: rogabat seniorem ut magis ac magis intentius pro eo oraret (II,7, lin. 7-8); necessarium est ergo ut magis magisque amplius exerceas opera manuum (II,9, lin. 11-12).

Ao terminar esta série de anotações sobre diversas formas de exprimir a comparação, não queremos deixar de mencionar uma ausência total. $\mathrm{O}$ advérbio comparativo plus, de tão larga sobrevivência no francês e no italiano, não aparece. Poderá ver-se aqui um indício, posto que débil, para lançarmos o nosso olhar em direç̧ão a outras terras, que não a Sul e a Ocidente dos Alpes, como lugar de tradução das Commonitiones?

c) FORMAS DE NEGAÇÃo

São normais os processos de negação utilizados nas Commonitiones, através de advérbios ou conjunções de tipo non, nunquam, $n e c$, nisi. Embora apareçam também noutros autores tardios, vamos assinalar o emprego de nihil, de minime e de nullus.

1 -É absolutamente normal o uso de nihil com o valor de 'nada'.

IV,17 (lin. 25-26): Interrogauit autem frater ille si nihil dixisset aliud. 
II,7 (lin. 33-35): ... si ille qui infirmatur non se abstineat a noxiis cibis, uel de aliis quae solent laedere infirmitates, nihil ei proficit cura et diligentia et sollicitudo medicorum.

Nesta última frase deparamos com non e nihil $\mathrm{cm}$ sentido c uso correntes. Mas há casos em que nihil substitui non. Trata-se de um avanço de nihil para terreno que lhe não pertencia no latim clássico. Exemplo: $\mathrm{O}$ abade Zenão estava tentado a roubar pepinos. $\mathrm{O}$ mau pensamento argumentava-lhe no íntimo: tollere.

I,14 (lin. 5-6): Nihil enim, inquit, grande est quid habeo

O uso de nihil aparece também reforçado com os advérbios omnino e penitus, ambos com o significado de 'absolutamente', 'completamente'. Aqui estão ambos, próximos um do outro:

IV,9 (lin. 8-10): ... coepit omnia holera cedendo confringere, ita ut nihil omnino remaneret. Videntes autem supradicti fratres nihil penitus dixerunt.

2 - Embora seja morfologicamente um superlativo, minime ć empregado por vezes com o valor de um simples non:

IV,1 (lin. 35-36): ... ne forsitan si pensionem pro seruitio meo minime intulero...

V,7 (lin. 13-14): Ecce, soror, audisti et cognonisti quia uiuo; ne contristeris autem quia minime me uidisti...

3 - De notar a preferência por nullus em vez de nemo, quer com valor masculino quer feminino:

I,16 (lin. 9-10): Cum autem solitarii in cellulis nostris fuerimus et nullus aduenerit...

IV,3 (lin. 9-10): ... praecepitque sequentibus se eunuchis ut nullus approximaret ad cellulam monachi.

IV,16 (lin. 41-42): ... egressus de monasterio fugit in eremum, ubi nullus eum agnosceret... 
V,3 (lin. 35): ... ego ueni ad te et nullus me cognonit. Trata-se aqui de um monge que visita um convento de freiras e nenhuma (= ninguém) o conheceu.

d) VALORes dos pronomes ILLE e IPSE

Assinalamos as várias significações que estes pronomes assumem nas Commonitiones $\left({ }^{179}\right)$.

1 - Ille apresenta, por vezes, o valor clássico de ênfase. No exemplo seguinte deve traduzir-se por «aquela famosa» força:

I,3 (lin. 6-8): Nihil fortius est in bestiis leone et tamen (...) cadit in laqueum et illa feralis et magna fortitudo eius humiliatur.

2 - Remete também, em bom uso clássico, para o objecto afastado, com pleno valor demonstrativo. É esse o valor do segundo e terceiro ille na frase:

II,5 (lin. 10-12): Haec autem cum audisset ille, post paucos dies abiit ad locum illum ubi positum erat corpus illius defunctae mulieris. O primeiro ille tem claro matiz de pronome pessoal.

$\mathrm{O}$ valor demonstrativo aparece também em expressões analíticas, antes de qui, quando em rigoroso estilo clássico bastaria o relativo:

IV,17 (lin. 16): Dicit ei ille qui emere uolebat: Da mihi codicem ut...

Outros exemplos deste último uso: II,6 (lin. 6); II,7 (lin. 32-33), VI,2 (lin. 35).

(179) Cf. G. L. TrAger, The use of the latin demonstratives (especially ille and ipse up to 600 A. D.) as the source of the romance article, New York, 1932; P. AEBISCHER, Contribution d la protohistoire des articles «illew et «ipse» dans les langues romanes in Cultura neolatina VIII (1948), pp. 181-203. 
3-É muito frequente nas Commonitiones o aparecimento de ille, illa a desempenhar as funções de pronome pessoal: ele, ela. Vimos mesmo acima um exemplo tirado de II,5 (lin. 11). Mas há muitos mais:

II,8 (lin. 27-28): Et ille ait: Dum in itinere quiescerem...; (lin. 31): Haec ille audiens deprecabatur eum...

V,7 (lin. 21-22): Haec autem illa cum audisset...

4-Muitas vezes ille perde a força demonstrativa $\mathrm{e}$ aproxima-se do simples artigo definido das linguas românicas.

Em IV,2 narra-se uma história de dois irmãos. Referindo-se ao mais velho, diz-se simplesmente (lin. 9): Surgensque senior frater... Redacção exacta. Mas repare-se o que está um pouco antes (lin. 4-5):

Quadam autem die, ad nesperam, secundum consuetudinem ille iunior frater accendens lucernam...

Outro exemplo com dois illos quase desprovidos de significado demonstrativo:

IV,19 (lin. 36-40): Ecce (...) laudaui et glorificaui illos mortuos et nihil mihi penitus dixerunt. Tunc dixit ei sanctus Macarius: Considera, fili, quoniam iniuriis et contumeliis exprobrasti illos mortuos et nihil tibi locuti sunt.

5 - Também ipse apresenta variadas significações. Os valores enfáticos de "tu próprio, ele mesmo, ela própria» e semelhantes ocorrem algumas vezes:

II,5 (lin. 9-10): Ipsa autem erat in cuius persona impugnabatur supradictus frater.

II,7 (lin. 15-17): Vidit (...) monachum et spiritum fornicationis in diuersis mulierum formis (...) et ipsum cum eis delectari; (lin. 39-41): Sed nisi et ipsi (...) quae Deo placita sunt fecerint...

Por vezes, este significado enfático é sublinhado pela presença de outro pronome:

II,7 (lin. 27): nisi et tu ipse laborem assumas...

IV,6 (lin. 1-2): dum adhuc iunior esset hic ipse beatus Poemen... 
6-O significado normal de ipse referido a um objecto afastado, (esse, aquele, o tal), quase com o valor de ille, encontra-se também:

I,10 (lin. 7-8): Et est aliud oleum praeter ipsum?

IV,17 (lin. 8-9): uidit in cellula eius codicem ipsum...

IV,17 (lin. 14-15): uoluit distrahere codicem ipsum...

7 - Muito frequente é o uso de ipse com a equivalência do pronome pessoal ele:

I,11 (lin. 18): Ipse uero audiens intellexit causam.

IV,10 (lin. 12-13): Ipsa uero cum omni ueneratione suscipiens senem...

IV,17 (lin. 11-12): (abbas)... intellexit quia frater ille furasset eum et noluit mittere post ipsum...

V,4 (lin. 3-4): Ipse autem sororem suam non acquieuit suscipere...

\section{e) VNVS A CAMINHO DO INDEFINIDO}

1 - Vnus tinha em latim clássico, quando usado com todo o rigor, o significado de «um só, único». Este valor aparece também nas Commonitiones, reforçado ainda por tantum:

V,2 (lin. 28-29): Dicebant ergo fratres quia unum tantum paximatium et quinque oliuas in cibo accipiebat.

2- O seu uso fez sempre parte de locuções com sentido partitivo. Com esta significação unus é usado quatro vezes, sendo ex a preposição preferida, pois de só entra uma vez em expressões deste género:

I,7 (lin. 11): Tunc surrexit a mensa unus ex senioribus et dixit... Cf. também II,6 (lin. 3) e VI,2 (lin. 22);

IV,16 (lin. 36-37): ... magnificabant eum tamquam unum de magnis patribus.

3 - No latim vulgar e tardio unus assume, por vezes, o valor de um pronome indefinido, já muito próximo do que 
virá a ser o artigo indefinido nas línguas românicas. As Commonitiones num só ponto nos dão uma ideia de unus poder caminhar neste sentido. Em lignum unum, id est, perticam, vemos um substantivo acompanhado de unum e o outro, que tem exactamente a mesma função, isolado, sem qualquer forma a acompanhá-lo. Ambos os substantivos estão em sentido indefinido.

VI,2 (lin. 15-17): Et uidit (...) duos uiros sedentes in equis, portantes super scapulas suas utrique lignum unum, id est, perticam longam...

Em Pelágio e Pascásio é mais frequente o valor indefinido de unus (Cf. Pascásio de Dume..., t. I, pp. 78, 80, 142-144). Poderá esta maior fidelidade aos valores clássicos de unus convidar-nos a pensar que as Commonitiones foram traduzidas fora do território da Romania?

\section{f) EXPRESSÃO DA RECIPROCIDADE}

1 - O pronome recíproco inuicem encontra-se em retirada no latim tardio, sendo substituído por locuções preposicionais. Nas Conmonitiones só em 3 apotegmas aparece a forma inuicem, duas vezes precedida de $a b$ :

I,13 (lin. 12-13): ... factum est ut circa horam nonam salutarent se inuicem...

IV,2 (lin. 3-4): ... insidiabaturque eis malignus diabolus ut quomodocumque eos separaret ab inuicem; (lin. 18-19): ... quoniam non praeualui separare eos $\mathrm{ab}$ inuicem.

VI,2 (lin. 23-25): Hi qui lignum portant (...) iustificantes semetipsos (...) cum exaltatione superbiae, non humiliantur inuicem.

2 - Todas as outras ocasiões em que o tradutor precisou de exprimir reciprocidade adoptou a fórmula inter se, que registámos 13 vezes. Damos a seguir o primeiro exemplo de cada capítulo:

I,11 (lin. 10-11): ... audinit cos loquentes inter se ac dicentes; cf. também I,13 (lin. 4 e 11); 
II,5 (lin. 7-8): Et dum inter se loquerentur... Cf. também II,8 (lin. 16 e 28-29);

IV,2 (lin. 24-25): ... referens eis haec omnia quae per malitiam daemones inter se loquebantur. Cf. também IV,2 (lin. 36); IV,8 (lin. 2);

V,8 (lin. 17-18): saepe audiui immundos spiritus daemonum loquentes inter se. Cf. também V,8 (lin. 42) e V,9 (lin. 5 e 9).

g) SITUAÇÃo DOS VERBos «DEPOENTES»

A posição intermédia que os chamados verbos depoentes ocupavam, já no latim clássico, entre a conjugação activa e a passiva - a forma, o aspecto exterior, a flexão é passiva, mas o significado é activo - fez com que se gerassem muitas confusões. No geral os verbos "depoentes" tendiam a tomar formas activas. No latim tardio a confusão aumenta quando se vêem verbos activos, da época clássica, a assumir formas «depoentes». Não restam, no entanto, dúvidas de que as flexões de tipo passivo entraram em desfavor. As línguas românicas têm só verbos passivos de forma perifrástica e a conjugação reflexa. O sistema de desinências que caracterizava os verbos passivos e "depoentes" desapareceu.

O texto das Commonitiones não é neste ponto dos mais caóticos. O tradutor mostra-se bastante atento. Algumas formas, porém, deixam transparecer a crise que reinava em época tardia entre os verbos "depoentes». Registamos alguns exemplos, por ordem alfabética.

$\operatorname{AESTIMO}(R)$ - Em IV,17 (lin. 19-20) lê-se: Iube considerare, pater, codicem istum et aestimari eum si ualet solidos sedecim.

Em causa está a construção de um imperativo perifrástico, como forma de delicadeza: iube considerare... et aestimari. Para considerare só o códice de Namur apresenta um infinito 
«depoente»: considerari. A forma activa é, com certeza, a original, tal como deveria ser em latim clássico.

$\mathrm{O}$ exame de aestimari é mais complicado. $\mathrm{O}$ verbo que significava 'apreciar, apreçar', na época clássica, era activo: aestimo. A lição que os manuscritos nos dão aqui é divergente. Os de Viena e Dresda escrevem, bem legível, aestimari. Esta forma só pode ser um infinito «depoente», dependente de iube. Preferimos esta lição não só por ser a dos melhores manuscritos, mas porque ela obedece a uma sintaxe mais regular. Iube seria seguido de dois infinitos: considerare et aestimari. Porém, os restantes manuscritos têm: aestimare. Para esta forma há duas interpretações possíveis: 1 - tomá-la como um infinito e então o verbo teria sido regularizado, passando-o para a voz activa; 2-considerá-la como um imperativo presente "depoente». Nesta segunda hipótese o verbo continuaria "depoente», mas a sintaxe perdia o equilíbrio. Teríamos primeiro um imperativo perifrástico - iube considerare e depois um imperativo "depoente» simples: aestimare. Apesar de sabermos que uma desigualdade de tratamento, após et, era possível, inclinamo-nos a pensar que o tradutor tomou aestimari como verbo «depoente». A regularização para aestimare é fruto de uma reelaboração iniciada no arquétipo $\gamma$.

$\operatorname{EXCVSO}(R)$ - Temos em V,3 (lin. 11-12) a frase: Ille autem excusabat, nolebatque de monasterio egredi. Não há problema com egredi, habitualmente «depoente». Diferente é o caso de excusabat. A transmissão manuscrita é uniforme em utilizar simplesmente a forma activa. Não há dúvida, porém, de que o verbo tem sentido reflexo. Nestas condições, a linguagem clássica escreveria excusare se. E esta emenda foi de facto introduzida por alguns manuscritos secundários. O facto de o tradutor não utilizar uma expressão reflexa leva-nos a supor que ele considerava a forma activa com valor reflexo, como se o verbo fosse excusor. 
FVRO $(R)$ - Em VI,6 há dois passos em que se vê a forma «depoente» furari, com sentido activo:

lin. 6: Tantum cessa et noli furari...

lin. 10-11: Tunc iam omnes sancti seniores considerantes quia non cessabat furari et abscondere...

Embora em alguns autores apareçam formas activas, como se o verbo fosse furo, furare, o tradutor das Commonitiones manteve-se fiel à norma clássica. Em ambos os passos acima transcritos a forma furari, um "depoente» com sentido activo, encontra-se sem qualquer variante nos códices que transmitem este apotegma, presente só nos arquétipos $\beta$ e $\delta$.

LVCROR - Este verbo "depoente" vem nas Commonitiones só uma vez, em II,6 (lin. 11-12): Volens autem lucrari et saluare animam eius frater suus... O sentido de lucrari é manifestamente activo. O tradutor manteve-se, pois, fiel à norma clássica. Apenas temos anotado um manuscrito secundário em que o infinito apresenta a forma activa lucrare.

$\operatorname{POENITEO}(R)$ - Já na época do bom latim se usava a forma activa ou a depoente deste verbo, sempre com valor reflexo. Nas Commonitiones lemos (I, 6, lin. 5): omnes sancti poeniteri habent in illo futuro beato saeculo... Este apotegma só se encontra nos arquétipos $\beta, \gamma$ e $\delta$. A forma «depoente»é a transmitida pelo manuscrito de Viena (o seu par de Dresda omite, infelizmente, esta palavra). Nos modelos $\gamma$ e $\delta$ a forma activa está bem clara. Não podemos, por isso, garantir com segurança qual a forma original do tradutor.

$R E F I C I O(R)$ - O sentido de 'restaurar, renovar, refazer' é o mais corrente, com valor activo. No latim tardio, todavia, reficio passou a designar também a acção reflexa de 'alimentar-se'. A seu lado criou-se, por isso, a conjugação "depoente»: reficior. Nas Commonitiones embora o sentido seja reflexo aparece, sem variantes, a forma activa tradicional (IV,3, lin. 19): Da mihi benedictionem, abba, ut reficiamus. 
REVEREO $(R)$ - Era possível, já na época clássica, empregar as formas activas ou as depoentes deste verbo, sem alterar o sentido activo: «reverenciar, adorar». Em III,1 (lin. 22-23) está escrito: ... quare non magis reuereri et timere debes maiestatem Omnipotentis Dei... Transmitido pelos arquétipos $\beta, \gamma$ e $\delta$, não há qualquer variante nos códices compulsados. Aqui temos um sinal de que a conjugação depoente não levantava ao tradutor das Commonitiones especial aversão.

$\operatorname{VOLVTO}(R)$ - Este verbo tem desde os tempos clássicos três possíveis empregos: 1 - 'rolar, voltar'; 2 - 'ser voltado'; 3 - 'voltar-se, revolver-se'. Nas Commonitiones nenhuma destas possibilidades foi utilizada. Lê-se em V,9 (lin. 10-11): Veniebant autem porci sordidissimi et morbo pleni et uolutabant se inter eos.

Digno de atenção é o facto de se ter escolhido uma forma reflexa com o uso de se. Na realidade, mesmo que não se preferisse uolutabantur, o reflexo se dispensava-se perfeitamente, visto que este conceito está também expresso por inter eos.

Temos assim mais uma amostra da redundância do estilo do tradutor.

ORTVS FVIT - Não deixemos de assinalar também que a tendência para a perda das desinências passivas deu origem ao desenvolvimento da conjugação perifrástica. Em vez de uma forma de presente do tipo oritur passou a usar-se ortus est. Consequência inevitável foi que, para exprimir o perfeito, já perifrástico na época clássica, houvesse de se recorrer a outra forma mais expressiva do passado. Daí a utilização de fui.

Este processo encontra-se também nas Conmmonitiones. Em IV,6 o apotegma principia: Item quodam tempore, dum adhuc iunior esset hic ipse beatus Poemen, uenerunt ad eum quam plurimi de uico eius, unde ortus fuit, petentes eum ut...

A conjugação passiva, tendo como auxiliar formas do perfeito, tinha-se divulgado bastante, pelo que não devem estra- 
nhar-se: parata fuerat (I,13, lin. 16); operati fuissent (II,6, lin. 2-3); egressus fuerat (II,6, lin. 6); defunctus fuero (IV,10, lin. 31); etc.

A colheita relativa aos verbos «depoentes» não é abundante. Isto mostra que o tradutor das Commonitiones, que tantas características sintácticas apresenta da época tardia, deveria viver numa região ou num meio cultural em que a desagregação da flexão passiva e "depoente» ainda não estava em falência total. Onde? Fora da Romania?

\section{h) CONJUNÇÕES COMPLETIVAS}

As orações completivas assumem nas Commonitiones todas as modalidades do latim clássico: infinitivas, interrogativas indirectas, $u t$, ne e conjuntivo, declarativas, etc.

São os verba dicendi et declarandi que merecem a nossa especial atenção. Não tanto porque haja novidades; mas pelas proporções das conjunções utilizadas. É sabido que estes

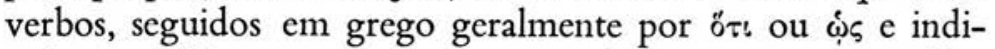
cativo, tendiam nas traduções para latim a ser construídos também com indicativo, precedido de quod, quia, quoniam, etc.

1 - O uso de quod como conjunção integrante é bastante raro nas Commonitiones. Registámo-la apenas 7 vezes. O facto não pode deixar de se estranhar, dado que, a par de quia e quoniam, é quod uma das conjunções mais empregadas no latim vulgar e no dos autores cristãos. Não está, no entanto, totalmente ausente.

GELASIVS 1 (145-147)

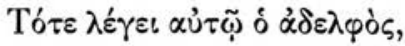

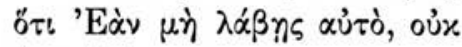
है $\chi \omega \dot{\alpha} \nu \alpha \dot{\alpha} \pi \alpha \nu \sigma t v$.
PELÁGIO XVI,1

Tunc dixit ei frater: Quia si non recipis eum, non possum securus esse. 


\section{COMMONITIONES IV,17 (lin. 33-36)}

Ille autem persistebat cum lacrimis poenitendo dicens: Quod si non susceperis codicem, domine pater, nullo modo requiescit anima mea.

Observe-se agora a uariatio do tradutor das Commonitiones junto de dois verbos declarativos.

V,8 (lin. 15-17): ... referebant ergo de eo quod frequenter dicebat patribus: Quia sicut mihi testis est Dominus Deus...

2-Mais frequente é já a conjunção quoniam, a qual, segundo a nossa contagem, aparece 16 vezes com valor integrante. Vejamo-la num texto com lugares paralelos:

NAU, 229

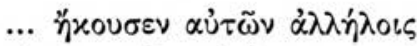

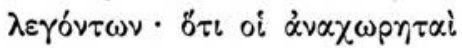

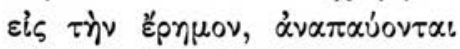
$\pi \lambda \varepsilon \varepsilon_{0} \nu \dot{\eta} \mu \tilde{\omega} \nu \tau \tilde{\omega} \nu$ ह่v rotvoßíols.
PELÁGIO $\mathrm{x}, 97$

... audiuit eos inter se dicentes: Quia solitarii uiri plus repausant in eremo quam nos in congregatione.

COMMONITIONES I,11 (lin. 10-12)

... et audiuit eos loquentes inter se ac dicentes: Quoniam isti eremitae magis melius ad refectionem cibantur quam qui in monasteriis conuersantur.

3-A conjunção integrante verdadeiramente preferida pelo tradutor é quia. Com efeito, empregou-a 81 vezes com este sentido. Um exemplo seguro: 
BENIAMIN 2(144)

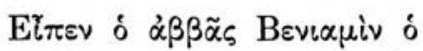

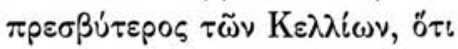

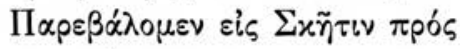

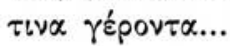

PELÁGIO IV,12

Dixit abbas Beniamin, qui erat presbyter in Cellis, quia cum applicuisset in Scythi ad quendam senem...

\section{COMMONITIONES I,9 (lin. 1-3)}

Referebat abbas Beniamin: Quia quodam tempore ego et presbyter de Cellia applicuimus ad quendam seniorem habitantem in eremo Sceti...

Seria fácil multiplicar estes exemplos paralelos para o uso de quia nas Commonitiones.

Considerando já os três paralelos acabados de apresentar concluímos: as Commonitiones variaram a tradução de ö $\tau$ por quod, quoniam e quia; Pelágio traduziu uniformemente por quia. Note-se ainda, mais uma vez, que Pelágio traduz literalmente; as Commonitiones têm, sem dúvida, também por base um texto grego, nestes três casos, muito próximo da versão que chegou até nós.

4-A palavra quomodo apresenta-se nas Commonitiones com diversas funções: advérbio interrogativo, conjunção causal, comparativa e integrante. Este último valor surpreende pela sua frequência, notória em relação aos hábitos de outros autores. Quomodo, depois de verbos declarativos, encontra-se 17 vezes, a partir do início do cap. IV. Não nos ocorre tê-la visto em capítulos anteriores.

IV,1 (lin. 1-3): Dicebant sancti seniores patres de quodam monacho iam seniore, in Sceti eremo commorante, quomodo seruus quorundam erat... Em grego (Mios 2 [301]) temos ö $\tau$; em Pelágio XV,31 está quia. 
IV,2 (lin. 21-22): Considerans enim quomodo magis seductio et perditio aniniarum est cultus idolorum...; (lin. 31-33): Dicebat enim quomodo omnem uirtutem aduersariorum nostrorum daemonum soluit uerae humilitatis intentio.

$5-$ Quatenus, conjunção registada com frequência com valor final, aparece também duas vezes a introduzir uma oração completiva.

IV,4 (lin. 13-14): Haec ergo apud semetipsum pertractans, definiuit quatenus excusaret magis... Observem-se, porém, dois passos seguidos com valor final, neste mesmo apotegma (lin. 38-39): ...quatenus possim...; (lin. 42-43) ...quatenus (...) exsoluat crimen...

IV,18 (lin.11-12): Vide ut dicas ei quatenus accipiat flagellum...

\section{i) ORAÇÕES INTERROGATIVAS}

1 - Não existe problema especial referente às interrogativas directas nas Commonitiones. A introduzi-las temos pronomes ou advérbios interrogativos: quis (IV,3 (lin. 22); IV,5 (lin. 4); quid (II,8 (lin. 20); II,10 (lin. 2); IV,11 (lin. 12); IV,16 (lin. 12); qui (plural) em IV,11 (lin. 13); numquid (II,2 (lin. 24); quapropter (II,6 (lin. 9-10); quare (III,1 (lin. 22); V,2 (lin. 43); V,4 (lin. 15); cur (IV,1 (lin. 27); IV,7 (lin. 24); VI,3 (lin. 7); VI,4 (lin. 6); per quot (V,4 (lin. 13); quomodo (I,4 (lin. 4), I,13 (lin. 16), I,16 (lin. 3), IV,3 (lin. 14-15), IV,12 (lin. 13), IV,16 (lin. 16); in quo (I,15 (lin. 3); quanto (I,15, lin. 6).

Apenas em I,7 (lin. 14-17) notamos uma interrogativa directa simples introduzida por an, partícula esta que no período clássico era empregada apenas no princípio do segundo membro das interrogativas duplas ou múltiplas. Aqui, porém, temos:

An ignoras quoniam, si qui propter laudem et gloriam palam faciunt abstinentiam suam, omnem laborem abstinentiae suae perdunt $(\ldots)$ ? 
2- Para as interrogativas indirectas temos a distinguir dois processos: ou se emprega um pronome ou advérbio interrogativo, ou se usa a partícula si.

IV,14 (lin. 5-6): Quid ageret, quo se nerteret nesciebat. Cf. também quid em IV,16: lin. 21 e 22; IV,18: lin. 3 e 16.

IV,3, (lin. 25-29): Beati estis uos, monachi, qui (...) solummodo de salute animarum uestrarum habetis sollicitudinem, quomodo ad uitam aeternam et ad caelestia praemia peruenire possitis.

IV,12 (lin. 20): Iube mihi mandare qualiter habeas, audiui enim te infirmari. Cf. também IV,10 (lin. 4-5); IV,19, (lin. 5).

O uso da partícula si é geralmente considerado como típico do latim vulgar ou como prova de influência do original grego. $\mathrm{Na}$ realidade, o seu emprego nesta função encontra-se ao longo de toda a história da língua latina.

Alguns casos bem nítidos:

IV,12 (lin. 29-31): Quomodo ualde sollicitus est abbas meus de infirmitate tua, ideo misit me requirere si melius habeas.

IV,12 (lin. 56-57): ... interroganit cum dicens: Dic mihi si dixisti fratri uerba quae... Cf. também depois de interrogauit, si em IV,17 (lin. 26) e IV,19 (lin. 29).

3 - Maior interesse desperta ainda o emprego de si a introduzir uma oração que classificamos de interrogativa directa. Em I,16 (lin. 3-5), uns irmãos fazem ao abade José esta pergunta:

Quomodo oportet nos suscipere aduenientes ad uisitandum nos peregrinos siue spiritales fratres, si oportet, inquiunt, propter eos relaxare regulam abstinentiae nostrae?

À primeira vista, parece que a interrogação deveria ser colocada depois do primeiro membro da frase, começado por quomodo. Na realidade, o segundo membro está intimamente ligado ao primeiro, pelo que nem sequer os separámos por "ponto e vírgula». A marcar o discurso directo lá está a forma intercalada inquiunt. Por isso o segundo membro, principiado 
por si, é também uma interrogação directa. Embora este uso seja raro, reparemos que em português também se pode introduzir uma interrogativa directa. Entre o povo poderá ouvir-se: Se o correio já terá vindo?

4-A este grupo das interrogativas indirectas andam intimamente associadas outras orações, habitualmente conhecidas por integrantes dubitativas. Nelas está, no entanto, implícita, uma interrogação. Por isso, o tradutor das Commonitiones introduziu-as por $s i$, como fez para outras interrogativas indirectas. O pensamento debate-se entre a dúvida e a interrogação.

I,14 (lin. 8-9): Oportet ergo et me ipsum probare debeo si possim sustincre tormenta...

IV,17 (lin. 16-17): Da mihi codicem ut possim probare si tanto pretio ualet. E logo a seguir, nas lin. 19-20: Iube considerare, pater, codicem istum et aestimari eum si ualet solidos sedecim.

\section{j) HiPotéticos HeLENISMOS DE SINTAXE}

1 - Em rigor, cremos que o tradutor das Commonitiones nunca se deixou escravizar pela sintaxe grega. Os exemplos acabados de apresentar sobre quod, quia, etc. a introduzir orações completivas, e si a iniciar interrogativas indirectas, podem ter sido reforçados pelo uso grego, mas explicar-se-iam só como manifestação de tendências "vulgares» da língua latina.

2- O mesmo se poderá dizer do infinitivo com nominativo. Para mais, o único exemplo deste tipo, que registámos, encontra-se numa capitulatio e nada podemos avançar, com segurança, sobre se as capitulationes já fariam parte do original grego ou não. Eis a expressão em causa:

IV capitulatio, n. XIX - De iunene qui uenit ad beatum Macarium desiderans monachus esse. 
Este texto é transmitido só por VDR. Nenhum manuscrito apresenta o esperado acusativo monachum. Concluímos que o nominativo se deve atribuir ao primeiro organizador latino da colectânea.

3 - Procurámos também estar atento ao emprego do chamado acusativo grego. Não recolhemos mais que três possíveis exemplos:

IV,12 (lin. 37-38): ... senior inflamatus inuidiac et iracundiae spiritum pergebat $u t . .$.

VI,4 (lin. 3-4): Et cum feteret bromosa aqua odorem, non permitebat ut...

Em vez de spiritum, só dum manuscrito secundário (do arquétipo $\eta$ ) temos registado o ablativo spiritu. $\mathrm{O}$ acusativo odorem já poderia ser mais discutido. Com efeito, os principais manuscritos estão assim distribuídos - odorem VBL: odore DR; omite esta palavra N. Os manuscritos secundários ativeram-se à lição de R.

Quanto ao passo de VI, 6, lin. 2: crat ibi quidam, schema quidem, monachus..., cf. adiante o nosso estudo sobre schema, pp. 255-256.

Esta relativa escassez de helenismos sintácticos poderá provar alguma coisa contra a hipótese de o original ser grego? Cremos que não. A situação das Commonitiones não é, neste aspecto, diferente da que encontramos em Pascásio, Martinho, Pelágio ou João (se bem que para julgar cabalmente os dois últimos devamos esperar uma edição crítica).

\section{4 - NOTAS SOBRE VOCABULÁRIO}

Ao dedicar este número ao léxico das Commonitiones não é nossa intenção fazer um estudo do tipo de um dicionarista que regista todas as palavras e os seus diversos cambiantes. 
Tão-pouco pretendemos examinar a semântica de cada vocabulo segundo o estilo da "escola de Nimega" $\left({ }^{180}\right)$. Nosso escopo é apenas apontar algumas palavras de maior interesse - ou pela sua origem ou pelo seu escasso uso ou por, de qualquer modo, chamarem a atenção de um classicista ou romanista.

1 - Comecemos por notar que, ao perscrutar algumas tendências do estilo do tradutor, já apontámos os principais diminutivos $\left({ }^{181}\right)$.

2 - Há um pequeno número de palavras ou expressões que são especialmente queridas do tradutor. Lembrem-se, por exemplo, as locuções para designar a vida monástica e o seu objectivo de perfeição espiritual $\left({ }^{182}\right)$.

O capítulo VI, De beato Arsenio, tem um longo título. A cdição de Rosweydus, em III,37, seguindo o arranjo do arquétipo $\delta$, incorpora mesmo o subtítulo no apotegma. O nosso texto separa bem o título e subtítulo de VI,1, que começa com estas palavras: Hic itaque Arsenius... A leitura atenta das Commonitiones mostra que esta expressão, hic itaque, era um formulismo do tradutor. Um pouco antes, em V,7, após o enunciado do tema da narração que versará de beato Theodoro, é notório o mesmo processo (linha 2): Hic itaque beatus Theodorus... E esta mesma expressão encontra-se também, estereotipada, em IV,17, após uma introdução de carácter homilético (linha 4): Hic itaque abbas Athanasius... Embora um pouco

$\left({ }^{180}\right)$ Sobre a origem, métodos e posição da "escola de Nimega» dentro da Linguística Geral, cf. Christine Mohrmann, De studie van het oudchristelijk grieks en latijn. Verleden, heden, toekomst. Afscheidscollege, 14 december 1973, edit. Spectrum,

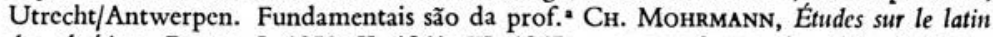
des chrétiens, Roma, I, 1958; II, 1961; III, 1965, - e os volumes das séries Latinitas Christianorum Primaena (n. XXII em 1972), Graecitas Christianorum Primaena (n. IV cm 1970) e os respectivos Supplementa (fasc. III cm 1970) editados por Dekker \& Van de Vegt, Nijmegen (Holanda).

(181) Cf. supra pp. 203-207.

(182) Cf. supra pp. 113-115. 
diferente, é o mesmo hábito de escrever que se regista em I,16 (lin. 12): Haec itaque audientes fratres... e em V,2 (lin. 9): Cum autem peruenisset hic ipse Pior...

O modo como principia este último exemplo lembra-nos um outro processo frequente nesta tradução. Registámos 27 inícios de frase por cumque, seguido de mais-que-perfeito ou por imperfeito do conjuntivo. Para que se verifique tratar-se dum autêntico «modismo» do tradutor, apontamos alguns exemplos de repetição num mesmo apotegma:

I,5 (lin. 9-10): Cumque aduenisset hora sexta...; (lin. 11-12): Cumque hora nona aduenisset...; (lin. 16): Cumque hora nona sedisset... Cf. outros exemplos repetidos em II,4 (três vezes); IV,12 (três vezes); IV,16 (duas vezes); V,7 (duas vezes), fora os outros exemplos que só se encontram uma vez num apotegma.

Além disso, é frequente o começo de frases por cum autem...; cum ergo...; cum cnim... Mas estes últimos processos são já, por si sós, menos significativos.

Nos 101 capítulos da coleç̧ão de apotegmas traduzidos por Pascásio de Dume não aparece nunca a palavra supradictus. Em contrapartida, este termo era da preferência do tradutor das Commonitiones. Registámos a sua presença 15 vezes: supradictus autem senior (I,11, lin. 9); pergere ad supradictum seniorem (II,2, lin. 9-10); impugnabatur supradictus fratrer (II,5 lin. 10); etc., etc.

Também Pascásio não usa nunca a palavra equivalente à anterior: supramemoratus. Nas Commonitiones encontra-se três vezes: quieuit omnis impugnatio a supramemorato fratre (II,3, lin. 12); uocauit autem senior supramemoratum discipulum... (IV,12, lin. 55-56); supramemoratus autem abbas... (IV,17, lin. 9-10).

Demos ainda outro exemplo de uma expressão do gosto do tradutor das Commonitiones. O superior dum mosteiro é designado uma só vez por praepositus $(\mathrm{V}, 8$, lin. 15). Em IV,18 (lin. 15-16) temos ad abbatem monasterii. A mesma 
pessoa é pouco depois chamada apenas abbas (lin. 19). Mas no resto desta longa narração (IV,18) o superior é tratado por pater monasterii (lin. 8-9,10,17). Em IV,16 só esta última designação aparece também (lin. 11 e 17). O mesmo acontece em V,7 (lin. 31). Como vimos já (183), quando enquadrada em contexto apropriado, a palavra pater pode referir-se ao fundador de uma ordem de religiosos, como é o caso de S. Pacómio.

3 - Os helenismos tiveram sempre entrada no latim, mesmo nos mais recuados tempos da idade arcaica. Com a conversão ao cristianismo de falantes da língua latina, há uma nova vaga de termos gregos que passaram a fazer parte da língua de Roma. Eles são tantos que por vezes nem nos apercebemos da sua origem. Tendo as Commonitiones sido traduzidas do grego, não admira que os helenismos aí se encontrem em abundância. Registamos por ordem alfabética os que recolhemos: abbas, alphabetum, angelus, apostolus, athleta, bromosus, chaos, colobus, daemon, diabolus, ecclesia, episcopus, epistola, eremita, eremus, enangelium, gastrimargia, haeresis, haereticus, idiota, monachus, monasterium, parabola, patriarcha, paximatium, plasma, proastium, propheta, prophetia, raphanus, schema, stomachum, synaxis e thymiama.

A maior parte destes vocábulos não precisa de qualquer comentário, pois tornaram-se comuns na língua latina que, do período tardio, transmitiu o seu uso à Idade Média. Daí entraram nas línguas modernas, não só românicas como também, alguns, nas germânicas.

(183) Cf. supra p. 105. 
4 - Passamos, pois, a algumas observações dos vocábulos de maior interesse, colocando-os por ordem alfabética $\left({ }^{184}\right)$.

APPLICO - Este verbo, sobretudo usado na linguagem corrente, tem concitado a atenção dos linguistas devido à permanência da sua forma simples - plicare - em algumas línguas românicas, entre as quais o português e o espanhol: chegar, llegar. Não vem aqui a propósito estudar a sua evolução semântica desde o originário 'dobrar' até ao valor de "chegar, ir junto de».

Nas Commonitiones está abonado três vezes:

I,9 (lin. 1-2): Referebat abbas Beniamin: Quia quodam tempore ego et presbyter de Cellia applicuimus ad quendam seniorem... IV,8 (lin. 10-11): Cum autem applicuissent, ad uesperum, ad eundem agrum pro longius...

V,7 (lin. 29-30): Cumque uenisset, applicuit in monasterium famularum Dei...

BROMOSVS - Diz-se do abade Arsénio, em VI,4 (lin. 1-5): cum operaretur sportas ex palmarum foliis, mittebat aquam in peluem ut infunderentur palmae. Et cum feteret bromosa aqua odorem, non permittebat ut aliam aquam mutaret, sed super illam fetidam aliam addebat aquam, ut semper feteret.

Em causa está o conjunto bromosa aqua odorem que é a lição de VBL, na qual bromosa aqua se encontram em nominativo; têm bromoso aqua odore $\mathrm{DR}$, fazendo um ablativo de bromoso odore, diferente de qualquer das lições anteriores.

Rosweydus explicou por duas vezes a sua palavra brumosa. Nas anotações (PL 73, col. 812, nota 9) diz que deve ser entendida como «aqua crassa et fetida. Glossae Isidori: Bromosa,

(184) Além dos dicionários mencionados nas pp. 164 e 165, servimo-nos também do Onomasticon rerum et uerborum difficiliorum, apenso por $\mathrm{H}$. RoswEYDVs à sua edição das Vitae Patrum e reproduzido na Patrologia Latina, t. 74, coll. 399-516. Este onomasticon não tem sido suficientemente utilizado pelos lexicólogos, apesar de bastante rico em observações e em documentação paralela. 
immunda). Voltou, porém, a comentar a palavra no Onomasticon (PL 74, coll. 416-417). Aí insiste em preferir a lição brumosa, apesar de citar outros autores que explicam bromosa como immunda, e bramosa com o mesmo significado.

Se bem que tenha acertado com o significado, Rosweydus não apurou a ortografia. Ora em grego temos o substantivo

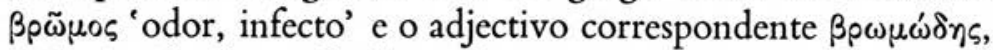
cujo significado é 'fétido, infecto'. Não há pois que hesitar: a grafia verdadeira é bromosus, com a significação de 'fétido, mal cheiroso'.

CAVSA - A palavra causa aparece nas Commonitiones com diversos significados: 1 - causa, razão, motivo (cf. II,6, lin. 23 e 27; IV,4, lin. 19; 2 - acusação, processo judicial (cf. IV,4, lin. 25 e 41); 3 - questão, problema (cf. I,1, lin. 2; II,6, lin. 23); IV capitulatio, n. V); $4-$ merece a nossa especial atenção o uso de causa com um significado muito próximo de 'coisa, matéria, assunto':

I,11 (lin. 18): Ipse uero audiens intellexit causam.

V,7 (lin. 54-56): si hic permansero, etiam saepe uidebo filium meum, cum inter alios fratres egreditur ad necessarias monasterii causas...

Este último sentido é bem claro na regra de S. Bento, de meados do séc. VI: omnium causarum difficilimum est se ipsum cognoscere (Reg. 35).

GASTRIMARGIA - O cap. III de Pascásio de Dume tem o título: De uincendo desiderio gulae; e no apotegma 7: nisi desiderium gastrimargiae in anima uenerit... Nas Commonitiones o tradutor foi mais explícito:

I,5 (lin. 22-24): ... per patientiam suam extinxit gastrimargiae, id est, gulae concupiscentiae, passionem.

I,8 (lin. 6-7): ... et nos cum pulsauerit spiritus gastrimargiae, id est, gulae concupiscentia in aliquas delectationes ac saturitatem uentris... 
Vê-se aqui ainda a preocupação de dar à transliteração do grego $\gamma \alpha \sigma \tau \rho \iota \mu \alpha \rho \gamma^{i} \alpha$ o seu equivalente latino. E mais adiante virá somente (I,15, lin. 2-3): non oportet monachum desideria gulae uentrisque facere.

A verdade é que o helenismo gastrimargia estava consagrado pelo menos desde os escritos de Cassiano, de cerca de 425. Podemos traduzi-lo por "gula, prazer da comida, gulodice", conforme o contexto.

Significará esta preocupação de traduzir, uma ânsia de purismo do intérprete latino das Commonitiones? Indicará que ele escreve numa região em que a terminologia ascética não estava ainda completamente assimilada ? Neste caso, devíamos desviar-nos da Gallia e olhar para a... Germania? Só outros indícios nos levam a propor esta interrogação $\left({ }^{185}\right)$.

GERMANVS - A afinidade semântica entre frater e germanus tem sido várias vezes estudada. Nas Commonitiones estes dois termos parece terem, entre si, perfeita equivalência. Veja-se um exemplo em que se fala de dois irmãos de sangue:

IV,2 (lin. 1): Erant duo fratres secundum carnem quidem germani. Aqui frater tem o valor, na língua de grupo do monaquismo e dos cristãos, de «membro da mesma profissão religiosa, monges». Para os caracterizar melhor, o texto acrescenta que além de serem «irmãos de religião» eram também «irmãos segundo a carne». Germanus implica, por isso, neste passo, uma confissão de consanguinidade.

Depois (lin. 5) fala-se do iunior frater e também do senior frater (lin. 9). Poderia aqui ainda pensar-se que frater designa só «irmão em religião». Mas veja-se a sequência, donde se conclui a perfeita identidade de significado entre frater e germanus (lin. 9-11):

Surgensque senior frater, coepit percutere fratrem suum cum furore. Ille uero, prostratus in terram, deprecabatur germanum

(185) Cf. supra p. 134. 
suum dicens: Magnanimus esto, domine, et ego... Domine acentua aqui apenas o respeito do irmão mais novo perante o mais velho. $\mathrm{O}$ apotegma tem ainda a palavra frater na linha 16 .

A mesma conclusão se tira de IV,5 onde fratres (lin. 5 e 8) se refere claramente aos «irmãos» de José, filhos todos de Jacob. Mas, variando o vocabulário, na mesma linha 8 diz-se que José podia argumentar aos mercadores: Quia germanus eorum ego sum. Esta identidade verifica-se também em V,6, o apotegma importado de Cassiano (186): germanus (lin. 1): frater (lin. 6,8).

O n. V,7 traz-nos nova elucidação, pois faz (lin. 8) de soror germana apenas uma fórmula reforçada. Com efeito, na linha 10, temos só germanum; e nas linhas 11, 12 e 13 só soror.

Com razão Meyer-Lübke e Ernout-Meillet sublinham a divisão semântica verificada no português e no castelhano: fratrem sobreviveu para designar membros da mesma organização religiosa, enquanto germanum se ligou exclusivamente ao parentesco de sangue, entre nós ainda representado por duas evoluções divergentes - irmão e mano.

IMPOSSIBILIS - Este adjectivo tem, no geral, sentido passivo, também documentado nas Commonitiones (II,7, lin. 25-26): Impossibile est enim discedere a te spiritum fornicationis immundum... No seu elogio do espírito de perfeição que reinava entre os monges de S. Pacómio, o autor vai até ao exagero, em V,8 (lin. 40-41): Impossibile enim est aliquem apud eos uerbum otiosum loqui...

O especial interesse deste estudo está no facto de o tradutor, uma vez, ter dado a impossibilis o valor activo de "sem poder, impotente». Embora não seja caso único (o Thesaurus LL cita exemplos desde a Itala, tradução da Bíblia que deve

(186) Cf. supra pp. 136-149. 
remontar ao século II p. C.) temos nas Commonitiones uma clara abonação:

V,8 (lin. 9-10): Impossibiles enim sunt daemones et imbecilles, cum quis nostrum ex tota fide (...) contendimus contra eos.

IN PRAESENTI - O n. IV,1 das Commonitiones fala-nos de um monge que antes fora escravo e a quem os seus senhores, cristãos, deram a liberdade. Em reconhecimento, o monge ia todos os anos pagar tributo de vassalagem aos antigos senhores. Estes queriam recusar-se a receber a oferta, mas o monge respondeu (lin. 19-21):

$\mathrm{Si}$ nolueritis accipere pensionem meam, ita decreui ut non reuertar in eremum, sed hic in praesenti permaneo et seruio uobis.

$\operatorname{Mios} 2(301)$

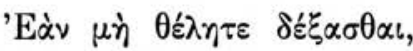

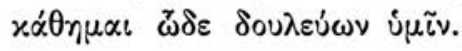

PELÁGIO $\mathrm{xV}, 31$

Credite mihi, quia si non uultis suscipere mercedes meas, remaneo hic et seruio uobis.

O grego e o lugar paralelo de Pelágio garantem-nos que as Commonitiones não são um original latino, apesar de terem uma expressão mais ampla.

É a locução preposicional que nos ocupa. Ela é exclusiva das Commonitiones e não a vimos noutros autores. Pelo contexto não satisfaz a interpretação: «no presente». Julgamos que o seu valor é: «em pessoa, pessoalmente». O monge afirma, pois, que se não lhe receberem o tributo, então, em vez deste símbolo de vassalagem, ficará ali, em pessoa, a servi-los.

IN TANTVM - Esta expressão aparece por três vezes nas Commonitiones: 
II,4 (lin. 1-4): Beato abbati Moysi (...) quodam tempore in tantum imposuit durissimam impugnationem fornicationis daemon ut non praeualeret sedere in cella sua.

V,1 (lin. 7-10): Valde enim euertitur et exterminatur de huiuscemodi sollicitudinibus stabilitas mentis et in tantum obscuratur lumen cordis, ut nec sentiat quis quantum laeditur et distrahitur anima in diuersis peruagationum cogitationibus.

Nestes dois casos in tantum precede imediatamente o verbo. Todavia, parece-nos que o seu sentido reforça o complemento directo. A locução tem valor de intensidade e poderemos traduzi-la, em ambos os passos, por "tão intensamente» ou, repetindo o advérbio, por "tanto, tanto". A preposição in tem valor de reforço. O conjunto in tantum introduz um pensamento que se completa na oração consecutiva, principiada por $u t$.

O terceiro lugar onde é usado in tantum é no n. V,6 o qual, como sabemos, não é um original latino do tradutor das Commonitiones, mas uma cópia levemente alterada de um texto de Cassiano $\left({ }^{187}\right)$, cuja parte final reproduzimos: Quem in tantum Christus ab intentione mortificationis adreptae uel modicum ad extrahendum bouem tuum non patitur relaxari, ut ne breuissimi quidem momenti indutias pro patris indulserit sepultura.

Como a seu tempo verificámos, a sintaxe de Cassiano é muito encadeada, pelo que se torna difícil estabelecer a pontuação do período e realizar uma tradução literal. O valor de in tantum é aqui menos explícito. Podemos, no entanto, estabelecer, parcialmente, a seguinte ordem directa: non patitur in tantum uel modicum relaxari ut... Também in tantum tem valor de reforço, neste caso, de uel modicum. Só aparentemente é paradoxal a tradução: "Cristo não permite, sequer um pouco, por mínimo que seja $(=$ in tantum) atrasar-se de modo a»...

(187) Cf. supra pp. 136-149. 
$M I S S A-E ́$ sempre com vivo interesse que na documentação dos séculos V e VI se procura averiguar o sentido da palavra missa. Com efeito, na Peregrinatio Aetheriae, que descreve uma viagem realizada aos lugares santos do Oriente cristão nos anos de 381 a 384, esta palavra aparece 72 vezes com o valor de "despedida" e 3 vezes com o sentido de "serviço religioso". Só no fim do séc. $\mathrm{V}$ passou a designar, com segurança, o «sacrifício eucarístico" ( $\left.{ }^{188}\right)$.

As Commonitiones têm em I,7 o seguinte passo (lin. 4-5): Praeparatus est autem eis omnibus cibus coctus, ut post completas missas ibi reficerent omnes fratres.

Pelo contexto não se pode definir se missas designa apenas "orações» ou o "sacrifício eucarístico".

Nos apotegmas em latim, nem Pascásio nem Martinho nem as pequenas colecções empregam a palavra missa. Em Pelágio, porém, o vocábulo encontra-se em IV: 27, 36, 69; VII,43 e IX,12. Em nenhum destes passos, com excepção talvez de IV,69, missa significa, com segurança, "celebração da eucaristia». Para este último conceito usam Pelágio (em IX,11) e Pascásio (em XLI, 1; LII,5; LVI,2; XC,3 e XCIII,11) o termo técnico oblatio. Há ainda em Pelágio, uma referência clara à Eucaristia. É em VII,24: eamus cata dominicum diem (...) et accipiamus corpus et sanguinem Christi. Só um outro termo poderia despertar a nossa atenção: agape, que se encontra em Pelágio em VII,46; X,46 e X,9 (este último com paralelo em Pascásio LII, $5^{2}$ onde é traduzido por caritatem). Mas agape significa aqui sempre "acto de caridade, esmola».

Concluímos, portanto, que muito provavelmente a expressão post completas missas em I,7 das Commonitiones tem apenas o

(188) Para a datação da Peregrinatio Aetheriae achamos decisivo e concludente o artigo de PAul Devos, La date du voyage d'Égérie in Analecta Bollandiana LXXXV (1967), pp. 165-194 e 381. Para a evolução semântica de missa, além dos dicionários, cf. A. A. R. BASTIAENSEN, Observations sur le vocabulaire liturgique dans l'Itinéraire d'Égérie, Nijmegen, 1962 e Сн. Mohrmann, Études sur le latin des chrétiens, t. II, 1961; t. III, 1965, Roma (paginação indicada no índice destas obras para o estudo de missa). 
valor de «após terem terminado as orações litúrgicas». Achamos, por isso, muito arriscado pretender tirar do uso de missas uma conclusão (ou mera suposição) sobre a data em que as Commonitiones foram traduzidas para latim.

MVSCATVS - Importa, em primeiro lugar, estabelecer bem o texto e o contexto onde se encontra o adjectivo muscatus. Em VI,4 as Commonitiones dizem-nos que o abade Arsénio não mudava a água onde tinha as folhas de palmeira para amolecerem, a fim de com elas fabricar cestos. Por isso, a água passava a cheirar mal. Quando os irmãos lhe perguntavam porque não renovava a água e suportava aquele mau cheiro, respondia (lin. 8-12):

... pro thymiamata et muscata et illa diuersa, quae in saeculari conuersatione sine intermissione fruebar, oportet me nunc (...) sustinere istiusmodi fetorem, pro suauissimo illo odore, ut in die iudicii de illo gehennae inenarrabili fetore liberet me Dominus...

Temos, para este texto, lugar paralelo em grego e latim:

ARSENIVS 18(92)

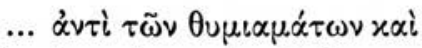

$\tau \tilde{\omega} \nu \dot{\alpha} \rho \omega \mu \alpha \dot{\alpha} \tau \omega \nu \tilde{\omega} \nu \dot{\alpha} \pi \dot{\lambda} \lambda \alpha \nu \sigma \alpha$

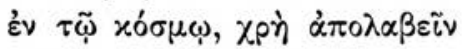

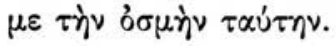

PELÁGIO IV,5

...p pro thymiamate et odoribus unguentorum, quibus in saeculo usus sum, opus est uti me nunc fetore isto.

O grego e a tradução de Pelágio correspondem-se perfeitamente. Quanto às Commonitiones, temos o mesmo sentido, assegurando assim idêntico fundo grego, mas também as frequentes amplificações típicas do reelaborador grego desta colectânea.

Deixando de parte pormenores de redundância, importa sublinhar uma repetição por paralelismo:

pro thymiamata et muscata et illa diuersa...

pro suauissimo illo odore... 
Este segundo membro e o que se segue até final é um acrescento do autor grego das Commonitiones. Um tradutor não iria tão longe. Para mais, lá está um dos tópicos do autor: in die iudicii de illo gehennae inenarrabili fetore $\left({ }^{189}\right)$.

A complicar a transmissão do texto temos a dupla regência da preposição pro. No primeiro grupo é seguida de acusativos neutros do plural (o que é normal em latim tardio); no segundo cólon rege ablativo (como era corrente na época clássica). A falta de compreensão desta dupla possibilidade de regência deu origem a alterações do texto do primeiro grupo.

Citamos apenas a lição dos manuscritos principais de $\beta$, $\gamma$ e $\delta$. Só $\mathrm{V}$ conservou thymiamata; mudaram para o ablativo thymiamate DRN. Não conheciam a palavra: B que escreveu timata; nem $\mathrm{L}$ que alterou para thymiamatita. A desinência de ambos vem, no entanto, confirmar a lição de V.

Muscata é o texto de VDR; myrrata escreve B; myrratis N; e musicata dulcedine interpretou $\mathrm{L}$, isolado.

Também illa diuersa, lição de VRBN, passou para o ablativo em $\mathrm{D}$ : illis diuersis, prosseguindo $\mathrm{L}$ isolado na omissão de et illa e mantendo apenas diuersa.

Este quadro crítico serve-nos para as duas palavras que os copistas, com certeza, desconheciam: thymiäma e muscatus. Vamos estudar agora a segunda, guardando a primeira para o seu lugar na ordem alfabética.

$\mathrm{O}$ adjectivo muscatus tem em Oribásio, médico do final do século IV, a sua mais antiga abonação. Trata-se de um derivado, construído sobre muscus, substantivo que é uma transliteração de $\mu$ ó $\chi \circ \varsigma$, nome que tem uma dupla significação: 1 -perfume, de origem asiática; 2-musgo, das pedras e das plantas. É evidente que no contexto é o sentido de "perfume, aroma» que serve ao pensamento. O neutro do plural muscata funciona como um adjectivo substantivado.

(189) Cf. supra pp. 110-1113. 
Dos modernos dicionaristas só o Thesaurus Linguae Latinae acerta com o vocábulo e sua significação. Mas já Rosweydus no comentário a esta palavra, que aparece no n. 39 do seu Livro III (PL 73, col. 812), a aproxima de dois lugares paralelos: um da Vita Pelagiae (implenit aerem ex odore musci); e outro da Vita Marcellae (fragrare musco mure). E no Onomasticon (PL 74, col. 471) trata mais desenvolvidamente de muscus, citando de novo muscata, Livro III, n. 39.

Cremos assim plenamente explicada a lição exacta, a origem e a significação de muscatus.

PARABOLA - Importa observar atentamente o significado preciso desta palavra. O grego $\pi \alpha \rho \alpha \beta o \lambda \dot{\eta}$, de que o latim é transliteração, era usado no sentido de "comparação, alegoria». Os dicionários registam também parabola com o valor de "discurso", em dois passos bíblicos. Mas é sabido que este vocábulo foi alargando o seu campo semântico, a ponto de ter suplantado, na linguagem corrente, uerbum e sermo. A partir do século IX já parabolare e parabola tinham o valor exacto de "falar» e de "palavra". Qual o sentido de parabola nas Commonitiones? Só aparece uma vez, em I,8 (lin. 1-5):

Solebat beatus abbas Poemen exponere fratribus de Scripturis prophetarum ubi dicit: "Quia nisi princeps cocorum Nabuchodonosor regis uenisset in Hierusalem utique non fuisset igne incensum templum Dominim. Hanc autem parabolam ex hoc exemplo ita exponebat spiritaliter dicens...

A primeira vista parece que parabolam (lin. 4-5) significa frase, palavra da Escritura. Analisando bem, está ali implícita uma alegoria. Contam-nos os capítulos XXIV e XXV do IV Livro dos Reis como Nabucodonosor, rei da Babilónia, se apoderou de Jerusalém. Mais tarde enviou o comandante do do seu exército, Nabuzardan, o qual succendit donium Domini et domum regis. 
Este facto era interpretado alegoricamente pelo abade Poemen, o qual dizia que o homem se deixa dominar primeiro pela gula, mas depois entram outros vícios na alma, que a consomem.

Por isso, chamar "chefe dos cozinheiros do rei da Babilónia» a Nabuzardan é já um modo pitoresco de falar do general que deitou fogo ao templo. Nabuzardan representa a gula; o incêndio total é figura do "fogo da concupiscência».

Parabola tem, pois, nas Commonitiones o sentido tradicional de «alegoria, parábola». Em nada este passo nos ajuda para marcar uma fase de transição a caminho das línguas românicas. Assim como seria forçar o sentido se atribuíssemos a parabola o valor de frase ou palavra, assim também julgamos descabido concluir daqui que o tradutor não era natural ou não vivia na Romania.

PAXIMATIVM - Esta palavra tem o significado de "pequeno pão, pão seco». A sua forma nas Commonitiones levanta alguns problemas, pelo que parece melhor começar por apresentar a questão. Falta-nos ainda (escrevemos a $25 \mathrm{de}$ Abril de 1974) o volume do Thesaurus Linguae Latinae que se ocupará da letra P. O estudo mais desenvolvido, que sobre este vocábulo conhecemos, ainda é o do Onomasticon colocado por Rosweydus em apêndice às suas Vitae Patrum (PL 74, coll. 480-482). Resumindo o seu trabalho, verificamos que há 5 palavras divergentes: paximatium, comentado por Santo Isidoro de Sevilha e abonado pelo Livro III de Rosweydus, nn. 4 e 31 (exactamente os que iremos discutir); paximates (genit. - atis), atestado em Pelágio e João, em Cassiano, Columbano, etc.; paxamas, que parece ser uma simples transliteração do grego bizantino; paxamadium $\mathrm{c}$ ainda paximadium. Às passagens apresentadas por Rosweydus podemos actualmente acrescentar mais: Pascásio I,3 (paximatia - acusativo do plural) c XCIII,11 (paximatiis - ablativo do plural). 
Vejamos agora as Commonitiones (ou seja, o texto completo de que foram extraídos os primeiros 40 números do Livro III de Rosweydus):

V,2 (lin. 28-29): Dicebant ergo fratres quia unum tantum paximatium et quinque oliuas in cibo accipiebat.

Não há qualquer variante significativa nos diversos manuscritos. Entendemos que se trata de um acusativo neutro do singular.

Mais complexo é o que se passa com I,5 (lin.16-18), segundo os manuscritos dos arquétipos $\beta$ e $\delta$ :

Cumque hora nona sedisset ut cibum caperet, uidit de sportella, ubi panis, id est, paximatia reposita erat, surrexisse fumum magnum...

$\mathrm{O}$ tradutor teve o cuidado de esclarecer o que significava paximatia, fazendo equivaler esta palavra a panis. É muito possível que, pelo facto de panis estar no singular, os copistas pensassem que paximatia era um nominativo feminino do singular, com o qual viram a concordar reposita; e por isso também fizeram com que o verbo tomasse a forma erat, no singular.

Do arquétipo $\gamma$ há dois manuscritos que têm este apotegma, representados por $\mathrm{P}$ e $\mathrm{R}$. Ora $\mathrm{P}$ mantém o singular erat; $\mathrm{R}$, porém, tem bem nítido o plural erant. Neste caso, já paximatia e reposita passam a nominativos neutros do plural. Não há dúvida de que, por quanto acabámos de ver há pouco, tanto fora das Conmonitiones como nestas, em V,2, o singular da palavra é o neutro paximatium. Por isso, bem fez o copista de $\mathrm{R}$ em ter conservado (ou emendado) o verbo para o plural.

Supomos que a concordância falsa paximatia... erat foi introduzida no hiperarquétipo $\alpha$ e daí passou a $\beta, \gamma$ e $\delta$. Foi o copista de R (ou um seu modelo) que, por conjectura ou por uma reflexão atenta, repôs a verdadeira concordância: paximatia reposita erant. Esta lição passou ao arquétipo $\eta$, representado por numerosos manuscritos, e aí a foi colher a edição de Rosweydus. Baseado no exame filológico e no testemunho de $\mathrm{R}$ repusemos nós também o plural erant. Concluímos, portanto, 
que o substantivo em causa é o neutro paximatium (sendo paximatia um plural neutro e não um singular feminino).

PRO LONGIVS - Significa «muito longe». Cf. o estudo feito anteriormente, p. 216.

PROASTIVM - Em IV,3 Poemen conta a visita do imperador Teodósio II a um monge, o qual (segundo se afirma nas lin. 3-6):

Habitabat autem in parua cellula foris ciuitatem, prope proastio qui uocatur in septimo, ubi solent imperatores egressi de ciuitate libenter degere.

Há duas expressões cuja lição importa fixar: in septimo só se encontra em $\mathrm{D}$; os outros manuscritos dão-nos leituras ininteligíveis: insemtimo VBNL insempthumo R. Quanto a proastio nenhum códice dá uma lição aceitável: prastio VDBNL e prascio $\mathrm{R}$.

Rosweydus emendou para prope proastium e escreveu também in Septimo (PL 73, col. 749, n. 19). Com sentido crítico, nas anotações 6 e 7 (col. 811-812) justifica a correcção por ele feita, em ambos os casos, a todos os manuscritos que conheceu.

No primeiro caso baseia-se em Cedrenus que conta, em grego, a mesma história e escreveu $\pi \rho \circ \alpha ́ \sigma \tau \varepsilon \iota 0 v$; no segundo fala da divisão da cidade de Constantinopla em regiões ou bairros, um dos quais, nos subúrbios, tinha o «número sete», conservando mesmo em latim a designação de hebdomon. E remete, em ambas as notas, para o Onomasticon. De facto, aí (PL 74, coll. 487-488) documenta a transliteração proastion e a sua tradução suburbanum; e sob a palavra septimum (coll. 503-504) explica mais desenvolvidamente os testemunhos para esta circunscrição da cidade de Constantinopla.

O problema de in septimo está, pois, suficientemente tratado. Quanto a prope proastio, Rosweydus viu o essencial da questão, mas deixou-se sugestionar pela regência de prope, preposição construída na época clássica com acusativo. Ora 
os nossos manuscritos dos melhores arquétipos, se bem que todos tenham a palavra errada, todos são também concordes na terminação - io. De facto, na época tardia (e Blaise cita um passo da Peregrinatio Actheriae) prope passou a construir-se também com ablativo. Além disso, nós dispomos hoje de textos gregos de apotegmas, paralelos deste número IV, 3 das Commo-

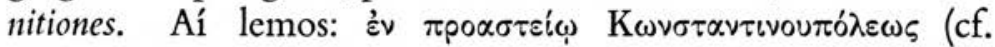
Patrologia Orientalis t. VIII, p. 169). A correcção deve fazer-se, pois, para prope proastio. E tudo fica esclarecido. A tradução que propomos é a seguinte: o monge «habitava numa pequena cela, fora da cidade, perto do bairro suburbano que tem o nome de Sétimo, por onde os imperadores, quando saem da cidade, costumam de bom grado passear".

Assim se restabelece o vocabulário, a sintaxe e o sentido exacto.

QVAPROPTER - Originariamente uma locução prepositiva, quapropter tornou-se em advérbio interrogativo. Neste sentido se encontra 2 vezes nas Commonitiones:

I,9 (lin. 6-7): ... diximus ei: Et quapropter, pater, uel in diebus festis non gustasti de ipso oleo?

II,6 (lin. 9-10): Quapropter non reuerteris ad cellulam?

Há um passo, porém, em que o valor interrogativo se encontra muito esbatido. Com dificuldade mesmo se divisa ali uma interrogativa indirecta:

I,6 (lin. 5-8): ... omnes sancti poeniteri habent (...) quapropter non amplius operati sint bona opera...

A nossa tradução é: «todos os santos hão-de ter pena pelo facto de não terem realizado mais boas obras".

RAPHANVS -- Lê-se a propósito de uma refeição oferecida pelo abadc Benjamin, em I,10 (lin. 3-5): Misit autem in condituram oleum, quod de semine raphanorum in locis illis solet fieri. 
Raphanus é uma importação do grego ṕápavos, já documentada, no latim profano, em Plínio, Columela e outros. Trata-se de uma espécie de rábano, de cujas raízes carnudas se fazia óleo.

Cremos que passamos a ter aqui a única abonação conhecida do latim dos cristãos, pois este apotegma é exclusivo das Commonitiones. Admira-nos, no entanto, que os dicionaristas não tenham já registado amplamente uma tal palavra. Com efeito, este apotegma foi interpolado na Palladii Lausiaca, cap. VI (PL 74, col. 352), onde o vocábulo podia ter sido recolhido desde as antigas edições.

Todavia, uma palavra da família de raphanus foi estudada por Rosweydus, a propósito de Pelágio IV,59, onde se fala de um vaso in quo erat modicum mellis; et aliud in quo erat raphanelaeum. Este número de Pelágio tem paralelo em Pascásio III,5: Erat autem uasculum paruum habens mel et alium uasculum simile habens oleum de lini semine expressum. Quer dizer que raphanelaeum de Pelágio é o mesmo que oleum de lini semine expressum.

Rosweydus na anotação 18 (PL 73, col. 988), a propósito de raphanelaeum e da sua ligação com raphanus remete para o seu Onomasticon (PL 74, col. 490). Aqui, após breve confronto de diversas edições, escreve: "Raphanelaeum quid sit describit Plinius lib. XIX, cap. 5, agens de raphano». E transcreve o passo em que Plínio celebra o valor do raphanus no Egipto "propter olei fertilitatem, quod et semine eius faciunt".

Temos, por conseguinte, que embora um derivado de raphanus já fosse observado nas Vitae Patrum, o vocábulo em si mesmo só se encontra nas Commonitiones. A um botânico

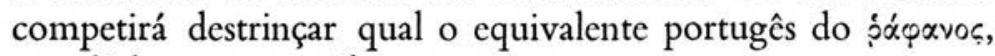
se o linho ou se o rábano.

RESOLVOR/RESOLVTIO - O significado destas duas palavras precisa de ser minuciosamente interpretado. Há que apreciá-las partindo do verbo simples: soluo. 
Em IV,2 (lin. 31-33) diz-se que «a verdadeira prática da humildade inutiliza (soluit) todo o poder dos nossos adversários, os demónios»; e em IV,13 (lin. 27-28) o abade Paulo ordena ao seu discípulo que trazia, presa, uma leoa: «solta-a (solue), pois, e larga-a».

Passemos aos compostos com o prefixo re-:

I,1 (lin. 11-13): Nam et somnus naturaliter inest homini, sed non in satietatem siue resolutionem corporis, quo possimus humiliare passiones ac uitia carnis.

II,2 (lin. 18-19): Ne pertimescas, neque resoluaris, neque abscondas cogitationes tuas.

II,7 (lin. 12-14): Eadem autem nocte reuelauit ei Dominus, quae circa illum monachum erant negligentiae et ignauiae resolutio, et delectationes corporeas cordis eius.

II,7 (lin. 39-43): Sed nisi et ipsi (...) quae Deo placita sunt fecerint, non eis proficient, negligentibus et resolutis, ad salutem animae orationes sanctorum.

No contexto de I,1 (lin. 12) resolutio significa «relaxamento, amolecimento". Por isso satietatem situe resolutionem corporis é a "saciedade ou amolecimento do corpo".

Em II,7 (lin. 14) ignaniae resolutio pode traduzir-se por "entrega à preguiça" ou "atitude de indolência», tendo resolutio o valor de "abandono, falta de resistência».

Quanto a resoluor tem em II,7 (lin. 18) o valor de "entregar-se, abandonar-se, desistir». Neque resoluaris quer dizer: "não te entregues» ou "não desistas».

Em II,7 (lin. 42) negligentibus et resolutis significa «desde que vivam na negligência e na desistência da luta».

A ideia fundamental de soluo 'desligar' recebe assim diversos matizes, de acordo com o contexto, nos compostos resoluor $\mathrm{e}$ resolutio. Precisamente a ideia de "resolução" ou "propósito" está ausente das Commonitiones. 
SACRAMENTVM - Só uma vez aparece nas Commonitiones a palavra sacramentum. $\mathrm{Na}$ longa história deste vocábulo, desde o latim clássico ao cristão e ao dos decretos conciliares da Igreja, é o significado de «juramento» o único que se adapta ao nosso texto.

Conta-nos o n. II,6 que dois irmãos foram à cidade. Um deles pecou e não queria mais voltar à vida religiosa. Então o outro, diz o texto, uolens autem lucrari et saluare animam eius frater suus,cum sacramento dixit ei: Quia et ego (...) lapsus sum... (lin. 11-13).

Embora a história contada tenha intuitos edificantes, não deixe de se notar que se trata de um juramento falso.

A transmissão manuscrita é quase uniforme na forma sacramentum. Um pequeno número de códices secundários, isolados, mesmo dentro do seu arquétipo, interpretou c substituiu por iuramento. A intenção e o juízo estão certos; a verdade da crítica textual foi ofendida.

SCHEMA - Em VI,6 conta o abade Daniel um episódio que começa por esta frase (lin. 1-3): dum in eremo Sceti esset beatus Arsenius, erat ibi quidam, schema quidem, monachus et furabatur de cella monachorum quodcumque inuenire potuisset.

$\mathrm{O}$ apotegma só se encontra nos arquétipos $\beta$ e $\delta$. O texto é de fixação difícil. Vejamos primeiro os lugares paralelos:

DANIEL 6(156)

"O $\tau \varepsilon \tilde{\eta \eta \eta े ~}$

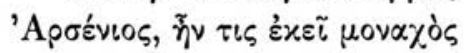

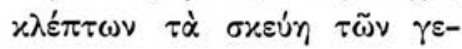

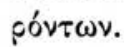

PELÁGIO $\mathrm{x}, 18$

... quando erat in Scythi abbas Arsenius, erat ibi monachus quidam rapiens ea quae habebant senes.

Examinando todos os manuscritos que contêm este apotegma, verificamos as seguintes lições (utilizando as siglas do stemma codicum): quidam scema quidem monachus VBLUM 
quidam scemate quidem monachus $\mathrm{Z}$ quidam scemate monachus $\mathrm{N}$ quidam selerosus monachus $\mathrm{D}$. Parece-nos hoje que a lição exacta é a de VBLUM. Todavia, quando, a princípio, examináramos apenas os manuscritos de Viena e Dresda, dada a evidência do erro de Dresda, pensámos em explicar a lição de V.

Com efeito, o manuscrito de Viena tem na palavra scema, por cima da letra $e$, o sinal $\mathrm{F}$ que chegámos a interpretar como um "digama», pelo que, primeiramente, lemos sceuma. Estamos agora convencido de que este sinal é um $h$ mal desenhado e que ficaria melhor entre $c e$, devendo por isso ler-se, post correctionem, schema.

Adoptando a lição schema, consideramos esta forma como um "acusativo grego", pelo que traduzimos: "havia aí um certo monge, só de hábito», isto é, apenas exteriormente... Os copistas de $\mathrm{N}$ e de $\mathrm{Z}$ alteraram para scemate, fazendo desta palavra, certamente, um ablativo de qualidade.

Explicada a dificuldade no estabelecimento do texto, notemos ainda que para o grego oxsún não há nas duas traduções latinas o equivalente, que seria uasa.

A relutância inicial em adoptarmos a lição schema devia-se também ao facto de esta palavra não nos ter nunca aparecido em Pascásio e Martinho nem, que nos lembre, noutras colecções latinas de apotegmas. Assegurada, porém, a justeza do termo, a pesquisa vocabular deu razão ao tradutor das Commonitiones.

Os dicionários registam a transliteração de $\sigma \chi \tilde{n} \mu \alpha$, aplicando-a ao "vestuário ou hábito» dos monges. Rosweydus, no Onomasticon, dedica um longo e bem documentado estudo sobre a imposição, progressiva, de um duplo «hábito» aos monges: ordo instituendi monachum parui schematis e ordo magni et angelici habitus (PL 74, coll. 495-499).

SEPTIMANA - Só encontramos uma vez esta palavra nas Commonitiones: 
II,3 (lin. 8-9): ... praeceperunt omni multitudini fratrum ut per totall septimanam amplius super consuetudinem ieiunarent. O registo deste vocábulo, que sobreviveu na língua corrente de todos os povos da antiga Romania, só tem interesse aqui por podermos compará-lo com outros tradutores de apotegmas. Pascásio, que traduziu por 555, em Dume, usa sempre septimana (Pasc. V,1; VII,2; XLVI,8; XCVI,4). Pelo contrário, Pelágio, que traduziu, em Roma, pouco antes de 547, emprega hebdomada (Plg. V,38; VI,4; VII,24; VIII,4; IX,12; X: 27, 44 e 109; XV,11; XVII,14).

Ora nós sabemos que Pelágio é mais literal e vulgar que Pascásio e o tradutor das Commonitiones. O emprego de septimana ou hebdomada não pode, portanto, trazer-nos qualquer ajuda para entrever o lugar e a data em que as Commonitiones foram traduzidas.

SERMO - Assim como parabola, como vimos há pouco, ainda não evoluiu nas Commonitiones para a "palavra» das línguas românicas, assim também sermo conserva os valores tradicionais. Não sendo necessário provar inovações, limitamo-nos a apontar os três significados que sermo apresenta nas Commonitiones:

1 - palavra (IV,2, lin. 12; IV,7, lin. 37; IV,19, lin. 33);

2 - conversa (II,5, lin. 8; V,9 lin. 17);

3 - expressão, frase (IV,11, lin. 12).

SYNAXIS - Trata-se de um termo que na linguagem corrente significava «reunião»; mas na língua dos cristãos tinha o valor técnico de "ofício religioso» e de "celebração eucarística». Nas Commonitiones encontra-se uma vez apenas:

IV,19 (lin. 75-76): Quod certe ad commonendum sensum nostrum cottidie in synaxi psallitur.

O contexto refere-nos uma exortação de Macário a um jovem; e é depois de ter citado dois versículos do salmo 37 que vem a frase acabada de transcrever. Os salmos eram cantados 
tanto nos ofícios de simples oração como nas celebrações da Eucaristia. Julgamos impossível garantir qual destes significados é indicado neste passo. Precisaríamos de mais pormenores para definirmos o sentido exacto.

THYMIAMA - Quando estudámos muscatus (pp. 246-248) apresentámos já o texto grego e a tradução latina do passo em que aparece a palavra thymiamata. Trata-se de uma transliteração do grego $\theta u \mu i \alpha \mu \alpha$, acentuada em latim thymiäma. Como então já mostrámos, o texto genuíno das Commonitiones apresenta um acusativo do plural regido por pro. Atendendo à raridade desta "regência», uns manuscritos alteraram para thymiamate e outros para... vocábulos inexistentes.

Resta-nos agora indicar o significado exacto desta palavra: thymiama é "o perfume do incenso, o fumo odoroso do incenso queimado». $\mathrm{Na}$ frase: pro thymiamata et muscata et illa diuersa (...) oportet me nunc sustinere istiusmodi fetorem, que se encontra em VI,4 (lin. 8-11), devemos traduzir: «em vez dos perfumes do incenso, dos aromas do musgo asiático e de outros diversos (...) convém que eu agora suporte este mau cheiro».

Rosweydus recolheu no Onomasticon (PL 74, coll. 511-512) várias abonações para o uso de thymiama. 


\section{Cap. IX - GENEALOGIA DOS PRINCIPAIS CÓDICES}

\section{A - Notas preliminares}

Feita a descrição externa dos principais manuscritos no cap. II (pp. 21-45), compete-nos agora demonstrar, do ponto de vista interno, isto é, pela análise crítica do texto, palavra por palavra, as relações de parentesco existentes entre os diversos códices.

Ao estudar Pascásio, demorámo-nos neste ponto, porque pretendemos então apresentar toda a história da transmissão e evolução do texto, desde o original até à edição de Rosweydus que, infelizmente, tomou como modelo o último e o pior de todos os arquétipos $\left({ }^{190}\right)$.

Foi nossa intenção, agora, restabelecer o texto genuíno das Commonitiones Sanctorum Patrum, estudando, para isso, com mais atenção, os manuscritos que pertencem aos arquétipos mais próximos do original. Quando chegarmos à conclusão de que, para além do arquétipo $\delta$, todos os demais são secundários, porque dependem dos primeiros quatro modelos e não estão mais em contacto com as fontes primitivas, então abreviaremos a nossa análise.

Torna-se conveniente avisar desde já que o conjunto de todos os manuscritos foi objecto da nossa atenção e que, nas suas linhas fundamentais, os grupos apresentados a partir do

(190) Cf. Pascásio de Dume..., t. II, pp. 293-398. 
arquétipo $\zeta$, inclusive, se encontram bem ajustados à descrição externa que deles fizemos em estudo anterior. Aliás, o nosso stemmma codicum inclui alguns exemplares desses arquétipos secundários $\left({ }^{191}\right)$.

Para a elaboração do stemma codicum e do texto crítico ativemo-nos às recomendações dos mais consagrados tratadistas $\left({ }^{192}\right)$.

(191) Cf. Pascásio de Dume..., t. II, pp. 192-215 e 233-253.

(192) Cf. bibliografia indicada em Pascásio de Dume..., t. I, pp. 154-155. Não deixemos de mencionar mais dois estudos recentes: J. Froger, La critique des textes et l'ordinateur, artigo de Vigiliae Christianae XXIV (1970), pp. 210-217; e R. LAUfer, Introduction à la textologie (Vérification, établissement, éditions des textes), Paris, 1972. 


\section{B - Siglas e sinais utilizados no "stemma codicum"}

A interpretação do quadro que publicamos na p. 262 obedece aos critérios mais correntes em trabalhos deste género.

Pretendendo nós reconstruir o original das Commonitiones designamos o presumível texto do tradutor por $x$. Como é evidente, o manuscrito primitivo, que supomos ser do século VI, não chegou até nós.

Pelas cópias de que dispomos, estamos convencido de que o texto original foi multiplicado num scriptorium, numa primeira tentativa de divulgação: é o hiperarquétipo $\alpha\left({ }^{193}\right)$. Só podemos reconstituir este modelo através de cópias independentes que dele se fizeram. São os arquétipos $\beta, \gamma$ e $\delta$. Os outros modelos de que nos chegaram manuscritos são todos dependentes destes três arquétipos. Dos arquétipos secundários, ou subarquétipos, só avançámos com o estudo desde $\varepsilon$ até $\theta$, incluindo neste as fontes do texto editado por Rosweydus.

Como já deixámos entrever, os arquétipos são indicados pelas letras minúsculas do alfabeto grego, a começar pelo princípio, em séric consecutiva. As linhas que ligam $\alpha$ a cada um dos arquétipos são suficientemente claras para se aperceber a proveniência de cada um. Como, a partir de $\delta$, há modelos contaminados, isto é, que dependem de dois arquétipos ou

(193) A designação de hiperarquétipo é apresentada por B. A. vAN GroNINGEN, Traité d'histoire et de critique des textes grecs, Amsterdam, 1963, p. 110. ROGER LAUfER, Introduction à la textologie, Paris, 1972, p. 34, dá-lhe o nome de "manuscrit fantôme". Os modelos dependentes do hiperarquétipo designamo-los sempre por arquétipos. Há ainda modelos que já só dependem de arquétipos (sem terem tido qualquer contacto com o hiperarquétipo). Chamar-lhes-emos arquétipo secundário ou dependente ou ainda subarquétipo. P. MaAs, Textkritik, Leipzig, 1960, p. 29, dá-lhes o nome de hiparquétipo. Pomos de parte esta designação pela facilidade com que na fala, na escrita e na leitura, se pode confundir com hiperarquétipo. 

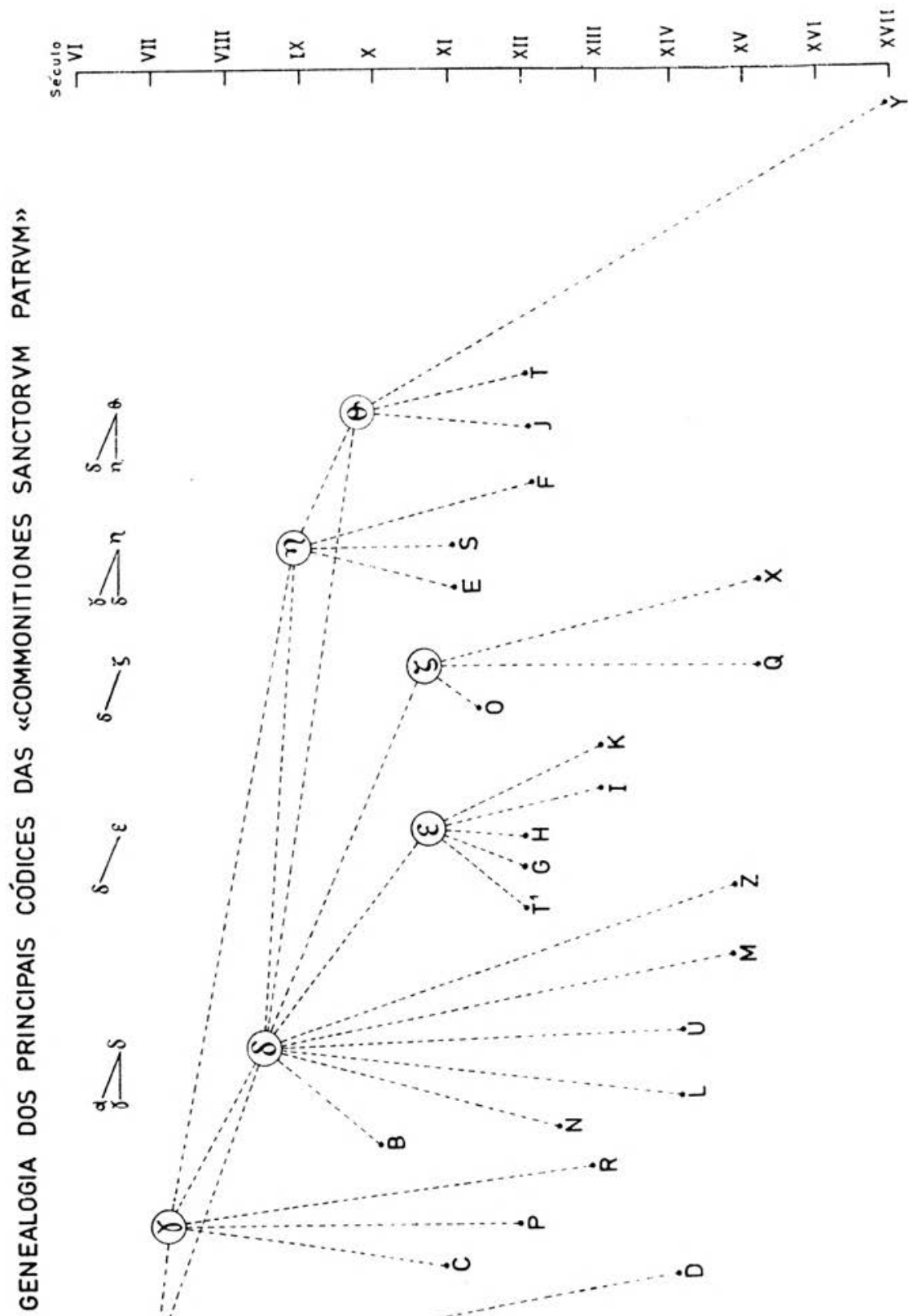

(\$)
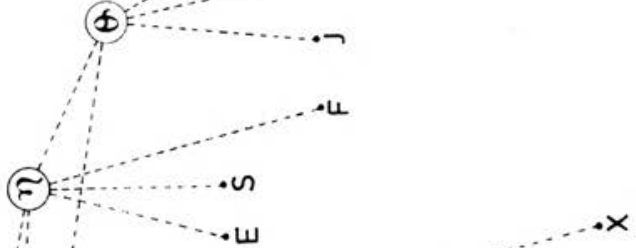

(n). $+\sigma$

$\because 0$
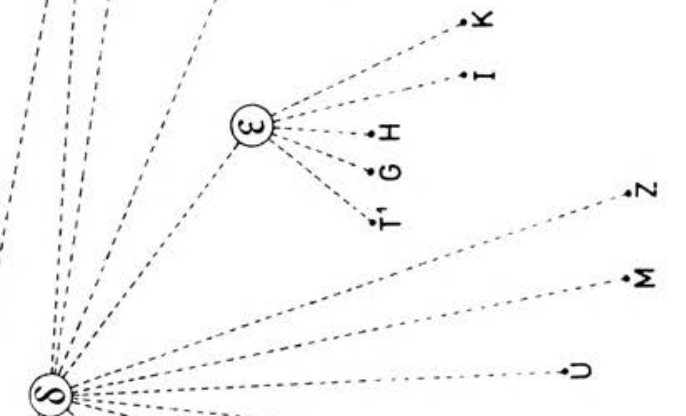

ב

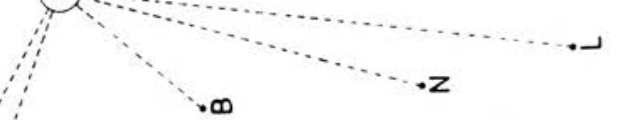

..$\propto$
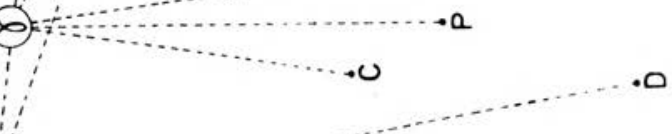

$\times$ (6). (-)

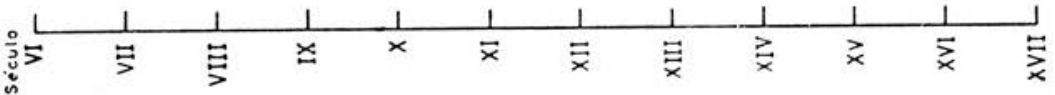


subarquétipos anteriores, damos para esses um esquema da sua origem ao longo da parte superior do quadro desenhado.

Nós só verificámos pormenorizadamente, a partir de $\eta$, um certo número de códices, da observação de cujo texto nos foi possível estabelecer a sua afinidade. Os códices estudados levam uma sigla, a saber, uma letra maiúscula do alfabeto latino. Para os manuscritos mais importantes adoptámos, na medida do possível, a letra correspondente à inicial da cidade ou biblioteca onde se encontram. Quando há vários manuscritos da mesma biblioteca, seguimos então o critério de voltar ao princípio do alfabeto latino e utilizar as letras (maiúsculas) que não estavam ainda ocupadas. Respeitámos, no entanto, algumas iniciais que, nos ensaios de aproximação do parentesco dos manuscritos, haviam sido dadas aos códices que vieram a reunir-se sob os arquétipos secundários $\eta$ e $\theta$.

As linhas vão todas tracejadas. Não há nenhuma que seja contínua. Isto significa não termos nós qualquer prova de que entre o arquétipo e o manuscrito que possuímos não tenha havido qualquer intermediário, pois é bem possível que sim.

O comprimento das linhas, de alto a baixo, revela imediatamente o século em que cada manuscrito foi copiado, se aferirmos o seu termo com a pauta do tempo que se encontra de cada lado do desenho.

Eis finalmente a identificação dos manuscritos de que vamos servir-nos, segundo a ordem por que aparecem no stemma ou genealogia dos códices:

V - Viena, Bibl. Nacional da Áustria 433, séc. XI.

A - Vaticano, Bibl. Apost. lat. 1201, séc. XI.

D - Dresda, Bibl. Nac. da Saxónia, A 207, séc. XIV.

C - Paris, Bibl. Nac. lat. 5601, séc. XI.

P - Paris, Bibl. Nac. lat. 2941, séc. XII.

R - Reims, Bibl. Municipal 1400, séc. XIII.

B - Berlim, Bibl. Nac. dos Tesouros Culturais da Prússia, ms. 780 , theol. lat. fol. 275 , séc. X. 
N - Namur, Museu de Arqueologia 12, séc. XII-XIII.

L - Londres, Museu Brit. add. 37400, séc. XIV.

U - Basileia, Bibl. da Universidade, B.V. 2, séc. XIV. $\mathrm{M}-$ Munique, Bibl. Est. Baviera, lat. 2540, séc. XV. Z - Munique, Bibl. Est. Baviera, lat. 23757, séc. XV. $\mathrm{T}^{1}-$ Troyes, Bibl. Munic. 777, séc. XII. G - Dijon, Bibl. Munic. 194, séc. XII. $\mathrm{H}-$ Londres, Museu Brit. add. 33518, séc. XII. I - Paris, Bibl. Nac. lat. 5624, séc. XIII.

K - Valenciennes, Bibl. Munic. 168, séc. XIII. O - Reims, Bibl. Munic. 1390, séc. XI-XII. Q - Danzig, Bibl. da Cidade 1950, séc. XV. X - Munique, Bibl. Est. Baviera, lat. $18535^{2}$, séc. XV. E - Einsideln, Bibl. Convent. 246, séc. XI. S - Paris, Bibl. Nac. lat. 10840, séc. XI. F - Paris, Bibl. Nac. lat. 3330, séc. XII. J - Munique, Bibl. Est. Baviera, lat. 17139, séc. XII. T - Troyes, Bibl. Munic. 777, séc. XII, ff. 1r-16r. Y - Editio Rosweydi (= PL 73, coll. 739-764). 


\section{I - Hiperarquétipo $\alpha$}

A necessidade de admitir um hiperarquétipo $\alpha$, que se perdeu, prova-se de diversos modos:

a) Devemos partir da hipótese que o original latino redigido pelo tradutor, em princípio, estaria correcto ou pelo menos sem omissões de palavras ou ainda confusões de títulos.

Ora há alguns erros que se encontram em todos os manuscritos. Nós concluímos que o modelo de que todos se serviram já continha essas faltas, impossíveis de atribuir ao tradutor. Isto é, entre o original latino e os arquétipos documentados, existiu um modelo, perdido, onde essas incorrecções foram introduzidas. Exemplos:

1 - Na IV capitulatio, n. XVII, estamos certo de que o título deve ser: De beati Athanasii miranda patientia $\langle e t\rangle$ humilitate. A prová-lo está o próprio título, tanto da capitulatio: De uirtute humilitatis et patientiae, como o incipit do cap. IV: De virtute humilitatis et patientiae. A presença da copulativa et está, pois, assegurada. Por isso, quando na capitulatio, sob o n. XVII, se lê no ms. V: patientie humilitate, supomos que pode ter havido um erro de ditado (interno ou externo), confundindo patientia et com patientiae, que depois foi escrito apenas patientie, por monotongação.

A mesma explicação vale para $\mathrm{D}$, pois este apenas assibila as dentais na forma paciencie. Quanto à lição de R: patientia hunilitatis, não tem defesa nem sentido a presença do genitivo humilitatis. Todos os outros manuscritos omitem a capitulatio. O tradutor deve ter escrito bem; foi quem copiou ou ditou que introduziu o crro, não mais emendado até agora. 
2 - Em IV,19 (lin. 23-24) só D tem: quam plurimis iniuriis multisque conuiciis ac maledictis affice etiam et lapida eos. Podemos, no entanto, garantir que affice já faltava no hiperarquétipo $\alpha$. Com efeito, nem os manuscritos de $\gamma$ e $\delta$ (que também tinham $\alpha$ ) nem V (o outro manuscrito de $\beta$ ) copiaram esta palavra. Um esquecimento coincidente $\mathrm{em}$ dois arquétipos diferentes e ainda, em consonância com estes, no manuscrito $\mathrm{V}$ (paralelo de D) levanta fortes reservas.

Quanto a nós, foi D que, por conjectura, restituiu a palavra affice. E cremos que procedeu com felicidade. Com efeito, adiante (lin. 27) vem a expressão iniuriis affecisset. Além disso, os verbos ligados por et são frequentes no contexto: collauda et glorifica (lin. 31), laudare et (...) glorificare (lin. 33), laudaui et glorificaui (lin. 37).

3 - Semelhantes observações se poderão fazer em V,8 (lin. 41), a propósito de erant, só introduzido em $\mathrm{R}$. Este verbo faz falta no texto; porém, nenhum outro manuscrito o reproduz. É quase certo que já $\alpha$, que $\beta$ e $\delta$ também possúam, perdera esta forma verbal, talvez por parecer uma aparente repetição auditiva do final da palavra anterior: didicerant erant (cf. pp. 172, 173).

4 - Vejam-se ainda outras correç̧ões que introduzimos no texto, emendando o hiperarquétipo $\alpha$, para remontarmos ao original latino: IV capitulatio (lin. 9); IV,3 (lin. 4); V capitulatio (lin. 9 e 11); e VI,3 (lin. 16).

5 - Há alguns erros nas capitulationes que nós próprio preferimos deixar permanecer, contentando-nos com chamar a atenção para eles neste momento. É bem possível que remontem ao próprio organizador primitivo das capitulationes.

$\mathrm{Na}$ I capitulatio os títulos correspondem, cada um a seu apotegma, desde I a VII. O n. VIII intitula-se: De expositione sancti Poemenii. De facto a narrativa de I,8 ajusta-se a esta 
indicação; mas note-se que ao mesmo apotegma se refere também o título IX: De principe cocorum Nabuchodonosor.

A I capitulatio prossegue com um número de avanço quando escreve em X lugar: De abbate Beniamin qui obtulit oleum sancto seniori, título este que corresponde a I,9.

Acontece, porém, que para o apotegma I,10 também atribuído ao abade Benjamim, não há qualquer título na capitulatio.

Sendo assim, o resumo anunciado na $I$ capitulatio n. XI: De monachis qui ad uisitandum eremitas perrexerunt corresponde já ao apotegma I,11.

Títulos e apotegmas passam a corresponder-se bem até ao fim. Observe-se, no entanto, que a I,16 correspondem dois títulos: XVI - De interrogatione fratrum ad abbatem Ioseph, e XVII - De susceptione peregrinorum sanctorum patrum.

Resumindo, o cap. I tem 16 apotegmas, mas XVII títulos, porque a I,9 correspondem dois títulos e a I,16 outros dois, mas o apotegma I,10 está excluído da capitulatio. Não nos julgamos autorizado a inventar um título para suprir uma lacuna que remonta, possivelmente, à organização primitiva.

Há ainda outras anomalias nas capitulationes. Na II temos só 10 apotegmas, mas há 11 títulos. Aqui, títulos e apotegmas equivalem-se de 1 a 10 . Porém, à II capitulatio n. XI: Exhortatio sancti Macarii ad monachos, corresponde o cap. III, que só tem um apotegma. Depois de II, 10 o texto é bem expresso, assinalando o explicit do cap. II. Do mesmo modo, o cap. III está perfeitamente demarcado com um incipit, embora não haja nova capitulatio, pois ficara deslocada e acrescentada atrás, sob o n. XI.

Também a $V$ capitulatio precisa de atenção. $O$ seu título, bem explícito, deveria ser repetido antes de V,I. Esta restituição parece-nos necessária e fácil. Quanto ao mais, repare-se que o capítulo V tem só 9 apotegmas, mas depois do n. IX vem ainda um novo título: $\mathrm{X}-$ De beato Arsenio, qui fuit quondam sublimis ualde in palatio imperatoris et postea magnus inter sanctos patres. 
Como se poderá verificar, este enunciado corresponde aproximadamente ao longo título do cap. VI. E para este último capítulo das Commonitiones não há qualquer capitulatio que resuma o conteúdo de cada um dos seus 6 apotegmas.

Estas deficiências faziam parte, sem dúvida, já do hiperarquétipo $\alpha$. A sua natureza é tão grave que não pode deixar de se atribuir à própria organização primitiva das Commonitiones. Por isso não tentámos qualquer correcção.

b) A cxistência do hiperarquétipo $\alpha$ é absolutamente necessária para explicar alguns apotegmas, ou lições, que foram salvos apenas por um arquétipo. Com efeito, se eliminássemos o hiperarquétipo $\alpha$, como poderia $\gamma$ ter elementos que faltam $\mathrm{cm} \beta$ ? E se é verdade que $\delta$ tem como principal modelo $\gamma$, como explicar a presença, em $\delta$, de apotegmas inteiros c de lições autênticas que faltam em $\gamma$, senão pelo recusro a $\alpha$, quando $\beta$ também não está correcto? Mas sobre a natureza dos arquétipos $\beta, \gamma$ e $\delta$, seus méritos e defeitos, passamos a ocupar-nos nos parágrafos seguintes. 


\section{II - Arquétipo $\beta$}

a) - A cxistência e valor deste arquétipo, representado pelos manuscritos VAD, torna-se evidente desde que observemos que apenas VD nos transmitem as capitulationes I, II e V e os apotegmas V,1 e VI,3.

Não se pense que as capitulationes, apesar dos erros que apontámos no parágrafo anterior, são uma tentativa de sistematização feita por $\beta$. Como veremos, o manuscrito mais completo do arquétipo $\gamma$ é $\mathrm{R}$. Ora $\mathrm{R}$ (que nunca dá sinais de depender de $\beta$, mas antes de remontar a um modelo comum, que é $\alpha$ ), tem também o incipit do cap. III e a IV capitulatio. As capitulationes já existiam, pois, em $\alpha$.

Além disso, VD têm o mérito de ter transmitido alguns passos que, por deficiência de cópia, foram omitidos noutros arquétipos.

Os casos mais salientes são:

1 - Em II,6 (lin. 11-14) há 26 palavras que foram omitidas por $\mathrm{D}$, cujo copista deu um salto de cópia de eodem ad eundem. Acontece, porém, que $\mathrm{R}$ tem neste passo um erro evidente (a te $\mathrm{VN}$ : autem $\mathrm{R}$ ) e que $\mathrm{N}$ apresenta duas variantes, que têm de se rejeitar perante a unanimidade de VR.

2 - Em V,7 (lin. 39-51) RN omitem 100 palavras, com o intuito evidente de abreviarem a narração, aqui transformada numa apologia baseada em citações bíblicas. Note-se ainda que, dentro deste fragmento, D omite parte das linhas 42-43 e tem 3 variantes. Ficamos, pois, a dever só a $\mathrm{V}$ a total integridade deste passo. 
b) Embora V seja o melhor destes manuscritos, ele cai também em diversas faltas. É fácil verificá-las percorrendo, por exemplo, as capitulationes só transmitidas por VD. Observa-se então que $\mathrm{V}$ omite umas palavras e deturpa outras. As adições espúrias de V são raras: cf. II,7 (lin. 35); V,8 (lin. 32). Para apresentar apenas um exemplo concreto das suas (relativamente) raras alterações, veja-se o trabalho realizado em V,8 (lin. 9) - impossibiles DRN: impotentes V. Não há dúvida de que $\mathrm{V}$ pretendeu resolver o problema do valor activo de impossibiles (cf. o estudo das pp. 242-243).

c) Quanto ao valor de D, fica realçada a sua valia nos casos em que $\mathrm{V}$ falha. Mas no geral $\mathrm{D}$ é muito mais deficiente. Contámos 18 omissões de 5 ou mais palavras. As maiores encontram-se em IV,1 (lin. 17-18) onde omite 11 palavra:; em IV,3 (lin. 37-39): 18 palavras; IV,4 (lin. 28-30): 21 palavras; IV,12 (lin. 64-65): 11 palavras; etc.

Perante esta real desvalorização de $\mathrm{D}$, as suas lições apenas se impõem quando $\mathrm{V}$ tem um erro evidente ou quando $\mathrm{D}$ está reforçado por manuscritos de outros arquétipos que foram também beber a $\alpha$.

Vamos tratar apenas o caso de mais difícil opção. Na II capitulatio, n. X temos: De fratre qui interrogabat sanctum Poemen dicens: Spiritus fornicationis et irae impugnat me, et responsio sancti Poemenis. O cólon final: et responsio sancti Poemenis falta em V. Deveríamos antes considerá-lo uma adição de D ? Pareceu-nos que não, argumentando a pari. Com efeito, na I capitulatio, n. VI, temos o seguinte título,sem qualquer variante, em VD: De quodam sancto seniore quem rogabant fratres ut cessaret de magno labore, et responsio eius. A construção dos títulos parece-nos paralela. Por isso acreditamos na fidelidade de D. 
d) Resta-nos apenas dizer uma palavra sobre o manuscrito A. Do arquétipo $\beta$ ele tem somente o $\mathrm{n}$. $\mathrm{V}, 1$, que não podia ir buscar a outra fonte, pois todos os outros arquétipos omitem este apotegma.

Colacionando A com VD verificámos que, além de algumas inovações próprias, A confirma a superioridade de V. Assim em V,1 nas linhas 5-6, as 8 palavras omitidas por D encontram-se em A, tal como em V. Na linha 10, contra o sentido do texto, tem D: praeuaricationum, ao passo que VA escrevem a palavra esperada: peruagationum.

Não precisamos de nos alongar mais. No estudo dos arquétipos seguintes ressaltará várias vezes a superioridade de $\beta$. Mas nem sempre... Por isso não o seguimos cegamente, mas só quando a discussão crítica o aconselhava. 


\section{III - Arquétipo $\gamma$}

$O$ arquétipo $\gamma$ encontra-se numa posição muito especial. Há 2 apotegmas transmitidos por CPR; 4 por CR; 13 por PR; e 37 só por R. Faltam-lhe, portanto, por completo, 5 narrativas.

a) O primeiro ponto que nos importa provar é que o arquétipo $\gamma$ não depende de $\beta$ e por isso tem de remontar a uma fonte mais pura, o hiperarquétipo $\alpha$.

1-O passo mais importante é I,3 (lin. 10-13): ... si uoluerit imperator aliquam aduersariorum obtinere ciuitatem, eis prius subtrahit cibaria et ita fame ac penuriae necessitate contriti humiliantur et subiciuntur imperio eius (cf. pp. 72-73 e 91-92).

As palavras que vão «a redondo» faltam no arquétipo $\beta$. Quanto a $\delta$, que tinha simultaneamente $\alpha \mathrm{e} \gamma$, poderia iludir-nos a lição que reproduzimos no nosso aparato crítico, por se encontrar em $\mathrm{N}$ : prius aquam tenet et escas eorum qui sunt in ciuitate et necessitate contriti...

Examinando, como tivemos de fazer sempre, os lugares paralelos, verifica-se que $\mathrm{N}$ foi buscar as palavras sublinhadas a Pelágio IV,19, onde o sentido do cólon transcrito se completa assim (retomando nós as últimas palavras): ... qui sunt in cinitate et fame periclitantes tunc subiciuntur ei.

Trata-se, de facto, de uma interpolação de Pelágio, mas devemos esclarecer que ela se lê apenas no manuscrito de Namur. Os outros testemunhos de $\delta$, BL etc., omitem também as palavras que faltam em $\beta$. Isto vem pôr-nos um problema grave: saber se $\delta$ remonta ao hiperarquétipo $\alpha$ ou se é antes dependente do arquétipo $\beta$. Trataremos desta questão ao 
iniciar o estudo de $\delta$ (pp. 280-283). De momento, interessa-nos realçar o valor de $\gamma$ para restituir o texto completo das Commonitiones.

2 - Há um outro passo, embora menor, que o arquétipo $\gamma$ nos conserva, mas que, por faltar em $\beta$ e $\delta$, apenas se pode explicar se admitirmos que $\gamma$ remonta a um modelo mais perfeito, ou seja, ao hiperarquétipo $\alpha$.

Em II,4 (lin. 19-21) diz ao abade Moisés o seu amigo Isidoro: Cognosce ergo quia pluriores sunt nobiscum, sicut dixit Eliseus propheta, quam cum illis. É quase literal esta transcrição do IV Livro dos Reis, cap. VI,16, pelo que deve ser tida como autêntica. Todavia, o segundo termo de comparação - quam cum illis - perdeu-se em toda a transmissão manuscrita, com excepção do ms. de Reims, Bibl. Municipal 1400, isto é, o único representante de $\gamma$ que nos transmite o n. II,4. Ao estudarmos o arquétipo contaminado $\delta$ tentaremos explicar este facto (p. 281).

b) 1 - Só há dois apotegmas comuns a CPR - IV: 13 e 17. As lições que lhes são exclusivas pertenciam, pois, seguramente ao arquétipo $\gamma$.

Principia assim o n. IV,13: Dicebant sancti seniores de discipulo abbatis Pauli nomine Ioanne... A identificação nomine Ioanne falta em CPR.

Uma outra omissão encontra-se em IV,17 (lin. 19-20): Iube considerare, pater, codicem istum... A palavra pater não se encontra em CPR.

2 - Comuns a CR temos apenas os 4 números seguintes: IV: $12,14,15$ e 16 . Eis algumas variantes em ambos: dictum.

Em IV,12 (lin. 29) supradictum foi transformado em saepe

Em IV,14 (lin. 5-6) lê-se: Quid ageret, quo se uerteret nesciebat. A ampliação foi reduzida com a supressão de quo se uerteret. 
Não há anotações especiais a fazer sobre IV,15. Mas em IV,16 notamos, entre outras, as seguintes concordâncias de CR (lin. 29-30): iussit ut accenderent ignem et misit in eum omnium fratrum mattulas. A expressão misit in eum devia ter sido mal interpretada pelo elaborador de $\gamma$, pois in eum é omitido em $\mathrm{CR}$, tendo talvez sido incluído na aberrante forma mise sunt em $\mathrm{C}$ e miserunt em $\mathrm{R}$. E nas linhas 35-36 na locução humilitatem fratris Eulalii, o nome Eulalii foi suprimido.

3 - São comuns a PR treze apotegmas - I: 1, 3, 5, 14; II: 5,7 ;V: 2,18 ; V: $5,8^{\text {b }}, 9$; VI: 2,5 . Damos apenas três exemplos:

Em I,14 (lin. 9-10) falta a expressão eadem hora no passo: Exsurgens autem eadem hora stetit in aestu quinque dies...

No contexto dado em IV,2 (lin. 15-16): propter humilitatem illius monachi qui prostratus in terram ueniam postulabat a fratre suo non praeualui in eis... as últimas quatro palavras faltam em PR.

Vejamos agora um passo mais amplo de V,8 (lin. 22-24): ... prosternit se in orationem, cum gemitu exorans adesse sibi diuinum auxilium, et ego nimio igne me exurente cum confusione egredior. Em vez de exorans têm só orans PR; a expressão et ego nimio igne me exurente está assim em P: ego autem nemine exurgente, e em R: ego autem illo exurgente. Como se vê, o arquétipo $\gamma$ deformou, por não ter percebido, o sentido desta locução. Está bem em P: cum confusione, mas tem R: cum grandi confusione.

Esta última variante coloca-nos perante um problema que não queremos examinar aqui a fundo: $\mathrm{P}$ devia ter também um modelo de $\beta$, pois várias vezes se afasta de $\gamma$ para dar a lição do texto genuíno. $\mathrm{O}$ acrescento de grandi pertencia ao arquétipo $\gamma$ e deste passou a $\eta$ e $\theta$.

$A$ influência de $\beta$ sobre $P$ torna-se evidente sobretudo nos dois últimos números - VI: 2 e 5 . Nestes, $\mathrm{P}$ está sempre do 
lado de VD, enquanto $\mathrm{R}$ ou se isola ou inova - e é seguido depois por $\delta$.

Algumas das suas adições ocorrer-nos-ão quando estudarmos o influxo de $\gamma$ sobre $\delta$ e $\eta$ (pp. 283-285 e 291-292).

4 - Restam-nos 37 apotegmas do arquétipo $\gamma$ só representados por R. Nestas condições é difícil, por vezes, saber se as variantes eram todas do arquétipo ou se foram introduzidas pelo copista de $\mathrm{R}$.

Com efeito, o copista de $\mathrm{R}$ (ou o seu modelo próximo) era bastante descuidado. Basta examinar algumas páginas do nosso aparato crítico para se observarem variantes sem qualquer razão plausível. Verificámos mesmo que em 10 casos são omitidas 4 ou mais palavras. Além de V,7 (lin. 39-51) onde (como dizemos, pp. $269,281,284) \mathrm{R}$ e o arquétipo $\delta$ dele dependente omitem 100 palavras, anotamos, por ordem, as principais omissões só de $\mathrm{R}$ (incluindo nós, para este cômputo, apotegmas que estão também abonados em C e P) - I,1 (lin. 21-22): 7 palavras; IV,12 (lin. 36-37): 8 palavras; IV,13 (lin. 9-12): 29 palavras; IV,17 (lin. 26-27): 7 palavras. Este panorama já nos adverte de que devemos tomar as variantes exclusivas de $\mathrm{R}$ com alguma reserva.

Observemos alguns casos concretos. O n. II, 5 encontra-se, no arquétipo $\gamma$, representado pelos manuscritos PR. O texto que apurámos como genuíno, de acordo com os arquétipos $\beta$ e $\delta$, tem a certo passo (lin. 9-10):

Ipsa autem erat in cuius persona impugnabatur supradictus frater.

A lição de R é a seguinte:

Ipsa autem erat persona de qua supradictus frater tentatus fuerat.

Perante esta variante, simplificadora do texto, examinemos agora o testemunho de P. Neste, a frase em causa tem a mesma forma de $\beta$ e $\delta$, com omissão apenas da palavra supradictus. 
$\mathrm{Na}$ IV capitulatio o n. III apresenta a seguinte forma em R: De monacho qui foras ciuitatem Constantinopolim fuit tempori Theodosi imperatoris in peruisa humilitatis exemplum Ioseph protulit.

Até imperatoris o título corresponde (apenas com a variante tempori Theodosi) ao que se encontra em VD. Mas que significa o acrescento: in peruisa...? É claro que o copista de $\mathrm{R}$ não compreendia o que escreveu. A solução deste problema julgamos encontrá-la na leitura do n. V desta IV capitulatio: De eodem sancto Poemene, quando conuenerunt ad eum plurimi monachorum et de causa humilitatis et exempli Ioseph.

Neste título omite $\mathrm{R}$ a segunda parte, desde et de causa... Supomos que no modelo de $\mathrm{R}$ esta segunda parte foi introduzida, indevidamente (por distracção ou cópia de uma correcção in margine), no fim do $\mathrm{n}$. III, transcrito acima. O copista seguinte transformou et de causa em in peruisa; et exempli em exemplum; protulit foi acrescentado para dar um verbo ao cólon. Mas que significa este novo cólon? - Nada. Aqui está um belo exemplo de galimatias...

O mais longo e cabal exemplo da capacidade de adulteração do texto, fornecida pelo copista de $\mathrm{R}$ (ou de um seu modelo) é, no entanto, o passo de IV,12 (lin. 56-63) que passamos a transcrever, em contraste com a lição dos arquétipos $\beta$ e $\delta$ e do próprio manuscrito $C$ (que representa, como sabemos, uma outra cópia do arquétipo $\gamma$ ):

VDNC

...interrogauit eum dicens:

Dic mihi si dixisti fratri uerba quae propter cellulam illam mandaui ut diceres ei.
R

... interrogauit eum dicens: Quando te mittebam ad eum, numquid loquebaris ei sicut pracipiebam?

fratri uerba] u. f. C fratri om. N propter cellulam illam] pro cellula $\mathrm{D}$ 
Tunc discipulus eius confessus est dicens: Vere, domine, dico. uerumtamen nihil eorum dixi quae mandabas ad eum. Haec audiens senior statim prostrauit se in terram........
Qui respondit: Vere domine dico.................................

uerumtamen nihil eorum dixi ei quae mandabas adesse. Et narrauit ei per ordinem cuncta quae gesserat. Audiens haec senior statim se prostrauit se in terra.

eius om. D est] ei add. $\mathrm{N}$ dico domine $\mathrm{C}$ dixi] ei add. $\mathrm{C}$ haec] autem add. $\mathrm{N}$

Não há paralelo latino de outro tradutor, onde $\mathrm{R}$ pudesse ir buscar tamanha alteração. Os testemunhos concordes dos outros 4 manuscritos não podem senão levar-nos à conclusão de que é espúrio o texto transmitido por $\mathrm{R}$.

c) Teremos que examinar várias vezes as relações de $\gamma$ com $\delta$. Convém provar neste momento que as inovações em causa foram introduzidas em $\gamma$, onde $\delta$ as foi buscar.

1 - Em primeiro lugar note-se que $\mathrm{R}$ tem o título do cap. III, a capitulatio IV e o apotegma IV, 5 - que faltam em $\delta$. Não pode deixar de se concluir que estava mais perto da fonte primitiva do que $\delta$. Além disso, há inovações de $\gamma$ que foram aperfeiçoadas ou retocadas em $\delta$.

Demos breves exemplos.

2-O n. II,6 é precedido pelo seguinte título em $\mathrm{R}$ : de duobus fratribus; e em $\mathrm{N}$ : de duobus monachis fratribus; e ainda em L: de duobus monachis qui perrexerunt in ciuitatem opera sua uendere. Resta alguma dúvida de que o título foi criado por $\mathrm{R}$ 
e depois se foi aperfeiçoando, sendo o acrescento monachis típico de $\delta$, pois se encontra em NL?

3- Principia IV,9 (lin. 1-3): Erant quidam duo fratres (...) quorum humilitatem et patientiam de sanctis collaudabant. Audiens quidam sanctus uir...

Repare-se para a segunda parte deste fragmento em RN: ...quorum humilitatem et patientiam multique (multi etiam $\mathrm{N}$ ) de sanctis patribus collaudabant. Audiens (autem N) quidam sanctus uir... Temos dois acrescentos de $\mathrm{R}$ multique e patribus, ambos retomados por $\mathrm{N}$, o qual ainda retocou um (multi etiam) e acrescentou uma palavra: autem. É claro, neste fragmento, que o texto mais tardio é o de $\mathrm{N}$. Esta versão de $\mathrm{N}$ foi retomada por ESY, apenas com a diferença que ES omitem autem, e Y em vez desta conjunção tem uero. Estamos, pois, a aproximar-nos do texto publicado por Rosweydus. A menção de ES far-se-á porque Y é contaminado de $\delta$ e $\eta$, isto é, dos manuscritos do tipo BNL e ES.

4-Curioso também o que se passa com VI,2. O abade Arsénio teve uma visão composta por três alegorias. A segunda é a seguinte (lin. 11-14):

Iterum autem ostendit ei alium hominem stantem super lacum et haurientem aquam de lacu, mittentemque eam in collectaculum et de alio pertuso defluebat aqua de subter in eundem lacum.

Esta é a lição segura e plenamente aceitável de $\beta$. O particípio pertusus 'furado', de uso raro e de leitura difícil quando se abrevia o prevérbio per-, veio complicar a lição de $\gamma$, o qual, não percebendo o que lia, tentou tornar o texto inteligível.

Segundo o original latino, um homem deitava água numa vasilha, mas a água que entrava por um lado saía pelo fundo, que estava roto, voltando assim ao lago. O reelaborador de $\gamma$ fez de pertuso: parte; acrescentou per foramina; e transformou lacum em locum. Eis a lição da parte final segundo R: 
... et de alia parte per foramina defluebat aqua de subter in eodem loco.

É esta interpretação, que ES foi colher a $\gamma$, a que se encontra em Y. Todavia, BNL permitem-nos reconstituir $\delta$ deste modo:

... et de alia parte per foramen defluebat aqua de (om. $\mathrm{N})$ subter (super L) in (om. N) eundem locum.

Cremos estar bem patente o que pretendíamos demonstrar: a alteração do texto principiou em $\gamma$. Aí foi $\delta$ buscá-la, introduzindo-lhe, por sua vez, inovações.

Este último exemplo já nos deixa também entrever que $\eta$ possuía $\gamma$, pois o reproduz com fidelidade. No estudo dedicado a $\delta$ e $\eta$ voltaremos a apresentar provas confirmadoras desta primeira observação. 


\section{IV - Arquétipo contaminado $\delta$}

O exame atento do texto de $\delta$ revela que este arquétipo, além de ter lições próprias, depende em grande parte de $\gamma$ e de $\alpha$ (ou $\beta$ ). Para atestar $\delta$ utilizaremos sobretudo os mais antigos manuscritos: BNL.

a) A ligação de $\delta$ a um modelo diferente de $\gamma$ é postulada, com evidência, pelo facto de $\delta$ conter três apotegmas que não se encontram em $\gamma$. É o caso de V,4; V,6; e VI,6, números estes que nenhum dos três manuscritos CPR transmite.

Há ainda alguns fragmentos que faltam em R, como o incipit do cap. II e outras omissões que assinalamos (pp. 27, 275 e 282), e que $\delta$ possui. Nestes casos, dada a natureza secundária de $\delta$, não há outro recurso senão admitir a sua ligação a $\alpha$ (ou $\beta$ ).

b) Ao demonstrarmos que há dois passos chegados até nós apenas através de $\gamma$, implicitamente ficou provado que, então, $\beta$ e $\delta$ coincidiam na omissão desses fragmentos (cf. supra, pp. 272-273).

1 - Com efeito, quando em I,3 (lin. 11-12) só PR nos dão 9 palavras da tradução genuína das Commonitiones, perguntamo-nos: se $\delta$ tivesse presente um modelo de $\alpha$, por que motivo omitiria o seu organizador estas palavras, uma vez que elas estavam de certeza em $\alpha$ e em $\gamma$ ? A omissão coincidente $\operatorname{com} \beta$ deixa-nos perplexo. Não teria antes o organizador de $\delta$ diante de si apenas $\beta$ e $\gamma$ ? Parece que sim. Mas então, insistimos nós, por que razão tendo ele essas palavras em $\gamma$, preferiria omiti-las, fiando-se em $\beta$ e reproduzindo assim uma frase que ficou truncada e obscura? Não é fácil encontrar resposta satisfatória. 
2- O mesmo problema se põe, c nos mesmos termos, para II,4 (lin. 20-21), onde só $\gamma$ nos dá um segundo termo de comparação ( 3 palavras), copiado da Bíblia. $\mathrm{Na}$ frase: pluriores sunt nobiscum, sicut dixit Eliseus propheta, quam cum illis, não vemos como possa ser negada a autenticidade de quam cum illis. Poderemos explicar a sua omissão $\mathrm{em} \beta$ como sendo fruto de uma distraç̧ão do copista, em parte aceitável porque o segundo termo de comparação vem no IV Livro dos Reis imediatamente a seguir a nobiscum - e o copista teria dado a frase por terminada ao mencionar a fonte bíblica: sicut dixit Eliseus propheta.

Se $\delta$ provém de $\alpha$ e $\gamma$, tinha diante de si, sem sombra de dúvida, o segundo termo de comparação. Porque o omitiria então? Se depende de $\beta$ e $\gamma$, porque haveria de preferir a lição lacunosa de $\beta$, em vez da exacta de $\gamma$ ? Distracção coincidente nos elaboradores de $\beta$ e $\delta$ ? Custa a acreditar, mas, com certos copistas, tudo é possível... A confirmar a viabilidade desta distracção, veja-se o nosso texto crítico, em que quam cum illis ficou isolado na p. 332. Facilmente um leitor ou copista poderia dar a citação por terminada no fim da nossa p. 331. Aqui está uma coincidência tipográfica, puramente casual, que nos permite ser benévolos para com os copistas...

3 - E todavia vejamos o que se passou em V,7. Trata-se de um longo relato a propósito do desprendimento da família. $\mathrm{O}$ arquétipo $\gamma$, só testemunhado por $\mathrm{R}$ (lin. 39-51), omite 100 palavras. Distracção? Descjo de abreviar? Não sabemos. O que menos podemos compreender é o facto de todos os manuscritos de $\delta$ também omitirem estas 100 palavras. Ora nós sabemos que o organizador de $\delta$ tinha à sua disposição o texto completo, quer o seu modelo fosse do hiperarquétipo $\alpha$, quer de $\beta$, pois VD transmitem-nos uma narrativa autêntica, a qual tem paralelo, mesmo para as citações bíblicas, nas Vidas de S. Pacómio. Não é, pois, possível duvidar da genuinidade deste fragmento. 
Estas omissões de $\delta$, ora comuns a $\beta$ ora iguais a $\gamma$, parecem levar-nos à conclusão de que $\delta$ é, de facto, contaminado de $\beta$ e $\gamma$. Mas continuemos a nossa análise, pois há novos elementos a aduzir.

c) A questão de saber se $\delta$ depende de $\alpha$ ou de $\beta$, à falta de provas claras no exame geral do texto, levou-nos a um estudo minucioso dos apotegmas e fragmentos omitidos por $\gamma$ (pp. 27, 275). Então, pensámos nós, poderá argumentar-se assim: se, nesses passos, $\delta$ nos der provas de um texto mais puro do que o de $\beta$, é porque remonta a $\alpha$; se a versão transmitida por $\delta$ ainda apresentar corrupções de $\beta$, é porque depende de $\beta$.

Devemos desde já declarar que esse longo estudo não nos presenteou com dados abundantes e insofismáveis. Dos pequenos fragmentos omitidos por $\mathrm{R}$ nada pudemos apurar que valha a pena transcrever. O mesmo se diga quanto ao n. V,4. O leitor poderá examinar este apotegma e verificará que não há entre VD e $\mathrm{N}$ nenhuma variante significativa para o nosso objectivo. Somámos 3 omissões e 3 adições de N. Independentemente de registar a sua presença também em BL etc., tais variantes apenas nos podem sugerir que $\delta$ é posterior a $\alpha$ e $\beta$, mas não provam nada a favor da dependência de $\alpha$ ou de $\beta$.

Já é um pouco diferente o caso do n. V,6. Como dissemos a seu tempo (pp. 136-149) este apotegma foi copiado, com breve reelaboração, das Conlationes de Cassiano. Só duas palavras nos interessam agora, para a crítica textual. Mas enquadremo-las no seu contexto para podermos ajuizar.

Nas Commonitiones V,6 (lin. 8-9) temos a expressão $e x$ nimia abstinentia ac solitudinis ingitate. Como dissemos, este apotegma é omitido por $\gamma$. Os dois manuscritos - VD - do arquétipo $\beta$ têm sollicitudinis. Dos manuscritos do arquétipo $\delta$ só $\mathrm{Z}$ omite o apotegma, dispondo nós portanto de 5 testemunhos. Têm solitudinis NLUM; sollicitudinis ac solitudinis é a lição de B. Concluímos daqui, pelo contexto, que solitudinis é a palavra que melhor se adapta. Ora esta é a que se encontra 
nos manuscritos da família $\delta$, à excepção de $\mathrm{B}$ que apresenta claro sinal de contaminar $\beta$ e $\delta$.

Felizmente temos possibilidade de comparar com o texto crítico das Conlationes XXIV,9. A expressão em causa tem aí a redacção: ex nimia continentiae ac solitudinis iugitate. Não resta qualquer dúvida de que $\delta$ tem o texto exacto, sendo sollicitudinis uma corrupção de $\beta$. Concluímos, pois, que $\delta$ depende de $\alpha$ e não de $\beta$. Foi o tradutor das Commonitiones que substituiu continentiae por abstinentiae e foi esta versão que se fixou em $\alpha$ e daí passou a $\delta$.

No final da n. V,6 das Commonitiones temos (lin. 16-18): ... non patitur relaxari ut ne breuissimi quidem momenti indutias (...) indulserit... A única variante neste passo consiste na substituição de ut por et em VDB. Vemos que et é a lição de $\beta \mathrm{e}$ que B (manuscrito contaminado) preferiu esta forma. Vejamos as Conlationes: lá está ut. É esta a lição, que confirmámos, de NLUM, isto é, de $\delta$, o qual, uma vez mais, tem melhor texto que $\beta$. Não há outra explicação a não ser a ligação directa de $\delta \operatorname{com} \alpha$. Temos que pôr de parte, com efeito, a hipótese de $\delta$ ter presente o próprio texto de Cassiano. Se assim fosse, teria certamente introduzido outras melhorias no seu arquétipo (cf. também pp. 144-146).

De todas as notas acabadas de apresentar sobre a ligação de $\delta$ a um modelo anterior, diferente de $\gamma$, as de maior valia ainda se nos afiguram as fornecidas pelo apotegma n. V,6. Por isso, preferimos dizer que o organizador de $\delta$ devia ter tido perante si, pelo menos, dois manuscritos que deram origem ao seu aspecto contaminado: um, evidente, do arquétipo $\gamma$; c o outro, embora mais difícil de determinar, seria do hiperarquétipo $\alpha$. Não nos parece absolutamente necessário postular também a presença do arquétipo $\beta$. Os factos poderão explicar-se todos partindo apenas $\operatorname{de} \alpha$ e $\gamma$.

d) A dependência de $\delta$, em relação a $\gamma$, pode provar-se de um duplo modo: 1 - citando exemplos nascidos em $\gamma$ e 
que, tendo passado a $\delta$, aí se mantiveram; $2-$ apresentando variantes criadas pelo elaborador de $\gamma$ e que, através de $\delta$, se prolongaram para outros arquétipos, incluindo, por vezes as primeiras edições impressas. Este último processo parece-nos o mais significativo, pela repercussão que as inovações obtiveram. Chamamos a atenção, pois, para as siglas de outros arquétipos e da edição de Rosweydus (esta representada por Y).

1 - O facto mais flagrante é a total ausência de capitulationes em $\delta$ e em todos os manuscritos seguintes. Ora, como já vimos (p. 269) esta supressão principiou em $\gamma$, o qual omite a I, II e V capitulationes. Seguindo este rumo, $\delta$ acabou por suprimir também a $I V$ capitulatio, que ainda subsistiu em $\gamma$ (cf. o texto crítico, pp. 311, 326, 342 e 378).

2 - Em II,2 (lin. 18-19) temos as frases: Ne pertimescas, neque resoluaris, neque abscondas cogitationes tuas. Ita enim confusus spiritus immundus discedet.

Depois de pertimescas (verbo que em $\mathrm{R}$ tem a forma permittas) foi acrescentado o vocativo, fili em RBNLOQESFJT Y; e a terminar a segunda frase temos, após discedet, o acrescento: a te, este introduzido só em $\delta$, pois se encontra em BNLO QESFJTY.

3 - No n. V,7 diz o abade Pacómio ao seu discípulo Teodoro (lin. 33-34): Itaque propter epistolas episcoporum, uade et uideat te mater tua. Utilizando um elemento de informação fornecido anteriormente (lin. 27-28), foram acrescentadas, depois de episcoporum, as palavras: qui scripserunt ad me em RBNLOQESFJTY.

É igualmente muito sintomática a omissão das linhas 39-51, feita primeiramente em $\mathrm{R}$ e daí passada a $\delta$, que tinha possibilidade de recuperar o salto, recorrendo a $\alpha$. A omissão destas 100 palavras não pôde mais ser reconstituída pelos arquétipos 
seguintes, uma vez que estes, como veremos (pp. 287-295) dependem exclusivamente de $\gamma$ e $\delta$. Do mesmo modo, a edição de Rosweydus apresenta esta importante lacuna.

4 - Mais curiosa ainda é a observação deste passo de VI,2 (lin. 29-30): propter superbiam cordis sui remanserunt foris de regno caelorum Christi exclusi. Qui autem caedebat ligna, homo est qui... Após regno introduziu $\mathrm{R}$ a palavra regis, que foi reassumida por ESJTY. Porém BNL, que tiveram acesso a $\alpha$, não aceitaram a amplificação, que também se não encontra $\mathrm{em}$ OX (mas está, estranhamente, em Q).

No entanto, já toda a série está de acordo em acrescentar depois de ligna: et super sarcinam adhuc (ad is $\mathrm{R}$ ) addebat RBNLOQXESFJTY. Note-se a "melhoria» do acrescento de $\mathrm{R}$ ad is, transformado em adhuc a partir de BNL.

5-É claro que, perante estas inovações começadas em $\mathrm{R}$ se pode perguntar: Não se tratará antes de fragmentos genuínos, colhidos por $\gamma$ em $\alpha$ e perdidos por $\beta$ ? Já respondemos a esta questão ao terminar o estudo de $\gamma$, mostrando que há elementos pouco claros e espúrios aparecidos só em $\gamma$ e depois retocados por $\delta$ (pp. 277-279). Aliás, não é só $\gamma$ que inova: $\delta$ faz o mesmo e, dum modo geral, todos os reelaboradores com poucos escrúpulos de crítica textual.

e) 1 - A individualidade de $\delta$ prova-se não apenas pela sua contaminação de $\alpha$ e $\gamma$, revelando assim utilizar uma dupla fonte, mas ainda por processos e inovações criadas pelo próprio elaborador de $\delta$, e que não passaram a qualquer outro modelo.

Esta individualidade ressalta logo da observação externa das Commonitiones. Pode garantir-se que foi o refundidor de $\delta$ quem organizou uma antologia equivalente aos $\mathrm{nn}$. 1-40 de Rosweydus, construindo para ela um prefácio, c colocou à parte os números que lhe pareceram menos significativos. Esta segunda parte das Commonitiones só se encontra nos manuscritos 
do grupo $\delta$. A sua ligação directa a $\alpha$ está suficientemente expressa pelo facto de só aqui ter subsistido (fora de $\beta$ ) o título geral da colecção de apotegmas. Como se poderá ver no nosso aparato crítico, antes do n. I,2, lá está o título completo: Incipiunt (com)monitiones sanctorum patrum, qui in studio spiritualis uitae senuerunt, quae ad instructionem iunioribus dixerunt fratribus $\mathrm{BN}$ (cf. p. 313).

2-Em I,14 (lin. 4-5) está escrito por VD: tolleret sibi ad refectionem de ipsis cucumeribus. Observemos que este final apresenta em $\gamma$ uma versão instável: de ipsis cucumeris R: ipsos cucumeres $\mathrm{P}$. Em $\delta$, porém, manteve-se o simples acusativo, como em P, mas substituiu-se de ipsis por aliquot, ficando a expressão: aliquot (aliquos L) cucumeres NL (em B há aqui um salto de eodem ad eundem, cf. texto de I,14, lin. 3 e 5). O que importa agora salientar é que a lição de $\delta$ não foi seguida por nenhum outro arquétipo que tivesse acesso simultaneamente a $\gamma$ e $\delta$. Por isso $\eta$ e $\theta$ guardaram a lição: de ipsis cucumeris (regularizando Y, por sua conta, tanto na lin. 3 como na lin. 5, para cucumeribus).

3-Em IV,19 (lin. 51-52) lê-se: ... Creator sustinuit ut nobis exempla patientiae et humilitatis praeberet.

É certo que o organizador de $\delta$ esqueceu a palavra exempla, do que resultou uma tentativa de adaptação: ... ut nobis patientiae (patientiam N) suae maiestatis et humilitatis praeberet, em BNLU.

Outros exemplos deste tipo podem descobrir-se na segunda parte das Commonitiones, só transmitida pelos manuscritos de $\delta$. 


\section{$\mathbf{V}$-Subarquétipo $\varepsilon$}

Entre uma coleç̧ão de apotegmas de Pascásio e Pelágio, têm os manuscritos de Troyes, Bibl. Mun. 777; Dijon, Bibl. Mun. 194; Londres, Brit. Mus. add. 33518; Paris, Bibl. Nac. lat. 5624; e Valenciennes, Bibl. Mun. 168, vestígios de elementos das Commonitiones que não foram seleccionados para a antologia que constitui os nn. 1-40 da edição de Rosweydus: são os nn. V,4; III,1 e, contaminada com Pelágio X,18, a segunda parte das Commonitiones VI,6.

Temos pouco texto para colacionar e, em qualquer dos casos, com poucas variantes significativas. Deixamos aqui a lição dos manuscritos de Troyes, Dijon e Valenciennes, designados, respectivamente, por $\mathrm{T}^{1}, \mathrm{G} \mathrm{e} \mathrm{K}$. Aliás, nestes fragmentos, os três códices revelaram-se absolutamente idênticos.

A clara impressão colhida do exame comparativo do texto é que $\varepsilon$ depende apenas de $\delta$. Além disso, o copista, que se serviu de $\delta$, introduziu breves alterações.

1 - De V,4 seleccionemos um pormenor (lin. 12-15): ... sed tamquam seruo Dei et monacho offeremus haec. Respondens beatus abba Martianus dixit eis: Per quot monasteria uenistis de itinere ad nos? Qui respondens dixit ei...

Deixámos a «redondo» as palavras sobre que incidem as variantes de $\mathrm{T}^{1} \mathrm{G}$ K: sed uelut seruo Dei et monacho offerimus haec. Et ille: Per quot monasteria inde uenistis de itinere ad nos? Qui respondit ei...

Comum a $\delta$ temos apenas, aqui, a variante offerimus: BNLT $^{1} \mathrm{GK}$. As outras alterações foram introduzidas só por $\varepsilon$. 
2 - Outro passo ainda de $\mathrm{V}, 4$, abreviando a citação (lin. 17-22): Ait ergo ad eum beatus Martianus: Ecce manifestatum est quia non ut seruo Dei... Noluit ergo suscipere. Orationem pro eis intentissime faciens (...) dimisit eos.

$\mathrm{O}$ texto de $\mathrm{T}^{1} \mathrm{GK}$ é o seguinte: Ait ad eum Martianus sanctus: Ecce est manifestum quia non ut seruo Dei... Noluit ergo suscipere, sed orationem pro eis intentissime faciens (...) dimisit eos.

Iguais a $\delta$ são a nova forma (mas não a inversão) manifestum est (est om. BN) BNL: est manifestum $\mathrm{T}^{1} \mathrm{GK}$; e ainda a adição de sed $\mathrm{NLT}^{1} \mathrm{GK}$. A palavra final eos falta em BNL. Como $\gamma$ omite este apotegma, parece que só resta a hipótese de $\varepsilon$ ter recorrido a $\alpha$ ou $\beta$. Mas será este pormenor suficiente para justificar uma contaminação? O elaborador de $\varepsilon$, que omitiu, substituiu e acrescentou outras palavras, como vimos nos dois exemplos apresentados, poderia também restituir facilmente eos.

3-O exame de III,1 e da parte de VI,6 que nos interessa, não oferece panorama diferente do acabado de apresentar, confirmando-se a ausência de qualquer necessidade de um hipotético recurso a $\alpha$ ou $\beta$. 


\section{VI - Subarquétipo $\zeta$}

A primeira impressão de quem observa, do ponto de vista externo, a constituição dos códices que contêm os nn. 1-40 de Rosweydus, precedidos do prólogo Vere mundum, é a de que os três manuscritos que constituem este subarquétipo, designados pelas siglas OQX, poderiam apresentar a primitiva reelaboração desta antologia das Commonitiones. O exame crítico do texto prova, no entanto, que não é assim. Esta redacção depende exclusivamente do modelo criado pelo organizador de $\delta$. Normalmente, utilizaremos apenas os testemunhos dos manuscritos $\mathrm{OQ}$.

a) Há de facto, inovações introduzidas em $\delta$ que só passaram ao arquétipo dependente $\zeta$, isto porque os arquétipos seguintes, $\eta$ e $\theta$, tinham possibilidade de recorrer, além de $\delta$, também a $\gamma$.

$1-\mathrm{O}$ n. I,5 (lin. 1-2) começa: Referebant nobis sancti seniores patres...

Em BNLOQ, e só nestes, depois de referebant foi acrescentado: quidam.

Aproveitamos o ensejo para caracterizar desde já outros arquétipos. A palavra patres foi suprimida em ESFJTY.

2- Em IV,2 (lin. 20-21) temos o conjunto: ... compunctum est cor eius in timore et amore Domini...

Só em BNLOQ notámos a inversão amore et timore. 
3 - De V,2 (lin. 12-16) recortamos: Quod et factum est ad augmentum uirtutum eius talis occasio (...). Remoratus est autem in eodem loco...

$\mathrm{O}$ singular uirtutis encontra-se em BNLOQT; a palavra é totalmente omitida por RSFJ; e Rosweydus substituiu-a por meritorum, no que o vemos isolado.

Em vez de est autem temos em RLQXE: est ergo; e ergo est em BNOSFT. Como se vê, nesta pequena variante os manuscritos estão divididos. No meio de tal confusão, Rosweydus suprimiu, sózinho, autem.

b) Há evidentemente outras inovações introduzidas em $\delta$ que passaram a $\zeta$ e a outros arquétipos. Mas então não por influência de $\zeta$, mas antes pelo recurso directo a $\delta$. Com efeito, as alterações, embora breves, feitas por $\zeta$ não se encontram noutros modelos.

1 - Veja-se a tendência para eliminar o diminutivo cellula. Em IV,17 (lin. 36-37) ... permansit apud beatum Athanasium in cellula eius... Só em OQX é uniforme o termo cella.

$\mathrm{E}$ em V,8 (lin. 38) está: ... discedebat unusquisque fratrum in cellulas suas... Uma vez mais, escrevendo cellas, OQX estão juntos contra todos os outros (à excepção de DL, que neste ponto se afastam dos seus pares).

2 - Até em pequenos pormenores se observa o isolamento de OQX. Por exemplo, em V,3 (lin. 18) na expressão parentes ac propinqui só em OQX a copulativa ac foi substituída por $e t$, segundo os manuscritos por nós colacionados. É pois estranho que Rosweydus apresente et, embora não devamos dar a este pequeno facto estilístico especial importância.

Não vale a pena insistir num modelo de tão escassa representação e sem descendência. 


\section{VII - Subarquétipo contaminado $\eta$}

Vamos dar a este arquétipo atenção mais demorada que aos dois precedentes, pois ele encontra-se entre os modelos a que recorreu o arquétipo que serviu de base à edição de Rosweydus. Observando as lições que lhe são próprias, podemos provar que se serviu, como fontes exclusivas, dos arquétipos $\gamma$ e $\delta$. Como é natural, há ainda inovações que foram introduzidas pelo seu organizador.

Vamos utilizar apenas os manuscritos designados pelas siglas ESF. Dado que são várias dezenas os códices que cabem dentro deste arquétipo e do seguinte $(\eta$ e $\theta$ ), não é de estranhar que por vezes a sua unidade não seja total. Cremos mesmo que, se fôssemos fazer um exame minucioso de todos estes manuscritos, eles se subdividiriam, muito provavelmente, em outros arquétipos secundários. Não julgamos, porém, que tal trabalho interessasse muito ao nosso objectivo, que é, agora, o de mostrar a diferença entre o texto genuíno e o da edição até ao presente utilizada, a de $\mathrm{H}$. Rosweydus.

a) Há vários testemunhos de uma ligação directa de $\eta$ ao arquétipo $\gamma$.

1 - Em primeiro lugar, lembre-se que já apresentámos, por outros motivos, 7 exemplos nos quais $\gamma$ se prolonga directamente em ESF, a saber: I,14 (lin. 3 e 5); IV, 17 (lin. 5); V,2 (lin. 16-22); V,8 (lin. 18, 23-24 e 39); e VI,2 (lin. 29-30). E estes exemplos são, de facto, os mais significativos, pela extensão que por vezes comportam. Desçamos agora a pontos mais miúdos. 
2-Em II,2 (lin. 5) temos: ... senior consolabatur eum spiritalibus uerbis...

Emenda R para: consolabatur eum docens spiritualibus... A esta versão se ativeram ESFJY, apesar de em $\delta$ se ter introduzido a preposição: de spiritualibus BL.

3 - Mesmo em questões de vocábulos isolados se nota a preferência de $\eta$ por $\gamma$. Em IV,13 (lin. 26-27) está a frase: Sicut $t u$ insensatus es... Foi $\gamma$, como o testemunham PR, que substituiu o qualificativo por insensibilis, que só volta a encontrar-se em ESFJY.

O mesmo se passa em IV,17 (lin. 5) onde a lição justa é membranis, mas $\mathrm{CPR}$ trocaram a palavra por pergamenis, no que foram seguidos só por ESFJY.

b) A derivação de $\eta$ da fonte $\delta$ está também bastante documentada.

1 - Já anteriormente apresentámos os seguintes exemplos, a propósito da sobrevivência de $\delta$ no arquétipo $\eta$ : I,5 (lin. 1-2); I,13 (lin. 14-15); II,6 (lin. 11 e 25); e V,2 (lin. 12-16).

O facto de, por vezes, nos casos acabados de evocar, OQX estarem na mesma linha de transmissão do texto em nada afecta a prova que pretendemos agora fazer. Com efeito, é certo que OQX também dependem de $\delta$, mas constituem um arquétipo secundário à parte, ao qual ESF nada foram buscar. Daí a validade da prova agora em questão.

2-O final de I,11 (lin. 34-35) é: ... antequam lucesceret latenter fugerunt. Acrescentaram: ex eodem loco BNLESFJTY.

3 - A narração de IV,3 (lin. 12) tem o passo: ... et non cognouit eum, que foi acrescentado em $\delta$ por: quod esset imperator BLOQESFJTY. 
4 - Vejam-se mais dois acrescentos em IV,8. Temos nas linhas 4-5: ... Isaac presbyter eis ordinaretur in ecclesia (...) ubi conuenit ommis multitudo monachorum... Mas lemos em BNLESFJTY: conuenit die et hora statuta.

E um pouco mais adiante, nas linhas 6-7: Audiens autem supradictus abbas Isaac, fugit in Aegyptum. Depois de Isaac acrescentam: huiuscemodi consilium BNLESFJTY.

c) Resta-nos apresentar algumas inovações surgidas em $\eta$. Repare-se, desde já, na presença também de JTY.

$1-\mathrm{Na}$ frase de II,6 (lin. 5-6): Cum autem reuersus uenisset, ille qui egressus fuerat frater dixit ei, - faltam as palavras ille qui egressus fuerat em ESFJY.

2 - Note-se em II,7 (lin. 41-43) o acrescento que não sublinhamos: - non eis proficient (...) ad salutem animae, minime cogitantibus, orationes sanctorum, em ESFJTY.

3-O n. IV,2 (lin. 39-40) termina: ... sentimus omnem nostram uirtutem marcescere, quia approximat eis, qui humilitatis uirtutem habent, gratia diuinae potentiae. A parte da oração relativa, que deixámos por sublinhar, foi omitida só por ESFJY. Repare-se que a edição de Rosweydus em vez de marcescere escreve marcere (erro evidente na PL 73, col. 749).

4 - No apotegma seguinte, IV,3 (lin. 31-32): Post haec autem ualde honorifice salutauit eum imperator et ita egressus est, encontra-se em todos os códices, mas foi acrescentado $a b$ eo por ESFJY.

5 - Observe-se esta curiosa alteração da forma sintética de um numeral, em IV,17 (lin. 15): petebat autem in pretio eius solidos sedecim. Em ESJ temos decem et sex; e vai mais longe F: decem et septem! Mas Rosweydus restabeleceu: sedecim. 


\section{VIII - Subarquétipo $\theta$}

\section{e edição de Rosweydus}

a) O modelo fundamental de que se serviram os manuscritos que designamos por JT e Y (=edição de Rosweydus) foi o arquétipo $\eta$. Nos 5 exemplos anteriores, em que apresentámos inovações introduzidas por $\eta$, verificámos já que essas novas alterações se encontram também, quase sempre, no grupo JTY. Não haverá, pois, necessidade de provar de novo que $\theta$ provém de $\eta$.

Precisamos, no entanto, de dar um esclarecimento. Tal como prevíramos, a unidade dos três textos que estamos agora a colacionar não é total. O grupo JY aparece muito mais coeso na identidade de inovações. Quanto a $\mathrm{T}$, embora seja indubitável que ele tem muitos traços criados por $\theta$, nota-se que $\mathrm{T}$ frequentemente apresenta uma lição melhor que JY. Estudámos atentamente a sua posição. Concluímos então que $\mathrm{T}$ é um manuscrito contaminado de $\theta$, que, além deste modelo, utilizou ainda outro códice, mais perfeito, da família $\delta$. Assim se explica que $\mathrm{T}$ ora tenha os erros de $\theta$ ora seja melhor que ele.

Como dissemos, julgamos a nossa análise do stemma codicum exaustiva até ao subarquétipo $\zeta$. $\mathrm{O}$ grande número de manuscritos que nos restam com o texto equivalente aos nn. 1-40 de Rosweydus, subdividir-se-iam em vários outros grupos, a começar em $\eta$.

Feita esta advertência sobre a relativa unidade de $\theta$, a partir do momento em que estudamos a sua dependência de $\eta$, podemos agora observar o outro modelo de que $\theta$ se serviu, isto é, o arquétipo $\delta$. 
b) A influência de $\delta$ está amplamente documentada. Alguns exemplos.

1 - Em IV,2 (lin. 33-34) lemos em $\beta \gamma \delta$ JTY: Denique Dominus noster Iesus Christus per humilitatem triumphauit... A omissão Iesus é uniforme em ESF, ao passo que $\theta$ foi buscar esta palavra a $\delta$.

2 - Eis um pequeno membro de frase de IV,10 (lin. 22-24): ... afflictionem tantae infirmitatis quae me ita per tantum consumit tempus ut necessarium habeam obsequium...

A expressão per tantum consumit tempus está perfeita em TY; têm: per tanta consumit tempora ES; construiram com ablativo: tanto consumit tempore $\mathrm{F}$; e tanto tempore consumit J.

3 - Um fragmento de IV,12 (lin. 58-59): Tunc discipulus eius confessus est dicens... Esta lição de $\beta$ e $\gamma$ conserva-se em SF; mas beneficiaram para confessus est ei BNLEJTY.

4-Em IV,17 (lin. 32-33) há esta despedida: Vade cum pace, frater, ecce cum uoluntate mea habe tu ipsum codicem. Depois de ecce acrescentaram iam BNLESTY. Parece que J contaminou ecce e iam, pois escreveu etiam. Em vez de habe tu introduziu-se em PR habeto, e esta falsa interpretação foi retomada por todos até Rosweydus.

5 - Ainda um erro, talvez de origem paleográfica. Em V,3 (lin. 32) está o demonstrativo no feminino: ... ut ueniret et uideret eam ante exitum suum. Esta é a lição perfeita que JT foram buscar a $\delta$. Com efeito, mudaram aqui para o masculino eum ESFY.

c) Como vemos, quanto mais o texto se afasta dos mode$\operatorname{los} \beta \gamma \delta$, mais se deteriora. Fizemos um estudo sobre os pontos em que Rosweydus se afastava mesmo de $\delta$ e $\eta$. Isto deveria 
equivaler às inovações introduzidas por $\theta$. De facto, mesmo em minúcias foi possível encontrar concordância com $\mathrm{J}$ ou $\mathrm{T}$.

1 - Eis um final de frase de II,8 (lin. 4-5): ... abiit in illum desertum locum requirens eum. Esta leitura, exacta, permanece em T. Mas escreve J: in illud desertum abiit requirens... Além da inversão e do uso do neutro illud, note-se a omissão de locum. Pois esta última palavra falta também em Y, que cortou igualmente illum. Os leitores de Rosweydus têm só: abiit in desertum requirens eum.

2 - Agora um passo em que $\mathrm{J}$ ora se liga a $\mathrm{T}$, ora se junta a Y. Diz-se em IV,12 (lin. 31-32): At ille haec audiens dixit: gratias ago, domine, sanctae caritati tuae... Haec audiens foi substituído em Y por: respondens; haec mantém-se em JT, mas audiens dixit foi transformado só $\mathrm{em} \mathrm{T}$ : remandauit ei dicens. Uma deficiente interpretação da grafia medieval sancte (= sanctae) deu origem a um imperativo prolongado: domine sancte, em JY.

3 - No passo seguinte verifica-se que apenas a palavra Deo é inovação comum a TY (IV,9, lin. 15-16): Gratias ago Saluatori nostro Christo quia... O passo está correcto em J; mas lê-se em T: gratias ago Deo Saluatori nostro Christo quia..., e em Y: gratias ago Deo meo quia...

d) Vemos assim como o texto genuíno das Commonitiones se foi adulterando de tal modo que chegou aos leitores da Patrologia Latina cheio de cortes, acrescentos, inversões e variantes de toda a ordem.

Demos, finalmente, alguns exemplos de corrupção que só verificámos em Rosweydus, segundo a reprodução da PL 73, indicando nós a seguir à sigla Y a coluna deste volume. 
Quando citamos a Patrologia temos em mente a única edição latina da antologia das Commonitiones ainda hoje verdadeiramente acessível. Não esquecemos, no entanto, uma precaução da Prof. ${ }^{2}$ Ch. Mohrmann: as transcrições da Patrologia não são criticamente seguras; há numerosas "gralhas" tipográficas.

1 - Eis uma inversão de palavras em II,7 (lin. 32-34): ... uerumtamen si ille qui infirmatur non se abstineat a noxiis cibis, uel de aliis quae solent laedere infirmitates, nihil ei proficit... Tem Y (746): ... uerumtamen si ille qui infirmatur a noxiis cibis, uel de aliis quae solent laedere infirmitates, abstinere noluerit, nihil ei proficit...

2 - Aproveitamos um salto de $\mathrm{Y}$ para mostrar variantes noutros manuscritos em IV,12 (lin. 62-64): Haec audiens senior statim prostranit se in terram ad pedes discipuli sui... Apenas $\mathrm{Y}$ omite in terram, conformando-se em tudo o mais com a boa lição que $\eta \mathrm{e} \theta$ receberam de $\delta$. Mas há outras lições, sendo o acrescento de autem uma inovação segura de $\delta$, passada, pelo menos, a $\zeta$ : Haec autem (NLOQF) audiens (aud. haec $\mathrm{R}$ ) senior (senior audiens $\mathrm{O}$ ) statim (se $\mathrm{R}$ ) prostrauit se in terram (terra $\mathrm{CR}$ in t. om. Y) ad pedes discipuli sui...

3 - Em V,9 (lin. 11-12) lê-se no texto de quase todos: Daemones enim in specie porcorum delectabantur superflua et uana loquela corum. Só Y introduziu per antes de superflua e transformou uana loquela em uaniloquia.

Temos, pois, registadas as seguintes variantes: Daemones enim (autem R etiam E) delectabantur (per Y) superflua et uana loquela (superfluam et uanam loquelam BLE uaniloquia $\mathrm{Y}$ ) eorum.

Cremos que a insistência em manuscritos agora englobados sob os arquétipos $\eta$ e $\theta$ apenas interessaria para uma história 
completa da degradação do texto. Um trabalho desse género fizemo-lo nós para Pascásio $\left({ }^{194}\right)$, mas não nos parece necessário retomá-lo agora. Qual a diferença entre o texto autêntico e o publicado na antologia que são os nn. 1-40 do Livro III de Rosweydus ficou já suficientemente demonstrado nas transformações que vimos registando desde o exame do arquétipo $\gamma$.

(194) Cf. Pascásio de Dume... t. II, pp. 300-398. 


\section{Cap. $\mathbf{X}$ - O PRÓlOGO ESPÚRIO}

\section{VERE MVNDVM}

Desde que tivemos de estudar o prefácio de Pascásio de Dume, que dedicou a sua tradução ao seu abade Martinho, o tema dos prólogos e das cartas dedicatórias passou a constituir objecto dos nossos interesses $\left({ }^{195}\right)$.

Como vimos ao estudar os manuscritos dos arquétipos $\beta$ e $\gamma$ (pp. 22-27), isto é, os que apresentam as Commonitiones Sanctorum Patrum como uma unidade perfeitamente identificável e distinta, esta nova colecção de apotegmas não é precedida de qualquer prólogo. Tal observação deverá ser suficiente para concluir que o prólogo, introduzido em arquétipos secundários, é tardio e, portanto, estranho ao autor e ao tradutor da coleç̧ão autêntica (cf. p. 285).

(195) Cf. Pascásio de Dume..., t. I, pp. 1-5 e a bibliografia aí indicada (p. 3). Para o estudo do presente capítulo convém ter ainda presente: $R$. DrAGUET, L'inauthenticité du "Prooemium" de l' Histoire Lausiaque in Mélanges L. Th. Lefort (= Le Muséon LIX) Louvain, 1946, pp. 529-534; J. LeROY, Les préfaces des écrits monastiques de Cassien in Revue d'Ascétique et de Mystique XLII (1966) pp. 157-180 (Toulouse); Albertino Martins Fiens, Gil Vicente e o prólogo, Lisboa, 1968 (tese defendida em Filologia Clássica, na Faculdade de Letras de Lisboa); J. L. LAurenti y A. Porqueras Mayo, Notas bibliográficas sobre el prólogo en la literatura greco-latina in Estudios Clásicos, 1969, pp. 109-116; K. THRAEDE, Grundzïge griechisch-römischer Brieftopik, München, 1970; M. B. O'BRIEN, Titles of address in christian epistolography to 543 A. D., Washington, 1930; Josefina Garau Marti, Salutaciones y dedicaciones en las cartas de $S$. Cipriano, S. Jerónimo y San Agustín, Salamanca, 1965; J. O’Callaghan, El trato de "padren en la correspondencia cristiana del siglo $V$ in Boletín de la Associación Española de Orientalistas, I (1965), pp. 151-153. 
É no arquétipo contaminado $\delta$ (pp. 27-43) que pela primeira vez se faz uma colectânea, em 40 números, das Commonitiones, aparecendo precedida por um prólogo iniciado pelas palavras: Vere mundum quis dubitet meritis stare sanctorum...

Como notou A.-J. Festugière, "O género hagiográfico tem as suas regras, como qualquer outro género literário. Uma destas regras consiste em fazer preceder a narrativa, mesmo quando ela está escrita num estilo claro e simples, de um prólogo redigido com mais ênfase, onde se encontram habitualmente um certo número de lugares comuns, próprios deste tipo de composições» (195).

Obedecendo, certamente, a este critério, o organizador da antologia, em 40 números, das Contmonitiones, forjou para ela um prólogo, de acordo com as regras do estilo.

O prólogo Vere mundum é, portanto, espúrio, construído por um compilador desconhecido, antes do século IX. Com efeito, embora os mais antigos exemplares que conhecemos deste texto sejam do século $\mathrm{X}$ - nos manuscritos de Paris, Bibl. Nac., fundo latino 3784 e Berlim, Bibl. Nac. dos Tesouros da Prússia, theol. lat. fol. 275 - há um manuscrito do século IX, de Munique, Bibl. do Estado da Baviera, lat. 14364, que já nos dá 4 apotegmas da compilação publicada por Rosweydus como Livro III das Vitae Patrum (197).

Para além deste critério externo e cronológico que nos mostra ser o prólogo Vere mundum, necessariamente, muito posterior à redacção grega e à tradução latina das Commonitiones (pois foi, sem dúvida, redigido pelo organizador do

(196) A.J. Festugrère, Lieux communs littéraires et thèmes de folk-lore dans l'hagiographie primitive in Wiener Studien LXXIII (1960), pp. 123-152. Os tópicos mais frequentes nos prólogos são estudados nas pp. 124-137; c o lugar comum da esimplicidade de estilo» nas pp. 129-131.

(197) Cf. sobre os manuscritos citados de Paris e de Munique, Pascásio de Dume..., t. II, pp. 68-69, 192; e 187, 209; sobre o ms. de Berlim, cf. a descrição feita neste livro, supra, pp. 27-33. 
arquétipo $\delta$ ), o exame interno da sua contextura demonstra também tratar-se de um arranjo secundário, feito por um plagiador.

O único autor que, até ao presente, se ocupou da génese e estilo do prólogo Vere mundum foi H. Rosweydus. Embora sejam falsas as suas conclusões quanto ao autor do prólogo, revelam-se muito pertinentes as suas observações estilísticas $\left({ }^{198}\right)$.

Como já tivemos ocasião de expor (p. 103), Rosweydus pensava que o seu Livro III fora originalmente escrito em latim ou pelo menos traduzido do grego por Rufino. Um dos argumentos em que se baseia consiste em provar que o prefácio do Livro III tem um estilo semelhante ao do Livro II ou Historia Monachorum - que Rosweydus pensava ser também de Rufino $\left(^{199}\right)$; o outro argumento é o facto de tanto o prólogo do Livro II como o do Livro III revelarem influência do proémio de Paládio à História Lausíaca $\left({ }^{200}\right)$.

Vimos já (pp. 103-104 e 120-121) que Rufino não pode ser o autor nem o tradutor das Commonitiones Sanctorum Patrum. Mas Rosweydus tinha razão quando argumentava que o prólogo Vere mundum foi escrito por quem conhecia o prefácio da Historia Monachorum e a carta de Paládio a Lauso, a ponto de esta última ter sido literalmente copiada na parte final. Julgamos ser nosso dever aproveitar, confirmar e desenvolver os indícios apresentados por Rosweydus.

No prólogo da Historia Monachorum (servimo-nos da edição da PL 21, coll. 387-390, indicando também as linhas donde transcrevemos) reflectem-se as seguintes ideias que

(198) H. Rosweydvs tratou deste prólogo nas suas Vitae Patrum, Prolegomenon V e nas anotações 2 e 3 ao seu Livro III (cf. PL 73, coll. 38-39 e 809-811). pp. $50-51$.

(199) Sobre os problemas de autor e tradutor da Historia Monachorum, cf. supra

(200) Sobre os problemas relativos à História Lausíaca, cf. supra pp. 53-56. 
hão-de ser mais tarde retomadas pelo abreviador das Commonitiones Sanctorum Patrum:

- a narração da vida dos santos padres servirá de exemplo à posteridade: ad posteritatis memoriam profutura (lin. 2-3);

- servirá, para os leitores, de doutrina e exemplo: nobis causa salutis (lin. 3); ex historia exemplum salutis atque doctrina pietatis aptissima (lin. 3-4); aedificationem futuram legentibus (lin. 11);

- os santos trocaram os prazeres do mundo pela vida sacrificada nos desertos: horrescere quidem saeculi illecebras (lin. 12); nihil terrenum, nihil carnale cupiunt (lin. 22); commanent autem per eremum dispersi et separati cellulis (lin. 27); hi nullam cibi aut indumenti aut illius horum sollicitudinem gerunt (lin. 31-32); plures autem et egregii per erenum dispersi (lin. 45);

- o estilo será simples e não acomodado à grandeza dos heróis da santidade: praecelsas uirtutes humili narrare sermone (lin. 7); aggrediar non tam ex stylo laudem requirens (lin. 10-11);

- a sua santidade é tal que alcança a misericórdia e o perdão de Deus para o mundo pecador: ... ut dubitari non debeat ipsorum meritis adhuc stare mundum (lin. 41-42).

Veja-se uma condensação de todos estes tópicos, a começar quase literalmente pelo último, na seguinte selecta do prólogo construído para preceder a antologia das Commonitiones:

Vere mundum quis dubitet meritis stare sanctorum(...) qui omnem luxuriae notam tota mente fugerunt, mundoque relicto eremi uasta secreta rimantur(...). Non ergo spernas simplicitatem et impolitos sermones(...), mei operis est (...) ut legentibus posteris conferrent ueritatis doctrinam et exempla salutis.

Poderá dizer-se que se trata de tópicos frequentes nos prefácios, sem ser necessário postular cópia de um trabalho anterior? Essa hipótese não serve, pelo menos, para as primeiras 7 palavras acabadas de transcrever. 
Há, porém, uma prova mais evidente de que o elaborador do Livro III de Rosweydus construiu um prólogo com materiais anteriores. Mais de metade da sua prosa, após o arranque inicial, é tirada textualmente de uma tradução da carta de Paládio a Lauso.

Encontra-se numa situação delicada a tradução latina desta carta. Rosweydus editou três séries de prólogos a preceder as suas três versões da História Lausíaca: uma tradução de Gentianus Hervetus (PL 73, col. 1087-1088); outra, antes do Heraclidis Paradisus (PL 74, coll. 249-252); e a terceira, antes da Palladii Lausiaca (PL 74, coll. 343-344). Mas Rosweydus conhecia ainda uma quarta tradução, pois a ela se refere explicitamente na nota 2 ao seu Livro III - é a que começa pelas palavras: Beatifico et admiror propositum tuum... E na nota 3 reproduziu esta versão (PL 73, coll. 810-811). Infelizmente, a edição de Rosweydus não é completa na transcrição da carta de Paládio a Lauso, segundo o trabalho deste quarto tradutor. Assim como nos falta uma edição crítica das duas versões latinas antigas da obra de Paládio, cremos que também desta quarta tradução do prefácio não há ainda um texto completo e rigorosamente estabelecido.

Não é aqui o lugar apropriado para editar a carta-prefácio iniciada pelas palavras Beatifico et admiror. Vamos apenas transcrever a sua parte final, segundo o manuscrito de Berlim, Biblioteca Nacional dos Tesouros Culturais da Prússia, ms. 780, theol. lat. fol. 275, do século X, fl. 91v:

Non ergo spernas simplicitatem et impolitos sermones, nec enim operis est diuinae doctrinae sophistice et eloquenter signare sermones, sed suadere mentes hominum in fide et operibus ueritotis, secundum quod scriptum est: "Aperi os tuum uerbo Dei»; et iterum: "Non spernas narrationem seniorum, et ipsi enim didicerunt a patribus». Denique sanctorum, id est, patriarcharum et prophetarum, Abraham scilicet et Isaac et Iacob, Moysi et Eliae et Ioannis, ideo descripta est fides et conuersatio non tantum ut illos glorificarent, quos certe Dominus glorificauerat et in regno suo gloriosos habebat, 
sed ut legentibus posteris conferrent ueritatis doctrinam et exempla salutis.

Salta imediatamente à vista que o organizador do prólogo Vere mundum, a partir de Non ergo spernas..., não se limitou apenas a inspirar-se em Paládio: copiou quase literalmente o fim da sua carta.

Ficaram, no entanto, marcas da dependência do seu trabalho - e até da sua imperícia. Note-se que as duas citações bíblicas, aduzidas por Paládio, foram suprimidas; a expressão id est mudou de lugar; e Dominus foi substituído por Deus. Estes dois últimos pontos têm pouca monta; o primeiro revela um abreviador.

Mais importante é um outro pormenor, só perceptível por quem coteje o prólogo Beatifico et admiror com o do Livro III de Rosweydus: Vere mundum. Em Paládio, a palavra patribus é o fim de uma citação do Eclesiástico, cap. VIII,11; e o elaborador do prólogo Vere mundum fez de patribus um princípio de frase! $\mathrm{O}$ conjunto resultante: patribus denique, deu que fazer aos copistas... O ablativo patribus não se enquadra bem dentro da sintaxe da frase. Por isso, muitos alteraram para patrum, genitivo que colocaram a concordar com sanctorum... A transmissão manuscrita primitiva $-\mathrm{e}$ daqui ressalta uma vez mais o valor originário do arquétipo $\delta$ (e $\zeta$ dele só dependente) - mantém-se, no entanto, fiel ao ablativo patribus. Veja-se como um pequeno erro ou descuido atraiçoou o forjador do prólogo Vere mundum!

Não restam, pois, dúvidas de que este prefácio não é do autor nem do tradutor das Commonitiones. Um compilador tardio seleccionou os principais apotegmas e fê-los preceder de um prólogo; mas assim como rebuscou narrativas, foi também colher à tradução da Historia Monachorum e da Palladii Lausiaca a inspiração e as palavras para o seu arquitectado prefácio. Por isso, não temos nós outra solução que não seja a de afastar o prólogo Vere mundum do texto das Commonitiones. 
Antes de fornecermos o texto crítico deste prólogo espúrio, digamos ainda uma palavra sobre a pretensa pessoa a quem a obra é dedicada - repare-se no vocativo: mi domine Fidose.

Quem é este Fidosus? O problema foi atentamente estudado por Rosweydus. A sua investigação dirige-se pelo caminho recto; só a conclusão é falsa, por carência de dados críticos.

Pensou Rosweydus (cf. PL 73, col. 811) que Fidosus poderia ser uma transliteração do grego, um antropónimo como Fidus e Fidelius. Depois, ao ver a influência de Paládio neste prólogo, reparou que, tanto na carta a Lauso como na Historia, aparece algumas vezes o epíteto fidelissimus dirigido a Lauso. «Parece-me, conclui Rosweydus, que Rufino escreveu Fidosus em vez de fidelissimus, e assim alude, de modo velado, a Lauso».

Como sabemos, Rufino não tem nada que ver nem com as Commonitiones nem com o prefácio Vere mundum. A criação do vocativo fidose, é obra do autor deste prólogo artificial. É possível que se inspire no fidelissime Lause de Paládio. Mas que é então fidosus? Não é, por certo, um nome próprio; não representa também qualquer destinatário concreto do prólogo ou da colecção de apotegmas. É apenas um adjectivo, forjado pelo autor deste prefácio, talvez por corruptela de uma abreviatura do tipo fid'lause. Em rigor, não significa nada nem ninguém. A sua origem encontra-se apenas na imitação desajeitada de um belo e nobre fidelissime Lause. Mas quem escreveu pela primeira vez, mi fidose, não tinha ninguém em mente. Disso podemos estar seguros.

E com a destruição da autenticidade do prólogo Vere mundum acabamos de desmantelar toda a obra que é o Livro III de Rosweydus. Trabalho negativo apenas? - Não. A prová-lo aí estão, restituídas pela primeira vez desde o século XIV, - que deverá passar a ser considerado como o "autêntico 
Livro III das Vitae Patrum» - as Commonitiones Sanctorum Patrum.

Pode o leitor saltar por cima do prólogo espúrio - e começar a leitura amena dos "conselhos dos santos padres, que foram envelhecendo no exercício da vida espiritual, conselhos que eles davam, para edificação, aos irmãos mais novos».

Ainda agora obra de edificação?-Q Que o seja! Mas obra também da laboriosa filologia. 


\section{Texto crítico do prólogo \\ Vere mundum...}

Vere mundum quis dubitet meritis stare sanctorum, horum scilicet quorum in hoc uolumine uita praefulget, qui omnem luxuriae notam tota mente fugerunt, mundoque relicto eremi uasta secreta rimantur, ibique, per terribiles rupes formidolosis antris excubantes, nec esuriunt nec sitiunt, quia dextera Dei sustentat eos et pascit. Horum meritis subleueris; horum supplicationibus, indulgentiam peccatorum merearis, $\mathrm{mi}$ domine fidose.

Non ergo spernas simplicitatem et impolitos sermones, nec enim operis est diuinae doctrinae sophistice et eloquenter

\section{INCIPIT - BNLOQESFJTY}

Incipit liber secundus Deo adiuuante. Prologus B Incipit prologus librisecundi $\mathrm{N}$ Incipit secundus $\mathrm{L}$ Incipit liber secundus. Prologus $\mathrm{O}$ Incipit prologus in secundam partem uitis patrum $\mathrm{Q}$ Incipit liber secundus de uita (de u. om. F) sanctorum patrum EF Incipit prologus $S$ Incipit prologus libri sequentis J Incipit prologus in uitas patrum $\mathrm{T}$ Prologus $\mathrm{Y}$.

1 dubitat $\mathrm{S}$ meritis] orationibus $\mathrm{N} 2$ scilicet] uidelicet $\mathrm{J}$ praefulgit $\mathrm{B} \quad 3$ fugierunt $\mathrm{B}$ mundumque relictum $\mathrm{B}$ 4 uasta] om. $\mathrm{O}$ et add. Q rimantur] et add. L $\left.5 \mathrm{nec}^{1}\right]$ non $\mathrm{Y}$ nec sitiunt] neque s. Y om. B 5-6 quia dextera Dei sustentat cos et pascit] q. d. D. (Domini Q) s. et p. e. (eos et p. Q) BQESFJY om. N 7 horum supplicationibus] supplicationibusque $\mathrm{N}$ indulgentiam peccatorum] $\mathrm{p}$. (om. LQ) ueniam BESFTTY merearis] sub- F 8 fidose om. J 9 simplicitate B impolitos] impolito B 9-10 impolitos... et om. Q 10 enim] mei add. Y diuinae doctrinae] diuini (-a B) d. (-a S) BNS Scripturaeque add. Y sophisticae NS eloquenter] loquenter B eloquentiae N 
signare sermones, sed suadere mentes hominum in fide et operibus ueritatis. Patribus denique sanctorum patriarcharum et prophetarum, id est, Abraham et Isaac et Iacob, Moysi et Eliae et Ioannis, ideo descripta est fides et conuersatio, non tantum ut illos glorificarent, quos certe Deus glorificauerat et in regno suo gloriosos habebat, sed ut legentibunt posteris conferrent ueritatis doctrinam et exempla salutis.

12 patribus denique] patrum d. (ergo J) NOFJTY $\left.13 \mathrm{et}^{2}\right] \mathrm{om}$. BNQFTY 14 descripta est fides] e. f. d. Q fides on. F et ${ }^{2} \mathrm{om} . \mathrm{F} \quad 15$ illos glorificarent] illi glorificarentur (-centur J) NJ in illis g. O i. glorificent (-caremus Y) QY certe om. J glorificauerat] -auit J 15-16 et... habebat om. J 16 suo om. B 16-17 conferrent] -ntur $\mathrm{N}$-ferat J 17 doctrina $\mathrm{N}$ salutis] Explicit prologus NT. 
COMMONITIONES SANCTORVM PATRVM

I I

TEXTO CRÍTICO 


\section{SIGLA ET MANVSCRIPTI}

V - Vindobonensis, Bibl. Nat. Austriae 433, saec. xI, ff. 113 v-165 r

D - Dresdensis, Bibl. Nat. Saxoniae, A 207, saec. xIv, ff. 188 r-216 v

R - Remensis, Bibl. Munic. 1400, saec. XIII, ff. 98 r-107 r

N - Namurcensis, Museum Archaeologicum 12, saec. XII-XIII, ff. 74 r$-84 \mathrm{v}$

$\mathrm{N}^{2}$-idem, sed ff. $108 \mathrm{v}-112 \mathrm{r}$ 
INCIPIVNT

\section{COMMONITIONES SANCTORVM PATRVM}

QVI IN STVDIO SPIRITALIS VITAE SENVERVNT, QVAE AD INSTRVCTIONEM IVNIORIBVS DIXERVNT FRATRIBVS

INCIPIVNT CAPITVLA

I - Quidam sanctorum patrum interrogantibus se monachis de abstinentiae ratione respondit quae competebant.

II - De beato Ioanne qui cognominabatur Colobus.

III - Interrogatio fratrum ad ipsum Ioannem de abstinentia.

IV - De seniore qui per multos annos in eremo habitabat et de responsione eius.

$\mathrm{V}-\mathrm{De}$ monacho quem statim a prima hora pellebant ita eum daemones ut famem nimiam et defectionem corporis pateretur.

VI - De quodam sancto seniore quem rogabant fratres ut cessaret de magno labore, et responsio eius.

VII - De reprehensibili abstinentia monachi in cella.

VIII - De expositione sancti Poemenii.

IX - De principe cocorum Nabuchodonosor.

$\mathrm{X}-\mathrm{De}$ abbate Beniamin qui obtulit oleum sancto seniori.

I - INCIPIVNT - VD om. RN

1 incipit D 2 commotio D 3 senuerint D 4 quam D I-XVII : quamquam textum habeat, numerationem capitulorum omittit D 7 abstinentia D 12 eius om. D 13 pellebant $\mathrm{om}$. V 19 Pomenii D 
$\mathrm{XI}-\mathrm{De}$ monachis qui ad uisitandum eremitas perrexerunt.

XII - De abbate Nitera qui fuit discipulus abbatis Siluani. 25 XIII - De sanctis duobus senioribus qui reficere obliti sunt.

XIV - De abbate Zenone.

XV - De doctrina abbatis Dioscori.

$\mathrm{XVI}$ - De interrogatione fratrum ad abbatem Ioseph.

XVII - De susceptione peregrinorum sanctorum patrum.

INCIPIVNT

\section{MONITA SANCTORVM PATRVM}

1 - Quidam sanctorum seniorum patrum interrogantibus se monachis de causa abstinentiae dixit: Oportet, filioli, ut odio habeamus omnem requiem praesentis uitae, siue delectationes corporeas ac uentris suauitatem, et honorem ab hominibus non

5 requiramus, et dabit nobis Dominus Christus caelestes honores et requiem in uita aeterna gloriosamque laetitiam cum angelis sanctis.

Idem autem senior dixit: Quia naturaliter inest homini esurire. Oportet autem sumere cibum ad necessitates corporis

24 Nitera] Nitria D

I-VDN om. R

30 sanctorum patrum om. D

$1-$ VDRN

1 quidam... patrum om. $\mathrm{R} \quad 2$ ut om. $\mathrm{R} \quad 4$ corporis $\mathrm{R}$ et honorem om. D non om. N 5 nobis Dominus Christus] C. D. n. D n. D. Christo R 6 uitam aeternam R 7 sanctis] suis $\mathrm{N} \quad 8 \mathrm{idem}]$ iste $\mathrm{D}$ autem] enim $\mathrm{R} \quad 9$ necessitatem $\mathrm{R}$ corporeas D 
sustentandas, non tamen in passionem seu saturitatem uentris. 10 Nam et somnus naturaliter inest homini, sed non in satietatem siue resolutionem corporis, quo possimus humiliare passiones ac uitia carnis. Satietas enim somni mentem, sensumque hominis stupidum, pigrumque reddit. Vigiliae autem tam sensum quam etiam mentem nostram subtiliorem ac puriorem efficiunt. Ita enim et sancti patres dixerunt quia uigiliae sanctae purificant et illuminant mentem. Sed etiam irasci naturaliter inest homini, sed non in commotione passionis, sed ut irascatur contra semetipsum ac uitia sua, ut facile emendare et a se abscidere possit. Necnon etiam si quid prauum et contra praecepta Dei uideamus alios agere, oportet nos contra uitia quidem eorum irasci, ipsos uero diligenter corripere et increpare ac monere, ut emendati saluentur et ad uitam aeternam perueniant.

2-Dicebant etiam sancti patres de sancto abbate Ioanne, qui cognominabatur Colobus, quia cum de messis opere reuerteretur ualde fatigatus repraesentabat se sanctis senioribus, factaque cum eis oratione statim pergebat ad cellulam suam;

10 sustentandas] -do $\mathrm{R}$ sustendas $\mathrm{D}$ passione $\mathrm{D}$ se $\mathrm{u}$ ] in add. $\mathrm{R}$ saturitatem] p. corr. $\mathrm{R}$ te $\mathrm{D} \quad 11$ inest naturaliter $\mathrm{R}$ 12 siue] seu $\mathrm{N}$ resolutionem] reuolutionem $\mathrm{N} \quad 14$ stupidum] stolidum $\mathrm{R} \quad$ reddet $\mathrm{V} 17$ etiam] et $\mathrm{N}$ irasci] ira $\mathrm{D}$ 18 commotionem R 18-19 sed ut irascatur contra semetipsum ac uitia sua ut] s. ut irasceretur c. s. ut u. sua D s. irasci oportet semetipsum c. u. s. ut $\mathrm{N} \quad 19$ a se] om. D ab se R 20 praua $\mathrm{R}$ 21 Dei praecepta $N \quad 21-22$ oportet nos contra uitia quidem eorum irasci] quidem om. D om. $\mathrm{R}$ 23-24 perueniant] ueniant $\mathrm{R}$

\section{2- VDRN ${ }^{2}$}

Incipit: incipiunt monitiones sanctorum patrum, qui in studio spiritualis uitae senuerunt, quae ad instructionem iunioribus dixerunt fratribus $N \quad 1$ etiam] autem $D$ patres] fratres $R \quad 2$ quia] qui $R \quad 3$ reuertebatur $R \quad$ repraesentabat]- asset $D$ repressi $R$ se om. R sanctis om. D 4 factaque] facta DR cellulam] cellam D 
5 et per multa tempora in silentio uacabat orationibus et lectionibus ac meditationibus Scripturarum sanctarum; et opera manuum cottidie exercens nullum ad se permittebat uenire.

Dicebat enim quoniam per occasionem in messis opere dispergitur et per uacationem patitur mentis intentio et ideo

10 diuersis cogitationibus obligatur. Addebat autem sibi magis abstinentiam dicens: Quia propter laborem messis in diebus illis cottidie panem in saturitate edebam, nunc autem quoniam in cellula mea quiesco, oportet me abstinentiam et uigilias addere ut compensetur et reparetur quod in illis diebus

15 intermissum est.

3-Quidam ex fratribus interrogauerunt hunc ipsum beatum Ioannem de causa abstinentiae et respondit eis dicens: Quia Daniel propheta dixit: «Panem in concupiscentia non comedi».

5 Dicebat etiam monendo fratres: Considerate, dilectissimi, quoniam nihil fortius est in bestiis leone et tamen propter

I,3 lin. 3-4 : Panem... comedi - cf. Dan. X, 3.

5 multum tempus $\mathrm{R}$ orationi $\mathrm{R} \quad 6$ meditationi $\mathrm{N}$ sanctarum Scripturarum RN 7 nullum] ullumque $\mathrm{R} \quad 8$ quoniam] cum add. $\mathrm{N} 9 \mathrm{et}^{1} \mathrm{om}$. $\mathrm{N}$ per uacationem] p. uagationem VN praeuaricationem $\mathrm{R}$ et ideo on. $\mathrm{R} 10$ obligata $\mathrm{R}$ magis sibi N 11 labores $\mathrm{R} \quad 12$ saturitate] $p$. corr. $\mathrm{R}$-em V satictate D 13 cellula] cella $\mathrm{D}$ me] in add. $\mathrm{R}$ abstinentia $\mathrm{R}$ uigiliis DR 14 compensentur D reparentur D 15 est] $\mathrm{dc}$ abstinentia add. $\mathrm{N}$

$$
3-\mathrm{VDRN}^{2}
$$

Incipit: de abstinentia eius $\mathrm{N} \quad 1 \mathrm{ex}$ ] de $\mathrm{R} \quad 2$ beatum om. $\mathrm{R}$ respondens eis dixit $\mathrm{R} \quad 5$ dicebat] enim add. $\mathrm{R}$ etiam] enim $\mathrm{N}$ 
uentrem suum cadit in laqueum et illa feralis et magna fortitudo eius humiliatur.

Tali etiam exemplo ipse beatus Ioannes instruebat fratres dicens: Quoniam si uoluerit imperator aliquam aduersariorum obtinere ciuitatem, eis prius subtrahit cibaria et ita fame ac penuriae necessitate contriti humiliantur et subiciuntur imperio eius. Similiter etiam passiones ac uitia corporis nostri: Si fame ieiuniorum atque uigiliarum labore macerentur, tunc etiam aduersariorum nostrorum daemonum humiliatur uirtus, quam per corporis nostri fortitudinem contra nos exercere solent.

4-Erat quidam senior in eremo interiore per multos annos in abstinentia et in omni studio spiritali nimis laborans. Aduenientesque ad eum quidam fratres admirati sunt dicentes: Quomodo toleras istum tam aridum et squalidum locum, pater ? Quibus ille respondens ait: Omnis labor totius temporis quo hic degeo nondum unius horae aeternorum tormentorum gehennae spatium habet. Oportet enim nos in paruo tempore uitae istius sustinere laborem et macerare passiones corporis nostri, ut inueniamus in illo futuro et aeterno saeculo, quod numquam deficiet, perpetuam repausationem.

7 laqueum] lacum $\mathrm{R} \quad 7-8$ magna fortitudo] magnitudo $\mathrm{R}$ 9 ipse om. N fratres om. DN 11-12 eis... penuriae] om. VD prius aquam tenet et escas eorum qui sunt in ciuitate et $\mathrm{N} 12$ necessitate] famis add. $\mathrm{V} \quad 13 \mathrm{ac}$ ] et $\mathrm{R} \quad 14$ ieiuniorum] nostrorum add. $\mathrm{R}$ atque] ac $\mathrm{R} \quad 15$ humiliatur daemonum $\mathrm{N}$

$$
\text { 4-VDRN }
$$

Incipit: de abstinenti seniore $\mathrm{N} \quad 1$ eremo om. $\mathrm{R} \quad 2$ et om. $\mathrm{R}$ spirituali $\mathrm{N} \quad 3$ aduenientesque] aduenientes autem $\mathrm{N}$ 4 istum tam aridum et squalidum locum] i. t. a. et calidum 1 . D in illo tam arido loco et squalido $\mathrm{R} \quad 6$ degeo] dego $\mathrm{N} \quad 7$ spatium om. $\mathrm{R}$ enim] inquit add. $\mathrm{N}$ in paruo nos $\mathrm{N}$ tempore] spatio $\mathrm{D} 9$ et om. $\mathrm{N} 10$ deficit $\mathrm{R}$ perpetuam] aeternam $\mathrm{N}$ repausationem] reparationem $R$ 
5-Referebant nobis sancti seniores patres de quodam fratre dicentes: Quoniam quodam tempore ita impugnabant eum daemones, ut statim prima hora tantam famem et defectionem corpori eius facerent, ut penitus sustinere non possit. Verumtamen ille dicebat in corde suo: Quia qualitercumque oportet me uel usque horam tertiam exspectare et postea cibum sumere. Cumque facta fuisset hora tertia item dicebat cogitationibus suis: Etiam et nunc uiolenter oportet me sustinere usque ad horam sextam. Cumque aduenisset

10 hora sexta infundebat panem aqua dicens: Dum hic panis infunditur oportet me etiam horam exspectare nonam. Cumque hora nona aduenisset, secundum consuetudinem complebat omnes orationes et psalmodiam secundum regulam et ponebat panem ut comederet. Hoc ergo per plurimos dies sustinuit.

15 Quadam ergo die similiter ab hora prima usque ad horam nonam fecit. Cumque hora nona sedisset ut cibum caperet, uidit de sportella, ubi panis, id est, paximatia reposita erant, surrexisse fumum magnum et egressum esse per fenestellam cellulae eius. Itaque ex illo die nec esuries nec defectio corporis

20 eius facta est. Sed magis ita corroboratum est in fide et abstinentia cor cius, ut etiam nec post biduum delectaret eum cibum accipere. Ita Dei gratia auxiliante certamini eius, per

\section{5-VDRN}

Incipit: de fratre qui ante horam comedebat $\mathrm{N} \quad 1$ referebant] quidam add. $\mathrm{N}$ nobis om. $\mathrm{R}$ seniores] seniles $\mathrm{N} 2$ ita om. $\mathrm{R} 3$ prima hora] h. p. $\mathrm{R}$ h. diei p. $\mathrm{N} \quad 5$ ? posset DRN 7 postea] tunc $\mathrm{RN}$ hora om. $\mathrm{N}$ item] ita $\mathrm{V}$ om. $\mathrm{R} 8$ dicebat] in add. $\mathrm{R}$ etiam] ecce $\mathrm{R} \quad$ 8-9 uiolenter oportet me] u. om. $\mathrm{D}$ o. me u. $\mathrm{R} 9$ adueniret $\mathrm{N} 10$ panem] in add. DR 11 horam om. $N \quad 12$ nona om. $\mathrm{R}$ aduenisset] uenisset $\mathrm{R}$ complebat] ex- D $13 \mathrm{et}^{1}$ ] ut $\mathrm{R} \quad 14$ ergo] autem N 15 quodam $\mathrm{N}$ horam om. $\mathrm{N} 17$ erant] erat VDN 18 fenestellam] fenestrellam DN 19 eius] suae R nec ex illa die D esuriens DR 19-20 corporis eius] e. c. $\mathrm{R} \quad$ c. ei $\mathrm{N}$ 
patientiam suam extinxit gastrimargiae, id est, gulae concupiscentiae, passionem.

6-Quendam sanctorum seniorum rogabant fratres dicentes ut iam cessasset de magnis laboribus quos in studio uitae spiritalis semper habuit. Ille autem respondit eis dicens: Credite mihi, filioli, quia Abraham, Isaac et Iacob, sancti patriarchae, et omnes sancti poeniteri habent in illo futuro beato saeculo uidentes illa inenarrabilia dona Dei, magna et ineffabilia bona, quae praeparauit Deus diligentibus se et custodientibus praecepta eius, quapropter non amplius operati sint bona opera et addiderint in studio sanctae uitae, dum in isto saeculo fuerunt.

7 - Dicebant etiam fratres de quodam fratre habitante in loco qui dicitur Cellia: Contigit autem ut in die festo omnes monachi in ecclesiam, quae est in eremo, conuenirent. Praeparatus est autem eis omnibus cibus coctus, ut post completas missas ibi reficerent omnes fratres. Erat autem ibi quidam frater et cum sedissent ad mensas uocauit fratrem, qui eis ministrabat, et dixit ei: Defer mihi salem, ut cum pane

I,6 lin. 7-8 : quae praeparauit...praecepta eius - cf. I Cor. II, 9; Deut. VII, 9.

23 patientiam] enim add. R suam] frater add. RN extinxit] superex-D

\section{6- VDRN ${ }^{2}$}

Incipit: de quodam sene $\mathrm{N} \quad 2$ cessaret DN 3 spiritualis $\mathrm{N} 4$ lacob] et add. $\mathrm{N} 5$ poeniteri] -re RN om. $\mathrm{D}$ beato om. $\mathrm{N} 6$ dona Dei magna et ineffabilia] d. D. et $\mathrm{m}$. i. $\mathrm{R}$ om. $\mathrm{N} 7$ praecepta] mandata D 8 non om. R sunt RN 9 addiderint] -erunt RN audierint D studium $\mathrm{R}$

\section{$7-\mathrm{VDRN}^{2}$}

1 etiam om. D 2 in die festo ut $\mathrm{N} \quad 4$ omnibus om. $\mathrm{R}$ R 5 reficerentur $\mathrm{D}$ disset $\mathrm{N}$ mensam $\mathrm{R}$ 
possim accipere. Tunc clamauit ille, qui ministrabat, alio fratri, audientibus cunctis, dicens: Da huic modicum salis ut

10 possit hic frater cum pane edere, quia coctum cibum non accipit. Tunc surrexit a mensa unus ex senioribus et dixit ei: Oportebat te, frater, in cella tua hodie carnem comedere quam istam talem uocem de tua abstinentia praesentibus cunctis dicere fratribus. An ignoras quoniam, si qui propter

15 laudem et gloriam palam faciunt abstinentiam suam, omnem laborem abstinentiae suae perdunt et non percipiunt mercedem a Domino, sed magis culpabiles inueniuntur in conspectu eius ?

8 - Solebat beatus abbas Poemen exponere fratribus de Scripturis prophetarum ubi dicit: "Quia nisi princeps cocorum Nabuchodonosor regis uenisset in Hierusalem utique non fuisset igne incensum templum Domini». Hanc autem para-

5 bolam ex hoc exemplo ita exponebat spiritaliter dicens: Quia et nos cum pulsauerit spiritus gastrimargiae, id est, gulae concupiscentia in aliquas delectationes ac saturitatem uentris, si qui sint obaudientes atque explentes uoluptates ac desideria

I,8 lin. 2-4 : Quia nisi... Domini-cf. IV Reg. XXV, 8-9.

8-9 alio fratri] -um -em DR -is -ibus $\mathrm{N} \quad 9$ huic] huc $\mathrm{V}$ 10-11quia... tunc om. $\mathrm{N} 11$ surrexit... senioribus] s. quidam senum $\mathrm{N} 12$ oportebat te] expedierat tibi $\mathrm{N}$ frater om. $\mathrm{N}$ hodie in cella tua magis carnes $\mathrm{N} 14$ dicere] dare $\mathrm{D}$ quoniam] quia $\mathrm{R}$ si om. D 15 gloriam] hominum add. $\mathrm{R}$ palam om. N 16 perdent $\mathrm{R} \quad 17$ magis] et add. R

$8-$ VDRN $^{2}$

Incipit: de abbate Poemen $\mathrm{N} \quad 1$ solebat] uolebat $\mathrm{D} \quad 2$ dicitur $\mathrm{N}$ nisi] Nabuzardam add. D 3 utique om. D 4 igni $\mathrm{R}$ incensum] suc- DN 5 exemplo] templo D spiritualiter $\mathrm{N}$ 6 nos] non add. R cum om. R 7 concupiscentiae D saturitatem] suauitatem $\mathrm{R} \quad 8$ qui] quos $\mathrm{R}$ quis $\mathrm{N}$ sint om. DRN obaudientes] -ens $\mathrm{N}$ obedientes $\mathrm{R}$ explentes] explens fuerit $\mathrm{N}$ uoluptates] uoluntates DN 
gulae, tunc incendetur igne libidinis templum Domini, id est, corpora nostra, sicut dicit Apostolus: «Nescitis quia corpora 10 uestra templum Dei est?" Si quis ergo uiolauerit templum Dei, disperdet illum Dominus.

9-Referebat abbas Beniamin: Quia quodam tempore ego et presbyter de Cellia applicuimus ad quendam seniorem habitantem in eremo Sceti et obtulimus ei modicum olei. Ille autem dixit nobis: Ecce illud modicum uasculum, quod ante triennium dedisti mihi, sic plenum manet usque hodie.

Nos autem haec audientes diximus ei: Et quapropter, pater, uel in diebus festis non gustasti de ipso oleo? Et respondens dixit nobis: Ideo nolui percipere ex eo ne forte consuetudo mihi fiat et requiram de suauitate olei conditos cibos et per occasionem suauis conditurae compellar descendere ad ciuitatem seu ad uicos emere oleum et reuerti ad eremum, iterumque descendere et reuerti ad cellulam meam et per hanc, ut dixi, occasionem descendendi et ascendendi incipiat uagare mens et sensus meus et perdam utilitatem secretioris uitae. Diabolus enim multiformis est et diuersa retia texit ut 15 capiat hominum mentes.

I, 8 lin. 10-11 : Nescitis... Dei est - cf. I Cor.: III, 16; VI, 15; VI, 19.

9 gulae] fecerit add. $\mathrm{R} \quad$ incendetur] -ntur D -itur R 11 uestra] nostra $N$ Dei est] est Dei $R$ Domini est $N$ Dei sunt $D$ 12 Dei] Domini RN illum] eum R Dominus] Deus D

9- VDRN ${ }^{2}$

2 Cellia] cella V 3 olei] oleum $\mathrm{R}$ om. D 4 ille... modicum om. D 5 dedistis $\mathrm{R} \quad 7$ non om. D et respondens om. R 8 nobis... eo om. R 9 conditos] editos $\mathrm{R}$ 10 per] hanc add. $\mathrm{R}$ conditurae $p$. corr. $\mathrm{R} 12$ cellulam] cellam $\mathrm{N} 13$ ut dixi occasionem] ut diximus o. $\mathrm{R}$ o. ut $\mathrm{d}$. $\mathrm{N}$ uagari $\mathrm{N} 14$ sensus meus et mens mea $\mathrm{N}$ utilitatem] humilitatem $\mathrm{N}$ 
Igitur nos haec audientes admirati sumus prudentiam et conuersationem sancti senioris.

10 - Item referebat nobis idem abbas Beniamin quia perrexissent ad quendam senem, qui tenuit eos ad refectionem et parauit eis lenticulae cibum coctum. Misit autem in condituram oleum, quod de semine raphanorum in locis illis solet

5 fieri. Nos autem diximus ei: Pater, magis de alio bono oleo mitte, ut possimus comedere. Ille autem hoc audiens et signo crucis se signans dixit nobis: Et est aliud oleum praeter ipsum? Ego hoc numquam audiui.

Erat enim ipse senior ex infantia sua in eremo nutritus et

10 semper permansit ibi apud sanctos seniores et neque in ciuitates neque in uicos aliquando egressus est.

11 - Egressi sunt aliquando de monasterio fratres ad uisitandum eos qui in eremo commorabantur patres. Cum autem uenissent ad quendam eremitam seniorem, suscepit eos cum gaudio et, sicut consuetudo est, apposuit eis mensulam.

5 Videns enim eos fatigatos de itinere, ideo ante horam nonam fecit eos reficere et quicquid habebat in cellula sua apposuit eis ut ederent et repausauit eos. Facto autem uespere, orationes

$10-$ VDRN $^{2}$

3 parauerat $\mathrm{D} \quad 3-4$ condituram $p$. corr. $\mathrm{R} \quad 4$ quod] quia $\mathrm{R}$ semine] erat add. $\mathrm{R}$ raphanorum] ferularum ut $\mathrm{R} \quad$ 4-5 solet fieri in locis illis D 5 alio om. D oleo bono R $7 \mathrm{se}$ crucis $\mathrm{V}$ signans] con- $\mathrm{R} \quad 8$ hoc] autem $\mathrm{R}$ haec $\mathrm{D} \quad 9$ in eremo nutritus] in e. et $\mathrm{n}$. $\mathrm{D} \mathrm{n}$. in e. $\mathrm{R} 10$ permansit] mansit DRN et om. DR ciuitate R 11 egressus] in- DN

11 - VDRN

Incipit: de his qui eremitas uisitabant $\mathrm{N} \quad 1$ aliquando om. $\mathrm{R}$ 2 uisitandos $\mathrm{R}$ commorabantur] commanebant $\mathrm{R} 3$ heremitarum $\mathrm{R} 4$ cum] grandi add. $\mathrm{N}$ mensulam] mensam $\mathrm{R}$ 5 uidit N ideo om. D 6 cellula] cella D 7 facto autem] factum est $\mathrm{R}$ orationes] orauerunt $\mathrm{D}$ 
et psalmos secundum consuetudinem compleuerunt, similiter etiam et nocte fecerunt. Supradictus autem senior separatim in alio loco quiescebat sibi et audiuit eos loquentes inter se ac dicentes: Quoniam isti eremitae magis melius ad refectionem cibantur quam qui in monasteriis conuersantur. Haec autem senior audiens tacuit. Et cum illuxisset dies arripuerunt iter, ut ad alium eremitam pergerent, qui in uicino eiusdem senis habitabat. Cum autem egrederentur dixit eis senior: Salutate eum ex me et dicite ei: Obserua et noli irrigare holera. Cum autem peruenissent ad illum alium seniorem dixerunt ei mandatum. Ipse uero audiens intellexit causam. Et tenuit eosdem fratres, deditque eis ut operarentur texentes sportas, sedensque cum eis ipse non cessauit de opere manuum. Vespere autem ad luminaria, addidit super consuetudinem alios psalmos et post completas orationes dixit eis: Nos quidem consuetudinem non habemus cibari cottidie, sed propter aduentum uestrum oportet nos hodie cenare. Et apposuit eis panes siccos et sal dicens: Quia propter uos debemus aliquid amplius cenare. Misit autem modicum aceti et salis et modicum olei. Et cum surrexissent de mensula, coepit iterum psallere usque prope lucem et dixit eis: Non possumus propter uos omnem canonem psallere, ideoque repausate modicum, quia de itinere fatigati estis. Cum autem factum fuisset mane, hora prima uoluerunt recedere $a b$ eo, sed non permisit senior dicens: Magis iubete

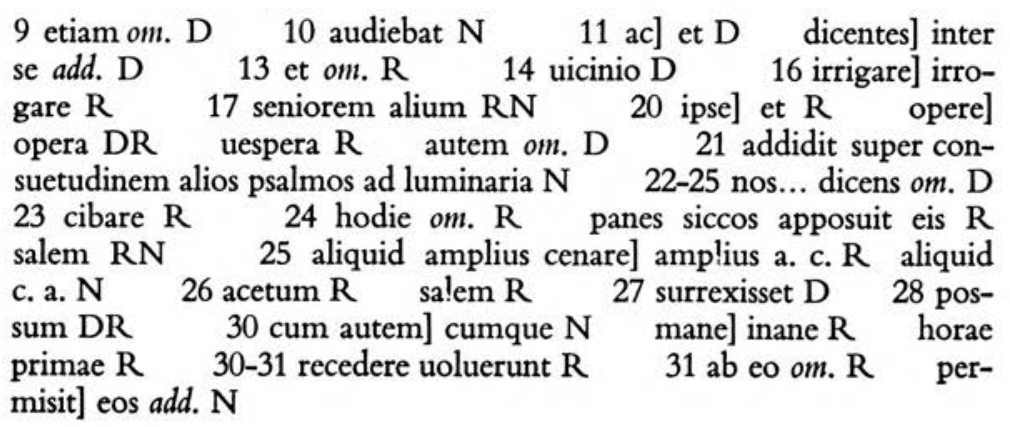


facere nobiscum aliquantos dies; non enim dimitto uos hodie, sed propter caritatem teneo uos uel alios tres dies. Illi uero haec audientes surrexerunt nocte et antequam lucesceret 35 latenter fugerunt.

12 - Referebant quidam fratres de abbate Nitera, qui fuit discipulus abbatis Siluani, quia, quando in cellula sua in monte Sina degebat, moderate abstinebat pro necessitate corporis. Quando autem episcopus ordinatus est in Pharan, nimis cons-

5 trinxit se ipsum in duriore abstinentia, et in uigiliis propensius atque in oratione intentius agebat. Haec autem uidens discipulus eius dixit ei: Quid est hoc, domine? Quia quando in eremo conuersabamur non tantum in abstinentia laborabas. Et respondit ei beatus uir dicens: Considera, frater, quoniam

10 ibi eremus erat et secreta uita ac paupertas; nunc autem egressi de eremo cum saecularibus hominibus conuersamur et multae et uariae occasiones nobis occurrunt et ideo timeo ne in fine uitae meae in aliqua occasione offendamus Dominum. Si enim sanctus apostolus Paulus, qui Christum in se loquentem

15 habebat et qui tantas uirtutes animi possidebat ut usque ad tertium caelum adhuc in corpore positus ascenderet, tamen dicebat: «Macero corpus meum et seruituti subicio, ne forsitan

I,12 lin. 14-16 : Paulus... ascenderet - cf. II Cor. XII, 2. lin. 17-18 : Macero... inueniar - cf. I Cor. IX, 27.

33 uero] autem D 34 hoc D nocte] surrexerunt add. repetens D 34-35 et antequam lucesceret latenter fugerunt] a. lucesceret et $f$. $l$. R ex eodem loco add. $\mathrm{N}$

$12-$ VDRN $^{2}$

2 cellula] cella $\mathrm{D}$

4-5 constrinxit] construxit $\mathrm{R}$

6 orationibus RN intentius] se add. N 12 nobis occasiones $\mathrm{R}$ $13 \mathrm{in}^{2} \mathrm{om}$. D offendam R $14 \mathrm{si}$ sic DR 15 qui... ut om. N animae uirtutes $\mathrm{R} \quad 16$ ascenderat $\mathrm{N} \quad 17$ seruituti] in seruitute $\mathrm{D}$ seruitudo $\mathrm{R}$ forsitan] forte $\mathrm{D}$ om. $\mathrm{R}$ 
aliis praedicans ipse reprobus inueniarn, - quid nos humiles et peccatores oportet facere?

13 - Quidam salutationis causa profectus est ad alium seniorem qui cum omni gaudio suscepit eum, pro cuius aduentu parauit ad refectionem senior lenticulae cibum coctum. Dixeruntque inter se ut prius ex more complerent orationes et psalmodiam et postea cibum caperent. Cum autem ingressi fuissent psallebant, totumque psalterium compleuerunt. Nam et de Scripturis sanctis, tamquam legentes, duas prophetias, absentes habentes, recitarunt. Iamque dies abierat, noxque similiter recedebat. Dum ergo orarent et intente psallerent, illuxit alia dies et tunc intellexerunt quia iam nox transisset. 10 Iterum autem inter se de uerbo Dei loquentes et spiritales sibi sensus exponentes, factum est ut circa horam nonam salutarent se inuicem atque ita reuersus est qui uenerat senex ad cellulam suam. Nam refectionem cibi, qui paratus fuerat, obliti sunt accipere. Vespere autem facto, inuenit senior ollam plenam sicut parata fuerat et contristatus dixit: Heu, quomodo obliti sumus recipere pulmentum istud?

\section{9 peccatores] pauperes $\mathrm{N}$}

\section{3 - VDRN}

Incipit: de illo qui ad eremum uenit salutare fratrem $\mathrm{N} \quad 1$ quidam] de senioribus sanctis add. $\mathrm{R}$ de sanctis senioribus $\mathrm{N} 2$ seniorem] eremitam add. $\mathrm{N} \quad 3$ senior om. $\mathrm{R} \quad 5$ psalmodias $\mathrm{N}$ 6 totumque] ac totum $\mathrm{R} \quad 7$ duos $\mathrm{R}$ prophetas per comp. $\mathrm{R}$ 8 absentes habentes om. DN recitauerunt D 8-9 iamque dies abierat noxque similiter recedebat] i. (itaque $\mathrm{N}$ ) d. a. (aberat $\mathrm{N}$ ) nox s. r. DN om. R 9 ergo] autem $\mathrm{R} \quad 10$ alia om. $\mathrm{R}$ 11 spirituales $N \quad 12$ exponentes sensus $R$ salutantes $R \quad 13$ atque ita] iter $\mathrm{R}$ quo $\mathrm{R}$ senex om. $\mathrm{D}$ 13-14 cellulam suam] cellam D 14 paratum $R \quad 15$ accipere] dum cibum spiritualem perceperunt add. N 16 paratum $\mathrm{R}$ et contristatus] contristatusque $\mathrm{R}$ heu om. $\mathrm{R} \quad 17$ recipere] per- $\mathrm{N}$ recidere $\mathrm{R}$ istud] illud $\mathrm{R}$ 
14 - Referebat nobis abbas Zeno quia aliquando dum proficisceretur ad Palestinam, fatigatus de labore itineris, resedit sub arbore. Erat autem in proximo ager plenus cucumeris. Cogitauit autem in corde suo ut surgeret et tolleret sibi ad 5 refectionem de ipsis cucumeribus. Nihil enim, inquit, grande est quid habeo tollere. Respondensque ipse sibi et cogitationibus suis, ait: Quia fures, praecipientibus iudicibus, in tormenta mittuntur. Oportet ergo et me ipsum probare debeo si possim sustinere tormenta quae latrones patiuntur. Exsurgens autem

10 eadem hora, stetit in aestu quinque dies, frixitque corpus suum et dixit cogitationibus suis: Quia non possum sustinere tormenta et ideo non oportet me furtum facere, sed magis exercere secundum consuedudinem opera manuum et de laboribus meis reficere, sicut Scriptura sancta dicit in psalmis: «Labores manuum 15 tuarum quia manducabis; beatus es et bene tibi erit». Quod certe cottidie in conspectu Domini psallimus.

15 - Dicebat sanctus abbas Dioscorus presbyter, qui in eremo Sceti habitabat: Quia non oportet monachum desideria gulae uentrisque facere. Nam in quo differt a saecularibus,

I,14 lin. 14-15 : Labores... tibi erit - cf. Ps. CXXVII, 2.

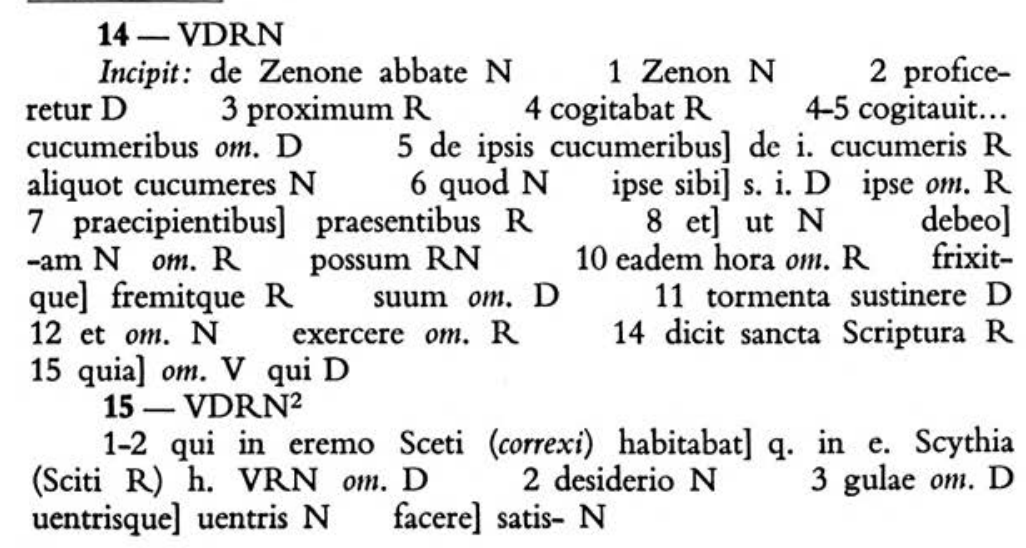


si expleat delectationes suas? Denique frequenter uidemus homines saeculares pro causa aegritudinis a deliciis et delectationibus se abstinere, ut sanitatem corporis adipiscantur. Quanto magis diligenter studere debet monachus pro salute et incolumitate animae suae, ut possit ad illas ueras et aeternas paradisi delicias et ad caelestis regni gloriam peruenire?

16-Quidam fratrum pergentes ad sanctum abbatem Ioseph, uirum perfectum, habitantem in Panepho, interrogauerunt eum dicentes: Quomodo oportet nos suscipere aduenientes ad uisitandum nos peregrinos, siue spiritales fratres, si oportet, inquiunt, propter eos relaxare regulam abstinentiae nostrae? Cumque haec audisset senior ita eis respondit dicens: Quando aduenerint ad nos fratres peregrini oportet suscipere eos cum gaudio et propter caritatem Dei relaxemus abstinentiam nostram in aduentu eorum. Cum autem solitarii in cellulis nostris fuerimus et nullus aduenerit, necessarium est ut studium abstinentiae nostrae secundum consuetudinem regulae teneamus. Haec itaque audientes fratres, tamquam uiri Dei praeceptum susceperunt uerbum eius. Et cum gratiarum actione reuersi sunt ad cellulas suas.

4 delectationes] cogitationes $\mathrm{D}$ uidimus $\mathrm{R} \quad 5$ pro causa aegritudinis om. N 6 se om. N sanitates $\mathrm{R} \quad 8$ et om. D 8-9delicias paradisi $\mathrm{R} \quad 9$ ad om. $\mathrm{R}$ $16-\mathrm{VDRN}^{2}$

1 fratres D 2 habitantem in Panepho] et add. V in P. h. R 3 eum om. $\mathrm{N} \quad 4$ spirituales $\mathrm{N} \quad 5$ inquiunt] inquit $\mathrm{V}$ om. $\mathrm{DN}$ regulam relaxare $\mathrm{D} \quad 6$ haec om. $\mathrm{R} \quad 7$ fratres] et add. $\mathrm{R}$ eos suscipere D 8 Dei om. RN 9 aduentum RN solitarii om. D 9-10 fuerimus in cellas nostras D 11 secundum consuetudinem regulae om. $\mathrm{D} \quad 12$ hoc $\mathrm{R}$ audientes om. $\mathrm{R}$ uiri] de dub. $\mathrm{R}$ om. $\mathrm{N} 14$ cellulas] cellas DN suas] Expliciunt monita sanctorum patrum add. VD 
INCIPIVNT CAPITVLA

\section{CONTRA SPIRITVM FORNICATIONIS}

I - De discipulo cuiusdam sancti senioris qui impugnabatur ab spiritu immundo fornicationis.

5 II - De alio fratre quem ualde idem spiritus impugnabat. III - De fratre quem idem spiritus fornicationis molestabat et abiit in ecclesiam et prostrauit se sanctis patribus.

IV - De beato abbate Moyse et de impugnatione eius.

$\mathrm{V}-\mathrm{De}$ monacho qui in eremo Sceti habitabat et in

10 cogitationibus laborabat et de quadam muliere.

VI - De duobus fratribus monachis qui in ciuitatem abierunt ut opera manuum distraherent.

VII - De alio fratre quem spiritus fornicationis impugnabat et abiit ad quendam sanctum patrem et confessus est 15 ei et rogabat ut oraret pro eo.

VIII - De monacho qui in eremo habitabat et de puella quae erat ex genere eius et abiit ad alium.

II - INCIPIVNT - VD om. RN

4 ab] a D 8 Moysi D 10 et om. D iudicibus $\mathrm{D}$ in om. D 15 et om. $\mathrm{D}$ rogat $\mathrm{V}$ qui $\mathrm{V}$
12 abierunt ]ad- D

16 in om. D
11 duobus] 14 est om. D 17 quae per comp. D: 
IX - De monacho quem impugnabat spiritus fornicationis et artem aliquando exercebat figuli.

$\mathrm{X}$ - De fratre qui interrogabat sanctum Poemen dicens: 20 Spiritus fornicationis et irae impugnat me, et responsio sancti Poemenis.

XI - Exhortatio sancti Macarii ad monachos.

II

INCIPIVNT

EXEMPLA SANCTORVM PATRVM CONTRA SPIRITVM FORNICATIONIS

1 - Discipulus cuiusdam sancti senioris impugnabatur a spiritu fornicationis, sed auxiliante gratia Domini resistebat uiriliter pessimis et immundis cogitationibus cordis sui, ieiuniisque et orationibus et in opere manuum affligebat se uehementer. Beatus autem senior uidens eum ita laborantem dixit ei: Si uis, o fili, deprecor Dominum ut auferat a te istam impugnationem. Ille uero respondens dixit: Video, pater, quia etsi laborem

19 exercuerat $\mathrm{V} 20$ Poemen] Panem D 21 impugnat] impignabat D 21-22 et responsio sancti Poemenis om. V 23 monachos] Expliciunt capitula add. VD

II - VDN om. R

incipiunt exempla sanctorum patrum contra spiritum fornicationis] i. capitula s. p. c. f. s. et immundas cogitationes cordis sui D sanctorum om. N

$1-$ VDRN

1 sancti om. D 3 sui om. D 3-4 ieiuniisque] ieiuniis $\mathrm{R}$ 4 opere] opera D 5 ei om. R 7 uero] autem D dixit] ei add. DN etsi] si $\mathrm{R}$ 
sustineo, sentio fructum tamen in me proficere bonum, quia per occasionem impugnationis huius et amplius ieiunio et 10 amplius in uigiliis et orationibus tolero. Verumtamen deprecor te ut exores pro me misericordiam Domini, ut det mihi uirtutem quatenus possim sustinere et certare legitime. Tunc sanctus senior dixit ei: Ecce nunc cognoui, fili, quia fideliter intelligis hoc spiritale certamen, per patientiam ad salutem

15 animae tuae proficiat. Ita enim et sanctus Apostolus dicit: "Certamen bonum certaui, cursum consumaui, fidem seruaui; de cetero reposita est mihi corona iustitiae, non solum autem mihi, sed et omnibus qui diligunt aduentum Domini».

2-Et alius etiam frater uehementer impugnabatur ab immundo spiritu fornicationis. Exsurgens autem nocte, abiit ad quendam sanctum probatum in uirtutibus seniorem, confessus est ei quam patiebatur impugnationem a spiritu fornicationis.

5 Haec cum audisset senior consolabatur eum spiritalibus uerbis de uirtute patientiae dicens, sicut scriptum est: «Viriliter agite et confortetur cor uestrum, omnes qui speratis in Domino».

II,1 lin. 16-18 : Certamen...Domini - cf. II Tim. IV, 7-8.

II,2 lin. 6-7 : Viriliter... Domino - cf. Ps. XXX, 25.

8 tamen fructum $\mathrm{N} 9 \mathrm{et}^{1}$ om. $\mathrm{N}$ amplius] in add. $\mathrm{N}$ 10 in om. $\mathrm{R}$ uigilias $\mathrm{R}$ orationes $\mathrm{R} 11$ te $\mathrm{om}$. $\mathrm{R}$ pro me om. D 13 ei om. N fideliter] spiritualiter N 14 spirituale $\mathrm{N}$ per patientiam om. D 14-15 ad salutem animae tuae proficiat] proficiet ad s. a. t. D ad s. aeternam a. t. proficiet (proficere R) RN 15 dicit] ait $\mathrm{D} \quad 18$ et omnibus] hiis $\mathrm{R}$ Domini] eius D

\section{2-VDRN}

Incipit: de fratre qui impugnabatur a fornicatione $\mathrm{N} \quad 1$ et om. N uehementer om. R 2 nocte] et add. V 3 sanctum] et add. RN in om. D seniorem] et add. R confessus] confessusque $\mathrm{N} \quad 4$ ei om. D impugnationem] impugnantiam $\mathrm{R}$ 5 eum] docens add. $\mathrm{R}$ spiritualibus RN 
Reuersusque est frater ad cellulam suam et ecce iterum impugnatio insistebat ei. Ipse autem festinabat denuo pergere ad supradictum seniorem. Videns autem eum senior, iterum docebat eum ut patienter et indefesse sustineret. Dicebatque ei: Crede, fili, quoniam mittet tibi Dominus Iesus Christus auxilium de caelo sancto suo, ut possis superare passionem hanc. Confortatus autem frater, monente sancto seniore, remeauit ad cellulam suam et iterum impugnatio ualde conturbauit cor eius; et statim eadem hora noctis reuersus est ad seniorem et deprecabatur eum ut intentius pro eo Dominum exoraret. Dixitque ei senior: Ne pertimescas, neque resoluaris, neque abscondas cogitationes tuas. Ita enim confusus spiritus immundus discedet. Nihil enim ita allidit uirtutem daemonum quomodo si quis secreta immundarum cogitationum reuelauerit sanctis ac beatissimis patribus. Viriliter age, o fili, et confortetur cor tuum et exspecta Dominum. Vbi enim durior pugna, ibi gloriosior erit et corona. Denique sanctus propheta Esaias dicit: «Numquid inualida est manus Domini ad saluandum aut aggrauata est auris eius ut non exaudiat?». Considera ergo, filiole, quia

II,2 lin. 22-23 : Viriliter...Dominum - cf. Ps. XXVI, 14.

lin. 24-26 : Numquid... exaudiat - cf. Is. LIX, 1.

8 est om. R cellulam] cellam DN 9 ci om. R festinauit RN 10 eum om. $\mathrm{N}$ iterum] ita $\mathrm{R} \quad 11$ crede] certa $\mathrm{R}$ credo $\mathrm{N}$ 12 quoniam] et add. $\mathrm{R}$ mittet tibi om. $\mathrm{R}$ Christus] dabit tibi add. $\mathrm{R}$ auxilium om. D 12-13 de caelo om. $\mathrm{R} 13$ suo om. R passionem hanc om. R 14 cellulam] cellam DN 15 conturbabat RN 16 noctis om. D est om. R 17 eum] dicens add. R pro eo om. R 18 ei om. R pertimescas] p. (permittas R) fili RN 19 confusus] confessus D spiritus immundus discedet] i. s. discedit $\mathrm{R}$ a te add. $\mathrm{N} \quad 22$ patribus] uiris $\mathrm{D} \quad \mathrm{o}$ om. $\mathrm{R} \quad 23 \mathrm{enim}$ om. $\mathrm{R} \quad 24$ erit om. $\mathrm{R}$ et om. $\mathrm{D} 25$ aggrauata] ingrauata $\mathrm{N} 26$ quia] qua $\mathrm{V}$ 
certamen tuum exspectat Dominus, tibique contra diabolum dimicanti parat aeternitatis coronam. Ideo monet nos sancta Scriptura dicens: "Quia per multas tribulationes oportet nos 30 introire in regnum caelorum». Haec autem audiens frater, confirmatum est cor eius in Domino et permansit apud seniorem, noluitque ultra reuerti ad cellam suam.

3-Quodam tempore impugnabatur quidam ex fratribus in passione fornicationis et contendebat intente, per abstinentiae constantiam, ut non condescenderet immundis desideriis carnis. Post haec autem ueniens die dominico in ecclesiam, quae est

5 in eremo monachorum, prostrauit se in terram cum lacrimis coram omni multitudine monachorum et confessus est eis quam patiebatur impugnationem. Haec autem audientes sancti seniores et presbyteri praeceperunt omni multitudini fratrum ut per totam septimanam amplius super consuetudinem ieiuna-

10 rent et uigilarent, deprecantes Dominum ac Saluatorem nostrum Iesum Christum ut effugaret daemonem fornicationis $a b$ eo. Et ex tunc quieuit omnis impugnatio a supramemorato fratre.

II,2 lin. 29-30 : Quia per... caelorum - cf. Act. XIV, 21.

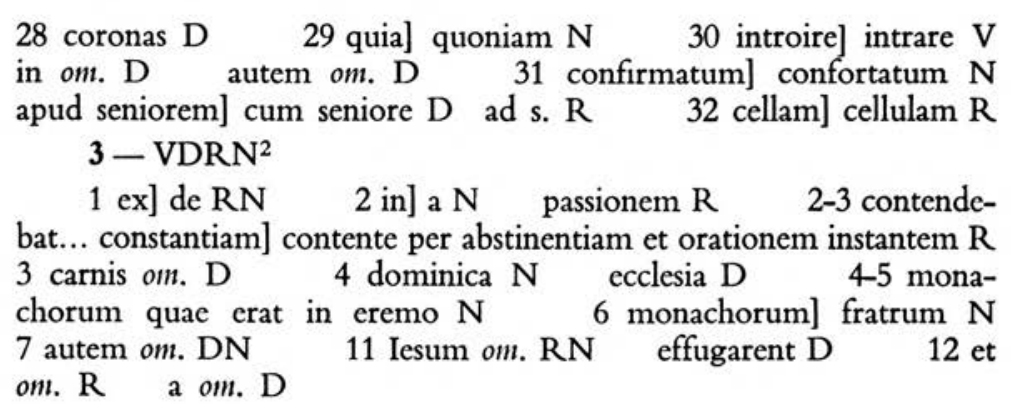


4 - Beato abbati Moysi, qui habitabat in loco qui appelatur Petra, quodam tempore in tantum imposuit durissimam impugnationem fornicationis daemon ut non praeualeret sedere in cella sua. Sed abiit ad sanctum abbatem Isidorum et retulit ei uiolentiam impugnationis suae. Cumque de Scripturis sanctis abbas Isidorus proferens testimonia consolaretur eum et ut ad cellulam suam reuerteretur rogaret, noluit abbas Moyses pergere ad cellam suam. Tunc abbas Isidorus pariter cum abbate Moyse ascenderunt in superiora cellulae suae et dixit ei Isidorus: Respice ad Occidentem et uide. Cumque respiceret, uidit multitudinem daemonum uehementer cum furore perturbari et quasi ad proelium praeparatos, festinantesque pugnare. Dixit autem ei abbas Isidorus: Respice iterum ad Orientem et uide. Cumque respiceret, uidit innumerabiles multitudines sanctorum angelorum, gloriosum et splendentem super lumen solis caelestium uirtutum exercitum. Ait autem ei abbas Isidorus: Ecce quos in Occidente uidisti ipsi sunt qui impugnant etiam sanctos Dei. Nam quos ad Orientem esse conspexisti ipsi sunt quos ad adiutorium sanctis suis mittit Dominus. Cognosce ergo quia pluriores sunt nobiscum, sicut dixit Eliseus propheta, 20

II,4 lin. 19-21 : Cognosce...illis - cf. IV Reg. VI, 16.

\section{4-VDRN}

Incipit: de abbate Moyse $\mathrm{N} \quad 1$ beatus abbas Moyses D qui om. D 2 imposuit] ei add. R 5 ei om. D 6 et om. D ad] in $\mathrm{N} 7$ cellulam] cellam D reuerteretur] rediret et $\mathrm{D} \quad$ rogaret] eum add. $\mathrm{R} \quad 8$ cellam] cellulam $\mathrm{R} \quad 9$ ascendit $\mathrm{N}$ superiora] supera $\mathrm{R}$ ei om. $\mathrm{N}$ Isidorus om. $\mathrm{R}$ 10 respexisset D 11 multitudines RN 13 ei om. D 14 innumerabilem multitudinem RN 14-15 sanctorum angelorum] a. s. $\mathrm{D}$ et add. $\mathrm{N} \quad 15$ gloriose $\mathrm{R}$ et om. $\mathrm{R}$ lumine $\mathrm{R}$ 17 Occidentem D etiam qui impugnant $\left.R \quad 18 \mathrm{ad}^{1}\right]$ in $D$ Oriente D 19 sanctis suis mittit] s. s. mittet V m. s. suis $R$ cognosce ergo om. $\mathrm{R}$ quia] qui $\mathrm{R} \quad 20$ plures $\mathrm{N}$ 
quam cum illis. Verum etiam et sanctus apostolus Ioannes dicit: "Quia maior est qui in nobis est quam qui in hoc mundo". Et ita confortatus in Domino sanctus abbas Moyses reuersus est ad cellam suam, gratias agens et glorificans Domini nostri

25 Iesu Christi bonitatis potentiam.

5 - Erat quidam frater in eremo Sceti, promptus et alacer in opere Domini et in spiritali conuersatione. Huic autem inimicus generis humani, diabolus, misit in cogitationes ut recordaretur cuiusdam nocte sibi mulieris pulchritudinem, et turba-

5 batur in cogitationibus cordis sui uehementer. Contigit autem ut ex dispensatione Domini alius quidam frater de Aegypto ueniret ad uisitandum eum in caritate Christi. Et dum inter se loquerentur euenit sermo ut diceret ille de Aegypto frater quia mortua est illa mulier. Ipsa autem erat in cuius persona

10 impugnabatur supradictus frater. Haec autem cum audisset ille, post paucos dies abiit ad locum illum ubi positum erat corpus illius defunctae mulieris et aperuit nocte sepulcrum eius et de pallio suo tersit saniem putredinis eius, reuersusque est ad cellam suam, ponebatque illum fetorem in conspectu suo 15 ct dicebat cogitationibus suis: Ecce habes desiderium quod

II,4 lin. 22 : Quia maior... mundo - cf. I Ioan. IV, 4.

21 quam cum illis om. VDN ctiam om. D Ioannes apostolus R 22 in nobis] nobiscum D in om. D 23 ita] his auditis N 24 ad] in $\mathrm{N}$ cellam] cellulam V 25 bonitatis] Saluatoris R oin. D 5 - VDRN

Incipit: de monacho qui habitabat in eremo Scythiae $\mathrm{N}$ 1 Sceti] Scythiae $\mathrm{N} 2$ in opere Domini] hians post Dominum $\mathrm{R}$ et om. R spirituali RN 3 in om. R 4 pulchritudinis $\mathrm{N}$ 6 ex dispensatione Domini (om. R) ut RN 7 uenit D 8 loquebantur $R \quad$ frater de Aegypto $N \quad 9-10$ erat... frater] erat persona de qua supradictus frater tentatus fuerat $\mathrm{R} \quad 11$ ille om. $\mathrm{R}$ 12 aperuit] in add. D 13 reuersusque] et reuersus RN 14 cellam] cellulam V 
quaerebas, satia te ex eo. Et ita in illo fetore cruciabat semetipsum usquequo cessaret $a b$ eo sordidissima impugnatio.

6 - Duo fratres monachi abierunt in proximam ciuitatem ut distraherent quae manibus suis per totum annum operati fuissent. Vnus autem ex eis egressus est ut quaedam sibi necessaria emeret. Alius autem solus in hospitio remansit et instigante diabolo cecidit in fornicationem. Cum autem reuersus uenisset, ille qui egressus fuerat frater dixit ei: Ecce distraximus quae necessaria erant; reuertamur nunc ad cellulam nostram. Respondens autem frater dixit ei: Non possum reuerti. Cumque deprecaretur eum frater suus dicens: Quapropter non reuerteris ad cellulam? Et ille confessus est ei dicens: Quia ego cecidi in fornicationem. Volens autem lucrari et saluare animam eius frater suus, cum sacramento dixit ei: Quia et ego, cum egressus essem a te, lapsus sum similiter in fornicationem. Verumtamen reuertamur et ponamus nos in poenitentiam. Omnia enim possibilia sunt Deo, ut poenitentibus nobis indulgentiam donare dignetur, ut non in aeterno igne tormentis et poenis in inferni tartaro cruciemur, ubi

II,6 lin. 15 : Omnia... sunt Deo - cf. Luc. I, 37.

16 eo] quo $\mathrm{R}$ in om. $\mathrm{R}$

6-VDRN

Incipit: de duobus monachis (om. $\mathrm{R}$ ) fratribus $\mathrm{RN} \quad 1$ duo] quidam add. $\mathrm{R} \quad 2-3$ operati fuissent] o. sunt $\mathrm{D}$ laborassent $\mathrm{R}$ 3 est om. V 4 remansit in hospitio D 5 cum] cumque $R$ 6 reuersus om. D 7 cellulam] cellam N 8 autem om. R frater] alius $\mathrm{R} \quad$ ei om. D 9 frater om. D 10 et om. $\mathrm{N}$ 11 ego] cum discessisti a me add. $\mathrm{N}$ fornicationem] ideo nolo reuerti add. N 11-14 uolens... fornicationem om. D 13 egressus essem] separatus fuissem $\mathrm{N}$ a te] autem $\mathrm{R}$ 13-14 in fornicationem similiter $\mathrm{N} \quad 14$ reuertamur] ad cellulam add. $\mathrm{N}$ 15 poenitentia $\mathrm{D}$ Deo] Domino N 15-16 poenitentibus] petentibus V 16-17 aeternum ignem D 17 in om. DR inferno D 
poenitentia non est, sed ignita semper et sine cessatione dira tormenta. Ita ergo reuersi sunt in cellulam suam. Abierunt

20 autem ad sanctos patres et prostrauerunt se ad uestigia eorum. Cum multo ululatu et lacrimis gementes confessi sunt quae euenisset eis ruina et tentatio. Quicquid autem praeceperunt sancti seniores et docuerunt eos in causa poenitentiae, ita omnia fecerunt. Ille ergo alius qui non peccauerat, sed pro fratre,

25 qui peccauerat, poenitentiam agebat, quasi et ipse peccasset. Videns autem Dominus laborem caritatis eius, infra pauco tempore reuelauit sanctis patribus qualis esset causa et quia propter caritatem illius, qui non peccauerat se afflixerat pro salute fratris. Idcirco indulgentiam donauit Dominus ei qui 30 peccauit. Ecce hoc ita est sicut scriptum est: "Qui posuit animam suam pro salute fratris sui».

7 - Alius enim quidam frater molestiam sustinebat a spiritu fornicationis. Abiit autem ad quendam probatissimum seniorem et deprecabatur eum dicens: Pone tibi sollicitudinem, beatissime pater, et ora pro me, quia grauiter me impugnat

II,6 lin. 30-31: Qui posuit... fratris sui-cf. Ioan. XV, 13; I Ioan. III, 16.

18-19 dira tormenta] t. dura $\mathrm{R} \quad 19$ in] ad DN 21 lacrimis gementes] 1. et $\mathrm{N} 21-22$ eis quae euenisset $\mathrm{R}$ tentationis $R \quad 23$ poenitentiae] sapientiae $D$ alius] frater add. $\mathrm{N}$ non om. $\mathrm{R}$ sed om. $\mathrm{N}$ 22 et om. $\mathrm{R}$ 24 ergo] uero $\mathrm{D}$ peccasset] eo quod multam caritatem circa eum haberet add. $\mathrm{N}$ 26-27 pauco tempore] -um -us D -a -ora RN 27 et om. D quia] se $a d d$. $\mathrm{R} \quad 28$ non om. $\mathrm{R}$ peccauerat] sed add. $\mathrm{D}$ et add. $\mathrm{N}$ se om. $\mathrm{R} 29$ salute] eius add. $\mathrm{R}$ donauerit $\mathrm{N}$ Dominus ei] ei D. R Dominus om. N 30 ita om. D

\section{7-VDRN}

1 enim on. RN molestiam sustinebat] molestiam om. D s. $\mathrm{m}$. $\mathrm{R}$ a] ab V 2 autem] ergo $\mathrm{R} \quad 3$ deprecabatur] precabatur $\mathrm{N}$ 
passio fornicationis. Haec cum audisset, senior orabat intente 5 diebus ac noctibus pro eo deprecans Domini misericordiam. Iterum autem ueniebat idem frater et rogabat seniorem ut magis ac magis intentius pro eo oraret. Similiter autem cum omni sollicitudine beatus senior orabat pro eo. Frequenter autem uenientem ad se monachum uidens senior et deprecantem se ut oraret, ualde contristatus admirabatur quia non exaudiret Dominus orationes eius. Eadem autem nocte reuelauit ei Dominus, quae circa illum monachum erant negligentiae et ignauiae resolutio, et delectationes corporeas cordis eius. Ita autem ostensum est sancto seniori: Vidit sedentem illum monachum et spiritum fornicationis in diuersis mulierum formis ante illum ludentem et ipsum cum eis delectari; angelum autem Domini astantem et indignantem grauiter contra eundem fratrem quia non surgebat neque prosternebat se in orationibus ad Dominum, sed magis delectabatur in cogitationibus suis. Haec ergo ostensa sunt per reuelationem sancto seniori. Cognouit autem quia culpa et negligentia illius monachi erat, ut non exaudirentur orationes eius. Et tunc dixit ei senior: Quia tua culpa est, frater, quia condelectaris cogitationibus malis. Impossibile est enim discedere a te spiritum fornicationis immundum, aliis orantibus et Deum pro te deprecantibus, nisi et tu ipse laborem assumas in ieiuniis et orationibus et

5 passio] spiritus $\mathrm{R}$ senior om. $\mathrm{N}$ orauit $\mathrm{R} \quad 6$ ac] et $\mathrm{D}$ pro eo om. D 8 ac magis] et m. D om. R 9 orabat] -uit $\mathrm{R}$ intentius add. RN 10 ad se ueniente monacho $\mathrm{R}$ deprecante $\mathrm{R} \quad 12$ ei om. $\mathrm{N} 14$ ignauiae] ignominiae $\mathrm{R}$ resolutio] -onis $\mathrm{D}$ dissolutio $\mathrm{R}$ cordis eius corporeae $\mathrm{N}$ 14-15 ita... seniori in margine $\mathrm{V} \quad 17$ ante illum] i. autem $\mathrm{N}$ ipsum om. $\mathrm{N}$ delectari] uidebat add. $\mathrm{N}$ 17-18 autem angelum $\mathrm{N}$ 18 indignantum $\mathrm{R} \quad 19$ neque] et non $\mathrm{D} 20$ Dominum] Deum $\mathrm{R}$ 21 sunt ostensa $\mathrm{N} \quad 22$ illius] eius $\mathrm{V} \quad 23$ eius] illius $\mathrm{V}$ 24 quia $^{1}$ ] quoniam D frater om. R quia ${ }^{2}$ qui RN $25 \mathrm{enim}$ est V 26 aliis orantibus] aliorum orationibus DN et] aliis add. N Deum om. $\mathrm{R}$ deprecantibus pro te $\mathrm{R} 27$ ipse om. $\mathrm{R}$ 
uigiliis multis, cum gemitu deprecans ut misericordiam suam et adiutorium gratiae suae praebeat tibi Dominus Christus, ut possis resistere malis cogitationibus. Nam et medici qui corporibus hominum medicamenta conficiunt et adhibent, quamuis omnia cum summa diligentia faciant, uerumtamen si ille qui infirmatur non se abstineat a noxiis cibis, uel de aliis quae solent laedere infirmitates, nihil ei proficit cura et dili-

35 gentia et sollicitudo medicorum. Similiter etiam et animae languoribus eueniet, licet cum omni intentione mentis et ex toto corde sancti patres, qui sunt medici spiritales, exorent misericordiam Christi Domini Saluatoris nostri pro eis qui orationibus eorum se postulant adiuuari. Sed nisi et ipsi cum

40 omni intentione mentis, tam in orationibus quam in omni opere bono spiritali, quae Deo placita sunt fecerint, non eis proficient, negligentibus et resolutis, ad salutem animae orationes sanctorum. Et haec audiens frater, compunctus est corde et cum omni sollicitudine, secundum doctrinam senioris, tam

45 in ieiuniis quam in orationibus et uigiliis, semetipsum afflixit et meruit misericordiam Domini. Et recessit $a b$ eo spiritus immundae passionis.

8 - Erat quidam monachus et habitabat in eremo. Quacdam autem puella, ex genere et cognatione eius, post plurimos

28 ut] om. D et add. R 29 suae] ut add. D om. R Dominus] Iesus add. RN 30 cogitationibus malis D 30-31 corporis $\mathrm{R} \quad 31$ adhibent] curam add. $\mathrm{D} \quad 31-32$ omnia quamuis $\mathrm{R}$ 32 cum om. D faciunt D 33 se abstineat] a. se R abstineat om. D de] ab R 34 infirmitates] infirmantes $N$ eis $\mathrm{R}$ proficiet $\mathrm{R} \quad 35 \mathrm{et}^{2}$ ] in add. $\mathrm{V} \quad 36$ euenit $\mathrm{D}$ licet] enim add. $\mathrm{V}$ mentis om. $\mathrm{R}$ et om. D 37 spirituales $\mathrm{N} 39$ sed om. R et ipsi om. R 41 bono om. RN spirituali RN placitas fuerint $\mathrm{R}$ fecerint] faciant $\mathrm{D}$ om. $\mathrm{R} \quad 43$ frater om. $\mathrm{R}$ corde om. R 46 spiritus om. R 47 immunda passio R

8-VDRN

Incipit: de monacho lapso $\mathrm{N}$ 
annos reperit in quo loco supradictus monachus habitaret et, instigante diabolo, abiit in illum desertum locum requirens eum. Quo inuento, ingressa est cellulam eius, asserens ei quia ex genere et parentela eius fuisset, mansitque ibi apud eum. Et cecidit in ruinam peccati cum ea. Erat autem alius monachus et ipse in eremo degens qui, cum ad refectionis horam uenisset, gillo, quem cum aqua ad potum sibi praeparauerat, uertebat se et tota illa aqua fundebatur in terram. Hoc autem per aliquot dies cum ad refectionem uenisset, ita fiebat et effundebatur in terram ut non possit bibere. Cogitauit autem apud semetipsum ut abiret ad illum alium monachum et diceret ei de gillone qui uertebat se et tota aqua effundebatur. Igitur cum in itinere, uespere facto, in quodam antiquo et diruto templo idolorum dormiret, audiuit daemones inter se loquentes: Quia in ista nocte praecipitauimus illum monachum in fornicationem. Et haec audiens admirabatur. Cum autem illuxisset dies, peruenit ad monachum et inuenit eum grauissima tristitia opressum et dixit ei: Quid faciam, frater, quia qua hora reficere uoluero statim gillo, quem ad usum aquae habeo, uertit se et effunditur aqua et non habeo quid bibam? Tunc respondit ei supradictus monachus: Tu quidem uenisti interrogare me quia gillunculus tuus uertit se et effunditur aqua; ego autem quid habeo facere, quia hac nocte cecidi in fornicationem? Respondensque frater dixit ei: Et ego hoc iam cognoui.

3 reperit] com- $\mathrm{R}$ percepit $\mathrm{N}$ habitabat $\mathrm{N} 4$ illum om. $\mathrm{R}$ desertum locum] 1. (-o R) d. (-o R) DR 5 cellulam] cellam $\mathrm{N}$ 6 eius et parentela $\mathrm{D}$ esset $\mathrm{N} \quad 7$ ruina $\mathrm{R} \quad 9$ sibi om. D 10 terra $\mathrm{V}$ haec D 11 cum per aliquot dies DR 12 effundebatur] aqua add. $\mathrm{N}$ terra VR non om. $\mathrm{R}$ posset DRN cogitabat $R \quad 15$ factum $R \quad 16$ idolorum templo $D \quad 18$ admirabatur] mirabatur $\mathrm{R} \quad 19$ ad... inuenit om. $\mathrm{R} \quad 20$ quia om. $\mathrm{R}$ 20-21 qua hora] h. q. me $D$ 22 effundetur $V$ quid] quae $R$ quod $N$ bibam] bibere possim $\mathrm{R} 23$ respondens $\mathrm{R}$ ei] sibi $\mathrm{D}$ monachus] dicens add. $\mathrm{N}$ quidem] inquit $\mathrm{N} 24$ uerti $\mathrm{D}$ 25 ego autem om. $\mathrm{R}$ quia] in add. DR qui $\mathrm{N} 26$ responditque $\mathrm{N}$ frater] et add. $\mathrm{N}$ hoc iam om. $\mathrm{R}$ 
Dixit autem ei alter: Et unde hoc potuisti cognoscere? Et ille ait: Dum in itinere nocte quiescerem, audiui daemones inter se loquentes et glorificantes de lapsu tuo et nimis contristatus 30 sum. Tunc respondens ille monachus dicit: Ecce ego egredior et uado in saeculum. Haec ille audiens, deprecabatur eum dicens: Noli hoc agere, frater, sed magis patienter sustine et permane in hoc loco. Nam mulierem expellamus et reuertatur ad locum suum. Manifeste enim ista exquisitio artis, maligni

35 diaboli est. Magis autem oportet ut maneas in hoc loco in afflictione cordis et corporis, et cum intimi cordis gemitu ac lacrimis usque in exitum uitae deprecare Domini ac Saluatoris nostri pietatem, ut possis inuenire misericordiam in die illo terribili magni iudicii Dei.

9-Erat quidam frater in eremo, habitabat autem in loco qui dicitur Cellia, et impugnabant eum daemones in passione fornicationis. Cogitauit autem apud semetipsum dicens: Quia forsitan oportet me magis in opere manuum labo-

5 rare, ut extinguatur carnalis sensus meus. Erat autem idem frater arti figulus. Exsurgens autem fecit ex luto et plasmauit quasi figuram mulieris et dixit cogitationibus suis: Ecce uxor tua; necessarium est ergo ut super consuetudinem addas

27 autem ei alter correxi: ei om. V alter om. VR autem om. D autem ei ille $\mathrm{N}$ hoc om. $\mathrm{R} 28$ nocte] -tu $\mathrm{R}$ om. N 29 glorificantes] gloriantes $\mathrm{N} \quad 30$ respondens ille monachus dicit] r. i. m. ait $\mathrm{D}$ respondit ei i. m. dicens (om. R) RN 31 uado in eras. D audiens ille $\mathrm{D} 32$ dicens om. $\mathrm{R} 33$ permane] mane $\mathrm{R}$ hunc locum $R \quad 34$ manifesta $N \quad 35$ hunc locum $R \quad 36$ afflictionem $\mathrm{R}$ intimo $\mathrm{N} \quad 37$ in] ad $\mathrm{N}$ exitu $\mathrm{R} \quad$ ac om. $\mathrm{R}$ 9-VDRN

Incipit: de eremita impugnato $\mathrm{N} \quad 1$ in eremo] et $\mathrm{R}$ autem om. $\mathrm{R} \quad 2$ in] spiritu add. $\mathrm{R} \quad 3$ cogitabat $\mathrm{R} \quad 4$ in opere] opera D 5 extinguatur] extenuetur $\mathrm{R}$ idem] om. D iste $\mathrm{R}$ 6 arti] -e RN auri D exsurgens autem] idem autem uxorem $R$ 7 quasi om. $\mathrm{N}$ 
in opere manuum tuarum. Et post aliquantos dies iterum similiter fecit ex luto et plasmauit quasi filiam sibi et dixit cogitationibus suis: Ecce generauit uxor tua filiam; necessarium est ergo ut magis magisque amplius exerceas opera manuum, ut possis pascere et uestire te et uxorem et filiam tuam. Et ita pro nimio labore macerauit corpus suum, ut non praeualeret iam supportare tantum laborem. Tunc dixit cogitationibus suis: Quia si non praeuales nimium istum sustinere laborem neque mulierem requiras. Videns autem Deus seruantem propositum mentis eius pro certamine castitatis, abstulit ab eo molestiam impugnationis daemonum. Et glorificauit Dominum super magnitudine gratiae eius.

10 - Quidam frater interrogauit beatum abbatem Poemen dicens: Quid faciam, pater, quia impugnat me passio fornicationis etiam et rapior in passionem furoris ? Et respondens dixit ei sanctus senior: Ideo utique Dauid propheta dicebat: "Quia leonem quidem percutiebam, nam et ursum frequenter suffocabam». Hoc autem intelligitur: Quia furorem abscidebam ab animo meo, fornicationem autem in laboribus affligebam.

\section{II,10 lin. 4-6 : Quia leonem... suffocabam - cf. I Reg. XVll, 34-36.}

9 in opere] opera D tuarum om. D 9-10 similiter om. R 10 sibi om. $\mathrm{R} \quad 11$ generauit uxor tua] u. t. genuit tibi $\mathrm{D}$ filiam om. $\mathrm{R} 12$ magisque] quam $\mathrm{R}$ ac magis $\mathrm{N}$ manuum] tuarum add. $\mathrm{R} \quad 13$ et uestire te et uxorem et filiam uam] u. et $\mathrm{f}$. tuam et uestire $\mathrm{R}$ te $\mathrm{om}$. $\mathrm{N}$ 13-14 ita pro nimio] i. prae $\mathrm{n}$. V nimium i. p. $R \quad 14$ macerabat $R \quad 15$ iam om. $R \quad 16$ praeuales] uales D 17 seruantem] seruentis $R$ seruens $N \quad 20$ magnitudinem $\mathrm{D}$ eius] suae $\mathrm{D}$ $10-$ VDRN

1 beatum om. D Poemen] Pamen D Phimenem R Poemenem $\mathrm{N} 2$ quid] uis add. D quia om. D $3 \mathrm{et}^{1} \mathrm{om} . \mathrm{R}$ 4 ei om. D propheta om. D 6 autem] ita add. RN intelligitur] -legitur $\mathrm{V}$ ita add. D 6-7 ab animo meo] apud -um -um $\mathrm{R}$ 7 labore R affligebam] Explicit de impugnatione (spiritus add. D) fornicationis add. VD Explicit add. R 


\section{EXHORTATIO SANCTI MACARII AD MONACHOS}

1 - Sanctus abbas Macarius commonebat saepe discipulos suos et docebat eos dicens: Mementote semper quia ante conspectum Dei Omnipotentis conuersamini, qui prospicit omnium hominum cogitationes et singulorum corda scrutatur.

5 Quod etiam et sanctae Scripturae testantur et Apostolus docet et dicit: "Viuus enim est sermo Dei et efficax et acutior omni gladio ancipiti et pertingens usque ad diuisionem animae ac spiritus et discretor cogitationum et intentionum cordis et non est ulla creatura inuisibilis in conspectu eius, omnia autem nuda

10 et aperta sunt oculis eius». Ideoque, fratres, si nos pulsauerit delectatio carnalis et concupiscentia fornicationis, festinemus repellere et abicere de corde nostro sordidissimam et pessimam cogitationem, inuocantes intentissime adiutorium Domini nostri Iesu Christi in orationibus ac ieiuniis, ut uirtute potentiae suae

15 eripiat nos et protegat et conterat Satanan sub pedibus nostris.

III,1 lin. 6-10 : Viuus... oculis eius - cf. Hebr. IV, 12-13.

\section{III - INCIPIT - VDR om. $\mathrm{N}^{2}$}

$1-\mathrm{VDRN}^{2}$

1 abba V commonebat] commendabat D saepe om. N 3 conspectu R 5 sancta Scriptura testatur R 6 et dicit] dicens RN enim om. $\mathrm{N} 7$ diuisionem] uisionem $\mathrm{D}$ ac] et $\mathrm{DN}$ 11 carnalis] carnis $\mathrm{N}$ et om. $\mathrm{R} \quad 12-13$ sordidissimam... cogitationem om. R 13 inuocantes] orantes $\mathrm{R}$ intentissime om. $\mathrm{R}$ 14 ut] et $\mathrm{N}$ suae] ut $\mathrm{N} \quad 15$ et protegat om. $\mathrm{R}$ 
Oportet enim ut etiam nosmetipsos corripiamus, dicamusque ad animam nostram: Quoniam delectatio quidem corporis, quae te male oblectat, ad modicum tempus est. Nam tormenta et cruciatus animae et corporis in igne aeterno gehennae in perpetuas permanent poenas. Illud etiam admonentes animam nostram, dicamus: $\mathrm{Si}$ erubescis homines similes tui peccatores, ne uideant te peccantem, quare non magis reuereri et timere debes maiestatem Omnipotentis Dei qui omnium secreta cordis considerat? Sicut Apostolus ait: "Omnia nuda et aperta sunt oculis eius». Talibus ergo cogitationibus si increpemus nosme- 25 tipsos, continuo timor Domini uenit in corde nostro et in amore castitatis confirmatur anima nostra, etiam et ad omnia praecepta Domini facienda incitamur, adiuuante nos gratia Domini nostri Iesu Christi, qui seruientibus sibi in sanctitate et castitate promisit caelestia et aeterna in illa gloriosa futuri saeculi uita donare et cum angelis sanctis in perpetuo luminis splendore semper gaudere.

III,1 lin. 24-25 : Omnia... oculis eius - cf. Hebr. IV, 13.

18 oblectat] de- $\mathrm{R} \quad 19$ ignem aeternum $\mathrm{R} \quad 20$ admonentes] ut (om. R) ad add. RN 21 erubescit hominis similis R 22 peccare $D$ non om. $R$ reuereri] uereri $N$ debes] negligis D Dei Omnipotentis $N$ omnia D 24 ait Apostolus $\mathrm{N}$ sunt] in add. $\mathrm{R} 25$ talia $\mathrm{N}$ cogitationibus] cogitantibus $\mathrm{N}$ increpamus $\mathrm{N} 26$ Domini] Dei $\mathrm{D}$ in $^{2}$ om. $\mathrm{R}$ amorem $\mathrm{N} 27$ confirmant $d u b$. D anima nostra etiam] $-\mathrm{m}$ $-\mathrm{m}$ e. $\mathrm{D}$ e. a. $\mathrm{n} . \mathrm{R}$ et om. $\mathrm{N} 30$ aeterna] bona add. $\mathrm{R}$ saeculi futuri $\mathrm{R} \quad 31$ et om. $\mathrm{RN}$ sanctis angelis $\mathrm{N}$ perpetuum $\mathrm{R}$ 31-32 splendorem $\mathrm{R} \quad 32$ gaudere] Explicit add. $\mathrm{V}$ amen add. R 


\section{IV}

INCIPIVNT CAPITVLA

\section{DE VIRTVTE HVMILITATIS ET PATIENTIAE MONITA SANCTORVM}

I - De monacho in eremo commorante qui seruus quo5 rundam erat.

II - De duobus fratribus monachis qui pariter manebant.

III - De monacho qui foras ciuitatem Constantinopolim fuit temporibus Theodosii imperatoris.

IV - De sancto Poemene, quae referebant sancti seniores.

$10 \mathrm{~V}-$ De eodem sancto Poemene, quando conuenerunt ad eum plurimi monachorum et de causa humilitatis et exempli Ioseph.

VI - De eodem sancto Poemene, quando a multis rogatus est ut peteret iudicem pro clausis in carcere.

15 VII - De humilitate et patientia sancti Agathonis.

VIII - De amore humilitatis sancti Isaac.

IX - De duobus fratribus simul habitantibus et sancto seniore qui uoluit probare humilitatem eorum.

$\mathrm{X}-$ De sancto seniore qui multo tempore in aegritudine 20 corporis laborabat.

$\mathrm{XI}-$ De beato Apollo ad quem adduxerunt uexantem.

IV - INCIPIVNT - VDR om. N

1 incipit $\mathrm{V} 2$ de uirtute] ad uirtutem $\mathrm{R}$ patientiae] sapientiae ac D 3 sanctorum] patrum religiosorum add. D patrum I capitulum add. $\mathrm{R} \quad 4$ in eremo commorante] c. in e. D in e. commanente $\mathrm{R} \quad 7$ Constantinopoli V 8 tempori $\mathrm{R}$ imperatoris] in peruisa humilitatis exemplum Ioseph protulit $R \quad 9$ Poemene] Poeme $\mathrm{V}$ Phimeni $\mathrm{R}$ quae correxi: quem per comp. VDR sancti] patres add. D 10 sancto om. D Poemene] Pamene D Phimeni R $\quad 11-12$ et de causa humilitatis et exempli Ioseph] c. h. exempli I. D om. R 17 et] de add. R sancto] senio add. D 19 multum $\mathrm{R} 20$ laborabat] labore $\mathrm{R} \quad 21$ adduxerunt] duxerunt $\mathrm{D}$ 
XII - De monacho qui habitabat in eremo et de optimo et Deo placito discipulo eius.

XIII - De discipulo abbatis Pauli qui leaenam ligatam ad monasterium perduxit.

XIV - De discipulo quem misit abbas suus ad hauriendam aquam.

$\mathrm{XV}-\mathrm{De}$ discipulo cuiusdam senioris quem misit seu iactauit de cella abbas eius.

XVI - De perfecta humilitate fratris Eulalii.

XVII - De beati Athanasii miranda patientia 〈et〉 humilitate.

XVIII - De monacho quem iussit abbas ut pasceret porcos.

XIX - De iuuene qui uenit ad beatum Macarium desiderans monachus esse.

\section{IV}

INCIPIVNT

\section{MONITA ET EXEMPLA SANCTORVM PATRVM DE VIRTVTE HVMILITATIS ET PATIENTIAE}

1 - Dicebant sancti seniores patres de quodam monacho iam seniore in Sceti eremo commorante, quomodo seruus quorundam erat et per singulos annos descendebat de eremo

$22 \mathrm{de}^{2}$ om. $\mathrm{R}$ optimum $\mathrm{R} 23$ Deo] de $\mathrm{D}$ placitum discipuli $\mathrm{R} 225$ perduxit] ad- $\mathrm{R} 22$ de cella abbas eius] de c. abbatis e. $\mathrm{V}$ a. e. de c. D 30 de... Eulalii om. D 31 patientia R: patientie VD et restitui humilitatis $\mathrm{R} 33$ cui $\mathrm{R}$ 34 iuuene] iuniore $\mathrm{R}$ beatum] abbatem add. $\mathrm{R} \quad 35$ esse] Expliciunt capitula add. VD

IV - VDRN

3 patientiae] sapientiae D I capitulum add. R

1 - VDRN

2 Sceti] Scythiae $\mathrm{N}$ commorante] commanente RN 
in Alexandriam ubi commanebant domini eius, deferens eis

5 pensionem sicut solent serui dare dominis suis. Nam domini eius magis reuerentiam propter timorem Dei habentes circa eum, honorabant occurrentes et salutantes eum, petentesque ut pro eis Dominum exoraret. Ille autem mittebat aquam in peluem et festinabat lauare pedes dominorum suorum cum omni humi-

10 litate obsequium eis cupiens exhibere. Ipsi uero nolebant acquiescere ut pedes eorum ablueret, sed dicebant ci: Noli, beatissime pater, aggrauare animas nostras. At ille respondens dicebat: Ego seruus uester sum; nam uos dominos meos esse Omnipotens Deus constituit et gratias ago Domino uestro, quia

15 dignati estis me permittere ut seruiam Domino uiuo et uero, Creatori ac Dominatori caeli et terrae et ideo detuli uobis pensionem seruitutis meae. Domini autem eius contendebant, nolentes accipere quam detulerat pensionem. Respondens autem senior dixit eis: Si nolueritis accipere pensionem meam,

20 ita decreui ut non reuertar in eremum, sed hic in praesenti permaneo et seruio uobis. Haec autem audientes domini eius, acquieuerunt suscipere pensionem ne contristaretur, sed magis ut reuerteretur ad loca eremi ad cellulam suam. Illud autem quod de pensione sua etiam nolentibus dabat dominis suis, 25 statim quod accipiebant pauperibus erogabant. Interrogantes autem eundem seniorem fratres, dixerunt: Obsecramus te, pater,

4 deferens] af- $D$ 5 nam] sed $\mathrm{N}$ mam D pro timore RN Dei om. D 8 peluim $\mathrm{N} \quad 11$ sed dicebant ei om. $\mathrm{R}$ 13 domini mei $\mathrm{R}$ esse] estis $\mathrm{R}$ add. D D. o. N constituit] uos add. $\mathrm{R}$ uestrol nostro DR 15 permittere me $\mathrm{R}$ Domino] Deo $\mathrm{N} 17$ seruitutis meae om. D 17-18 domini... pensionem] om. D d. autem contemnentes et nolentes accipere p. R 18-19 respondens autem senior dixit eis] dixit cetera omittens $\mathrm{R} \quad$ r. a. monachus d. e. $\mathrm{N} \quad 19$ si... meam om. $\mathrm{R}, 20$ ita] iterum $\mathrm{R}$

6 propter timorem] p. ani7 petentesque eum $\mathrm{D}$ 12 aggrauare] grauare $\mathrm{R}$ 14 omnipotens Deus] esse om. D 26 dixerunt] ei add. $\mathrm{N}$

21 autem 
ut dicas nobis cur cum tanta intentione pensionem pro seruitio tuo etiam nolentibus et nimis resistentibus tibi dominis ingessisti? Ad haec respondens senior dixit: Ego, fratres, ideo festino pro seruitio, quod tamquam dominis meis debeo, 30 pensionem per singulos annos adimplere eis, ut quicquid iam cum adiutorio Domini in ieiuniis et orationibus seu in sanctis uigiliis uel in omni opere spiritali, Christo Domino adiuuante, laborauero, hoc mihi in aeternam uitam et salutem animae meae proficiat, ne forsitan si pensionem pro seruitio meo minime intulero, iam totus spiritalis labor meus ad illorum mercedem proficiat, qui me permiserunt Christo Domino deseruire et spiritaliter conuersari.

2- Erant duo fratres secundum carne mquidem germani, uerumtamen utrique in spiritali proposito monachi exsistentes, insidiabaturque eis malignus diabolus ut quomodocumque eos separaret $\mathrm{ab}$ inuicem. Quadam igitur die, ad uesperam, secundum consuetudinem ille iunior frater accendens lucernam posuit super candelabrum. Faciente autem malitia daemonum, ruit candelabrum et exstincta est lucerna. Per hanc autem occasionem insidiabatur malignus ut eos in litem incenderet. Surgensque senior frater, coepit percutere fratrem suum cum furore. Ille uero, prostratus in terram, deprecabatur germanum

27-28 pro seruitio tuo pensionem $\mathrm{N} \quad 28$ tibi dominis] tibi om. D d. tuis $\mathrm{N} \quad 31$ iam om. $\mathrm{R} \quad 33$ spirituali $\mathrm{RN} \quad 34$ aeternam uitam] -a $-\mathrm{a} \mathrm{D}$ u. a. $\mathrm{N}$ et] in $\mathrm{D} \quad 35$ proficiant $\mathrm{R}$ 36 totus spiritalis labor meus] totos spirituales labores meos $\mathrm{R}$ t. spiritualis $1 . \mathrm{m}$. N 37 proficiant $\mathrm{R} \quad 38$ spiritualiter RN conuersare $\mathrm{R}$

2-VDRN

Incipit: de duobus fratribus $\mathrm{N}$ secundum capitulum $\mathrm{R} \quad 1$ carnem] saeculum D 2 spirituali $\mathrm{N} 3$ eis om. D ut om. $\mathrm{R}$ quomodocumque] quomodo $\mathrm{R} \quad 6$ super] supra $\mathrm{N} \quad 8$ occasione $\mathrm{D}$ insidiabatur] eis add. $\mathrm{N}$ malignus] diabolus add. $\mathrm{N}$ eos in litem incenderet] ad 1. e. inuicem incitaret $\mathrm{R} 99$ surgitque $\mathrm{R}$ frater] et add. $\mathrm{R}$ 9-10 cum furore fratrem suum RN 10 terra $\mathrm{RN}$ 
suum dicens: Magnanimus esto, domine, et ego rursum accendo lucernam. Ergo quia non respondit ei turbulentum sermonem, statim malignus daemon confusus recessit $a b$ eis et pergens eadem nocte nuntiauit principi daemoniorum dicens: Quoniam

15 propter humilitatem illius monachi qui prostratus in terram ueniam postulabat a fratre suo non praeualui in eis, uidensque Deus humilitatem eius, effudit super eum gratiam suam et ego sentio me ualde torqueri atque cruciari, quoniam non praeualui separare eos ab inuicem. Haec autem uerba audiens

20 sacerdos idolorum qui ibi commanebat, compunctum est cor eius in timore et amore Domini nostri Iesu Christi. Considerans enim quomodo magis seductio et perditio animarum est cultus idolorum, relinquens omnia, festinanter perrexit ad sanctos patres ad monasterium et referens eis haec omnia quae

25 per malitiam daemones inter se loquebantur. Cumque monitis salutaribus instruxissent eum sancti patres de doctrina Domini Saluatoris, baptizatus est et sancti propositi monachorum uitam arripuit. Et adiuuante et cooperante gratia Domini factus est probatissimus monachus, tantumque ueneratus

30 est et tenuit uirtutem humilitatis, ut omnes nimiam humilitatem eius mirarentur. Dicebat enim quomodo omnem uirtutem aduersariorum nostrorum daemonum soluit verae humilitatis intentio; denique Dominus noster Iesus Christus per

11 magnanimis $\mathrm{R}$ 12 sermonem] uerbum $\mathrm{D}$ spiritus D 14 daemoniorum] daemonum RN 13 daemon] chi humilitatem $\mathrm{D}$ terram $\mathrm{RN}$ et add $\mathrm{V} 15$ illius monatrem suum $\mathrm{R}$ non... eis om. $\mathrm{R} \quad 17$ gratiam suam super eum $\mathrm{R}$ 18 ego] inquit add. $N$ atque cruciari] om. D et c. R 19 praeualui] ualui $\mathrm{N}$ eos separare (-ri $\mathrm{R}$ ) $\mathrm{DR}$ autem] omnia add. $\mathrm{RN}$ 20 qui ibi] quibus $\mathrm{D}$ compunctus $\mathrm{N}$ corde $\mathrm{N} 21$ eius om. $\mathrm{N}$ amore et timore $\mathrm{N} 24$ et om. DR referens] retulit $\mathrm{N}$ 25 cumque] in add. R 26 eum om. R 27-28 uitam monachorum R 30 et tenuit om. D 30-31 humilitatem eius] eius om. D e. h. R 31 mirarentur] ad- $\mathrm{R} \quad 32$ uera $\mathrm{R}$ 
humilitatem triumphauit diabolum et omnem eius uirtutem contriuit. Addebat etiam dicens quoniam frequenter audisset daemones inter se loquentes: Quia quando ad iracundiam succendimus corda hominum, si quis sustinuerit patienter iniuriarum conuicia et conuersus magis rogauerit ea quae ad pacem sunt dicens: "Quia ego peccaui», statim sentimus omnem nostram uirtutem marcescere, quia approximat eis qui humili- 40 tatis uirtutem habent gratia diuinae potentiae.

3-Referebat autem beatus senior Poemen fratribus dicens: Quomodo fuit quidam nuper monachus in Constantinopoli, temporibus Theodosii imperatoris. Habitabat autem in parua cellula foris ciuitatem, prope proastio qui uocatur in septimo, ubi solent imperatores egressi de ciuitate libenter degere. Audiens autem imperator quod ibi esset quidam monachus solitarius, qui nusquam egrediebatur de cella, coepit deambulando pergere ad eum locum ubi erat supradictu; monachus, praecepitque sequentibus se eunuchis ut nullus approximaret ad cellulam monachi. Ipse autem solus perrexit, 10 pulsauitque ostium cellulac. Surrexit autem monachus et

34 uirtutem eius DR 37 hominum] nostra $D \quad 39$ ego peccaui] p. nimis $D \quad 40$ uirtutem nostram $N$ approximat] proximat $R$ qui] cum $R$ 40-41 humilitatis uirtutem] u. h. D h. uirtute $R$ 41 habent om. $\mathrm{R}$ diuina $\mathrm{D}$ potentiae om. D

\section{3-VDRN}

Incipit: III capitulum $\mathrm{R}$ de quodam monacho $\mathrm{N} \quad 1$ autem om. D Poemen] Panem D Phimen R fratribus om. N 2-3 Constantinopolis D 3 temporibus om. R habitat D 4 prope] in D proastio correxi $(\pi \rho \circ \alpha \sigma \tau \varepsilon i \omega)$ : prastio VDN prascio $\mathrm{R}$ 4-5 in septimo] insemtimo VN insempthuno $\mathrm{R} \quad 5$ libenter om. D 7 solitarius om. $R \quad 9$ eunuchis] enuchis D om. R 10 cellulam] cellam D monachi] illius add. N perrexit] ad add. R 11 pulsauitque om. R 
aperuit ei et non cognouit eum. Tulerat enim sibi coronam de capite suo ut non cognosceretur. Post orationem autem resederunt pariter et interrogauit eum imperator dicens: Quo-

15 modo sancti patres degunt in Aegypto? Respondensque monachus ait: Omnes exorant Dominum pro salute uestra. Aspiciebat autem imperator intente cellulam ipsam et nihil in ca uidit nisi paucos panes siccos in sporta pendentes. Et dixit ci: Da mihi benedictionem, abba, ut reficiamus. Statimque

20 festinauit monachus et misit aquam et salem et misit buccellas et comederunt pariter. Porrexitque ei calicem aquae et bibit. Tunc dixit imperator: Scis quis sim ego? Respondens monachus dixit: Nescio. Quis es, domine? Dixit ei: Ego sum Theodosius imperator et ob deuotionem ueni huc. Hoc cum audisset

25 monachus prostrauit se ante illum. At ille dixit: Beati estis uos, monachi, qui securi ac liberi de negotiis saeculi tranquillam et quietam perfruetis uitam et solummodo de salute animarum uestrarum habetis sollicitudinem, quomodo ad uitam aeternam et ad caelestia praemia peruenire possitis. In ueritate enim dico

30 tibi quia certe in regnum natus sum et nunc in regno degeo et numquam sine sollicitudine cibum capio. Post haec autem ualde

12 cognoscebatur $\mathrm{N}$ eum om. N sibi om. D 12-13 tulerat... cognosceretur om. N 14 resederunt] sederunt D imperator om. R 15 degunt] degent $\mathrm{V}$ om. $\mathrm{R}$ Aegyptum $\mathrm{R}$ respondensque] res$\begin{array}{llll}\text { pondit } \mathrm{R} & 16 \text { monachus] et add. } \mathrm{R} & \text { exorent } \mathrm{D} & \text { Dominum] }\end{array}$ Deum RN uestra] tua $\mathrm{R} 17$ imperator om. $\mathrm{R}$ intente] in add. D et om. D 18 sporta] sportella $\mathrm{D}$ et om. R 20 salem et aquam R 21 ei om. RN 22 tunc] Theodosius add. $\mathrm{N}$ dixit imperator] imperator om. DR i. d. ei $\mathrm{N}$ scis] sis D qui $\mathrm{V}$ sum $\mathrm{RN}$ respondit $\mathrm{R}$ monachus] et add. $\mathrm{R} 23$ quis es domine] q. sis d. D d. q. es $\mathrm{R} \quad$ dixit $^{2}$ ] dicit $\mathrm{R} \quad 24$ et... huc om. $\mathrm{R}$ audisset] uidisset $\mathrm{D} 26$ liberi] estis add. $\mathrm{N} 26-$ -27 tranquillam et quietam] -la et (tranquillaque N) -ta DN 27 perfruetis] om. $\mathrm{R}$ perfruimini DN uita DN $\left.\mathrm{et}^{2}\right] \mathrm{om}$. D. non add. $\mathrm{R} 28$ quomodo] quo $\mathrm{N} 29$ praemia] regna $\mathrm{D}$ peruenire possitis] perueniatis $\mathrm{D} 30$ regno $\mathrm{RN}$ degeo] dego $\mathrm{RN}$ 
honorifice salutauit eum imperator et ita egressus est. Eadem autem nocte coepit intra se cogitare famulus Dei dicens: Quomodo non oportet me iam in loco hoc esse. Multi enim non solum de populo sed etiam et de palatio et de senatoribus quam plurimi, exemplum imperatoris secuti, ad uidendum me uenturi sunt et honorem mihi tamquam seruo Dei deferre non cessabunt. Et illi quidem haec propter nomen Dei facturi sunt. Ego autem timeo ne forsitan malignus diabolus mihi subripiat et libenter incipiam eos suscipere et condelectetur cor meum laudibus et honoribus eorum. Et per haec iam incipio uirtutem humilitatis perdere et laudes atque honores hominum delectari. Haec igitur omnia homo Dei secum cogitans, eadem nocte fugit inde et perrexit in Aegyptum ad sanctos patres in eremum. Itaque consideremus, fratres dilectissimi, cum quanta sollicitudine uirtutem humilitatis custodire famulus Dei studuit, ut in caelesti regno aeternam gloriam pro labore sanctae uitae suae, quam propter nomen Domini exercuerat, percipere a Christo Domino mereretur.

4-De hoc autem ipso sancto Poemen referebant alii sancti seniores dicentes: Quia quodam tempore cum aduenisset iudex prouinciae, audiensque sanctam opinionem beati Poeme-

32 imperator om. $\mathrm{R} \quad 34$ me om. V iam] etiam DR hoc loco RN $35 \mathrm{et}^{1}$ om. DN 37-39 et... sunt om. D 38 et om. N haec om. $\mathrm{R}$ Dei] Domini N 39 forsitan om. D mihi om. R 40 eos] ego $\mathrm{R} \quad 41$ laudes $\mathrm{R}$ et honoribus] honori $R \quad 42$ incipiam $D N$ laudibus $N$ honores] $-e D$ -ibus N 43-44 cogitans secum R 44 inde om. R et perrexit] perrexitque $R$ 45-46 dilectissimi] de eo $R$ 46-47 custodire famulus Dei] D. f. seruare D 47 caelesti regno] et add. D caeleste regnum $\mathrm{R} \quad 48$ qua $\mathrm{V} \quad 49$ a om. $\mathrm{D}$ 4-VDRN

Incipit: de sancto Poemen $\mathrm{N} \quad 1$ autem om. $\mathrm{N}$ sancto om. $\mathrm{R}$ 2 sancti om. D 3 audiensque] audiens DN beati] sancti $\mathrm{N}$ 
nis, desiderabat uidere eum, misitque nuntium deprecando ut

5 susciperet eum. Beatus autem Poemen contristatus est ualde, cogitans apud semetipsum: Quia si coeperint personae nobiles uenire ad salutandum et honorandum me, manifestum est quia iam et alii multi etiam populares homines frequentabunt ad me et necesse est ut per haec perturbentur secreta uitae meae.

10 Conuersationem autem et humilitatis gratiam quam cum tanto labore, auxiliante Domino, a iuuentute mea studui custodire, forsitan subripiente maligno diabolo perdam et uanae gloriae incurram laqueos. Haec ergo apud semetipsum pertractans, definiuit quatenus excusaret magis et non susciperet iudicem.

15 Contristatus autem iudex quia non eum suscepisset, ait ad officium suum: Quomodo non merui uidere hominem Dei, peccatis meis imputo. Verumtamen nimis desiderabat per quam occasionem uideret sanctum uirum. Excogitabat autem huiuscemodi causam quae occasionem ei praeberet uidendi eum.

20 Comprehendens enim filium sororis beati Poemenis misit in carcerem, ut per istam occasionem aut susciperet iudicem aut certe ipse ueniret ad rogandum iudicem. Dixitque ad officium suum ut non contristaretur sanctus senior: Mandate ei, si uoluerit uenire ad me, necesse est ut statim educamus

25 eum de carcere. Talis est enim causa eius quae non possit impune transire. Audiens autem haec mater iuuenis, id est, soror sancti Poemenis, abiit in eremum ubi erat frater eius.

4 deprecandum R 6 semetipsum] dicens add. R 7 est om. R 8 iam om. D ad om. D 9 ut om. R perturbentur] conturbetur $\mathrm{R} \quad 10$ conuersatio $\mathrm{R}$ autem om. $\mathrm{R}$ gratia $\mathrm{R}$ 14 et] ut $\mathrm{R} 17$ desiderabat] -uit $\mathrm{N}$ uidere add. D per om. $\mathrm{N}$ quam] aliquam D 18-19 uideret... occasionem om. N 18 uidere D excogitauit D autem om. $\mathrm{R} 19$ quam D ei praeberet] expraeberet D sibi p. N 21 carcere R 23 ut] et add. D mandauit D 25 enim est RN 26 autem om. D 
Stabatque ad ostium cellulae eius cum multo fletu et ululatu, rogans eum ut descenderet ad iudicem et rogaret pro filio eius. Beatus autem Poemen non solum nihil ad eam dixit, sed nec ostium ei aperuit ut ingrederetur ad eum. Tunc illa coepit maledicere ei ac dicere: Durissime et impiissime et ferrea uiscera gerens, quomodo te tantus dolor fletus mei non flectit ad misericordiam, quomodo ipsum unicum filium habeo quem in periculo mortis uideo constitutum. Tunc senior mandauit ei per fratrem qui sibi ministrabat: Vade, dic ei: Poemen filios non genuit; ideo non dolet. Haec autem audiens iudex dixit amicis suis: Scribite ad eum ut uel epistolam precatoriam faciat ad me, quatenus possim eum dimittere. Tunc etiam quam plurimis suadentibus sanctus senior scripsit ad iudicem dicens: Iubeat nobilitas tua diligenter requirere causam illius; et si quid dignum morte admisit moriatur, quatenus in hoc praesenti saeculo exsoluat crimen peccati sui, ut euadat aeternas ac perpetuas gehennae poenas; sin autem nihil dignum morte commisit, quod iustum uidetur legibus ita de eo iube disponere.

28-30 stabatque... eius om. D 28 ululatu] eiulatu R 29 ad iudicem om. $\mathrm{R} \quad 30$ nihil ad eam] nihil om. $\mathrm{D}$ ad e. $\mathrm{n} . \mathrm{N}$ dixit] non exiit $\mathrm{D} \quad 31$ ei ostium $\mathrm{R} \quad 32$ ei om. $\mathrm{D} \quad$ ac] et $\mathrm{D}$ 33 gerens] ferens $\mathrm{D}$ te $o m$. $\mathrm{R} \quad 34$ flectit] flectet te $\mathrm{R}$ -35 quem habeo $\mathrm{N} \quad 35$ mortis periculo $\mathrm{D} \quad 36$ sibi] ei $\mathrm{R}$ ministrabat] dicens add. N 37 Poemen filios non genuit ideo non dolet] i. n. d. P. f. n. g. cum duplice puncto supra ideo certe ut inuersionem indicaret $\mathrm{V}$ P. f. n. g. (cognouit D) i. n. d. (i. n. d. om. R) DR 38 dixit om. D scribe D 38-39 precatoriam] rogatoriam D 39 possim eum] p. ipsum $D$ e. p. $R \quad 40$ etiam] iam $R$ suadentibus] uadentibus $R \quad 41$ requirere] in- $D R$ requiri $N$ 42 morti V 43 saeculi praesenti N 45 morti V commisit] ad- $\mathrm{R} \quad 46$ disponi $\mathrm{N}$ 
5-Quodam tempore uenerunt quam plurimi monachorum ad sanctum Poemen. Cumque de sanctae Scripturae diuersis capitulis dissereret eis, interrogauit eos dicens: Dicite mihi: Quis uendidit sanctum Ioseph? Respondentesque dixe-

5 runt ei: Quoniam fratres eius distraxerunt eum. Dicit eis beatus senior: Non ita est, sed humilitas eius et patientia uendidit eum, quia pro humilitate patienter ferens noluit resistere fratribus suis. Nam si uoluisset dicere: Quia germanus eorum ego sum, non potuissent eum distrahere. Sed tacuit

10 et non contradixit, sed cuncta Omnipotentis Dei commisit iudicio. Vnde manifeste ostenditur quoniam humilitas sua distraxit eum. Iterumque eadem humilitatis eius gratia, per dispensationem diuinae prouidentiae, constituit eum regem ac principem totius terrae Aegypti.

15 Non solum in hoc praesenti saeculo regnum ei humilitas contulit, sed etiam in caelesti et perpetuo regno gloriose cum omnibus regnat sanctis. Oportet nos ergo, filioli, constanter ac fortiter uirtutem humilitatis tenere, cum omni patientia tribulationes atque iniurias pro causa iustitiae sustinere, ut ad aeternam 20 caelestemque gloriam peruenire possimus.

IV,5 lin. 4-14: Quis uendidit... Aegypti - cf. Gen: XXXVII, 25-28; XLI, 33-46.

\section{5 - VDR om. N}

Incipit: Quintum $\mathrm{R} \quad 2$ sancta Scriptura $\mathrm{R} \quad 3$ diuersis om. D dissereret ]discereret D interrogabat R 5 ei om. DR eius om. D 6 est ita D humilitatis $\mathrm{R}$ et om. R 11 quoniam] quia $R \quad 12$ iterumque] itaque $D$ iterum $R$ humilitas $D$ $13 \mathrm{ac}$ et $\mathrm{D} 14$ totius om. D 15 praesente $\mathrm{D} 16$ contulit] in- D etiam om. V gloriosae V 19-20 ut possimus ad... peruenire $R$ 
6 - Item quodam tempore, dum adhuc iunior esset hic ipse beatus Poemen, uenerunt ad eum quam plurimi de uico eius, unde ortus fuit, petentes eum ut descenderet et peteret iudicem, quoniam quam plurimi ex eodem uico reclusi tenebantur in carcere. Beatus autem Poemen dixit eis: Permittite me interim tribus diebus quiescere et postmodum descendo ad iudicem. Postquam autem reuersi sunt ad uicum suum, ingressus in cellulam suam prostrauit se in orationibus ad Dominum dicens: Domine Deus, Creator et Saluator humani generis, exaudi me peccatorem seruum tuum, qui nosti multiformes insidias aduersariorum daemonum qui impugnant nos et festinant diuersis occasionibus inquietare secretam uitam nostram, ut separent mentem nostram de timore et amore tuo, Domine. Ideoque deprecor maiestatem diuinae potentiae tuae, Christe Domine, Saluator noster, ne permittas me talem gratiam habere apud iudicem saeculi istius, ut audiat petitionem meam, sed magis aduersetur me et non praestet quae petiero ab eo. Si enim praestiterit mihi quae petiero, manifestum est quia turbatur secreta conuersatio mea. Non enim permittunt me homines requiescere in loco isto, sed uenientes per singula deprecantur me, ut pro eis suggeram iudicibus pro causis corum. Post haec autem descendit et abiit ad iudicem et rogabat eum pro his qui in carcere

\section{6- VDRN ${ }^{2}$}

Incipit: sextum capitulum $\mathrm{R} \quad 1$ item om. $\mathrm{N}$ iunior] iuuenior $\mathrm{R}$ hic om. RN 2 ipse om. $\mathrm{N}$ Poemen] Pamen D Phimen $\mathrm{R} 44$ quam om. $\mathrm{D}$ reclusi] con- $\mathrm{N} \quad 8$ in ${ }^{1}$ ad $\mathrm{R}$ cellulam] cellam DN $9 \mathrm{et}$ ac $\mathrm{R} \quad 10$ seruum om. D 12 festinant] nos add. $\mathrm{R} \quad 14$ ideoque] ideo $\mathrm{N}$ deprecor] precor $\mathrm{R}$ 15 tuae om. $\mathrm{N} \quad 17 \mathrm{mihi} \mathrm{N}$ non] audiat neque add. D 18 si... petiero om. D 19 turbatur] con- R 20 permittent RN requiescere in loco isto homines $\mathrm{D} \quad 21$ deprecantur] -ntes $\mathrm{R}$ -abuntur $\mathrm{N} 22$ iudicibus] iudicium et $\mathrm{N}$ 
tenebantur. Responditque iudex dicens ei: Non oportet, famule

25 Dei, ut pro homicidis ac sepulcrorum uiolatoribus intercedas, quoniam et lex diuina tales exsceleratos homines iubet punire. Considera ergo quia non possum tibi praestare quae postulas. Haec autem cum audisset beatus Poemen, laetificatus est ualde quod non praestiterat ei iudex quae postulauerat et reuersus

30 est in cellulam suam.

7 - Fuit etiam de magnis patribus senior nomine Agathon, nominatissimus in uirtute humilitatis et patientiae. Quodam autem tempore perrexerunt ad uisitandum eum fratres, audientes enim de eo quod magnam humilitatem haberet. Volentesque

5 probare si uere humilitatis patientiam possideret, dixerunt ei: Multi scandalizantur in te, pater, quia nimis uitio superbiae tenearis et ideo alios despicias et pro nihilo eos habeas, sed et detractiones aduersus fratres non cessas loqui. Affirmant etiam quam plurimi quod haec ideo agas, quia fornicationis uitio

10 tenearis et, ne solus uidearis errare, idcirco non cessas de aliis detrahere. Ad haec senior respondens ait: Haec omnia quae dixistis uitia in me esse cognosco, nec possum negare tantas iniquitates meas. Procidensque pronus in terram adorabat eosdem fratres dicens: Deprecor uos, fratres, ut intentius pro

15 me misero et multis peccatis obnoxio Christum Dominum

24 tenebantur] retinebantur $R \quad$ respondit iudex et dixit $D \quad 26$ et om. D exsceleratos] excelleratores D sceleratos $\mathrm{RN}$ puniri $\mathrm{N}$ 27 quia] quoniam N 28 beatus om. N Poemen] Pamen D Phimen $\mathrm{R} 29$ quod] quia $\mathrm{R}$ praestaret $\mathrm{D}$ et reuersus] et om. V reuersusque D 30 cellulam] cellam DRN 7-VDRN

Incipit: de sancto Agathone $\mathrm{N} 1$ patribus] fratribus $\mathrm{R}$ quidam add. $\mathrm{N} \quad 4$ enim om. $\mathrm{N} \quad 5$ uerae $\mathrm{N} 6$ pater om. R superbiae uitio D 7 et $^{3}$ om. D 8 non] ne R cesses $\mathrm{V}$ etiam] enim $\mathrm{N} 9$ agis $\mathrm{N} 10$ idcirco] ideo $\mathrm{N}$ cesses $\mathrm{V}$ de om. DN $12 \mathrm{nec}$ non $\mathrm{D} 13$ pronus om. $\mathrm{R}$ terra R 14 deprecor] precor RN 15 obnoxio] obnixo D 
exorare non cessetis, ut indulgentiam tribuat iniquitatibus meis multis ac malis. At supradicti fratres addentes dixerunt ei: Non te lateat etiam hoc, quia haereticum te esse quam plurimi affirmare uoluerunt. Hoc autem cum audisset senior, dixit eis: Licet malis multis et peccatis obnoxius sim, tamen haereticus penitus non sum. Absit hoc ab anima mea. Tunc omnes fratres qui ad eum uenerunt, prostrauerunt se in terram ad pedes eius, obsecrantes eum ac dicentes: Precamur te, abba, ut dicas nobis cur tanta uitia et peccata dicentibus nobis de te, in nullo commotus es, de uerbo autem haeretici ualde te commouisti et abominatus es nec sufferre potuisti auditum? Dicit eis senior: Illas priores culpas atque peccata propter humilitatem sustinui, ut peccatorem me esse crederetis. Nouimus enim quia si custodiatur humilitatis uirtus magna, salus est animae. Nam Dominus et Saluator noster Iesus Christus, cum ei iudaei multas contumelias et conuicia irrogassent, patienter cuncta tolerauit, ut nobis humilitatis praeberet exempla. Immissi etiam falsi testes, multa aduersus eum falsa dixerunt; et usque ad mortem crucis patienter cuncta sustinuit. Ita enim et apostolus Petrus praedicat dicens: "Christus passus est pro nobis, nobis relinquens exemplum ut sequamur uestigia eius». Oportet igitur ut patienter cum humilitate cuncta aduersa

IV,7 lin. 31-32 : indaei... tolerauit - cf. Mat: XXVI, 67-68; XXVII, 27-31; Marc: XIV, 65; XV, 16-19; Luc. XXII, 63-65 ; Ioan. XIX, 2-3.

lin. 35-37: Christus... uestigia eius - cf. I Petr. II, 21.

17 ac] et $\mathrm{R}$ at] ad hoc (haec N) RN 18 hoc om. R 19 uolunt RN 20 malis] aliis $\mathrm{R}$ et om. $\mathrm{R}$ sim] sed D tamen] nam $\mathrm{R} 21$ hoc om. D 22 uenerant RN $23 \mathrm{ac}]$ et D 25 nullo] -um $\mathrm{R}$ ullo D 26 audito $\mathrm{R} 27$ dixit $\mathrm{N}$ ei D 28 crederetis] -ritis D credatis $\mathrm{R} 29$ uirtus] uiros $\mathrm{V}$ 30 Iesus om. R 31 ei om. D et conuicia om. R irrogassent] inter- $\mathrm{R} \quad 32$ tolerabat $\mathrm{R} \quad 32-33$ exemplum $\mathrm{N} \quad 33$ immissi] missi $R \quad 36$ nobis relinquens] r. n. $R$ uobis $r$. N sequamini $N$ 
sustineamus. Nam sermonem quem de haeretico dixistis non potui sustinere et ualde abominatus sum, quia haeresis separatio

40 a Deo est. Haereticus enim separatur a Deo uiuo et uero et coniungitur diabolo et angelis eius. Alienatus enim a Christo, iam non habet Deum quem exoret pro peccatis suis; ex omni parte periit. Si autem conuersus fuerit ad ueram et catholicam sanctae ecclesiae fidem, suscipitur a bono et pio Saluatore

45 nostro Christo, et reconiungitur Deo uero Creatori ac Saluatori nostro Christo, qui est in Patre Filius semper cum Sancto Spiritu. Ipsi gloria in saecula saeculorum. Amen.

8-De amore humilitatis sancti Isaac.

Consilium inter se habuerunt seniores patres: et omnes monachi habitantes in eremo Sceti consenserunt ut beatus pater Isaac presbyter eis ordinaretur in ecclesia, quae in ipso eremo

5 sita est, ubi conuenit omnis multitudo monachorum qui in illa eremo conuersantur. Audiens autem supradictus abbas Isaac, fugit in Aegyptum et abscondit se in quodam agro inter frutecta, arbitrans indignum se esse honore presbyterii. Quam plurimi autem fratres monachi sequebantur, ut comprehende-

10 rent eum. Cum autem applicuissent, ad uesperum, ad eundem agrum pro longius, ut reficerent fatigati de itinere, erat enim

38 de om. R 39 et] sed D $39-40$ a Deo separatio D 40 separatus $\mathrm{R} \quad 42$ suis] quia add. N 43 ueram] et sanctam add. D 44 pio et bono R 45 Christo om. N ac Saluatori om. D 46-47 Spiritu Sancto R 47 ipsi gloria in saecula saeculorum. Amen] i. g. in saeculorum s. A. $\mathrm{R}$ om. $\mathrm{N}$

\section{8 - VDRN}

1 sancti Isaac om. $\mathrm{N} \quad 2$ inter se habuerunt seniores] h. s. i. se $\mathrm{R}$ i. se h. sancti seniores $N \quad 3$ Sceti] Scythiae et N 4 ipsa RN 5 conuenit] die et hora statuta add. $\mathrm{N}$ illa] ipsa $\mathrm{R} \quad 6$ conuersatur D autem supradictus om. D abbas Isaac] I. abba R huiuscemodi consilium add. $\mathrm{N} \quad 8$ se indignum honore presbyterii esse (om. N) DN 10-11 in eodem agro $\mathrm{R} \quad 11$ pro] paulo $\mathrm{N}$ 
nox, dimiserunt asellum qui eis sumptus portabat in iter, ut pasceret. Cum autem pasceret asellus, peruenit in locum ubi supradictus abbas Isaac latitabat. Cumque illuxisset dies, requirentes monachi asellum, peruenerunt ad eundem locum ubi senior se occultauerat et admirantes ualde dispensationem diuinam, comprehendentes ligare et constringere eum uoluerunt et ita perducere. Venerabilis autem senior non permisit dicens: Iam non possum contradicere uobis, quia forsitan uoluntas Dei est, ut licet indignus, suscipiam ordinationem presbyterii.

9- Erant quidam duo fratres monachi pariter in cellula commanentes, quorum humilitatem et patientiam de sanctis collaudabant. Audiens quidam sanctus uir, uoluit probare si ueram perfectamque humilitatem haberent; uenit ad uisitandum cos. Cumque cum gaudio suscepissent eum et ex more complessent orationes et psalmodiam, et egressus esset foris cellulam, uidit paruum hortum ubi sibi holera faciebant. Apprehensoque baculo, cum toto impetu coepit omnia holera cedendo confringere, ita ut nihil omnino remaneret. Videntes autem supradicti fratres nihil penitus dixerunt; sed nec uultum tristem aut turbatum habentes, rursum ingressi cellulam, uespertinas orationes complentes, adorantes eum dixerunt: Si praecipis,

12 eis om. D in itinere portabat $\mathrm{R}$ 12-13 pasceretur $\mathrm{N}$ 13 pasceret] -retur $\mathrm{V}$-endo iret $\mathrm{N}$ in] ad $\mathrm{D} 14$ Isaac om. $\mathrm{N}$ latitabat] latebat $\mathrm{R} \quad 16 \mathrm{se} \mathrm{om} . \mathrm{V} \quad 17$ constringere et ligare $\mathrm{N}$ 20 est om. $\mathrm{R} \quad \mathrm{ut}]$ iam D ordinationem] ordinem $\mathrm{N}$

\section{9-VDRN}

Incipit: de humilitate duorum fratrum $\mathrm{N} 1$ pariter om. $\mathrm{N}$ cellula] cella $\mathrm{N} 2$ patientiam] multique add. $\mathrm{R}$ multi etiam add. $\mathrm{N}$ sanctis] patribus add. RN 3 audiens] autem add. $\mathrm{N}$ uolens $\mathrm{R} \quad 4$ uenit] uenitque $\mathrm{N}$ uisitandos $\mathrm{R} \quad 6$ psalmodiam] -a $\mathrm{R}$-as $\mathrm{N} \quad \mathrm{et}^{2}$ om. DRN esset] est $\mathrm{D}$ om. RN foris] foras RN 7 apprehendensque D 8 baculum D cedendo om. R $10 \mathrm{nec}$ ) ne D 11 cellulam] cellam R 12 orationes] horas D 
domine, ut eamus et eum qui remansit caulem coquentes gustemus, quia iam hora est ut cibum sumamus. Tunc

15 senior adorauit eos dicens: Gratias ago Saluatori nostro Christo, quia uideo Spiritum Sanctum requiescere in uobis et ideo hortor ac moneo uos, carissimi fratres, ut usque in finem custodiatis sanctae humilitatis et patientiae uirtutem, ut ipsa in regno caelesti uos magnos ac sublimes in conspectu Domini faciat

20 apparere.

10 - Erat quidam in coenobio iam senex probatissimus monachus et incurrit grauissimam aegritudinem. Confectusque nimia et intolerabili infirmitate per longum tempus laborabat in doloribus multis nec inuenire poterant fratres qualiter

5 succurrerent aegritudini, quomodo ea quae necessitas infirmitatis eius expetebat non habebant in monasterio. Audiens autem quaedam famula Dei de afflictione infirmitatis eius, deprecata est patrem monasterii, ut eum ad cellulam suam tolleret et ministraret ei, maxime autem quia facilius inuenire

10 possit in ciuitate, quae necessaria aegritudini eius uidebantur. Praecepit ergo pater monasterii ut portarent eum fratres ad

13 ut om. $\mathrm{N}$ caulem] callem $\mathrm{R} \quad 15$ eum $\mathrm{D}$ Christo] Deo D Domino add. R 16 uos R 17 ac moneo] moneoque $\mathrm{R}$ fratres carissimi $\mathrm{RN}$

$10-$ VDRN

Incipit: de sene infirmato $\mathrm{N} 2$ incurrit] in add. $\mathrm{N}$ aegritudinem] infirmitatem D 3 infirmitate] aegritudinem D longum] multum $\mathrm{R} 4$ doloribus] laboribus $\mathrm{N}$ inuenire] adinuenire RN qualiter fratres $\mathrm{R} \quad 5$ aegritudini] eius add. RN 7 quaedam om. $\mathrm{D} \quad 8$ deprecauit $\mathrm{V}$ eum] eam add. $\mathrm{R}$ cellulam] cellam V 9 tolleret] duceret $\mathrm{R}$ 9-10 inuenire possit] i. -set $\mathrm{D}$-ri - sent $\mathrm{R} \quad 10$ ciuitate] et add. $\mathrm{R}$ eius aegritudini RN uiderentur $\mathrm{R}$ 
cellulam famulae Dei. Ipsa uero cum omni ueneratione suscipiens senem, propter nomen Domini ministrabat ei, pro retributione mercedis aeternae, quam credebat a Christo Saluatore nostro recipere. Cumque per tres et amplius annos sedule 15 obsequeretur et ministraret famulo Dei, coeperunt homines mente corrupti secundum scabiem mentis suae suspicari, quod non sinceram haberet senior conscientiam de uirgine quae ministrabat ei. Audiens autem haec senior, exorabat diuinitatem Christi Domini dicens: Tu Domine Deus noster, qui solus cognoscis omnia et uides quia multi dolores sunt aegritudinis et miseriae meae, et afflictionem tantae infirmitatis quae me ita per tantum consumit tempus ut necessarium habeam obsequium huius famulae tuae, quae mihi propter nomen tuum ministrat, tribue ei, Domine Deus meus, condignam mercedem in uita aeterna, sicut dignatus es propter bonitatem tuam promittere his qui propter nomen tuum egenis et infirmis suum exhibent ministerium. Cum autem approximassent dies transitus eius, conuenerunt ad eum quam plurimi sancti seniores et fratres de monasterio. Dixit eis senior: Obsecro uos, domini patres et fratres, ut cum defunctus fuero tollatis baculum meum et plantate eum super sepulcrum meum; et cum radices miserit feceritque fructum, tunc scietis quia

IV,10 lin. 26-28 : dignatus... ministerium - cf. Mat. XXV, 34-40.

12-13 suscipiens] eum add. RN ei] et add. $\mathrm{R}$ pro] propter $\mathrm{R}$

14 Christo om. N

17 suae om. $\mathrm{R}$ 15 annos et amplius D 21 cognoscis] ag- D 24 huius om. DR 26 propter] per $\mathrm{D}$ -uit $\mathrm{R} \quad 30$ dixit eis] et $\mathrm{d}$. $\mathrm{N}$
feceritque] et fecerit $\mathrm{N}$ sciatis $\mathrm{R}$ multo dolore $\mathrm{D} \quad 22$ afflictionis $\mathrm{R}$ propter] per D 25 Domine om. $\mathrm{R}$ 28-29 approximassent] adproximasset $D$ 33 cum] si $R$ radicem $R$ 
munda est conscientia mea a famula Dei quae mihi ministrauit; 35 si autem non fronduerit, scitote quia non sum mundus ab ea. Cum ergo uir Dei exisset de corpore, secundum praeceptum eius sancti seniores plantauerunt baculum eius super sepulcrum ipsius et fronduit. Accedentique tempore protulit fructum et admirati sunt omnes glorificantes Dominum. Ad tale enim

40 miraculum etiam de uicinis regionibus multi uenientes magnificabant gratiam Saluatoris. Nam et nos ipsam arbusculam uidimus et benediximus Dominum qui protegit in omnibus in sinceritate et ueritate sibi seruientes.

11 - Quodam tempore ad beatum abbatem Apollo duxerunt ad cellulam eius quendam uexantem qui fortiter a daemonio torquebatur. Cumque triduum obseruarent, qui cum eo uenissent, deprecantes senem ut eum in nomine Christi

5 precibus ad Dominum fusis curaret, respondit senior, et dixit eis, non se esse huius meriti ut daemonibus imperaret. Cum autem persisterent qui uenerant rogantes eum flentes et nimis deprecantes, tandem quieuit. Cum autem in nomine Domini Saluatoris nostri Christi imperaret daemoni dicens: «Exi,

34 ministrabat $\mathrm{N} \quad 35 \mathrm{si}] \sin \mathrm{N} \quad$ scitote quia om. $\mathrm{R} \quad 36$ ergo] autem $\mathrm{R}$ de] a $\mathrm{N} \quad 38$ ipsius] eius $\mathrm{R}$ accedenteque $\mathrm{R}$ 39 Dominum] Deum RN 40-41 magnificabant] glorificabant $D$ 41-42 uidimus ipsam arbusculam $\mathrm{R} \quad 42$ Dominum] Deum $\mathrm{R}$ in omnibus] omnes $\mathrm{R}$

\section{$11-$ VDRN}

Incipit: de demoniaco (post corr.) abbate Appoline $\mathrm{N} \quad 1$ tempore] abeuntes add. $\mathrm{D}$ quidam add. $\mathrm{N}$ beatum abbatem Appolo] b. a. Apollinem $\mathrm{R}$ cellam abbatis Apollinis N 1-2 duxerunt] ad- hominem (om. R) RN 2 ad cellulam eius quendam uexantem] in (ad D) cellula (-m D) e. q. u. DR om. N 2-3 qui fortiter a daemonio] q. ualde a d. $\mathrm{D}$ a d. que $\mathrm{f} . \mathrm{R} \quad 3$ cumque] per add. $\mathrm{R}$ triduo $\mathrm{N} 4$ uenerant $\mathrm{N}$ deprecati sunt $\mathrm{D}$ eum om. D 5 Dominum] Deum RN 8 quieuit] ac- RN 8-9 Saluatoris Domini D 9 nostri] Iesus add. D 
immunde spiritus, de plasma Dein, tunc daemon respondens dixit ei: Ego quidem imperante uirtute Christi egredior, tamen interrogo te sermonem ut dicas mihi quid est quod scriptum est in Euangelio: Qui sunt haedi et qui sunt oues? Respondens autem senior dixit ei: Haedi quidem iniusti sunt, inter quos et ego sum peccator qui multis peccatis obnoxius sum; oues autem Deus nouit qui sunt. Tunc exclamauit daemon uoce magna dicens: Propter humilitatem tuam stare omnino non possum. Et statim egressus est de homine quem obsederat. Videntesque qui adstabant omnes dederunt gloriam Deo.

12 - Referebant sancti seniores nobis dicentes: Quia fuit quidam monachus in eremo Sceti, uenit autem ad uisitandum sanctos patres qui habitabant in loco qui dicitur Cellia, ubi multitudo monachorum diuisis cellulis habitabant. Cumque non inueniret ad praesens cellulam ubi possit manere, quidam de senioribus habens aliam uacantem cellulam, dedit ei dicens: Interim repausa in hac cellula, donec inuenias ubi possis manere. Cumque ad uisitandum eum conuenirent quam plurimi fratres, desiderantes $a b$ eo audire uerbum salutis

IV,11 lin. 13 : Qui sunt... oues - cf. Mat. XXV, 32.

10 plasmate RN 10-11 respondens dixit] -it et (om. D) d. (dicens D) DN $13 \mathrm{qui}^{2}$ ] quae $\mathrm{R} \quad 14-15$ iniusti... et om $\mathrm{R}$ 17 uoce magna daemon $R \quad 18$ non possum omnino $D$ egressus est statim D 19 uidentesque] uidentes $\mathrm{R}$

\section{$12-$ VDRN}

Incipit: de sene qui cellulam suam praestitit $\mathrm{N} 1$ referebant] de- $\mathrm{R} 22$ Sceti] Scythiae N 4 diuisis cellulis habitabant] d. (diuersis D) c. h. (-tat V) VD diuersas habebant cellulas R d. h. c. $\mathrm{N} 5$ possit manere] posset $\mathrm{m}$. $\mathrm{R} \mathrm{m}$. posset $\mathrm{DN} \quad 7$ inuenies $\mathrm{D} \quad 7-8$ manere possis $\mathrm{D}$ 
10 aeternae, habebat enim gratiam spiritalem docendi uerbum Domini, uidens autem ille senior qui ei ad habitandum praestiterat cellam, inuidiac liuore cor eius uulneratum est et indignari coepit ac dicere: Quomodo ego tantis temporibus in hoc loco habito et non ad me conueniunt fratres nisi

15 rarissime, et hoc in diebus festis, et ecce ad istum impostorem paene cottidie fratres quam plurimi uadunt? Dixit autem discipulo suo: Vade et dic ei ut egrediatur de cella illa, quomodo necessaria mihi est. Cum autem perrexisset discipulus eius ad illum fratrem dixit ei: Mandauit abbas meus sanctitati tuae:

20 Iube mihi mandare qualiter habeas, audiui enim te infirmari. Ipse uero remandauit ei: Ora pro me, domine pater, quia ualde stomachum doleo. Reuersus autem discipulus, dixit abbati suo: Nimis rogat angelum tuum, ut uel duos dies iubeas indutias dare, ut possit sibi aliam cellulam prouidere.

25 Transactis autem tribus diebus, iterum misit discipulum suum dicens: Vade, dic ei ut egrediatur de cellula. Nam si rursus distulerit, dices ad eum quia continuo uenio et cum baculo cedendo expello eum de cella mea. Pergens autem discipulus ad supradictum fratrem dixit ei: Quomodo ualde sollicitus

30 est abbas meus de infirmitate tua, ideo misit me requirens si melius habeas. At ille haec audiens dixit: Gratias

10 enim] etiam V spiritualem N 11 Domini] Dei D autem om. N senior ille V 12 cellam] cellulam RN et om. D 13 indignare $\mathrm{V}$ quomodo om. $\mathrm{N} \quad 14$ loco hoc $\mathrm{V} \quad 15$ istum om. $\mathrm{R}$ impostorem] in pastorem $\mathrm{D}$ inposteriorem $\mathrm{R} \quad 16$ quam] tam D 17 ad discipulum suum $\mathrm{RN}$ cella] cellula $\mathrm{D}$ 19 illum] alium D 20 mandari DN qualiter] te add. DN infirmare $\mathrm{R} 21$ remandauit] dicens add. $\mathrm{N} 23$ tuum] a te add. D ut om. D 24 iubeas] om. D ei add. RN dari N alia cellula R 25 suum om. $\mathrm{N} 26$ cellula] cella mea (om. R) RN 27 uenio ct] -am et $\mathrm{R}$ om. $\mathrm{N} \quad$ cum om. $\mathrm{R} 28$ expellam $\mathrm{R}$ cella] cellula $\mathrm{V}$ mea om. $\mathrm{R} 29$ supradictum] saepe dictum $\mathrm{R}$ fratrem] et add. D om. R quomodo om. N 30 abba V 30-31 requirere $\mathrm{D} 31$ dixit] ei $a d d . \mathrm{D}$ 
ago, domine, sanctae caritati tuae, quia sollicitus es de me; uerumtamen precibus tuis melius habeo. Reuersus autem discipulus dixit abbati suo: Etiam et nunc satis deprecatur sanctitatem tuam dicens ut usque diem dominicum expectes eum et statim egredietur. Cum autem aduenisset dominicus dies et non egrederetur, accipiens uectem senior, inflamatus inuidiac et iracundiae spiritum pergebat ut cedendo expelleret eum de cella. Accedens autem discipulus eius dixit ei: Si iubes, pater, praecedo te et uideo, ne forsitan aliqui fratres ad salutandum eum uenerunt et si uiderint te scandalizentur. Praecessit ergo discipulus eius et ingressus ad eum: Ecce, inquit, abbas meus uenit ad salutandum te. Egredere ergo celerius et cum gratiarum actione occurre ei, quia pro nimia caritate et dilectione uenit ad te. Qui statim surgens, cum nimia alacritate occurit ei. Cumque uidisset eum, antequam proximaret prostrauit se protinus in terram, adorabatque senem cum gratiarum actione dicens: Retribuat tibi Dominus, carissime pater, bona aeterna pro cellula quam mihi propter nomen eius praestitisti et in caelesti Hierusalem inter sanctos suos Christus Dominus tibi gloriosam et splendidam praeparet mansionem. Haec autem audiens senior, compunctus est corde et proiciens baculum cucurrit in amplexum eius et osculatus est eum et duxit eum ad cellulam suam ut pariter cum gra-

32 sanctae] sancte pater $R \quad 33$ uerumtamen] in add. V 34 et om. $\mathrm{N}$ satis deprecatur] satis om. $\mathrm{R}$ d. s. $\mathrm{N} \quad 35$ tuam sanctitatem $\mathrm{N}$ dicens om. $\mathrm{R}$ usque] ad add. $\mathrm{R}$ dominicam $\mathrm{N}$ 36 eum om. $\mathrm{R}$ egreditur $\mathrm{N}$ aduenisset] uenisset $\mathrm{N}$ 36-37 cum... egrederetur om. $\mathrm{R} \quad 37$ inuidia $\mathrm{R} \quad 39$ accedens] audiens D 40 praecedam DR te om. $\mathrm{R}$ uidebo $\mathrm{R}$ fratres om. $\mathrm{R} \quad 41$ uenerint $\mathrm{RN} \quad 42$ praecedens $\mathrm{R}$ eum] dixit add. R 43 te om. R 44 et om. R 46 alacritate] claritate D 47 proximaret] ap- $\mathrm{R}$ protinus] om. $\mathrm{R}$ pronus $\mathrm{N} 48$ retribuat] restituat $\mathrm{R} \quad 52$ autem om. $\mathrm{N} \quad 53$ amplexu $\mathrm{R} \quad 54$ et duxit] adduxitque $\mathrm{R}$ et in- $\mathrm{N}$ eum ${ }^{2}$ ] illum $\mathrm{N}$ ad] in $\mathrm{N}$ cellulam] cellam DN 
55 tiarum actione perciperent cibum. Vocauit autem senior supramemoratum discipulum et interrogauit eum dicens: Dic mihi si dixisti fratri uerba quae propter cellulam illam mandaui ut diceres ei. Tunc discipulus eius confessus est dicens: Vere, domine, dico quomodo propter humilitatem quam

60 tibi exhibere debeo, tamquam patri et domino, ideo non audebam respondere tibi aliquid quando mittebas me ad eum, uerumtamen nihil corum dixi quae mandabas ad eum. Haec audiens senior statim prostrauit se in terram ad pedes discipuli sui dicens: Ex hodierna die tu meus pater esto et ego disci-

65 pulus tuus, quoniam te festinante et moderante, cum timore et caritate Dei agente, et meam et illius fratris animam de peccati laqueo Christus Dominus liberauit. Pro uoto enim et sancta sollicitudine et intentione discipuli, qui perfecte in caritate Christi diligebat abbatem suum et anxius timebat ne

70 per inuidiae et iracundiae uitium aliquid tale ageret pater eius spiritalis, ut perderet omnes sanctos labores, quos ab ineunte aetate in Christi seruitio pro uitae aeternae praemiis laborauerat, ideo Dominus donauit gratiam suam ut in pace Christi pariter laetarentur.

55 perciperent] ac- $\mathrm{N}$ 56 supramemoratum] -dictum $\mathrm{N}$ om. $\mathrm{D}$ discipulum] suum add. RN $57-59$ dic... dicens] quando te mittebam ad eum numquid loquebaris ei sicut praecipiebam? Qui respondit R 57 fratri om. N propter cellulam illam] pro cellula D 58 eius om. D est] ei add. N 62 dixi] ei add. $\mathrm{R}$ ad cum] adesse et narrauit ei per ordinem cuncta quae gesserat $\mathrm{R}$ 62-63 haec audiens] a. h. $\mathrm{R}$ h. autem a. N 63 statim] se add. $\mathrm{R}$ terra $\mathrm{R}$ 64-65 ex... tuus om. $\mathrm{D}$ 64 pater meus $\mathrm{N} 65$ moderante] moderate $\mathrm{V}$ et add. $\mathrm{N}$ 66 Dei et caritate D 68 sancta om. R 69 caritatis N 69-72 diligebat... Christi om. $\mathrm{N} \quad 70$ per] pro $\mathrm{R}$ uitio $\mathrm{R}$ eius om. D 71 spiritualis $R \quad$ ut] et DR $7 ;-72$ ab ineunte aetate] in abeunte et a te $\mathrm{D}$ ab ineunti $\mathrm{R} \quad 73$ ideo Dominus donauit] ideoque d. D. $\mathrm{R}$ d. eis D. $\mathrm{N}$ 
13 - Dicebant sancti seniores de discipulo abbatis Pauli nomine Ioanne, quomodo magnam haberet humilitatem et uirtutem oboedientiae ut etiam difficiles causas, imperante ei abbate, in nullo penitus contradiceret, sed nec leuiter in aliquo murmurabat. Cum autem necessarius esset, in monasterii utensilibus, fimus boum, misit eum abbas in proximum uicum, ut requireret ibi fimum boum et in celeritate afferret ad monasterium. Erat autem in illo loco mala bestia leaena. Statim ergo egressus, supradictus discipulus eius Ioannes ibat secundum praeceptum abbatis. Cumque pergeret, dixit abbati: Domine, audiui quam plurimos dicentes quia in illo loco bestia leaena sit. Tunc senior quasi ioculariter dixit ei: Si uenerit super te, tene et alliga eam et adduces eam tecum. Cum autem peruenisset ad locum iam uespere, statim egressa leaena irruit super eum. Ille autem comprehendens, tenere eam uoluit, sed illa excutiens se de manu eius aufugit. Sequebatur autem eam dicens: Quia abbas meus praecepit ut alligatam perducam te ad eum. Continuo autem stetit bestia et tenens eam, reuertebatur ad monasterium. Dum autem retardaret in itinere, abbas nimis sollicitus pro eo tristabatur grauiter; et ecce subito superuenit discipulus eius tenens ligatam leaenam. Quod cum uidisset senior, admiratus ualde, gratias agebat Saluatori

\section{$13-$ VDRN}

Incipit: de monacho et leaena $\mathrm{N} \quad 2$ nomine Ioanne om. $\mathrm{R}$ 3 etiam] in add. DR difficillimis causis $\mathrm{R} 4$ penitus om. D leuiter] leniter $\mathrm{N} \quad 5$ murmuraret $\mathrm{RN}$ necessarius esset] -um e. (esse D) DR in monasterii om. D 6 fimum D abbas] suus add. $\mathrm{N}$ proximo uico $\mathrm{R} \quad 7$ in] cum $\mathrm{R} \quad 8$ loco illo $\mathrm{V}$ 9-12 statim... sit om. $\mathrm{R} \quad 9$ ergo om. $\mathrm{N} \quad 10$ abbati] suo add. $\mathrm{N}$ 11 domine] pater add. $\mathrm{N}$ loco] mala add. $\mathrm{N} 12$ dicit $\mathrm{V}$ 13 adduc $\mathrm{N} 14$ egressa] est add. D leaena] et add. D 15 autem] uero $\mathrm{N}$ comprehendens] ap- $\mathrm{R} 16$ uolebat $\mathrm{R}$ sed om. $\mathrm{R} 17$ alligatam] ligatam $\mathrm{N} 19$ retardaret] reuerteretur $\mathrm{D}$ in] de D 20 pro eo om. R tristabatur] con- N et om. D 21 eius om. $\mathrm{N}$ 
nostro Domino. Dixit autem ei discipulus suus: Ecce, domine, sicut praecepisti adduxi ligatam leaenam. Volens autem senior 25 humiliare sensum eius ne extolleret se in cogitationibus discipulus eius, ait ei: Sicut tu insensatus es, ita etiam et istam insensibilem bestiam adduxisti. Solue ergo et dimitte eam ut pergat ad locum suum.

14 - Quidam de sanctis senioribus misit discipulum suum ad hauriendam aquam; pro longius autem erat puteus a cella senioris. Oblitus est autem tollere funem discipulus eius de qua hauriret aquam. Cumque peruenisset ad puteum, contris-

5 tatus est ualde, quia longe erat cella eorum. Quid ageret, quo se uerteret nesciebat; dubitabat enim ad cellam reuerti. Tunc anxius nimis prostrauit se in orationem cum lacrimis dicens: Domine, miserere mihi secundum magnam misericordiam tuam, qui fecisti caelum et terram, mare et omnia quae in eis

10 sunt, qui facis mirabilia magna solus, miserere mei propter seruum tuum qui misit me. Et cum surrexisset de oratione, exclamauit dicens: $\mathrm{O}$ putee, putee, misit me seruus Christi abbas meus ut hauriam aquam. Statim autem ascendit aqua sursum usque ad os putei. Et cum implesset lagenam suam frater,

IV,14 lin. 8-9 : Domine... tuam - cf. Ps. L, 1.

23 ei om. D suus] eius RN 25 cogitationibus] suis add. RN 26 eius] suus $\mathrm{R}$ ei om. $\mathrm{R}$ insensatus] insensibilis $\mathrm{R} \quad 27$ bestiam om. D eam om. R

\section{$14-$ VDRN}

Incipit: de monacho et puteo $\mathrm{N} \quad 1$ suum om. $\mathrm{R} \quad 2$ puteus om. $\mathrm{R}$ cella] cellula $\mathrm{R} \quad 3$ autem] itaque $\mathrm{N}$ tollere] ut tolleret D 4 quo $\mathrm{RN}$ aqua $\mathrm{R}$ perueniret $\mathrm{D} \quad 5$ est om. R 5-6 quo se uerteret om. R 6 enim] autem $\mathrm{N}$ 7 nimis om. $\mathrm{R}$ oratione $\mathrm{N} \quad 8$ mei D 10 qui facis om. $\mathrm{R}$ 11 et cum] cumque $R \quad 12$ Christi] Dei D abba V 14 impleuisset D 
abscessit glorificans potentiam Domini Saluatoris. Aqua autem putei reuersa est ad locum suum.

15 - Quidam de sanctis habebat discipulum nomine Petrum et solitarius cum illo habitabat. Quodam autem die indignatus aduersus eum expulit eum de cella et clausit post eum ostium. Ille uero permansit ibi et non recessit quoquam, sed orabat, flebatque. Post duos autem dies, aperiens ostium senior inuenit eum ibi stantem et nimis laetatus est, considerans patientiam et ueram humilitatem eius et complexus eum induxit in cellulam; et perseuerauit cum sene usque in exitum eius.

16 - Fuit quidam frater in monasterio nomine Eulalius, nimis gratia humilitatis ornatus. Si quid igitur, ut solet, culpabile admisissent negligentiores fratres, excusantes culpas suas, supradictum fratrem asserebant esse culpabilem. Cumque argueretur a senioribus non negabat, sed prosternebat se in terram adorans eos, dicebat se peccasse et negligenter fecisse. Cum autem iterum ac frequenter accusarent eum et, secundum regulam monasterii, biduana ac triduana ieiunia ei indicerentur, ille omnia patienter tolerabat. Ignorantes autem fratres quia

15 Domini om. N

$15-$ VDRN $^{2}$

1 sanctis] patribus add. R 2 solitarius] solicitus D quadam $\mathrm{N} 3$ indignatus] indignanter $\mathrm{R}$ 3-4post eum om. $\mathrm{R}$ 4 quoquam] quodam $\mathrm{R} \quad 5$ aperuit $\mathrm{D}$ 5-6 senior ostium $\mathrm{D}$ 8 induxit] duxit D cellulam] c (cellam D) suam DN

16 - VDRN

Incipit: de fratre Eulalio $\mathrm{N} \quad 2-3$ culpabile ut solet $\mathrm{N}$ 4 esse om. N 5 senioribus] fratribus add. RN 6 terram] et add. R eos] eum D om. R dicebat] -que N 7 ac] et R 8-11triduana... conuenientes: codex $N$ in extremitate inferiori laceratus est, ideoque aliqua uerba desiderantur $\quad 8$ ei om. $\mathrm{R}$ indicerentur] inducerent $\mathrm{R}$ 9 ille] ista $R$ 
10 hace omnia pro humilitatis uirtute patienter sustineret, conuenientes pariter maxime seniores fratres ad patrem monasterii, dixerunt ei: Considera, pater, quid faciendum est, quamdiu enim possumus sustinere negligentias et damna, quac frater Eulalius facit in monasterio? Iam paene omnia uasa et uten-

15 silia monasterii confracta sunt et exterminata per negligentiam eius. Quomodo ergo iste talis tolerandus est ? Respondensque pater monasterii ait: Interim paucos dies sustineamus, fratres, et postea ordinetur de eo quod competit fieri. Haec dicens dimisit fratres. Ingressus uero cellulam, prostrauit se in oratio-

20 nibus, obsecrans misericordiam Domini, ut ei manifestare dignaretur quid ordinare aut definire possit de saepe dicto fratre. Tunc reuelatum est ei quid ageret. Conuocauit ergo omnes fratres abbas, dixitque eis: Credite mihi, fratres, quia magis opto mattulam fratris Eulalii, cum humilitate ac patientia

25 eius, quam omnia opera corum dumtaxat qui, murmurantes in cordibus suis, operantur in monasterio. Vt autem ostendat uobis Dominus quale meritum apud Deum habeat hic ipse frater, praecipio uobis ut deferantur mihi mattulae omnium fratrum. Quas cum detulissent, iussit ut accenderent ignem et

10 sustineret] toleraret $\mathrm{D} \quad 12$ faciendum] fiendum $\mathrm{R} \quad 13$ possimus D 14-15 utensilia et uasa $\mathrm{N} 15$ pro negligentia $\mathrm{R}$ 16 quomodo] quando $\mathrm{D}$ respondensque] eis add. $\mathrm{R}$ respondens $\mathrm{N}$ 18 ordinabitur $\mathrm{R}$ de eo om. $\mathrm{R}$ quod] ut $\mathrm{R}$ dixit $\mathrm{D}$ 19 fratres] $\cos \mathrm{R}$ ingressus] -que $\mathrm{R}$ uero] in add. $\mathrm{D}$ om. $\mathrm{R}$ cellulam om. R 19-20 oratione N 20 Domini] Dei N manifestare] mandare $\mathrm{R} \quad 21$ ordinauerat $\mathrm{R}$ aut] ut $\mathrm{R}$ possit] -sint D -set $\mathrm{N}$ saepe dicto] supradicto DR 22 reuelatum est ei] reuelauit ei Dominus $\mathrm{R} 23$ dixitque] et dixit $\mathrm{N}$ credite] audite $\mathrm{R}$ me $\mathrm{R} 24$ mattulam] mappulam $\mathrm{R}$ ac] et RN 25 dumtaxat] taxat $\mathrm{D} 26$ suis] murmurantes add. repetens $\mathrm{D}$ ostendat] suadebat $\mathrm{R} \quad 27$ uobis] nos $\mathrm{R}$ habeat apud Deum $\mathrm{R} 28$ praecepit $\mathrm{R}$ uobis om. $\mathrm{R}$ deferentur $\mathrm{R}$ mihi om. DR mattulae] mappulae $\mathrm{R}$ 
misit in eum omnium fratrum mattulas, quae statim omnes combustae sunt, praeter mattulam fratris Eulalii, quae integra reperta est et non est combusta. Cumque hoc uidissent fratres omnes, timuerunt ualde et, prosternentes se in terram, ueniam et indulgentiam Christum Dominum postulabant et collaudantes admirabantur nimis patientiam et humilitatem fratris Eulalii. Denique ex eo honorabant et magnificabant eum, tamquam unum de magnis patribus. Istos autem honores et laudes non poterat sustinere frater Eulalius dicens: Vae mihi infelici, quia perdidi humilitatem, quam tantis temporibus acquirere auxiliante et adiuuante me Christo Domino festinaui. Consurgens itaque nocte, egressus de monasterio, fugit in eremum, ubi nullus eum agnosceret et ibi in spelaeo habitauit. Noluit enim temporales hominum laudes, sed caelestem aeternamque gloriam a Saluatore nostro in futuro percipere saeculo.

17 - Beati abbatis Athanasii laudabilem humilitatis et patientiae uirtutem oportet ut cognoscatis, quatenus admirabilem magnanimitatem et tranquillitatem animae eius consi-

30 miserunt $\mathrm{R}$ in eum om. $\mathrm{R}$ mappulas fratrum $\mathrm{R} \quad 30$ -31 mattulas... praeter om. D 31 mattulam] mappulam $R \quad 32$ est et om. D hoc om. N 34 indulgentiam] a add. RN Christo RN Domino RN 35 admirabatur D 36 fratres $R$ Eulalii om. $\mathrm{R} \quad 36-39$ et... tantis: in codice $\mathrm{N}$ aliqua uerba desiderantur quia folium laceratum est 39 humilitatem] meam add. $\mathrm{R}$ quam] quia $R \quad 39-40$ per tanta tempora $R \quad 40$ me om. $D R$ 41 nocte om. D de monasterio egressus D 42 ubi] ut $\mathrm{D}$ nullus] ullus $\mathrm{R}$ spelaeo] specu $\mathrm{R} \quad 43$ habitabat $\mathrm{R} \quad 44 \mathrm{Sal}-$ uatore] Christo add. $\mathrm{N}$ nostro] Christo add. D

$$
17-\text { VDRN }
$$

Incipit: de abbate Anastasio $\mathrm{N} 1$ Athanasii] Anastasii RN humilitatem $\mathrm{R} \quad 2$ cognoscatis] ag- $\mathrm{D}$-entes $\mathrm{R} \quad 3$ magnanimitatem] magnitudinem $\mathrm{R}$ animi $\mathrm{RN}$ 
derantes, imitemur exemplo. Hic itaque abbas Athanasius

5 habebat codicem in membranis ualde optimis scriptum, qui decem et octo ualebat solidos. Totum enim uetus et nouum Testamentum scriptum habebat. Cum autem quidam frater uenisset ad eum uisitandi gratia, uidit in cellula eius codicem ipsum, concupiuit furatusque est eum et abiit. Supramemo-

10 ratus autem abbas, cum requisisset eadem die ad legendum codicem et non inuenisset, intellexit quia frater ille furasset eum et noluit mittere post ipsum nec requirere eum, ne post furtum etiam et periuria adderentur. Descendens autem frater ille in eam quae in proximo erat ciuitatem, uoluit distrahere

15 codicem ipsum; petebat autem in pretio eius solidos sedecim. Dicit ei ille qui emere uolebat: $\mathrm{Da}$ mihi codicem ut possim probare si tanto pretio ualet. Dedit ergo codicem, ut probaret eum. Statim autem cum ipso codice perrexit ad sanctum Athanasium et rogabat eum dicens: Iube considerare, pater,

20 codicem istum et aestimari eum si ualet solidos sedecim, quoniam tantum pretium petit qui distrahit eum. Dixit autem abbas Athanasius: Quia bonus est codex et ualet tanto pretio. Reuersus autem qui emere uolebat, dixit distrahenti: Ecce accipe pretium, quia ostendi codicem abbati Athanasio et dixit

25 mihi: "Quia bonus est codex et ualet tantum». Interrogauit

4 Athanasius] Anastasius RN 5 membranis] pergamenis $\mathrm{R}$ optimum R 7 habebat scriptum $\mathrm{R} \quad 8$ gratia uisitandi $\mathrm{R}$ 9 ipsum] et add. RN furatusque est eum] ipsumque furatus est $R$ 10 autem om. N abbas] Anastasius add. N legendum] de- $\mathrm{R}$ 11 codicem] suum add. $\mathrm{N}$ inuenisset] eum add. $\mathrm{D}$ furasset] furatus est (esset RN) DRN 13 etiam om. $N$ periurium R adderetur R 14 ille om. R 16 ille om. D 17 tanto pretio ualet] -um -ii u. N -um u. -ium DR ergo] ei D 18 autem] ergo $R$ frater ille add. N 19 Athanasium] Anastasium RN considerari $\mathrm{N}$

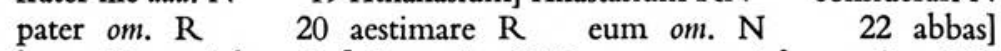
beatus $\mathrm{R}$ Athanasius] Anastasius RN tanto pretio] -um -ium DR -um -ii N 24 Athanasio] Anastasio N 
autem frater ille si nihil dixisset aliud. Cui respondit ille et ait: Crede mihi quia penitus nihil mihi aliud dixit. Haec cum audisset frater ille dixit: Quia iam recogitaui et nolo distrahere codicem. Compunctus enim corde, festinanter perrexit ad abbatem Athanasium et prostrauit se in terram ad pedes eius cum fletu et lacrimis poenitendo rogabat ut resusciperet codicem. Sed non acquiescebat abbas dicens: Vade cum pace, frater; ecce cum uoluntate mea habe tu ipsum codicem. Ille autem persistebat cum lacrimis poenitendo dicens: Quod si non susceperis codicem, domine pater, nullo modo requiescit anima mea. Post haec recepit codicem. Nam frater ille permansit apud beatum Athanasium in cellula eius usque in exitum uitae suae.

18 - Erat quidam monachus in eremo degens et coepit intra se cogitare, quae iam uirtutum merita possideret, et orauit intente dicens: Domine, ostende mihi quid minus in sancta conuersatione habeo, ut tua gratia auxiliante adimplere ualeam quod deest mihi. Dominus autem Deus noster, qui

IV,18 lin. 5-7 : Deus... uenire - cf. I Tim. II, 4.

26 autem] eum add. $\mathrm{R}$ nihil] beatus Anastasius add. $\mathrm{N}$ 26-27 cui...quia om. $\mathrm{R} \quad 27$ quia om. $\mathrm{D} 28$ dixit] ei add. $\mathrm{N}$ recogitaui] frater $a d d$. N 29 codicem」 meum add. N 30 Athanasium] Anastasium RN eius] et add. R et precabatur add. N 31 et om. D rogabat om. $\mathrm{N}$ resusciperet] sus- $\mathrm{R}$ re- $\mathrm{N}$ codicem] suum add. N 32 acquiescebat] ei add. $\mathrm{N}$ cum pace om. $\mathrm{R}$ 33 ecce] est add. $\mathrm{R}$ iam add. $\mathrm{N}$ habe tu] habeto $\mathrm{RN} 34$ poenitendo] petendo eum $N$ quod] quoniam $R$ quia $N \quad 35$ codicem domine pater om. D nullo modo requiescit] non quiescit D 36 codicem] suum add. $\mathrm{N}$ nam om. $\mathrm{R}$ ille om. $\mathrm{N} 37$ Athanasium] Anastasium RN cellula] cella DN

$18-\mathrm{VDRN}^{2}$

3 minus] munus D 5 Deus om. D 
uult omnes homines saluos fieri et ad agnitionem ueritatis uenire, ut humiliaret sensum eius et cogitationem, reuelauit ei dicens: Vade ad monasterium illius abbatis et ipse pater monasterii quicquid tibi dixerit hoc facere debes. Reuelauit

10 autem Deus etiam patri monasterii dicens: Ecce ille monachus, qui in uicina eremo habitat, uenit ad te. Vide ut dicas ei quatenus accipiat flagellum et mitte eum ut pascat porcos. Cum autem uenisset senior, pulsauit ostium monasterii et ingressus est ad patrem monasterii. Cumque alterutrum sibi

15 pacem dedissent, facta oratione dixit eremita ad abbatem monasterii: Dic mihi, pater, quid me oporteat facere, ut saluetur anima mea. Tunc monasterii pater: Siquid dixero, obaudis ut facias? At ille respondens ait: Quicquid mihi praeceperis, domine, facio. Dicit ei abbas: Accipe istud flagellum

20 et uade pasce porcos. Quam plurimi autem homines, qui eum beatum pro sancta conuersatione credebant, uidentes eum porcos pascere dicebant: Ecce eremita ille, de quo magna opinio erat, amens factus porcos pascit. Videns autem Dominus humilitatem et promptam oboedientiam eius ac patientiam, quia sustinuit

25 opprobria et subsannationes hominum, effudit super eum largam gratiam suam, ut etiam daemones eum contremiscerent. Reuersusque est in eremum ad cellulam suam.

6 ad om. R ueritatis om. R 7 et cogitationem eius RN 9 dixerit tibi $\mathrm{R}$ hoc om. $\mathrm{R}$ fecere $\mathrm{D} 11$ habitabat $\mathrm{N}$ 13 senior] ad monasterium add. N 13-14 et ingressus est ad patrem monasterii] om. D est om. V 13-15 et... abbatem] cum autem admissus fuisset post orationem factam dixit patri $\mathrm{N} 15$ eremita om. R abbate D 16 oporteat me D 17 monasterii pater] p. $\mathrm{m}$. ait $\mathrm{N}$ siquid] tibi add. $\mathrm{R}$ si $\mathrm{N} 18$ mihi om. $\mathrm{R}$ 19 domine om. D 20 uade] et add. R 21 uidentes] autem add. D 21-22 pascere porcos $\mathrm{N} 24$ promptam] propter D tantam $\mathrm{R}$ 25 obprobrium $R \quad 26$ eum daemones $R \quad 27$ cellulam] cellam $\mathrm{N}$ suam om. $\mathrm{N}$ 
19 - Quodam tempore cum ad beatum Macarium quidam uenisset, desiderans in proposito monachorum seruire Christo, et deprecaretur sanctum senem, ut instrueret ac doceret et ex fonte doctrinae salutaris, quae in eo per Sancti Spiritus gratiam abundabat, confirmaret et qualiter possit iuuante Domino insidias atque impugnationes maligni euadere praemoneret, respondensque beatus Macarius ait: $\mathrm{Si}$ uere ex toto corde desideras renuntiare huic mundo, filiole, et adhaerere Domino Saluatori sicut dicit propheta in psalmo: "Adhaesit anima mea post te, me autem suscepit dextera tua", parata enim est dextera Domini confugientes ad se suscipere, oportet te renuntiare huic mundo et omnes actus eius abicere, sicut dicit Apostolus scribens ad Colossenses: «Mortui enim, inquit, estis huic mundo et uita uestra abscondita est cum Christo in Domino. Cum autem Christus apparuerit uita uestra, tunc et uos apparebitis cum ipso in gloria». Haec audiens iunior dixit: Crede mihi, beatissime pater, quia et mentem meam alienaui $\mathrm{ab}$ hoc mundo et $\mathrm{ab}$ omnibus quae in mundo sunt, ut iam tamquam mortuus degeam in huius temporis uita. Cognoui enim quoniam temporalia et transitoria atque corruptibilia sunt 20 omnia, quae in hoc mundo uidentur esse bona.

IV,19 lin. 9-10 : Adhaesit... tua - cf. Ps. LXII, 9. lin. 13-16 : Mortui... gloria - cf. Col. III, 3-4.

\section{$19-\mathrm{VDRN}^{2}$}

2 propositum $\mathrm{R} \quad 3 \mathrm{ut}$ ] eum add. $\mathrm{R}$ instrueret] eum add. $\mathrm{N}$ 5 posset DN 7 respondensque] respondens RN 8 et om. D adhaerere] adhaere D 10 autem om. $\mathrm{N}$ enim est] est e. D enim om. R 12 actus] sanctos D 13 inquit estis] e. i. R inquit om. N 15 Domino] Deo $\mathrm{N}$ autem] enim $\mathrm{R} 17 \mathrm{et}]$ ita $\mathrm{R} \quad 18$ omnibus] hominibus $\mathrm{R} \quad$ in] hoc add. $\mathrm{R} \quad 18-19$ ut iam] utinam $\mathrm{D} 19$ degeam] degam $\mathrm{N} 21$ bona esse uidentur D 
Tunc dicit ei senior: Audi me, fili, et uade ad sepulcra mortuorum et quam plurimis iniuriis multisque conuiciis ac maledictis taffice etiam et lapida eos, ut prouocati irritentur 25 aduersum te. His auditis iunior statim perrexit ad monumenta mortuorum. Cumque secundum beati senioris praeceptum multis eos, ut putabat, iniuriis affecisset, reuersus ad sanctum Macarium dixit ei quod fecerat. Interrogauitque eum senior, si nihil ei respondissent illi mortui. Et respondens dixit: Nihil

30 penitus dixerunt, domine. Iterum autem praecepit ei dicens: Perge crastino die et multis praeconiis collauda et glorifica eos. Abiitque iterum frater ad sepulcra mortuorum, coepitque laudare et honorificis sermonibus glorificare eos dicens: Vos magni estis et sancti et similes apostolicis uiris et iustitia

35 magna in uobis est. Et alias quam plurimas laudes cum ad eos dixisset reuersus ad cellulam dixit seniori: Ecce secundum praeceptum tuum, domine pater, laudaui et glorificaui illos mortuos et nihil mihi penitus dixerunt. Tunc dixit ei sanctus Macarius: Considera, fili, quoniam iniuriis et contumeliis expro40 brasti illos mortuos et nihil tibi locuti sunt.

Ita ergo et tu, si uis saluus esse et in sancto proposito placere Saluatori nostro Christo, imitare ipsum Dominum Saluatoremque nostrum, sicut dicit Ioannes apostolus et euangelista: "Quoniam qui dicit se in Christo manere, debet 45 quemadmodum ille ambulauit et ipse ambulare». Et in Euangelio

IV,19 lin. 44-45 : Quoniam... ambulare - cf. I Ioan. II, 6.

22 dixit $\mathrm{R} \quad 23$ conuiciis ac] conuiciare $\mathrm{N} \quad 24$ affice existimo per coniecturam scripsisse D: om. VRN etiam et] et tamen D et om. N 26 mortuorum: explicit hic textus huius apophthegmatis in $\mathrm{R} \quad 27$ eos om. D 28 eum om. $\mathrm{N}$ senior] senex D 29 ei respondissent] r. ei D ei om. $\mathrm{N}$ respondens] ei add. D 30 domine dixerunt V 36 cellulam] cellam $\mathrm{N} \quad 37$ pater om. N 38 penitus mihi D 42 imitari D 
legimus quoniam Iudaei multas iniurias, instigante eos diabolo, in Dominum nostrum Saluatorem dixerunt, Samaritanum eum et daemonium habentem et in Beelzebub, principe daemoniorum, eicientem daemonia; nam et seductorem eum ausi sunt dicere. Et haec omnia patienter Dominus, caeli ac terrae Creator, sustinuit ut nobis exempla patientiae et humilitatis praeberet. Nam si uoluisset potentiam suae maiestatis ostendere et uindicare iniurias, omnem subito mundum in chaos deduceret et nec genus hominum nec ipse appareret mundus, sed in momento omnia interirent. Verumtamen noluit haec facere inenarrabilis Christi Domini pietas, qui non ad puniendum, sed ad saluandum uenerat mundum. Ideo enim patienter sustinuit omnia, ut nobis exempla patientiae et humilitatis ostenderet. Vnde et sequentibus se discipulis dicebat: «Discite a me quia mitis sum et humilis corde et inuenietis requiem animabus uestris». Sed et omnes a saeculo sancti, tam prophetae quam apostoli, et opprobriis et iniuriis ac diuersis afflicti tormentis semper immobilem uirtutem patientiae et humilitatis tenuerunt et nequaquam humanis laudibus sunt decepti. Res-

IV, 19 lin. 47-48: Samaritanum... habentem-cf. Ioan. VIII, 48.

lin. 48-49: Beelzebub... daemonia - cf. Marc. III, 22; Mat. IX, 34; XII: 24, 27; Luc. XI, 15.

lin. 49-50: seductorem... dicere - cf. Ioan. VII, 12; Mat. XXVII, 63.

lin. 56-57: Domini... mundum - cf. Ioan. III, 17.

lin. 59-61: Discite... uestris - cf. Mat. XI, 29.

47 in Dominum nostrum Saluatorem] in S. D. N dixerunt] scilicet add. N Samaritanum eum] e. S. esse D eum om. N 48 daemonium... principe om. D 48-49 daemoniorum] daemoniosum D 49-50 ausi sunt eum $\mathrm{N} 51$ Creator om. D exempla om. N patientiae] $-\mathrm{m}$ suae maiestatis $\mathrm{N} 56$ pietas] bonitatis add. N 57 patienter enim V 58 omnia sustinuit $\mathrm{N}$ 62 et $^{1} \mathrm{om}$. $\mathrm{N}$ 
65 puentes namque inanis gloriae praesentis uitae uanos rumores, illam solam caelestem aeternamque gloriam concupiscunt qui Christo placere desiderant, quae ex Deo est et permanet in aeternum, cuius claritatis splendorem nulla humana lingua potest exponere. Haec igitur exempla patientiae et humili-

70 tatis considerans, filiole, si quando irrogatae tibi fuerint iniuriae, fortissime uirtutem patientiae et humilitatis custodi et imitare prophetam, qui dixit: «Ego autem tamquam surdus non audiebam et sicut mutus non aperiens os suum et factus sum sicut homo non audiens et non habens in ore suo increpa-

75 tionem». Quod certe ad commonendum sensum nostrum cottidie in synaxi psallitur. Caue etiam ne uanam gloriam laudesque hominum delecteris et perdas omnia quae laborando in bonis operibus acquisieris, fructusque ieiunii et abstinentiae tuae uigiliarumque et orationum mercedem in aeterna uita

80 non consequaris a Domino. Quia ipse dixit in Euangelio de eis qui laudes hominum quaerunt: "Amen dico uobis quia perceperunt mercedem suam». Et alia multa sunt quae de cauenda uana gloria sanctae Scripturae nos admonere non cessant. Caue ergo, o fili, et neque ad irrogatas iniurias

85 exardescat in iracundiam animus tuus, et si incitatum fuerit cor tuum, ipse tamen districte in timore Domini refrena $a b$ iracundia animum tuum, ut possis uirtutem humilitatis ac

IV,19 lin. 72-75 : Ego autem... increpationem - cf. Ps. XXXVII, 14-15. lin. 81-82: Amen ... suam - cf. Mat. VI: 2, 16.

66 solam om. D 74-75 increpationem] redargutionem N 76 synaxi] psalmo D 76-77 uanam gloriam laudesque] u. g. laudes $\mathrm{V}$ uana gloria laudeque $\mathrm{N} \quad 77$ perdes V 79 orationis D 80 non om. DN consequeris $\mathrm{N} 81$ qui] de bono opere add. $\mathrm{N}$ hominum om. $\mathrm{N} \quad 82$ perceperunt] re- $\mathrm{N}$ multa] quidem $\mathrm{N}$ 83 nos admonere om. $N \quad 84$ cessant] tacent $N$ et] ut D 85 iracundia D $86-87$ ipse... tuum om. DN 
patientiae custodire. Et tunc ueraciter ostendis quod promisisti dicens: Quia tamquam mortuus degeas in hoc mundo, si nihil turbulentum respondeas eis qui tibi iniurias irrogant, 90 sicut nec illi de monumentis mortui in quos multas iniurias et conuicia dixisti et nihil tibi penitus responderunt. Ideoque oportet ut fortiter custodiamus uirtutem humilitatis ac patientiae, quatenus possimus ad caelestia praemia et ad aeternae uitac gloriam peruenire, sicut dicit in Apocalypsi Dominus: "Tene quod habes, ne alius accipiat coronam tuam».

IV,19 lin. 95-96 : Tene... tuam - cf. Apoc. III, 11.

88 et om. $\mathrm{N}$ ostendens D 89 degeas] degas $\mathrm{N} \quad 90$ eis om. D 92 ideoque] ideo $\mathrm{N} 94$ caelestia praemia] caelestem patriam $\mathrm{N}$ $\mathrm{ad}^{2}$ om. V 96 tuam] Explicit de uirtute humilitatis et patientiae add. VD 


\section{V \\ INCIPIVNT CAPITVLA \\ DE DOCTRINA AD MONACHOS}

I - De doctrina seu monitis patrum ad monachos, qualem 5 habere.

oportet affectum circa corporales parentes seu propinquos

II - De sancto Pior, qui fuit discipulus beati Antonii.

III - De sancto abbate Ioanne.

IV - De famulo Dei Martiano.

$\mathrm{V}$ - De famula Dei et fratre eius.

10 VI - De abbate Apollo et fratre eius.

VII - De beato Theodoro, discipulo sancti Pachomii.

VIII - De sancto Pachomio, commonitionem qui solebat referre fratribus de insidiis aduersariorum daemonum.

IX - De sancto seniore cui talem gratiam donauerat

15 Christus, ut uidere possit quae alii non uidebant.

$\mathrm{X}-$ De beato Arsenio, qui fuit quondam sublimis ualde in palatio imperatoris et postea magnus inter sanctos patres.

$$
\text { V-INCIPIVNT - VD om. RN }
$$

2 de doctrina om. V 6 Piore D 8 Martiano] Martino D 9 famula correxi: famulo VD 11 beato] abbate $\mathrm{D}$ discipuli $\mathrm{V}$ Pachomii correxi: Pagomii V Pagamii D 12 communitione V quae $\mathrm{V} 15$ posset $\mathrm{D} 16$ beato] abbate D 17 patres] Expliciunt capitula add. $\mathrm{V}$ 


\section{V}

$<$ INCIPIT

\section{DE DOCTRINA AD MONACHOS>}

1 - Sanctus ac beatissimus Antonius, uerus in Christo pater monachorum, praecipiebat discipulis suis et saepe monebat eos ut memoriam carnalium parentum ac propinquorum absciderent de cordibus suis et actibus eorum, nullam haberent sollicitudinem, ut libera et expedita mente, absque aliqua sollicitudine corporali, adhaerere Deo anima sine intermissione intentius possit. Valde enim euertitur et exterminatur de huiuscemodi sollicitudinibus stabilitas mentis et in tantum obscuratur lumen cordis, ut nec sentiat quis quantum laeditur et distrahitur anima in diuersis peruagationum cogitationibus. Oportet enim et ualde conuenit ut pro salute animarum parentum ac propinquorum suorum monachi intente semper Dominum exorare non cessent, ut eripiat et saluet eos de superueniente huic mundo ignis aeterno iudicio et ut mereantur habere partem in uero aeternoque lumine iustorum, cum aduenerit Christus, Filius Dei, rex aeternus, in gloria maiestatis suae cum angelis sanctis et cum omnibus uirtutibus et potestatibus caelestibus iudicare uiuos et mortuos in die illo magno et terribili iudicii Dei. Ita enim debent monachi pro suis parentibus interuenire et deprecari Dominum, ut aeternam

$\mathbf{V}-\langle$ Incipit de doctrina ad monachos $\rangle:$ uide titulum capitulationis praecedentis

1-VD om. RN

Incipit: incipit de sancto Antonio $\mathrm{V} \quad 1 \mathrm{ac}$ hac $\mathrm{D}$ 5-6 ut... sollicitudine om. D 6 corporalem D 10 peruagationum] praeuaricationum D 12 semper om. D 14 igne D iudicii D ut et D 16 gloriam D 17-18 angelis... iudicare ui- om. D 20 ut] et add. D 
salutem mereantur accipere in uita perpetua, et regno Iesu Christi Domini nostri sors eorum inueniatur. Amen.

2 - Fuit quidam eremita Pior nomine, de antiquis patribus, quem beatus Antonius adolescentem in sancto proposito monachorum instruxit. Demoratus autem apud beatum Antonium annos paucos, cumque uiginti et quinque esset annorum,

5 abiit ad alium secretum eremi locum, ut solitarius habitaret, hoc etiam uolente et consentiente beato Antonio. Dixitque ei: Vade, Pior, et habita ubi uolueris et cum tibi per aliquam rationabilem occasionem reuelauerit Dominus, uenies ad me.

Cum autem peruenisset hic ipse Pior ad locum qui situs

10 est inter Nitriam et eremum Sceti, fodit puteum, cogitans apud seipsum: Quomodo qualemcumque aquam inuenero, oportet me ipsa contentum esse. Quod et factum est ad augmentum uirtutum eius talis occasio. Tantum enim falsa et amara inuenta est aqua, ut si quis ad eum uisitandi gratia

15 ueniret, in proprio uasculo aquam sibi portaret. Remoratus est autem in eodem loco annis triginta. Magis enim consuetudo est uiris sanctis contra delectationes proprias repugnare. "Diligentibus enim Deum, sicut dicit Apostolus, omnia cooperantur in bonum», siue enim lucrum inueniant, siue damnum

V,2 lin. 18-19 : Diligentibus... bonum - cf. Rom. VIII, 28.

21 accipere] ac D et] in add. D regnum D

2-VDRN

Incipit: de sancto Piore $\mathrm{N} \quad 3$ autem] est add. DN 4 annorum esset V 6 et om. R ei] sanctus Antonius add. R 8 rationabilem] rationalem $\mathrm{D}$ uenias $\mathrm{N} 9$ Pior om. D 10 Sceti] Scythiae RN fodit] ef- R cogitans] autem add. D 11 seipsum] ipsum D semet- RN 13 uirtutum] -is $\mathrm{N}$ om. $\mathrm{R}$ talis occasio om. N enim] et add. N 14 gratia uisitandi $\mathrm{R}$ 15 uenisset $\mathrm{D} 16$ est autem] est om. $\mathrm{V}$ e. ergo $\mathrm{R}$ ergo e. $\mathrm{N}$ loco eodem D 16-22 magis... bonum om. R 18 enim] autem $\mathrm{N}$ 
sustineant, etiam et iniurias patienter sustinent et honoribus non exaltantur. Nam et infamia et bona fama omnia eis cooperantur ad bonum. Dicebant ergo fratres ut recederet de loco ipso propter amaritudinem aquae. Ipse autem dixit eis: $\mathrm{Si}$ amaritudinem et laborem abstinentiae fugiamus et uelimus requiem in hoc mundo habere, post exitum uitae huius non percipimus illa aeterna et uere dulcia bona, nec fruemur illis perpetuis beati paradisi deliciis.

Dicebant ergo fratres quia unum tantum paximatium et quinque oliuas in cibo accipiebat, et hoc deambulando foris.

Etiam et hoc affirmabant de eo multi sanctorum patrum, quia triginta et amplius annis ex eo quo egressus est de domo parentum suorum, nunquam ei suasum est, etiam cum defunctos audisset parentes suos, ut pergeret ad requirendum seu uisitandum propinquos suos. Verumtamen soror eius cum esset uidua, habens duos filios iam adolescentulos, misit eos in eremum ad requirendum fratrem suum Piorem. Qui circueuntes diuersa monasteria requirentes eum, uix tamen inuenientes eum, dixerunt ei: Nos filii sororis tuae sumus, quae nimio desiderio optat te uidere, ante exitum suum. Ipse uero non acquieuit

V,2 lin. 21-22 : infamia... bonum - cf. II Cor. VI, 8; Rom. VIII, 28.

20 sustinent] sustineant D 21 exaltentur D infamiam et bonam famam D omnia om. D 22 cooperentur D ad] in DN ergo] ei add. RN 23 ipso] illo D 24 eis om. D 25-26 huius uitae $R \quad 26$ percipiemus RN 27 illas perpetuas $\mathrm{V}$ delitias $\mathrm{V} 28$ paximatium] paxmatium $\mathrm{V}$ parimatum D 29 in cibo om. D 30 et hoc om. D de eo multi sanctorum patrum] de eo om. D multo s. p. de eo $\mathrm{R} \quad 31$ eo om. RN 32 eis $\mathrm{R}$ suasum] uisus $\mathrm{R} 33$ requirendum] in- D querendum $\mathrm{N}$ seu] ad add. D 34 propinquos] proximos $\mathrm{R}$ 36 requirendum] querendum $\mathrm{N}$ Pior RN circueuntes] cum $\mathrm{RN}$ 37 monasteria] circuissent add. RN eum ${ }^{1}$ om. D tamen] tandem $R$ eum $^{2}$ ] illum RN 
40 petitioni eorum. Perrexerunt autem adolescentes ad hominem Dei beatum Antonium, indicantes ei pro qua causa uenissent. Misit autem beatus Antonius et uocauit eum ad se, dixitque ei: Quare, frater, tanto tempore non uenisti ad me? Qui respondens dixit ei: Praecepisti mihi, beatissime pater, ut cum

45 per aliquam occasionem reuelaret mihi Dominus, tunc uenirem ad te. Ecce usque hactenus non mihi reuelatum est. Dicit ei beatus Antonius: Vade ut uideat te soror tua. Tunc assumpsit secum alium monachum et perrexit ad locum et domum sororis suae. Et stans foris prope ianuam atrii, clausis oculis,

50 ut non uideret sororem suam, stetit. Illa autem ueniens proiecit se ad pedes eius; de nimio autem gaudio angustata est. Dicit ei beatus Pior: Ecce ego sum Pior, frater tuus. Vide ergo me quantum uolueris. Et post haec statim reuersus est ad eremum in cellulam suam. Hoc autem fecit ad erudiendum monachos,

55 ut non daretur eis licentia cum libitum eis fuerit uisitare parentes uel propinquos suos.

3 - Etiam et abbas Ioannes qui commanebat in Thebaida, in monte qui uocatur Calamus, habebatque sororem quae ex infantia in sancto proposito conuersabatur. Ipsa enim erudiuit et docuit fratrem suum eundem abbatem Ioannem, ut relin-

5 queret uanitates saeculi huius et ingrederetur in monasterium. Cum autem ingressus fuisset in monasterium, per uiginti et

44 cum om. V 45 reuelauerit $\mathrm{R} \quad 46$ usque om. $\mathrm{N} \quad 47 \mathrm{ut}]$ et D te om. D sororem tuam D $48 \mathrm{et}^{2}$ ad add. R 49 clausus $\mathrm{V} 51$ autem] enim $\mathrm{N}$ angustata] angusta $\mathrm{D}$ angustiata $\mathrm{RN} 55$ daret $\mathrm{D}$

\section{$3-$ VDRN}

1 et om. D in Thebaida] om. $\mathrm{R}$ in Thebaidae $\mathrm{N} \quad 2$ in om. N habebatque] habebat RN sororem om. D 5 uanitatem D in om. N 6 autem om. D in om. N et om. $\mathrm{N}$ 
quatuor annos non est regressus de monasterio, nec uisitauit sororem suam. Illa uero nimis desiderabat uidere eum. Nam frequenter scribebat et mittebat ad eum epistolas, petebatque ut ante exitum eius de hoc corpore ueniret ad eam, ut in caritate Christi de praesentia sua laetarentur. Ille autem excusabat, nolebatque de monasterio egredi. Venerabilis autem famula Christi, iterum scribit ad eum dicens: Quia si nolueris uenire ad me, necesse me est ut ego ueniam ad te, ut post tanta tempora adorare merear sanctam caritatem tuam. Haec cum audisset supradictus abbas Ioannes, contristatus est nimis et cogitauit apud seipsum dicens: Quomodo si permisero ut ad me ueniat soror mea, de cetero licentia datur ut alii parentes ac propinqui nostri ueniant ad uisitandum me. Ideoque tractauit magis, ut ipse pergeret et uisitaret sororem suam. Accepit etiam alios secum duos fratres de monasterio et cum uenissent ad ianuam monasterii sororis suae clamauit dicens: Benedicite et audite peregrinos. Egressa est autem soror eius cum alia famula Dei et aperuit ianuam et penitus non cognouit fratrem suum. Ipse autem cognouit sororem suam, sed non est locutus uerbum, ne forte in uoce cognosceret eum. Monachi uero qui cum ipso erant dixerunt: Rogamus te, domina mater, ut iubeas nobis aquam dare ad bibendum, quia de itinere fatigati sumus. Cum accepissent et bibissent aquam, facientes orationem et gratias

7 regressus] e- RN $8 \mathrm{nam}$ ] et add. R 10 in om. D 11 laetaretur D 13 Christi] Dei soror eius RN scribit] -psit $R$ -bebat $\mathrm{N}$ dicens ad eum $\mathrm{R} 14$ me est] me om. D mihi e. $\mathrm{R}$ e. mihi $\mathrm{N}$ ego om. DN 15 sanctam caritatem] sanctitatem $\mathrm{R}$ haec] autem add. RN audisset] dixisset R 16 cogitabat RN 17 seipsum] semet- $\mathrm{N} 18$ dabitur $\mathrm{R}$ ut] et add. $\mathrm{R} 19$ tractauit] apud semetipsum (se N) add. RN ut magis RN 20 pergeret et uisitaret] iret uisitare D 20-21 alios secum duos fratres] s. a. d. f. D a. d. f. s. R 21 ianuam om. $\mathrm{R} 22$ monasterium $\mathrm{R} 23$ cum om. D 27 dixerunt] ad eam add. RN 28 dari aquam $\mathrm{N}$ cum] autem add. RN 
30 agentes Deo, discesserunt et reuersi sunt ad monasterium suum. Post aliquantos autem dies, iterum scripsit ad eum soror sua, ut ueniret et uideret eam ante exitum suum et orationem faceret in monasteriolo eius. Tunc ille scripsit ad eam et direxit epistolam per monachum de monasterio suo dicens: Quia

35 praestante gratia Christi, ego ueni ad te et nullus me cognouit. Ipsa uero egressa es ad nos et dedisti nobis aquam et accepi de manibus tuis et bibi et, gratias agens Domino, reuersus sum in monasterium. Sufficiat ergo tibi quia uidisti me. Ergo ulterius non mihi sis molesta, sed ora pro me incessanter ad

40 Dominum nostrum Iesum Christum.

4- Sed et de famulo Dei Martiano simile exemplum referemus. Soror enim eius cum filio suo abiit ad eum in monasterium, ut post multa tempora uisitaret eum. Ipse autem sororem suam non acquieuit suscipere nec uidere, filium

5 autem eius suscepit, qui intente deprecabatur eum et petebat ut susciperet tunicam et pallium, quod detulissent ei. Sed noluit penitus suscipere dicens: Quia ab infantia mea usque ad hanc horam Dominus Deus gubernauit me, etiam et usque in finem exitus mei ipse mihi praebet omnia quae necessaria sunt.

10 Non enim expedit a parentibus carnalibus haec exspectare uel suscipere. Ille autem prostrauit se ad pedes eius dicens: Non tamquam parenti, sed tamquam seruo Dei et monacho offeremus haec. Respondens beatus abba Martianus dixit eis: Per quot

30 discesserunt] re- $\mathrm{N} \quad 31$ autem om. $\mathrm{R}$ scripsit] re- $\mathrm{N}$ 32 eam] illum $\mathrm{R} \quad 33$ monasteriolo] monasterio $\mathrm{D}$ eius] suo $\mathrm{N}$ scripsit] re- RN 37 Domino] Deo $\mathrm{N} 38$ ergo om. N 39 ad om. RN 40 Iesum Christum om. $\mathrm{R}$

4- $\mathrm{VDN}^{2}$ om. $\mathrm{R}$

1 et om. D 2 referamus D 4 sororem] quidem add. N 6 quae $\mathrm{N} 8$ me gubernauit $\mathrm{N}$ etiam om. $\mathrm{N}$ et orn. $\mathrm{D}$ 12 offerimus $\mathrm{N} 13$ respondens] autem add. $\mathrm{N}$ abba] abbas $\mathrm{D}$ om. $\mathrm{N}$ 
monasteria uenistis de itinere ad nos? Qui respondens dixit ei: Plurima monasteria transiuimus. Et quare, inquit, non dedistis ex his uestimentis eis tamquam seruis Dei et monachis? Ipse uero respondens dixit: Quia nulli aliquid dedimus. Ait ergo ad eum beatus Martianus: Ecce manifestatum est quia non ut seruo Dei et monacho, sed tamquam parenti et propinquo uestro haec ad me detulistis. Noluit ergo suscipere. Orationem pro eis intentissime faciens pro salute animarum eorum Dominum deprecatus est et dimisit eos. Praecepitque eis ut ulterius numquam uenirent ad eum.

5 - Sed et alius quidam monachus abiit ad sororem suam ut uisitaret eam. Audierat enim eam aegrotantem in monasterio. Erat enim ipsa famula Dei nominata in sancta conuersatione. Itaque non acquieuit illa suscipere et uidere fratrem suum, ut non per occasionem eius ingrederetur in monasterium feminarum. Sed mandauit ei dicens: Vade, domine frater, et ora pro me. Praestante enim gratia Dei et Saluatoris nostri, uidebo te in futuro saeculo, in regno Domini nostri Iesu Christi.

6- Ad hunc igitur senem cum germanus suus intempesta nocte uenisset, petens ut de monasterio suo paulisper egressus ad eleuandum bouem qui in paludis caeno cecidisset,

14 monasterium D 17 dedimus] detulimus $\mathrm{N} 18$ eum] eos D manifestatum est] manifestum N 20 ad me] mihi N suscipere] sed add. N 22 eos om. $\mathrm{N}$

5-VDRN

1 monachus quidam D 2 enim om. V eam om. D 3 enim] et add. N 4 et uidere om. N 5 per occasionem eius non D in om. $\mathrm{N}$ monasterio $\mathrm{V} 7$ Saluatoris] Domini add. $\mathrm{N} 8$ in regno] om. D et r. R 9 Christi] amen add. D

6- $\mathrm{VDN}^{2}$ om. $\mathrm{R}$

3 eleuandum] leuandum $\mathrm{D}$ quem $\mathrm{N}$ cecidisse $\mathrm{N}$ 
flebiliter quaerebatur ut ei praeberet auxilium, quia eum solus 5 non posset eruere. Cui abbas Apollo instanter obsecranti: Cur, ait, iuniorem fratrem nostrum, quem praeteriens uiciniorem quam me habueras, non rogasti? Cumque ille, mortem olim sepulti fratris oblitum et ex nimia abstinentia ac solitudinis iugitate uelut impotem mentis existimans, respondisset: Quem10 admodum poteram eum de sepulcro, qui ante annos quindecim obiit, inuocare? Et abbas Apollo respondit dicens: Ignoras ergo me quoque ante annos uiginti huic mundo fuisse defunctum? Nullaque iam posse de huius cellulae sepulcro, quae ad praesentis uitae pertineant statum, tibi conferre solacia, 15 quem in tantum Christus ab intentione abrenuntiationis mundi arreptae uel modicum ad extrahendum bouem tuum non patitur relaxari ut ne breuissimi quidem momenti indutias sequenti se discipulo pro patris indulserit sepultura.

7 - Etiam de beato Theodoro oportet nos exempla uirtutum proferre. Hic itaque beatus Theodorus, discipulus fuit sancti Pachomii, uiri de magnis patribus, qui fuit pater infinitae multidutinis monachorum, multorumque monasteriorum pater,

V,6 lin. 15-18 : Christus... sepultura - cf. Mat. VIII, 21-22; Luc. IX, 59-60.

4 ut om. $\mathrm{N}$ solus eum $\mathrm{N} 5$ possit $\mathrm{V}$ eruere] erigere $\mathrm{D}$ leuare $\mathrm{N}$ cui om. N 5-6 ait cur N 6 nostrum om. D 7 me quam D 8 oblitum] obitum D et om. N solitudinis] sollicitudinis VD 9 impotem] inposte D existimans] extimans D 11 inuocaret D et om. N 12 ante om. D uiginti annos N 14 pertinent $\mathrm{N} 15$ quae $\mathrm{N} 17$ ut] et VD 18 sepulturae D

\section{7-VDRN}

Incipit: de beato Theodoro $\mathrm{N}$ 1-2 exempla uirtutum] u. e. D uirtutem om. $\mathrm{R} \quad 3$ sancti] beati $\mathrm{R}$ magnis] sanctis $\mathrm{RN}$ 4 multorumque monasteriorum pater] om. $\mathrm{D}$ multorum quoque m. p. N 
in partibus Thebaidae. Cum enim in omnibus sanctitatis 5 fulgeret uirtutibus, etiam prophetiae gratiam a Domino meruit. Multa enim futura reuelauit ei Dominus. Quodam autem tempore, supradicti beati Theodori soror germana uenit ad monasterium, in quo conuersabatur idem Theodorus, ut post multa tempora uideret germanum suum. Cumque nuntiassent ei de aduentu sororis eius, misit continuo duos monachos qui obseruabant ad ianuam monasterii, mandauitque per eos sorori suae dicens: Ecce, soror, audisti et cognouisti quia uiuo; ne contristeris autem quia minime me uidisti, sed magis considera uanitatem et instabilitatem praesentis mundi et conuerte cor tuum et apprehende sanctae uitae conuersationem, ut peruenire possis ad aeternam uitam et ad caelestia bona, quae praeparauit diligentibus se Dominus et facientibus mandata eius. Tracta ergo apud te, quia haec sola est uera et firma spes, ut faciat homo praecepta Domini, ut mereatur peruenire ad gloriosa et aeterna promissa Domini Saluatoris nostri Christi. Haec autem illa cum audisset, statim compuncta corde, lacrimas fundebat in conspectu Domini et ingressa in monasterium uirginum famularum Dei, quod in eodem uico constructum erat et, procedente tempore, multiplicabantur in sancto proposito famulae Christi.

Haec ita gesta cum audisset mater eorum, deprecata est episcopos et dederunt ei epistolas ad supradictum sanctum

5-6 fulgeret sanctitatis $\mathrm{N} \quad 7$ reuelabat $\mathrm{DN} \quad 8$ germana om. $\mathrm{N}$ 9 monasterium] eum $\mathrm{N}$ in... Theodorus om. $\mathrm{N} 10$ nuntiassent] -set D an- N 12 ad om. D 14 minime me] me om. D me m. N 16 et om. $\mathrm{R}$ apprehendens $\mathrm{R} 18$ Dominus diligentibus se $\mathrm{N} \quad 19$ sola haec $\mathrm{D}$ est om. N 20 Domini] Dei RN ut] ne D gloriosam D 21 nostri] Iesu add. N 23 et] post paululum add. RN ingressa] est add. RN monasterio D 25 procedenti RN multiplicabatur $\mathrm{R} \quad 26$ famula $\mathrm{R}$ Christi] Dei $\mathrm{R} 28$ ei] sibi $\mathrm{D}$ supradictum om. D 
Pachomium, patrem monasteriorum, pro filio eius. Cumque 30 uenisset, applicuit in monasterium famularum Dei et direxit epistolas ad patrem monasterii, obsecrans ut uideret filium suum. Beatus autem Pachomius uocauit filium eius Theodorum et dixit ei: Audiui quia mater tua aduenit propter te. Itaque propter epistolas episcoporum, uade et uideat te mater tua.

35 Dicit ei Theodorus: Praecepisti mihi, domine, ut uideam matrem meam? Si ergo abiero uidere eam, post tantam scientiam spiritalem, uereor ne culpabilis inueniar apud Deum. Etenim oportebat me fortitudinem animae meae ad exemplum aliorum fratrum demonstrare. Ideoque uereor ne magis offen-

40 diculum praebere uidear tantae multitudini. Denique filii Leui non pepercerunt, sed interfecerunt parentes et fratres suos, ut placarent iram Domini. Ego ergo nec matrem habeo, nec aliquid de isto transitorio mundo. Cum enim determinatum atque ordinatum esset, sub Esdra pontifice et propheta, ut

45 proicerent uxores suas alienigenas et dimiserunt eas cum filiis suis et dixerunt Esdrae pontifici: "Sicut praecipit lex Domini Dei nostri fecimus et dimisimus uxores nostras alienigenas cum filiis». Licet enim alienigenae essent uxores, tamen affectus cruciabat corda et uiscera torquebat patrum et coniugum

50 disiunctionis praecepto, sed praeualuit in animis eorum legis

V,7 lin. 40-42 : filii... Domini-cf. Exod. XXXII, 23-29. lin. 46-48 : Sicut... filiis - cf. I Esdr. X, 10-12.

29 monasterii $\mathrm{N} \quad 30$ monasterio $\mathrm{R}$ famulorum $\mathrm{D}$ direxerit D 31 obsecrantes D 32 eius] suum V 33 audiui] audi D fili add. RN 34 episcoporum] qui scripserunt ad me add. RN et] ut $\mathrm{N} \quad 35$ praecipis $\mathrm{V} \quad 36$ meam om. $\mathrm{R} \quad 37$ spiritualem $\mathrm{N}$ Deum] Dominum $\mathrm{R} 38$ oportet $\mathrm{D}$ me om. $\mathrm{R}$ animi mei RN 39 fratrum om. D 39-51 ideoque... reuerentia om. RN $42-43$ ego... mundo om. D 46 praecepit D 49 torquebantur D $\mathrm{et}^{2}$ ] ex D 
Domini reuerentia. Audiens autem mater eius, quia non acquieuit uidere eam, nimio affectu feruens in filium, noluit remeare ad domum suam, sed permansit in monasterio uirginum dicens: Quomodo si hic permansero, etiam saepe uidebo filium meum, cum inter alios fratres egreditur ad necessarias monasterii causas et monitis atque exhortationibus eius proficere possum in sanctam conuersationem. Doctrinaque eius spiritalis confirmat cor meum, ut merear peruenire ad aeternam uitam, quam promisit Dominus noster Iesus Christus diligentibus se.

Multa autem et magnifica per sanctum Pachomium fecit

Dominus mirabilia. Nam et a daemonibus obsessos frequenter, inuocato Christi Domini nomine, curauit multos etiam diuersas aegritudines sustinentes et paralyticis orationibus eius misertus est Dominus.

8 - Multo tempore beatus abbas Pachomius contra immundissimos daemones certamen bonum certauit, sicut athleta ueritatis, tamquam et beatus Antonius. Denique intentissimis precibus exorauit Dominum, ut somnum non caperet per aliquod tempus, quatenus noctibus ac diebus peruigil permaneret contra aduersarios daemones dimicando, donec prosterneret et superaret eos, sicut dicit in psalmo: «Et non

V,8 lin. 7-8 : Et non... deficiant - cf. Ps. XVII, 38.

52 eam] in add. $\mathrm{R}$ om. $\mathrm{N}$ filio $\mathrm{R} \quad 55$ egredietur $\mathrm{RN}$ 56 atque] et RN eius om. R 57 sancta conuersatione $\mathrm{N}$ spiritualis RN 58 confirmabit RN uitam] gloriam D requiem RN 61-62 frequenter inuocato Christi Domini nomine] i. C. n. f. $\mathrm{N} \quad 62$ multis $\mathrm{R}$ etiam] et $\mathrm{D}$ diuersas] aduersas $\mathrm{R}$ 63 sustinentibus $\mathrm{R} \quad$ paralyticos $\mathrm{V} 64$ Dominus om. $\mathrm{V}$

$$
\text { 8-VDRN }
$$

1 multo] quoque add. $\mathrm{N}$ abba $\mathrm{V} \quad 4 \mathrm{ut}$ ] ut add. repetens $\mathrm{R}$ 5 aliquot $\mathrm{V}$ diebus ac noctibus RN 6 dimicantes $\mathrm{D}$

7 dicitur $\mathrm{N}$ 
conuertar, donec deficiant». Praestitit ergo et concessit ei Dominus petitionem eius. Impossibiles enim sunt daemones 10 et imbecilles, cum quis nostrum ex tota fide et ex tota intentione cordis, feruente sancto desiderio et adiuuante nos uirtute Saluatoris nostri Christi, contendimus contra eos.

Referebant autem nobis fratres de eodem beatissimo patre Pachomio, qui fuit, ut diximus, multorum monasteriorum

15 in regione Tabennensiotarum praepositus, referebant ergo de eo quod frequenter dicebat patribus: Quia sicut mihi testis est Dominus Deus, saepe audiui immundos spiritus daemonum loquentes inter se diuersasque ac uarias artes suas, quas contra seruientes Deo, maxime contra monachos habent. Quidam

20 enim ex eis dicebat: Quomodo ego durissimum hominem habeo et quotiens ei immitto peruersas cogitationes, ille statim surgit et prosternit se in orationem, cum gemitu exorans adesse sibi diuinum auxilium, et ego nimio igne me exurente cum confusione egredior. Item alius daemon dicebat: Ego ad illum

25 quem obseruo, cum ei cogitationes in corde misero, consentit et suscipit et facit eas. Saepe enim exardescere eum in iracundiam facio et in contentiones rixae et pigritiam orationis et dormitationem in psalmodia et non contradicit mihi. Ideo-

8 praestitit] per- $\mathrm{R} \quad$ et] non add. R ei om. DR 9 petitiones suas D impossibiles] impotentes $\mathrm{V} \quad 11$ sancto] Dei $\mathrm{N}$ nos om. D 12 contendit D 15 Tabennensiotarum] Thebanensiotarum $\mathrm{D}$ Thebenensiotarum $\mathrm{N} 16$ quod] quoniam $\mathrm{R}$ patribus] fratribus RN 16-17 testis est mihi D 17 Dominus om. $\mathrm{R}$ daemonum] daemoniorum $\mathrm{D}$ om. $\mathrm{N} 18$ diuersasque] diuersas DR suas] referentes add. N 19 seruientes Deo] D. s. et $N 20$ enim] autem $N$ dicebant $D$ ego] ad add. $\mathrm{R} 21$ habeo] certamen add. $\mathrm{R}$ peruersas] diuersas $\mathrm{D}$ 22 prosternet $\mathrm{V}$ exorans] orans $\mathrm{R} 23$ et... exurente] ego autem illo exurgente $\mathrm{R}$ cum] grandi add. $\mathrm{R} \quad 25$ misero] e- $\mathrm{R}$ 27 in om. $R$ contentiones] intentiones $R$ pigritia $D$ orationis] in oratione $\mathrm{R} \quad 28$ dormitatione $\mathrm{R}$ psalmodia] $-\mathrm{m} \mathrm{D}$ in canto add. $\mathrm{R}$ 
que, fratres mei dilectissimi, semper oportet ut custodiatis sensum et animum uestrum, inuocantes nomen Domini nostri Iesu Christi, et secundum praecepta Dei conuersamini, tam in orationibus et psalmodia, sicut dicit Apostolus: «Instantes orationi et uigilantes in eam. Ideoque cum compunctione et timore cordis uigilantibus, non praeualebunt nocere uos aduersarii et immundissimi daemones. Ipse autem beatus pater noster Pachomius docebat fratres ut semper memores essent uerbi Dei in salute animarum suarum. Postmodum uero discedebat unusquisque fratrum in cellulas suas, operantes manibus suis et meditantes quae de sanctis Scripturis didicerant. Impossibile enim est aliquem apud eos uerbum otiosum loqui, sed ea tantum quae de sanctis Scripturis didicerant, ${ }^{\dagger}$ erant inter se conferentes et exponentes de capitulis sanctarum Scripturarum, quae ad timorem et amorem Domini confirmarent et illuminarent animas eorum.

9- Fuit quidam uir magnus de sanctis patribus cui talem gratiam donauerat Christus, reuelante ei Spiritu Sancto, ut uidere possit quod alii non uidebant. Referebat ergo sanctis patribus dicens: Quia aliquando quam plurimi sedentes fratres,

$\mathrm{V}, 8$ lin. 32-33 : Instantes... in ea - cf. Rom. XII, 12.

31 conuersemini $\mathrm{N}$ tam om. $\mathrm{N} 32$ orationibus] quam add. $\mathrm{R}$ psalmodiis $\mathrm{N}$ instantes] estote add. V 34 timore] et tremore add. N nocere uos] n. uobis $\mathrm{D}$ uobis $\mathrm{n} . \mathrm{N} 37 \mathrm{Dei}]$ dicentes add. D 38 discedebat] decedebant $\mathrm{R}$ celullas] cellas $\mathrm{D}$ 39 de om. D sanctis] sacris D 40 enim est] e. erat $R$ est e. N 41 ea tantum] et tamen D erant existimo coniecisse R: om. VDN 42 et exponentes] exponunt $\mathrm{N} \quad 43$ ad timorem et amorem] et a. et $t$. D et a. om. $\mathrm{R}$ 9-VDRN

Incipit: de quodam sancto abbate (dub.) $\mathrm{N} \quad 1$ magnus om. $\mathrm{N}$ patribus] senioribus RN 3 posset DRN uidebant] -runt $\mathrm{V}$ 4 quia] quomodo $\mathrm{D}$ 
5 simul loquebantur et conferebant inter se de sanctis Scripturis, quae ad salutem pertinent animarum. Stabant autem circa eos sancti angeli, laetantes et hilari uultu considerantes; delectabantur enim de eloquio Domini. Cum autem aliud quodcumque inter se loquerentur, statim angeli sancti recedebant longius

10 indignantes contra eos. Veniebant autem porci sordidissimi et morbo pleni et uolutabant se inter cos. Daemones enim in specie porcorum delectabantur superflua et uana loquela corum. Beatus autem senior haec uidens, abiit ad cellulam suam et per totam noctem, cum grandi fletu et ululatu, gemendo deflebat

15 miserias nostras. Exhortabantur ergo sancti patres per monasteria et commonebant fratres dicentes: Cauete, fratres, a multiloquio et ab otiosis sermonibus linguam, quia malus, interitus animae generatur et non intelligimus quomodo per haec et Deo et sanctis angelis odibiles sumus. Dicit enim Scriptura

20 diuina: «Per multiloquium non effugies peccatum». Haec enim infirmam et uacuam efficiunt mentem atque animam nostram.

V,9 lin. 20 : Per multiloquium... peccatum - cf. Prov. X, 19.

5 inter se et conferebant $\mathrm{R} \quad 6$ pertinerent $\mathrm{N}$ stabant autem] s. a. add. repetens D 7 et] in R 7-8 delectabatur D 8 aliud] aliquid $\mathrm{R} \quad 9$ loquebantur $\mathrm{D} \quad 11 \mathrm{enim}$ ] autem $\mathrm{R}$ 12 eorum loquela $\mathrm{N} \quad 13$ cellulam] cellam $\mathrm{R} \quad 15$ exhortabatur DN ergo] autem D sanctos $\mathrm{N} 16$ et] ut $\mathrm{N}$ commonerent $\mathrm{N}$ cauete] cohibete $\mathrm{R} \quad 17$ malos $\mathrm{N} 18$ generant $\mathrm{N}$ quomodo] quia $\mathrm{N}$ et ${ }^{2}$ om. N 19-20 diuina Scriptura D 21 efficiunt] effugiunt $\mathrm{R}$ nostram om. D 
INCIPIT

\section{DE BEATO ARSENIO}

QVI FVIT IN PALATIO SVBLIMIS SVB THEODOSIO IMPERATORE. CVIVS FILIOS. ID EST, ARCADIVM ET HONORIVM, AVGVSTOS, DE BAPTISMO SVSCEPIT

1 - Hic itaque Arsenius, desiderio diuini amoris accensus, relinquens omnem huius saeculi gloriam temporalem, perrexit ad eremum Sceti, ut inter sanctos patres secretam $a b$ omni strepitu mundi huius ageret uitam, ut separatus ab illecebris et delectationibus corporalibus cum tota mentis intentione adhaereret Domino Saluatori, sicut scriptum est: "Adhaesit anima mea post te, me autem suscepit dextera tua».

Dicebant ergo de eo sancti seniores: Quia sicut cum in saeculi conuersatione esset, nimis pretiosis uestimentis prae omnibus utebatur; ita postmodum in eremo Sceti degens, 10

VI,1 lin. 6-7 : Adhaesit... tua - cf. Ps. LXII, 9.

\section{VI - INCIPIT - VDRN}

1-3 incipit... qui] de conuersione Arsenii $\mathrm{N}$ om. $\mathrm{R} \quad 3$ fuit] quondam add. D quidam uir add. RN imperatore] nomine Arsenius add. RN 5 augustus $\mathrm{D}$

$1-$ VDRN

1 accensus] suc- $N \quad 3$ Sceti] Scythiae RN secretam] et quietam add. RN 5 corporalibus et delectationibus $\mathrm{N} \quad 7$ autem om. RN 8 sicut] hic D 9 pretiosa uestimenta V 10 ita] itaque D postmodum] post mundum $\mathrm{D}$ Sceti] Scythiae RN 
studebat ut ab omnibus monachis uiliora et despecta uestimenta haberet.

2 - Dicebat etiam abbas Daniel quomodo sanctus Arsenius referebat fratribus dicens, quasi de alio audisset, sed quantum datur intelligi ipse talem uidit uisionem: Quia sedebat, inquit, quidam de senioribus in cellula sua et subito uenit uox ad

5 eum dicens: Egredere foras et ostendam tibi opera hominum. Et surrexit, inquit, et egressus est foras. Duxit autem eum et ostendit ei aethiopem nigrum, cum securi caedentem ligna et facientem grandem sarcinam et tentabat subleuare sarcinam illam et prae magnitudine non poterat portare eam. Sed 10 abiit et caedebat iterum alia ligna et addebat super illam sarcinam. Iterum autem ostendit ei alium hominem stantem super lacum et haurientem aquam de lacu, mittentemque eam in collectaculum et de alio pertuso defluebat aqua de subter in eundem lacum. Iterum dixit ei: Veni, sequere me,

15 ostendam tibi aliud. Et uidit quasi quodam aedificium templi et duos uiros sedentes in equis, portantes super scapulas suas utrique lignum unum, id est, perticam longam, uolentesque pariter ingredi per portam templi illius, non permittebat eos lignum, quod ex aduerso portabant, ingredi per portam illam. Non 20 enim se humiliabat alter alteri, sed contendebant utrique

11 ut om. Dab] in D om. RN despectiora RN 2-VDRN

2 referebat] de add. D sed] ut add. V 3 intelligi] intelli D talem] tamen $\mathrm{R} 4$ senioribus] monachis add. RN 4-5 ad eum om. D 5 hominum opera D 6 inquit om. DN est om. D 7 secure V 9 eam portare $\mathrm{R}$ sed] et add. V 10 abiit] redibat RN illam] ipsam D 12 mittentemque] ac mittentem RN 13 alia RN pertuso] parte per foramina (foramen N) RN defluebat] e- D de om. N 14 in om. N eundem lacum] eodem loco $\mathrm{R}$ e. locum $\mathrm{N}$ sequere] sequerere $\mathrm{R}$ $\mathrm{me}$ ] et add. R 16 uiros om. $\mathrm{R}$ in equis sedentes $\mathrm{R} \quad 18$ illius] huius $\mathrm{D} 20$ humiliabat se $\mathrm{N}$ 
pariter ingredi uolentes et non praeualebant. Non enim humiliauit se unus ex eis, ut alii daret locum. Exposuit ergo ei has uisiones dicens: Hi qui lignum portant, hi sunt qui habent iugum sanctum monachorum, sed iustificantes semetipsos in corde suo cum exaltatione superbiae, non humiliantur inuicem. Noluerunt enim ambulare in humilitatis uia Domini Saluatoris nostri Iesu Christi qui dixit: "Discite a me quia mitis sum et humilis corde et inuenietis requiem animabus uestris». Ideoque propter superbiam cordis sui remanserunt foris de regno caelorum Christi exclusi. Qui autem caedebat ligna, homo est qui oneratus est multis peccatis et super sarcinam peccatorum suorum addit semper alia peccata, quem oportebat magis poenitentiam agere de prioribus peccatis, sed negligens emendare uitia peccatorum priorum, magis alia super priora addit peccata. Ille autem qui aquam de lacu hauriebat, homo est qui aliqua bona operatur, sed quia mala etiam amplius per peccata operatur, ideo pereunt et defluunt etiam bona opera quae faciebat. Oportet ergo hominem, sicut dicit Apostolus, "cum timore et tremore salutem suam operari».

VI,2 lin. 27-28 : Discite... uestris - cf. Mat. XI, 29. lin. 39 : cum timore... operari - cf. Phil. II, 12.

21 praeualebant] ualebant $D$ non ${ }^{2}$ ] nec $R \quad 22$ ei] eis $R$ 23 portabant $R \quad 25$ cordibus suis $D$ exaltatione] exultatione $V N$ 26 enim om. D uiam D Domini om. N Saluatoris] Domini add. repetens D 27 a me om. N 29 regno] regis add. R 30 exclusi] excelsi $\mathrm{D}$ expulsi $\mathrm{N}$ ligna] et super sarcinam ad is (huc $\mathrm{N}$ ) addebat add. RN 31 est] in add. V 32 semper om. $\mathrm{N}$ magis] ut add. RN 33 ageret RN 34 magis] om. R et add. N addit supra priora RN 36 bona aliqua $\mathrm{D}$ quia] qui D 36-37 per peccata] pro peccatis $\mathrm{D}$ om. $\mathrm{R} \quad 37$ ideo pereunt et defluunt] om. D i. p. et delentur $\mathrm{R} \quad 38$ faciebat] facit a malis superatur $D$ facit $R$ 
3 - Idem beatus Arsenius interrogabat quendam aegyptium uenerabilem monachum de diuersis cogitationibus et impugnatione daemonum. Superuenit autem quidam de amicis antiquis eius, uidensque eum sollicite et intente requirentem a

5 monacho ait ad eum: Valde admiror, pater, quia cum tanta eruditione perfecte studeris tam graecae quam latinae scientiae, cur $\mathrm{ab}$ isto inerudito et idiota homine requiras quae ad salutem animae conueniunt?

Respondens autem beatus Arsenius ait: Licet tam graece

10 quam latine, ut dicis, eruditus sim, tamen alphabetum uerae scientiae huius aegyptii non didici.

Dicebat autem beatus Arsenius fratribus: Quia cella studiosi monachi, qui festinat uirtutes animi possidere et omnia praecepta Saluatoris nostri Christi Domini adimplere, similis est

15 fornaci Babyloniae, ubi tres pueri uidere meruerunt Filium Dei; etiam est columna luminis, ubi Dominus locutus est Moysi.

4 - Dicebat abbas Daniel de abbate Arsenio: Quia cum operaretur sportas ex palmarum foliis, mittebat aquam in peluem ut infunderentur palmae. Et cum feteret bromosa aqua odorem, non permittebat ut aliam aquam mutaret, sed super

5 illam fetidam aliam addebat aquam, ut semper feteret. Interrogabant autem eum fratres dicentes: Cur non permittis,

VI,3 lin. 15-16 : fornaci... filium Dei-cf. Dan. III, 12-97.

lin. 16 : columna... Moysi - cf. Exod: XIII, 21-22; XIV, 1-4.

3-VD om. RN

5 admiror] miror D 13 animac D 16 est $^{1}$ correxi: in VD

4-VDRN

1 dicebat] autem add. RN 3 peluim $\mathrm{N}$ bromosa] -o DR om. N 4 odorem] -e DR om. $\mathrm{N}$ mutarent RN 6 autem om. $\mathrm{R}$ 
pater, ut aqua mutetur, sed pessimo fetore tota cellula tua repletur? Respondens autem beatus senior ait: Quomodo pro thymiamata et muscata et illa diuersa, quae in saeculari conuersatione sine intermissione fruebar, oportet me nunc dum in hoc corpore sum sustinere istiusmodi fetorem, pro suauissimo illo odore, ut in die iudicii de illo gehennae inenarrabili fetore liberet me Dominus, ut non cum illo diuite qui epulabatur in isto mundo deliciose et splendide condemnetur anima mea.

5 - Quidam de fratribus dixit beato Arsenio: Ecce, pater, meditari festino de sanctis Scripturis quae didici et non sentio compunctionem in corde meo, quomodo non intelligo uirtutem Scripturae diuinae, unde et ualde contristatur anima mea. Respondens autem beatus Arsenius ait: Oportet te, o fili, incessanter meditari eloquia Domini. Audiui enim quia dixit beatus abba Poemen et alii multi sanctorum patrum, quomodo incantatores illi qui serpentes solent incantare, non intelligunt ipsi uerba quae loquuntur, sed serpentes audientes intelligunt uirtutem uerborum illorum et conquiescunt et subduntur eis. Ita ergo et nos faciamus, quamuis enim non

VI,4 lin. 13-15 : cum illo... anima mea - cf. Luc. XVI, 19-31.

7 tua om. N 8 repleatur D 9 thymiamate DRN muscata] myrratis $\mathrm{N} \quad$ illis diuersis $\mathrm{D} \quad 10$ nunc om. $\mathrm{R} \quad 11$ corpore] tempore $\mathrm{R}$ istiusmodi] istius mundi sustinere $\mathrm{D} \quad 12 \mathrm{de}$ illo om. $\mathrm{R}$ gehennae] et add. D

5-VDRN

Incipit: interrogatio ad abbatem Arsenium $\mathrm{N} 1$ de] ex D beato Arsenio dixit $\mathrm{N}$ ecce] beatissime add. $\mathrm{RN} 4$ diuinae om. D 5 Arsenius] senior $\mathrm{V} \quad 6$ incessanter] instanter D enim] autem $\mathrm{N} 7$ dixit om. $\mathrm{D}$ beatus om. $\mathrm{N}$ abbas DN Poemen] Pamen D multi om. N 9 ipsi] illa add. R 
ualemus intelligere diuinarum Scripturarum uirtutem, sed tamen daemones audientes diuini uerbi uirtutem terrentur et effugati discedunt, non sustinentes eloquia Spiritus Sancti, quae

15 per seruos suos prophetas et apostolos est locutus.

6 - Dicebat abbas Daniel: Quia dum in eremo Sceti esset beatus Arsenius, erat ibi quidam, schema quidem, monachus et furabatur de cella monachorum quodcumque inuenire potuisset. Beatus autem Arsenius festinabat saluare animam eius, fecitque 5 ei cellulam prope suam cellulam et dixit ei: $\mathrm{Si}$ quid necessarium habes, ego tibi praebeo. Tantum cessa et noli furari et condemnare animam tuam in aeternum ignem gehennae in iudicio Dei. Misit autem ad quendam amicum suum et accepit solidos et nummos et uestimenta et dedit ei. Post haec autem

10 iterum inuentus est in furto. Tunc iam omnes sancti seniores considerantes quia non cessabat furari et abscondere, expellentes effugauerunt eum dicentes: Quia si fuerit aliquod uitium in fratre oportet nos sustinere, sicut dicit etiam Apostolus: «Vos firmiores, sustinete infirmos in fide, ut possint salui fieri». Et

15 necessarium est secundum praeceptum Apostoli ita fieri. Furem autem non expedit sustinere, maxime quia saepe commonitus non cessat. Sed et suam animam perdit, qui talis est, et omnem congregationem perturbat fratrum.

VI,6 lin. 13-14 : Vos firmiores... infirmos - cf. Rom. XV, 1.

12 ualemus] ualeamus $\mathrm{R}$ uim add. $\mathrm{N}$ uirtutem sed om. $\mathrm{N}$ 14 effugati] fugati $\mathrm{D}$ discedunt] a nobis add. RN 15 seruos suos] sanctos $\mathrm{N}$ locutus est $\mathrm{N}$ 6- $\mathrm{VDN}^{2}$ om. $\mathrm{R}$

1 Sceti om. D 2 schema quidem] selerosus D schemate $\mathrm{N}$ selerosus D 5 prope] iuxta $N$ cellulam suam $N \quad 6$ et $^{1} \mathrm{om} . \mathrm{N}$ 7-8 gehennae in iudicio] iudicio g. D 8 quendam om. D 10 iterum inuentus est] iterum om. D inuentus e. i. N 12 aliquod] paruum add. N 13 nos om. D 14 infirmiores V 17 et $^{1}$ om. D 18 perturbat fratrum] f. p. $\mathrm{N}$ Explicit de beato Arsenio add. $\mathrm{V}$ 
Í NDICES 



\section{I}

\section{MANUSCRITOS}

\section{(por ordem alfabética das localidades)}

Basileia, Biblioteca da Universidade, B. V. 2, séc. xIv - 15, 40-43, 65, 255, 256, 263, 282, 283, 286.

Berlim, Biblioteca Nacional dos Tesouros Culturais da Prússia, theol. lat. fol. 36 , séc. $\mathrm{xv}-20$.

- - ms. 780, theol. lat. fol. 275, séc. $\mathrm{xI}-15,27-33,34,35,37$, $42,65,66,176,177,178,211,239,247,251,255,256$, $263,278,279,280-286,287,288,289,292,293,295,297$, 300, 303, 307.

Bona, Biblioteca da Universidade 362, séc. xv -20 .

Bruxelas, Biblioteca Bolandiana 27, séc. xv -15 .

Bruxelas, Bibl. Real da Bélgica, 3177 (7462-81), séc. xIII - 125 .

Cambrai, Bibl. Municipal 817 - séc. xIv-xv - 126.

Danzig, Biblioteca da Cidade 1950, séc. $x v-29,264,284,285$, 289-290, 292, 297, 307.

Dêventer, Biblioteca do Ateneu 35, séc. xv - 20 .

Dijon, Biblioteca Municipal 194, séc. XII - 44, 264, 287-288.

Dresda, Biblioteca Nacional da Saxónia, A 207, séc. xIv - 14, 15, 16, $23-24,29,65,66,122,126,145,147,166,168,173,174$, $176,177,178,188,189209,210,211,212,226,227,235$, $239,247,251,263,265-266,269-271,275,276,281,282$, $283,286,310$.

Einsideln, Biblioteca Conventual 246, séc. XI $-264,278,279,284$, 285, 289, 290, 291-293, 295, 297, 307.

Londres, Museu Britânico, additiones 33518, séc. XII - 44, 264, 287. - - - additiones 37400 , séc. xIv - 15, 32, 34-36, 37, 38, 42, 65, $123,174,176,177,178,211,212,239,247,251,255,256$, $263,278,279,280-286,287,288,289,290,292,293,295$, 297, 307. 
Melk, Biblioteca do Mosteiro Beneditino 8, séc. xv - 124 .

Munique, Biblioteca do Estado da Baviera, latino 2540, séc. $\mathrm{xv}-15$, 34, 36-38, 65, 255, 256, 263, 282, 283.

- - lat. 14364 , séc. IX - 300 .

— - lat. 17139, séc. XII $-264,284,285,289,290,292,293$, 294-296, 307.

— - lat. 18475 , séc. XI-XII -124 .

— - lat. $18535^{2}$, séc. $x v-29,264,285,289-290,292$.

- lat. 21544 , séc. $\mathrm{xv}-20$.

- — lat. 22035, séc. XII -20 .

- - lat. 23418 , séc. $\mathrm{xIV}-20$.

- lat. 23591 , séc. $\mathrm{XI}-20$.

— - lat. 23757, séc. $\mathrm{xv}$ - 38-40, 65, 255, 263, 282.

Namur, Museu de Arqueologia 12, séc. XII-XIII - 15, 26, 32, 33-34, $35,37,42,65,145,146,173,174,176,177,178,180,188$, $210,212,225,247,251,263,272,278,279,280-286,287$, 288, 289, 290, 292, 293, 295, 307, 310.

Oxford, Bibl. Bodleiana, canon. 395, séc. xv -124 .

Paris, Biblioteca Nacional, fundo latino 2941, séc. XII $-25-26$, 123, 130, 250, 263, 272-274, 275, 280, 286, 292.

—, — lat. 3330, séc. XII - 264, 284, 289, 291-293, 295, 297, 307.

- - lat. 3784 , séc. $\mathrm{X}-\mathrm{XI}-300$.

— - lat. 5601, séc. $\mathrm{XI}-24-25,263,272-274,275,276,280$, 292, 297.

—, lat. 5624, séc. XIII - 44-45, 264, 287.

- - - lat. 10840, séc. XI - 211, 264, 278, 279, 284, 285, 289, 290, 291-293, 295, 307.

Poitiers, Bibl. da Cidade 249, séc. xv -126.

Praga, Biblioteca Universitária VII. D. 2, séc. XIV -20.

,-- XIII. E. 6 , séc. XIII-XIV -20 .

,-- III. C. 15 , séc. $x v-20$.

Reims, Biblioteca Municipal 1390 , séc. XI-XII $-29,125,264,266$, 284, 285, 289-290, 292, 297, 307.

-1400 , séc. XIII - 15, 26-27, 65, 66, 122, 130, 145, 176, 177, $178,210,211,212,235,239,247,250,251,263,265-266$, 269, 270, 272-279, 280, 281, 282, 284, 285, 290, 292, 297, 310.

Salamanca, Biblioteca Universitária 2537, séc. XIII - 132 .

Seo de Urgel, Arquivo Capitular, anno 938, séc. $\mathrm{x}-132$.

Troyes, Biblioteca Municipal 777, séc. XII - pp. 43-44, 125, 264, 284, 285, 287-288, 289, 290, 292, 293, 294-296, 307. 
Udine, Biblioteca Arquiepiscopal, fundo da Abadia de Moggio 7, séc. $\mathrm{IX}-20$.

Valenciennes, Biblioteca Municipal 168, séc. XIII - 45, 125, 264, 287-288.

Vaticano, Biblioteca Apostólica, latino 1201, séc. XI - 22-23, 263, 269, 271.

- - - Urbinat. 396, séc. xv - 124.

Vercelli, Arquivo Capitular LX, séc. XIII - 124.

Viena, Biblioteca Conventual de Santa Maria dos Escoceses 324, séc. xv $-20,126$.

Viena, Biblioteca Nacional da Áustria 433, séc. xI-14, 16, 22, 29 , $33,45,65,66,122,145,147,166,168,173,176,177,178$, $188,189,209,210,211,212,226,227,235,239,247,251$, $255,256,263,265-266,269-271,275,276,281,282,283$, $286,310$.

,--4410 , séc. xIv -20 .

- - — 4793, séc. $\mathrm{xv}-20$.

Vyssí Brod, Biblioteca Conventual 53, séc. $\mathrm{xv}-20$.

Wolfenbütel, Biblioteca do Arquiduque Augusto, cod. Guelf. 59. 6. Aug. $2 .^{\circ}$, séc. XII-XIII -20 .

,-- cod. Guelf. 85. 3. Aug. $8^{\circ}$, séc. xIv -20 . 


\section{BIBLIOGRAFIA}

AEBISCher (P.) - Contribution à la proto-histoire des articles «ille», et «ipse» dans les langues romanes in Cultura Neolatina, VIII, 1948.

Amélineau (E.) - De Historia Lausiaca. Quaenam sit huius ad monachorum Aegyptiorum historiam scribendam utilitas, Parisiis, 1887.

_- Histoire des monastères de la Basse-Égypte. Vies des saints Paul, Antoine, Macaire, Maxime Domèce, Jean le Nain, etc., Paris, 1894.

Arrufat (Antoni Ramón i) - Historia Lausiaca, text revisat i tradució, Barcelona, 1927.

Babel, revista sobre problemas de tradução, cf. nota 143.

BARDY (G.) - La question des langues dans l'Église ancienne, t. I, Paris, 1947.

BASTIAENSEN (A. A. R.) - Observations sur le vocabulaire liturgique dans l'Itinéraire d'Égérie, Nijmegen, 1962.

- Le cérémonial épistolaire des chrétiens latins in Graecitas et Latinitas Christianorum Primaeua, Supplementa, Fasc. II, Nouiomagi, 1964.

Barlow (Claude W.) - Martini Episcopi Bracarensis opera omnia, New Haven, 1950.

- Martin of Braga, Paschasius of Dumium, Leander of Seville (= Iberian Fathers, vol. I), Washington, 1969.

- Paschasius of Dumium, Sayings of the greek fathers in Classical Folia, New York, t. 26, 1972; t. 27, 1973.

Batlle (Columba Maria) - Contribució a l'estudi de Pascasi de Dumi i la seva versió de Verba Seniorum in Estudis Románics, VIII, 1961, Barcelona.

- "Vetera Noua». Vorläufige kritische Ausgabe bei Rosweyde fehlender Väterspruche in Festschrift Bernard Bischoff, Stuttgart, 1971.

—, Die Adhortationes Sanctorum Patrum ( Verba Seniorum») im lateinischen Mittelalter, Münster, 1972.

Blaise (A.) - Dictionnaire latin-français des auteurs chrétiens, Turnhout, 1954.

_-, Manuel du latin chrétien, Strasbourg, 1955. 
Blatt (F.) - Remarques sur l'histoire des traductions latines in Classica et Mediaeualia, I, 1938.

BolÉo (Manuel de Paiva) - Os valores temporais e modais do futuro imperfeito e do futuro perifrástico em português, Coimbra, 1973.

BollandianI (Hagiographi) - Catalogus codicum hagiographicorum latinorum antiquorum saeculo XVI qui asseruantur in bibliotheca nationali Parisiensi, t. II, Bruxellis, 1890.

__, Bibliotheca Hagiographica Latina, Bruxellis, t. I, 1898-1899; t. II, 1900-1901.

Bousset (Wilhelm) - Komposition und Charakter der Historia Lausiaca in Nachrichten von der königlichen Gesellschaft der Wissenschaf-ten zu Göttingen, Philologisch-historische Klasse, 1917.

_- Zur Komposition der Historia Lausiaca in Zeitschrift für die neutestamentliche Wissenschaft, XXI, 1922.

- Apophthegmata. Studiem zur Geschichte des ältesten Mönschtums, Tübingen, 1923.

Brenno (Silveira) - A arte de traduzir, S. Paulo, 1954.

BUDGE (E. A. Wallis) - The book of Paradise being the histories and sayings of the monks and ascetics of the Egyptian desert by Palladius, Hieronimus and others, I-II, Text, translation, London, 1904.

- The wit and wisdom of the christian fathers of Egypt, Oxford, 1934.

Butrer (Cuthbert) - The Lausiac History of Palladius, Cambridge, t. I, 1898; t. II, 1904.

Campos (J. A. Segurado e) - A tragédia "Octauia", 2 vols. Lisboa, 1972.

CAmpos (Julio de) - El propositum monástico en la tradición patrística in La Ciudad de Diós, El Escorial, 1968.

Catalogue of additions to the manuscripts in the British Museum in the years 1906-1910, London, 1912.

Catalogus codicum manuscriptorum bibliothecae Regiae, t. IV, Parisiis, 1744.

Chadwick (O.) - John Cassian. A study in primitive monasticism, Cambridge, 1950.

- Western ascetism. Selected texts. The sayings of the fathers, The Conferences of Cassian, The Rule of St. Benedict, Philadelphia, 1958.

Chaine (M.) - Le texte original des apophtegmes des Pères in Mélanges de la Faculté Orientale, Université de Saint Joseph, Beyrouth, $\mathrm{V}, 1912$.

—, La double recension de l'Histoire Lausiaque dans la version copte in Revue de l'Orient Chrétien, XXV, 1925-1926.

Cintra (Luís Filipe Lindey) - "Tu" e "Vós" como formas de tratamento de Deus em orações e na poesia em língua portuguesa in Revista da Faculdade de Letras de Lisboa, III Série, n. 13, 1971. (= Sobre "formas de tratamento" na língua portuguesa (Ensaios), Lisboa, 1972. 
Climent (M. Bassols de) - Sintáxis histórica de la lengua latina, Barcelona, I, 1945; II, 1948.

Curti (Carmelo) - Due articoli Eusebiani, Noto, 1971.

DaIN (A.) - Les manuscrits, Paris, 1964.

Defensor De Ligugé - Scintillarum Liber in Patrologia Latina, t. 88, Parisiis, 1862.

DeKkeRS (E.) - Les traductions grecques des écrits patristiques latins in Sacris Erudiri, V, 1953.

Delehaye (Hippolyte) - L'oeuvre des Bollandistes à travers trois siècles, 1615-1915, Bruxelles, 21959.

Deseille (P.) - Les saints moines d'Orient, Namur, 1959.

Devos (Paul) - La date du voyage d'Égérie in Analecta Bollandiana, LXXXV, 1967.

- Les nombres dans l' "Historia Monachorum in Aegypto", in Analecta Bollandiana XCII, 1974, Bruxelles.

DöRRIE (H.) - Passio SS. Machabaeorum. Die antike lateinische Übersetzung des IV Makkabäerbuches, Göttingen, 1938.

Draguet (René) - L'inauthenticité du "Prooemium" de l'Histoire Lausiaque in Mélanges L. Th. Lefort (= Le Muséon, LIX) 1946 (Louvain).

— Les Pères du Désert, Paris, 1949.

_- Un nouveau témoin du texte $G$ de l'Histoire Lausiaque (Ms. Athènes 281) in Analecta Bollandiana LXVII, 1949.

Dufresne (Ch., Du Cange), Glossarium mediae et infunae latinitatis, Parisiis, 1840.

EKLUND (S.) - The periphrastic, completive and finite use of the present participle in latin, with special regard to translations of christian textes in Greek up to 600 A. D., Uppsala, 1970.

Elizalde (M. de) - Dichos de los padres del desierto. Suplemento a la serie alfabética in Cuadernos Monásticos VI, 1972, Victoria.

Enciclopedia Cattolica, IX, Vaticano, 1952.

ERnout (A.) et Meillet (A.) - Dictionnaire étymologique de la langue latine, Paris, 1959.

FARIA (Ernesto) - Fonética histórica do latim, Rio de Janeiro, 1957.

—, Gramática Superior da Língua Latina, Rio de Janeiro, 1958.

FESTUGière (A.-J.) - Le problème littéraire de l'Historia Monachorum in Hermes LXXXIII, 1955, Wiesbaden.

—, Lieux communs littéraires et thèmes de folk-lore dans l'Hagiographie primitive in Wiener Studien, LXXIII, 1960.

- Historia Monachorum in Aegypto (= Subsidia Hagiographica, n. 34), Bruxelles, 1961.

- Les moines d'Orient, IV/1: Enquête sur les moines d'Égypte, Paris, 1964 (= Subsidia Hagiographica, n. 53, Bruxelles, 1971). 
- Les moines d'Orient, IV/2 - La première vie grecque de Saint Pachôme, Paris, 1965.

Fiens (Albertino Martins) - Gil Vicente e o prólogo, Lisboa, 1968.

Fliche (A.)-Martin (V.) - Histoire de l'Église t. III, Paris, 1939.

Forcellini (A.) - Vit (V. de) - Totius latinitatis lexicon, Prato, I-VI, 1858-1875.

Frank (S.) - Mönche im fruhchristlichen Ägypten, Dusseldorf, 1967.

Freire (José Geraldes) - A versão latina por Pascásio de Dume dos "Apophthegmata Patrum», Coimbra, 1971, t. I e II.

- Manuscritos das "Sententiae Patrum Aegyptiorum" de S. Martinho de Dume in Repertorio de Historia de las Ciencias Eclesiásticas en España, Salamanca, 1971.

- - Traductions latines des "Apophthegmata Patrum" in Mélanges Christine Mohrmann, Nouveau recueil offert par ses anciens élèves, Utrecht-Anvers, 1973.

Froger (J.) - La critique des textes et l'ordinateur in Vigiliae Christianae, XXIV, 1970.

FRIDH (Âke) - Le problème de la passion des saintes Perpétue et Félicité, Göteborg, 1968.

FUGIER (H.) - Recherches sur l'expression du sacré dans la langue latine, Paris, 1963.

GARITte (G.) - Le texte grec et les versions anciennes de la vie de Saint Antoine in Studia Anselmiana, XXXVIII, 1956.

GARNEFELD (G.) - Elucidationes sacrae in quinque libros de imaginibus antiquorum eremitarum, Coloniae Agripinae, 1621.

Gonçalves (Francisco Rebelo) $-A$ expressão "tranquilitas uestra" de um passo de Eutrópio in Humanitas, II, 1948.

GöTZE - Die Merkwürdigkeiten der königlichen Bibliothek zu Dresden ausführlisch beschriben und mit Unmerkungen erläutert, I, Dresden, 1743.

Graecitas Christianorum Primaeua, Nouiomagi, IV, 1970.

Grandgent (C. H.) - Introducción al latín vulgar, Madrid, 1952.

GuIllén (J.) - Estilística Latina, Salamanca, 1954.

—_, Gramática Latina, Salamanca, 1960.

Guy (Jean-Claude) - Remarques sur le texte des apophthegmata patrum in Recherches de Science Religieuse, XLIII, 1955.

_- Notes sur l'évolution du genre apophtegmatique in Revue d'Ascétique et de Mystique, XXXII, 1956.

-_, Les apophthegmata patrum in Théologie de la vie monastique, Lyon-Paris, 1961.

- Recherches sur la tradition grecque des Apophthegmata Patrum, Bruxelles, 1962. 
—, Jean Cassien, Institutions Cénobitiques, Paris, 1965.

—- Les apophthegmes des Pères du Desert, Série alphabétique, Textes de Spiritualité Orientale, n. ${ }^{\circ}$, Abbaye de Bellefontaine, Bégrolles-en-Mauges, 1966.

Haadsma (R. A.) et Nuchelmans (J.) - Précis de latin vulgaire suivi d'une anthologie annotée, Groningen, 1963.

Halkin (F.) - Les vies grecques de S. Pachôme in Anacleta Bollandiana XLVII, 1929.

—- L'Histoire Lausiaque et les vies grecques de S. Pachôme in Anacleta Bollandiana, XLVIII, 1930.

—-, Sancti Pachomii Vitae Graecae, Bruxelles, 1932.

- Bibliotheca Hagiographica Graeca, t. III, Bruxelles, 1957.

Halm (C.), Laubmann (G.), Meyer (G.) - Catalogus codicum latinorum Bibliothecae Regiae Monachensis, secundum Andreae Schmellerii indices, Monachii, t. II, pars IV, 21969.

Heussi (Karl) - Der Ursprung des Mönchtums, Tübingen, 1936.

HiLdeberTI (Cenomanensis episcopi) - Carmina Minora, recensuit A. Brian Scott, Leipzig, 1969.

Hofmann (J. B.) - El latín familiar, Madrid, 1958.

Hofmann (J. B.); Szantyr (A.) - Lateinische Syntax und Stilistik, München, 1965.

Holmes (J. S.) - The nature of translation: Essays on the theory and practice of literary translation, The Hague-Paris, 1970.

Honigmann (E.) - Heraclidas of Nissa (about 440 A. D.) in Patristic Studies, coll. Studi e Testi, t. 173, Vaticano, 1953.

Hopfner (Theodor) - Über die koptisch- saidischen Apophthegmata Patrum Aegyptiorum und verwandte griechische, lateinische, koptisch-bohairische und syrische Sammlungen in Akademie der Wissenschaften in Wien, Philosophisch-historische Klasse, Denkschriften LXI, 1919 (sessão de 5 de Julho de 1916, em Praga).

Hoppenbrouwers, (H. W. F. M.) - La plus ancienne version latine de la vie de S. Antoine par S. Athanase, Utrecht-Nijmegen, 1960.

- Conuersatio in Graecitas et Latinitas Christianorum Primaeua, Supplementa, fasc. I, Nouiomagi, 1964.

_- La technique de la traduction dans l'Antiquité d'après la première version latine de la Vita Antonii in Mélanges Christine Mohrmann. Nouveau recueil offert par ses anciens élèves, Utrecht-Anvers, 1973.

Journel (M.-J. Rouet de) - Jean Moschus, Le pré spirituel, Paris, 1946.

Labriolle (P. de) - Apophtegmata Patrum in Dictionnaire d'Histoire et de Géographie Ecclésiastiques, Paris, III, 1924.

—, Histoire de la littérature latine chrétienne, Paris, 1947. 
LADEUZe (P.) - Étude sur le cénobitisme pachomien pendant le $I V .^{e}$ siècle et la première moitié du $V . e$, Louvain, 1888.

LAMPe (G. W. H.) - A patristic greek lexicon, Oxford, 1968.

Latinitas Christianorum Primaeua, Nouiomagi, XXII, 1972.

LAUfer (Roger) - Introduction à la textologie (Vérification, établissement, éditions des textes), Paris, 1972.

Laurenti (J. L.) y Mayo (A. Porqueras) - Notas bibliográficas sobre el prólogo en la literatura greco-latina in Estudios Clásicos, 1969.

Lefort (L.Th.) - Les vies coptes de Saint Pachôme et ses premiers successeurs, Louvain, 1943.

Lehmann (P.) - Pseudoantike Literatur des Mittelalters in Erforschung des Mittelalters, t. III, Stuttgart, 1960.

Leloir (L.) - La Bible et les Pères du Désert d'après les deux collections armeniennes des apophtegmes in La Bible et les Pères, Strasbourg, 1971.

LEROY (J.) - Les préfaces des écrits monastiques de Cassien in Revue d'Ascétique et de Mystique, XLII, 1966 (Toulouse).

Leumann (M.) - Lateinische Laut- und Formenlehre, München, 1963. Lewis (Ch. T.) and Short (Ch.) - A latin dictionary, Oxford, 1962. Lidell (H. G.); Scott (R.); Jones (H. S.) - A greek english lexicon, Oxford, 1966.

LöFsTEDT (Bengst) - Studien ïber Sprache der longobardischen Gesetze. Beiträge zur frühmittellateinischen Latinität, Lund, 1961.

LöFSTEDT (Einar) - Philologischer Kommentar zur Peregrinatio Aetheriae, Darmstadt, ${ }^{3} 1962$.

—, Syntactica, I e II, Lund, ${ }^{3} 1957$.

—, Late latin, Oslo, 1959.

LORIÉ (L. Th.) - Spiritual terminologie in the latin translations of the Vita Antonii, with reference to fourth and fifth century monastic literature (= Latinitas Christianorum Primaeua, 11), Utrecht-Nijmegen, 1955.

Lucot (A.) - Palladius. Histoire Lausiaque, Texte grec, traduction française, introduction, Paris, 1912.

LUNDSTRÖM (Sv.) - Übersetzungstechnische Untersuchungen auf dem Gebiete der christlichen Latinität, Lund, 1955.

Luz (Marilina dos Santos) - Fórmulas de tratamento em português arcaico, Coimbra, 1958.

MaAs (Paul) - Textkritik, Leipzig, 1960.

Magueijo (Custódio) - Helenismo sintáctico e estruturas latinas, Évora, 1973.

Malpique (Cruz) - Filosofia do plágio (Ensaio), Braga, 1955.

Marion (L.) - Histoire de l'Église, t. I, 1942. 
Marouzeau (Jules) - L'ordre des mots dans la phrase latine, I: Les groupes nominaux; II: Le verbe; Volume complémentaire avec exercices d'application et bibliographie, Paris, 1953.

Marti (Josefina Garau) - Salutaciones $y$ dedicaciones en las cartas de S. Cipriano, S. Jerónimo y San Agustín, Salamanca, 1965.

Martins (Mário) - Correntes da filosofia religiosa em Braga dos séculos IV a VII, Porto, 1950.

—_, João Cassiano. Fragmentos em medievo-português in Estudos de Literatura Medieval, Braga, 1956.

Maurer Junior (Th. H.) - Gramática do latim vulgar, Rio de Janeiro, 1959.

Meershoek (G. Q. A.) - Le latin biblique d'après Saint Jérome. Aspects linguistiques de la rencontre entre la Bible et le monde classique, Nijmegen-Utrecht, 1966.

Meyer (R. T.) - Palladius. The Lausiac History, translated and annoted, Westminster (Maryland), 1965 (= Ancient Christian Writers, n. 34).

MEYER-LüBKE (W.) - Romanisches etymologisches Wörterbuch, Heidelberg, 1968.

Meyer (G.) und Buckhardt (M.) - Die mittelalterlichen Handschriften der Universitätsbibliothek Basel, Abt. B. I Band, Basel, 1960.

Migne (J.-P.) - Patrologia Latina, Parisiis, tt. 20, 21, 49, 73, 74, 88, 103.

—-, Patrologia Graeca, t. 65, reedição da Livraria Brepols, Turnhout (Bélgica), s/d.

Mohrmann, (Christine A. E. M.) - Note sur la version latine la plus ancienne de la vie de Saint Antoine par Saint Athanase in Antonius Magnus Eremita (= Studia Anselmiana, 38), 1956.

_-, Études sur le latin des chrétiens, Roma, I, 1958; II, 1961; III, 1965.

- De studie van het middeleuws latijn. Verleden, heden, toekomst. Afscheidscollege, 10-XI-1973, Amsterdam.

- De studie van het oudchristelijk grieks en latijn. Verleden, heden, toekomst. Afscheidscollege, 14-XII-1973, Edit. Spectrum, Utrecht-Antwerpen.

MOINES DE SOLESMES - Abbé Isaie, Recueil ascétique, introduction et traduction par les... (= Spiritualité Orientale, n. 7), Abbaye de Bellefontaine, Bégrolles-en-Mauges, 1970.

Monteiro (Ofélia Milheiro Caldas de Paiva) - Um conto desconhecido de Herculano: "Destruição de Áuria», Coimbra, 1973.

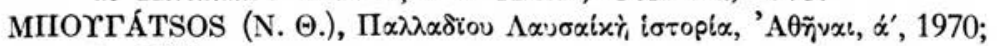
$\beta^{\prime}, 1972$.

Moreira (A. Montes) - Potamius de Lisbonne et la controverse arienne, Louvain, 1969. 
Nau (F.) - Histoire de Tais. Publication de textes grecs inédits et de divers autres textes et versions in Annales du Musée Guimet, XXX, 1903, Paris.

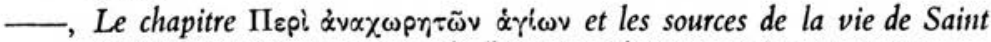
Paul de Thèbes in Revue de l'Orient Chrétien, Paris, X, 1905.

_- Histoires des solitaires égyptiens in Revue de l'Orient Chrétien, vols. XII-XIV (1907-1909), XVII-XVIII (1912-1913).

-, Recueil de monographies, IV in Patrologia Orientalis, VIII, 1912.

Niermeyer (J. F.) - Mediae latinitatis lexicon minus, Leiden, 1965.

Nikitin (P.) - Das griechische "sketische" Paterikón und seine alte lateinische Übersetzung in Vizantysky Vremennik, XXII, 1915-1916 in Byzantinische Zeitschrift XXIII, 1914, Leipzig, 1920.

NoRBerg (Dag) - Syntaktische Forschungen auf den Gebiete des spätlateins und des frühen Mittellateins, Uppsala, 1943.

—, Beiträge zur spätlateinischen Syntax, Uppsala, 1944.

Norden (E.) - Die antike Kunstprosa von VI. Jahrhundert vor Christus bis in die Zeit der Renaissance, II Band, Stuttgart, ${ }^{51958 .}$

- Die römische Literatur. Mit Anhang: Die lateinische Literatur im Übergang von Altertum zum Mittelalter, Leipzig, 1961.

O'Brien (M. B.) - Tittles of address in christian epistolography to 543 A. D., Washington, 1930.

O'Callaghan (J.) - El trato de "padre" en la correspondencia cristiana del siglo $V$ in Boletín de la Associación Española de Orientalistas, I, 1965.

Pereira (Maria Helena da Rocha) - Sobre a autenticidade do fragmento 44 Diehl de Anacreonte, Coimbra, 1961.

—, Obras médicas de Pedro Hispano, Coimbra, 1973.

Petschenig (M.) - Ioannis Cassiani Opera. Conlationes XXIV, Vindobonae, 1886 (= Corpus Scriptorum Ecclesiasticorum Latinorum, 13).

—, Institutionum libri XII, Vindobonae, 1888 (= C. S. E. L., 17).

Pichery (E.) - Jean Cassien. Conférences, 3 vols., Paris, 1955, 1958, 1959 (= Sources Chrétiennes, 42, 54, 64).

Pontes (José Maria da Cruz) - A obra filosófica de Pedro Hispano Portugalense, Coimbra, 1972.

Preuschen (E.) - Palladius Helenopolitanus et Rufinus Tyranius. Ein Beitrag zur Quellenkunde des ältesten Mönschtums, Giessen, 1897.

Oldfather (W. A.) - Studies in the text tradition of St. Jerome's Vitae Patrum, Urbana, 1943.

PÉTRÉ (H.) - Éthérie. Journal de voyage, Paris, 1964.

Regnault (Lucien) - Maitres spirituels au désert de Gaza: Barsanuph, Jean et Dorothée, Abbaye de Solesmes, 1967. 
—_, Connaissez-vous les Pères du Désert? in La Vie Spirituelle, n. 582, 1971.

—_, L'enfance spirituelle chez les Pères du Désert in Vie Thérésienne, n. $45,1972$.

Regnault (L.); Dion (J.), Oury (G.) - Les sentences des Pères du Désert. Recension de Pélage et Jean, Abbaye de Saint Pierre de Solesmes, Sablé-sur-Sarthe, 1966.

Regnault (L.) et Moines De Solesmes - Les sentences des Pères du Desert. Nouveau recueil. Apophtegmes inédits ou peu connus, Solesmes, 1970.

Reis (Scbastião Martins dos) - Evangelhos e Actos dos Apóstolos, Porto, 1973.

Rertzenstein (R.) - Historia Monachorum und Historia Lausiaca, Göttingen, 1916.

Rose (Valentin) - Verzeichniss der lateinischen Handschriften der königlichen Bibliothek zu Berlin, Band II, Berlin, 1903.

Rosweydvs (Heribertus) - Vitae Patrum siue historiae eremiticae libri decem, Antuerpiae, ${ }^{1} 1615,{ }^{2} 1628$.

Salonius (A. H.) - Vitae Patrum. Kritische Untersuchungen ïber Text, Syntax und Wortschatz des spätlateinischen Vitae Patrum, Bücher III, V, VI, VII, Lund, 1920.

Schanz-Hosius (C.) und KRüGeR (G.) - Geschichte der römische Literatur, IV Teil, II Band, München, 1959.

Seabra (Manuel de) - Antologia da Poesia Provençal Moderna, Lisboa, 1972.

—, Miyamoto Masao, Da arte e da morte, Lisboa, 1973.

Siegmund (A.) - Die Überlieferung der griechischen christlichen Literatur in der lateinischen Kirche bis zum zölften Jahrhundert, München, 1949.

Sonres (Luís Ribeiro) $-A$ linhagem cultural de S. Martinho de Dume, I-Fundamentos, Lisboa, 1963.

Sprachwissenschaft und Übersetzen. Symposium an der Universität Heidelberg, II, 1969 (cf. nota 143).

SPRINGHettr (Aemilius) - Institutiones styli latini, Romac, 1954.

STEYEN (P. A. W.) - Stylistische opmerkingen aangaande het gebruik der deminutiva in het latijn, Nijmegen, 1953.

Supplementa - Latinitas et Graecitas Christianorum Primaeua, Fasciculus III, 1970, Nouiomagi.

Thraede (K.) - Grundzïge griechisch-römischer Brieftopik, München, 1970.

Tovar (António) - Sintáxis, Madrid, 1946. 
Trager (G. L.) - The use of the latin demonstrative (especially ille and ipse up to $600 \mathrm{~A}$. D.) as the source of the romance article, New York, 1932.

Urbel (Justo Pérez de) - Los monjes españoles en la Edad Media, I, Madrid, ${ }^{2} 1945$.

VÄÄNÄNEN (V.) - Introducción al latín vulgar, Madrid, 1968.

Van Cranenburg (H.) - La vie latine de Saint Pachôme, traduite du grec par Denys le Petit (= Subsidia Hagiographica, n. ${ }^{\circ} 46$ ), Bruxelles, 1969.

Van den Besselaar (Joseph) - Introdução aos Estudos Históricos, São Paulo, 1970.

VAn Der Meer (F.); Mohrmann (Christine) - Atlas van de oudchristelijk wereld, Amsterdam, 21961.

VAN DER STRAETEN (J.) - Les manuscrits hagiographiques de Charleville, Verdun et Saint-Mihiel, (= Subsidia Hagiographica, 56) Bruxelles, 1974.

Van Groningen (B. A.) - Traité d'histoire et de critique des textes grecs, Amsterdam, 1963.

VON KAROLSFELD (Franz Schnorr) - Katalog der Handschriften der königlichen öffentlichen Bibliothek zu Dresden, Leipzig, I, 1882.

WAGNER (Monica) - Rufinus, the translator, Washington, 1945.

White (H. G. E.) - The monasteries of the Wadi 'n Natrun. Part II: The history of the monasteries of Nitria and Scétis, New York, 1932.

WinkelmanN (F.) - Spätantike lateinische Übersetzungen christlicher griechischer Literatur in Theologische Literaturzeitung, XCII, 1967.

Wrigth (F. A.) and Sinclair, (T. A.) $-A$ history of later latin literature from the middle of the fourth to the end of the seventeenth century, London, 1969.

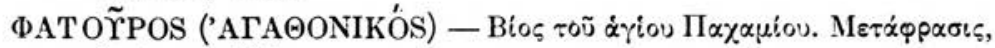
'A $\theta \tilde{\eta} v \alpha \iota, 1971$.

Ziegler (K.) - M. T. Cicero, De Republica, Lipsiac, 1965.

—, Plagiat in Realencyclopädie der klassischen Altertumswissenschaft von Pauly-Wissowa, vol. 40, 1, Stuttgart, 1950. 


\title{
ÍNDICE ONOMÁSTICO
}

\author{
A) \\ Do estudo filológico \\ (página)
}

Abrã̃o (abade) - 136, 137, 140.

AвRAнAм (patriarcha)-109, 303, 308.

ACÁCIO - 118 .

AeBischer (P.) - 221.

Agathon - 39, 64, 85, 97, 101, 117, 183, 202, 211.

Agostinho (S.) -299 .

Amélineau (E.) - 53, 97.

ANASTÁSIO - 30 .

ANTONIVS / ANTÃo - 16, 33, $37,96,97,98,100,101,105$, $106,107,113,119,124,159$, 193, 194, 204.

ANUB - 64, 98.

Apollo / Apollónio - 32, 101, $136,137,138,140,147,148$, 181, 210, 211.

ARCídio - 97.

ARrinNo - 16.

ArRufat (A. R.) - 54, 61.

ARséNIO - 5, 30, 32, 40, 64, 65, $71,72,76,77,80,81,86,88$, $97,98,100,101,103,119,155$, 156, 166, 167, 190. 211, 213, 236, 239, 246, 255, 267, 278.
Atanásio (abade) - 101, 202, 236, 265, 290.

AtanÁsio (S.) - 16, 33, 67, 96, 97, 159.

BARDY (G.) - 126, 159.

BarLoW (C. W.) $-6,47,133$, 160, 161.

BARONIVS - 103.

BARONTO - 39.

BARSANUPH - 47.

BARTELINK (G.) - 54 .

Bastiaensen (A. A. R.) - 199, 245.

Batile (C. M.) - 13, 14, 20, $46,48,56,120,121,124,126$, 127, 128, 132, 161, 207.

Benjamim - 63, 101, 211, 231, 239, 252, 267.

Bento (S.) - 127, 128, 132, 140, 165, 240.

Bischoff (B.) - 14 .

Blaise (A.) - 164, 170, 199, 252.

Blatt (F.) - 159 .

BoÉCIO - 133, 159.

BolÉo (M. P.) - 198. 
Bolandistas - 9, 15, 17, 22, 50, 51, 61.

BousSET (W.) - 17, 48, 54, 56, 94, 95, 96, 99, 102, 104, 116, 120, 136.

BRENNo (Silveira) - 159 .

BUCKHARDT (M.) - 15, 41.

Budge (E. A. W.) - 54, 99.

BUTLER (C.) $-16,17,54,55$, 56, 96, 104, 120.

Campos (J. A. S. e) - 134 .

Campos (Júlio de) - 113 .

Cassiano (João) - 48, 49, 56, $62,64,106,123,124,125$, $128,136-149,152,160,205$, $215,241,242,244,249,282$, 283.

Cassiodoro - 133, 159.

Cedrenvs - 251.

Cesáreo (de Arles) - 133.

Chadwick (O.) - 140 .

Chaine (M.) - 16, 54, 94.

Ć́́cero - 16.

Cintra (L. F. L.) - 199.

Cipriano (S.) - 299.

Cirilo - 97.

Clemente (de Alexandria) - 16 .

Climent (M. Bassols de) -170 .

Columbano - 249.

Columela - 253.

Crisóstomo (S. João) -140 .

CRónio (abade) - 97.

CurTI (C.) - 134.

DAIN (A.) - 16 .

DANIEL (abade) - 64, 80, 98, 101, 119, 211, 255.

Daniel (profeta) - 91, 168.

David (profeta) - 134, 210.

Defensor - 129, 130, 131, 132, 133.
DekKers (E.) -159 .

Delehaye (H.) -17 .

Deseille (P.) -96 .

Devos (P.) - 51, 245.

Dion (J.) -47 .

Dionísio (o Exíguo) - 61, 127, 133.

Dióscoro - 50, 51, 52, 96, 101, 211.

DомЕ́CIO - 97.

DOROTEU - 47.

DöRRIE (H.) -159 .

Draguet (R.) - 17, 54, 99, 299.

Du Cange - 164 .

EKLUNd (S.) - 159.

Elias - 303, 308.

ELISEU - 273, 281.

Elizalde (M.) -6, 47.

ÉNIO - 166.

EPICTETo - 16.

ERNOUT (A.) - 164, 170, 242.

ETÉRIA - 16, 208, 245, 252.

EUfrósINA - 35.

EuLÁLIO - 39, 75, 76, 101, 176, 202, 274.

EUPRÉPIO - 64.

EuséBIO - 134.

EvÁGRIO - 96, 103, 140, 149.

FARIA (E.) - 144, 170.

Festugière (A.-J.) - 50, 51, 60, $61,70,162,300$.

FIDELIVS -305 .

FIDOsvs - 305, 307.

Fidvs -305 .

FIENS (A. M.) -299.

FILOTEU - 49, 62, 64.

Fuiche (A.) -96 .

Fontaine (J.) -140 .

ForCelini (A.) - 164, 166.

Frank (S.) -51 . 
Freire (J. G.) - 13, 14, 20, 61, 161, 208 (cf. também: Pascásio de Dume, t. I; t. II).

FRIDH (A.) - 134.

Froger (J.) -260 .

FrontóNIO - 22, 28, 33, 35, 38, $65,66$.

FugieR (H.) -102 .

Garitte (G.) - 159.

GARNeFeld (G.) - 103, 120.

Gelásio (abade) - 64, 229.

Gelásio (papa) - 124 .

Gélio (Aulo) - 166 .

Germano - 136.

Gonçalves (F. R.) - 199.

GöTZE - 24.

Grandgent (C. H.) - 144, 154.

Gregório (S.) - 25.

Gregório (de Tours) - 133 .

GuIlLÉN (J.) - 167, 170.

Guy (J.-C.) - 6, 17, 47, 99, 116, 140.

HaAdsma (R. A.) -154 .

HaLKin (F.) - 61, 64, 127.

HERACLIDES - 22, 49, 54, 55, 61, 62, 64, 303.

Herculano (A.) - 134 .

Hervetvs (G.) - 54, 303.

Heussi (K.) - 96, 99.

Hieronimvs (ver Jerónimo).

HilARĨ̃o - 28, 33, 36, 46, 124.

HiLdeberTvs (Cenomanensis) -121 .

HiLdegARDIS - 165 .

Hofmann (J. B.) - 167, 154.

Holmes (J. S.) -159 .

Honigmann (E.) -54 .

HONÓRIO - 97.

HOPFNER (Th.) - 16, 17, 95, 96, 104, 150, 151, 152, 158, 161.
HOPPENBROUWERS (H.W.) -16 , $113,159$.

Hosivs (C.) -133 .

Іасов (patriarcha) - 109, 242, 303, 308.

IsAAC (patriarcha) - 109, 303, 308. IsAAC (presbítero) - 64, 74, 97, 101, 152, 153, 204, 211, 216. 293.

Isaías (abade) - 47.

IsAísS (profeta) - 134 .

Isidoro (abade) - 97, 101, 116, 180, 273.

IsIDORo (de Pelúsio) - 97.

Isidoro (de Sevilha) - 129, 130, 239.

JAZARGUet (M. $\left.{ }^{11 e}\right)-140$.

JeRóNimo (S.) - 36, 37, 46, 54, $104,106,121,122,123,124$, 126, 128, 134, 151, 159, 299.

Jo ño (abade e monge) - 37,68 , 98, 99, 101, 206, 211.

Jõ̃o (Baptista) - 303, 308.

Jõ̃o (Cólobo) - 63, 67, 68, 72, 91, 93, 97, 115, 119, 174.

Jõ̃o (discípulo de Paulo) - 64, 74, 75, 273.

Jõ̃o (Elecmosinário ou Alexandrino) -25 .

Jo ̃̃o (de Gaza) - 47.

Jo Ão (subdiácono) - 13, 15, 23, $24,25,33,35,43,47,48,56$, $61,63,64,71,73,74,95,99$, $113,118,121,122,126,128$, 132, 150, 151, 161, 163, 235. Јов -210 .

JoNes (H. S.) -165.

José (abade) - 63, 75, 90, 99, 101, 211, 233, 267. 
José (patriarca) - 242, 276.

Journel (M.-J. Rouet de) - 96.

JuLiño (S.) -37 .

Júlio (S.) -37 .

KRÜGER (G.) - 133.

LABRIOLle (P.) - 17, 134.

LADEUZE (P.) - 106.

LAMPE (G. W. H.) - 165 .

LAUfer (R.) - 260, 261.

LAUReNTI (J. L.) - 299.

LAUSo - $51,54,61,63,64,96$, 140, 299, 301, 303, 304, 305.

LÁZARO - 134.

LeANDRo (de Sevilha) - 47.

LeFort (L. Th.) - 61, 299.

LehmanN (P.) - 127.

LELOIR (L.) -47.

LEROY (J.) - 140, 299.

LeumanN (M.) -144 .

LEwIS (Ch. T.) -164 .

LIDDEL (H.) -165 .

LÖFSTEDT (B.) -208.

LöFsTEDT (E.) - 208 .

LoRIÉ (L. Th. A.) - 113 .

Lucot (A.) -54 .

LuNDSTRÖM (Sv.) - 159 .

Lutero (M.) - 13, 132.

Luz (M. S.) - 199 .

MAAS (P.) -261 .

MACABEUS - 159 .

MACÁRIO (S.) - 31, 64, 66, 69, $70,96,97,100,101,110,115$, $176,183,211,214,222,234$, 257, 267.

Magueijo (C.) - 159 .

MALCo - 28, 33, 36, 38, 39, 46, 124.

MalpiQue (Cruz) - 148 .

Manitius (M.) - 133 .

Marcella - 248.

Marcial (S.) -25 .
Marciano (imperador) - 98 .

Marciano (monge) - 36, 101, 147, 287, 288.

Maria (Egipcíaca) - 37 .

MARINA - 39.

Marouzeau (J.) - 167, 182.

Marti (J. Garau) - 299.

Martin (V.) - 96.

Martinho (de Dume) - 13, 20, $21,24,39,46,47,48,56,71$, $94,95,99,100,122,124,126$, $127,128,132,133,134,151$, $160,163,208,215,235,245$, 256, 299.

Martins (M.) - 127, 140.

Masao (M.) - 160 .

MAURer JÚNIOR (Th. H.). - 154.

Mayo (A. Porqueras) - 299.

MAZICES - 98.

MeERShoek (G.) - 159 .

Meillet (A.) - 164, 242.

Menandro - 16.

Meyer (G.) - 15, 41.

Meyer (R. T.) - 54 .

MeYer-LÜBKE (W.) - 164, 242.

Migne (J.-P.) - 13, 96, 104, 125, 129, 139, 158.

Mios - 63, 115, 231, 243.

MohrmanN (Ch.) - 10, 14, 96, 151, 159, 161, 197, 208, 236, 297.

Moisés (abade) - 63, 68, 97, 101, 171, 180, 244, 273.

Moisés (chefe de Israel) - 166 . 167, 303, 308.

Monteiro (O. M. C. P.) - 134, Moreira (A. M.) - 134 .

Moschvs (J.) -96 .

$\mathrm{M} \pi \alpha \tau i \sigma \tau \alpha \tau \circ \varsigma$ ( (. M.) -54 .

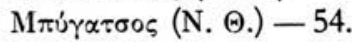

NABUCODONOSOR - 248, 267. 
NABURDAZAN $-248,249$.

NATANAEL $-27,122$.

NAU (F.) - 16, 57, 58, 60, 63, $64,75,82,84,89,98,101$, $109,110,111,112,115,155$, $164,166,167,170,206,207$, $215,230$.

Niermeyer (J. F.) -164.

NESTOR - 209.

Nikitin (P.) -16 .

NiLO (S.) -22 .

Nítera / Netras - 31, 63, 74, 87, 101, 211.

NoRBerg (D.) -208 .

NORDEN (E.) -133.

Nuchelmans (J.) -154 .

O'BRIEN (M. B.) - 299.

O'Callaghan (J.) -299.

OCtávia - 134 .

OldFATHER (W. A.) -46 .

Olímpio - 63, 195.

Oribásio - 247.

Orígenes - 134, 140, 149.

ORSIESIVS - 106.

OURY (G.) -47 .

Pacómio (S.) - 33, 37, 40, 41, 42, 49, 61, 62, 64, 96, 101, $105,106,107,147,148,163$, 172, 188, 242, 281, 284.

PAFNÚCIO - 97, 98.

PALÁdIO - 14, 16, 17, 23, 26, $28,33,35,37,38,42,43,44$, $46,48,49,50,51,53,54,55$, $56,60,61,63,64,96,106$, $122,126,136,253,301,303$, 304, 305.

PASCÁSIO - 6, 7, 8, 9, 13, 14, $15,17,19,20,21,22,23,24$, $25,26,29,33,35,36,37,39$, $40,43,44,45,46,47,48,49$,
$52,55,56,57,58,59,61,62$, $63,64,65,68,71,72,73,74$, $75,76,77,78,79,80,82,83$, $85,90,91,92,93,94,95,97$, $98,99,100,102,103,104$, $113,117,118,121,122,123$, $124,125,126,127,128,130$, $131,132,133,151,152,154$, $155,156,157,160,161,163$, 175, 183, 191, 196, 197, 204, 208, 209, 215, 235, 237, 240, $245,249,253,256,257,259$, 261, 287, 298, 299, 300.

PASTOR - 100, 155.

Paula - 37.

Paulo (Apóstolo) - 70, 88.

Paulo (de Tebas) - 16, 23, 26, $28,33,36,46,96,97,99,101$, 122, 124, 254, 273.

PAULY - 148.

Pedro (Apóstolo) - 86.

PeDRo (disć́pulo) - 101.

Pedro Hispano - 16.

Pelágia (Santa) - 35, 37, 248.

Pelácio (diácono) - 13, 15, 23, $24,25,26,28,33,35,37,38$, $39,41,42,43,44,45,47,48$, $49,55,56,57,58,59,61,63$, $64,68,69,70,71,72,73,74$, $75,76,77,80,81,84,85,86$, $88,89,90,91,95,99,100$, $102,112,113,117,121,122$, $123,126,128,130,131,132$, $150,151,152,155,156,157$, $161,163,164,165,166,167$, $168,169,170,174,175,182$, $183,184,185,186,187,191$, 193, 195, 196, 206, 207, 215, $229,230,231,235,243,245$, $246,249,253,255,257,272$, 287.

Petrónio - 106. 
Petschenig (M.) - 62, 140, 141. PicherY (E.) - 137, 140, 141, 146, 149, 160.

Pfor - 64, 96, 101, 119, 168, 169, 180, 189, 204, 207, 209, 210.

PLíNIO - 253.

Poemen $-30,32,34,39,63$, $64,69,73,92,98,99,100$, $111,118,119,131,155,156$, $171,174,190,201,208,209$, $210,214,223,228,248,251$, 270, 276.

Pontes (J. M. da Cruz) -16 .

Postumiano - 45, 103, 125.

Preuschen (E.) -53 .

PropérCio - 205.

Pseudo-Agostinho - 149 .

Pseudo-Calístenes - 149.

Pseudo-Crisóstomo - 149.

Pseudo-Dionísio - 149.

Pseudo-Ovídio - 149.

Pseudo-Rufino - 104, 121.

Pseudo-Salústio - 149.

PSEUDO-SÉNECA - 149 .

PotÂMIO - 134 .

RaMalHo - (A. C.) - 10.

Regnault (L.) - 9, 47, 48, 49, 61.

ReIs (S. M. dos) -160 .

Reitzenstein (R.) - 54 .

Pereira (M. H. da Rocha) -10 , 16, 134.

ROMEU - 64.

Rose (V.) - 28.

Rosweydvs (H.) - 6, 7, 13, 14, $15,17,18,19,20,21,22,23$, $26,28,29,30,31,33,34,35$, $36,37,38,39,40,41,42,43$, $44,45,46,47,48,49,50,53$, $54,55,56,60,62,63,64,65$,
94, 103, 104, 120, 121, 122, $123,124,125,127,130,132$, $136,150,157,164,165,171$, $173,174,178,210,236,239$, $240,248,249,250,251,253$, $256,259,260,261,278-298$ $($ passim $=\mathrm{Y}), 300,301,303$, 304, 305.

RuFino - 6, 13, 50, 51, 52, 53, $55,62,103,104,120,121$, 122, 124, 128, 134, 150, 151, 157, 159, 162, 301, 305. (Ver também Pseudo-Rufino).

Salonivs (A. H.) - 104, 121, $122,150,151,152,164,165$, 208.

SCHANZ (M.) -133.

Scotr (A. B.) -121 .

ScotT (R.) - 165 .

SeAbra (M. de) -160 .

SÉNECA - 134.

SHORT (Ch.) - 164 .

Siegmund (A.) -159 .

SilvaNo - 98, 101.

SiMEÃo - 37 .

Sinclair (T. A.) - 134 .

SisOES - 63, 91 .

SoARes (L. R.) - 127, 128.

SOZÓMENO - 162.

SPEIER (W.) - 127.

SPRINGHETTI (Aem.) - 167.

STEYen (P. A. W.) - 203.

SeVero / Sulpício - 24, 48, 123, 125.

SZANTYR (A.) - 167, 174.

TÁrsis - 20, 21, 39, 57, 127.

TEODORO - 67, 82, 83, 96, 101, $105,106,107,147,148,236$, 284.

TeOdósio I -97. 
Teodósio II (Júnior) - 68, 98, 200, 251, 276.

Té́filo (de Alexandria) - 97.

Thomas (F.) - 170 .

TheOPHILES -62 .

Timóteo - 50 .

TOVAR (A.) -170 .

Thraede (K.) - 299.

Trager (G. L.) -221 .

Urbel (J. Pérez de) - 104.

VÄÄNÄNEN (V.) - 144, 154.

WAGNER (M.) - 151 .

VaLLarsivs (D.) - 104, 120, 124.
Van den Besselahr (J.) - 126 .

VAN DER MEER (F.) -96 .

Van der Straeten (J.) - 17.

VAN Groningen (B. A.) -261 .

Vicente (Gil) - 299.

VIr (F. de) - 164.

Von Karolsfeld (F. S.) - 24 .

White (H. G. E.) - 96, 98.

WINKELMANN (F.) -159 .

WIsSOWA - 148 .

WRIGTH (F. A.) - 134 .

Zeno - 39, 63, 98, 101, 211, 220.

Ziegler (K.) - 16, 148.

B)

\section{Do texto das "Commonitiones»}

(capítulo e apotegma)

$\alpha)$

NOMES DE PESSOAS

Abraham (patriarcha) - I, 6.

AgATHON - IV capit. VII; IV, 7.

Antonivs - V, 1; V, 2; V, 8.

Apollo - IV capit. XI; IV, 11; V capit. VI; V, 6.

ArCadivs - VI, titulus.

ARsenivs - V capit. X; VI, titulus; VI, 1; VI, 2; VI, 3; VI, 4; VI, 5; VI, 6.

Athanasivs - IV capit. XVII; IV, 17.
Beelzebvb - IV, 19.

BENIAMIN - I capit. X; I, 9; I, 10.

Daemon / Diabolvs / spiritvs - I, 3; I, 9; II capit. I, II, III, VII, IX, X; II titulus; II, 1; II, 2; II, 3; II, 4; II, 5; II, 6; II, 7; II, 8; II, 9; IV, 2; IV, 3; IV, 4; IV, 7; IV, 11: IV, $18 ; \mathrm{V}, 8$. 
Daniel (abbas) - VI, 2; VI, 4; VI, 6.

Daniel (propheta) - I, 3 .

DAvid - II, 10.

Devs / Dominvs - I, 1; I, 5; I, $6 ; 1,7 ; 1,8 ; 1,12 ; 1,13$;

I, 14; I, 16; II, 1; II, 2; II, 3; II, 4; II, 5; II, 6; II, 7; II, 8; II, 9; III, 1; IV capit. XII; IV, 1; IV, 2; IV, 3; IV, 4; IV, 5; IV, 6; IV, 7; IV, 8; IV, 9; IV, 10; IV, 11; IV, 12; IV, 14; IV, 16; IV, 18; IV, 19; V capit. IV, V; V, 1; V, 2; $\mathrm{V}, 3 ; \mathrm{V}, 4 ; \mathrm{V}, 5 ; \mathrm{V}, 7 ; \mathrm{V}, 8$; V, 9; VI, 3; VI, 5; VI, 6.

Diosconvs - I capit. XV; I, 15.

EuIsevs - II, 4.

EsaIAS (propheta) - II, 2.

ESDRAS - V, 7.

EvLALIVs (frater) - IV capit. XVI; IV, 16.

Filivs (Deus) -IV, 7; V, 1; VI, 3.

HoNorivs - VI, titulus.

IACOB (patriarcha) - I, 6 .

Iesve /Christvs / Salvator-I, 1; I, 12; II, 2; II, 3; II, 4; II, 5; II, 7; II, 8; III, 1; IV, 1; IV, 2; IV, 3; IV, 6; IV, 7; IV, 9; IV, 10; IV, 11; IV, 12; IV, 13; IV, 14; IV, 16; IV, 19; V capit., IX; V, 1; V, 2; V, 3; V, 5; V, 7; V, 8; VI, 1; VI, 2; VI, 3. IOANNES (abbas) - V capit. III; $\mathrm{V}, 3$.

IOANNES (apostolus) - II, 4; IV, 19.
Ioannes Colobvs - I capit. II, III; I, 2; I, 3.

IOANNES (discipulus Pauli) - IV, 13.

IOSEPH (abbas) - I capit. XVI; I, 16.

IOSEPH (patriarcha) - IV capit. V; IV, 5.

IsAAC (abbas) - IV capit. VIII; IV, 8.

IsAAC (patriarcha) $-\mathrm{I}, 6$.

IsIDORVs - II, 4.

LeVI $-V, 7$.

Macarivs - II capit. XI; III incipit; III, 1; IV capit. XIX; IV, 19.

Martianvs - V capit. IV; V, 4. Moyses (abbas) - Il capit. IV; II, 4.

Moyses (ductor populi) - VI, 3 .

NABVCHODONOSOR-I capit. IX; I, 8.

Nitera - I capit. XII; I, 12.

PAсноміvs - V capit. VII, VIII; $\mathrm{V}, 7 ; \mathrm{V}, 8$.

Pater (Deus) - IV, 7.

Pavlvs (abbas) - IV capit. XIII; IV, 13.

Pavlvs / Apostolvs - I, 8; I, 12; II, 1; III, 1; IV, 19; V, 2; V, 8; VI, 2; VI, 6.

Petrvs (apostolus) - IV, 7.

Petrvs (discipulus) - IV, 15.

Pror - V capit. II; V, 2.

Poemen - I capit. VIII; I, 8; II capit. X; II, 10; IV capit. IV, 
V, VI; IV, 3; IV, 4; IV, 5;

IV, 6; VI, 5 .

Satanas - III, 1.

Silvanvs - I capit. XII; I, 12.

SPIRITVS SANCTVS - IV, 7; IV, 9; IV, 19; V, 9; VI, 5.
THEODORvs - V capit. VII; V, 7.

Theodosivs I - VI, titulus.

TheoDosivs II - IV capit. III; IV, 3.

ZENO - I capit. XIV; I, 14.

及)

\section{LOCALIDADES}

(capítulo e apotegma)

Aegyptus - II, 5; IV, 3; IV, 5; Palestina - I, 14.

IV, $8 . \quad$ Panepho-I, 16.

Alexandria - IV, $1 . \quad$ Petra - II, 4.

Babylonia - VI, 3.

Calamus - V, 3 .

Pharan - I, 12.

Cellia -I, 7; I, 9; II, 9; IV, 12.

Scetis - I, 9; I, 15; II capit. V;

Constantinopolis - IV capit. III; IV, 3.

Hierusalem -I, 8; IV, 12.

Nitria - V, 2.

II, 5; IV, 1; IV, 8; IV, 12;

V, 2; VI, 1; VI, 6.

Sina -I, 12 .

Tabennensiotae $-\mathrm{V}, 8$.

Thebaida - V, 3; V, 7 . 


\title{
VOCABULÁRIO LATINO
}

\author{
(página do estudo filológico)
}

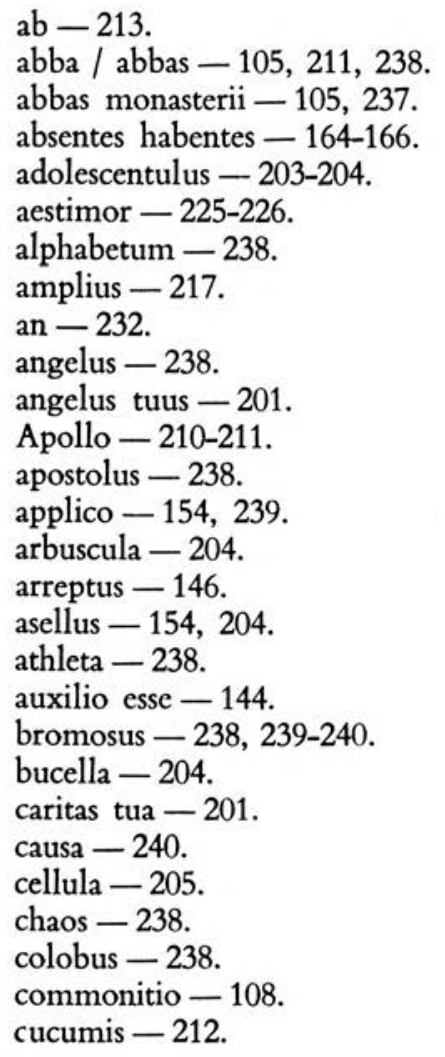

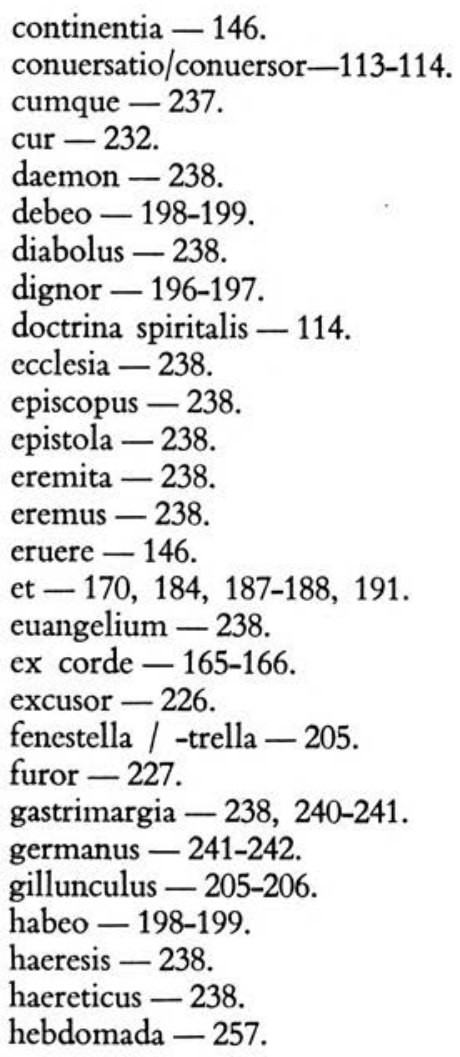

continentia -146 .

conuersatio/conuersor-113-114.

cumque -237.

cur -232 .

daemon -238

debeo - 198-199.

diabolus -238 .

dignor - 196-197.

doctrina spiritalis - 114

ccclesia -238 .

episcopus -238

epistola -238 .

eremita -238 .

eremus -238 .

eruere -146 .

et $-170,184,187-188,191$.

euangelium -238 .

ex corde $-165-166$

fenestella / -trella -205 .

furor -227 .

gastrimargia - 238, 240-241.

germanus - 241-242.

gillunculus - 205-206.

habeo - 198-199.

haeresis -238 .

hebdomada -257 . 
hic itaque $-236-237$.

idiota -238 .

ille - 221-222.

implorare ut -142 .

impossibilis - 242-243, 270.

impotis - 146.

in praesenti -243 .

in quo -232 .

in tantum $-243-244$.

intempestus - 146 .

intentio mentis - 114, 185.

inter se - 224-225.

iubeo - 198, 199, 201.

iugum sanctum monachorum -114 .

inuicem -224 .

inuocare -146 .

ipse $-222-223$.

iugitas - 145, 146.

labor spiritalis -114 .

lucror -227 .

magis $-170,171,195,213$, 217-218.

melius - 195, 213, 216-217.

maxime - 218-219.

mensula - 206 .

mereor - 196-197.

minime -220 .

missa - 245-246.

monachus -238 .

monasteriolum -206 .

monasterium -238 .

monitio - 108 .

muscatus - 246-248.

necesse est - 174-175.

nihil - 219-220.

nobilitas tua - 131, 201.

nullus - 220-221.

numquid -232 .

obseruare -114 .

olim -146 .

omnino -220 . opus spiritale $-114,185$.

ortus fuit -228 .

parabola - 238, 248-249.

pater - 105, 107, 172, 238.

pater monasterii - 105, 108, 238.

patriarcha -238 .

paximatium $-238,249-251$.

penitus -220 .

per -93 .

per quot -232 .

petere ut -142 .

Pior -210 .

plasma - 212, 238.

Poemen - 208-209.

possit - 176, 184.

possum - 196-197.

prae - 213-214.

praebere - 143, 144.

praepositus - 105, 107, 237.

pro longius - 154, 216, 251.

poeniteor -227 .

propheta -238 .

proastium - 238, 251-252.

prophetia -238 .

propior -146 .

propositum - 114, 184.

psallere - 164, (cf. p. 116).

quaero - 143, 144.

quanto -- 232 .

quapropter $-232,252$.

quare -232 .

quatenus -232 .

qui / quid / quis -232 .

quia -- 91, 157, 229, 230-231.

quod $-229-230$.

quomodo - 157, 231-232, 233.

quoniam - 157, 229-230.

raphanus $-238,252-253$.

reficior -227 .

resoluor / resolutio - 253-254.

reuereor -228 .

sacramentum -255 . 
sanctitas tua - 201, 202.

sanctus - 101-102.

schema - 80-81, 238, 255-256.

scientia spiritalis - 114 .

scriptura - 156-157.

se (reflexo) - 226, 228.

senior - 154, 215, 219.

septimana - 256-257.

sermo -257.

seruitium Christi - 114 .

si - 91, 233-234.

solacia -146 .

sportella $-206-207$.

stomachum -238 . studium -114 .

super $-185,213,218$.

supradictus - 154, 237.

supramemoratus -237 .

synaxis $-238,257-258$.

tamquam legentes - 164, 166.

thymiama $-238,246-247,258$.

tu / uos -200 .

uasculum -207.

uita sancta / secreta -114 .

unus $-223-224$.

uolutor -228 .

ut $-171-172$. 


\section{ALGUNS TEMAS DE INTERESSE}

\section{não sugeridos pelo «Índice Geral»}

Obras salvas por um só manuscrito - 16 .

Obras largamente difundidas - 46.

Actualidade dos apotegmas - 47-48.

O problema da Historia Monachorum - 50-51.

O problema da Palladii Lausiaca - 53-56 e 303-304.

Literalismo como norma de tradução - 57, 158-163.

Fontes históricas para a época dos apotegmas - 96 .

Falsificações literárias - 126-127.

Data das principais colecções latinas de apotegmas - 132-133.

História da Literatura Latina nos séculos v c vi -133-134.

Identificação literária pelo estilo - 134 .

Cassiano (seu valor literário) -139-140.

O plágio nas literaturas $-148-149$.

Latim vulgar - 144 e 154 .

Latim dos cristãos (escola de Nimega) - 113 e 236.

Latim tardio (escola sueca) -208.

Dicionários latinos e gregos - 164 c 165 .

Estilísticas - 167.

Sintaxes latinas - 170 .

Respeito pela lição dos manuscritos - 167-168, 175-178, 188, 209. Automatismo do tradutor (ou erros de ditado?) 171, 175, 178, 188-189, 265.

lectio difficilior - 174 e 188.

crux - 172-173; 266 (2 e 3), 374, 391.

correxi $-166-168,265$ (1) e 266 (4), 324, 338, 342, 343, 347,

378 (bis), 396.

carta-prefácio (tópicos) - 299-302. 


\section{ÍNDICE GERAL}

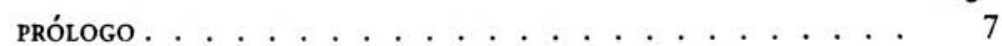

I - ESTUDO FILOLÓGICO . . . . . 11

Cap. I - uma nova coleç̧̃̃o de apotegmas . . . . . 13

CAP. II - MANUSCRITOS CONHECIDOS . . . . . . . . . . . . 19

- Arquétipo $\beta \ldots \ldots \ldots \ldots . \ldots . \ldots 21$

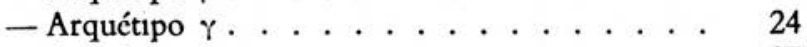

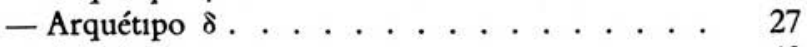

- Arquétıpo $\varepsilon \ldots \ldots \ldots . \ldots . \ldots 43$

Cap. III - em busca de lugares paralelos . . . . . . . 47

- Explicação das abreviaturas e números do quadro dos lugares paralelos . . . . . . 59

- Quadro dos apotegmas das Commonitiones e dos seus lugares paralelos . . . . . . . . 63

CAP. IV - CONSTITUIÇÃo UNITÁRIA, EXTERNA E INTERNA, DA COLECÇño . . . . . . . . . . 65

Cap. V - processos de composiçño e de traduÇão . . . 71

1 - Preliminares sobre o texto grego utilizado 71

2-Tradução literal (ou quase) . . . . . . . 76

3 - Breves retoques e pequenas ampliações do texto . . . . . . . . . . . . . . . 79

4 - Longo desenvolvimento, incluindo citações bíblicas. . . . . . . . . . . 83

5 - Alteração do sentido primitivo . . . . . 87

6-Qualidades do tradutor . . . . . . . . 89

CAP. VI - trêS PROBLemas: dATA, AUtOR E tRADUtor . . . 94 1 - A data . . . . . . . . . . . . . . 94 


$$
\begin{aligned}
& \text { Pags. } \\
& \text { 2-O autor ............. } 103 \\
& \text { - Alguns tópicos do autor. . . . . . } 107 \\
& \text { A - A felicidade celeste como prémio . . } 108 \\
& \text { B - O dia de juizo e o castigo eterno . . } 110 \\
& \text { C - Elogio da perfeição espiritual na vida } \\
& \text { 3-O tradutor . . . . . . . . . . . } 120 \\
& \text { — Data e local da tradução . . . . . . . } 127
\end{aligned}
$$

CAP. VII — um apotegma importado de Cassiano . . . . . 136

Cap. VIII - eXame linguístico do latim das Commonitiones . . 150

1 - Opinião de Hopfner e de Salonius . . . . 150

2-Comparação com Pascásio e com Pelágio 152

3 - O texto latino é uma tradução; não é um original . . . . . . . . . . . . 157

4-Latim obscuro, esclarecido pelo grego . . 163

5 - Construção sintáctica descuidada . . . . . 169

6-Concordância ad sensum . . . . . . . . . 179

7-Artifício na ordem das palavras . . . . 181

8 - Colocação do antecedente após o pronome relativo. . . . . . . . . . 186

9-Omissão de uma palavra ou expressão . . 189

10 - Amplidão de estilo e perífrases solenes . . . 192

a) Ênfase que já deveria estar no original grego............ 192

b) Amplidão de estilo, atribuível ao tradutor 195

c) Perífrases de dignor, mereor, possum + infinitivo. . . . . . . . . . . 196

d) Outras expressões perifrásticas . . . . . 197

11 - Formas de tratamento . . . . . . . . . . 199

12 - Diminutivos (por ordem alfabética) . . . . . 203

13 - Várias anotações sobre morfologia e sintaxe 208

a) Flexão nominal . . . . . . . . . . 208

b) Formas de comparação . . . . . . . . 212

c) Formas de negação . . . . . . . . . 219

d) Valores dos pronomes ille e ipse . . 221 
Pags.

e) Vuus a caminho do indefinido ....

g) Situação dos verbos "depoentes" (por ordem alfabética) . . . . . . . 225

h) Conjunções completivas . . . . . . 229

i) Orações interrogativas . . . . . . 232

j) Hipotéticos helenismos de sintaxe . . 234

14 - Notas sobre vocabulário . . . . . . . 235

- modismos do tradutor . . . . . . 236

— vocabulário por ordem alfabética . . 239

CAP. IX - GENEALogia dos PRINCIPAis códices . . . . . . 259

A - Notas preliminares. . . . . . . . 259

B - Siglas e sinais utilizados no stemma codicum 261

I - Hiperarquétipo $\alpha \ldots \ldots \ldots 265$

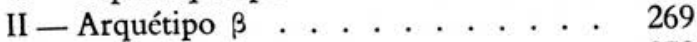

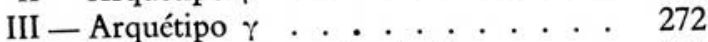

IV - Arquétipo contaminado $\delta \ldots . . .280$

$\mathrm{V}$-Subarquétipo $\varepsilon \ldots \ldots . . . .287$

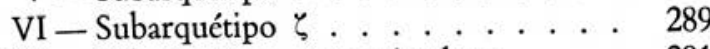

VII - Subarquétipo contaminado $\eta \ldots .291$

VIII - Subarquétipo $\theta$. . . . . . . . . . . 294

—Edição de Rosweydus. . . . . . 295

CAP. X - O PRÓLOGO ESPÚRIO VERE MVNDVM . . . . . . 299

- Texto crítico do prólogo Vere mundum . . . . . . . . . 307

II - TEXTO CRÍTICO . . . . . . 309

CAP. I- Monita SANCtorvm PATRVM . . . . . . . . 311

CAP. II — CONTRA SPIRITVM Fornicationis . . . . . . . 326

CAP. III - exhortatio SANCti Macari ad monachos . . . 340

Cap. IV - de virtvte hVmilitatis et patientiae . . . . . 342

CAP. V - DE doctrina AD MONAChos . . . . . . . 378

Cap. VI - de beato arsenio . . . . . . . . . . . . 393 
I Manuscritos Pdgs.

II Bibliografia. . . . . . . . . . . . . . . 404

III Índice onomástico:

A) Do estudo filológico . . . . . . 414

B) Do texto das Commonitiones:

๔) Nomes de pessoas . . . . . 420

ß) Localidades......... 422

IV - Vocabulário latino . . . . . . . . . . . . . . . . . 423

$\mathrm{V}$-Alguns temas de interesse não sugeridos pelo «Índice geral» 426

VI - Índice Geral . . . . . . . . . . . . . . . . . . . . 427 


\section{CORRIGENDA}

$\mathrm{Na}$ página 64 o lugar grego paralelo

de Commonitiones VI,5 é NAU 184b (e não N 148 ${ }^{\mathrm{b}}$ )

- cf. o respectivo texto grego e paralelos latinos

nas pp. 155-156. 



\section{PUBLICAÇÕES \\ DO \\ INSTITUTO DE ESTUDOS CLÁSSICOS}

FACULDADE DE LETRAS - COIMBRA - PORTUGAL

PereirA, Maria Helena da Rocha - Hélade (Antologia da Cultura Grega). Coimbra, 3.² edição, 1972.

PereirA, Maria Helena da Rocha-Greek Vases in Portugal. Coimbra, 1962.

Fernandes, João - A oração sobre a Fama da Universidade (1548). Introdução, tradução e notas de JoRge Alves Osório. Coimbra, 1967.

Ésquilo - As Suplicantes. Introdução, tradução e notas de ANA Paula Quintela Ferreira Sottomayor. Coimbra, 1968.

EURÍPIDES - Andrómaca. Introdução, tradução e notas de JosÉ Ribeiro Ferreira. Coimbra, 1971.

Cataldo Parísio Sículo - Martinho, verdadeiro Salomão. Prólogo, tradução e notas de Dulce DA Cruz Vieira. Introdução e revisão de Américo da Costa Ramalho, Coimbra (no prelo). 


\title{
PUBLICAÇÕES
}

DO

\section{CENTRO DE ESTUdOS CLÁSSICOS E HUMANÍSTICOS}

\author{
(INSTITUTO DE ALTA CULTURA) \\ FACULDADE DE LETRAS - COIMBRA — PORTUGAL
}

Pulquério, Manuel de Oliveira - Problemática da tragédia sofocliana, Coimbra, 1968.

Ramalho, Américo da Costa - Estudos sobre a época do Renascimento, Coimbra, 1969.

Freire, José Geraldes - A versão latina por Pascásio de Dume dos "Apophthegmata Patrum». Tomo I: Introdução cultural; Pascásio como tradutor; texto crítico. Tomo II: Descrição dos manuscritos; genealogia dos códices. Coimbra, 1971.

Actas do "Colóquio sobre o ensino do latim», Coimbra, 1973.

FreIre, José Geraldes - Commonitiones Sanctorum Patrum. Uma nova colecção de apotegmas. Estudo filológico; texto crítico. Coimbra, 1974.

EURípIDES - Ifigénia em Áulide. Introdução e tradução de CARLOS Alberto Pais de Almeida, Coimbra (a sair brevemente). 
IMPRESSÃO

Simões \& Linhares, Lda.

Av. Fernando Namora, no 83 - Loja 4 3000 Coimbra 
Em 1615, Heribertus Rosweydus publicou no livro III, "auctore probabili Rufino", no livro VII "interprete Paschasio" e num terceiro apêndice, as "Aegyptiorum patrum sententiae...Martino Dumiensi episcopo interprete". O trabalho do Jesuíta permaneceu durante séculos a única edição de acesso para as traduções latinas dos Apotegmas dos Padres do Deserto feitas entre os sécs. V e VI.

Uma vez clarificada, em 1971, a versão latina do Liber Geronticon de Octo Principalibus Vitiis de Pascásio de Dume, numa edição que ordena materiais conhecidos, mas mal atribuídos, José Geraldes Freire veio dar a conhecer uma tradução latina dos Apotegmas em grego inteiramente nova, nesta edição crítica e análise linguística e literária pela primeira vez saída à luz em 1974. Esta reconstituição de um novo livro de Apotegmas com seis capítulos e onze números totalmente inéditos, as Commonitiones Sanctorum Patrum, expõe a verdade acerca de um livro que havia sido copiado pela última vez enquanto unidade temática no séc. XIV (ms. de Dresden, A 207, ff. 188r-216v), mas que chegou irreconhecível ao livro III das Vitae Patrum de Rosweydus. 